OECD Reviews of School Resources

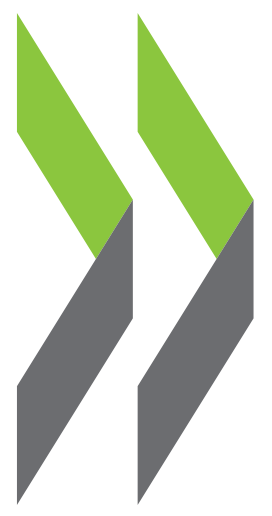

\title{
Working and Learning Together
}

RETHINKING HUMAN RESOURCE POLICIES FOR SCHOOLS

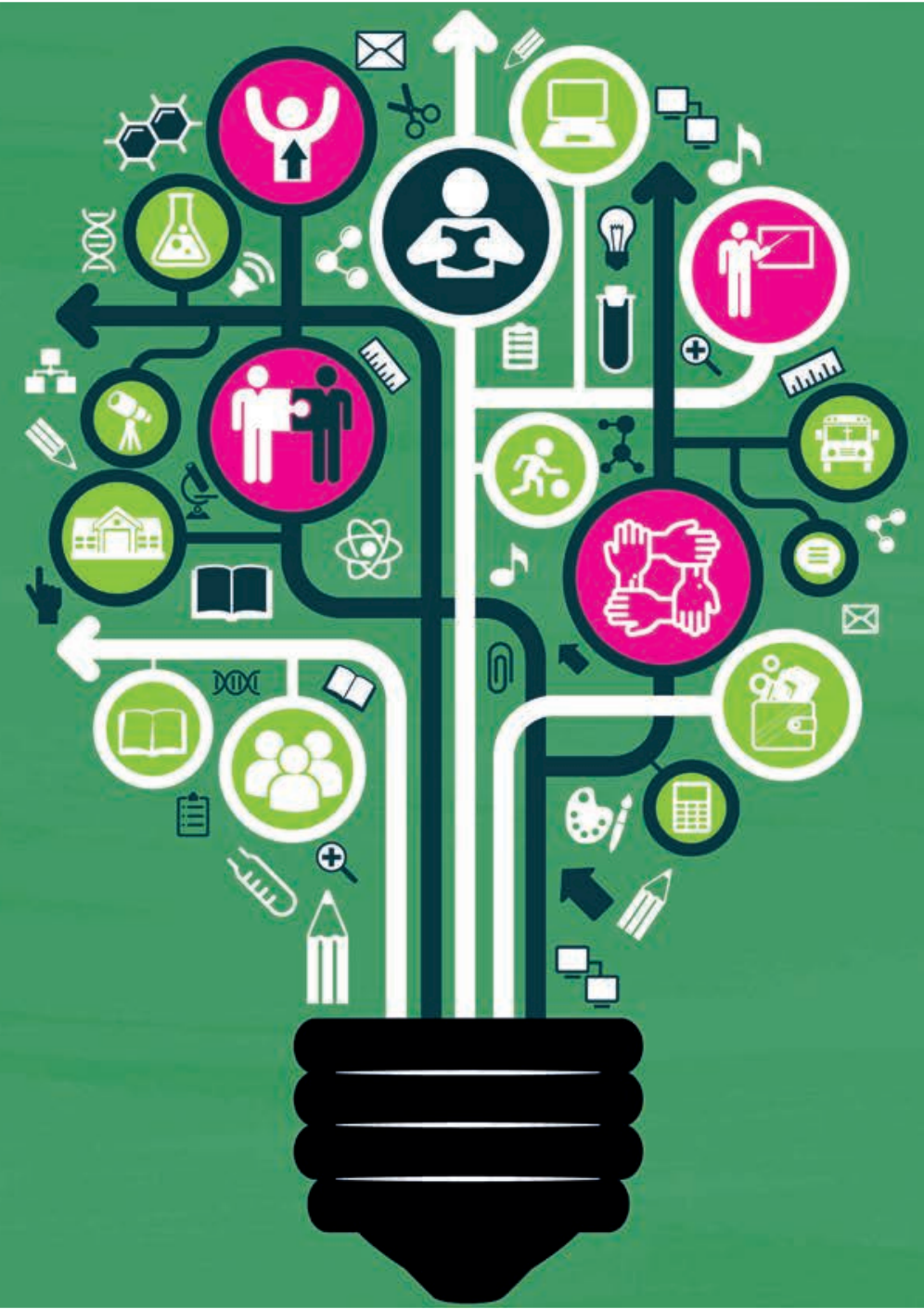





\title{
Working and Learning Together
}

\author{
RETHINKING HUMAN RESOURCE POLICIES \\ FOR SCHOOLS
}


This work is published under the responsibility of the Secretary-General of the OECD. The opinions expressed and arguments employed herein do not necessarily reflect the official views of OECD member countries.

This document, as well as any data and any map included herein, are without prejudice to the status of or sovereignty over any territory, to the delimitation of international frontiers and boundaries and to the name of any territory, city or area.

Please cite this publication as:

OECD (2019), Working and Learning Together: Rethinking Human Resource Policies for Schools, OECD

Reviews of School Resources, OECD Publishing, Paris, https://doi.org/10.1787/b7aaf050-en.

ISBN 978-92-64-97057-1 (print)

ISBN 978-92-64-98196-6 (pdf)

OECD Reviews of School Resources

ISSN 2413-4333 (print)

ISSN 2413-3841 (online)

The statistical data for Israel are supplied by and under the responsibility of the relevant Israeli authorities. The use of such data by the OECD is without prejudice to the status of the Golan Heights, East Jerusalem and Israeli settlements in the West Bank under the terms of international law.

Photo credits: Cover @ VLADGRIN/Shutterstock.com.

Corrigenda to OECD publications may be found on line at: www.oecd.org/about/publishing/corrigenda.htm.

(c) OECD 2019

You can copy, download or print OECD content for your own use, and you can include excerpts from OECD publications, databases and multimedia products in your own documents, presentations, blogs, websites and teaching materials, provided that suitable acknowledgement of OECD as source and copyright owner is given. All requests for public or commercial use and translation rights should be submitted to rights@oecd.org. Requests for permission to photocopy portions of this material for public or commercial use shall be addressed directly to the Copyright Clearance Center (CCC) at info@copyright.com or the Centre français d'exploitation du droit de copie (CFC) at contact@cfcopies.com. 


\section{Foreword}

This report is the third in a series of thematic comparative reports which brings together findings from the OECD Review of Policies to Improve the Effectiveness of Resource Use in Schools (School Resources Review). The first report, The Funding of School Education: Connecting Resources and Learning, was published in 2017 and analysed school funding policies. The second report, Responsive School Systems: Connecting Facilities, Sectors and Programmes for Student Success, published in 2018, analysed the organisation of school infrastructure and services. This third report in the series analyses human resource policies defined as those actions that shape who school staff are and what they do, through decisions on careers, staff distribution, and professional learning.

The School Resources Review was launched in 2013 to help countries learn from one another by exchanging best practices, and to gather and disseminate evidence on effective school resource policies. The project highlights issues and explores ideas that may be difficult to raise in national debates. It seeks to inform discussions among stakeholders with new perspectives that are based on research and evidence from different contexts.

This publication draws extensively on the experience of the 21 school systems that were actively engaged in its preparation. These systems vary significantly in their economic and social contexts, and illustrate a wide range of approaches in their policies. This approach allows the report to take a comparative perspective on key issues. Although the analysis also considers the broader research literature and evidence from other OECD and partner countries, it is nevertheless important to acknowledge that the report - to a certain extent reflects the practices and priorities of the participating countries.

Readers should not take the examples cited in the report to reflect international best practice, but rather as an illustration of a wide range of experiences and lessons learned. In addition, readers should bear in mind that initiatives that work well in one context are not necessarily transferable to others. The review has attempted to be sensitive to this by analysing policies in relation to the values, vision and organisation of different countries' school systems, as well as their broader economic, social, political and cultural contexts.

This report was co-authored by Luka Boeskens, Deborah Nusche and Thomas Radinger (co-ordinator) from the OECD Directorate for Education and Skills and David Liebowitz (University of Oregon, formerly with the OECD), with analytical contributions from Makito Yurita (on secondment to the OECD from Japan's National Institute for School Teachers and Staff Development). The work on this report was led by project manager Deborah Nusche under the responsibility of Paulo Santiago, Head of the Policy Advice and Implementation Division. David Liebowitz co-ordinated the initial structure and outline of this report, with analytical contributions from Samuel Kim. Yael Jacoby and Aoife Kenna provided research assistance and summarised key areas of the literature during their internships with the project. Cláudia Sarrico contributed to shaping the report as interim project manager between April and October 2018. Claire Berthelier was responsible for copy-editing, formatting and layout. Rachel Linden supported the report's production; Sophie Limoges assisted with the design of the publication cover; Alison Burke supported communications and dissemination. 



\section{Acknowledgements}

This report would not have been possible without the support of the 21 school systems that have been actively engaged in the OECD School Resources Review. Participating countries committed substantial resources and opened their school resource policies to review and debate. National co-ordinators (listed in Annex C) played a key role in this exchange, enriching discussions with their insights from diverse contexts and co-ordinating their countries' participation in the project. The OECD Education Policy Committee (EDPC), the Group of National Experts (GNE) on School Resources, and the delegates to both bodies provided essential support and analytical guidance since the inception of the project, and offered valuable feedback on drafts of this document.

Leading up to this report, Mr Bernhard Chabera, Senior Advisor of the Austrian Federal Ministry for Education, Science and Research, chaired the Group of National Experts. Mr Philippe Dieu, Analyst at the International Relations Directorate of the Ministry of the Wallonia-Brussels Federation, and Ms Kadi Serbak, Analyst at the Estonian Ministry of Education and Research, were vice-chairs to the group. Until November 2017, the group was chaired by Mr Jørn Skovsgaard, Senior Advisor at the Danish Ministry of Education, and vice-chairs Ms Marie-Anne Persoons, Policy advisor with the Flemish Ministry of Education and Training, and Mr Matej Šišković, Director of the Education Policy Institute, Ministry of Education, Science, Research and Sport of the Slovak Republic. Ms Shelley Robertson, Chief Advisor for International Education at the New Zealand Ministry of Education, served as vice-chair for the GNE from May 2014 to May 2015 and chaired the group's first meeting. The dedication, leadership and support of the GNE's chairs and vice-chairs for this work is gratefully acknowledged.

The School Resources Review and this report also benefited from the active involvement of different stakeholders with an interest in education. The Business and Industry Advisory Committee to the OECD (BIAC) and the Trade Union Advisory Committee to the OECD (TUAC) participated as permanent observers in meetings of the GNE on School Resources and had the opportunity to comment on drafts of this report. During individual country reviews, students, parents, teachers, school leaders, policy makers, researchers and employers made their time available to meet with review teams and provide their perspectives on resource issues, including human resource policies.

This report was prepared within a broader framework of collaboration and partnership with the European Commission (EC), which was established for the OECD School Resources Review. The support of the EC has covered part of the participation costs for members of the European Union Erasmus + programme and contributed significantly to the preparation of the series of thematic comparative reports, including this publication. The European Commission's support for the School Resources Review is gratefully acknowledged. The review team would like to thank colleagues at the EC Directorate-General for Education and Culture, in particular Mónika Képe-Holmberg and Marco Montanari (Unit B.2: Schools and Multilingualism under the leadership of Michael Teutsch), and many others whose contributions are acknowledged in Annex C. 
In addition, we are grateful for the collaboration with the following partners and their valuable inputs into this report: Eurocities, Eurydice (Education Information Network in Europe), the Inter-American Development Bank (IDB), the International Labour Organization (ILO), the IMTEC Foundation (International Movement Towards Educational Change), the Organising Bureau of European School Student Unions (OBESSU), the United Nations Educational, Scientific and Cultural Organization (UNESCO), UNESCO's Global Education Monitoring Report team (GEMR), and the UNESCO International Institute for Educational Planning (IIEP).

The review is indebted to the many experts who contributed to the country review visits and the resulting country review reports that are part of the publication series OECD Reviews of School Resources (for the composition of the country review teams, see Annex C). Their expertise, analytical contributions to the country-specific reports and professional exchanges with OECD Secretariat members provided the foundation for the comparative perspective and analysis of this report. From the OECD team, David Liebowitz, Deborah Nusche, Thomas Radinger, Paulo Santiago and Claire Shewbridge assumed leadership for the individual country reviews on which this report is based. Important contributions to the country reviews were also made by Anna Pons (who led the review of Kazakhstan), Tracey Burns (who participated in the review of Uruguay), Alfonso Echazarra (who participated in the review of Colombia) and Gonçalo Lima (who participated in the review of Portugal). The review of Kazakhstan was undertaken in co-operation with the World Bank.

The background reports prepared by participating countries provided a further important source of information and thanks are due to all those who contributed to their production. In addition to this publication, by November 2019, the review had generated 18 reports by participating countries, 12 reports by external review teams and multiple working papers, all of which are available on the OECD website at www.oecd.org/education/schoolresourcesreview.htm.

Within the OECD Directorate for Education and Skills, the work on the School Resources Review was carried out by the Policy Advice and Implementation Division, under the leadership of Paulo Santiago (since August 2016) who also managed the School Resources Review between 2013 and 2016, and previously Yuri Belfali (from October 2014 to July 2016) and Michael Davidson (from January 2013 to September 2014). Claire Berthelier provided editorial support and took responsibility for the administrative work within the review, the organisation of meetings and communication with the countries. The team would also like to thank Andreas Schleicher for his overall guidance and support for the project.

Gratitude is due to former team members who supported the work of the project at different stages. Macarena Ares Abalde, Alfonso Echazarra, Gonçalo Lima, Francesc Masdeu Navarro, Joris Ranchin and Alette Schreiner provided substantial input into the project's knowledge base. Tala Fakharzadeh, Anna Gromada, Gaëlle Leduc, Antoine Papalia, Kerstin Schophol and Oliver Sieweke provided research assistance and summarised key areas of the literature on school resources during their internships.

The OECD review team is grateful to numerous colleagues within the OECD who provided valuable input and advice at different stages of the report's production. In particular, the report benefited from collaboration with OECD teams working on Early Childhood Education and Care (ECEC), the Initial Teacher Preparation (ITP) Study, the Strength Through Diversity project, the Programme for International Student Assessment (PISA), the Teaching and Learning International Survey (TALIS) and the INES (Indicators of 
Education Systems) Network for the Collection and the Adjudication of System-Level Descriptive Information on Educational Structures, Policies and Practices (NESLI). Special thanks are due to Pablo Fraser and Cláudia Sarrico for valuable comments on earlier versions of this report. 



\section{Table of Contents}

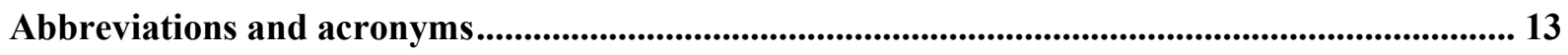

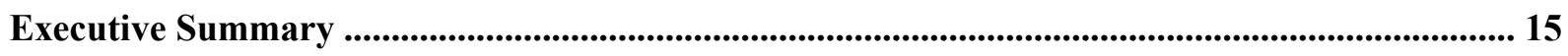

Six policy approaches to support effective working environments in schools ............................. 19

Policy 1: Designing career structures with opportunities for professional growth .......................... 20

Policy 2: Establishing salary scales that attract new entrants and reward growing expertise............ 22

Policy 3: Reviewing the staff mix and working time arrangements in schools ............................. 25

Policy 4: Ensuring an effective and equitable distribution of school staff .................................... 27

Policy 5: Adopting a broad vision of initial preparation for teaching and school leadership ............ 29

Policy 6: Supporting continuing professional learning and collaboration ................................... 31

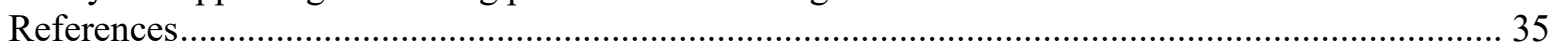

Chapter 1. Why focus on effective human resource policies for schools? ........................................ 39

1.1. Teachers, leaders and other school staff matter for student learning and well-being ................ 40

1.2. Human resource policies shape working and learning environments in schools ...................... 44

1.3. Human resource policies influence effectiveness and efficiency of spending ......................... 50

1.4. Human resource policies need to be carefully designed and implemented............................... 53

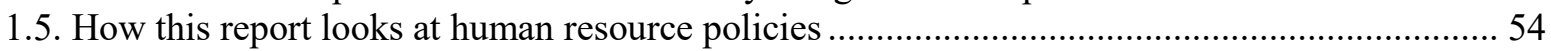

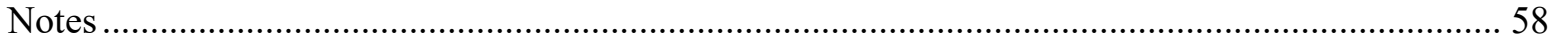

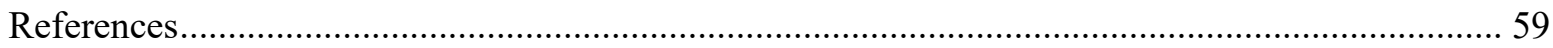

Annex 1.A. Towards an international perspective on the mix of staff in schools .......................... 65

Annex 1.B. School staffing frameworks in OECD review countries (ISCED 2), 2018 ................. 74

Chapter 2. Raising the attractiveness of a career in schools................................................................ 113

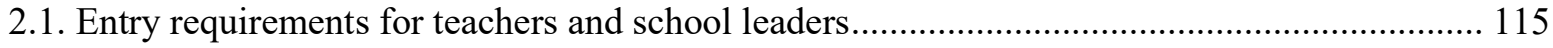

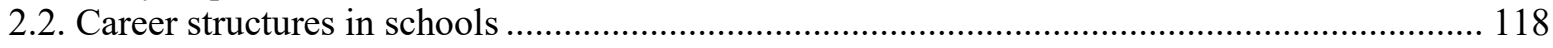

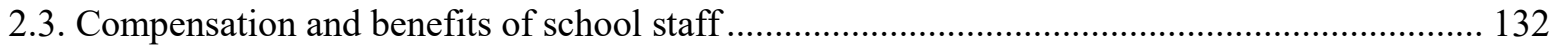

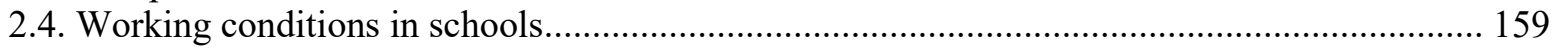

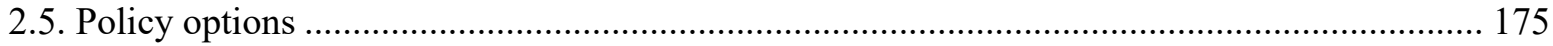

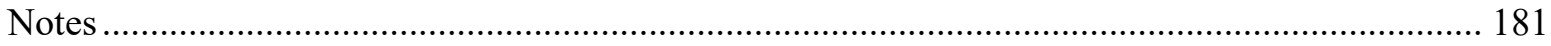

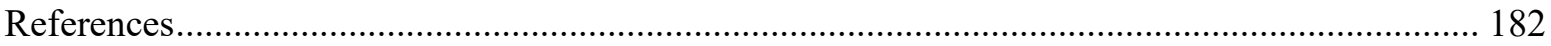

Chapter 3. Distributing teachers, school leaders and other school staff effectively .................... 191

3.1. Inequities in the distribution of teachers and school leaders between schools ....................... 192

3.2. Supply of teachers, school leaders and other school staff.................................................. 195

3.3. Management and use of resources for school staffing ..................................................... 204

3.4. Staff selection into particular schools and positions .......................................................... 224

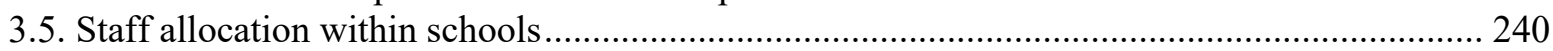

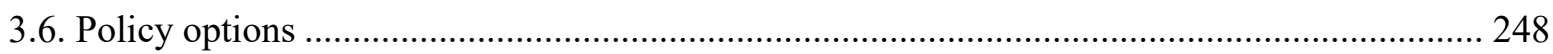

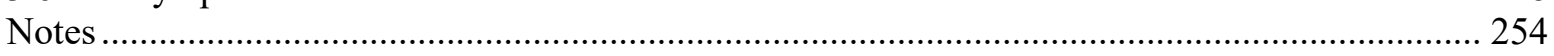

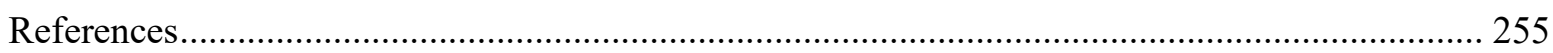


Chapter 4. Promoting powerful professional learning for school staff

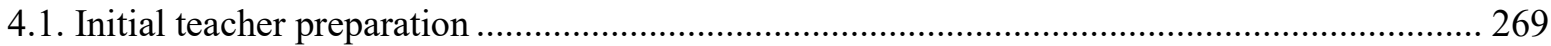

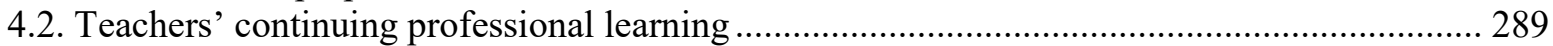

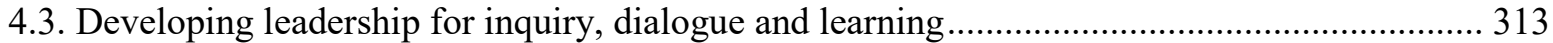

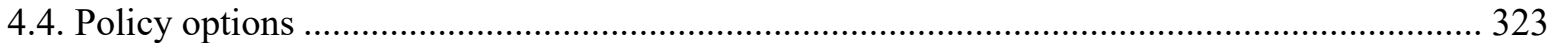

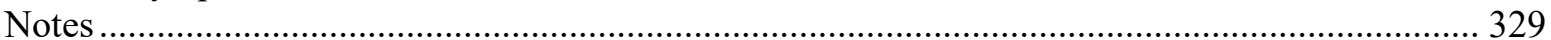

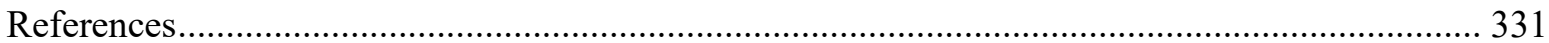

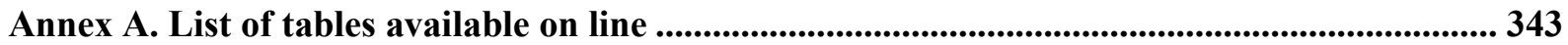

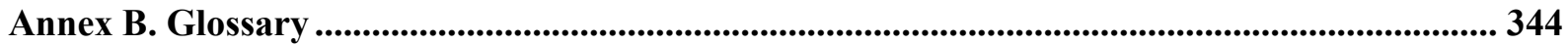

Annex C. How the School Resources Review was conducted .................................................... 348

\section{Tables}

Table 1.1. Policy dimensions and aspects of analysis covered in this report ...................................... 45

Table 2.1. Vertical career structures for teachers (ISCED 1-3), 2018 ........................................... 121

Table 2.2. Factors influencing school principals' salaries (ISCED 1-3), 2018 .............................. 153

Table 3.1. Responsibility for school staff employment (ISCED 2), 2018 ..................................... 205

Table 3.2. Responsibility for employing and recruiting teachers (ISCED 2), 2018 …................... 206

Table 3.3. Professional support staff provided through resource centres (ISCED 2), 2018.............. 208

Table 3.4 Responsibility for appointment of intermediate school leaders (ISCED 1-3), 2018 .......... 228

Table 3.5. Involvement in school principal recruitment process (ISCED 1-3), 2018 ...................... 230

Table 3.6. Priority criteria for selection of teacher candidates (ISCED 1-3), 2018 ......................... 236

Table 3.7. Financial incentives for teachers and school principals to work in disadvantaged or rural

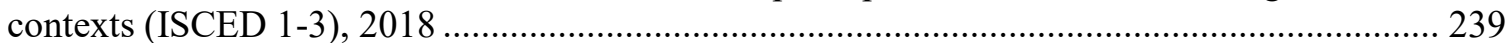

Table 4.1. Practical experience during initial teacher education (ISCED 1-3), 2018 ..................... 273

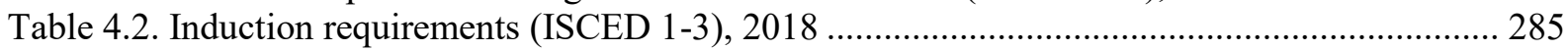

Table 4.3. Requirements and incentives for participation in professional development (ISCED 1-3),

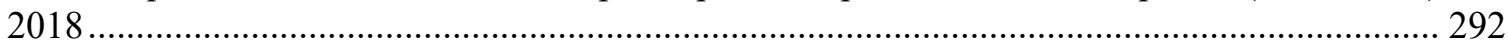

Table 4.4. Professional development providers, 2018 ............................................................... 297

Table 4.5. Teamwork among teachers within schools (ISCED 1-3), 2018 ..................................... 301

Table 4.6. Opportunities for teacher and school leader collaboration beyond the individual school

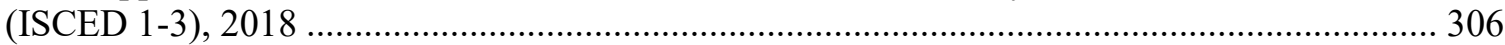

Table 4.7. School principal preparation requirements (ISCED 1-3), 2018 .................................... 315

Table 4.8. Development requirements and opportunities for intermediary formal school leadership

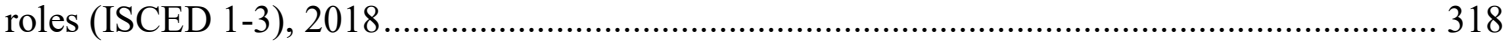

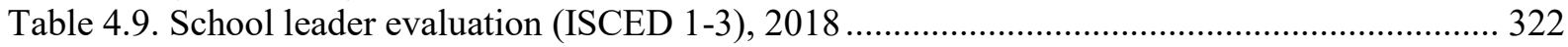

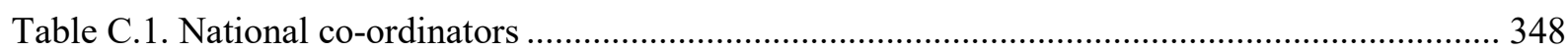

Table C.2. European Commission contribution to country reviews................................................ 349

Table C.3. Country contacts for the qualitative data collection ................................................... 351

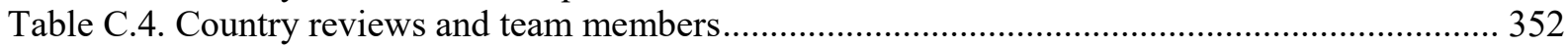




\section{Figures}

Figure 1.1. Change in pedagogical support staff (ISCED 2), 2013-2018....................................... 42

Figure 1.2. Change in administrative and managerial staff (ISCED 2), 2013-2018 ........................ 43

Figure 1.3. Human resource policies for schools: a conceptual framework ..................................... 48

Figure 1.4. Share of current expenditure spent on staff and other resources, 2016.......................... 51

Figure 1.5. Contribution of various factors to salary cost of teachers per student (ISCED 1), 2017 .... 52

Figure 2.1. Teachers' salaries relative to earnings of tertiary-educated workers, 2011-17............... 134

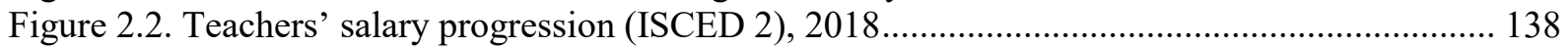

Figure 2.3. Criteria for awarding additional compensation to teachers (ISCED 1-3), $2018 \ldots \ldots \ldots \ldots \ldots . .140$

Figure 2.4. Minimum and maximum statutory salaries for teachers and school heads (ISCED 2),

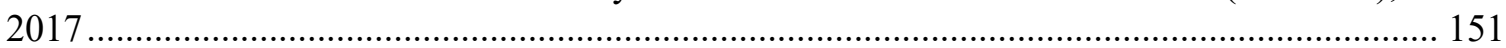

Figure 2.5. Responsibilities for human resource management in public education (ISCED 2), 2017157

Figure 2.6. Teachers' working hours (ISCED 2), 2018........................................................... 161

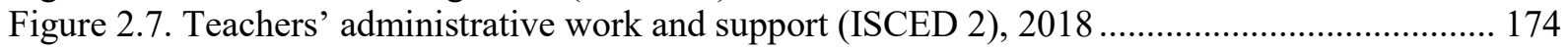

Figure 3.1. Relationship between socio-economic differences in science performance and in teacher

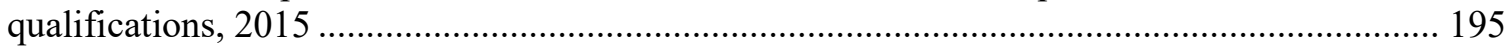

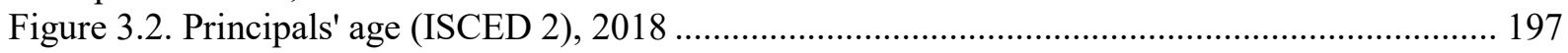

Figure 3.3. Employment status of teachers, full time or part time (ISCED 2), 2018 ..................... 222

Figure 3.4. Shortages of school resources (ISCED 2), 2018 …................................................ 223

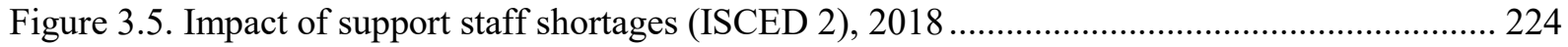

Figure 3.6. Teachers' job satisfaction with their work environment, by teaching experience (ISCED

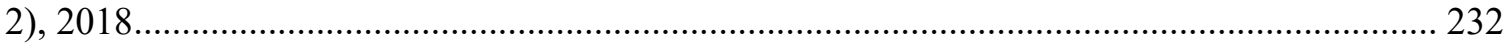

Figure 3.7. Distribution of novice teachers by concentration of students from socio-economically

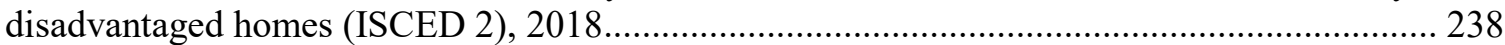

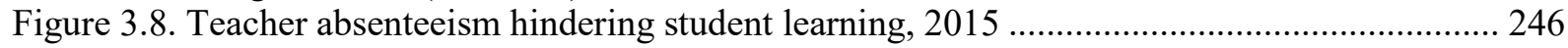

Figure 4.1. Teachers' sense of preparedness for different elements of teaching (ISCED 2), 2018 ..... 271

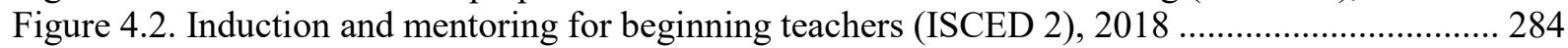

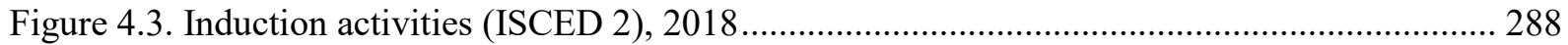

Figure 4.4. Teachers' needs for professional development (ISCED 2), 2018 ............................... 291

Figure 4.5. Teachers' working time spent teaching (ISCED 2), 2017 ........................................ 294

Figure 4.6. Participation in professional development activities (ISCED 2), 2018......................... 295

Figure 4.7. Type of professional development attended by teachers (ISCED 2), 2018 .................. 298

Figure 4.8. Impact of teacher appraisal and feedback systems in schools (ISCED 2), 2013 ............. 309

Figure 4.9. Principals' needs for professional development (ISCED 2), 2018 ............................... 314

Figure 4.10. Relevance of professional development on offer (ISCED 2), 2018 ............................. 321

Annex Figure 1.A.1. Tasks and responsibilities required of teachers (ISCED 2), 2017 ................... 66

Annex Figure 1.A.2. Teaching requirement of school principals by level of education, 2018 ........... 67

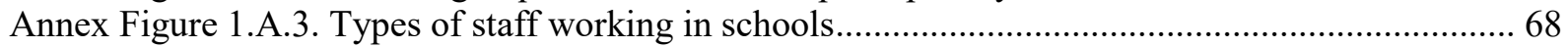

Annex Figure 1.A.4. Distribution of responsibilities in public education (ISCED 2), 2017............... 72

\section{Boxes}

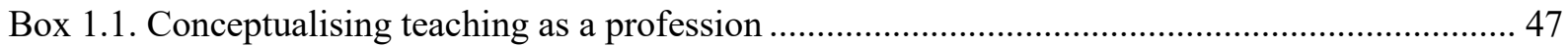

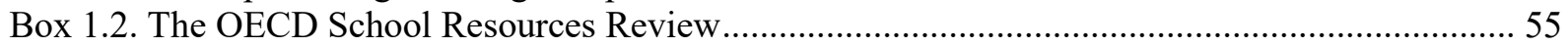

Box 2.1. Multi-stage structure of the teaching career in Estonia...................................................... 122

Box 2.2. Vertical and horizontal career progression in the Slovak Republic ................................... 126 
Box 2.3. Evaluations of performance-based compensation systems in the United States.................. 146

Box 2.4. Group-based incentives for school leaders in Chile ..................................................... 154

Box 2.5. Workload-based models of teacher working time ........................................................... 163

Box 3.1. Private school provision and teacher labour markets........................................................ 194

Box 3.2. Scholarships to attract high-quality candidates into teaching ......................................... 203

Box 3.3. Professional health and social support provided through resource centres......................... 209

Box 3.4. Professional support provided for schools and students through labour and social affairs

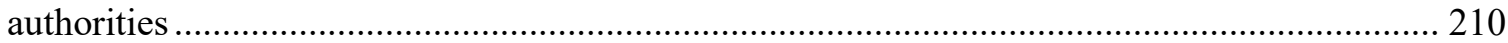

Box 3.5. School leadership teams in Kazakhstan...................................................................... 212

Box 3.6. Targeted funding to provide specialised support staff for schools ................................... 215

Box 3.7. Building capacity for the recruitment of substitutes ..................................................... 247

Box 4.1. A Flying Start: Improving Initial Teacher Preparation Systems..................................... 270

Box 4.2. Collaboration between initial teacher education and school education in the Netherlands.. 275

Box 4.3. Urban teacher residencies in the United States .............................................................. 277

Box 4.4. Models for staff support: induction, mentoring and coaching ....................................... 283

Box 4.5. Induction processes in OECD review countries .......................................................... 286

Box 4.6. Developing schools as learning organisations in Wales (United Kingdom)...................... 289

Box 4.7. Large-scale teacher coaching in Colombia: Programa Todos a Aprender ......................... 299

Box 4.8. Types of teacher collaboration in schools in Ontario (Canada) ......................................... 303

Box 4.9. Collaboration between schools in New Zealand and the United States............................. 308

Box 4.10. Approaches to school principal preparation in OECD review countries ......................... 315

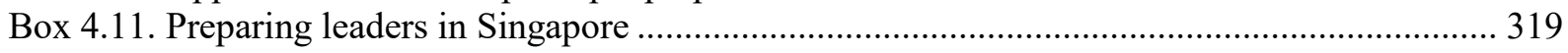

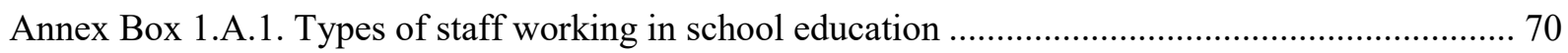

\section{Follow OECD Publications on:}

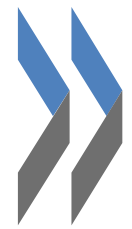

Y http://twitter.com/OECD_Pubs

f http://www.facebook.com/OECDPublications

in. http://www.linkedin.com/groups/OECD-Publications-4645871

- http://www.youtube.com/oecdilibrary

AlecD $h$ http://www.oecd.org/oecddirect/

\section{This book has...}

StatLinks :

A service that delivers Excel ${ }^{\circledR}$ files from the printed page!

Look for the StatLinks तins at the bottom of the tables or graphs in this book. To download the matching $E x c e{ }^{\circledR}$ spreadsheet, just type the link into your Internet browser, starting with the https://doi.org prefix, or click on the link from the e-book edition. 


\section{Abbreviations and acronyms}

\begin{tabular}{ll}
\hline CBR & Country Background Report \\
CPD & Continuing Professional Development \\
EC & European Commission \\
ECEC & Early Childhood Education and Care \\
ECTS & European Credit Acquisition and Transfer System \\
EU & European Union \\
GNE & Group of National Experts \\
ICT & Information and Communication Technology \\
IDB & Inter-American Development Bank \\
ILO & International Labour Organization \\
ITP & Initial Teacher Preparation \\
ISCED & International Standard Classification of Education \\
OECD & Organisation for Economic Co-operation and Development \\
PIAAC & OECD Programme for the International Assessment of Adult Competencies \\
PISA & OECD Programme for International Student Assessment \\
PPP & Purchasing Power Parity \\
SEN & Special Educational Needs \\
SES & Socio-economic Status \\
SDG & Sustainable Development Goal \\
TALIS & OECD Teaching and Learning International Survey \\
UNESCO & United Nations Educational, Scientific and Cultural Organization \\
VET & Vocational Education and Training \\
\hline
\end{tabular}





\section{Executive Summary}

This report constitutes the third in a series of thematic comparative reports which brings together the findings of the OECD Review of Policies to Improve the Effectiveness of Resource Use in Schools (School Resources Review). It provides ideas for governments to design effective human resource policies and achieve their education policy objectives.

Following an introductory chapter highlighting the importance of human resource policies, the report's remaining chapters focus on the following thematic areas:

- How careers, salaries and working conditions can be designed to attract and motivate talented individuals to pursue a career in school education;

- How teaching, leadership and other staff can best be matched to schools and students, and the most effective staff be matched to those that need them the most;

- How professional learning systems can support the continuous growth of school staff and improve teaching and leadership capacity in schools.

Chapter 1 sets the context for this report by conceptualising school staff as a vital resource of today's school education systems. It highlights the positive impact that teachers, school leaders and other staff can have on student learning, and the role of human resource policies in strengthening, recognising and preserving this impact.

From a financial perspective, the importance of school staff is evident in the investments that school systems make in their workforce. Given the labour-intensive nature of school education, spending on staff constitutes the largest expenditure item in any OECD country. Human resource policies that influence who school staff are and what they do can have a substantial impact on education spending and involve investment trade-offs that should be informed by the best possible evidence of effectiveness as well as an analysis of the particular context in which they take place.

\section{Raising the attractiveness of a career in schools}

Chapter 2 describes policies that can help countries attract talented individuals to a career in school education and sustain their motivation over time. Attracting motivated individuals to work in schools is a pressing concern in many OECD countries, particularly those with rising student enrolments or a large share of staff approaching retirement age.

Individuals choose a career in school education for a wide range of reasons and the factors that matter for their entry into the profession may not be the same that convince them to remain on the job in the long run. Evidence suggests that extrinsic factors are of secondary importance for those who have chosen to enter and remain in their profession. Nevertheless, the attractiveness of school careers, salaries and working conditions compared to those of alternative occupations does affect the propensity of young people to undergo initial teacher preparation and stay in the profession during their first years.

In addition, failing to provide supportive employment conditions for staff in schools is likely to have detrimental effects on their well-being, and ultimately, their willingness to 
remain in the profession and their capacity to provide high quality learning environments for their students.

This chapter analyses policy alternatives to help school systems i) design career structures with opportunities for professional growth and specialisation, ii) establish salary scales to attract new entrants and retain experienced staff and iii) provide supportive working conditions, working time arrangements and task profiles to sustain staff motivation over time.

\section{Distributing teachers, school leaders and other school staff effectively}

Chapter 3 discusses policies to support the effective and equitable staffing of schools. All schools need competent teachers, leaders and other staff to ensure high-quality instruction, leadership, administration and ancillary services. But schools vary in their geographical location, internal organisation and student population and therefore require a different staffing mix (e.g. in terms of type and numbers), to support student learning and development in their particular context.

Many countries have difficulties in matching supply and demand for teachers and school leaders. Even where school systems manage to attract a sufficient number of high-quality candidates for recruitment in the school sector, they typically still face shortages and/or oversupply of candidates to fill positions in particular schools, depending on their geographical location, socio-economic context and specific subject areas on offer.

Inequities in the distribution of staff across schools in different socio-economic circumstances are particularly problematic in many countries. Even within schools, the least experienced teachers may be assigned to the students who face the greatest difficulties.

This chapter provides a set of policy alternatives to support an effective and equitable distribution of staff between and within schools. Beyond systematic forecasting of supply and demand, this requires i) transparent, stable and equitable staff funding mechanisms, ii) effective and fair recruitment processes and iii) efforts to attract professionals to where they can have the biggest impact.

\section{Promoting powerful professional learning for school staff}

Chapter 4 documents the importance of moving beyond simplified models for staff development towards an evolutionary process comprising initial preparation and continuing professional learning. Creating a professional learning environment in which teachers and leaders feel individually and collectively supported is essential to unleash their potential to realise the transformative impacts of highly effective teaching and leadership.

This begins by preparing cohorts of teachers and school leaders who are ready for the particular context in which they will work and providing them with rigorous, applied preparation programmes that require demonstration of in-classroom teaching or in-school leadership skills. It continues through the early years of new teaching and leadership roles through a successful induction and mentorship programme that promotes rapid learning and skill development in the setting where staff will do the work - schools.

But professional learning does not end after the initial years in a new position. Schools must increasingly embrace processes that structure the school as a place where professional learning is an ongoing part of the day-to-day work of the organisation, where school staff work collaboratively to help each other learn, where systems exist to capture and codify 
knowledge, and where explicit supports exist to develop leadership capacity among all adults. Where professional learning emerges from evaluation, systems should be designed to ensure that evaluation accomplishes its growth-oriented intent.

This chapter proposes policy alternatives to i) bring strategy and process improvements to initial teacher preparation, from initial education to induction, ii) conceive professional learning as part of larger continuous adult learning and improvement processes in schools and iii) mobilise the potential of evaluation to serve as a formative developmental tool for teachers and school leaders. 



\section{Six policy approaches to support effective working environments in schools}

\section{Teachers, school leaders and other school staff matter educationally and financially}

The staff working in schools are probably the most important resource for today's education systems - both educationally and financially. There is a solid evidence base indicating that teachers are key in improving learning opportunities for students, likely more than anyone else in children's lives outside their families (Kraft, 2019 [1] ; Jackson, 2018 ${ }_{[2]}$; Chetty, Friedman and Rockoff, 2014 $4_{[3]}$; Rivkin, Hanushek and Kain, 2005 $5_{[4]}$ ).

School leaders, in turn, play a pivotal role in raising school quality and creating the environments in which teachers continuously improve their competencies to support student learning (Branch, Hanushek and Rivkin, 2012 [5]; Coelli and Green, 2012 [6]; Pont, Nusche and Moorman, 2008 $[7])$. Beyond teachers and school leaders, there are many other types of staff whose contribution to the holistic learning of students and the overall improvement of schools is increasingly recognised across OECD school systems (Masdeu Navarro, 2015 $[8]$ ).

From a financial perspective, the importance of teachers and other school staff is reflected in the investments that school systems make in their human resources. Spending on staff constitutes the largest expenditure item in any OECD education budget. However, countries apportion vastly different levels of resources to staff salaries, ranging from less than $65 \%$ to more than $85 \%$ of their operating budgets (OECD, 2019 $\left.9_{[9]}\right)$.

While the level of teachers' salaries remains the most important source of variation between countries, other factors also shape overall expenditure levels. For example, choices to provide or require smaller class sizes, longer teacher working hours or less instructional time per teacher all increase the number of teachers required and raise per student spending. Decisions about employment conditions, the staff mix in schools and the types of professional learning offered also influence spending patterns.

The related resource trade-offs, as well as many others discussed in this report, represent important policy choices that should be informed by an analysis of national and local contexts and the best possible evidence of effectiveness.

\section{The importance of human resource policies}

Effective human resource policies for schools can contribute to strengthening, recognising and preserving the positive impact that school staff have on students by creating supportive working environments in schools. At the same time, they can optimise the use of available funds for school education by matching staff resources to school needs and making informed choices about investments in career pathways, salary structures, working conditions and professional learning opportunities. 
By human resource policies, this report broadly refers to the regulations and principles of action that shape who school staff are and what they do, through their direct influence on careers, staff distribution and professional learning. The OECD School Resources Review identified a set of common challenges in the design and implementation of human resource policies that emerged in some form or another in all participating countries. Most prominently, these included the following:

- Careers, salaries and working conditions remain unattractive and act as a barrier for talented individuals to pursue a career in teaching or school leadership.

- The most effective and experienced teacher and leadership staff are often not matched to the schools and students that need them the most.

- Traditional professional development systems often fall short of supporting continuous growth for those supporting learning in schools.

Based on the experience of the countries participating in the OECD review, this chapter provides a set of six policy approaches that may help countries address these challenges. While the report highlights the need to consider all adults who work in schools and contribute to their effectiveness, the systematic analysis of these policies focuses on teachers and school leaders due to the limited availability of information on other staff.

It is important to keep in mind that human resource policies are shaped by national, local and school contexts and that initiatives that work well in one context are not necessarily transferable. Nonetheless, the experiences of different countries can help distil useful ideas and lessons learned from systems that have sought for better ways to support the individual and collective impact that school staff can have on students' learning and well-being.

\section{Policy 1: Designing career structures with opportunities for professional growth}

The traditional teaching career has often been described as "flat" and providing few opportunities for advancement or diversification. It is therefore possible for many teachers to have the same set of responsibilities from the first to the last day of their career. In such contexts, the only way for motivated teachers to grow in their careers may be to leave the classroom and take up roles in school leadership or the education administration. This can be to the detriment of student learning since it risks depriving them of their most effective teachers. In addition, the competencies required for school leadership are quite different and there is no guarantee that the best teachers will make for the most effective leaders.

Well-designed career structures have the potential to enhance the effective deployment of staff and their knowledge and skills in schools. They provide a means to recognise good performance, match individuals to responsibilities that fit their skills and interests, and increase long-term motivation and retention (Crehan, 2016 $[10]$; Natale et al., 2013 ${ }_{[11]}$ ). Teachers' careers can offer both vertical and horizontal opportunities for professional growth. Along the vertical dimension, teachers' careers may take the form of a ladder, structured around a succession of formal positions or roles with distinct task profiles and progressively increasing responsibility within the classroom. Along the horizontal dimension, career structures may provide teachers with opportunities to focus on and assume responsibilities in a specific area of expertise inside or outside the classroom, often involving specialisation in a particular aspect of the teaching profession.

In some countries, teachers have very limited room for vertical career advancement but opportunities for horizontal specialisation may offer ways for them to develop their skills in a particular area. Other systems have successfully combined both vertical and horizontal 
career pathways. Such "career lattice structures" allow teachers to specialise in a particular role through horizontal diversification and advance their career in this role through vertical progression. For example they may offer a number of parallel (horizontal) streams - e.g. a teaching track, a leadership track, and a curriculum design track, each comprising several stages of (vertical) career advancement. Singapore's career structure provides one such example (see Chapter 2).

The majority of OECD review countries do not provide a separate career track for school leadership roles and either treat them as the final stage of the teaching career or a mere extension of the teachers' role that they can assume alongside their teaching duties. While a deep understanding of effective teaching is key for a pedagogical leadership role, other competencies are also essential for school leadership. Acknowledging the distinct responsibilities of leadership positions in schools by providing them with a dedicated career structure can help in communicating the importance of leadership roles while raising their status and attractiveness to potential candidates.

Similarly to teachers, school leaders typically have few opportunities for promotion and specialisation, except by applying for positions outside of schools (e.g. in the local education administration). In addition, some countries rely on fixed-term contracts or a maximum service time for school leaders. While renewable contracts provide the opportunity to periodically reassess and acknowledge principals' performance, uncertainty about employment opportunities beyond a given contract can be a significant source of stress and make leadership roles less attractive.

However, a number of OECD countries have developed multi-stage career structures for school leadership. Such structures can extend both ways from the principal's role and include formal middle leadership positions as well as so-called "system leadership" positions extending beyond principal-ship in a single school. Middle leadership positions can provide teachers with an opportunity to test out and prepare for school leadership. At the same time, they allow schools to distribute leadership responsibilities across several individuals and create a pipeline for future school leaders. At the other end of the career ladder, system leadership roles can harness the capacity of experienced leaders to contribute to system-wide improvement by preserving and spreading good practice, for example as cluster leader or in improvement partnerships with other schools (Hopkins, Nusche and Pont, 2008 $[12])$.

Reforming career structures in schools can pose a series of implementation challenges when it comes to ensuring sufficient resources, building political consensus, and creating broad ownership of the new system. The introduction of new formal positions which are associated with additional responsibilities and remuneration can create uncertainty among teachers and be perceived as threatening the profession's egalitarian norms, especially where the profession had previously operated on the basis of a single-stage career structure. A lack of clarity around what new roles would entail and how to move into them, concerns that the reform would create divisions among teachers, or its perceived association with other changes to teachers' working conditions can contribute to the failure of career structure reforms. Involving stakeholders from the outset in the design of new career structures and clearly communicating the goals of reform is therefore critical to build support for reform plans and avoid unintended consequences.

Reforming career standards also requires the careful management of the transition process. When determining the standards for teachers' initial assignment to a career stage and for their subsequent promotion, mistakes can be made in both directions. Setting the bar too low can diminish the career structure's credibility and have significant fiscal consequences 
if too many teachers are promoted. Likewise, setting the bar too high may lead to frustration and reduce the career structure's motivating effect. Some of these risks can be minimised by carefully piloting the assignment system and adjusting its standards accordingly to ensure that expectations are high, but realistic. The link between career steps and teachers' salaries is another challenge in the design and implementation of teachers' career structures. Since most career structures are linked to compensation, projecting the new career structure's long-term resource needs is critical to ensure its fiscal sustainability.

\section{Policy 2: Establishing salary scales that attract new entrants and reward growing expertise}

According to OECD estimates, teachers' salaries are lower than those of similarly educated workers in almost all countries with available information, although they tend to increase with the level of education $\left(\mathrm{OECD}, 2019_{[9]}\right)$. Teacher shortages are often concentrated in specific subject areas and many schools have difficulty in recruiting teachers with mathematics or science qualifications or technical skills who could command higher salaries in the general labour market. Policy makers and academics have therefore considered differentiating teachers' salaries based on their training or subject areas to reflect their opportunity costs of pursuing a teaching career (Kershaw and McKean, $\left.1962_{[13]}\right)$. However, in most systems, the principle of uniform salary scales has imposed limits on subject-based pay differentiation.

For school leadership positions, salaries need to be attractive not only compared to positions with similar levels of responsibility in the public and private sectors, but also compared to senior teachers among whom most school leaders are recruited. While maximum salaries for school leaders typically exceed those of teachers, the salary ranges for teachers and leaders overlap in nearly all systems. In a number of countries, this means that school leaders' salaries may be inferior to those of their senior teachers. Establishing separate salary scales for school leadership roles, including principals and deputy principals, can provide a good basis to recognise their distinct responsibilities both financially and through the articulation of a separate career ladder.

Comparatively low salaries are frequently regarded as one of the factors contributing to shortages of qualified candidates for school-level positions. Data from the OECD Programme for International Student Assessment (PISA) 2015 confirm that 15-year-old students in OECD countries with higher teacher salaries are more likely to expect entering a teaching career $\left(\mathrm{OECD}, 2018_{[14]}\right)$. Very low salaries for teacher and school leaders can impede a system's ability to attract high-quality individuals, alongside a range of detrimental consequences for staff, including low levels of motivation and the accumulation of excessive working hours or multiple jobs to make up for low compensation (Santiago et al., 2016[15]; Santiago et al., 2016 $[16]$; Shewbridge et al., 2016 ${ }_{[17]}$ ).

While compensation and benefits are important policy levers to influence the extrinsic motivation of individuals to pursue a career in the school sector, there is no one-size-fits-all solution to the design of effective salary scales. Instead, policy makers must consider the specific challenges of their system and the characteristics of their local labour markets. For example, broader economic developments, such as the level of private sector wages or unemployment rates need to be taken into account when reflecting on whether and up to which point higher starting salaries can be an effective means to attract high-performing candidates into teaching. 
To understand the relative attractiveness of salaries for school staff, it is important to consider not only lifetime earnings, but also how compensation is distributed over the course of a career. Many OECD school systems face the dual challenge of providing competitive starting salaries to attract high-calibre entrants to the teaching profession while also seeking to retain, motivate and recognise experienced, high-quality teachers through salary increases. Countries may therefore face a trade-off between the benefits of higher starting salaries and greater pay rises over the course of the career.

Compressing the salary scale can free up resources to increase starting salaries at the expense of salaries for more experienced staff and thereby attract more students to teaching and reduce turnover in the early years of teachers' careers. Austria's 2015 teacher service code provides an example of a reform towards a more compressed salary scale (see Chapter 2). On the other hand, increasing the rate at which salaries rise over the course of a teacher's career can create space to provide higher salaries at the top end of the scale. Such scales may serve to retain and motivate more experienced staff or offer a wider scope for salary differentiation among teachers.

In addition to linking salaries to seniority, many systems seek to incentivise continuous improvement by differentiating compensation based on teachers' and leaders' education and training, responsibilities or performance.

In many OECD countries, teachers receive some form of compensation for attaining further formal qualifications (e.g. degrees that exceed the countries' minimum requirements or qualifications in additional subjects). In some systems, teachers also receive financial rewards for the successful completion of continuing professional development (CPD) activities (OECD, 2019 $\left.{ }_{[9]}\right)$. Such education-based differentiation in teachers' salaries can serve as an incentive for teachers to update and enhance their skills throughout their career. One of the concerns around linking course credits directly to financial rewards is that teachers' participation might become disconnected from their professional improvement. The Slovak Republic has sought to address this through a requirement for schools to establish regulations which specify the conditions under which salary rises linked to professional development credits are approved (see Chapter 2).

Many countries recognise and financially reward teachers who fulfil tasks or specialise in particular roles that go beyond the official requirements of their jobs, for example supporting new teachers as part of mentorship and induction programmes, leading extracurricular activities or taking over managerial roles such as serving as the head of a department (OECD, 2019[9]). The financial compensation of additional tasks and responsibilities can provide recognition for teachers' efforts on relatively objective grounds and incentivise contributions that benefit the school community as a whole. At the same time, task-based rewards offer no direct recognition of or incentives for improvements in teaching quality (Conley and Odden, 1995 $[18]$ ).

Other forms of differentiated pay have aimed to more explicitly link teacher pay to their assessed effectiveness in supporting student learning. In theory, performance-based compensation is meant to motivate teachers to improve their practice and raise students' achievement by rewarding effective teaching. However, research from different contexts has shown the difficulty of measuring performance at the level of individual teachers and the potential perverse effects of doing so, such as narrowing the curriculum or reducing teachers' efforts on tasks not explicitly rewarded by the programme (Ballou and Springer,

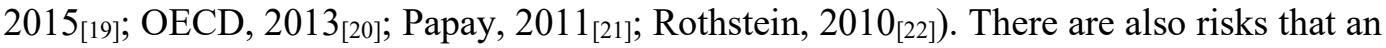
excessive reliance on extrinsic incentives undermines teachers' intrinsic motivation and negatively impacts on collegial relationships (Bénabou and Tirole, 2003 ${ }_{[23]}$; Frey, $1997_{[24]}$ ). 
Some countries have introduced incentive structures based on collective rather than individual performance, with the hope that they might encourage collaboration and collective improvement. Such incentives may exist for schools as a whole as is the case in Colombia and/or for school leadership teams as in Chile (see Chapter 2). Research finds that the larger the groups on which collective performance rewards are based, the weaker the incentives they provide for individual behavioural change. Consistent with this, their impact on student achievement has tended to be relatively small in the few existing robust evaluations (Jackson, Rockoff and Staiger, 2014 [25]; Goodman and Turner, 2013 [26]).

As discussed above, linking salaries to career advancement creates a more indirect link between teachers' growing expertise and their compensation and can address some of the challenges associated with conventional performance pay. First, this can combine extrinsic rewards for high performance (in the form of salary increases) with intrinsic rewards in the form of professional opportunities and responsibilities that grow in line with their knowledge and skills. Second, this offers both beginning and experienced teachers realistic goals based on their current position on the career ladder and a clear pathway to achieve them. Implementing such systems may require countries to further develop and integrate their teaching standards, appraisal systems, career structures and salary scales.

While absolute and relative salary levels are an important factor shaping the financial attractiveness of a career in schools, other aspects associated with remuneration should also be taken into account when assessing their competitiveness. In many OECD review countries, for example, teachers and leaders are civil servants and have a high level of job security or access to benefits like pension programmes, tax exemptions, family allowances and annual leave entitlements that workers in comparable private sector positions do not. The competitiveness of their salaries should therefore be assessed against a relevant comparison group, bearing in mind both financial and non-financial benefits.

Reforming salaries in education can pose significant implementation challenges. Compensation reforms will involve a degree of uncertainty about the size and distribution of their benefits and are likely to cause resistance among those who fear to lose out, whether in absolute or relative terms. Engaging in an open dialogue with stakeholders and involving them in reform and implementation processes are key principles of effective governance. This includes the relevant unions representing teachers in different sectors and at different levels of administration. To build and sustain trust for the implementation of reforms, they must be underpinned by clear communication, consensus building among the various stakeholders, and a process for prioritising competing claims on resources. Failing to effectively engage stakeholders in the design of compensation reforms can come at a high cost and some OECD review countries have had to delay or abandon their projects in the face of stakeholders' resistance (Liebowitz et al., 2018 ${ }_{\text {[27] }}$ ).

The experience of OECD review countries also highlights the importance of anticipating the costs and challenges involved in compensation reforms. For example, although adjusting the slope of salary scales and shifting resources towards their lower or upper end can be budget neutral in theory, fiscal consequences are often hard to predict and reforms may involve significant transition costs over the course of their implementation (Nusche et al., 2016 $[28]$ ). Policy makers also need to bear in mind the inertia of reform processes and the significant amount of time that it can take for a change in teachers' compensation systems to reach all or even just a majority of the profession. 


\section{Policy 3: Reviewing the staff mix and working time arrangements in schools}

The pressures faced by teachers and school leaders in their daily work are well documented, as are the prevalence and harmful impact of stress, exhaustion and burnout in schools. Teachers' work is highly complex and involves a great variety of responsibilities and activities that compete for their time during the school day and week. In addition to regular classroom instruction, teachers are usually expected, among other things, to spend time preparing their lessons, correcting students' work, collaborating with their peers, counselling students, communicating with parents, engaging in professional learning and whole-school development.

In some countries, the OECD review teams also observed that teachers had to assume a significant share of administrative and secretarial tasks (sometimes in return for a reduced teaching load), due to a lack of sufficient support (Nusche et al., 2016 $6_{[28]}$ ). This not only reduces the time that teachers can spend on improving instruction, but it is also inefficient given that teachers' time tends to be more highly remunerated than that of administrative staff. In addition, the distribution of administrative tasks among teachers has been a cause for concern in some OECD review countries since beginning teachers have been reported to be disproportionately burdened with these duties (Nusche et al., 2016 $6_{[28]}$ ).

Surprisingly, across countries, there is no statistically significant association between the average proportion of teachers' working time devoted to general administrative tasks and the average number of administrative or managerial staff employed by their schools. Some of the systems with the highest number of support staff are also those whose teachers devote the largest share of their working time to administrative tasks. At the same time, teachers in some other countries perform little administrative work despite a low number of support staff. This indicates that the employment of additional support staff might neither be sufficient nor necessary to ease teachers' administrative burden. Technological solutions can certainly play a role in alleviating some of the challenges associated with administrative overload, as can reduced bureaucracy and effective reporting systems.

In many OECD school systems, service codes and other statutes that regulate how teachers spend their time are based on a narrow conception of the profession (Nusche et al., 2015 [29]; Santiago et al., 2016 ${ }_{[15]}$ ). They primarily regulate teaching hours, (i.e. the time teachers are expected to spend on classroom instruction) while only vaguely defining non-teaching time. Such teaching load systems fail to provide any formal recognition for the important work that teachers perform outside of the classroom and make it more difficult for school leaders to plan staff time based on a holistic conception of their tasks. As a consequence, teachers may work excessive hours or not find enough time to pursue important non-teaching tasks.

To address these challenges, all factors contributing to teachers' workload - including their non-teaching obligations - should be taken into account when determining their teaching and working hours. Reflecting the time teachers are expected to commit to non-instruction tasks in service codes and working regulations is an important step to bring regulations more closely in line with the reality of teachers' work in schools. Estonia provides an example for a country shifting from a teaching load towards a workload system (see Chapter 2).

Arguably, school leaders face even greater challenges than teachers in allocating their time among tasks associated with organisational management and pedagogical leadership. In addition to the various dimensions of their leadership role, some principals also have substantial teaching duties. But even where they can dedicate themselves exclusively to 
leadership there is considerable disagreement over the kinds of activities that effective school leaders should prioritise. Studies drawing on time-use data find that some forms of pedagogical leadership are more effective than others. The time principals spend on teacher coaching, evaluation, and developing the school's educational programme, for example, seems associated with achievement gains, while time spent on informal classroom walkthroughs appears to be less effective, particularly if they are not integrated in the schools' broader improvement strategy (Grissom, Loeb and Master, 2013 [30] $)$.

Considering the intense demands placed on school leaders' schedules, their effectiveness depends on an ability to prioritise and manage their time efficiently, which may include identifying priorities, remaining organised, setting achievable goals and monitoring one's progress towards them. Considering that time-management skills are comparatively easy to impart, offering training to principals could therefore be a means to increase their time spent on high-priority tasks and reduce stress. But a precondition for this is to build a shared understanding of priorities for principals to spend their time on, for example through a set of leadership standards, jointly developed with the profession.

Another consideration is to shift some responsibilities for school management, professional evaluation and pedagogical leadership to permit those responsible for each task to be able to do so effectively. This might take various forms, such as specific school-based leadership functions responsible for operations, administration or student behaviour management to unload these tasks from the instructional school leader. Depending on their size, schools in Kazakhstan, for example, employ school leadership teams dividing responsibilities for overall leadership, academic, educational and economic affairs (see Chapter 3). As discussed above, establishing roles for teachers to take on leadership tasks mobilises their growing expertise while at the same time providing attractive opportunities for professional growth within the teaching career. Alternatively or in addition, school systems might assign additional school leaders to each school, with the potential for schools to decide how to divide up responsibilities based on their particular needs and available staff and their skills.

Decisions about the right staff mix in schools involve significant resource trade-offs and should be informed by evidence that is relevant for particular contexts. Such choices also require a shared understanding among key stakeholders about the types of tasks and responsibilities that are expected of teachers and school leaders and the roles they may take on as they develop in their career. Carefully designed task profiles or professional standards can play a key role in clarifying and reaching agreement about expected roles and responsibilities among various stakeholders in a system.

Needs-assessment studies are one tool to help determine the staffing needs of schools and inform future resource allocations. Such studies would examine what roles are currently performed by staff, how their time is spent, what needs schools have and which types of staff would help fulfil related responsibilities. As part of such a needs assessment, it would be valuable to explore the extent to which identified needs could be addressed by investing in increased training for all school staff, including teachers. In some cases, such investments may be a more efficient and effective use of resources than the employment of additional untrained support staff. In other cases, identified needs may require the employment of additional staff and changes to the staffing mix. Where staff can be employed to relieve teachers or school leaders by responding to less complex school needs (e.g. procurement or student discipline), a change in staffing may secure potential savings.

The governance and funding of different types of staff, including teacher and school leadership positions, will shape the staffing mix in school systems. In decentralised systems, regulations and funding allocations provide potential steering mechanisms, for 
instance in the form of minimum staffing ratios or targeted funding (see Chile and New Zealand for targeted funding initiatives in Chapter 3). Horizontal and bottom-up accountability (e.g. through school boards) can help ensure an effective use of resources for school staffing $\left(\mathrm{OECD}, 2017_{[31]}\right)$. Where responsibilities for the employment and funding of different types of staff are split, collaboration will be essential to manage the effective staffing of schools and related trade-offs. This includes relevant authorities outside of the school sector which may provide essential professional support services.

The effective provision of staff also depends on the effective organisation of the school network (OECD, 2018[32]). Where feasible, the sharing of specialised staff across a number of schools may help ensure a broad provision of related services, although it may involve trade-offs in the level of involvement and collaboration that can be expected of staff in individual schools. Where the organisation of school education changes (e.g. the organisation of the school day and learning time), governance and funding arrangements for different types of staff often need to be reviewed, as does the preparation and training of different types of staff and the creation of new staff roles.

\section{Policy 4: Ensuring an effective and equitable distribution of school staff}

Identifying high-potential graduates at the point of hiring is an important challenge for any recruitment process. In the school sector, evidence indicates that most externally observable teacher characteristics are weak predictors of actual teacher performance in the classroom (Rockoff et al., 2011 [33]; Boyd et al., 2008 ${ }_{[34]}$ ). In addition, teachers who are effective in improving students' cognitive skills may not necessarily be equally effective in supporting students in developing their non-cognitive skills, such as resilience, growth mindset, self-efficacy and behaviour in class (Gershenson, 2016 $6_{[35]}$ ). Therefore a broad range of competences, including affective and motivational skills, should be taken into account in hiring processes.

School systems vary in the extent to which their schools are autonomous in recruiting their own staff. Experience from different countries indicates that school involvement in staffing decisions can help avoid misallocations and frustrations for both schools and teachers, facilitate the matching of staff profiles to the needs of particular schools and contribute to greater job satisfaction by allowing applicants to choose their workplace and build a sense of commitment to a particular school (Nusche et al., 2015 [29]; Shewbridge et al., 2016 [17]). At the same time, there are concerns that school autonomy in recruitment may lead to greater disparities in staff qualifications and experiences among schools, with more advantaged schools being able to attract better candidates. There are also variations among schools in the extent to which they have the capacity, time, expertise and resources to effectively manage all aspects of selection and recruitment processes (DeArmond, Gross and Goldhaber, 2010 [36]; Liu and Johnson, 2006 [37])

International data suggest that inequities in the distribution of teachers can be observed both in systems with higher-level teacher recruitment and those with school-based teacher recruitment $\left(\mathrm{OECD}, 2018_{[14]}\right)$. This indicates that an effective distribution of teachers depends not only on the level of decision making on recruitment but also on recruitment processes, incentives and teacher preferences. Transparency, trust and fairness in the recruitment process are important considerations to attract and select the best candidates (Finan, Olken and Pande, $2015_{[38]}$ ). It is therefore essential to build adequate capacity to ensure screening and selection processes are well managed. Transparent and timely information systems, and requirements to advertise vacancies as widely as possible should also be in place. 
Particular potential seems to lie in ensuring that schools and the education administration work together to build effective teacher recruitment systems. Some countries, such as states in Germany, have mixed systems in place, which allow schools to have a say in their recruitment while some of the logistical and administrative demands are handled at a higher level. In such a system, education authorities can also support particular schools that have difficulty recruiting sufficient or high-quality staff. Schools may be allowed to express their preferences over a given number of centrally-ranked candidates, be involved in the selection process, or recruit a certain share of their teaching force locally. Student teacher placements as part of initial education are another route for schools to identify and hire teachers whose profiles match their needs.

Inequities in the distribution of staff across schools in different socio-economic circumstances are problematic in many countries. Data from PISA show that teachers in the most disadvantaged schools are less qualified or experienced than those in the most advantaged schools in more than a third of the participating school systems (OECD, $\left.2018_{[14]}\right)$. There is less evidence on inequities in the distribution of leadership staff, but some studies suggest that principals may sort into schools along similar patterns so that those with less experience and qualifications typically work in more challenging contexts (Loeb, Kalogrides and Horng, 2010[39]).

The distribution of staff across schools crucially depends on the preferences and choices of individual teachers and school leaders, as well as on the selection and transfer regulations and financial incentives in place. In systems with central teacher allocations, teachers with the highest rank may be allowed to choose their school. In decentralised systems, schools or local authorities may have to safeguard statutory rights of teachers, such as giving preference to teachers with a permanent contract or with greater seniority.

Together with teachers' preferences for working in particular schools, seniority-based systems often channel beginning teachers to schools that are considered more difficult. As new teachers often struggle with classroom realities before adapting and improving their practice (Jensen et al., 2012 $[40]$ ), this may reduce their sense of efficacy and make them more likely to move to another school or to leave teaching altogether.

Research on teacher preferences also suggests that teachers typically prefer to work close to their homes, families and friends, even when they gain their initial teaching qualification elsewhere (Engel and Cannata, 2015 $5_{[41]}$; Boyd et al., 2005 [42]). This suggests that teacher labour markets are geographically relatively small and the pool of prospective teachers available to work in a given school is likely limited. In specific areas facing teacher shortages, "Grow your own" strategies can therefore play an essential role for meeting the demand for teachers (see Colombia and Mexico for the role of teacher education in rural areas in Chapter 3) (Echazarra and Radinger, 2019 [43]; Sipple and Brent, 2015 [44] $_{\text {). }}$.

Some school systems have introduced financial incentives for teachers to work in areas of need, such as higher salaries in schools enrolling large proportions of students from disadvantaged backgrounds, differential pay for particular expertise, or scholarships and subsidies for working in disadvantaged schools. In some contexts, monetary incentives have shown promising results to distribute teachers where they are needed the most. But such policies will work differently depending on the design and size of the incentives and the general framework for teacher employment and career progression. Financial incentive schemes therefore require adequate evaluation and monitoring. For example, in some contexts, financial incentives have been shown to be effective in attracting teachers to rural schools, but less so to remote schools (Pugatch and Schroeder, 2014 ${ }_{[45]}$ ). 
Of course, non-financial incentives also matter. For example, recognising experience in difficult or remote schools for staff career development is a further option. Research shows that most teachers are highly motivated by the intrinsic benefits of teaching, namely working with children and young people and helping them develop and learn (OECD, $\left.2019_{[46]}\right)$. Professional factors, such as opportunities to take on extra responsibilities and to engage in research and innovation, then also need to be taken into account as do working conditions, such as preparation time, leadership, collegiality, accountability demands, class size or facilities. Hence, it is equally important to ensure that all schools, and especially those in challenging circumstances, provide attractive conditions for staff to work in.

\section{Policy 5: Adopting a broad vision of initial preparation for teaching and school leadership}

Initial preparation can be conceived of as a continuum that comprises initial or pre-service education, but also support for staff during their first years on the job, be it through formal or informal induction or mentoring. Initial teacher and leader preparation should thus provide beginning school staff with a coherent learning experience across coursework, practical training, induction and early career development (OECD, 2019 $\left.{ }_{[47]}\right)$.

Designing initial preparation so it presents a continuum requires a vision of teachers and school leaders as continuous learners. It also firmly broadens the range of actors involved in initial preparation. While most student teachers, teacher educators and researchers belong to the tertiary education system, most teacher mentors, school leaders and policy makers operate in the school system. Positive feedback loops can then play an important role in driving change as can cross-institutional and multilevel partnerships to build a coherent initial preparation system that engages different stakeholders.

Schools often have little say over the design of initial education programmes, whereas initial education institutions often have little say over the design of school induction programmes and other support schemes provided to beginning teachers or leaders. A coherent approach to initial preparation would involve collaboration between both to provide an authentic and reflective practical training and induction experience for new staff. Strong partnerships would go beyond regular discussions between schools and tertiary institutions on operational issues such as practical training placements, and also include the joint design, evaluation and improvement of programmes. This also requires dedicated time, sustainable funding, and professional responsibility, agency and trust.

Higher education institutions should consider partnering with local school networks to identify the particular challenges specific to their communities that early career teachers face and then design their curriculum in response. Ensuring that practicing teachers who serve as co-operating or supervising mentors have a say in the design of curricula will be critical to both tailor learning for prospective teachers and provide leadership and growth opportunities for expert practitioners. The Netherlands present an example for an innovative partnership between initial education and networks of schools (see Chapter 4).

In many OECD countries, initial preparation is unduly focussed on disciplinary knowledge at the expense of opportunities to practice pedagogical skill. Sizeable proportions of teachers in some countries report completing their initial education feeling unprepared for the realities of the classroom (OECD, 2019 $\left.9_{[46]}\right)$. While in almost all OECD review countries the education of prospective teachers entails some requirement for practical experience in school, expectations for pre-service school-based hours of practice vary widely across and sometimes within countries. 
Where prospective teachers have limited opportunities for practical experience they lose opportunities to practice instructional skills in settings in which they will have to later apply them. A rich body of literature suggests this may leave them unprepared to transfer learning from the higher education classroom to the primary and secondary context (Feuer et al., $2013_{[48]}$; O'Neill and Stephenson, 2012 ${ }_{[49]}$ ). These challenges of transferring academic skills to school realities are also relevant for other types of school staff. For instance, school social workers in many contexts would also benefit from more practical applications in their training (Finigan-Carr and Shaia, 2018 [50]).

Similarly, for school leadership, there is widespread recognition that new leaders are typically insufficiently prepared for the realities of leading a school. While some systems have more or less extensive pre-service school leadership preparation approaches, others have no set requirements for preparation beyond a teaching qualification. Still others only require training within a fixed amount of time once appointed to remain in the position. Clear and consistent expectations for initial preparation that combine instructional, management and operational skill development, both theoretically and in practice, are critical to improve school leader development. The French Community of Belgium has recently sought to strengthen its school leader preparation through an increase in training hours (see Chapter 4).

Ensuring practical experience of high quality is essential for all prospective teachers and school leaders. For example, simply placing student teachers in classrooms with poor models for instruction, weak guidance and supervision will not yield better prepared novice teachers. Education authorities may set requirements regarding the qualifications of staff hosting prospective educators, oversee quality through external screening bodies and/or identify and support particular schools and mentors in these schools to provide a suitable learning environment. From a resource perspective, shifting credits away from higher education course settings to practicum or internship experiences will require some readjustments. Higher education institutions may find that they will need to prioritise hiring more practitioner instructors rather than academic researchers.

Models of clinical practice in education, based on the medical residency system, can bring research-based understanding of teaching and learning into dialogue with the professional understanding of experienced teachers (see Chapter 4 for examples). These residencies invert the learning model so that the majority of candidate teachers' and leaders' time is spent in school. They integrate aspects of traditional university classroom preparation with the on-the-job learning of alternative pathways into an immersive learning experience. Urban teacher residencies in the United States have been evaluated, with most studies revealing improved retention outcomes for teachers entering the profession through these residencies and potential learning gains for students of teachers prepared through the residency pathway (Guha, Hyler and Darling-Hammond, 2016 [51]; Papay et al., 2012 [52]).

The transition from initial education to classroom teaching is a critical stage in preparing teachers and helping them to be effective in the classroom. Many teachers report significant struggles early in their careers related to classroom management and understanding school social systems (Schuck et al., 2017 $7_{[53]}$ ). Evidence suggests lower levels of productivity in terms of student learning outcomes early in teachers' and school leaders' careers (Papay and Kraft, 2015 $\left.5_{[4]}\right)$. At the same time, early career professionals bring with them enthusiasm and recent training that can be potentially valuable for schools to innovate and for team learning among staff.

A number of countries have made efforts to promote induction for teachers so they are successful in launching their career and joining the profession (see examples from Austria, 
Chile and Estonia in Chapter 4). Such programmes often seek to bridge the gap between theory and practice, address workload challenges, provide strategies in classroom management and understanding the school culture. Intensive teacher coaching focussed on improving classroom practice has been demonstrated across multiple contexts to improve teaching practice and student achievement outcomes (Kraft and Blazar, 2016 [55]; Campbell and Malkus, 2011 $\left.1_{[56]}\right)$. Reviews of traditional mentoring programmes, focussed more on providing general advice rather than responding directly to observed classroom practice, have found more mixed effects (Ingersoll and Strong, 2011 ${ }_{[57]}$ ).

Common challenges in developing effective induction include a lack of alignment between initial preparation and induction curricula and obstacles to connecting induction with continuing professional learning. Quality induction processes also need to consider implementation challenges. The cost of effective induction programmes can be high, as teaching load reductions, programme curricula and regular training for participants and mentors or coaches will need to be funded. Thus, school systems considering to invest in induction programmes must carefully estimate the relative costs and expected benefits of each policy option to determine their value. School systems will need to find efficiencies or make trade-offs with other resources, such as class size, to invest in this resource.

\section{Policy 6: Supporting continuing professional learning and collaboration}

Professional learning does not end after the initial years in a new position. To be effective, it needs to be considered as a continuous process, contextualised in clear system-wide and school goals, and then schools must redefine themselves as places of continuous learning for both children and adults (Kools and Stoll, 2016 [58]; Opfer and Pedder, 2011 [59]) However, many have expressed concerns regarding the effectiveness of traditional types of professional development, in the form of one-time or short-series externally provided learning courses, and impact evaluations frequently fail to establish a link to improved teaching and learning outcomes (Garet et al., 2016[60]; Harris and Sass, 2011 [61]; Jacob and Lefgren, 2004 $[62])$.

Research points to some features of more effective traditional professional development. These include embedding learning in the already ongoing work of schools, continuing learning over an extended period and a focus on a concrete set of teaching skills (Opfer, $\left.2016_{[63]}\right)$. Promising improvements to traditional course-based forms of professional development include the creation of regional training centres to learn about schools' particular needs and the delivery of locally provided courses corresponding to these needs.

However, formal professional development activities, in the form of university-affiliated courses, centrally or locally provided trainings or online activities are certainly only one component in a coherent professional learning plan. The majority of skills required of teachers are not easily transmitted in a set number of training days. Therefore, regular coaching, mentoring and collaboration opportunities hold particular promise for promoting reflection and practice improvement among teachers. The critical aspect is that such ongoing learning experiences are aligned to school (and potentially system) goals. This ensures that colleagues can work together on their improvement.

Several countries have introduced supports to encourage teachers' participation in different forms of professional learning such as time and leave entitlements. However, there can be challenges in securing substitute teachers to provide coverage permitting teachers to leave their classrooms during this time. One way to address this is for schools to plan specific arrangements for managing the school calendar, such as a number of professional learning 
days on which schools may suspend classes and/or clear arrangements for student teachers or other school staff to substitute for those engaged in professional development.

In most countries, however, substantial time in teachers' schedules exists outside of mandatory teaching hours, which might be refocussed on professional learning. While teachers schedules are clearly taxed with many responsibilities outside of time spent teaching in front of students, ample room exists to restructure grading, administrative and other requirements to provide additional release time opportunities to pursue professional learning. Policy makers should also pay particular attention to school leaders' time availability to lead professional learning, which will likely require restructuring leadership structures in schools.

Research shows it is particularly important for professional learning to make a specific connection to an individual teachers' practice or to a problem within the school (Timperley et al., $2007_{[64]}$ ). Teachers will not improve by understanding theory and evidence alone, but through numerous activities such as observation, demonstration, practice, and feedback (Joyce and Showers, 2002 $[65]$ ). However, in the OECD Teaching and Learning International Survey (TALIS) 2018, a large proportion of educators report never to engage in school-embedded professional development practices like peer-observation or coaching (OECD, 2019, p. 159 and Table I.5.7 $[46]$ ).

Many OECD countries have educator appraisal systems in place that attempt to accomplish the following goals: i) use the evaluation process to provide feedback and stimulate learning for the teacher or leader and ii) use the evaluation process to hold staff accountable for low effort or skill (OECD, 2013 ${ }_{[20]}$; Radinger, 2014 $\left.{ }_{[66]}\right)$. In some school systems, appraisal policy priorities aim at one at the expense of the other. In other systems, appraisal policy attempts to accomplish both aims simultaneously, but struggles to effectively resolve conflicts between the two. While few of the OECD review countries emphasise the accountability dimensions of teacher appraisal, the appraisal's function as a formative tool to build capacity was often also underdeveloped. Typically, limited structures were in place for tying teacher learning, either in the form of professional development or structured improvement plans, with the outcomes of the appraisal process.

Assigning individualised, structured instructional coaching to teachers, either with designated positions or matching effective teachers with less effective ones, has shown promise in improving students' learning outcomes (Kraft and Blazar, 2016 ${ }_{[55]}$ ). However, there are also indications that the benefits of coaching are substantially reduced in larger coaching programmes serving many teachers at a time. One of the challenges in large-scale programmes is to find high-quality coaches for large numbers of teachers. This challenge is only amplified at the leadership level since far fewer experienced school leaders exist.

Colombia's Let's All Learn programme (Programa Todos a Aprender, PTA) provides an interesting example for a systematic coaching initiative (see Chapter 4). School systems which have no tradition of teacher coaching might begin by recruiting coaching staff to support, perhaps, only early career and struggling teachers. Once awareness of these programmes becomes more widespread, interest in serving in these roles (and willingness to receive support) may grow. School systems that already have pockets of instructional coaching (or similar) roles might consider the use of technology (e.g. video-based coaching) to allow current coaches to have a wider reach. Ongoing monitoring and evaluation have an important role to play in ensuring effectiveness as coaching programmes and initiatives go to scale. 
Ultimately, any system considering bringing coaching programmes to all teachers will face two budgetary options. The first option would be to invest significantly in these dedicated coaching positions, including in efforts to recruit coaches and provide ongoing support for coaches to ensure their coaching remains of high quality. The second option is to integrate coaching responsibilities into the duties of existing classroom teachers who would continue to have teaching as their primary responsibility. They might receive either small periods of non-instructional time or an additional stipend to provide feedback to their colleagues. The second option has the benefit of being less costly and coaches in these roles would have both current teaching experience and credibility. The evident drawbacks is that their attention will be spread thin and the quality of their coaching may suffer as a result.

In addition to using teacher (and other staff) appraisals to inform professional learning at the individual level, results from individual appraisals can be aggregated or whole-school evaluation results can replace them to generate topics for professional development. Understood as such, evaluation-informed professional development can explicitly recognise the ecological context in which teachers and leaders work. Teachers improve most when they work in supportive environments of peers seeking to improve on similar dimensions (Johnson, Kraft and Papay, 2012[67]). Thus, a collective focus to linking appraisal with development holds promise.

Collaboration can help to build up trust and social capital in schools that enables the unlearning of old assumptions and habits, the development of new understandings and practices, and the possibility to solve collective action problems. In addition, collaboration and peer learning are important for making the most of other types of staff who may work in schools (Masdeu Navarro, 2015 $5_{[8]}$ ). Social workers, for example, can support teachers struggling with student behavioural issues (Finigan-Carr and Shaia, 2018[50]).

Collaborative learning communities that entail active and shared discussions can provide safe environments for teachers to challenge tacit assumptions on what works and why. While many schools and systems have traditions of staff meetings (e.g. departmental or grade-level meetings), these are distinct in nature from learning teams. Schools, teachers and leaders can of course benefit from the traditional work of such meetings, but these types of activities tend to change teaching practice minimally.

The work of effective learning teams requires minimally i) regular, dedicated time in working schedules, ii) leadership roles, including for practicing teachers, iii) supports in the form of protocols or defined work processes to ensure work remains focussed on instructional and organisational improvement and iii) a school culture that tolerates and encourages peer-to-peer feedback and innovation.

Such opportunities, particularly defining time in staff schedules, represent significant resource investments. While resource-constrained systems may find it tempting to seek to minimise these expenditures by focussing only on the schedule time, this may ultimately lead to the inefficient reality of increased costs with minimal improvements. Policy makers interested in the potential benefits of school-based learning teams should budget for the relatively smaller supports for team leader capacity development and resources to support the teams' work, such as ongoing professional development, support networks of schools sharing similar learning goals, electronic teaching libraries, or other tools to support adult learning.

To support continuing professional learning at the school and system level, it is important that schools and systems codify the knowledge they gain about which teaching processes are and are not effective. Since causal research designs and evaluations are costly and time 
intensive and require specific competencies, one option may be to collect insights across multiple staff on the effectiveness of particular teaching strategies. Such a process of external knowledge development which would include both cross-school and research-practice partnerships is a critical part of developing a generalisable knowledge base in teaching.

Just as codifying internally developed knowledge is important, so too are networks for collaboration and knowledge sharing across schools, also to enable schools to combat their isolated natures and gain insights from effective practices in near or distant peer institutions. Teachers, leaders and other school staff stand to benefit from networks and school-to-school collaborations.

External advisory networks of pedagogical experts can support broader knowledge creation and sharing within a system. Some systems have created central bodies of learning consultants working with schools in their improvement efforts and facilitating peer exchange between schools (see an example from Denmark in Chapter 4). Their work can be based on both evidence from research and practical knowledge from the field, creating a circle of learning between the central and the local level. Technology offers new ways to connect schools and staff for learning and to codify knowledge via digital platforms. 


\section{References}

Ballou, D. and M. Springer (2015), "Using student test scores to measure teacher performance", Educational Researcher, Vol. 44/2, pp. 77-86, http://dx.doi.org/10.3102/0013189x15574904.

Bénabou, R. and J. Tirole (2003), "Intrinsic and extrinsic motivation", Review of Economic Studies, Vol. 70/3, pp. 489-520, http://dx.doi.org/10.1111/1467-937x.00253.

Boyd, D. et al. (2008), "The narrowing gap in New York City teacher qualifications and its implications for student achievement in high-poverty schools", Journal of Policy Analysis and Management, Vol. 27/4, pp. 793-818, http://dx.doi.org/10.1002/pam.20377.

Boyd, D. et al. (2005), "The draw of home: How teachers' preferences for proximity disadvantage urban schools", Journal of Policy Analysis and Management, Vol. 24/1, pp. 113-132, http://dx.doi.org/10.1002/pam.20072.

Branch, G., E. Hanushek and S. Rivkin (2012), "Estimating the effect of leaders on public sector productivity: The case of school principals", NBER Working Papers, No. 17803, National Bureau of Economic Research, Cambridge, MA, http://dx.doi.org/10.3386/w17803.

Campbell, P. and N. Malkus (2011), "The impact of elementary mathematics moaches on student achievement", The Elementary School Journal, Vol. 111/3, pp. 430-454, http://dx.doi.org/10.1086/657654.

Chetty, R., J. Friedman and J. Rockoff (2014), "Measuring the impacts of teachers II: Teacher value-added and student outcomes in adulthood", American Economic Review, Vol. 104/9, pp. 2633-2679, http://dx.doi.org/10.1257/aer.104.9.2633.

Coelli, M. and D. Green (2012), "Leadership effects: school principals and student outcomes", Economics of Education Review, Vol. 31/1, pp. 92-109, http://dx.doi.org/10.1016/j.econedurev.2011.09.001.

Conley, S. and A. Odden (1995), "Linking teacher compensation to teacher career development", Educational Evaluation and Policy Analysis, Vol. 17/2, pp. 219-237, http://dx.doi.org/10.3102/01623737017002219.

Crehan, L. (2016), Exploring the impact of career models on teacher motivation, UNESCO International Institute for Educational Planning (IIEP), Paris, http://unesdoc.unesco.org/images/0024/002462/246252e.pdf (accessed on 11 July 2018).

DeArmond, M., B. Gross and D. Goldhaber (2010), "Is it better to be good or lucky? Decentralized teacher selection in 10 elementary schools", Educational Administration Quarterly, Vol. 46/3, pp. 322-362, http://dx.doi.org/10.1177/0013161x10365824.

Echazarra, A. and T. Radinger (2019), "Learning in rural schools: Insights from PISA, TALIS and the literature", OECD Education Working Papers, No. 196, OECD Publishing, Paris, https://dx.doi.org/10.1787/8b1a5cb9-en.

Engel, M. and M. Cannata (2015), "Localism and teacher labor markets: How geography and decision making may contribute to inequality", Peabody Journal of Education, Vol. 90/1, pp. 84-92, http://dx.doi.org/10.1080/0161956X.2015.988533.

Feuer, M. et al. (2013), Evaluation of teacher preparation programs: Purposes, methods and policy options, National Academy of Education, Washington, DC, https://naeducation.org/publications (accessed on 15 July 2019).

Finan, F., B. Olken and R. Pande (2015), "The personnel economics of the state", NBER Working Papers, No. 21825, National Bureau of Economic Research, Cambridge, MA, http://dx.doi.org/10.3386/w21825. 
Finigan-Carr, N. and W. Shaia (2018), "School social workers as partners in the school mission", Phi Delta Kappan, Vol. 99/7, pp. 26-30, https://doi.org/10.1177/0031721718767856.

Frey, B. (1997), "On the relationship between intrinsic and extrinsic work motivation", International Journal of Industrial Organization, Vol. 15/4, pp. 427-439, http://dx.doi.org/10.1016/s01677187(96)01028-4.

Garet, M. et al. (2016), Focusing on mathematical knowledge: The impact of content-intensive teacher professional development (NCEE 2016-4010), US Department of Education, Institute of Education Sciences, Washington, DC, https://ies.ed.gov/ncee (accessed on 15 June 2019).

Gershenson, S. (2016), "Linking teacher quality, student attendance, and student achievement", Education Finance and Policy, Vol. 11/2, pp. 125-149, http://dx.doi.org/10.1162/EDFP a 00180.

Goodman, S. and L. Turner (2013), "The design of teacher incentive pay and educational outcomes: Evidence from the New York City Bonus Program", Journal of Labor Economics, Vol. 31/2, pp. 409420, http://dx.doi.org/10.1086/668676.

Grissom, J., S. Loeb and B. Master (2013), "Effective instructional time use for school leaders: Longitudinal evidence from observations of principals", Educational Researcher, Vol. 42/8, pp. 433444, http://dx.doi.org/10.3102/0013189X13510020.

Guha, R., M. Hyler and L. Darling-Hammond (2016), The Teacher Residency: An Innovative Model for Preparing Teachers, Learning Policy Institute, Palo Alto, CA, https://learningpolicyinstitute.org/product/teacher-residency. (accessed on 23 June 2018).

Harris, D. and T. Sass (2011), "Teacher training, teacher quality and student achievement", Journal of Human Resources, Vol. 95, pp. 798-812, http://dx.doi.org/10.1016/j.jpubeco.2010.11.009.

Hopkins, D., D. Nusche and B. Pont (eds.) (2008), Improving School Leadership, Volume 2: Case Studies on System Leadership, OECD Publishing, Paris, https://dx.doi.org/10.1787/9789264039551-en.

Ingersoll, R. and M. Strong (2011), "The impact of induction and mentoring programs for beginning teachers", Review of Educational Research, Vol. 81/2, pp. 201-233, http://dx.doi.org/10.3102/0034654311403323.

Jackson, C. (2018), "What do test scores miss? The importance of teacher effects on non-test score outcomes", Journal of Political Economy, Vol. 126/5, pp. 2072-2107, http://dx.doi.org/10.1086/699018.

Jackson, C., J. Rockoff and D. Staiger (2014), "Teacher effects and teacher-related policies", Annual Review of Economics, Vol. 6/1, pp. 801-825, http://dx.doi.org/10.1146/annurev-economics-080213040845 .

Jacob, B. and L. Lefgren (2004), "The impact of teacher training on student achievement qusaiexperimental evidence from school reform efforts in Chicago", Journal of Human Resources, Vol. 39/1, pp. 50-79, http://dx.doi.org/10.2307/3559005.

Jensen, B. et al. (2012), The Experience of New Teachers: Results from TALIS 2008, TALIS, OECD Publishing, Paris, http://dx.doi.org/10.1787/9789264120952-en.

Johnson, S., M. Kraft and J. Papay (2012), "How context matters in high-need schools: The effects of teachers' working conditions on their professional satisfaction and their students' achievement", Teachers College Record, Vol. 114/10, pp. 1-39, https://www.tcrecord.org.

Joyce, B. and B. Showers (2002), Student achievement through staff development, Association for Supervision and Curriculum Development, Alexandria, VA.

Kershaw, J. and R. McKean (1962), Teacher Shortages and Salary Schedules, RAND Corporation, Santa Monica, CA.

Kools, M. and L. Stoll (2016), "What Makes a School a Learning Organisation?”, OECD Education Working Papers, No. 137, OECD Publishing, Paris, http://dx.doi.org/10.1787/5jlwm62b3bvh-en. 
Kraft, M. (2019), "Teacher effects on complex cognitive skills and social-emotional competencies", Journal of Human Resources, Vol. 54/1, pp. 1-36, http://dx.doi.org/10.3368/jhr.54.1.0916.8265r3.

Kraft, M. and D. Blazar (2016), "Individualized coaching to improve teacher practice across grades and subjects: New experimental evidence", Educational Policy, Vol. 0/0, pp. 1-36, http://dx.doi.org/10.1177/0895904816631099.

Liebowitz, D. et al. (2018), OECD Reviews of School Resources: Portugal 2018, OECD Reviews of School Resources, OECD Publishing, Paris, https://dx.doi.org/10.1787/9789264308411-en.

Liu, E. and S. Johnson (2006), "New teachers' experiences of hiring: Late, rushed, and information-poor", Educational Administration Quarterly, Vol. 42/3, pp. 324-360, http://dx.doi.org/10.1177/0013161x05282610.

Loeb, S., D. Kalogrides and E. Horng (2010), "Principal preferences and the uneven distribution of principals across schools", Educational Evaluation and Policy Analysis, Vol. 32/2, pp. 205-229, http://dx.doi.org/10.3102/0162373710369833.

Masdeu Navarro, F. (2015), "Learning support staff: A literature review", OECD Education Working Papers, No. 125, OECD Publishing, Paris, https://dx.doi.org/10.1787/5jrnzm39w451-en.

Natale, C. et al. (2013), Creating Sustainable Teacher Career Pathways: A 21 st Century Imperative, Pearson \& National Network of State Teachers of the Year (NNSTOY), https://www.nnstoy.org/download/career_pathways/Final\%20updated\%20Research\%20Report.pdf (accessed on 11 October 2018).

Nusche, D. et al. (2015), OECD Reviews of School Resources: Flemish Community of Belgium 2015, OECD Reviews of School Resources, OECD Publishing, Paris, http://dx.doi.org/10.1787/9789264247598-en.

Nusche, D. et al. (2016), OECD Reviews of School Resources: Austria 2016, OECD Reviews of School Resources, OECD Publishing, Paris, http://dx.doi.org/10.1787/9789264256729-en.

OECD (2019), A Flying Start: Improving Initial Teacher Preparation Systems, OECD Publishing, Paris, http://dx.doi.org/10.1787/cf74e549-en.

OECD (2019), Education at a Glance 2019: OECD Indicators, OECD Publishing, Paris, https://dx.doi.org/10.1787/f8d7880d-en.

OECD (2019), TALIS 2018 Results (Volume I): Teachers and School Leaders as Lifelong Learners, TALIS, OECD Publishing, Paris, https://dx.doi.org/10.1787/1d0bc92a-en.

OECD (2018), Effective Teacher Policies: Insights from PISA, PISA, OECD Publishing, Paris, http://dx.doi.org/10.1787/9789264301603-en.

OECD (2018), Responsive School Systems: Connecting Facilities, Sectors and Programmes for Student Success, OECD Reviews of School Resources, OECD Publishing, Paris, https://dx.doi.org/10.1787/9789264306707-en.

OECD (2017), The Funding of School Education: Connecting Resources and Learning, OECD Reviews of School Resources, OECD Publishing, Paris, http://dx.doi.org/10.1787/9789264276147-en.

OECD (2013), Synergies for Better Learning: An International Perspective on Evaluation and Assessment, OECD Reviews of Evaluation and Assessment in Education, OECD Publishing, Paris, http://dx.doi.org/10.1787/9789264190658-en.

O'Neill, S. and J. Stephenson (2012), "Does classroom management coursework influence pre-service teachers' perceived preparedness or confidence?", Teaching and Teacher Education, Vol. 28/8, pp. 1131-1143, https://doi.org/10.1016/j.tate.2012.06.008.

Opfer, D. (2016), "Conditions and Practices Associated with Teacher Professional Development and Its Impact on Instruction in TALIS 2013", OECD Education Working Papers, No. 138, OECD Publishing, Paris, https://dx.doi.org/10.1787/5jlss4r01rg5-en. 
Opfer, V. and D. Pedder (2011), "Conceptualizing teacher professional learning”, Review of Educational Research, Vol. 81/3, pp. 376-407, http://dx.doi.org/10.3102/0034654311413609.

Papay, J. (2011), "Different tests, different answers", American Educational Research Journal, Vol. 48/1, pp. 163-193, http://dx.doi.org/10.3102/0002831210362589.

Papay, J. and M. Kraft (2015), "Productivity returns to experience in the teacher labor market: Methodological challenges and new evidence on long-term career improvement", Journal of Public Economics, Vol. 130, pp. 105-119, http://dx.doi.org/10.1016/j.jpubeco.2015.02.008.

Papay, J. et al. (2012), "Does an urban teacher residency increase student achievement? Early evidence from Boston", Educational Evaluation and Policy Analysis, Vol. 34/4, pp. 413-434, http://dx.doi.org/10.3102/0162373712454328.

Pont, B., D. Nusche and H. Moorman (2008), Improving School Leadership, Volume 1: Policy and Practice, OECD Publishing, Paris, http://dx.doi.org/10.1787/9789264044715-en.

Pugatch, T. and E. Schroeder (2014), "Incentives for teacher relocation: Evidence from the Gambian hardship allowance", Economics of Education Review, Vol. 41, pp. 120-136, http://dx.doi.org/10.1016/j.econedurev.2014.04.003.

Radinger, T. (2014), "School leader appraisal - A tool to strengthen school leaders' pedagogical leadership and skills for teacher management?", European Journal of Education, Vol. 49/3, http://dx.doi.org/10.1111/ejed.12085.

Rivkin, S., E. Hanushek and J. Kain (2005), "Teachers, schools, and academic achievement", Econometrica, Vol. 73/2, pp. 417-458, http://dx.doi.org/10.1111/j.1468-0262.2005.00584.x.

Rockoff, J. et al. (2011), “Can you recognize an effective teacher when you recruit one?", Education Finance and Policy, Vol. 6/1, pp. 43-74, http://dx.doi.org/10.1162/EDFP_a_00022.

Rothstein, J. (2010), "Teacher quality in educational production: Tracking, decay, and student achievement*", Quarterly Journal of Economics, Vol. 125/1, pp. 175-214, http://dx.doi.org/10.1162/qjec.2010.125.1.175.

Santiago, P. et al. (2016), OECD Reviews of School Resources: Uruguay 2016, OECD Reviews of School Resources, OECD Publishing, Paris, https://dx.doi.org/10.1787/9789264265530-en.

Santiago, P. et al. (2016), OECD Reviews of School Resources: Slovak Republic 2015, OECD Reviews of School Resources, OECD Publishing, Paris, https://dx.doi.org/10.1787/9789264247567-en.

Schuck, S. et al. (2017), "The experiences of early career teachers: new initiatives and old problems", Professional Development in Education, Vol. 44/2, pp. 209-221, http://dx.doi.org/10.1080/19415257.2016.1274268.

Shewbridge, C. et al. (2016), OECD Reviews of School Resources: Czech Republic 2016, OECD Reviews of School Resources, OECD Publishing, Paris, http://dx.doi.org/10.1787/9789264262379-en.

Sipple, J. and B. Brent (2015), "Challenges and Strategies Associated with Rural School Settings", in Ladd, H. and M. Goertz (eds.), Handbook of Research in Education Finance and Policy, Routledge, New York, NY and Abingdon, OX.

Timperley, H. et al. (2007), Teacher Professional Learning and Development: Best Evidence Synthesis Iteration, New Zealand Ministry of Education, Wellington, http://www.educationcounts.govt.nz/publications/curriculum/2515/15341 (accessed on 6 April 2019). 


\section{Chapter 1. Why focus on effective human resource policies for schools?}

This report analyses policies that can help countries strengthen, recognise and preserve the positive impact that teachers, school leaders and other school staff have on their students. This chapter introduces and provides the context for the subsequent analysis. First, it highlights the importance of school staff for student learning and well-being. Second, the chapter sets out the report's conceptual framework of human resource policies, emphasising the broad range of objectives human resource policies should contribute to and the importance of adopting a vision of collective improvement in schools. It also discusses the design, resourcing and implementation challenges of human resource policy reforms. Finally, the chapter lays out the report's methodology and evidence base. The annex to this chapter describes the broad range of staff that work in and with schools internationally and in individual OECD review countries.

The statistical data for Israel are supplied by and under the responsibility of the relevant Israeli authorities. The use of such data by the OECD is without prejudice to the status of the Golan Heights, East Jerusalem and Israeli settlements in the West Bank under the terms of international law. 


\subsection{Teachers, leaders and other school staff matter for student learning and well-being}

The people working in schools are a vital resource for today's education systems. There is a solid evidence base indicating that teachers are key in improving learning opportunities for students, likely more than anyone else in children's lives outside their families, and that teachers can have long-term impacts on adult outcomes, such as earnings and tertiary education attendance (Chetty, Friedman and Rockoff, 2014 ${ }_{[1]}$; Rivkin, Hanushek and Kain, $2005_{[2]}$; Rockoff, 2004 ${ }_{[3]}$ ). More recent research has documented teachers' impact on other desirable outcomes, including students' behaviours at school, such as attendance and drop-out (Liu and Loeb, 2019[4]; Gershenson, 2016 ${ }_{[5]}$; Koedel, 2008 ${ }_{[6]}$ ), and non-cognitive skills, such as resilience, growth mindset and self-efficacy (Kraft, 2019 [7]; Blazar and Kraft, $2016_{[8]}$; Jennings and DiPrete, 2010[9]). As Jackson $\left(2018_{[10]}\right)$ found, these social and behavioural outcomes are in fact more predictive of long-run outcomes such as intention to attend tertiary education.

School leaders, in turn, play a pivotal role in raising teaching quality (Coelli and Green, 2012[11]; Branch, Hanushek and Rivkin, 2012 [12]; Witziers, Bosker and Krüger, 2003 [13]; Hallinger and Heck, 1998 ${ }_{[14]}$ ). As empirical studies from the United States suggest, effective school leadership may help reduce teacher turnover, strategically retain high-performing teachers, and dismiss teachers with performance concerns (Grissom and Bartanen, 2018 ${ }_{[15]}$; Kraft, Marinell and Shen-Wei Yee, 2016 $\left.6_{[16]}\right)$. Long-standing research and policy discourse have stressed the importance of pedagogical leadership in particular, that is of creating the environments in which teachers continuously improve their competencies to support student learning (OECD, 2016 ${ }_{[17]}$; OECD, 2013 ${ }_{[18]}$; Pont, Nusche and Moorman, 2008 ${ }_{[19]}$; Robinson, Lloyd and Rowe, 2008 $\left.{ }_{[20]}\right)$. More recent research points to some forms of pedagogical leadership that are more effective than others (Grissom, Loeb and Master, 2013 [21]), and to the importance of organisational management and other skills

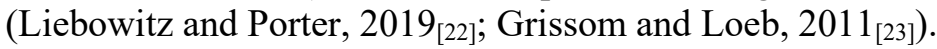

Beyond teachers and school leaders, there are many other adults whose contributions to the holistic learning of students and the overall improvement of schools are increasingly recognised (Heller, 2018 ${ }_{[24]}$; Masdeu Navarro, 2015[25]). Teacher aides may support teachers in providing instruction to students, while professional support staff may assist the instructional programme or provide health and social services to students. As the OECD review shows, in many countries guidance counsellors and school librarians, as well as doctors, nurses, psychologists, social workers and social pedagogues work in or with schools. Some countries also have dedicated support staff for the inclusion of special needs students or the creation of a good school climate. Administrative, maintenance and operations staff support school management and operation. The OECD review illustrates the wide range of staff that may work in and with schools (see Annex 1.A and Annex 1.B).

Which types of staff are employed, by whom and where will depend on many contextual factors in a school system, including its educational goals, curricula and school network organisation as well as the distribution of responsibilities and regulations for school staffing. While some staff will work directly in schools, others will support the delivery of education externally. Where schools collaborate and share staff, experience and knowledge, staff resources extend beyond the individual school and support education quality more broadly. With the inclusion of children with special needs, for instance, special needs schools and their staff have taken on a broader role in a number of school systems, supporting inclusive instruction across mainstream schools (OECD, 2018[26]). 
In addition, in many countries, psychological, medical and paramedical staff are employed in specialised resource centres and work across a number of schools.

In the context of broad, future-oriented learning goals and related changes to the organisation of schools, a number of school systems are reconsidering the distribution and roles of different types of staff in their schools to ensure they collectively support student learning and well-being both inside the classroom and the broader school context. Changes to the organisation of the school day in Austria and Denmark, for example, have required the presence of different types of staff in schools to support equity and holistic student learning (Nusche et al., 2016 [27]; Nusche et al., 2016 ${ }_{[28]}$ ). Similarly, the inclusion of children with special needs in the Czech and Slovak Republics has led to changes in the mix of staff in schools (Santiago et al., 2016[29]; Shewbridge et al., 2016[30]).

The OECD Teaching and Learning International Survey (TALIS) regularly asks principals to report on the staff resources of their school (see Figure 1.1 and Figure 1.2) (OECD, $2019_{[31]}$; OECD, 2014 $\left.[32]\right){ }^{1}$ These figures need to be interpreted with care, given their self-reported nature and the role of factors such as the size of schools (number of students and teachers) and the organisation of the school network, as well as the task profile of different staff, including teachers. Nevertheless, they give an idea of the presence of other staff types besides teachers and leaders in schools.

As the data show, there are considerable differences in the presence of different types of staff across school systems. There are more than two pedagogical support staff per ten teachers in Alberta (Canada), Chile, Iceland, New Zealand and Sweden, but there is less than one pedagogical support staff position for every twenty teachers in Austria, Belgium, Colombia and Italy. In a number of school systems, the presence of pedagogical support staff has increased significantly over recent years, notably in the Czech Republic, Denmark, Finland, Sweden, and the Slovak Republic. In England (United Kingdom), there were fewer pedagogical support staff per teacher in 2018 than in 2013. The share of administrative and managerial staff has remained more stable, with changes only reported for Italy and Spain. 
Figure 1.1. Change in pedagogical support staff (ISCED 2), 2013-2018

Number of pedagogical support staff per ten teachers

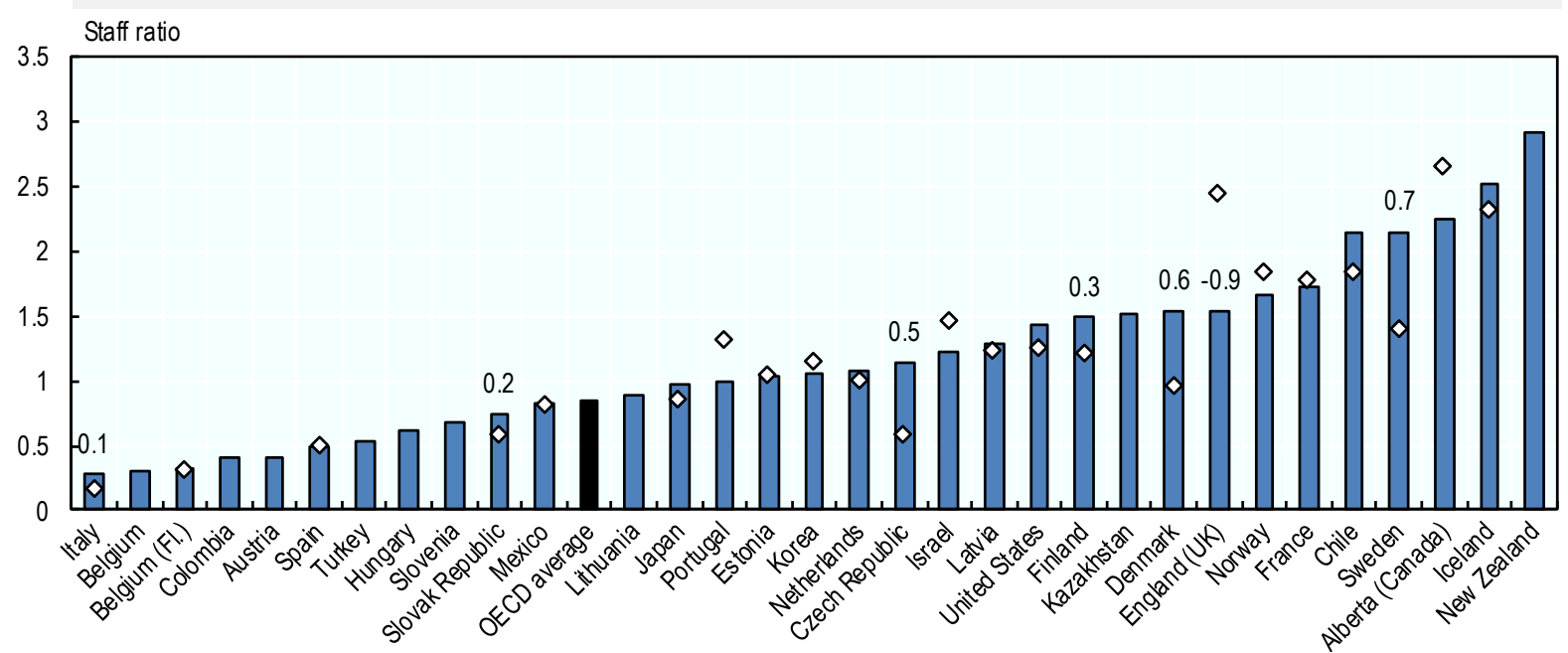

Notes: Pedagogical support staff includes all teacher aides or other non-teaching professionals who provide instruction or support teachers. These data are reported by principals and represent the average of school-level data (both public and private) in each country. The education provision in these schools may extend across ISCED levels (e.g. in schools that offer both lower and upper secondary education) and therefore may not apply only to teachers or students in lower secondary education. Statistically significant changes between 2013 and 2018 are indicated above the bars. The OECD average corresponds to the arithmetic mean of the estimates for OECD countries or economies with available data. On 25 May 2018, the OECD Council invited Colombia to become a Member. While Colombia is included in the OECD average reported in this figure, at the time of its preparation, Colombia was in the process of completing its domestic procedures for ratification and the deposit of Colombia's instrument of accession to the OECD Convention was pending.

Sources: OECD (2019), TALIS 2018 Results (Volume I): Teachers and School Leaders as Lifelong Learners, OECD Publishing, Paris, https://doi.org/10.1787/1d0bc92a-en, Table I.3.74.; OECD (2014), TALIS 2013 Results: An International Perspective on Teaching and Learning, OECD Publishing, Paris, https://doi.org/10.1787/9789264196261-en, Table 2.18. 


\section{Figure 1.2. Change in administrative and managerial staff (ISCED 2), 2013-2018}

Number of administrative and managerial personnel per ten teachers

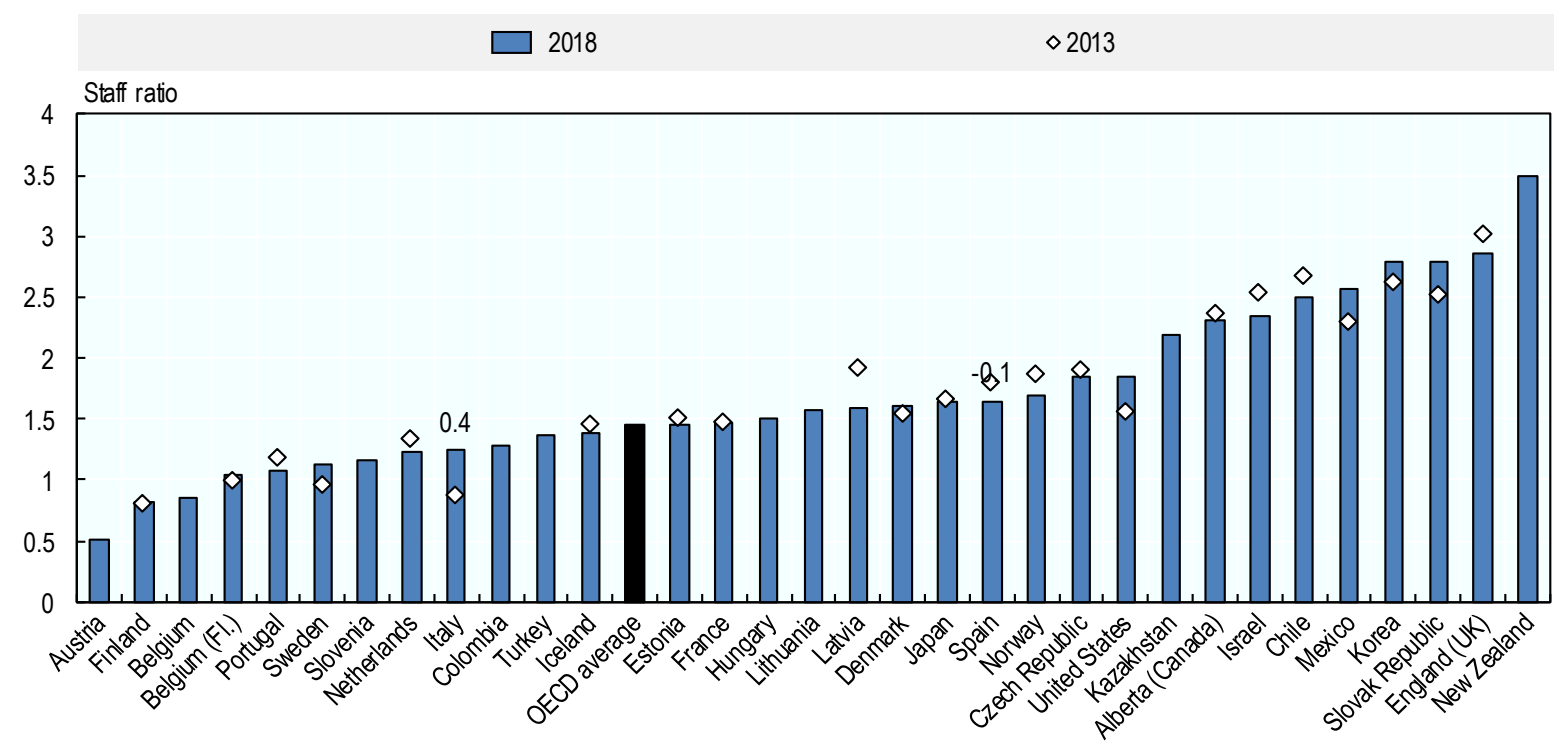

Notes: School administrative staff includes receptionists, secretaries and administration assistants, while management staff includes principals, assistant principals and other management staff whose main activity is management. These data are reported by principals and represent the average of school-level data (both public and private) in each country. The education provision in these schools may extend across ISCED levels (e.g. in schools that offer both lower and upper secondary education) and therefore may not apply only to teachers or students in lower secondary education. Statistically significant changes are indicated above the bars. The OECD average corresponds to the arithmetic mean of the estimates for OECD countries or economies with available data. On 25 May 2018, the OECD Council invited Colombia to become a Member. While Colombia is included in the OECD average reported in this figure, at the time of its preparation, Colombia was in the process of completing its domestic procedures for ratification and the deposit of Colombia's instrument of accession to the OECD Convention was pending.

Sources: OECD (2019), TALIS 2018 Results (Volume I): Teachers and School Leaders as Lifelong Learners, OECD Publishing, Paris, https://doi.org/10.1787/1d0bc92a-en, Table I.3.74; OECD (2014), TALIS 2013 Results: An International Perspective on Teaching and Learning, OECD Publishing, Paris, https://doi.org/10.1787/9789264196261-en, Table 2.18.

StatLink 세s https://doi.org/10.1787/888934026183

Despite the presence of a broad range of staff in schools, much remains to be understood about their roles and task profiles and how they support the provision of education. The evidence on the educational benefits of learning support staff, for instance, is quite mixed. While some forms of support, such as student guidance counsellors, have been shown to improve teachers' perceptions of the school climate and reduce misbehaviour (Reback, $2010_{[33]}$ ), there is no conclusive evidence on the relative effectiveness of different staff types. For example, benefits were found for the use of community teacher assistants in India by Banerjee et al. (2007[34]) and for the use of ancillary teaching staff in Australia by Cobb-Clark and Jha $\left(2016_{[35]}\right)$, but no impact was found related to the deployment of teacher aides in the United States (Mosteller, 1997[36]).

Arguably, however, the presence of a wide range of staff has the potential to enable schools to better meet their individual students' academic, social and emotional needs. Even staff 
who are not directly linked to student instruction may participate in the creation of a good learning environment. Staff providing essential ancillary services, such as transportation, cleaning and school meals, also contribute to student safety and well-being, for example (Meals, 2018[37]).

The experience of the OECD review illustrates these points. In Sweden, individual schools and municipalities reportedly involve canteen staff and technicians to add to the learning of students in areas like nutrition and technology. In Portugal, technical and operational assistants supervise students during non-instructional periods in the cafeteria, recess and hallways and support student engagement by de-escalating and re-integrating disruptive students into class (Liebowitz et al., 2018 $8_{[38]}$ ). Moreover, different types of staff may help ensure supportive working conditions for teachers and school leaders, for instance by taking over tasks and helping them focus on other responsibilities, as is the case for secretaries, accountants and laboratory assistants.

Conversely, depending on different system goals and cultural traditions, teachers or school leaders taking on particular tasks that are traditionally associated with other staff categories may also be seen as part of an overall educational vision. In Japan, for example, teachers are expected to perform a range of pedagogical non-teaching tasks besides teaching. According to the Japanese Ministry of Education, Culture, Sports, Science and Technology, this includes supervising children as they clean the school and help serve school lunches to classmates, all of which seeks to cultivate balanced life skills, including a solid academic ability, richness in mind, and a healthy body (OECD, 2018, p. 53[39]).

As is explored in this report, it is thus important for schools and school systems to take a holistic view of the staff mix they have in schools, the tasks and responsibilities that are expected of different staff and the way different staff use their time (see Annex 1.A).

\subsection{Human resource policies shape working and learning environments in schools}

In the context of this report, human resource policies broadly refer to the regulations and principles of action that shape who school staff are and what they do, through their direct influence on careers, staff distribution and professional learning.

The OECD review identified a set of common challenges in the design and implementation of human resource policies that emerged in some form or another in the participating countries. Most prominently, this includes the following:

- Careers, salaries and working conditions remain unattractive and may act as a barrier for talented individuals to pursue a career in teaching or school leadership.

- The most effective and experienced teacher and school leadership staff are rarely matched to the schools and students that need them the most.

- Traditional professional development systems often fall short of supporting continuous growth for those supporting learning in schools.

Following this introductory chapter, the subsequent chapters will focus on policies to address these challenges, notably to i) develop attractive and motivating careers for school staff, ii) distribute school staff effectively and equitably and iii) support powerful professional learning. The report highlights the need to consider all adults who work in schools and points to how they can contribute to their effectiveness wherever possible (see Annex 1.A and Annex 1.B). However, due to the limited availability of comparable 
information on other staff, the systematic analysis of this report focuses on teachers and school leaders.

Each chapter will provide comparative data, evidence from research as well as policy experiences and evaluations from participating countries. Table 1.1 provides an overview of the more specific aspects of inquiry of these policy dimensions.

Table 1.1. Policy dimensions and aspects of analysis covered in this report

\begin{tabular}{|c|c|c|}
\hline & Policy dimension & Aspects of analysis \\
\hline Chapter 2 & Attractive and motivating careers & $\begin{array}{l}\text { Setting entry requirements at the right level } \\
\text { Designing career structures with opportunities for promotion and specialisation } \\
\text { Establishing salary scales to attract new entrants and reward improvement } \\
\text { Improving working conditions, working time arrangements and task profiles }\end{array}$ \\
\hline Chapter 3 & $\begin{array}{l}\text { Effective and equitable staff } \\
\text { distribution }\end{array}$ & $\begin{array}{l}\text { Forecasting staffing needs to match supply and demand } \\
\text { Financing school staff to meet school needs } \\
\text { Matching staff mix to individual schools } \\
\text { Providing effective staff to high-needs schools } \\
\text { Assigning teachers within schools to promote effectiveness and equity }\end{array}$ \\
\hline Chapter 4 & Powerful professional learning & $\begin{array}{l}\text { Designing initial preparation of teachers and school leaders } \\
\text { Linking initial education to practice in schools } \\
\text { Making off-site professional development more effective } \\
\text { Strengthening school-based professional learning and collaboration } \\
\text { Supporting knowledge development and professional networks } \\
\text { Refocussing professional evaluation on improvement }\end{array}$ \\
\hline
\end{tabular}

Further, in terms of scope, this report considers human resource policies and practices that may be designed at different levels of school systems - from the central level to individual schools - and, where relevant, how they interact. This also reflects that countries differ greatly in the governance of their school systems. The report covers all levels of mainstream school education, from primary to upper secondary education (ISCED levels 1-3) and seeks to recognise differences in human resource policies between levels of school education wherever possible given the available data. Private providers - publicly funded or not make up a considerable part of student enrolment in some countries (see (OECD, 2018 $8_{[26]}$ ) and $\left.\left(\mathrm{OECD}, 2017_{[40]}\right)\right)$. This report focuses on human resource policies for teachers in the public school sector, which may also apply to teachers in publicly funded private schools depending on the school system concerned.

\subsubsection{Strengthening, recognising and preserving the impact of school staff on students}

This report aims to identify human resource policies that support effective working and learning environments in schools. It finds that effective human resource policies leverage the professional agency of teachers, school leaders and other school staff. Thereby, they contribute to strengthening, recognising and preserving the positive impact that school staff can have on students and their learning.

The ultimate objective of policies discussed in this report is to create conditions in which school staff can best support student learning. However, the impact of human resource policies on student learning is not direct, but rather the product of a variety of mediated effects and underlying mechanisms. The influence of teachers, school leaders and other staff on their students operates through their capacity to design effective classroom and 
school-wide processes. This capacity can, in turn, be enhanced through effective human resource policies.

Of course, student learning is affected by multiple factors, many of which are beyond the control of individual teachers, school leaders and other staff. In particular, social and economic backgrounds also significantly shape students' academic achievement and well-being (OECD, 2018 [41] ; OECD, 2017 $[42]$; Sirin, 2005 [43]). As illustrated by Albornoz et al. $\left(2018_{[44]}\right)$, the responses of different actors within school systems (parents, students, teachers, school leaders and policy makers) also interact, making it difficult to predict outcomes and attribute them to a particular cause (also see Todd and Wolpin (2003 [45])). Although student achievement as measured on standardised tests is often the main outcome considered in empirical studies of policy effectiveness, this report aims to widen the perspective by taking a broad approach to student learning (more on this in the next section) and relating it to other desirable policy outcomes.

Besides creating the conditions for effective teaching and learning, human resource policies typically aim to create effective working environments for school staff. In this context, stated objectives generally include staff well-being and job satisfaction at the individual level, as well as social status or professional cultures at the level of the school or the profession as a whole. While many of these, in turn, influence the capacity of adults to support student learning through high quality teaching and leadership, they are also important in their own right and will be considered as independently desirable policy goals and outcomes throughout this report.

Human resource policies influence both individual and collective capacity in schools. They can help ensure that schools are staffed with well-prepared individuals who benefit from motivating working conditions and opportunities for professional learning (their individual resources), but also that adults in schools work together in effective ways and solve local problems (their collective or social resources). While the practices of individuals working in schools and their qualifications and experience are important, so are the collective processes, cultures and interactions between staff that contribute to the success of a school as a whole (Papay and Kraft, 2017 $[46]$; Johnson, 2009 $[47]$ ).

Finally, human resource policies may also seek to strengthen the professionalism of teachers and school leaders. Professionalism is a historically changing and socially constructed concept that can be understood in different ways (see Box 1.1 for definitions). However, a recurrent dimension in most definitions of professionalism is a focus on the autonomy and responsibility of the profession to exercise a degree of self-regulation.

In the context of this report, teachers' and school leaders' professional agency - that is their active contribution to shaping their work and its conditions (Biesta, Priestley and Robinson, $\left.2015_{[48]}\right)$ - emerged as a key element of successful human resource policies. The analysis of policies developed in the countries participating in the School Resources Review confirmed in many contexts that the active engagement of teachers and school leaders in shaping the parameters of their work was crucial to successful teaching and school leadership. Professional agency, which results from the interplay of individual efforts, available resources and contextual and structural factors (Biesta and Tedder, 2007 [49]) thus constitutes an important element of individual and collective capacity of teachers and school leaders, shaping both policy and practice in school education. 


\section{Box 1.1. Conceptualising teaching as a profession}

The concept of teacher professionalism has been used in educational research and policy for many decades with changing definitions (Holroyd, 2000[50]). Most definitions of a "professionalised" workforce include references to one or several of the following dimensions of professionalism, articulated by Millerson $\left(1964_{[51]}\right)$ over 60 years ago, namely the existence of:

- a body of knowledge and skills that professionals should master (cognitive dimension)

- a particular service orientation and self-regulatory and distinctive ethics (normative dimension)

- approaches to evaluating and ensuring the competence of professionals so as to differentiate the profession from other occupations (evaluative dimension).

The OECD Teaching and Learning International Survey (TALIS) defines teaching as a profession underpinned by five pillars (OECD, 2019[31]):

- the knowledge and skills base, which includes shared and specialised knowledge, as well as standards for access to the profession and development of specific skills through pre-service training and in-service professional development

- the status and standing of the profession, captured through the ethical standards expected of professional workers, the intellectual and professional fulfilment of the job, and the working regulations applying to teaching (such as competitive reward structures on par with professional benchmarks and room for career progression)

- peer control, which relies upon self-regulated and collegial professional communities that provide opportunities for collaboration and peer feedback to strengthen professional practices and the collective identity of the profession

- responsibility and autonomy, captured through the degree of autonomy and leadership that teachers and school leaders enjoy in their daily work, to make decisions and apply expert judgement and to inform policy development at all levels of the system, so that professionalism can flourish

- the perceived prestige and societal value of the profession.

While often lacking conceptual clarity, the notion of professionalism has been used over time to advance different aims. In some contexts, the concept has been used as a means to improve the status, salary and conditions of teachers (Hargreaves, 2002 [52]; Englund, 2002 [53]; Freidson, 1994[54]; Fox, 1992 ${ }_{[55]}$; Hoyle, 1974 $\left.{ }_{[56]}\right)$. Other, more prescriptive and managerial interpretations have set professionalism as a means to ensure public confidence in teachers' performance in relation to goals and standards, typically set "from above" at the system level (Sachs, 2015[57]; Hoyle, 2001 [58]; Ozga, 1995[59]; Sockett, $1996_{[60]}$; Troman, 1996 $\left.6_{[61]}\right)$ and McClelland, 1990 cited in Evetts $\left(2003_{[62]}\right)$. Finally, more contextually defined and democratic interpretations of professionalism "from within" highlight the importance of teachers' own agency in contributing to defining and achieving objectives for their students, their school, the community, the system and the profession itself (Sachs, 2015 [57]; Evans, 2008 ${ }_{[63]}$; Newman and Clarke, 1997 [64]; Day and Sachs, 2005 $\left.{ }_{[65]}\right)$ and McClelland, 1990 cited in Evetts (2003 [62]). 
Figure 1.3. Human resource policies for schools: a conceptual framework

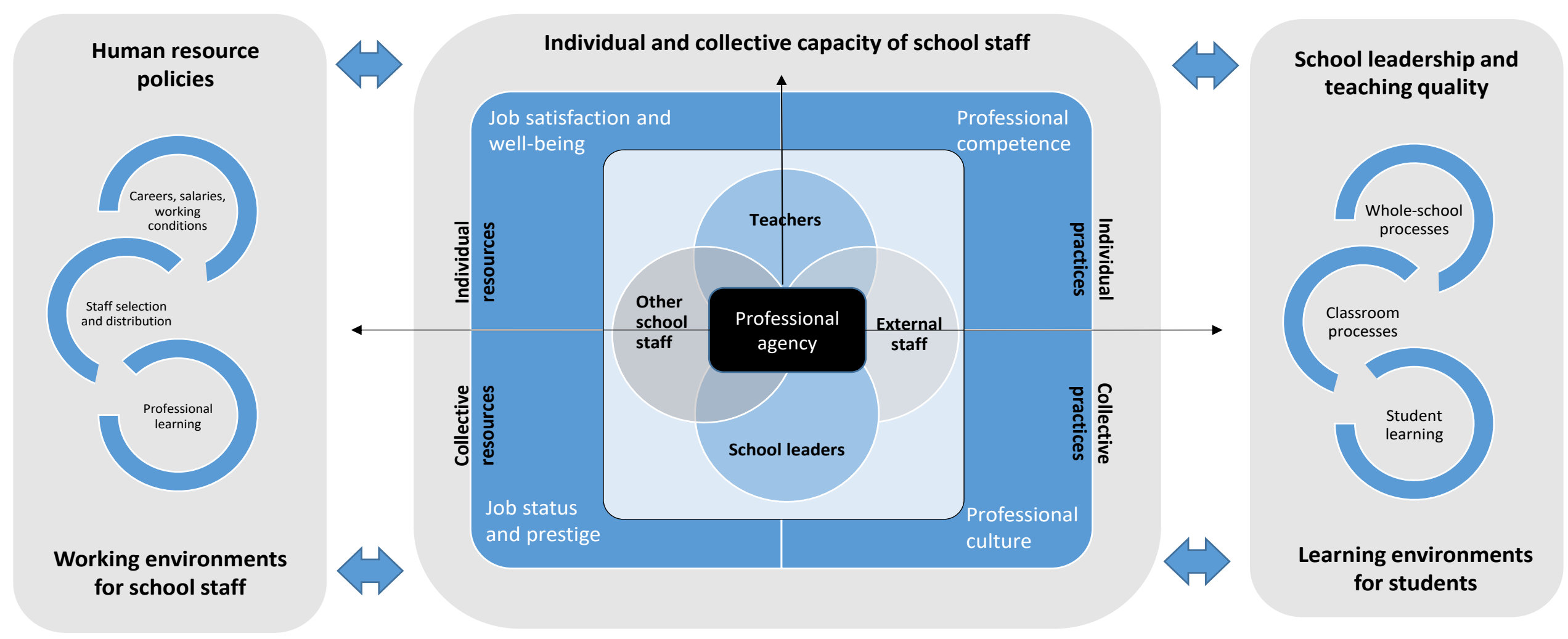




\subsubsection{Supporting collaborative learning, teaching and leadership in schools}

This report understands student learning in a broad sense to encompass the acquisition of academic skills, but also social, emotional and ethical skills, which matter in individuals' lives and for the creation of productive, equitable and socially cohesive societies (Levin, 2012[66]; Heckman, Stixrud and Urzua, 2006 $\left.6_{[67]}\right)$. As OECD (2017, p. 19 $9_{[42]}$ ) highlights, "schools are not only places where students acquire academic skills; they are also where children develop many of the social and emotional skills that they need to thrive". Such broader learning outcomes are also recognised in the United Nations 2030 Agenda for Sustainable Development which "calls for education that goes beyond the transfer of knowledge and desirable behaviours by focusing on multiple perspectives - economic, ecological, environmental and socio-cultural - and by developing empowered, critical, mindful and competent citizens" to address complex sustainability issues (UNESCO, $\left.2016_{[68]}\right)$.

In this context, the OECD's Future of Education and Skills 2030 project sets out an aspirational vision for the future of education supporting such broader goals. The project's learning framework is built around the concept of "student agency", defined as the capacity to set a goal, reflect and act responsibly to effect change in different contexts. The concept is rooted in the principle that students have the ability and the will to positively influence their own lives and the world around them. The framework highlights however that agency does not simply mean student autonomy or choice; agency is exercised in a social context where students interact with their peers, teachers, families and communities, hence the goal is also to build students "co-agency" with others (OECD, 2019[69]).

If education systems are serious about student agency and collaboration as key goals, these concepts also need to be modelled by schools and the adults working in them. In general, learning depends also on how the school as a social context supports teaching and student engagement (Bryk et al., 2010 $[70]$ ). Depending on the context, building a professional culture around a sense of collective responsibility for students, common expectations for both students' learning and staff performance and shared beliefs about teaching and learning can be an important part of a school's improvement strategy. The professional culture among staff in a school can then be a key dimension for school improvement - besides other factors such as a sense of identity, community and belonging, and the incorporation of improvement processes into regular work practices (Bellei et al., 2016 [71]).

Collaboration between teachers constitutes a powerful form of professional learning as highlighted in Chapter 4 of this report. More broadly, through collaboration and co-ordination, students may benefit from the combined skills and experiences of all staff rather than the unique strengths and personal limitations of an individual staff member. Collaboration across classrooms and school grades and broader school-based activities can ensure that staff in schools co-ordinate their efforts and are more knowledgeable about the academic, social and emotional needs of their students. Based on such knowledge of their students' holistic needs, teachers, school leaders and others can then decide how best to address them (Kraft et al., 2015 [72]; Johnson, 2009 ${ }_{\text {[47] }}$ ). Moreover, as highlighted in Chapter 4, schools that work with a wide range of staff may draw on diverse knowledge and skills to support professional learning through collaboration (e.g. between canteen staff and home economics teachers on nutrition; between social workers and teachers on school climate; between school librarians and teachers on media literacy). 
While the benefits of collaborative cultures in schools are widely recognised, there is still limited knowledge regarding the policy frameworks that best support them. Attempts to impose professional collaboration may be counter-productive and overcrowd staff schedules with time requirements that may inhibit self-initiated forms of collaboration and innovation. On the other hand, relying only on professional agency without providing supports in the form of dedicated time, evidence-based protocols and policy environments that encourage collaboration, feedback and innovation risks leaving many schools and students behind (Hargreaves and O'Connor, 2018 $[73]$ ).

This report builds on the recognition that effective collaboration in schools can increase both staff satisfaction and students' growth. It also highlights that a focus on the collective improvement of teaching and leadership in a school rather than just the individual improvement of teachers and leaders requires a change in perspective throughout all aspects of human resource policies, including recruitment, career structures, professional learning and evaluation.

\subsection{Human resource policies influence effectiveness and efficiency of spending}

From a financial perspective, the importance of teachers, school leaders and other school staff is borne out in the investments that school systems make in their staff. In many countries, the educational workforce makes up a substantial part of public employment, and, as shown in Figure 1.4, spending on staff constitutes the largest expenditure item in any OECD education budget. On average across the OECD, school systems allocate around $80 \%$ of their annual expenditure to staff salaries. In 2016, across OECD countries, an estimated $63 \%$ of current spending on schools was allocated to teacher salaries and another $15 \%$ to the salaries of other staff. However, countries apportion vastly different levels of resources to teacher and staff salaries, ranging from less than $65 \%$ of the operating budget in the Czech Republic and Finland to more than $85 \%$ in Belgium, Colombia and Luxembourg (OECD, 2019, pp. 340, Table C6.2.[74]). 
Figure 1.4. Share of current expenditure spent on staff and other resources, 2016

Public and private institutions in primary, secondary and post-secondary non-tertiary education

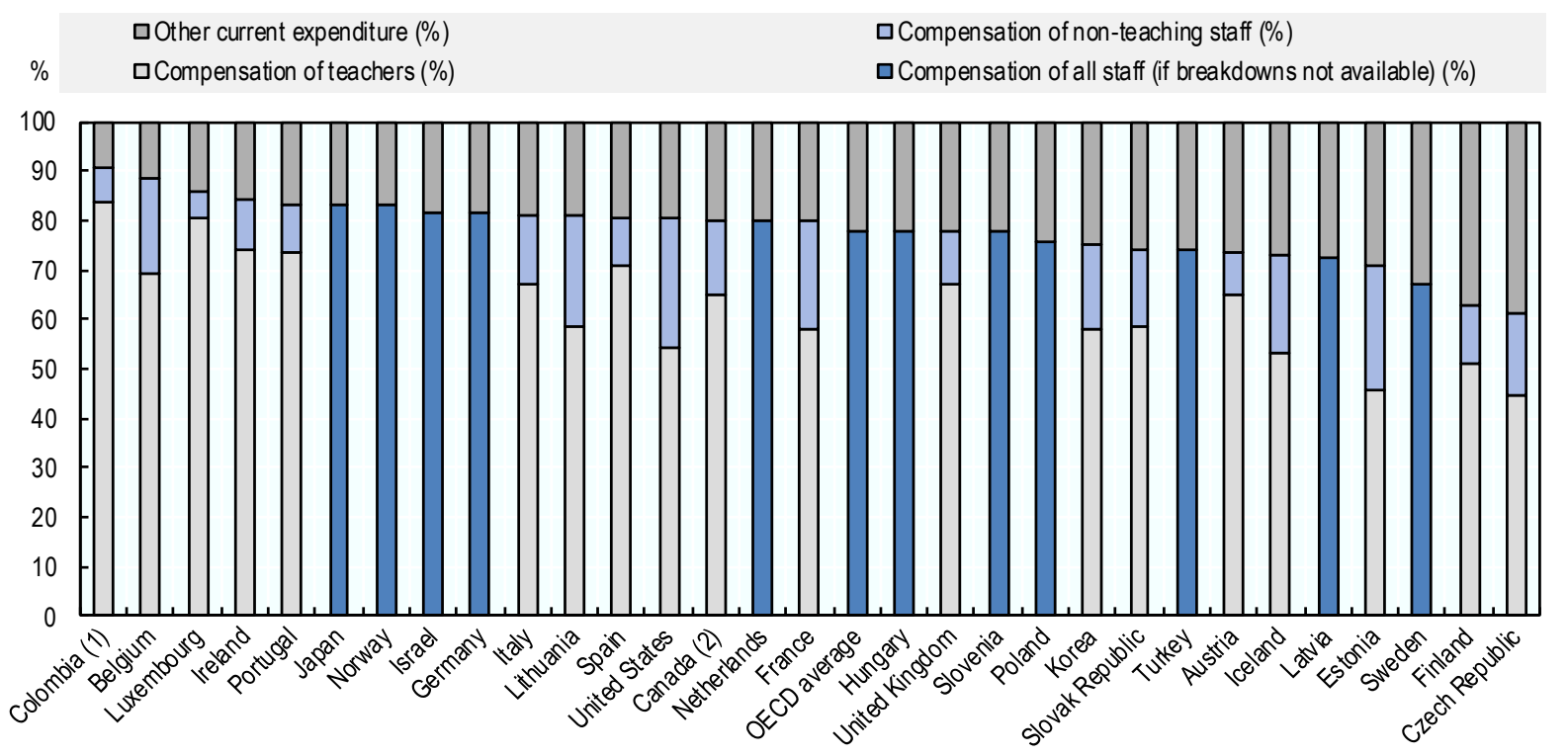

Notes: Countries are ranked in descending order of the share of all staff compensation in primary, secondary and post-secondary non-tertiary institutions. The variation in the share of expenditure allocated to non-teaching staff salaries also reflects differences in the definitions of staff categories across countries. On 25 May 2018, the OECD Council invited Colombia to become a Member. While Colombia is included in the OECD average reported in this figure, at the time of its preparation, Colombia was in the process of completing its domestic procedures for ratification and the deposit of Colombia's instrument of accession to the OECD Convention was pending.

1. Year of reference 2017.

2. Primary education includes pre-primary programmes.

Source: OECD (2019), Education at a Glance 2019: OECD Indicators, OECD Publishing, Paris, https://doi.org/10.1787/f8d7880d-en, Figure C6.2.a., Table C6.2.

\section{StatLink 제내 https://doi.org/10.1787/888934026202}

This report analyses human resource policies from both an educational and a resource effectiveness perspective, wherever possible. Figure 1.5 illustrates cross-country variations in staff expenditure, highlighting some of the factors that explain different levels of staff spending. While the level of teachers' salaries is the most important source of variation between countries, other factors also shape overall spending levels.

As illustrated by the figure, choices to offer or require smaller class sizes, longer teacher working hours or less instructional time per teacher all increase the number of teachers required and raise per student spending. As will be explored in the report, decisions about employment conditions, the staff mix in schools and the types of professional learning on offer also influence expenditure levels. These investment trade-offs, as well as many others discussed in this report, represent important policy decisions that should be informed by an analysis of national and local contexts and the best possible evidence of effectiveness. 


\section{Figure 1.5. Contribution of various factors to salary cost of teachers per student (ISCED 1),} 2017

In USD (US dollars) converted using PPPs (Purchasing Power Parities) for private consumption

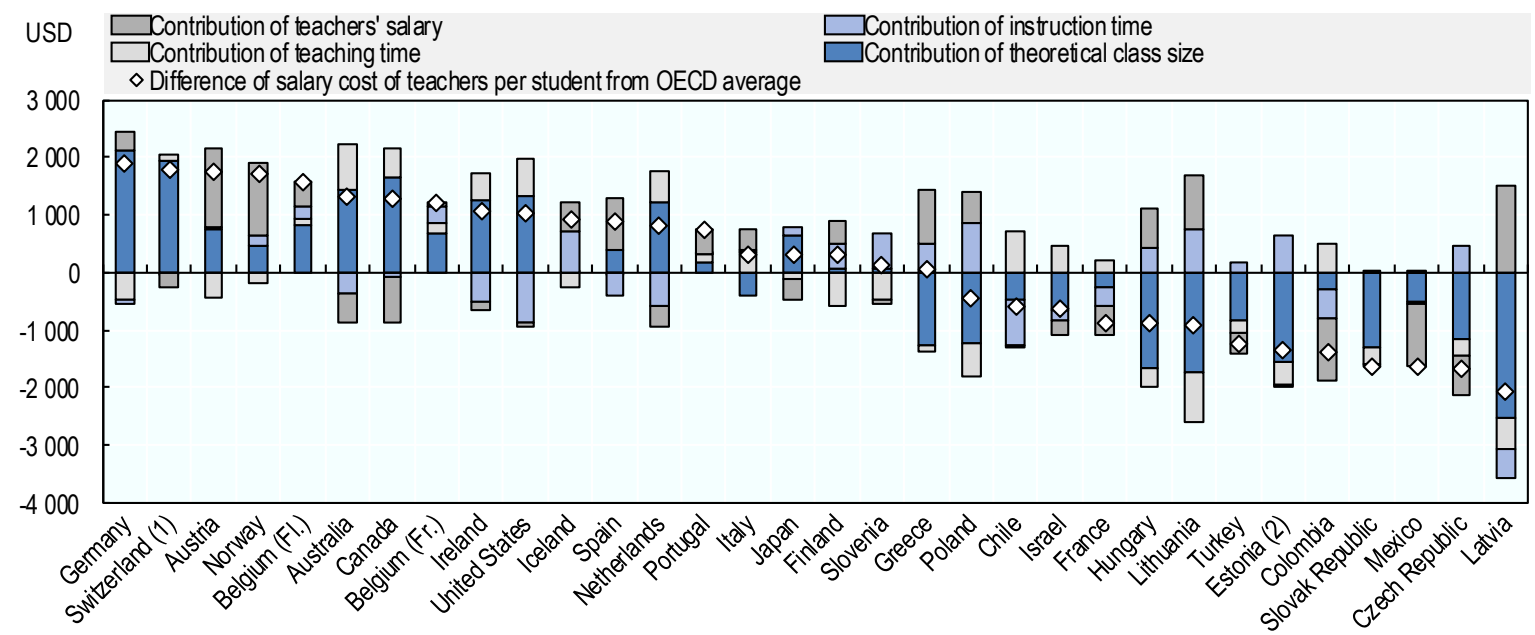

Notes: This figure shows the contribution (in USD) of the factors influencing the difference between salary cost of teachers per student in the country and the OECD average. For example, in Poland, the salary cost of teachers per student is USD 429 lower than the OECD average. Poland has a smaller theoretical class size (+ USD 521) and less teaching time (+ USD 864) than the OECD average, both of which push the salary cost of teachers up. However, this is more than compensated for by below-average teachers' salaries (- USD 1226) and below-average instruction time (- USD 588), which push the cost down. Teachers' salaries refer to annual statutory salaries in public institutions. Countries and economies are ranked in descending order of the difference between the salary cost of teachers per student and the OECD average.

1. Teachers' statutory salaries after ten years of experience instead of 15 years.

2. Teachers' statutory salaries at the start of their career instead of after 15 years of experience.

Source: OECD (2019), Education at a Glance 2019: OECD Indicators, OECD Publishing, Paris, https://doi.org/10.1787/f8d7880d-en, Figure C7.2, Table C7.2.

StatLink 제개 https://doi.org/10.1787/888934026221

As the experience of OECD review countries suggests, the overall resource implications of human resource policy changes are often underestimated in the design stage. To be effective, human resource policies must recognise important resource trade-offs and be implemented in ways that are sensitive to the unique contexts and cultures of schools and school-level professions. This report will articulate various policy options and describe the nuances and subtleties required to implement successful human resource policies in different contexts.

Likewise, human resource policies must be complemented by supportive funding mechanisms that are based on sufficient levels of spending and that are aligned with policy priorities and educational objectives. As research from the United States suggests, the level of resources matters, even if still more needs to be understood in what contexts and how (Jackson, 2018 ${ }_{[75]}$ ). Insufficient investments in professional staff or spending reforms driven by reductions in teachers' salaries, initial education and professional learning may make a career in schools less attractive and motivating, thus crowding out the best and most qualified professionals. School funding is discussed in depth in the project's dedicated thematic report (see OECD $\left(2017_{[40]}\right)$ ). 
Given the labour-intensive nature of school education, policy decisions on human resources in schools have a substantial impact on educational spending. School education is costly and getting more so, reflecting a continuous increase in the cost of human resources since public sector services which rely on non-routine tasks have limited potential for growth in productivity over time (Wolff, Baumol and Saini, 2014[76]; Baumol, 2012[77]).

Furthermore, rapid social and technological change requires continuous investments in professional learning to prepare teachers, school leaders and other staff to meet the changing needs in classrooms and educational provision. In other words, the cost of human resources in school education is rapidly growing to cover both intrinsic and extrinsic needs of continuing professional learning for adults in schools to maintain the effectiveness and relevance of their practice.

\subsection{Human resource policies need to be carefully designed and implemented}

Many countries find that reforms are necessary to make careers in schools more attractive and motivating, distribute staff more effectively and equitably, and promote professional learning that meets individual, school and system goals. However, reforming policies that directly influence working environments in schools can pose significant design and implementation challenges (Viennet and Pont, 2017 $[78]$ ). Human resource policy reforms often involve a degree of uncertainty about the distribution of their benefits and are likely to cause resistance among those who feel they lose out, whether in absolute or relative terms. Policy makers also need to bear in mind the inertia of reform processes and the significant amount of time that it can take for a change in policy that applies to new staff to reach all or even just a majority of the profession.

The complex governance arrangements underpinning policies for school staff further complicate the design and implementation of reforms since they may require multiple levels of government to act in concert and social partners and professional organisations to be involved. Engaging in open dialogue with stakeholders and involving them in reform design and implementation processes are key principles of effective governance (Burns and Köster, 2016[79]).

To build and sustain trust for their implementation, human resource policies must be underpinned by clear communication, consensus building among the various stakeholders, and processes for prioritising competing claims on resources. At a system level, the involvement of teacher and school leader unions and professional bodies in defining the parameters of their roles and the conditions needed to carry them out effectively is key to preserving and mobilising staff professionalism (OECD, 2015 [80]).

Special attention also needs to be paid to the role of school leadership as the interface between system-level policy changes and school-based initiatives (Pont, Nusche and Moorman, 2008 $\left.8_{[19]}\right)$. School leaders' capacity to shape and implement policy changes in a way that makes sense in their local context is essential for reforms to be meaningful at the school level. This requires support mechanisms as well as opportunities for professional exchange, regular feedback, mentoring and professional learning. The time demands placed on school leaders also need to be reviewed carefully.

Across national contexts, school leaders often report working excessive hours. Simply demanding more of school leaders in terms of changing working processes and leading professional improvement in their school is unlikely to either generate positive results or improve their recruitment and retention. In this context, a critical consideration is to redistribute resources within schools and systems to shift some responsibilities for school 
management, professional evaluation and pedagogical leadership to permit those responsible for each task to be able to do so effectively (see in particular Chapter 2).

Teachers' involvement in the decision-making processes that affect their work can provide a means for schools to mobilise leadership capacity at all levels (Ingersoll, Sirinides and Dougherty, 2017 ${ }_{[81]}$; York-Barr and Duke, 2004 $\left.{ }_{[82]}\right)$. It can offer teachers an opportunity to communicate and address their needs while assuming greater collective responsibility for their school's improvement. An extensive body of research points to professional autonomy as a key dimension of job characteristics that affect workers' sense of self-efficacy, their satisfaction and intrinsic motivation (Hackman and Oldham, 1976[83]). It has also been shown to affect turnover rates among some groups of teachers (Ingersoll and May, $\left.2012_{[84]}\right)$. Fostering trusting relationships that allow professionals to individually or collectively take control over their work and working conditions can therefore strengthen their individual motivation and self-efficacy and generate positive outcomes at the organisational and system level.

\subsection{How this report looks at human resource policies}

This report was prepared as part of a major OECD study on the effective and equitable use of school resources resulting in the publication series OECD Reviews of School Resources. This publication series encompasses thematic comparative reports that synthesise the review's major findings on school resource policies, drawing on evidence from research and the project's country-specific analyses. The three thematic reports published thus far cover the following topics: i) the funding of school education (OECD, 2017 [40] $)$, ii) school facilities, sectors and programmes (OECD, 2018 $\left.{ }_{[26]}\right)$ and iii) human resource policies (present report). Box 1.2 provides more information on the main features of the study.

This report on human resource policies builds on previous policy-based work undertaken by the OECD as part of the Teachers Matter and Improving School Leadership projects (Pont, Nusche and Moorman, 2008 ${ }_{[19]}$; OECD, 2005[85]), and the organisation's large-scale surveys TALIS and PISA and the data and insights they generate on the role of teachers, school leaders and other staff in school systems.

This report also links to and supports the wider international agenda of the United Nation's Sustainable Development Goals (SDGs) adopted in September 2015, which recognise the important role of teachers and teaching for effective learning at all levels of education. Sustainable Development Goal 4 to ensure "inclusive and equitable quality education and promote lifelong learning opportunities for all" includes a commitment to: "ensure that teachers and educators are empowered, adequately recruited, well-trained, professionally qualified, motivated and supported within well-resourced, efficient and effectively governed systems" (UNESCO, 2016, p. 8[86])

Target 4.c of the SDGs relates specifically to teachers: "By 2030, substantially increase the supply of qualified teachers, including through international co-operation for teacher training in developing countries, especially least developed countries and small island developing States" (United Nations, 2015 [87]). Other targets, means of implementation, and indicators of Goal 4 indirectly address the contribution of teachers to quality education. For example, the intent underlying indicator 4.7.1 is to monitor the "[e]xtent to which i) global citizenship education and ii) education for sustainable development, including gender equality and human rights, are mainstreamed at all levels in: a) national education policies, b) curricula, c) teacher education and d) student assessment" (UNESCO, 2016, p. 79 [86]). 
This present report on human resource policies is also related to similar work undertaken by other international organisations. In 2015, UNESCO's International Task Force on Teachers for Education for All $\left(2015_{[88]}\right)$ published a teacher policy development guide. Drawing on experiences and good practices among its members, the International Labour Organization (ILO) published a Handbook of good human resource practices in the teaching profession in 2012 (ILO, 2012 [89]). In 1966, both organisations published a Recommendation concerning the Status of Teachers, an international instrument which provides guidance for governments, employers, teacher unions, and other stakeholders in the crafting of effective teacher policies (UNESCO/ILO, 2016 ${ }_{[90]}$ ).

\section{Box 1.2. The OECD School Resources Review}

The OECD Review of Policies to Improve the Effectiveness of Resource Use in Schools (also known as the School Resources Review) was launched in 2013. This review is conducted in collaboration with countries and under the guidance of the OECD Group of National Experts (GNE) on School Resources, a subsidiary body of the OECD Education Policy Committee (EDPC). The GNE on School Resources comprises representatives from all participating countries and other OECD countries. It guides the review and facilitates the exchange of information and experiences concerning school resources among countries. Between May 2014 and November 2019, the GNE on School Resources held six official meetings at the OECD in Paris. These were open to all OECD member countries and observers to the Education Policy Committee as well as to the Trade Union Advisory Committee to the OECD (TUAC) and the Business and Industry Advisory Committee to the OECD (BIAC).

The review aims to respond to the strong interest in the effective use of school resources evident at national and international levels. It provides analysis and policy advice on the use of school resources to help governments achieve quality, efficiency and equity objectives in school education. It focuses on primary and secondary levels, although links to other levels of education are also established where relevant.

\section{Key issues for analysis}

School systems use a broad range of resources. This review primarily considers three types of closely interlinked resources:

- school funding (e.g. education spending, funding allocation mechanisms)

- school networks (e.g. school size, location, facilities, sectors and programmes)

- school staff (e.g. teachers, school leaders, professional support staff).

Other resources, in particular time and information and communication technologies (ICT) may be considered in a second stage of the project.

The overarching policy question guiding the review is "What policies best ensure that school resources are effectively used to improve student outcomes?"

The analysis is structured around three dimensions of policy:

- governance (who makes decisions about resource use and how are they implemented)

- distribution (how to allocate resources across different priorities) 
- management (how to plan, evaluate and follow up on resource use).

\section{Review objectives and methodology}

The work of the School Resources Review is designed to support governments in developing effective national education policies. In particular, the project proposes policy options to ensure that school resources are effectively and equitably used to improve student outcomes. The project provides opportunities for countries to learn from one another by exchanging best practices, and to gather and disseminate evidence on effective resource policies. Through the public dissemination of its results, the project also seeks to inform policy debates on school resources among relevant stakeholders.

The project involves a reflection about the policy implications of the currently available evidence on the use of school resources in a wide range of national settings. The evidence it draws on includes relevant academic and policy papers published in peer-reviewed journals, detailed information provided by countries on their school resource policies, as well as the experience and perspectives of a wide range of stakeholders in participating countries. The work is undertaken through a combination of desk-based analysis, country reviews and periodic meetings of the GNE on School Resources, which provides feedback on substantive documents and determines priorities for analytical work.

The work is organised in three overlapping strands:

- An analytical strand draws together different types of evidence - international indicators, country background reports (CBRs), academic research and policy papers - to understand the factors that shape resource use in school systems and develop a comparative perspective on resource policy issues.

- A country review strand provides individual countries with policy advice on resource issues tailored to their priorities, drawing on international evidence and the insights obtained by a team of experts visiting the country. For each country review, a team of up to five reviewers (including at least two OECD Secretariat members) analyses the country background report and subsequently undertakes an intensive case study visit of about eight days in length. Each study visit aims to provide the review team with a variety of perspectives on school resource policies and includes meetings with a wide variety of stakeholders. Country review reports are published in the series OECD Reviews of School Resources.

- A synthesis strand with the preparation of a series of thematic comparative reports. These blend analytical and review evidence and provide an overview of common challenges and policy options on specific themes.

\section{Collaborations}

This report was prepared within a broader framework of collaboration and a partnership with the European Commission (EC), which was established for the OECD School Resources Review. The support of the EC has covered part of the participation costs for members of the European Union Erasmus + programme and contributed significantly to the preparation of the series of thematic comparative reports, including this publication. The review of Kazakhstan was undertaken in co-operation with the World Bank.

Other international agencies collaborating with the project include Eurocities, the European Agency for Special Needs and Inclusive Education, the European Investment Bank (EIB) Eurydice (Education Information Network in Europe), the Inter-American 
Development Bank (IDB), the International Labour Organization (ILO), the IMTEC Foundation (International Movement Towards Educational Change), the Organising Bureau of European School Student Unions (OBESSU), the Standing International Conference of Inspectorates (SICI), the United Nations Educational, Scientific and Cultural Organization (UNESCO), UNESCO's Global Education Monitoring Report team (GEMR), and the UNESCO International Institute for Educational Planning (IIEP).

Social partners are also involved through the contribution of the Trade Union Advisory Committee to the OECD (TUAC) and the Business and Industry Advisory Committee to the OECD (BIAC), which participate in the GNE as Permanent Observers.

\subsubsection{The evidence base}

The analysis in this report is based on multiple sources of evidence, including, first and foremost, the analysis of countries actively participating in the review. In 2019, 21 school systems were actively engaged in the review and are referred to as the "OECD review countries" throughout this report. These 21 school systems represent a wide range of economic, social and cultural contexts. The diversity in approaches to their human resource policies enables this report to take a comparative perspective on key policy issues. In addition, this report seeks to go beyond information collected from OECD review countries by drawing on data collections and case studies from across the OECD and beyond, as well as the relevant international research literature.

The OECD review countries also took part in a collection of qualitative data on the main features of their human resource policies and prepared a detailed background report, following a standard set of guidelines. By November 2019, 12 of these school systems had also conducted a country review, undertaken by a review team consisting of members of the OECD Secretariat and external experts. Country reviews provide an independent analysis by the review team of identified strengths and challenges in the use of resources in these countries. In their analysis, the review teams drew on information gathered through interviews with a broad range of stakeholders, including social partners, during a main country review study visit.

This report draws on four main sources of information:

- Twelve country review reports completed by OECD-led review teams for the following school systems: Austria, Belgium (Flemish Community), Chile, Colombia, the Czech Republic, Denmark, Estonia, Kazakhstan, Lithuania, Portugal, the Slovak Republic and Uruguay.

- Eighteen country background reports completed by the following school systems: Austria, Belgium (Flemish Community), Belgium (French Community), Chile, Colombia, the Czech Republic, Denmark, Estonia, Iceland, Kazakhstan, Lithuania, Luxembourg, Portugal, the Slovak Republic, Slovenia, Spain, Sweden and Uruguay.

- Twenty-one responses to a qualitative data collection on national approaches to human resource policies provided by the following school systems: Australia, Austria, Belgium (Flemish Community), Belgium (French Community), Chile, Colombia, the Czech Republic, Denmark, Estonia, Iceland, Kazakhstan, Lithuania, Luxembourg, Mexico, Portugal, the Slovak Republic, Slovenia, Spain, Sweden, Turkey and Uruguay. 
- A range of literature reviews bringing together research findings on relevant issues. Published literature reviews and analytical papers include, among others, OECD working papers on learning in rural schools and learning support staff.

\subsubsection{The importance of context}

When reading this report, it is important to keep in mind that the contexts within which human resource policies operate can vary markedly across countries depending on their historical traditions, educational cultures and economic and social conditions. Policy initiatives that work well in one national context are not necessarily transferable. The review has attempted to be sensitive to this through an approach that analyses human resource policies in relation to the values, vision and organisation of school systems in different countries as well as the broader economic, social, political and cultural contexts in which they operate.

It is important to note that not all policy directions apply equally across countries. In a number of cases, the ideas for policy are already in place, while for others they may have less relevance. The implications also need to be treated cautiously since in some instances the research base is not sufficiently strong enough across a number of countries to draw confident conclusions. Rather, the discussion attempts to distil potentially useful ideas and lessons from the experiences of countries that have been searching for better ways to mobilise, recognise and preserve the impact of their adults working in schools.

\subsubsection{The structure of this report}

The report has five chapters. Following Chapter 1 which lays out the importance of effective human resource policies for effective working and learning environments, Chapters 2-4 are concerned with the key substantive issues of human resource policies: attractive and motivating careers (Chapter 2); effective and equitable school staffing (Chapter 3); and powerful professional learning (Chapter 4). The chapters provide a description of policies and practices in countries, analyse strengths and weaknesses of different approaches, and provide ideas for policy.

Notes

\footnotetext{
${ }^{1}$ Note that the definitions provided to school principals are not exactly the same as those that are used throughout this report.
} 


\section{References}

Albornoz, F., S. Berlinski and A. Cabrales (2018), "Motivation, resources, and the organization of the school system”, Journal of the European Economic Association, Vol. 16/1, pp. 199-231, http://dx.doi.org/10.1093/jeea/jvx001.

Banerjee, A. et al. (2007), "Remedying education: Evidence from two randomized experiments in India", The Quarterly Journal of Economics, Vol. 122/3, pp. 1235-1264, http://dx.doi.org/10.1162/qjec.122.3.1235.

Baumol, W. (2012), The Cost Disease: Why Computers Get Cheaper and Health Care Doesn't, Yale University Press, New Haven, London, http://www.jstor.org/stable/j.ctt32bhj9.

Bellei, C. et al. (2016), "School improvement trajectories: an empirical typology", School Effectiveness and School Improvement, Vol. 27/3, pp. 275-292, http://dx.doi.org/10.1080/09243453.2015.1083038.

Biesta, G., M. Priestley and S. Robinson (2015), "The role of beliefs in teacher agency", Teachers and Teaching, Vol. 21/6, pp. 624-640, http://dx.doi.org/10.1080/13540602.2015.1044325.

Biesta, G. and M. Tedder (2007), "Agency and learning in the lifecourse: Towards an ecological perspective", Studies in the Education of Adults, Vol. 39/2, pp. 132-149, http://dx.doi.org/10.1080/02660830.2007.11661545.

Blazar, D. and M. Kraft (2016), "Teacher and teaching effects on students' attitudes and behaviors", Educational Evaluation and Policy Analysis, Vol. 39/1, pp. 146-170, http://dx.doi.org/10.3102/0162373716670260.

BMBWF (2019), Das Autonomiepaket der Bildungsreform [The autonomy package of education reform], https://bildung.bmbwf.gv.at/schulen/autonomie/index.html (accessed on 15 May 2019).

BMBWF (2019), Personal an ganztägigen Schulformen [Staff in all-day school forms], https://bildung.bmbwf.gv.at/schulen/gts/pers/index.html (accessed on 15 June 2019).

Branch, G., E. Hanushek and S. Rivkin (2012), "Estimating the effect of leaders on public sector productivity: The case of school principals", NBER Working Papers, No. 17803, National Bureau of Economic Research, Cambridge, MA, http://dx.doi.org/10.3386/w17803.

Bryk, A. et al. (2010), Organizing schools for improvement: lessons from Chicago, University of Chicago Press, Chicago.

Burns, T. and F. Köster (eds.) (2016), Governing Education in a Complex World, Educational Research and Innovation, OECD Publishing, Paris, https://dx.doi.org/10.1787/9789264255364-en.

Chetty, R., J. Friedman and J. Rockoff (2014), "Measuring the impacts of teachers II: Teacher value-added and student outcomes in adulthood", American Economic Review, Vol. 104/9, pp. 2633-2679, http://dx.doi.org/10.1257/aer.104.9.2633.

Cobb-Clark, D. and N. Jha (2016), "Educational achievement and the allocation of school resources", Australian Economic Review, Vol. 49/3, pp. 251-271, http://dx.doi.org/10.1111/1467-8462.12159.

Coelli, M. and D. Green (2012), "Leadership effects: school principals and student outcomes”, Economics of Education Review, Vol. 31/1, pp. 92-109, http://dx.doi.org/10.1016/j.econedurev.2011.09.001.

Day, C. and J. Sachs (2005), "Professionalism, Performativity and Empowerment: Discourses in the Politics, Policies and Purposes of Continuing Professional Development", in Day, C. and J. Sachs (eds.), International Handbook on the Continuing Professional Development of Teachers, McGrawHill Education, New York, NY. 
Educational Policy Institute (2015), OECD Review of Policies to Improve the Effectiveness of Resource Use in Schools: Country Background Report of the Slovak Republic, Ministry of Education, Science, Research and Sport, Bratislava, http://www.oecd.org/education/school-resources-review.

Englund, T. (2002), “Are professional teachers a good thing?”, in Goodson, I. (ed.), Teachers' Professional Lives, Routledge, London.

Eurydice (2019), Database of National Education Systems, https://eacea.ec.europa.eu/nationalpolicies/eurydice/national-description_en.

Evans, L. (2008), "Professionalism, professionality and the development of education professionals", British Journal of Educational Studies, Vol. 56/1, pp. 20-38, http://www.jstor.org/stable/20479569.

Evetts, J. (2003), “The sociological analysis of professionalism”, International Sociology, Vol. 18/2, pp. 395-415, http://dx.doi.org/10.1177/0268580903018002005.

Fox, C. (1992), "What do we mean when we say 'professionalism'? A language usage analysis for public administration", The American Review of Public Administration, Vol. 22/1, pp. 1-17, http://dx.doi.org/10.1177/027507409202200101.

Freidson, E. (1994), Professionalism Reborn: Theory, Prophecy and Policy, The University of Chicago Press, Chicago.

Gershenson, S. (2016), "Linking teacher quality, student attendance, and student achievement", Education Finance and Policy, Vol. 11/2, pp. 125-149, http://dx.doi.org/10.1162/edfp a 00180.

Grissom, J. and B. Bartanen (2018), "Strategic retention: Principal effectiveness and teacher turnover in multiple-measure teacher evaluation systems", American Educational Research Journal, Vol. 20/10, pp. 1-42, http://dx.doi.org/10.3102/0002831218797931.

Grissom, J. and S. Loeb (2011), "Triangulating principal effectiveness: How perspectives of parents, teachers, and assistant principals identify the central importance of managerial skills", American Educational Research Journal, Vol. 48/5, pp. 1091-1123, http://dx.doi.org/10.3102/0002831211402663.

Grissom, J., S. Loeb and B. Master (2013), "Effective instructional time use for school leaders: Longitudinal evidence from observations of principals", Educational Researcher, Vol. 42/8, pp. 433444, http://dx.doi.org/10.3102/0013189X13510020.

Hackman, J. and G. Oldham (1976), "Motivation through the design of work: Test of a theory", Organizational Behavior and Human Performance, Vol. 16/2, pp. 250-279, http://dx.doi.org/10.1016/0030-5073(76)90016-7.

Hallinger, P. and R. Heck (1998), "Exploring the principal's contribution to school effectiveness: 19801995*”, School Effectiveness and School Improvement, Vol. 9/2, pp. 157-191, http://dx.doi.org/10.1080/0924345980090203.

Hargreaves, A. (2002), “Teachers' professional lives: Aspirations and actualities”, in Goodson, I. (ed.), Teachers' professional lives, Routledge, London.

Hargreaves, A. and M. O'Connor (2018), "Solidarity with solidity", Phi Delta Kappan, Vol. 100/1, pp. 2024, http://dx.doi.org/10.1177/0031721718797116.

Heckman, J., J. Stixrud and S. Urzua (2006), "The effects of cognitive and noncognitive abilities on labor market outcomes and social behavior", Journal of Labor Economics, Vol. 24/3, pp. 411-482, http://dx.doi.org/10.1086/504455.

Heller, R. (2018), “The editor's note: Who matters?”, Phi Delta Kappan, Vol. 99/7, pp. 4-4, http://dx.doi.org/10.1177/0031721718767851.

Holroyd, C. (2000), “Are assessors professional?", Active Learning in Higher Education, Vol. 1/1, pp. 2844, http://dx.doi.org/10.1177/1469787400001001003. 
Hoyle, E. (2001), "Teaching: Prestige, status and esteem", Educational Management Administration \& Leadership, Vol. 29/2, pp. 139-152, https://doi.org/10.1177\%2F0263211X010292001.

Hoyle, E. (1974), "Professionality, professionalism and control in teaching", London Educational Review, Vol. 3/2, pp. 13-19.

ILO (2012), Handbook of good human resource practices in the teaching profession, International Labour Organization, Geneva, https://www.ilo.org/sector/Resources/publications/WCMS_187793/lang-en/index.htm (accessed on 25 July 2019).

Ingersoll, R. and H. May (2012), "The magnitude, destinations, and determinants of mathematics and science teacher turnover", Educational Evaluation and Policy Analysis, Vol. 34/4, pp. 435-464, http://dx.doi.org/10.3102/0162373712454326.

Ingersoll, R., P. Sirinides and P. Dougherty (2017), "School leadership, teachers' roles in school decisionmaking, and student achievement", CPRE Working Papers, No. 2, Consortium for Policy Research in Education, University of Pennsylvania, http://repository.upenn.edu/cpre workingpapers (accessed on 25 June 2019).

International Task Force on Teachers for Education for All (2015), Teacher Policy Development Guide: Summary, UNESCO, Paris, https://unesdoc.unesco.org/ark:/48223/pf0000235272 (accessed on 25 July 2019).

Jackson, C. (2018), "Does school spending matter? The new literature on an old question", NBER Working Paper, No. 25368, National Bureau of Economic Research, Cambridge, MA, http://dx.doi.org/10.3386/w25368.

Jackson, C. (2018), "What do test scores miss? The importance of teacher effects on non-test score outcomes", Journal of Political Economy, Vol. 126/5, pp. 2072-2107, http://dx.doi.org/10.1086/699018.

Jennings, J. and T. DiPrete (2010), “Teacher effects on social and behavioral skills in early elementary school", Sociology of Education, Vol. 83/2, pp. 135-159, http://dx.doi.org/10.1177/0038040710368011.

Johnson, S. (2009), "How best to add value? Strike a balance between the individual and the organization in school reform", EPI Briefing Papers, No. 249, Economic Policy Institute, Washington, DC, https://www.epi.org/publication/bp249 (accessed on 15 July 2019).

Koedel, C. (2008), "Teacher quality and dropout outcomes in a large, urban school district", Journal of Urban Economics, Vol. 64/3, pp. 560-572, http://dx.doi.org/10.1016/j.jue.2008.06.004.

Kraft, M. (2019), "Teacher effects on complex cognitive skills and social-emotional competencies", Journal of Human Resources, Vol. 54/1, pp. 1-36, http://dx.doi.org/10.3368/jhr.54.1.0916.8265r3.

Kraft, M., W. Marinell and D. Shen-Wei Yee (2016), "School organizational contexts, teacher turnover, and student achievement: Evidence from panel data", American Educational Research Journal, Vol. 53/5, pp. 1411-1449, http://dx.doi.org/10.3102/0002831216667478.

Kraft, M. et al. (2015), "Educating amid uncertainty”, Educational Administration Quarterly, Vol. 51/5, pp. 753-790, http://dx.doi.org/10.1177/0013161x15607617.

Levin, H. (2012), "More than just test scores", Prospects, Vol. 42/3, pp. 269-284, http://dx.doi.org/10.1007/s11125-012-9240-z.

Liebowitz, D. et al. (2018), OECD Reviews of School Resources: Portugal 2018, OECD Reviews of School Resources, OECD Publishing, Paris, https://dx.doi.org/10.1787/9789264308411-en.

Liebowitz, D. and L. Porter (2019), "The effect of principal behaviors on student, teacher, and school outcomes: A systematic review and meta-analysis of the empirical literature", Review of Educational Research, p. 003465431986613, http://dx.doi.org/10.3102/0034654319866133. 
Liu, J. and S. Loeb (2019), "Engaging teachers: Measuring the impact of teachers on student attendance in secondary school", Journal of Human Resources, pp. 1216-8430R3, http://dx.doi.org/10.3368/jhr.56.2.1216-8430r3.

Masdeu Navarro, F. (2015), "Learning support staff: A literature review", OECD Education Working Papers, No. 125, OECD Publishing, Paris, https://dx.doi.org/10.1787/5jrnzm39w451-en.

Meals, A. (2018), “Who’s really driving student outcomes?”, Phi Delta Kappan, Vol. 99/7, pp. 31-34, http://dx.doi.org/10.1177/0031721718767857.

Millerson, G. (1964), The Qualifying Associations: A Study in Professionalization, Routledge, London.

Ministerio de Educación (2018), Estatuto de los Asistentes de la Educación Pública Ley 21.109, http://www.leychile.cl (accessed on 25 June 2019).

Ministerio de Educación Nacional (2015), Decreto Único Reglamentario del Sector Educación (Decreto 1075 de 2015), https://www.mineducacion.gov.co/portal/Normatividad (accessed on 15 June 2019).

Ministry of Education, Y. (2016), OECD Review of Policies to Improve the Effectiveness of Resource Use in Schools: Country Background Report of the Czech Republic, Czech Ministry of Education, Youth and Sports, Prague, http://www.oecd.org/education/school-resources-review.

Mosteller, F. (1997), "The Tennessee study of class size in the early school grades", Bulletin of the American Academy of Arts and Sciences, Vol. 50/7, p. 14, http://dx.doi.org/10.2307/3824562.

National Agency for School Evaluation (2015), OECD Review of Policies to Improve the Effectiveness of Resource Use in Schools: Country Background Report of Lithuania, National Agency for School Evaluation, Vilnius, http://www.oecd.org/education/school-resources-review/reports-for-participatingcountries-country-background-reports.htm.

Newman, J. and J. Clarke (1997), The managerial state: Power, politics and ideology in the remaking of social welfare, Sage, London.

Nusche, D. et al. (2016), OECD Reviews of School Resources: Austria 2016, OECD Reviews of School Resources, OECD Publishing, Paris, https://dx.doi.org/10.1787/9789264256729-en.

Nusche, D. et al. (2016), OECD Reviews of School Resources: Denmark 2016, OECD Reviews of School Resources, OECD Publishing, Paris, http://dx.doi.org/10.1787/9789264262430-en.

OECD (2019), Education at a Glance 2019: OECD Indicators, OECD Publishing, Paris, http://dx.doi.org/10.1787/f8d7880d-en.

OECD (2019), OECD Future of Education and Skills 2030 Conceptual learning framework. Concept note: OECD Learning Compass 2030, OECD, Paris, http://www.oecd.org/education/2030-project (accessed on 25 July 2019).

OECD (2019), TALIS 2018 Results (Volume I): Teachers and School Leaders as Lifelong Learners, TALIS, OECD Publishing, Paris, https://dx.doi.org/10.1787/1d0bc92a-en.

OECD (2018), Education Policy in Japan: Building Bridges towards 2030, Reviews of National Policies for Education, OECD Publishing, Paris, https://dx.doi.org/10.1787/9789264302402-en.

OECD (2018), Equity in Education: Breaking Down Barriers to Social Mobility, PISA, OECD Publishing, Paris, https://dx.doi.org/10.1787/9789264073234-en.

OECD (2018), Responsive School Systems: Connecting Facilities, Sectors and Programmes for Student Success, OECD Reviews of School Resources, OECD Publishing, Paris, https://dx.doi.org/10.1787/9789264306707-en.

OECD (2017), PISA 2015 Results (Volume III): Students' Well-Being, PISA, OECD Publishing, Paris, https://dx.doi.org/10.1787/9789264273856-en.

OECD (2017), The Funding of School Education: Connecting Resources and Learning, OECD Reviews of School Resources, OECD Publishing, Paris, https://dx.doi.org/10.1787/9789264276147-en. 
OECD (2016), School Leadership for Learning: Insights from TALIS 2013, TALIS, OECD Publishing,

Paris, https://dx.doi.org/10.1787/9789264258341-en.

OECD (2015), Education Policy Outlook 2015: Making Reforms Happen, OECD Publishing, Paris, https://dx.doi.org/10.1787/9789264225442-en.

OECD (2014), TALIS 2013 Results: An International Perspective on Teaching and Learning, TALIS, OECD Publishing, Paris, https://dx.doi.org/10.1787/9789264196261-en.

OECD (2013), Leadership for 21st Century Learning, Educational Research and Innovation, OECD Publishing, Paris, https://dx.doi.org/10.1787/9789264205406-en.

OECD (2005), Teachers Matter: Attracting, Developing and Retaining Effective Teachers, Education and Training Policy, OECD Publishing, Paris, https://dx.doi.org/10.1787/9789264018044-en.

Ozga, J. (1995), "Deskilling a Profession: Professionalism, Deprofessionalination and the New Managerialism", in Busher, H. and R. Saran (eds.), Managing teachers as professionals in school, Kogan Page, London.

Papay, J. and M. Kraft (2017), "Developing workplaces where teachers stay, improve and succeed", in Quintero, E. (ed.), Teaching in Context: How Social Aspects of School and School Systems Shape Teachers' Development \& Effectiveness, Harvard Education Press, Cambridge, MA.

Pont, B., D. Nusche and H. Moorman (2008), Improving School Leadership, Volume 1: Policy and Practice, OECD Publishing, Paris, https://dx.doi.org/10.1787/9789264044715-en.

Radinger, T. et al. (2018), OECD Reviews of School Resources: Colombia 2018, OECD Reviews of School Resources, OECD Publishing, Paris, https://dx.doi.org/10.1787/9789264303751-en.

Reback, R. (2010), "Schools' mental health services and young children's emotions, behavior, and learning", Journal of Policy Analysis and Management, Vol. 29/4, pp. 698-725, http://dx.doi.org/10.1002/pam.20528.

Rivkin, S., E. Hanushek and J. Kain (2005), "Teachers, schools, and academic achievement", Econometrica, Vol. 73/2, pp. 417-458, http://dx.doi.org/10.1111/j.1468-0262.2005.00584.x.

Robinson, V., C. Lloyd and K. Rowe (2008), "The impact of leadership on student outcomes: An analysis of the differential effects of leadership types”, Educational Administration Quarterly, Vol. 44/5, pp. 635-674, http://dx.doi.org/10.1177/0013161x08321509.

Rockoff, J. (2004), "The impact of individual teachers on student achievement: Evidence from panel data", American Economic Review, Vol. 94/2, pp. 247-252, http://dx.doi.org/10.1257/0002828041302244.

Sachs, J. (2015), “Teacher professionalism: Why are we still talking about it?”, Teachers and Teaching, Vol. 22/4, pp. 413-425, http://dx.doi.org/10.1080/13540602.2015.1082732.

Sánchez, J. (2018), OECD Review of Policies to Improve the Effectiveness of Resource Use in Schools: Country Background Report for Colombia, Ministerio de Educación Nacional, Bogotá DC, http://www.oecd.org/education/schoolresourcesreview.htm.

Santiago, P. et al. (2017), OECD Reviews of School Resources: Chile 2017, OECD Reviews of School Resources, OECD Publishing, Paris, https://dx.doi.org/10.1787/9789264285637-en.

Santiago, P. et al. (2016), OECD Reviews of School Resources: Slovak Republic 2015, OECD Reviews of School Resources, OECD Publishing, Paris, http://dx.doi.org/10.1787/9789264247567-en.

Shewbridge, C. et al. (2016), OECD Reviews of School Resources: Czech Republic 2016, OECD Reviews of School Resources, OECD Publishing, Paris, http://dx.doi.org/10.1787/9789264262379-en.

Sirin, S. (2005), "Socioeconomic status and academic achievement: A meta-analytic review of research", Review of Educational Research, Vol. 75/3, pp. 417-453, http://dx.doi.org/10.3102/00346543075003417. 
Sockett, H. (1996), "Teachers for the 21 st century: Redefining professionalism", NASSP Bulletin, Vol. 80/580, pp. 22-29, https://doi.org/10.1177\%2F019263659608058004.

Todd, P. and K. Wolpin (2003), "On the specification and estimation of the production function for cognitive achievement", The Economic Journal, Vol. 113/485, pp. F3-F33, http://dx.doi.org/10.1111/1468-0297.00097.

Troman, G. (1996), "The rise of the new professionals? The restructuring of primary teachers' work and professionalism", British Journal of Sociology of Education, Vol. 17/4, pp. 473-487, http://dx.doi.org/10.1080/0142569960170404.

UNESCO (2016), Education 2030: Incheon Declaration and Framework for Action for the Implementation of Sustainable Development Goal 4, UNESCO, Paris, https://unesdoc.unesco.org/ark:/48223/pf0000245656.

UNESCO (2016), Global Education Monitoring Report 2016: Education for People and Planet: Creating Sustainable Futures for All, UNESCO, Paris, https://en.unesco.org/gem-report/allreports (accessed on 25 July 2019).

UNESCO/ILO (2016), The ILO/UNESCO Recommendation concerning the Status of Teachers (1966) and the UNESCO Recommendation concerning the Status of Higher Education Teaching Personnel (1997) - Revised edition 2016, International Labour Office, Sectoral Policies Department, Geneva, https://www.ilo.org/wcmsp5/groups/public/---ed_dialogue/--sector/documents/normativeinstrument/wcms_493315.pdf (accessed on 25 July 2019).

United Nations (2015), Transforming Our World: The 2030 Agenda for Sustainable Development, Resolution adopted by the General Assembly on 25 September 2015, https://sustainabledevelopment.un.org/post2015/transformingourworld (accessed on 25 July 2019).

Viennet, R. and B. Pont (2017), "Education policy implementation: A literature review and proposed framework", OECD Education Working Papers, No. 162, OECD Publishing, Paris, https://dx.doi.org/10.1787/fc467a64-en.

Witziers, B., R. Bosker and M. Krüger (2003), "Educational leadership and student achievement: The elusive search for an association", Educational Administration Quarterly, Vol. 39/3, pp. 398-425, http://dx.doi.org/10.1177/0013161X03253411.

Wolff, E., W. Baumol and A. Saini (2014), "A comparative analysis of education costs and outcomes: The United States vs. other OECD countries", Economics of Education Review, Vol. 39, pp. 1-21, http://dx.doi.org/10.1016/j.econedurev.2013.12.002.

York-Barr, J. and K. Duke (2004), "What do we know about teacher leadership? Findings from two decades of scholarship", Review of Educational Research, Vol. 74/3, pp. 255-316, http://dx.doi.org/10.3102/00346543074003255. 


\section{Annex 1.A. Towards an international perspective on the mix of staff in schools}

\section{A range of staff with different roles and responsibilities work in and with schools supporting student learning and well-being}

School systems employ a diverse range of staff in both instructional and non-instructional roles and positions to work in and with schools. This includes:

- $\quad$ staff responsible for school leadership and direct instruction, notably school leaders and teachers, but also teacher aides

- professional pedagogical, health and social support staff

- administrative, maintenance and operations staff (see Annex Box 1.A.1 for definitions).

Which types of staff are employed, by whom and where depends on a number of factors, as discussed in the following section. Notably, this includes the functions of different types of staff, i.e. the way their roles and responsibilities are defined. For example, while teachers' roles are broad and complex everywhere, there are differences in the non-teaching activities that are defined in regulations (and for which teachers may be trained and/or compensated) (see Annex Figure 1.A.1), and the roles that teachers may grow into as part of their career (see Chapter 2).

In addition, teachers often perform voluntary tasks such as extracurricular activities, student teacher support, guidance counselling and school or other management activities (OECD, 2019 $\left.{ }_{[74]}\right)$. Also the role of school leaders differs, which will influence the other types of staff that are required in schools. In some countries, school leaders hold teaching responsibilities; in others, they dedicate themselves fully to school leadership and management (see Annex Figure 1.A.2), to mention just one cross-country difference. 


\section{Annex Figure 1.A.1. Tasks and responsibilities required of teachers (ISCED 2), 2017}

For teachers of general programmes in public institutions, OECD countries

\section{$\square$ Mandatory}

$\square$ Voluntary at the discretion of individual teachers

\section{$\square$ Required, at the discretion of individual schools}

$\square$ Not required
Mandatory or Required, at the discretion of individual schools

- Not applicable

$\square$ Mandatory, or Voluntary at the discretion of individual teachers

Tasks

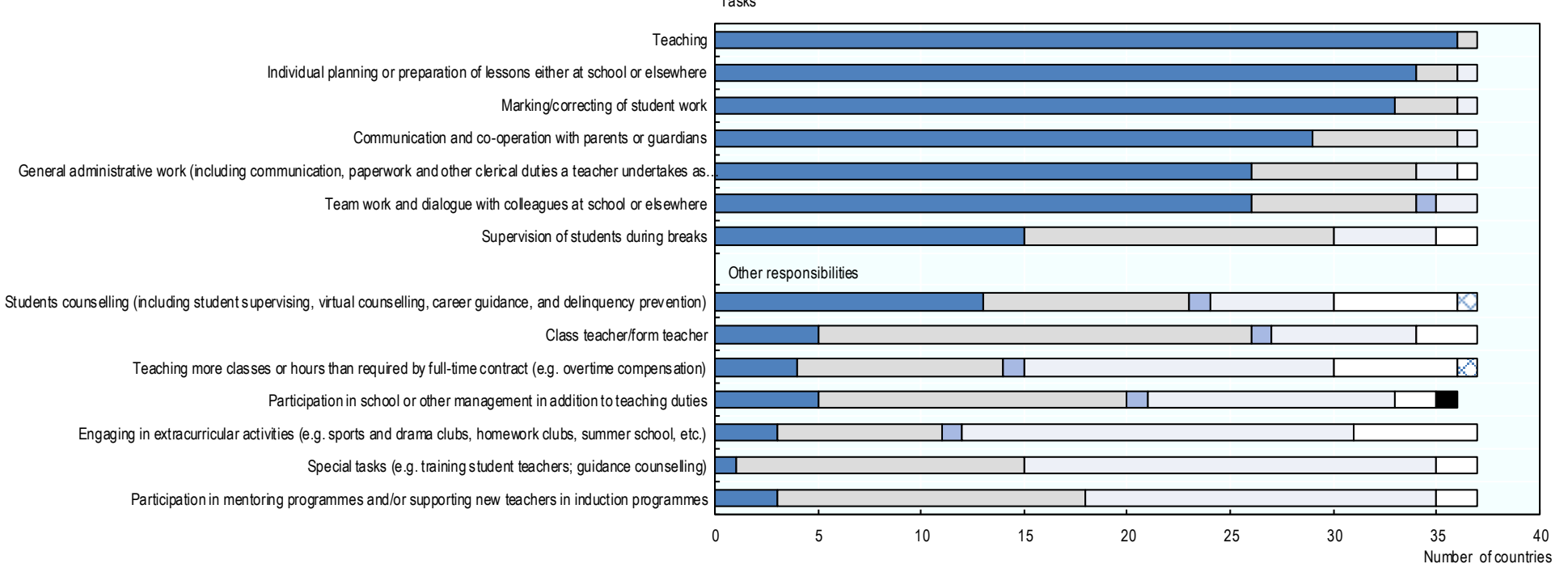

Note: On 25 May 2018, the OECD Council invited Colombia to become a Member. While Colombia is included among the countries for which data are reported in this figure, at the time of its preparation, Colombia was in the process of completing its domestic procedures for ratification and the deposit of Colombia's instrument of accession to the OECD Convention was pending.

Source: OECD (2019), Education at a Glance 2019: OECD Indicators, OECD Publishing, Paris, https://doi.org/10.1787/f8d7880d-en, Tables D4.3.a. and D4.3.b.

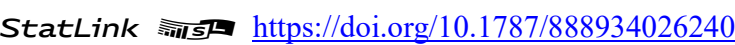


Annex Figure 1.A.2. Teaching requirement of school principals by level of education, 2018

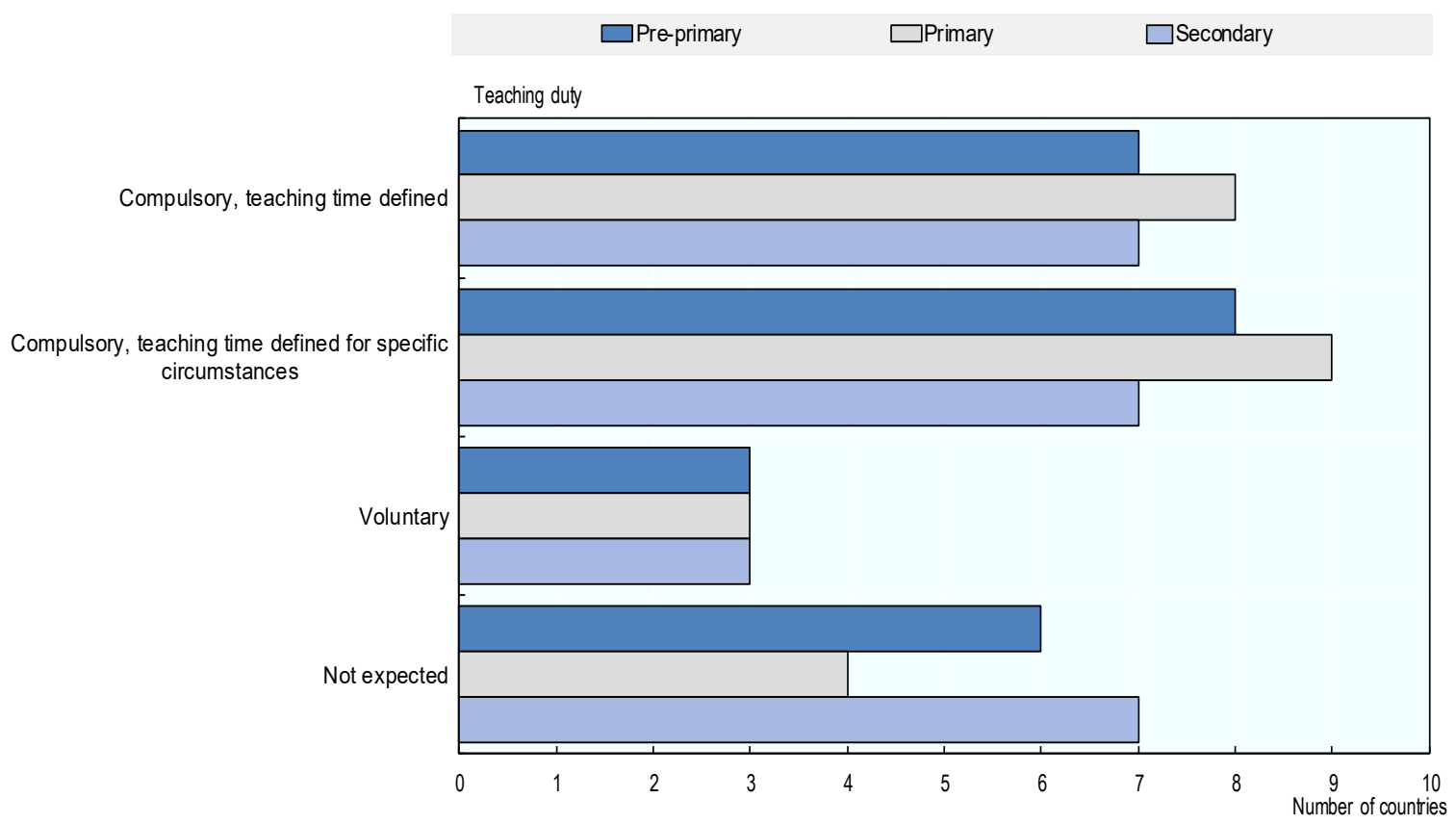

Note: The figure refers to responsibilities in public institutions as defined explicitly in regulations and/or steering documents. The secondary level of education includes both general and vocational programmes in lower and upper secondary education.

Source: OECD (2019), Education at a Glance 2019: OECD Indicators, OECD Publishing, Paris, https://doi.org/10.1787/f8d7880d-en, Figure D4.a.

StatLink 제으 https://doi.org/10.1787/888934026259

The OECD review illustrates the wide range of staff that may work in and with schools besides teachers and school leaders (see Annex Figure 1.A.3 and Annex 1.B). There is no comparative information about the employment regulations for school staff other than teachers and school leaders. However, the experience of the OECD review indicates that some types of staff may be regulated under the same legislation that applies to teachers and school leaders while others may not.

In the Czech Republic, for example, the Pedagogical Workers Act applies to teachers, but also different types of professional support staff (Ministry of Education, 2016 [91]). In Chile, by contrast, a specific statute stipulates the rights and duties of education assistants, a category of staff which brings together those who contribute to the delivery of education in professional, technical, administrative or auxiliary roles but are not teachers or school leaders (Ministerio de Educación, 2018 [92]).

\section{Professional support staff working in and with schools}

Looking more specifically at the type of professional support roles that exist in countries, many school systems employ professional pedagogical support staff such as guidance counsellors and school librarians, as well as health and social professionals, such as doctors, nurses, psychologists, social workers and social pedagogues. Depending on the role and the national context, some types of professional support staff may have been teachers prior 
to assuming their new role or even continue teaching in their new role albeit with a reduced teaching load.

\section{Annex Figure 1.A.3. Types of staff working in schools}

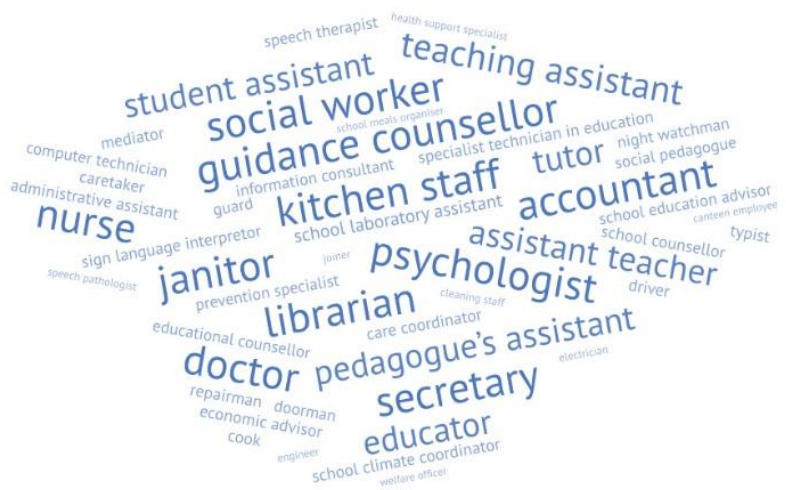

A number of countries have established dedicated professional support staff roles to promote the inclusion of special needs students, for example:

- In Colombia, the Secretaries of Education of territorial entities certified to provide education can employ different support professionals (profesionales de apoyo), such as sign language interpreters, mediators and typists, to support the inclusion of students with special educational needs (SEN), for which they receive resources through the country's fiscal transfer mechanism (Sánchez, 2018 [93]; Ministerio de Educación Nacional, 2015 [94]).

- In Lithuania, schools can employ special educational needs specialists as professional pedagogical support staff to promote inclusive education (National Agency for School Evaluation, 2015 [95]).

- In Spain, the Autonomous Communities can employ a range of specialist support staff, in particular Teachers specialised in Therapeutic Pedagogy (PT), Teachers specialised in Hearing and Speech (AL), and Technical Teachers of Community Service (PTSC) (Eurydice, 2019 $9_{[96]}$ ).

In addition, some countries have created dedicated professional pedagogical support staff related to the school climate and student safety and well-being:

- In Chile, for example, a national initiative to foster a positive school environment was supported by creating the role of school climate co-ordinators (encargado de convivencia escolar) responsible for creating an action plan and implementing related measures at the school level (Santiago et al., 2017, p. 192 ${ }_{[97])}$.

- In the Czech Republic, school prevention specialist positions have been established at schools since the late 1990s. These specialists typically lead the development and implementation of a school prevention programme to address risky behaviours among students, such as truancy, addiction, violence, and bullying. They also advise and train other staff in the identification and prevention of risky behaviours (Ministry of Education, 2016, p. 83 [91]; Eurydice, 2019 [96] $)$. 
- In Denmark, behaviour, contact and well-being counsellors (Adfcerd-KontaktTrivsel, AKT), support social processes in schools and areas related to behaviour, psychology and well-being. They can support individual students in and outside the classroom and work together with teachers in the classroom to help offer differentiated teaching according to students' needs. AKT counsellors can also initiate training in schools related to social issues, the development of social skills and inclusive communities, or general health education and the prevention of bullying and violence at school (Nusche et al., 2016, p. 149 $9_{[28]}$ ).

Of course, where such roles do not exist, other types of staff - including teachers - may fulfil related responsibilities as part of their task profile as the example of Colombia illustrates. In Colombia, school counsellors (orientadores) have the role to help resolve conflicts in school, foster the respect of human rights and the free personal development of students, support students with learning difficulties, provide guidance to parents and students, and develop activities with other institutions (Radinger et al., 2018, p. $212_{[98]}$ ).

Also within countries, roles of different staff may overlap to some extent in the responsibilities their function entails. For example, in the Slovak Republic, there are social educators who perform tasks related to the prevention and intervention of risky behaviours with a focus on disadvantaged students. In addition, educational counsellors fulfil a range of tasks, including academic and vocational guidance, but also the prevention of risky behaviours, while teachers can take on tasks in the area of behavioural interventions as prevention co-ordinators (Educational Policy Institute, 2015, pp. 114, 116 [99]; Eurydice, $\left.2019_{[96]}\right)$.

Depending on the system, professional support staff may work in schools, externally (i.e. in the form of resource centres that provide specialised and multidisciplinary expertise and staff such as social workers and medical professionals), or both. Also other public authorities outside of the school sector may provide specialised staff and services, such as career guidance or social and youth support and complement staff resources available within school education. Such external services may also provide opportunities for career development for school staff as discussed in Chapter 2.

Of course, externally employed staff can still work closely with and in schools, for instance where staff from specialised resource centres are shared across schools and work in different schools for some part of their working week. This may be the case for the psychological and paramedical staff working in Centres for Student Guidance (Centrum voor Leerlingenbegeleiding, CLB) in the Flemish Community of Belgium, for instance, which may have agreements with schools for staff to be present during school hours. Similarly, in the French Community, the staff of Centres for Psychological, Medical and Social Services (Centre Psycho-Médico-Social, CPMS) play an important role within schools, collaborating closely with teachers and school principals.

In addition, with the greater inclusion of children with special needs in mainstream education, special needs schools and their staff have taken on a broader role in a number of systems, supporting inclusive instruction across a number of mainstream schools (OECD, $\left.2018_{[26]}\right)$. The Flemish Community of Belgium again provides an example, having recently created support networks for special needs students in mainstream education, which include both mainstream and special needs schools. Through the support network, specialised staff, such as psychologists and paramedical personnel, attached administratively to a special needs school, work for and in mainstream schools of the same network. 
Schools typically can also draw on pedagogical guidance provided through the education administration, such as an education ministry or school inspection, or dedicated education advisory services that provide consulting, research and expertise to schools (see in particular Chapter 3 for further details).

\section{Annex Box 1.A.1. Types of staff working in school education}

The UNESCO-UIS/OECD/EUROSTAT (UOE) Manual on concepts, definitions and classifications for the Data collection on formal education provides a framework to classify educational staff for all levels of education (ISCED 0 through 8). This classification is based on the primary or major functions performed by staff and organises staff into four main functional categories: i) instructional personnel, ii) professional support for students; iii) management/quality control/administration; and iv) maintenance and operations personnel. Three of these four main functions contain sub-functions with specialised types of staff.

Given the scope and focus of this report, the following provides definitions for the relevant functions and sub-functions for ISCED 1-3 mainstream settings. This excludes, for instance, higher-level management and administrative personnel, which are not covered in this report. For consistency with the analysis in this report, the manual's main function of "classroom teachers" is referred to as "teachers"; the sub-function of "school-level management" is referred to as "school leaders". In the UOE manual, instructional staff includes both teachers and teacher aides; professional support includes pedagogical, health and social support staff.

Readers should note that national classifications and terminology of staff types may differ and that roles of staff may overlap depending on their defined tasks and responsibilities.

Teachers are employed in a professional capacity to guide and direct the learning experiences of students, irrespective of their training, qualifications or delivery mechanism (i.e. face-to-face or at distance). Teaching involves planning, organising and conducting group activities whereby students' knowledge, skills and competencies develop as stipulated by the educational programme in which they participate.

This includes classroom teachers and other teachers who work with students as a whole class in a classroom, in small groups in a resource room, or one-on-one inside or outside a regular classroom. This excludes educational staff who have few or no teaching duties but whose primary function is not teaching (e.g. it is managerial or administrative) as well as student teachers, teacher aides and paraprofessionals.

School leaders cover professional personnel who are responsible for school management/administration. This includes principals, assistant principals, headteachers, assistant headteachers, and other management staff with similar responsibilities. It excludes receptionists, secretaries, clerks, and other staff who support the administrative activities of the school.

Teacher aides include teacher aides and other para-professional personnel who are employed on a full-time or part-time basis by an education system and non-professional personnel who support teachers in providing instruction to students. This excludes student teachers or other personnel who do not get paid for their employment. 
Professional pedagogical support staff covers professional staff who provide services to students to support their instructional programme. In many cases, they were licensed originally as teacher but then moved into other professional positions in education systems. This staff classification includes in particular the following types of personnel: guidance counsellors, librarians, and attendance officers.

Professional health and social support staff covers all personnel employed in education systems who provide health and social support services to students. This includes notably the following types of personnel:

- health professionals such as doctors, dentists, ophthalmologists, optometrists, hygienists, nurses, and diagnosticians

- psychiatrists and psychologists

- $\quad$ speech pathologists and audiologists

- social workers.

School-level administrative personnel covers all personnel who support the administration and management of the school. It includes receptionists, secretaries, bookkeepers and clerks.

Maintenance and operations personnel covers personnel who support the maintenance and operation of schools, school security, and ancillary services, such as the transportation of students to and from school, food services operations. It includes the following types of personnel:

- masons, carpenters, electricians, locksmiths, maintenance repairers, painters and paperhangers, plasterers, plumbers, and vehicle mechanics

- bus drivers and other vehicle operators, construction workers, gardeners and groundskeepers, bus monitors and crossing guards, cooks/food caterers, custodians, food servers, dormitory supervisors, and security guards.

Source: UNESCO-OECD-Eurostat (2018), UOE Data Collection on Formal Education: Manual on Concepts, Definitions and Classifications, pp. 42-48, UNESCO-OECD-Eurostat, Montreal, Paris, Luxembourg, http://uis.unesco.org/sites/default/files/documents/uoe2016manual_11072016_0.pdf,accessed 19 July 2019.

\section{Which factors influence the mix of staff and their task profiles in school systems?}

Many factors influence the mix of staff and task profiles in school systems. First, the educational goals and curriculum requirements of school systems will influence the type of staff that are needed and the roles that they fulfil. For example, in line with Japan's vision for a holistic education, teachers are expected to perform a range of pedagogical non-teaching tasks besides teaching. This includes supervising children as they clean the school and help serve school lunches to classmates, all of which seeks to cultivate balanced life skills, including a solid academic ability, richness in mind, and a healthy body (OECD, 2018, p. 53 [39]).

Second, the distribution of responsibilities for the provision of education will play a role for the staff mix and their responsibilities across the system. Where schools hold greater autonomy for the management of their staff, budgets and/or educational programmes, they will require different staffing levels and expertise than in systems in which the education administration fulfils related responsibilities (Annex Figure 1.A.4). 
For example, in some school systems, education authorities retain most resourcing responsibilities to allow school leaders to focus on their pedagogical role while others give them extensive financial autonomy. Responsibility for financial matters requires more time and specific knowledge and skills, but also allows school leaders to align budget allocations with pedagogical needs (OECD, 2017 $[40])$. The role of school leaders can then include areas as diverse as leadership and management; resource responsibilities; staff and team development; quality management and development; school and lesson planning; and community relations (Pont, Nusche and Moorman, 2008 $[19])$.

\section{Annex Figure 1.A.4. Distribution of responsibilities in public education (ISCED 2), 2017}

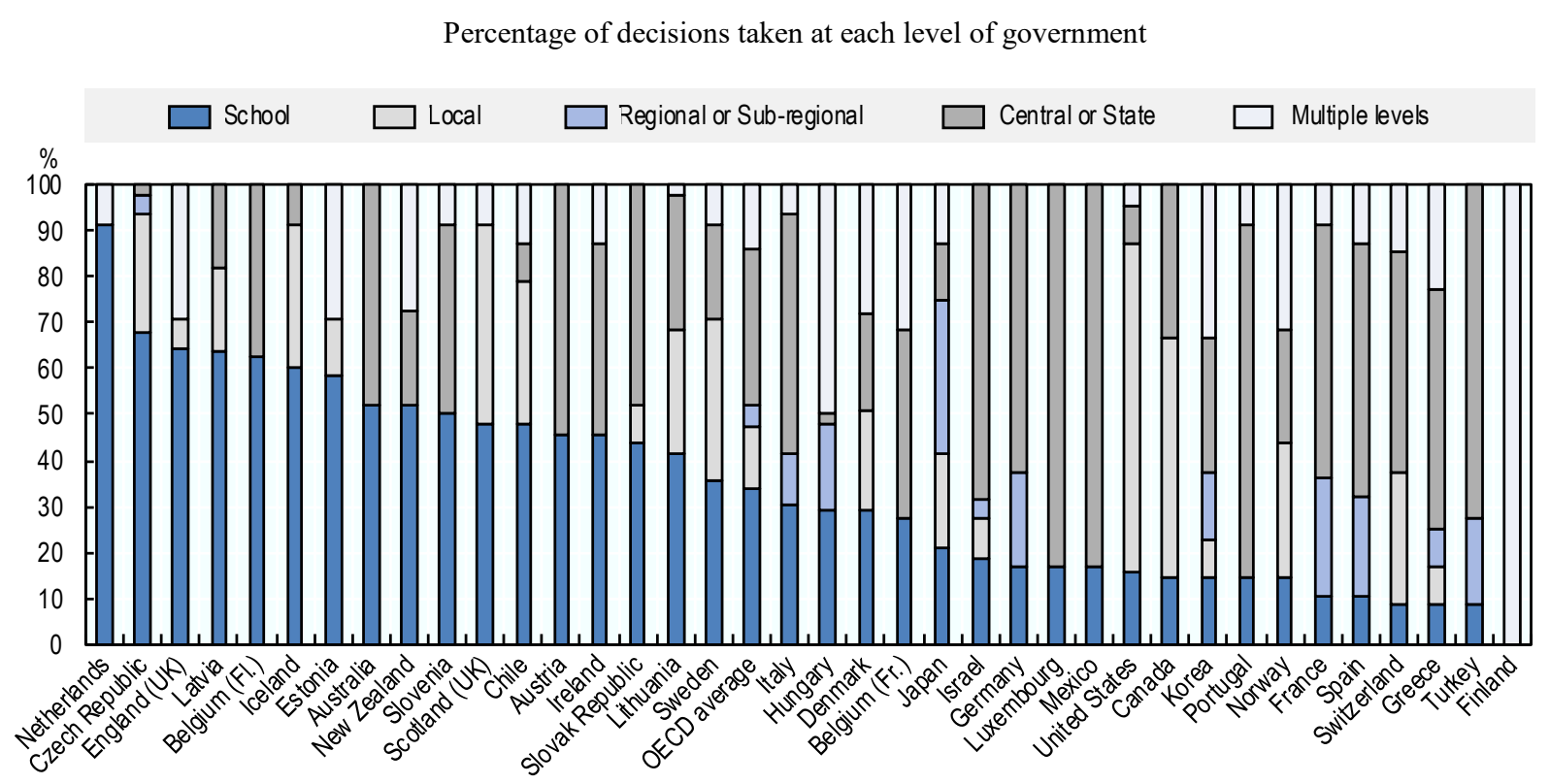

Notes: Countries are ranked in descending order of the percentage of decisions taken at the school level. The OECD average in this figure includes Lithuania. For a definition of the levels of governance, see the Glossary in Annex B to this report.

Source: OECD (2018), Education at a Glance 2018: OECD Indicators, OECD Publishing, http://dx.doi.org/10.1787/eag-2018-36-en, Figure D6.1. and Table D6.1.

StatLink 젠ㅁ https://doi.org/10.1787/888934026278

Third, the programmes that schools offer may influence the staffing roles and mix within schools, in particular in relation to leadership functions. Among OECD review countries, specific leadership functions exist for example for vocational education and training (VET) programmes. In Austria, technical VET schools and colleges, may have department heads, subject heads and construction yard/workshop managers with an adjusted teaching load. In the French Community of Belgium, leadership positions in vocational upper secondary education include also workshop leadership roles (Chef de travaux d'atelier and Chef d'atelier). In the Slovak Republic, VET schools count with heads of practical training.

Fourth, the organisation of school provision, such as the size of schools, the length of the school day or the level of inclusion of children with special needs in mainstream schools will be factors influencing the need for different types of staff. Larger schools may have more specialised staff while smaller schools may share staff or have teachers fulfiling different roles, sometimes with a reduced teaching load (e.g. for the management of the 
school library and instructional materials). Changes in the organisation of school education will usually influence the staffing of schools and the mix of staff that is required.

- In Austria, where school education was traditionally provided in the mornings only, the expansion of all-day schooling has been a priority to increase equity in educational opportunities and to meet the demand for day care as more children grow up in single-parent families or with both parents working full-time. Longer school days, of course, require additional and different types of staff to cover the additional time (e.g. for extracurricular activities and homework) (Nusche et al., $\left.2016_{[27]}\right)$. Staff that are responsible for children during the recreational time include, among others, educators for learning support (Erzieherinnen und Erzieher für die Lernhilfe) and educators for recreation (Freizeitpädagoginnen und Freizeitpädagogen). Specialised tertiary courses have been established for their preparation (e.g. for children's personal development and social learning, diversity and conflict management in the case of recreational educators) (BMBWF, $\left.2019_{[100]}\right)$.

- In Denmark, a reform of the Folkeskole (public primary and lower secondary education) entailed the creation of longer and more varied school days (e.g. through greater involvement of local sports clubs and cultural associations). This also entailed changes to staffing with the greater use of pedagogues in schools. Pedagogues are professionals trained to support all stages of human development from birth to old age and focussed on children's and young people's comprehensive development, which includes their intellectual, social, emotional, neuromuscular, ethical, moral and aesthetic development (Nusche et al., 2016 ${ }_{[28]}$ ).

- In the Slovak and Czech Republics, inclusion policies have resulted in an increase in the number of teaching assistants to support the learning of students with disabilities and gifted children in mainstream schools (Santiago et al., 2016 [29]; Shewbridge et al., 2016 [30]).

- In several school systems, including Austria, the Flemish Community of Belgium, Colombia and Portugal, different approaches to organising schools in clusters have changed leadership structure and roles. Most recently, in Austria, schools have been given the possibility to form a school cluster under joint management since September 2018. The school cluster management takes over the tasks of the previous school management and receives a cross-site leadership function. Each school location with more than 200 students also has an area manager, who supports the cluster management at the location. Department heads, subject heads or administrators remain at the schools where they had been provided prior to the establishment of the cluster. Schools not organised as cluster may have a principal, deputy principal and administrator positions (BMBWF, 2019 [101]). 


\section{Annex 1.B. School staffing frameworks in OECD review countries (ISCED 2), 2018}

The country profiles describe central frameworks for the provision of staff in public education, working primarily within schools (with the exception of resource centres). They are based on information available through country background and country review reports as well as Eurydice descriptions of national education systems (Eurydice, 2019 [96]). Resource centres refer to institutions operated by education authorities that provide centralised services and specialised staff, typically to ensure effective provision of staff to schools and communities. Responsibility for employment describes the natural or legal person with whom the employee has an employment relationship and with whom the employee has established an employment contract. For the definition of different types of staff and levels of governance and administration, see Annex B at the end of this report. 


\section{Austria}

\section{Instructional and leadership staff}

\begin{tabular}{|c|c|c|c|}
\hline Staff type & Roles defined in regulations & Basis for creating positions & Responsibility for employment \\
\hline Teachers & $x$ & $\begin{array}{l}\text { Based on central regulations, managed } \\
\text { by Boards of Education (depending on } \\
\text { numbers of students, subjects taught, } \\
\text { language tuition requirement, all-day } \\
\text { school model) }\end{array}$ & Boards of Education \\
\hline Teacher aides & $x$ & $x$ & $x$ \\
\hline \multirow{5}{*}{ School leaders } & \multirow[b]{2}{*}{$\begin{array}{l}\text { Schools organised as clusters: Cluster } \\
\text { leaders at schools hosting the clusters, } \\
\text { Area managers at other schools }\end{array}$} & $\begin{array}{l}\text { Cluster leaders: Based on central } \\
\text { regulations (minimum number of } \\
\text { ten teachers) }\end{array}$ & \multirow[b]{2}{*}{ Boards of Education } \\
\hline & & $\begin{array}{l}\text { Area managers: Based on central } \\
\text { regulations (at schools within school } \\
\text { cluster with }>200 \text { students, except the } \\
\text { school hosting the clusters, where the } \\
\text { cluster leaders operate) }\end{array}$ & \\
\hline & \multirow{3}{*}{$\begin{array}{l}\text { Schools not organised as clusters: } \\
\text { School principals, Deputy principals, } \\
\text { Administrators (federal schools only) }\end{array}$} & $\begin{array}{l}\text { School principals: based on central } \\
\text { regulations (minimum school size of ten } \\
\text { teachers) }\end{array}$ & \multirow{3}{*}{ Boards of Education } \\
\hline & & $\begin{array}{l}\text { Deputy principals: based on central } \\
\text { regulations (can be appointed by the } \\
\text { Boards of Education at the suggestion } \\
\text { of principals) }\end{array}$ & \\
\hline & & $\begin{array}{l}\text { Administrators: based on central } \\
\text { regulations (can be appointed at } \\
\text { schools with at least } 8 \text { classes and no } \\
\text { deputy or department heads appointed } \\
\text { at the school) }\end{array}$ & \\
\hline
\end{tabular}




\section{Professional support staff}

Staff positions primarily created directly in schools

\begin{tabular}{llll}
\hline Staff type & Roles defined in regulations & Basis for creating positions & Responsibility for employment \\
\cline { 2 - 3 } $\begin{array}{l}\text { Professional pedagogical } \\
\text { support staff }\end{array}$ & Librarians, Guidance counsellors & $\begin{array}{l}\text { At discretion of education } \\
\text { authorities }\end{array}$ & Boards of Education \\
\cline { 2 - 3 } $\begin{array}{l}\text { Professional health and } \\
\text { social support staff }\end{array}$ & $\begin{array}{l}\text { Doctors, Psychologists, Social } \\
\text { workers }\end{array}$ & $\begin{array}{l}\text { At discretion of education } \\
\text { authorities }\end{array}$ & $\begin{array}{l}\text { Federal schools: Central } \\
\text { education authorities }\end{array}$ \\
\cline { 2 - 4 } & & $\begin{array}{l}\text { Provincial schools: State } \\
\text { education authorities }\end{array}$ \\
\hline
\end{tabular}

Resource centres providing specialised staff for

Professional pedagogical

support

Professional health and social support
Additional psychological support staff available externally to schools (service available for students, teachers, parents and principals, provided by the Boards of Education at psychological counselling centres situated in the provinces or upon request directly at schools)

Administrative, maintenance and operations staff

\begin{tabular}{|c|c|c|c|}
\hline Staff type & Roles defined in regulations & Basis for creating positions & Responsibility for employment \\
\hline \multirow[b]{2}{*}{ Administrative staff } & \multirow[b]{2}{*}{ Administrative assistants } & \multirow[b]{2}{*}{ At discretion of authorities } & $\begin{array}{l}\text { Federal schools: Central } \\
\text { education authorities }\end{array}$ \\
\hline & & & $\begin{array}{l}\text { Provincial schools: State } \\
\text { education authorities/Local } \\
\text { authorities }\end{array}$ \\
\hline \multirow{2}{*}{$\begin{array}{l}\text { Maintenance and } \\
\text { operations staff }\end{array}$} & Federal schools: Janitors & \multirow[b]{2}{*}{ At discretion of authorities } & $\begin{array}{l}\text { Federal schools: Central } \\
\text { education authorities }\end{array}$ \\
\hline & $\begin{array}{l}\text { Provincial schools: Based on } \\
\text { state regulations }\end{array}$ & & $\begin{array}{l}\text { Provincial schools: State } \\
\text { education authorities/Local } \\
\text { authorities }\end{array}$ \\
\hline
\end{tabular}

x: not applicable

1. The country profile for Austria reflects the situation of 2019.

2. Since 2019, human resources (incl. teacher allocations and support staff) in federal and provincial schools are administered in joint federal-provincial Boards of Education. For maintenance and operations staff, central regulations specify the obligation for provincial and local authorities to provide such staff, but this is regulated by the provinces through implementing legislation.

3. In federal schools, teacher positions are allocated to schools based on required teaching hours for the number of students. In provincial schools, teacher positions are allocated to schools largely according to staff plans based on the number of students, but provincial education authorities have discretion to alter allocations. Schools receive additional teacher allocations based on teaching hours required for the implementation of central priorities (e.g. full-day schooling).

4. Since September 2018, schools can form a school cluster under joint management. 


\section{Belgium (Flemish Community)}

\section{Instructional and leadership staff}

\begin{tabular}{|c|c|c|c|}
\hline Staff type & Roles defined in regulations & Basis for creating positions & Responsibility for employment \\
\hline Teachers & $\mathrm{x}$ & $\begin{array}{l}\text { At discretion of schools, in } \\
\text { consultation with school providers }\end{array}$ & School providers (school boards) \\
\hline Teacher aides & $x$ & $x$ & $x$ \\
\hline \multirow{4}{*}{ School leaders } & $\begin{array}{l}\text { Promotion positions: Principals, } \\
\text { Technical advisers-co-ordinators }\end{array}$ & \multirow{2}{*}{$\begin{array}{l}\text { Principals: based on state regulations } \\
\text { (in all schools) }\end{array}$} & \multirow{4}{*}{ School providers (school boards) } \\
\hline & $\begin{array}{l}\text { Selection positions: Assistant } \\
\text { principals, Technical advisers and } \\
\text { Co-ordinators }\end{array}$ & & \\
\hline & $\begin{array}{l}\text { In groups of schools: Managing } \\
\text { directors }\end{array}$ & \multirow{2}{*}{$\begin{array}{l}\text { Other school leaders: At discretion of } \\
\text { school providers }\end{array}$} & \\
\hline & $\begin{array}{l}\text { In combined schools: } \\
\text { Co-ordinating directors }\end{array}$ & & \\
\hline
\end{tabular}

\section{Professional support staff}

Staff positions primarily created directly in school

\begin{tabular}{|c|c|c|c|}
\hline Staff type & Roles defined in regulations & Basis for creating positions & Responsibility for employment \\
\hline $\begin{array}{l}\text { Professional pedagogical } \\
\text { support staff }\end{array}$ & $x$ & $\mathrm{x}$ & $\mathrm{x}$ \\
\hline Health and social support staff & $\mathrm{x}$ & $\mathrm{x}$ & $\mathrm{x}$ \\
\hline
\end{tabular}

Resource centres providing specialised staff for

\begin{tabular}{ll}
\hline $\begin{array}{l}\text { Professional pedagogical } \\
\text { support }\end{array}$ & $\begin{array}{l}72 \text { Centres for Student Guidance (Centrum voor Leerlingenbegeleiding,CLB) (run by state education } \\
\text { authorities): Career guidance services }\end{array}$ \\
\cline { 2 - 2 } $\begin{array}{l}\text { Professional health and social } \\
\text { support }\end{array}$ & $\begin{array}{l}72 \text { Centres for Student Guidance (Centrum voor Leerlingenbegeleiding, CLB) (run by state education } \\
\text { authorities): Psychologists, Social workers, Medical doctors and Nurses }\end{array}$ \\
\cline { 2 - 2 } & 25 support networks (for students with specific needs) (run by state education authorities) \\
\hline
\end{tabular}


Administrative, maintenance and operations staff

\begin{tabular}{llll}
\hline \multirow{2}{*}{ Staff type } & Roles defined in regulations & Basis for creating positions & Responsibility for employment \\
\cline { 2 - 4 } Administrative staff & $\begin{array}{l}\text { Administrative assistants } \\
\text { (e.g. Secretaries, Accountants) }\end{array}$ & At discretion of school providers & School providers (school boards) \\
\cline { 2 - 4 } $\begin{array}{l}\text { Maintenance and operations } \\
\text { staff }\end{array}$ & $\begin{array}{l}\text { Maintenance staff (e.g. Cooks, } \\
\text { Repairmen) }\end{array}$ & At discretion of school providers & School providers (school boards) \\
\hline
\end{tabular}

$\mathrm{x}$ : not applicable

1. For public schools, the school provider is an autonomous public body. Teachers are employed by school providers, but salaries are paid directly by the state authorities.

2. Since the late 1990s, the Flemish education authorities have encouraged collaboration between schools. School associations receive additional resources which can be used for the employment of additional leadership and administrative staff. 


\section{Belgium (French Community)}

\section{Instructional and leadership staff}

\begin{tabular}{|c|c|c|c|}
\hline Staff type & Roles defined in regulations & Basis for creating positions & Responsibility for employment \\
\hline Teachers & $x$ & $\begin{array}{l}\text { At discretion of school providers, } \\
\text { based on state regulations }\end{array}$ & $\begin{array}{l}\text { School providers (state, regional or } \\
\text { local education authority depending } \\
\text { on the school network) }\end{array}$ \\
\hline Teacher aides & $x$ & $x$ & $x$ \\
\hline \multirow[b]{2}{*}{ School leaders } & Promotion positions: Principals & \multirow{2}{*}{$\begin{array}{l}\text { Based on state regulations (school } \\
\text { size) }\end{array}$} & \multirow{2}{*}{$\begin{array}{l}\text { School providers (state, regional or } \\
\text { local education authority depending } \\
\text { on the school network) }\end{array}$} \\
\hline & $\begin{array}{l}\text { Selection positions (e.g. Deputy } \\
\text { principals) }\end{array}$ & & \\
\hline
\end{tabular}

\section{Professional support staff}

Staff positions primarily created directly in schools

\begin{tabular}{|c|c|c|c|}
\hline Staff type & Roles defined in regulations & Basis for creating positions & Responsibility for employment \\
\hline $\begin{array}{l}\text { Professional pedagogical } \\
\text { support staff }\end{array}$ & $x$ & $x$ & $x$ \\
\hline Health and social support staff & $x$ & $x$ & $x$ \\
\hline
\end{tabular}

Resource centres providing specialised staff for

\begin{tabular}{ll}
\hline $\begin{array}{l}\text { Professional pedagogical } \\
\text { support }\end{array}$ & $\begin{array}{l}\text { Centres for Psychological, Medical and Social Services (Centre Psycho-Médico-Social, CPMS) (run by state } \\
\text { education authorities): Career guidance through educational psychologists }\end{array}$ \\
\cline { 2 - 3 } & $\begin{array}{l}\text { Centres for Psychological, Medical and Social Services (Centre Psycho-Médico-Social, CPMS) (run by state } \\
\text { education authorities): Psychologists, Social workers, Nurses, Care co-ordinators, Parademical staff }\end{array}$ \\
\cline { 2 - 2 } $\begin{array}{l}\text { Professional health and social } \\
\text { support }\end{array}$ & $\begin{array}{l}\text { Service for Health at School (Services de Promotion de la Santé à l'école, PSE) (run by state education } \\
\text { authorities) }\end{array}$ \\
\cline { 2 - 2 } & School-reintegration services (Services d'accrochage scolaire, SAS) (run by state education authorities)
\end{tabular}


Administrative, maintenance and operations staff

\begin{tabular}{llll}
\hline \multirow{2}{*}{$\begin{array}{l}\text { Staff type } \\
\text { Administrative staff }\end{array}$} & Roles defined in regulations & Basis for creating positions & Responsibility for employment \\
\cline { 2 - 4 } & $\begin{array}{l}\text { Economic advisers (Éducateurs } \\
\text { économes), Executive secretaries, } \\
\text { (Secrétaires de direction), } \\
\text { Secretaries (Secrétaires) }\end{array}$ & $\begin{array}{l}\text { At discretion of school providers, } \\
\text { but within state regulations }\end{array}$ & $\begin{array}{l}\text { School providers (state, regional, } \\
\text { local education authorities } \\
\text { depending on the school network) }\end{array}$ \\
\cline { 2 - 4 } $\begin{array}{l}\text { Maintenance and operations } \\
\text { staff }\end{array}$ & $\begin{array}{l}\text { Maintenance staff, Caretakers } \\
\text { (Concierges) }\end{array}$ & $\begin{array}{l}\text { At discretion of school providers, } \\
\text { but within state regulations }\end{array}$ & $\begin{array}{l}\text { School providers (state, regional, } \\
\text { local education authorities } \\
\text { depending on the school network) }\end{array}$ \\
\hline
\end{tabular}

x: not applicable

1. For public schools, the school providers are the state, regional and local education authorities (depending on the school network). Teachers are employed by school providers, but salaries are paid directly by the state authorities.

2. Each school has a total number of teacher-periods (nombre total de périodes-professeurs, NTPP), which may be distributed by stage, grade, or group of grades, based on the number of regular students attending the school on 15 January of the previous school year. Teacher-periods can be used by each secondary school, with a maximum of $3 \%$ of the total number of teacher-periods, for activities such as class council, class administration and co-ordination. The teacher-periods calculated in this way can be allocated according to students' educational needs, in consultation with the educational team, without prejudice to the programming rules that define the conditions required for the opening of new options and sections.

3. In vocational upper secondary education, selection positions include also workshop leadership roles (Chef de travaux d'atelier and Chef d'atelier) are employed.

4. The economic adviser (Éducateur économe) supports the school principal in resource management and accounting, and manages the administrative and maintenance staff. The executive secretary supports administrative management.

5. The staff of Centres for Psychological, Medical and Social Services (Centre Psycho-Médico-Social, CPMS) play an important role within schools, collaborating closely with teachers and school principals. 


\section{Chile}

\section{Instructional and leadership staff}

\begin{tabular}{|c|c|c|c|}
\hline Staff type & Roles defined in regulations & Basis for creating positions & Responsibility for employment \\
\hline Teachers & $x$ & At discretion of school providers & School providers \\
\hline Teacher aides & $\begin{array}{l}\text { Teaching assistants (Asistentes de } \\
\text { la educación) }\end{array}$ & At discretion of school providers & School providers \\
\hline \multirow{4}{*}{ School leaders } & Principals & \multirow{4}{*}{ At discretion of school providers } & \multirow{4}{*}{ School providers } \\
\hline & Deputy principals (Subdirectores) & & \\
\hline & $\begin{array}{l}\text { Heads of technical-pedagogical } \\
\text { units (Jefes de unidades técnico- } \\
\text { pedagógicas) }\end{array}$ & & \\
\hline & $\begin{array}{l}\text { General inspectors (Inspectores } \\
\text { generales) }\end{array}$ & & \\
\hline
\end{tabular}

\section{Professional support staff}

Staff positions primarily created directly in schools

\begin{tabular}{|c|c|c|c|}
\hline Staff type & Roles defined in regulations & Basis for creating positions & Responsibility for employment \\
\hline \multirow{2}{*}{$\begin{array}{l}\text { Professional pedagogical } \\
\text { support staff }\end{array}$} & $\begin{array}{l}\text { School climate co-ordinators } \\
\text { (Encargado de convivencia } \\
\text { escolar) }\end{array}$ & \multirow{2}{*}{$\begin{array}{l}\text { At discretion of school providers, } \\
\text { but within central regulations } \\
\text { (schools must have a school } \\
\text { climate co-ordinator) }\end{array}$} & \multirow{2}{*}{ School providers } \\
\hline & $\begin{array}{l}\text { Education assistants with } \\
\text { function of school librarians } \\
\text { (Bibliotecario Encargado CRA) }\end{array}$ & & \\
\hline Health and social support staff & $\begin{array}{l}\text { Education assistants (Asistentes } \\
\text { de la educación) with functions of } \\
\text { educational psychology, social } \\
\text { work, nursing, speech and } \\
\text { language therapy, etc. }\end{array}$ & $\begin{array}{l}\text { At discretion of school providers, } \\
\text { but within central regulations }\end{array}$ & School providers \\
\hline
\end{tabular}

Resource centres providing specialised staff for

Professional pedagogical

support

Professional health and social support $x$ 
Administrative, maintenance and operations staff

\begin{tabular}{llll}
\hline Staff type & Roles defined in regulations & Basis for creating positions & Responsibility for employment \\
\cline { 2 - 4 } & $\begin{array}{l}\text { Education assistants (Asistentes } \\
\text { de la educación) with functions of } \\
\text { secretary, accountant, IT support, } \\
\text { Administrative staff }\end{array}$ & $\begin{array}{l}\text { At discretion of school providers, } \\
\text { but within central regulations }\end{array}$ & School providers \\
\cline { 2 - 4 } $\begin{array}{l}\text { legalvice, etc. } \\
\text { Maintenance and operations }\end{array}$ & $\begin{array}{l}\text { Education assistants (Asistentes } \\
\text { se la educación) with functions of } \\
\text { maintenance }\end{array}$ & $\begin{array}{l}\text { At discretion of school providers, } \\
\text { but within central regulations }\end{array}$ & School providers \\
\hline
\end{tabular}

x: not applicable

1. In 2017, national legislation transferred responsibility for the provision of public school education from local authorities (municipalities) to a new intermediate level in the form of local education services. Local education services are led by a national Directorate for Public Education within the Ministry of Education. Responsibilities are being transferred gradually until 2025 (with an intermediate evaluation to review the process and the possibility for the President of the Republic to postpone completion of the transfer until 2030). 2. Regulations specify that schools must provide suitable teaching/managing professionals, technical-pedagogical and classroom staff in line with school needs according to level, modality and student numbers.

3. The Teaching Statute (Ley 19.070) describes teaching, directive and technical-pedagogical support functions, but does not establish a fixed structure for each school. For example, in the case of remote and multigrade schools, the school provider decides whether there is a principal or a teacher in charge (profesor encargado) who receives a special bonus for their function. Also, school principals selected through the System of High Public Service (Alta Dirección Pública), may or may not choose to assign the positions of deputy principal or head of the technical-pedagogical unit. Heads of the Technical-Pedagogical Unit are in charge of curricular activities, General Inspectors of a range of organisational aspects such as student admission, staff and class management and school discipline.

4. Education assistants (Asistentes de la educación) are regulated by law and can fulfil pedagogical, administrative or operational responsibilities.

5. The National Board of School Assistance and Scholarships (Junta Nacional de Auxilio Escolar y Becas, JUNAEB) has also established programmes to provide psychological and social support for vulnerable students at the risk of drop-out. The Programme to Support School Retention (Programa de Apoyo a la Retención Escolar) for example is targeted at students at risk and provides socio-emotional support to students and communities. Services are provided by a multidisciplinary group (social worker, psychologist and teacher) which is in close contact with local social services (see https://www.junaeb.cl/programa-de-apoyo-a-laretencion-escolar). 


\section{Colombia}

\section{Instructional and leadership staff}

\begin{tabular}{|c|c|c|c|}
\hline Staff type & Roles defined in regulations & Basis for creating positions & Responsibility for employment \\
\hline Teachers & $\mathrm{x}$ & $\begin{array}{l}\text { At discretion of regional and local } \\
\text { education authorities certified to } \\
\text { provide education, based on central } \\
\text { regulations (technical relations for } \\
\text { the ratio of students to teachers and } \\
\text { teachers per group of students) }\end{array}$ & $\begin{array}{l}\text { Regional and local education } \\
\text { authorities certified to provide } \\
\text { education (Certified territorial } \\
\text { entities) }\end{array}$ \\
\hline Teacher aides & $x$ & $x$ & $x$ \\
\hline \multirow{3}{*}{ School leaders } & School cluster leaders (Rector) & $\begin{array}{l}\text { Based on central regulations (in all } \\
\text { school clusters) }\end{array}$ & \multirow{3}{*}{$\begin{array}{l}\text { Regional and local education } \\
\text { authorities certified to provide } \\
\text { education (Certified territorial } \\
\text { entities) }\end{array}$} \\
\hline & Rural directors (Director Rural) & \multirow{2}{*}{$\begin{array}{l}\text { Based on central regulations } \\
\text { (depending on the size of the } \\
\text { school cluster for co-ordinators and } \\
\text { the size of individual rural school } \\
\text { sites for rural directors) }\end{array}$} & \\
\hline & Co-ordinators (Coordinador) & & \\
\hline
\end{tabular}

\section{Professional support staff}

Staff positions primarily created directly in schools

\begin{tabular}{|c|c|c|c|}
\hline Staff type & Roles defined in regulations & Basis for creating positions & Responsibility for employment \\
\hline \multirow{3}{*}{$\begin{array}{l}\text { Professional pedagogical } \\
\text { support staff }\end{array}$} & School counsellors (Orientador) & \multirow{3}{*}{$\begin{array}{l}\text { At discretion of regional and local } \\
\text { education authorities certified to } \\
\text { provide education }\end{array}$} & \multirow{3}{*}{$\begin{array}{l}\text { Regional and local education } \\
\text { authorities certified to provide } \\
\text { education (Certified territorial } \\
\text { entities) }\end{array}$} \\
\hline & $\begin{array}{l}\text { Support teachers (Docente de } \\
\text { apoyo) }\end{array}$ & & \\
\hline & $\begin{array}{l}\text { Support professionals } \\
\text { (Profesional de Apoyo): Sign } \\
\text { language Interpreters, Mediators, } \\
\text { Typists }\end{array}$ & & \\
\hline Health and social support staff & $x$ & $x$ & $x$ \\
\hline
\end{tabular}

Resource centres providing specialised staff for

Professional pedagogical

support

Professional health and social

support $x$ 
Administrative, maintenance and operations staff

\begin{tabular}{|c|c|c|c|}
\hline Staff type & Roles defined in regulations & Basis for creating positions & Responsibility for employment \\
\hline Administrative staff & $\begin{array}{l}\text { Technical, administrative and } \\
\text { operational staff as defined in the } \\
\text { job classification and } \\
\text { nomenclature for the public } \\
\text { function (e.g. Administrative } \\
\text { assistants [auxiliar administrativo], } \\
\text { Executive secretaries [secretario } \\
\text { ejecutivo], Secretaries [secretario]) }\end{array}$ & $\begin{array}{l}\text { At discretion of regional and local } \\
\text { education authorities certified to } \\
\text { provide education, based on } \\
\text { central regulations }\end{array}$ & $\begin{array}{l}\text { Regional and local education } \\
\text { authorities certified to provide } \\
\text { education (Certified territorial } \\
\text { entities) }\end{array}$ \\
\hline $\begin{array}{l}\text { Maintenance and operations } \\
\text { staff }\end{array}$ & $\begin{array}{l}\text { Technical and operational staff as } \\
\text { defined in the job classification } \\
\text { and nomenclature for the public } \\
\text { function (e.g. Drivers } \\
\text { [conductores]) }\end{array}$ & $\begin{array}{l}\text { At discretion of regional and local } \\
\text { authorities, based on central } \\
\text { regulations (cleaning and vigilance } \\
\text { need to be contracted externally } \\
\text { through a third party) }\end{array}$ & $\begin{array}{l}\text { Regional and local authorities } \\
\text { (Certified and non-certified } \\
\text { territorial entities) }\end{array}$ \\
\hline
\end{tabular}

x: not applicable

1. Decentralisation in education has been managed by a process of certification of departments (the regional level) and districts and municipalities (the local level). All departments and large municipalities are certified to provide pre-school and school education and referred to as certified territorial entities (Entidades Territoriales Certificadas, ETC). Education in municipalities that have not been certified (referred to as non-certified municipalities [municipios no-certificados]) is under the responsibility of the respective department and its Secretary of Education. Non-certified municipalities support the management of the teaching staff and provide data and information to their department. Non-certified municipalities furthermore manage a small amount of financial resources they receive through fiscal transfers (Sistema General de Participaciones, SGP) and can contribute their own resources for school infrastructure, maintenance and quality. The allocation of teacher positions is largely based on staff plans approved by the Ministry of National Education in line with technical relations for the ratio of students to teachers and teachers per group of students. Secretaries of Education of certified territorial entities can fund additional teacher positions from their own resources, but this is the exception. Certified regional and local education authorities also receive resources through the fiscal transfer system for the inclusion of students with special needs. These resources should be invested primarily in the temporary employment of pedagogical support staff, approved annually by the central education authority, to hire supports required by students, prioritising sign language interpreters, mediators, and typists, as well as didactic materials.

2. Certified regional and local education authorities may also establish positions of education supervisors (supervisors de educación) responsible for the supervision of groups of schools, but these are not established by all education authorities.

3. The primary role of school counsellors (orientadores) is to develop strategies that promote a positive school climate and peaceful coexistence inside and outside of school. In schools with a school library, there may also be a teacher librarian (docente bibliotecario).

4. Resources from the fiscal transfer system (Sistema General de Participaciones, SGP) that certified regional and local education authorities can dedicate to administrative costs are authorised by the central education authority. Most administrative staff work in Secretaries of Education. 


\section{Czech Republic}

\section{Instructional and leadership staff}

\begin{tabular}{llll}
\hline Staff type & \multicolumn{1}{c}{ Roles defined in regulations } & Basis for creating positions & Responsibility for employment \\
\cline { 2 - 4 } & & At discretion of schools & Schools (as legal entity) \\
\cline { 2 - 4 } Teachers & Pedagogue's assistants, Educators & At discretion of schools & Schools (as legal entity) \\
\cline { 2 - 4 } & Principals & Based on central regulations (in all & School founders \\
\cline { 2 - 4 } & Schools) & Schools (as legal entity) \\
\cline { 2 - 4 } & Deputy principals & At discretion of schools & Seol leaders
\end{tabular}

\section{Professional support staff}

Staff positions primarily created directly in schools

\begin{tabular}{|c|c|c|c|}
\hline Staff type & Roles defined in regulations & Basis for creating positions & Responsibility for employment \\
\hline \multirow{3}{*}{$\begin{array}{l}\text { Professional pedagogical } \\
\text { support staff }\end{array}$} & $\begin{array}{l}\text { School education (career) } \\
\text { advisers }\end{array}$ & \multirow{3}{*}{$\begin{array}{l}\text { At discretion of schools, but } \\
\text { based on central regulations }\end{array}$} & \multirow{3}{*}{ Schools (as legal entity) } \\
\hline & Prevention specialists & & \\
\hline & $\begin{array}{l}\text { School special educational needs } \\
\text { specialists }\end{array}$ & & \\
\hline Health and social support staff & School psychologists & At discretion of schools & Schools (as legal entity) \\
\hline
\end{tabular}

Resource centres providing specialised staff for

\begin{tabular}{|c|c|}
\hline \multirow{3}{*}{$\begin{array}{l}\text { Professional pedagogical } \\
\text { support }\end{array}$} & $\begin{array}{l}\text { Pedagogical and psychological counselling centres (pedagogicko-psychologická poradna) and special } \\
\text { education centres (speciálně pedagogické centrum) (run by regional education authorities or other legal } \\
\text { entities): Career guidance }\end{array}$ \\
\hline & Career Guidance Centre of the National Institute for Education (run by central education authority) \\
\hline & Information and guidance centres of the Labour Office (run by central authority) \\
\hline $\begin{array}{l}\text { Professional health and social } \\
\text { support }\end{array}$ & $\begin{array}{l}\text { Pedagogical and psychological counselling centres (pedagogicko-psychologická poradna) and special } \\
\text { education centres (speciálně pedagogické centrum) (run by regional education authorities or other legal } \\
\text { entities) }\end{array}$ \\
\hline
\end{tabular}


Administrative, maintenance and operations staff

\begin{tabular}{llll}
\hline Staff type & Roles defined in regulations & Basis for creating positions & Responsibility for employment \\
\cline { 2 - 4 } Administrative staff & Not centrally regulated & At discretion of schools & Schools (as legal entity) \\
\cline { 2 - 3 } $\begin{array}{l}\text { Maintenance and operations } \\
\text { staff }\end{array}$ & Not centrally regulated & At discretion of schools & Schools (as legal entity) \\
\hline
\end{tabular}

$\mathrm{x}$ : not applicable

1. School founders of the second stages of basic education (ISCED 2) are typically municipalities. While regions are mainly founders of schools offering secondary education (ISCED 3) (regions), some also provide the second stage of basic education. A significant part of funding for the remuneration of school staff comes from the national budget, so there are rules which regulate the conditions of this financing, while it is up to schools to organise their particular staffing.

2. Students are entitled through the Education Act to get a form of education that respects their individual educational needs. The positions of school education adviser and prevention specialist are to be established in all schools; school education advisers carry a reduced teaching load (1-5 hours depending on school size).

3. There are two types of pedagogue's assistant: i) pedagogue's assistant who performs a direct pedagogical activity in a class in which students with special educational needs are educated, or in a school providing for the education of students in the form of individual integration, ii) pedagogue's assistant who performs a direct pedagogical activity consisting of auxiliary educational work at school, in a school facility providing for interest education, in a school educational or accommodation facility, in a school facility for institutional or protective education or in a school facility for preventive and educational care. Educators provide mainly interest, educational and recreational activities, including learning support, in line with the school educational programme. 


\section{Denmark}

\section{Instructional and leadership staff}

\begin{tabular}{llll}
\hline Staff type & Roles defined in regulations & Basis for creating positions & Responsibility for employment \\
\cline { 2 - 4 } Teachers & $\mathrm{x}$ & $\begin{array}{l}\text { At discretion of schools, sometimes } \\
\text { based on local frameworks }\end{array}$ & $\begin{array}{l}\text { Local education authorities } \\
\text { (municipalities) }\end{array}$ \\
\cline { 2 - 5 } Teacher aides & At discretion of schools, sometimes & $\begin{array}{l}\text { Local education authorities } \\
\text { (municipalities) }\end{array}$ \\
\cline { 2 - 5 } & Peaching assistants & based on local frameworks & $\begin{array}{l}\text { At discretion of schools, sometimes } \\
\text { becal education authorities }\end{array}$ \\
\hline
\end{tabular}

\section{Professional support staff}

Staff positions primarily created directly in schools

\begin{tabular}{|c|c|c|c|}
\hline Staff type & Roles defined in regulations & Basis for creating positions & Responsibility for employment \\
\hline \multirow{3}{*}{$\begin{array}{l}\text { Professional pedagogical } \\
\text { support staff }\end{array}$} & Pedagogues & \multirow{3}{*}{ At discretion of schools } & \multirow{3}{*}{ Schools } \\
\hline & $\begin{array}{l}\text { Behaviour, contact and well-being } \\
\text { counsellors (Adfærd-Kontakt- } \\
\text { Trivsel, AKT) }\end{array}$ & & \\
\hline & Counsellors & & \\
\hline Health and social support staff & $\begin{array}{l}\text { Psychologists, School nurses, } \\
\text { Welfare officers }\end{array}$ & $\begin{array}{l}\text { At discretion of schools, } \\
\text { sometimes based on local } \\
\text { frameworks }\end{array}$ & Schools \\
\hline
\end{tabular}

Resource centres providing specialised staff for

\begin{tabular}{ll}
\hline $\begin{array}{l}\text { Professional pedagogical } \\
\text { support }\end{array}$ & 52 Youth guidance centres (Uddannelses- og erhvervsvejledere) (run by local authorities) \\
\cline { 2 - 2 } $\begin{array}{l}\text { Professional health and social } \\
\text { support }\end{array}$ & $\begin{array}{l}\text { Specialised knowledge and counselling organisations (Videns - og Specialrådgivningsorganisation, VISO) (run by } \\
\text { central authorities) }\end{array}$ \\
\cline { 2 - 2 } & \begin{tabular}{l} 
Pedagogical-psychological counselling units (Pædagogisk-psykologisk rådgivning, PPR) (run by local authorities) \\
\hline
\end{tabular} \\
\hline
\end{tabular}


Administrative, maintenance and operations staff

\begin{tabular}{llll}
\hline \multirow{2}{*}{ Staff type } & Roles defined in regulations & Basis for creating positions & Responsibility for employment \\
\cline { 2 - 4 } Administrative staff & Secretaries & $\begin{array}{l}\text { At discretion of schools, } \\
\text { sometimes based on local } \\
\text { frameworks }\end{array}$ & Schools \\
\cline { 2 - 4 } Maintenance and operations & $\begin{array}{l}\text { At discretion of schools, } \\
\text { staff }\end{array}$ & $\begin{array}{l}\text { Sometimes based on local } \\
\text { frameworks }\end{array}$ & Schools \\
\hline
\end{tabular}

$\mathrm{x}$ : not applicable

1. According to the Folkeskole Act, it is the responsibility of each school (ISCED 1-2) to provide variation in teaching methods, teaching materials, subjects etc. in order to meet the needs and prerequisites of each student. 2. As defined in legislation, the municipality is the employer of instructional and leadership staff. However, municipalities may delegate this responsibility to schools. In some municipalities, there are a minimum number of teachers required, based on the number of classes the municipality determines a school should have. Otherwise, the school principal can typically determine which types of and how many staff members are employed.

3. Local authorities may define additional leadership positions at their own discretion.

4. AKT counsellors (Adferd-Kontakt-Trivsel) are specialist teachers with a focus on social processes in schools and areas related to behaviour, psychology and well-being. They can support individual students in and outside of classrooms and work together with teachers in the classroom to help offer differentiated teaching according to students' needs. AKT counsellors can also initiate training in schools related to social issues, the development of social skills and inclusive communities, or general health education with a focus on social well-being and the prevention of bullying and violence at school.

5. Pedagogues might be compared to recreational instructors, play workers or social workers in other contexts. In all of their work, pedagogues focus on the importance of play and children's and young people's comprehensive development, which includes their intellectual, social, emotional, neuromuscular, ethical, moral and aesthetic development. 


\section{Estonia}

\section{Instructional and leadership staff}

\begin{tabular}{llll}
\hline Staff type & Roles defined in regulations & Basis for creating positions & Responsibility for employment \\
\cline { 2 - 4 } Teachers & \multicolumn{1}{c}{$\begin{array}{l}\text { At discretion of school owners (local } \\
\text { education authorities) }\end{array}$} & Schools \\
\cline { 2 - 4 } & Assistant teachers & $\begin{array}{l}\text { At discretion of schools (school } \\
\text { principal) (within framework of } \\
\text { school owner) }\end{array}$ & Schools \\
\cline { 2 - 4 } & Principals & $\begin{array}{l}\text { Based on central regulations } \\
\text { (established in all schools) }\end{array}$ & $\begin{array}{l}\text { School owners (local education } \\
\text { authorities) }\end{array}$ \\
\cline { 2 - 4 } & Heads of studies & $\begin{array}{l}\text { At discretion of schools (school } \\
\text { principals) (within framework of } \\
\text { school owner) }\end{array}$ & Schools \\
\hline
\end{tabular}

\section{Professional support staff}

Staff positions primarily created directly in schools

\begin{tabular}{llll}
\hline Staff type & Roles defined in regulations & Basis for creating positions & Responsibility for employment \\
\cline { 2 - 4 } $\begin{array}{l}\text { Professional pedagogical } \\
\text { support staff }\end{array}$ & Guidance counsellors, Librarians & $\begin{array}{l}\text { At discretion of schools (within } \\
\text { framework of school owner) }\end{array}$ & Schools \\
\cline { 2 - 4 } Health and social support staff & $\begin{array}{l}\text { Speech therapists, Social } \\
\text { pedagogues, Psychologists, } \\
\text { Nurses }\end{array}$ & $\begin{array}{l}\text { At discretion of schools (within } \\
\text { framework of school owner) }\end{array}$ & Schools \\
\hline
\end{tabular}

Resource centres providing specialised staff for

\begin{tabular}{ll}
\hline $\begin{array}{l}\text { Professional pedagogical } \\
\text { support }\end{array}$ & Career guidance provided by Unemployment Insurance Fund, Töötukassa) (from 2019) (run by central authority) \\
\cline { 2 - 2 } $\begin{array}{l}\text { Professional health and social } \\
\text { support }\end{array}$ & $\begin{array}{l}\text { Regional counselling centres (Rajaleidja) providing special education, psychology, speech therapy and social } \\
\text { pedagogy (run by central education authority) }\end{array}$ \\
\hline
\end{tabular}


Administrative, maintenance and operations staff

\begin{tabular}{llll}
\hline \multirow{2}{*}{ Staff type } & Roles defined in regulations & Basis for creating positions & Responsibility for employment \\
\cline { 2 - 4 } Administrative staff & Secretaries etc. & At discretion of school owners & Schools \\
\cline { 2 - 4 } $\begin{array}{l}\text { Maintenance and operations } \\
\text { staff }\end{array}$ & $\begin{array}{l}\text { Security, Maintainance workers, } \\
\text { Cleaning staff, Kitchen staff etc. }\end{array}$ & At discretion of school owners & Schools \\
\hline
\end{tabular}

x: not applicable

1. The role and the tasks of assistant teacher is not defined in central regulations. If an assistant teacher position is created in a school, it is up to the school principal to decide which specific tasks this position entail. Typically, assistant teachers support teachers in classes with special needs students. 


\section{Iceland}

Instructional and leadership staff

\begin{tabular}{|c|c|c|c|}
\hline Staff type & Roles defined in regulations & Basis for creating positions & Responsibility for employment \\
\hline Teachers & $\mathrm{x}$ & $\begin{array}{l}\text { At discretion of local education } \\
\text { authorities }\end{array}$ & $\begin{array}{l}\text { Local education authorities } \\
\text { (municipalities) }\end{array}$ \\
\hline Teacher aides & $x$ & $x$ & $x$ \\
\hline \multirow[b]{2}{*}{ School leaders } & Principals & .. & \multirow[b]{2}{*}{$\begin{array}{l}\text { Local education authorities } \\
\text { (municipalities) }\end{array}$} \\
\hline & Assistant principals & $\begin{array}{l}\text { Based on central regulations } \\
\text { (school size minimum of } \\
60 \text { students) }\end{array}$ & \\
\hline
\end{tabular}

\section{Professional support staff}

Staff positions primarily created directly in schools

\begin{tabular}{llll}
\hline \multirow{2}{*}{$\begin{array}{l}\text { Staff type } \\
\text { Professional pedagogical } \\
\text { support staff }\end{array}$} & Roles defined in regulations & Basis for creating positions & Responsibility for employment \\
\cline { 2 - 4 } & $\begin{array}{l}\text { Librarians, Educational/Nocational } \\
\text { counsellors }\end{array}$ & $\begin{array}{l}\text { At discretion of schools/local } \\
\text { education authorities, based on } \\
\text { central regulations }\end{array}$ & $\begin{array}{l}\text { Schools/Local education } \\
\text { authorities }\end{array}$ \\
\cline { 2 - 4 } Health and social support staff & Doctors and Nurses & $\begin{array}{l}\text { Central authority (health } \\
\text { department) }\end{array}$ \\
\cline { 2 - 4 } & $\begin{array}{l}\text { Speech therapists, Social } \\
\text { pedagogues, Psychologists, } \\
\text { Sign-language translators }\end{array}$ & $\begin{array}{l}\text { At discretion of schools/local } \\
\text { education authorities }\end{array}$ & $\begin{array}{l}\text { Schools/Local education } \\
\text { authorities }\end{array}$ \\
\hline
\end{tabular}

Resource centres providing specialised staff for

Professional pedagogical
support
$\begin{aligned} & \text { Professional health and social } \\ & \text { support }\end{aligned}$


Administrative, maintenance and operations staff

\begin{tabular}{|c|c|c|c|}
\hline Staff type & Roles defined in regulations & Basis for creating positions & Responsibility for employment \\
\hline Administrative staff & .. & $\begin{array}{l}\text { At discretion of schools/local } \\
\text { education authorities }\end{array}$ & $\begin{array}{l}\text { Schools/Local education } \\
\text { authorities }\end{array}$ \\
\hline $\begin{array}{l}\text { Maintenance and operations } \\
\text { staff }\end{array}$ & .. & $\begin{array}{l}\text { At discretion of schools/local } \\
\text { education authorities }\end{array}$ & $\begin{array}{l}\text { Schools/Local education } \\
\text { authorities }\end{array}$ \\
\hline
\end{tabular}

$\mathrm{x}$ : not applicable

... missing

1. Based on the Compulsory School Act, all children have the right to suitable instruction and care. All students at the compulsory level have the right to receive educational and career guidance and counselling within the compulsory school by appropriate specialists. 
Kazakhstan

Instructional and leadership staff

\begin{tabular}{llll}
\hline Staff type & \multicolumn{1}{c}{ Roles defined in regulations } & Basis for creating positions & Responsibility for employment \\
\cline { 2 - 4 } Teachers & \multicolumn{1}{c}{$\mathrm{x}$} & Based on central regulations & Schools \\
\cline { 2 - 4 } Teacher aides & $\mathrm{x}$ & $\mathrm{x}$ & $\mathrm{x}$ \\
\cline { 2 - 4 } School leaders & Principals & Based on central regulations & Local education authorities (Rayon) \\
\cline { 2 - 4 } & Deputy principals & & \\
\hline
\end{tabular}

\section{Professional support staff}

Staff positions primarily created directly in schools

\begin{tabular}{llll}
\hline \multirow{2}{*}{ Staff type } & Roles defined in regulations & Basis for creating positions & Responsibility for employment \\
\cline { 2 - 4 } $\begin{array}{l}\text { Professional pedagogical } \\
\text { support staff }\end{array}$ & Chief librarians & Based on central regulations & Schools \\
\cline { 2 - 4 } Health and social support staff & $\begin{array}{l}\text { Nurses, Medical attendants, } \\
\text { Educational psychologists }\end{array}$ & Based on central regulations & Schools \\
\hline
\end{tabular}

Resource centres providing specialised staff for

Professional pedagogical

support

Professional health and social

support
$\mathrm{X}$

$\mathrm{X}$

Administrative, maintenance and operations staff

\begin{tabular}{llll}
\hline \multirow{2}{*}{ Staff type } & Roles defined in regulations & Basis for creating positions & Responsibility for employment \\
\cline { 2 - 3 } Administrative staff & $\begin{array}{l}\text { Heads of households, Chief } \\
\text { accountants, Accountants, Clerks, }\end{array}$ & Based on central regulations & Schools \\
& Secretaries & \\
\cline { 2 - 3 } $\begin{array}{l}\text { Maintenance and operations } \\
\text { staff }\end{array}$ & $\begin{array}{l}\text { Staff for work on complex } \\
\text { maintenance of buildings, Guards, } \\
\text { Doormen }\end{array}$ & Based on central regulations & Schools \\
\hline
\end{tabular}


$\mathrm{x}$ : not applicable

1. The "Standard Staffing of Public Educational Organizations and List of Teaching Positions and Equal-Status Employees" (Decree no. 77, 2008) establishes the number staff required in each school on the basis of its type, education level, and number of consolidated classes.

2. The number and type of teaching positions is strictly regulated by central norms, especially through curriculum requirements, typical staff structures and student numbers. The overall number of teaching hours is used to determine the number of teachers needed as well as their teaching workload, once up to nine teaching hours have been allocated to each school leader. Also the number and types of deputy principals and their specific tasks are set in legislation. 


\section{Lithuania}

\section{Instructional and leadership staff}

\begin{tabular}{|c|c|c|c|}
\hline Staff type & Roles defined in regulations & Basis for creating positions & Responsibility for employment \\
\hline Teachers & $x$ & $\begin{array}{l}\text { At discretion of schools, based on } \\
\text { central regulations and subject to } \\
\text { approval of school founder (local } \\
\text { authority }\end{array}$ & Schools \\
\hline Teacher aides & $\begin{array}{l}\text { Student assistants (general } \\
\text { programmes), Tutors (vocational } \\
\text { programmes) }\end{array}$ & At discretion of schools & Schools \\
\hline \multirow{3}{*}{ School leaders } & Principals & \multirow{2}{*}{$\begin{array}{l}\text { At discretion of school founders } \\
\text { (local authorities) }\end{array}$} & \multirow[b]{2}{*}{ School founders (local authorities) } \\
\hline & $\begin{array}{l}\text { Deputies for education (general, } \\
\text { vocational, non-formal, SEN, etc.) }\end{array}$ & & \\
\hline & $\begin{array}{l}\text { Heads of department for education } \\
\text { (general, vocational, non-formal, } \\
\text { SEN, etc.) }\end{array}$ & At discretion of schools & Schools \\
\hline
\end{tabular}

\section{Professional support staff}

Staff positions primarily created directly in schools

\begin{tabular}{llll} 
Staff type & Roles defined in regulations & Basis for creating staff positions & Responsibility for employment \\
\cline { 2 - 4 } $\begin{array}{l}\text { Professional pedagogical } \\
\text { support staff }\end{array}$ & $\begin{array}{l}\text { School special educational needs } \\
\text { specialists, Social pedagogues, } \\
\text { Library staff, Information } \\
\text { consultants }\end{array}$ & $\begin{array}{l}\text { At discretion of schools, based on } \\
\text { central regulations and subject to } \\
\text { approval of school founder (local } \\
\text { authority) }\end{array}$ & Schools \\
\cline { 2 - 5 } & Health support specialists, School & $\begin{array}{l}\text { At discretion of schools, based on } \\
\text { central regulations and subject to } \\
\text { approval of school founder (local }\end{array}$ & Schools \\
Health and social support staff & authority) & \\
\hline
\end{tabular}

Resource centres providing specialised staff for

Professional pedagogical

support

Professional health and social support
Psychological Pedagogical Services may be organised by school founders (local authorities)

Psychological Pedagogical Services may be organised by school founders (local authorities) 
Administrative, maintenance and operations staff

\begin{tabular}{|c|c|c|c|}
\hline Staff type & Roles defined in regulations & Basis for creating positions & Responsibility for employment \\
\hline Administrative staff & $\mathrm{x}$ & $x$ & $x$ \\
\hline $\begin{array}{l}\text { Maintenance and operations } \\
\text { staff }\end{array}$ & $\begin{array}{l}\text { Kitchen staff, Support staff } \\
\text { (Engineers, Electricians, Joiners, } \\
\text { Cleaning staff, Duty personnel } \\
\text { and Drivers, etc.) }\end{array}$ & $\begin{array}{l}\text { At discretion of schools, subject to } \\
\text { approval of school founder (local } \\
\text { authority) }\end{array}$ & Schools \\
\hline
\end{tabular}

x: not applicable

1. The central education authority specifies funding for curriculum implementation depending the number of student groups and size of the groups (a group basket) and the school leader decides on the teaching loads for teachers. Schools propose their allocations for teachers to the school founder, which confirms the number of full-time teaching staff positions. Teachers may be general education teachers, non-formal education teachers, or vocational teachers. Local authorities provide funding for the employment of teacher aides.

2. The Law on Education ensures psychological assistance; social pedagogical assistance; and special pedagogical and special assistance. The central education authority stipulates a recommended per student spending on vocational and career guidance and for providing pedagogical and psychological services. School leaders are responsible for preparing and managing the school budgets which are then approved by the owner of the school. School visits of the review team revealed that the number of both teaching and non-teaching staff is usually approved by the municipality directly, though in some cases schools have some autonomy in deciding the number of non-teaching staff.

3. There are two types of professional support staff, those working with students and those working with schools and the community. School psychologists work mainly with individual students; social pedagogues with the community.

4. Psychological Pedagogical Services may be organised at the discretion of local authorities, typically depending on the size of the municipality and the number of educational institutions in the municipality. Small municipalities usually buy services from a provider which might be in another municipality. 
Mexico

Instructional and leadership staff

\begin{tabular}{|c|c|c|c|}
\hline Staff type & Roles defined in regulations & Basis for creating positions & Responsibility for employment \\
\hline Teachers & $x$ & $\begin{array}{l}\text { Based on central regulations by } \\
\text { Federal Education Authority } \\
\text { (autoridad educativa federal) }\end{array}$ & $\begin{array}{l}\text { Federal education authority } \\
\text { (autoridad educativa federal) and } \\
\text { Local education authorities } \\
\text { (autoridad educativa local) }\end{array}$ \\
\hline Teacher Aides & $x$ & $x$ & $x$ \\
\hline \multirow{3}{*}{ School leaders } & Principals (Personal Directivo) & \multirow{3}{*}{$\begin{array}{l}\text { Based on central regulations by } \\
\text { Federal Education Authority } \\
\text { (autoridad educativa federal) }\end{array}$} & \multirow{3}{*}{$\begin{array}{l}\text { Federal education authority } \\
\text { (autoridad educativa federal) and } \\
\text { Local education authorities } \\
\text { (autoridad educativa local) }\end{array}$} \\
\hline & $\begin{array}{l}\text { Management Deputy Principals } \\
\text { (Subdirector de Gestión) }\end{array}$ & & \\
\hline & $\begin{array}{l}\text { Academic Deputy Principals } \\
\text { (Subdirector Académico) }\end{array}$ & & \\
\hline
\end{tabular}

\section{Professional support staff}

Staff positions primarily created directly in schools

\begin{tabular}{llll}
\hline Staff type & Roles defined in regulations & Basis for creating staff positions & Responsibility for employment \\
\cline { 2 - 4 } $\begin{array}{l}\text { Professional pedagogical } \\
\text { support staff }\end{array}$ & Librarians, Guidance counsellors & Based on central regulations & $\begin{array}{l}\text { Federal education authority } \\
\text { (autoridad educativa federal), } \\
\text { Local education authorities } \\
\text { (autoridad educativa local) }\end{array}$ \\
\cline { 2 - 4 } Health and social support staff & $\begin{array}{l}\text { Psychologists, Psychiatrists, Social } \\
\text { workers, Speech pathologists }\end{array}$ & $\begin{array}{l}\text { Depending on the size of the } \\
\text { school and only at its request }\end{array}$ & $\begin{array}{l}\text { Local education authorities } \\
\text { (autoridad educativa local) }\end{array}$ \\
\hline
\end{tabular}

Resource centres providing specialised staff for

\begin{tabular}{ll}
\hline Professional pedagogical & Yes \\
support & Yes \\
\cline { 2 - 2 } $\begin{array}{l}\text { Professional health and social } \\
\text { support }\end{array}$ & \\
\hline
\end{tabular}


Administrative, maintenance and operations staff

\begin{tabular}{llll}
\hline \multirow{2}{*}{$\begin{array}{l}\text { Staff type } \\
\text { Administrative staff }\end{array}$} & Roles defined in regulations & Basis for creating staff positions & Responsibility for employment \\
\cline { 2 - 4 } & Administrative staff & $\begin{array}{l}\text { Depending on the size of the } \\
\text { school and only at its request }\end{array}$ & $\begin{array}{l}\text { Local education authorities } \\
\text { (autoridad educativa local) }\end{array}$ \\
\cline { 2 - 5 } $\begin{array}{l}\text { Maintenance and operations } \\
\text { staff }\end{array}$ & $\begin{array}{l}\text { Maintenance, Night watchmen, } \\
\text { Security Staff }\end{array}$ & $\begin{array}{l}\text { Depending on the size of the } \\
\text { school and only at its request }\end{array}$ & $\begin{array}{l}\text { Local education authorities } \\
\text { (autoridad educativa local) }\end{array}$ \\
\hline
\end{tabular}

$\mathrm{x}$ : not applicable

1. Teacher positions include: Class Teacher (Personal Docente Frente a Grupo) and Teacher for Specific Topics: Special Education, Physical Education, Arts, Languages (Personal Docente Especial: Educación Física, Actividades Artísticas, Actividades Tecnológicas y de Idiomas). 


\section{Portugal}

\section{Instructional and leadership staff}

\begin{tabular}{|c|c|c|c|}
\hline Staff type & Roles defined in regulations & Basis for creating positions & Responsibility for employment \\
\hline Teachers & $x$ & Based on central regulations & Central education authority \\
\hline Teacher aides & $x$ & $x$ & $x$ \\
\hline \multirow{3}{*}{ School leaders } & School cluster principals & Based on central regulations & \multirow{3}{*}{ Central education authority } \\
\hline & $\begin{array}{l}\text { Deputy principals, Assistant } \\
\text { principals }\end{array}$ & $\begin{array}{l}\text { Based on central regulations (size of } \\
\text { school cluster in number of students } \\
\text { and complexity of educational } \\
\text { services) }\end{array}$ & \\
\hline & $\begin{array}{l}\text { Technical and Pedagogic assessors, } \\
\text { Department heads, School } \\
\text { co-ordinators }\end{array}$ & $\begin{array}{l}\text { At discretion of school principal and } \\
\text { school board (General Council) }\end{array}$ & \\
\hline
\end{tabular}

\section{Professional support staff}

Staff positions primarily created directly in schools

\begin{tabular}{|c|c|c|c|}
\hline Staff type & Roles defined in regulations & Basis for creating positions & Responsibility for employment \\
\hline $\begin{array}{l}\text { Professional pedagogical } \\
\text { support staff }\end{array}$ & $\mathrm{x}$ & $\mathrm{x}$ & $\mathrm{x}$ \\
\hline Health and social support staff & $\begin{array}{l}\text { Psychology and guidance services } \\
\text { (Serviços de Psicologia e } \\
\text { Orientação, SPO): Psychologists, } \\
\text { Social workers }\end{array}$ & Based on central regulations & Schools \\
\hline
\end{tabular}

Resource centres providing specialised staff for

\footnotetext{
Professional pedagogical support

Professional health and social support
}

$\mathrm{X}$

93 specialised resources centres for inclusion (Centros de Recursos para a Inclusão, CRI) (run by central education authority) 
Administrative, maintenance and operations staff

\begin{tabular}{llll}
\hline Staff type & Roles defined in regulations & Basis for creating staff positions & Responsibility for employment \\
\cline { 2 - 4 } Administrative staff & $\begin{array}{l}\text { Technical assistants (assistentes } \\
\text { técnicos) }\end{array}$ & Based on central regulations & Local authorities \\
\cline { 2 - 4 } Maintenance and operations staff & $\begin{array}{l}\text { Operational assistants (assistentes } \\
\text { operacionales) }\end{array}$ & Based on central regulations & Local authorities \\
\hline
\end{tabular}

x: not applicable

1. Central regulations (Organisation of the School Year [organização do ano letivo] define the class size and staffing rules for schools, published on a yearly basis by the Secretary of State for Education. School clusters make a proposal for their teacher staff allocation that takes into account planned strategic projects and the estimated number of classes previously approved by the Directorate General of Schools (Direção-Geral dos Estabelecimentos Escolares, DGEstE) on the basis of the estimated distribution of students. The directorate reviews, corrects as necessary and ultimately validates the network of class offerings for each school and the entire system. The allocation of operational and technical assistants is based on student enrolment need and the complexity of the facility and services (for operational assistants). Psychology and guidance services are established by law in all school clusters.

2. Technical and operational assistants have responsibilities ranging from performing office administrative tasks to supervising students during non-instructional periods in the cafeteria, recess and hallways, to serving as student engagement staff by de-escalating and re-integrating disruptive students into class, to assisting with laboratory experiments. 


\section{Slovak Republic}

\section{Instructional and leadership staff}

\begin{tabular}{|c|c|c|c|}
\hline Staff type & Roles defined in regulations & Basis for creating positions & Responsibility for employment \\
\hline Teachers & $\mathrm{x}$ & $\begin{array}{l}\text { At discretion of schools (as a legal } \\
\text { entity) }\end{array}$ & Schools (as a legal entity) \\
\hline \multirow{2}{*}{ Teacher aides } & $\begin{array}{l}\text { Teaching assistants for students with } \\
\text { disabilities }\end{array}$ & \multirow{2}{*}{$\begin{array}{l}\text { Based on request of local education } \\
\text { authority (as school founder) and } \\
\text { approved by the central education } \\
\text { authority ( based on number of } \\
\text { children from socially deprived } \\
\text { families) }\end{array}$} & \multirow{2}{*}{ Schools (as a legal entity) } \\
\hline & $\begin{array}{l}\text { Teaching assistants for students } \\
\text { from socially deprived environment }\end{array}$ & & \\
\hline \multirow[b]{3}{*}{ School leaders } & Principals & $\begin{array}{l}\text { Based on central regulations } \\
\text { (teaching workload is decreased } \\
\text { defined by school size) }\end{array}$ & $\begin{array}{l}\text { Local education authorities (as } \\
\text { school founder) }\end{array}$ \\
\hline & Deputy principals & $\begin{array}{l}\text { At discretion of school (as a legal } \\
\text { entity) (teaching workload is } \\
\text { decreased defined by school size) }\end{array}$ & \multirow[b]{2}{*}{ Schools (as a legal entity) } \\
\hline & $\begin{array}{l}\text { Class teachers, Mentors, Heads of } \\
\text { education counsellors, Heads of } \\
\text { practical training at VET schools, } \\
\text { Heads of field of study, Heads of } \\
\text { subject committee or Heads of } \\
\text { methodology association, } \\
\text { Co-ordinators of specific work }\end{array}$ & $\begin{array}{l}\text { At discretion of school, subject to } \\
\text { consultation in pedagogical board } \\
\text { (roles are assigned to teachers) }\end{array}$ & \\
\hline
\end{tabular}

\section{Professional support staff}

Staff positions primarily created directly in schools

Staff type

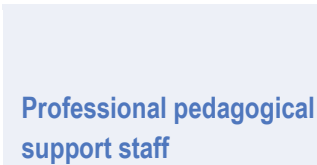

Health and social support staff
Roles defined in regulations

\begin{tabular}{lll} 
& $\begin{array}{l}\text { At discretion of schools, after } \\
\text { consultation in pedagogical board } \\
\text { (roles are assigned to teachers, } \\
\text { teaching workload is decreased } \\
\text { based on central regulation by } \\
\text { advisers }\end{array}$ & school size) \\
\hline $\begin{array}{l}\text { School psychologists, School } \\
\text { speech therapists, Social } \\
\text { educators }\end{array}$ & $\begin{array}{l}\text { At discretion of schools (as a legal } \\
\text { entity) }\end{array}$ & Schools (as a legal entity) \\
\hline
\end{tabular}

Resource centres providing specialised staff for
Professional pedagogical support

Professional health and social support
Pedagogical and Psychological Consulting and Prevention Centres (run by central education authority): Career advisers

Pedagogical and Psychological Consulting and Prevention Centres (run by central education authority): Psychologists, Special educators, Special educators in field, Speech Therapists, Social educators, Therapists 
Administrative, maintenance and operations staff

\begin{tabular}{llll}
\hline Staff type & Roles defined in regulations & Basis for creating staff positions & Responsibility for employment \\
\cline { 2 - 5 } Administrative staff & $\begin{array}{l}\text { Not defined by central regulation } \\
\text { (but typically includes controllers, } \\
\text { accountants, secretaries etc.) }\end{array}$ & $\begin{array}{l}\text { At discretion of schools (as a legal } \\
\text { entity) }\end{array}$ & Schools (as a legal entity) \\
\cline { 2 - 5 } $\begin{array}{l}\text { Maintenance and operations } \\
\text { staff }\end{array}$ & $\begin{array}{l}\text { Not defined by central regulation } \\
\text { (but typically includes school } \\
\text { keepers etc.) }\end{array}$ & $\begin{array}{l}\text { At discretion of schools (as a legal } \\
\text { entity) }\end{array}$ & Schools (as a legal entity) \\
\hline
\end{tabular}

x: not applicable

1. Schools with Grades 1-9 and upper secondary schools all operate as legal entities and are responsible for managing their human resources. In pre-primary schools and schools with Grades 1-5 only, the school founder decides if the school is a legal entity or not. Overall, around $80 \%$ of schools are legal entities. In schools which are not a legal entity, the local education authorities (in their function as school founder) are responsible for staff employment, and approve the creation of teaching and other staff positions.

2. Budgets are typically managed in collaboration between schools, school founders and school boards. Schools (or school founders in the case of schools that are not a legal entity) are required to spend the personnel normative defined by the central education authority on staff. The central normative is mainly based on the number of students, school size and student characteristics.

3. Teaching assistants for children with disabilities are funded directly from the central budget and the Ministry of Education determines the allocation of posts in response to founders' requests. For teaching assistants for children from socially deprived families there are centrally earmarked funds to be spent at schools attended by such children.

4. Students have a right to education that reflects their educational needs and possibilities in its content, forms and methods. Students have the right to free guidance. The structure and assignment of educational counsellors and career advisers as career positions in schools is decided by the school principal. In schools that do not have the status of a legal entity, local education authorities are responsible for staff employment and approve the creation of positions as proposed by schools. 


\section{Slovenia}

\section{Instructional and leadership staff}

\begin{tabular}{|c|c|c|c|}
\hline Staff type & Roles defined in regulations & Basis for creating positions & Responsibility for employment \\
\hline Teachers & $x$ & $\begin{array}{l}\text { At discretion of schools, based on } \\
\text { central regulations and subject to } \\
\text { approval of local education } \\
\text { authority (as school founder) }\end{array}$ & School (principal) \\
\hline Teacher aides & School laboratory assistants & $\begin{array}{l}\text { At discretion of schools, based on } \\
\text { central regulations and subject to } \\
\text { approval of local education } \\
\text { authority (as school founder) }\end{array}$ & School (principal) \\
\hline \multirow{3}{*}{ School leaders } & Head teachers & Based on central regulations & School (school board) \\
\hline & Assistant Head Teachers & $\begin{array}{l}\text { Based on central regulations } \\
\text { (based on school size, with at least } \\
18 \text { classes) }\end{array}$ & School (principal) \\
\hline & Heads of Unit or Branch & $\begin{array}{l}\text { At discretion of school, based on } \\
\text { central regulations }\end{array}$ & School (principal) \\
\hline
\end{tabular}

\section{Professional support staff}

Staff positions primarily created directly in schools

\begin{tabular}{llll}
\hline Staff type & Roles defined in regulations & Basis for creating positions & Responsibility for employment \\
\cline { 2 - 4 } $\begin{array}{l}\text { Professional pedagogical } \\
\text { support staff }\end{array}$ & $\begin{array}{l}\text { Counselling services providing } \\
\text { career guidance, School librarians }\end{array}$ & $\begin{array}{l}\text { Based on central regulations, and } \\
\text { subject to central approval }\end{array}$ & Schools \\
\cline { 2 - 4 } Health and social support staff & $\begin{array}{l}\text { Counselling services, School } \\
\text { meals organisers }\end{array}$ & $\begin{array}{l}\text { Based on central regulations, and } \\
\text { subject to central approval }\end{array}$ & Schools \\
\hline
\end{tabular}

Resource centres providing specialised staff for

Professional pedagogical
support
Professional health and social
support

Employment service (public institutions run by central authority): Career guidance

Counselling Centres for Children, Adolescents and Parents; Community Health Centres (run by local authorities): Speech therapists, Psychologists, Medical doctors, Nurses

National Institute of Public Health, National Education Institute (for procedures for the placement of SEN students), Centres for Education of SEN children, Social Work Centres (run by central authority) 
Administrative, maintenance and operations staff

\begin{tabular}{llll}
\hline \multirow{2}{*}{$\begin{array}{l}\text { Staff type } \\
\text { Administrative staff }\end{array}$} & Roles defined in regulations & Basis for creating positions & Responsibility for employment \\
\cline { 2 - 4 } & $\begin{array}{l}\text { Secretaries, Accountants, } \\
\text { Bookkeepers, Administrators }\end{array}$ & $\begin{array}{l}\text { At discretion of schools, based on } \\
\text { central regulations, and subject to } \\
\text { central approval }\end{array}$ & Schools \\
\cline { 2 - 5 } $\begin{array}{l}\text { Maintenance and operations } \\
\text { staff }\end{array}$ & Janitors, Cooks, Cleaners & $\begin{array}{l}\text { At discretion of schools, based on } \\
\text { central regulations, and subject to } \\
\text { central approval }\end{array}$ & Local education \\
authorities/Schools
\end{tabular}

$\mathrm{x}$ : not applicable

1. In Slovenia, the principal is referred to as the head teacher, the assistant principal as assistant head teacher.

2. Central criteria and standards (Rules on norms and standards for the implementation of the basic school programme) specify teaching responsibilities of teaching staff, the criteria for the provision of the counselling service, libraries, administrative, account-keeping and technical services and the classroom and grouping criteria. School principals are responsible for organising and managing their staff, but must do so according to central norms and regulations, and require the approval of the central ministry before publishing a vacancy notice. Schools propose their staff placement and structure, based on central regulations. Local education authorities (municipalities) and the central education authority approve the suggested job structure and final number of student groups.

3. Counselling services and a librarian are required by law in all schools. Counselling services are made up of psychologists, social pedagogues, education specialists, social workers, special and rehabilitation pedagogues, and inclusive pedagogues. 


\section{Spain}

Instructional and leadership staff

\begin{tabular}{llll}
\hline Staff type & Roles defined in regulations & Basis for creating positions & Responsibility for employment \\
\cline { 2 - 4 } & \multicolumn{1}{c}{ Teachers } & Based on central regulations & $\begin{array}{l}\text { State education authorities } \\
\text { (Autonomous Community) }\end{array}$ \\
\cline { 2 - 4 } Teacher aides & Specialist technicians in education & $\begin{array}{l}\text { At discretion of state education } \\
\text { authorities }\end{array}$ & $\begin{array}{l}\text { State education authorities } \\
\text { (Autonomous Community) }\end{array}$ \\
School leaders & Principals, Heads of studies & Based on state regulations & $\begin{array}{l}\text { State education authorities } \\
\text { (Autonomous Community) }\end{array}$ \\
\hline
\end{tabular}

\section{Professional support staff}

Staff positions primarily created directly in schools

\begin{tabular}{llll}
\hline \multirow{2}{*}{$\begin{array}{l}\text { Staff type } \\
\text { Professional pedagogical } \\
\text { support staff }\end{array}$} & Roles defined in regulations & Basis for creating positions & Responsibility for employment \\
\cline { 2 - 4 } & $\begin{array}{l}\text { Technical Teachers of Community } \\
\text { Service (PTSC), Library staff }\end{array}$ & $\begin{array}{l}\text { At discretion of state education } \\
\text { authorities }\end{array}$ & $\begin{array}{l}\text { State education authorities } \\
\text { (Autonomous Communities) }\end{array}$ \\
\cline { 2 - 4 } & $\begin{array}{l}\text { Counsellors, Psychologists, } \\
\text { Pedagogues, Psycho-pedagogues, }\end{array}$ & & State education authorities \\
(Autonomous Communities)
\end{tabular}

Resource centres providing specialised staff for

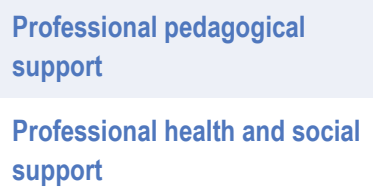

May be organised by state education authorities 
Administrative, maintenance and operations staff

\begin{tabular}{|c|c|c|c|}
\hline Staff type & Roles defined in regulations & Basis for creating positions & Responsibility for employment \\
\hline Administrative staff & $\begin{array}{l}\text { Administrative staff (Clerks, } \\
\text { Administrators, Administrative } \\
\text { assistants) }\end{array}$ & $\begin{array}{l}\text { At discretion of state education } \\
\text { authorities }\end{array}$ & $\begin{array}{l}\text { State education authorities } \\
\text { (Autonomous Communities) }\end{array}$ \\
\hline $\begin{array}{l}\text { Maintenance and operations } \\
\text { staff }\end{array}$ & $\begin{array}{l}\text { General services staff (Janitors, } \\
\text { Cleaning staff, Kitchen assistants } \\
\text { and managers, Canteen } \\
\text { employees) }\end{array}$ & $\begin{array}{l}\text { At discretion of state education } \\
\text { authorities }\end{array}$ & $\begin{array}{l}\text { State education authorities } \\
\text { (Autonomous Communities) }\end{array}$ \\
\hline
\end{tabular}

$\mathrm{x}$ : not applicable

1. Every school year, the state education authorities allocate the teacher resources for each public institution in their territory, on the basis of the educational stage; the number of units; size; opening hours; the supplementary services it provides; the characteristics of its population; and the specific needs to be determined by the management team of the institution.

2. State education authorities may establish additional school leadership roles and positions to carry out tasks related to administration, financial management and pedagogical organisation (e.g. deputy principal, deputy head of studies, deputy administrator).

2. The planning and offer of non-teaching service personnel who carry out education and/or health support tasks and clerical and service personnel come under the competence of the state education authorities. The presence of all support staff in schools depends on the needs identified by the education authority with the approval of the school management, educational inspectorate and with prior medical diagnosis provided by families. Each school year, staff are allocated and staff are typically employed on occupational contracts, both indefinite and temporary.

3. Specialist technicians provide additional support and education to special needs students (e.g. assisting them on the school bus, etc.). They also monitor hallways during classroom changes, supervise classrooms when the teacher is absent, etc.

4. In the majority of schools, teachers usually have an assigned time at the library.

5. Counsellors, psychologists, pedagogues and psycho-pedagogues co-ordinate educational guidance within schools through dedicated Guidance Departments or Units, or externally in the form of Educational and Psycho-pedagogical Guidance Teams, Early Care Teams or Specific Teams. 


\section{Sweden}

\section{Instructional and leadership staff}

\begin{tabular}{llll}
\hline Staff type & Roles defined in regulations & Basis for creating positions & Responsibility for employment \\
\cline { 2 - 4 } Teachers & $\mathrm{x}$ & At discretion of schools & $\begin{array}{l}\text { Local education authorities } \\
\text { (municipalities) }\end{array}$ \\
\cline { 2 - 4 } Teacher aides & At discretion of schools & $\begin{array}{l}\text { Local education authorities } \\
\text { (municipalities) }\end{array}$ \\
\cline { 2 - 4 } & School principal & At discretion of schools & $\begin{array}{l}\text { Local education authorities } \\
\text { (municipalities) }\end{array}$ \\
\hline
\end{tabular}

\section{Professional support staff}

Staff positions primarily created directly in schools

\begin{tabular}{llll}
\hline \multirow{2}{*}{$\begin{array}{l}\text { Staff type } \\
\text { Professional pedagogical } \\
\text { support staff }\end{array}$} & Roles defined in regulations & Basis for creating positions & Responsibility for employment \\
\cline { 2 - 4 } Health and social support staff & $\begin{array}{l}\text { Career and guidance counsellors, } \\
\text { Librarians, Welfare officers }\end{array}$ & At discretion of schools & $\begin{array}{l}\text { Local education authorities } \\
\text { (municipalities) }\end{array}$ \\
\cline { 2 - 4 } & $\begin{array}{l}\text { School medical officers, school } \\
\text { nurse, Psychologists, Counsellors }\end{array}$ & $\begin{array}{l}\text { At discretion of schools, based on } \\
\text { central regulations }\end{array}$ & $\begin{array}{l}\text { Local education authorities } \\
\text { (municipalities) }\end{array}$ \\
\hline
\end{tabular}

Resource centres providing specialised staff for

Professional pedagogical

support

Professional health and social support $\mathrm{x}$

May be organised by local education authorities (municipalities)

Administrative, maintenance and operations staff

\begin{tabular}{llll}
\hline Staff type & Roles defined in regulations & Basis for creating positions & Responsibility for employment \\
\cline { 2 - 4 } Administrative staff & Not centrally regulated & At discretion of schools & $\begin{array}{l}\text { Local education authorities } \\
\text { (municipalities) }\end{array}$ \\
\cline { 2 - 4 } $\begin{array}{l}\text { Maintenance and operations } \\
\text { staff }\end{array}$ & $\begin{array}{l}\text { Caretakers, School meal } \\
\text { personnel, Cleaning staff, } \\
\text { Computer technicians }\end{array}$ & At discretion of schools & $\begin{array}{l}\text { Local education authorities } \\
\text { (municipalities) }\end{array}$ \\
\hline
\end{tabular}


$\mathrm{x}$ : not applicable

1. The scope for allocating resources for teachers depend on the resources received from the local education authorities. The school principal is responsible for ensuring that teachers receive the support they need (e.g. through smaller classes, additional staff resources to a class or one or more students), but this is not centrally regulated. Schools are also free to organise their management team. There can be one or more deputy principals as a support function to the principal. In vocational education, there are often department heads who are responsible for the training in their department. Teacher assistants are rare.

2. All students have the right to adjustments, educational support and guidance depending on their needs. Students should have access to a school medical officer, school nurse, psychologist and a counsellor. The entitled school healthcare is free of charge. Student nurses are required in all schools. 


\section{Turkey}

\section{Instructional and leadership staff}

\begin{tabular}{lccc}
\hline Staff type & \multicolumn{1}{c}{ Roles defined in regulations } & Basis for creating positions & Responsibility for employment \\
\cline { 2 - 4 } Teachers & $\mathrm{x}$ & Based on central regulations & Central education authority \\
\cline { 2 - 4 } Teacher aides & $\mathrm{x}$ & $\mathrm{x}$ & $\mathrm{x}$ \\
\cline { 2 - 4 } & $\begin{array}{l}\text { School principals, Chief deputy } \\
\text { principals, Deputy principals }\end{array}$ & Based on central regulations & Central education authority \\
\hline
\end{tabular}

\section{Professional support staff}

Staff positions primarily created directly in schools

\begin{tabular}{llll}
\hline Staff type & Roles defined in regulations & Basis for creating staff positions & Responsibility for employment \\
\cline { 2 - 4 } $\begin{array}{l}\text { Professional pedagogical } \\
\text { support staff }\end{array}$ & Counsellors & $\begin{array}{l}\text { At discretion of central education } \\
\text { authority }\end{array}$ & Central education authority \\
\cline { 2 - 4 } Health and social support staff & $\mathrm{x}$ & $\mathrm{x}$ & $\mathrm{x}$ \\
\hline
\end{tabular}

Resource centres providing specialised staff for

Professional pedagogical

support

Professional health and social

support $\mathrm{x}$

$\mathrm{X}$

\section{Administrative, maintenance and operations staff}

\begin{tabular}{llll}
\hline \multirow{2}{*}{ Staff type } & Roles defined in regulations & Basis for creating staff positions & Responsibility for employment \\
\cline { 2 - 4 } Administrative staff & $\begin{array}{l}\text { Accountants, Officers, Data } \\
\text { Preparation and Control Operators }\end{array}$ & $\begin{array}{l}\text { At discretion of central education } \\
\text { authority }\end{array}$ & Central education authority \\
\cline { 2 - 5 } $\begin{array}{l}\text { Maintenance and operations } \\
\text { staff }\end{array}$ & Cleaning staff, Technicians & $\begin{array}{l}\text { At discretion of central and } \\
\text { regional education authorities }\end{array}$ & $\begin{array}{l}\text { Central and regional education } \\
\text { authorities }\end{array}$ \\
\hline
\end{tabular}

x: not applicable

1. The number of teachers and deputy principals to be assigned to schools are determined by the size of the school (number of students, number of classrooms). There is one principal for each school. 


\section{Uruguay}

\section{Instructional and leadership staff}

\begin{tabular}{|c|c|c|c|}
\hline Staff type & Roles defined in regulations & Basis for creating positions & Responsibility for employment \\
\hline Teachers & $x$ & $\begin{array}{l}\text { Based on central regulations, with } \\
\text { input from the school inspection } \\
\text { (based on school size, number of } \\
\text { groups, social and economic } \\
\text { vulnerabilities) }\end{array}$ & $\begin{array}{l}\text { Central education authorities } \\
\text { (Education Councils) }\end{array}$ \\
\hline Teacher aides & $x$ & $x$ & $x$ \\
\hline School leaders & Principals, Deputy principals & $\begin{array}{l}\text { Based on central regulations (based } \\
\text { on school type, enrolments, for } \\
\text { general secondary schools, the } \\
\text { organisation of classes over the day, } \\
\text { number of groups in a school) }\end{array}$ & $\begin{array}{l}\text { Central education authorities } \\
\text { (Education Councils) }\end{array}$ \\
\hline
\end{tabular}

\section{Professional support staff}

Staff positions primarily created directly in schools

\begin{tabular}{lllll}
\hline Staff type & Roles defined in regulations & Basis for creating positions & Responsibility for employment \\
\cline { 2 - 2 } $\begin{array}{l}\text { Professional pedagogical } \\
\text { support staff }\end{array}$ & $\begin{array}{l}\text { Pedagogical support staff } \\
\text { providing assistance to students }\end{array}$ & Based on central regulations & $\begin{array}{l}\text { Central education authorities } \\
\text { (Education Councils) }\end{array}$ \\
\cline { 2 - 3 } Health and social support staff & \begin{tabular}{l} 
Social educators (educador social) \\
\cline { 2 - 3 }
\end{tabular} & $\begin{array}{l}\text { Psychologists, Social workers } \\
\text { (trabajador social) }\end{array}$ & Based on central regulations & $\begin{array}{l}\text { Central education authorities } \\
\text { (Education Councils) }\end{array}$ \\
\hline
\end{tabular}

Resource centres providing specialised staff for

Professional pedagogical

support

Professional health and social support
$\mathrm{X}$ 
Administrative, maintenance and operations staff

\begin{tabular}{llll}
\hline Staff type & Roles defined in regulations & Basis for creating positions & Responsibility for employment \\
\cline { 2 - 4 } & Secretaries, Administratives & Based on central regulations & $\begin{array}{l}\text { Central education authorities } \\
\text { (Education Councils) }\end{array}$ \\
\cline { 2 - 4 } $\begin{array}{l}\text { Maintenance and operations } \\
\text { staff }\end{array}$ & Cleaning staff, Maintenance staff & Based on central regulations & $\begin{array}{l}\text { Central education authorities } \\
\text { (Education Councils) }\end{array}$ \\
\hline
\end{tabular}

x: not applicable

1. Teacher allocations are defined based on the number of student groups (classes) the individual school should operate (per education cycle, programme and course. These are calculated based on the estimation of enrolment levels together with the modality of the school and the type of programme/course. The number of additional teaching staff for each school is discretionary and depends strongly on the assessment of needs undertaken by inspections.

2. Pedagogical support staff providing assistance to students include, for example, teacher leaders (profesores adscriptos a la dirección), pedagogical counsellor teachers (profesor orientador pedagógico)and bibliographic counsellor teachers (profesor orientador bibliográfico).

3. Social educators and psychologists do not work in all schools. Social educators work in general lower secondary education with tutoring or other programmes which require closer support. Social educators articulate activities and other type of joint work with local actors, they work in networks and co-ordinate with governmental and non-governmental institutions. They are part of the interdisciplinary team (together with the psychologist and the social worker). 



\section{Chapter 2. Raising the attractiveness of a career in schools}

This chapter analyses how entry requirements, career structures, compensation and working conditions can help to attract, retain and motivate effective staff working in schools and specifically teachers and school leaders. It explores how the horizontal and vertical structure of teachers' careers can provide opportunities for professional growth within the classroom and offer clear pathways to positions of educational leadership. The chapter also considers how policies can shape working conditions in ways that enable teachers and leaders to employ their skills effectively, as well as the role that autonomy and teachers' voice play in strengthening the profession. The chapter emphasises implementation challenges and considers under which conditions employment reforms are most likely to have the desired effect on staff, schools and students. The chapter concludes with a set of ideas that policy makers may consider as they develop responses for their particular contexts, challenges and goals.

The statistical data for Israel are supplied by and under the responsibility of the relevant Israeli authorities. The use of such data by the OECD is without prejudice to the status of the Golan Heights, East Jerusalem and Israeli settlements in the West Bank under the terms of international law. 
Attracting talented individuals to a career in schools is a pressing concern in many OECD countries, particularly those with rising student enrolments or a large share of teachers, school leaders or other staff approaching retirement age. Retaining the best teachers and leaders, motivating them throughout their careers and enabling them to use their talents effectively to foster student learning and well-being is at the heart of what makes a successful education system. Raising the status of a career in schools has been a priority for education policy makers not only because it is critical for systems to attract the next generation of quality candidates to the profession. The social status of teachers and school leaders is also a reflection of the status quo and can indicate whether a system's current human resource policies are well designed to promote educational success.

The OECD Teaching and Learning International Survey (TALIS) points to significant differences in the social and professional status of teachers and the public perception of a career in schools among OECD review countries (OECD, 2019 [1]; OECD, 2014[2]). The status of teachers and school leaders is driven not only by the material but also by the intellectual fulfilment that the work in schools provides, and it often mirrors the extent to which teachers and leaders are capable, enabled and trusted to act upon their professional expertise. Not surprisingly then, there is more than one way to raise the status and attractiveness of a career in schools and - depending on national contexts - this is rarely straightforward, especially with limited resources.

Individuals choose a career in school education for a variety of reasons, but evidence from TALIS 2018 suggests that the great majority of serving teachers were motivated by a strong commitment to public service and the social impact of teaching. When asked about their decision to become a teacher, across the OECD, $92 \%$ of lower secondary teachers reported that it was important to them to influence the development of children and young people and $88 \%$ said they were motivated by the profession's contribution to society (OECD, 2019 , p. $\left.123_{[1]}\right)$. The tasks that teachers, leaders and other school staff perform - working with young people and inspiring them to learn - thus continue to be powerful sources of intrinsic motivation.

At the same time, a substantial number of teachers report that extrinsic characteristics, including career prospects $(61 \%)$, job security $(71 \%)$ and the ability to reconcile their work schedule and private life (66\%) also mattered for their decision to join teaching (OECD, 2019 , p. $\left.123_{[1]}\right)$. This is consistent with evidence that the attractiveness of careers, salaries and working conditions in schools - compared to those in alternative professions - affects the supply of school-level professionals, the propensity of young people to enter initial teacher preparation and the retention of early-career staff. Furthermore, working conditions, salaries and administrative workload rank at the top of practicing teachers' concerns in many OECD systems (OECD, 2019, p. 110 $[1])$. These results underline the importance of providing a working environment that allows teachers to focus on their instruction. They also suggest that inspiring young people to learn might only be a source of continuing motivation if teachers can pursue their work under conditions that make it intellectually stimulating and enjoyable.

Intrinsic and extrinsic motivations are thus closely intertwined and school systems need to consider both when seeking to raise the attractiveness of a career in schools, to motivate school staff and to enable them to support student learning. With this in mind, this chapter analyses how entry requirements, career structures, compensation and working conditions can help to attract, retain and motivate effective staff working in schools and specifically teachers and leaders. It explores how the horizontal and vertical structure of teachers' careers can provide opportunities for professional growth within the classroom and offer 
clear pathways to positions of educational leadership. The chapter also considers how national and sub-national policies can shape working conditions in ways that enable teachers and leaders to employ their skills effectively, as well as the role that autonomy and teachers' voice play in strengthening the profession.

Throughout its analysis, the chapter emphasises implementation challenges and considers under which conditions employment reforms are most likely to "reach the classroom" and have the desired effect on staff and the professional capacity in schools. The chapter concludes with a set of ideas that policy makers may consider as they develop responses for their particular contexts, challenges and goals.

\subsection{Entry requirements for teachers and school leaders}

Attracting, selecting and retaining effective school staff is critical for the success of education systems. Entry requirements regulate both the path to initial qualifications (e.g. the admission to initial teacher education or alternative pathways into the teaching career), as well as the conditions that school staff need to fulfil to assume and remain in their positions. They can therefore have a profound impact on both the quality and the quantity of those pursuing a career in schools. In addition, by signalling the level of knowledge and skills expected of school staff, entry requirements contribute to shaping the social status of their roles. Given the critical influence that entry requirements have on the profession as a whole, professional bodies, such as Ireland's Teaching Council and the Teaching Council of Aotearoa New Zealand, sometimes take a leading role in their definition (OECD, 2013 [3]).

Considering the differences in school systems' recruitment needs and labour markets, there is considerable cross-country variation in entry requirements and debate over the desirable level of selectivity, the appropriate criteria, and the point at which high-quality candidates can be most effectively identified. In addition to the attainment of minimum qualification requirements, aspiring teachers undergo a recruitment process for particular positions (see Chapter 3) and - especially in the case of school leaders - typically have to demonstrate further training and experience. While many OECD countries allow graduates of initial teacher education to start teaching directly after gaining their qualification, they may also need to pass additional hurdles once they have assumed their role, such as probation periods or certification processes that require them to demonstrate their competence after a given time on the job or periodically throughout their career.

\subsubsection{Setting high or low entry requirements for the teaching profession}

Policy makers have pursued different strategies to ensure that teachers of the highest calibre enter and remain in the classroom. Notably, school systems performing highly in the OECD Programme for International Student Assessment (PISA) have very different approaches to the selection of candidates for the teaching profession (OECD, 2019 $9_{[4]}$ ). While Korea and Chinese Taipei, for example, set competitive examinations at both the start and the end of initial teacher education, other high-performing countries, including Australia, England (United Kingdom), Estonia, Norway, Singapore and Slovenia make no use of competitive examinations at either point (OECD, 2018, p. 46 $6_{[5]}$ ).

Similar variation can be seen not only in the mechanism, but also the timing of selection. While some systems have chosen to screen candidates early on, using rigorous admission criteria for initial teacher education or qualification requirements for beginning teachers, others defer the selection process by reducing barriers to entry and instead evaluating 
teachers for retention based on their proven effectiveness on the job (Staiger and Rockoff, $\left.2010_{[6]}\right)$. Each of these two models has its benefits and drawbacks and there are long-standing debates over which entry requirements are best suited to raise the quality of teachers.

Concerns about the academic skills of prospective teacher candidates recurrently feature in policy discussions around education quality and were evident in a number of OECD review countries, including Chile, Colombia and Portugal but also other systems such as Norway (Liebowitz et al., 2018 [7]; Radinger et al., 2018 ${ }_{[8]}$; Santiago et al., 2017 ${ }_{[9]}$; Norwegian Ministry of Education and Research, Oslo, 2017 $[10])$. Indeed, PISA 2015 data find that 15 -year-olds who intend to work as teachers have, on average, lower scale scores in maths (16 points) and reading (12 points) (OECD, 2018 $\left.{ }_{[5]}\right)$, while some high-performing school systems, such as Korea, Finland, Singapore and Hong Kong are said to draw their future teachers from the upper deciles of the achievement distribution (Auguste, Kihn and Miller, 2010 [11]; Barber and Mourshed, 2007 [12]).

At the same time, evidence from the OECD Programme for the International Assessment of Adult Competencies (PIAAC) 2013 Survey of Adult Skills and the OECD Adult Literacy and Life Skills (ALL) assessment suggests that - while the distribution of teachers' skill profiles varies substantially across countries and is positively related to student outcomes - teachers' skill profiles are usually above the country-wide average and compare favourably to those of other highly educated workers in many countries (Hanushek, Piopiunik and Wiederhold, 2019[13]; Golsteyn, Vermeulen and de Wolf, 2016[14]).

Nevertheless, concerns about the selection of teaching candidates have motivated some countries to raise their admission standards for initial teacher education. In Denmark, for example, concerns about the quality of candidates and high dropout rates (which were as high as $41 \%$ in 2005 ) led to a reform of the allocation of study places, which was previously based solely on students' performance in upper secondary education. The new admissions process continues to allow students with the highest marks to enrol directly but requires all other candidates to sit an examination and take part in an interview to gain admission. Early reports from 2014 suggested that the reform had led to a slight decrease in dropout rates (Nusche et al., 2016, p. 144[15]).

Others have questioned the use of more rigorous selection processes at the start of initial teacher education and high barriers to entering the profession, pointing to the difficulty of assessing teachers' effectiveness prior to their entry into the classroom (Staiger and Rockoff, 2010[6]). Introducing additional hurdles, they argue, risks to screen out potential high-quality teachers based on a narrow set of criteria that are only modestly associated with future performance (Kane, Rockoff and Staiger, 2008 ${ }_{[16]}$; Boyd et al., 2008 $8_{[17]}$ ). Cross-sectional evidence from US states also suggests that barriers for certification, such as state examinations or course requirements, can depress the overall supply of teachers (Hanushek and Pace, $1995_{[18]}$ ) and may discourage high-potential candidates with diverse backgrounds from entering the teaching profession (Vegas and Ganimian, 2013 ${ }_{[19]}$ ), which can be a concern for systems facing acute teacher shortages.

By contrast, reducing the barriers that teachers need to take prior to entering the classroom may not only help alleviate issues of teacher shortages, but also give schools and/or education authorities the possibility to assess whether a teacher is adequately carrying out their roles and responsibilities to satisfactory standards based on their actual practice. At the same time, where entry requirements for initial preparation and into the profession are low, there is the risk that low-performing teachers may enter and remain in the classroom 
unless there are effective processes for identifying and supporting or - in the worst case dismissing them. Some countries have sought to address this dilemma by combining moderate entry requirements with a probationary period, re-certification requirements or high-stakes appraisals. This introduces a high bar for retention decisions after a few years of work experience, rather than at the point of initial certification.

In the Czech Republic, for example, there were plans at the time of the OECD review to complement the screening of candidates at the start of initial teacher education with an assessment after their first year of practice to determine whether teachers can remain in the profession (Shewbridge et al., 2016, p. 150[20]). At the time of writing, a planned amendment to the Pedagogical Workers Act (which regulates the profession in the country) was proposing an induction period of two years. A new career structure in Chile introduced a similar hurdle that teachers must take four to eight years after entering the profession (see Table 2.1) (Santiago et al., 2017, p. $253_{[9]}$ ). Raising the extent of practical experience as an integral part early on in teacher education programmes is another option to ensure initial qualifications meaningfully reflect teachers' practical skills in the classroom while at the same time giving student teachers an opportunity to consider their motivation and career choice based on a realistic impression of the profession.

\subsubsection{Differences in qualification requirements across levels and sectors}

Required qualifications may differ for teachers across levels of education, across different sectors, and even among teachers working in the same school. This partly reflects the fact that not all teachers of a school perform the same work and that their qualifications may evolve in line with changing task profiles and responsibilities over the course of their career. For instance, qualification requirements in vocational education and training typically differ from those in general education, given the specific nature of practical courses. In the Flemish Community of Belgium, Chile, the Czech Republic and Estonia, vocational trainers do not require standard teaching qualifications, but instead professional experience, sometimes combined with some training or certificate in teaching and pedagogy. Allowing for some diversity in teachers' qualification requirements can also support schools in recruiting staff who bring a diverse mix of skills and expertise (see Chapter 3 on staff recruitment). Furthermore, different qualification requirements may exist side by side during transition periods following reforms to raise qualification levels.

However, generalised differences in qualification requirements for teachers at different levels of education (e.g. for primary versus secondary education) are rarely justified by the nature of their work and can have a number of undesirable consequences. In some cases, discrepancies in qualification requirements across levels have harmed both the status and supply of highly qualified graduates to teach at lower levels of education and led to resource imbalances that are at odds with the widely recognised benefits of investing in the early years (Woessmann, 2008 $[21]$; Cunha et al., 2006 $6_{[22]}$ ).

Differences in degree requirements across levels of education remain widespread in OECD countries. Austria, Denmark, Hungary, Luxembourg, Poland, Spain and Switzerland, for example, require higher degrees to teach in general lower and/or upper secondary schools than at the primary level (OECD, 2019, p. 392[23]). These differences are even more pronounced for teachers at the pre-primary level. Even though a bachelor's degree has become the minimum qualification in 27 of the 37 OECD and partner countries (2017, p. $43_{[24]}$ ), the Slovak Republic, for example, requires them to have obtained as little as an upper secondary qualifications (in contrast to qualifications at the master's level for teachers at the other levels of education) (Santiago et al., 2016 [25] $)$. 
Generalised differences in teaching requirements can also make it difficult to respond to changes in demand by employing teachers flexibly across levels or sectors. For example, in many systems, including several OECD review countries like the Czech Republic, special education teachers working in separate schools have a different type of certification than those in mainstream education. This has reportedly created difficulties or even undermined efforts to move towards the greater inclusion of students with special needs since their teachers would need to be re-certified to work in mainstream settings (OECD, 2018 , p. $275_{[26]}$; Shewbridge et al., 2016, p. $75_{[20]}$ ). Likewise, in school systems where students are tracked into different programmes, distinct professional requirements can lead to variations in teaching quality across tracks, thus amplifying the effects of student segregation and contributing to inequities (OECD, 2018 $\left.8_{[5]}\right)$.

\subsubsection{Entry requirements and pathways into school leadership}

Defining minimum qualifications and entry requirements for school leaders not only serves to ensure that minimum standards are met - it also affects their professional status and may help in attracting school leader candidates of the highest calibre. The majority of principals in OECD systems have a background as teachers and applicants for school leadership positions are commonly required to fulfil minimum requirements pertaining to their teaching qualifications and experience (Pont, Nusche and Moorman, 2008[27]). These criteria underline school leaders' pedagogical leadership role, which requires an intimate understanding of teaching practices and experience in applying it. The minimum teaching experience required to become a school leader does not vary widely among OECD review countries, ranging from five years in Austria, Portugal, Kazakhstan and the Slovak Republic or six years in Chile and Colombia to nine years in Uruguay (see Chapter 4). Nevertheless, there is a growing awareness that a successful teaching record alone is not sufficient to ensure that school leaders can fulfil their role successfully.

Research increasingly recognises the positive effect that well-prepared school leaders can have on their students' learning outcomes (see Chapter 1) and a growing number of school systems are conceiving of school leadership as a specialist occupation that requires rigorous preparation and distinct entry requirements. In some countries, leadership candidates are therefore required to demonstrate experience in managerial positions or to undergo specific leadership training to prepare them for their new responsibilities. Other OECD review countries do not require school leaders to demonstrate any training beyond their initial teacher education or mandate their participation in leadership training only once they are appointed to their positions. A more detailed description of school leaders' recruitment is provided in Chapter 3; the preparation of school leaders is discussed in Chapter 4.

\subsection{Career structures in schools}

Career structures can be thought of as a set or sequence of recognised professional positions with associated tasks and responsibilities, as well as the rules that govern individuals' progression across these positions. The traditional teaching career has often been described as "flat" and as providing few opportunities for advancement or diversification (OECD, $2005_{[28]}$; Bacharach, Conley and Shedd, 1986 ${ }_{[29]}$; Lortie, 1975 $\left.{ }_{[30]}\right)$. It is therefore not inconceivable for many teachers to perform the same kinds of tasks and have the same responsibilities from the first to the last day of their career. Likewise, in many systems, the only way for teachers to meaningfully advance their careers is to leave the classroom and take up roles in school leadership or the education administration. This lack of opportunities for promotion and specialisation risks to lessen teachers' motivation, make the profession 
less attractive and create mismatches between teachers' and school leaders' competencies and the tasks they perform.

Well-designed career structures have the potential to enhance the individual and collective professional capacity of teachers and school leaders. They provide a means to recognise good performance, to increase long-term motivation and retention, and to assign staff to roles and responsibilities that are commensurate with their evolving capabilities and thereby use their full potential. There are reasons to believe that these functions of an articulated career structure are particularly important in the teaching profession, given that teachers tend to receive little external recognition. In the absence of feedback through formal evaluations or tangible results of their work, teachers are often expected to be highly self-motivated and thrive on indirect recognition, for example through their students' success. There are different ways in which the articulation of vertical career paths and their horizontal diversification could help to overcome these challenges.

\subsubsection{The structure of teachers' careers}

Teachers' career structures can be differentiated both vertically and horizontally. Along the vertical dimension, teachers' careers may take the form of a ladder, structured around a succession of formal positions or roles with distinct task profiles and progressively increasing responsibilities within the classroom. These vertical career stages are organised hierarchically, building on one another and requiring increasing levels of experience or skill. They are also typically - although not necessarily - associated with increasing compensation. Along the horizontal dimension, career structures may provide teachers with opportunities to focus on and assume responsibilities in a specific area of expertise inside or outside the classroom. Rather than the advancement in a hierarchy or an expansion of responsibilities, these lateral career movements often involve the specialisation in a particular aspect of the teaching profession. Some career structures combine both vertical and horizontal dimensions, offering multiple pathways of advancement and more individualised career trajectories.

\section{Vertical progression in the teaching career}

The teaching profession has traditionally been characterised by single-stage career structures that offer few opportunities for teachers to advance their careers within the classroom. It should be noted that single-stage career structures do not necessarily preclude teachers' professional growth and recognition. In Portugal, for example, teachers working under a new service code introduced in 2002 can progress across ten salary increments, conditional on school-based evaluations and an external assessment for steps 2 and 4 (Liebowitz et al., 2018, p. 197 $\left[{ }_{[7]}\right)$. Yet, single-stage career structures offer limited scope to recognise teachers' growing experience and effectiveness by increasing their professional responsibilities. Teachers seeking to assume greater responsibilities within these contexts may be required to leave the classroom and take on more managerial tasks, for example as school leaders. This process can be to the detriment of student learning since it risks depriving them of their most effective teachers. At the same time, teachers with the most advanced pedagogical skills may not make for the most effective school leaders.

Well-defined multi-stage career structures promise to redress some of these issues by providing teachers with opportunities to advance their careers within the classroom. This can enable teachers to use their expertise more effectively by assigning them responsibilities that are commensurate with their skills. For instance, highly effective teachers are better able to cope with larger class sizes and are more efficient in their lesson 
preparation, which could allow them to take on additional teaching hours, students or classes. In addition, experienced teachers may be able to coach and mentor their less experienced colleagues (Jensen et al., 2012[31]).

Differentiated task profiles in multi-stage career structures can also provide education authorities, professional bodies or school principals with a means to publicly recognise and reward teachers' skills and professional growth (Nusche et al., 2016, p. 173 [32]). They can therefore play a distinct role in teachers' long-term motivation, even in the absence of end-of-year bonuses or other incentives that are more common in non-teaching professions (Crehan, 2016[33]; Natale et al., 2013 [34]).

A little less than half of OECD review countries provide their teachers with multi-stage vertical career structures that offer opportunities for promotion based on a succession of formal positions with distinct task profiles in the classroom (see Table 2.1 below). Distinct from seniority- or performance-based salary increments, these career stages are characterised by progressively increasing responsibilities and expectations. While vertical career advancement is often voluntary and tied to centrally or locally administered certification procedures, some countries require teachers to apply for higher career stages after a given amount of time, using these hurdles as an implicit means to identify teachers with performance concerns.

Despite their importance, multi-stage career structures are not the only way to provide public recognition for teachers' increasing pedagogical competencies. In the Slovak Republic, for example, an annual national teacher's day provides an occasion to acknowledge, reward and celebrate successful teachers (Santiago et al., 2016 ${ }_{[25]}$ ). Teacher awards, such as the Premio Compartir in Colombia are another means to motivate and highlight the achievements of outstanding educators (Radinger et al., 2018, p. 278 ${ }_{[8]}$ ). In the United States, the National Teacher of the Year Program serves a similar function since 1952 by bringing together State Teachers of the Year and publically recognising their contributions to the education system. Likewise, in Kazakhstan, teachers who have demonstrated exceptional performance can be selected at annual education conferences to receive a prize (The Best Teacher Award) and financial reward (OECD/The World Bank, 2015, p. 92[35]).

Another way to reward teachers by non-monetary means is to offer them time off to engage in further study or fund their participation in part-time continuing education programmes. In Colombia, for example, the government provides scholarships for teachers to take part in an integrated master's degree programme that accompanies teachers in developing an improvement plan for classroom practices in their school (Sánchez, 2018[36]). Chapter 4 discusses some of these complementary means of recognition in more detail. 
Table 2.1. Vertical career structures for teachers (ISCED 1-3), 2018

OECD review countries, public schools

\begin{tabular}{|c|c|c|c|c|c|c|c|c|c|c|}
\hline \multirow[t]{2}{*}{ Country } & \multirow{2}{*}{$\begin{array}{l}\text { Type of structure } \\
\text { (No. of stages) }\end{array}$} & \multicolumn{5}{|c|}{ Criteria for stage advancement } & \multicolumn{2}{|c|}{$\begin{array}{l}\text { Process for stage } \\
\text { advancement }\end{array}$} & \multicolumn{2}{|c|}{$\begin{array}{l}\text { Duration of appointment } \\
\text { to a career stage }\end{array}$} \\
\hline & & $Q$ & C & Ex & $P$ & $\mathrm{PD}$ & $E$ & $\mathrm{Ce}$ & $\mathrm{OE}$ & FT \\
\hline Austria & Single-stage & & & & & & & & & \\
\hline Belgium (FI.) & Single-stage & & & & & & & & & \\
\hline Belgium (Fr.) & Single-stage & & & & & & & & & \\
\hline Chile (1) & Single-stage & & & & & & & & & \\
\hline Colombia & Single-stage & & & & & & & & & \\
\hline Czech Republic & Multi-stage (6) & $\checkmark$ & $\checkmark$ & $\checkmark$ & & & $\checkmark$ & & $\checkmark$ & \\
\hline Denmark & Single-stage & & & & & & & & & \\
\hline Estonia & $\begin{array}{l}\text { Multi-stage ( } 4 \text { : general, } \\
\text { 3: vocational) }\end{array}$ & & $\checkmark$ & & & & & $\checkmark$ & $\checkmark$ & $\checkmark$ \\
\hline Iceland & Single-stage & & & & & & & & & \\
\hline Kazakhstan & Multi-stage (5) & & $\checkmark$ & $\checkmark$ & & & & $\checkmark$ & & $\checkmark$ \\
\hline Lithuania & Multi-stage (4) & $\checkmark$ & $\checkmark$ & $\checkmark$ & & $\checkmark$ & & $\checkmark$ & $\checkmark$ & \\
\hline Luxembourg & Single-stage & & & & & & & & & \\
\hline Mexico & Multi-stage & & $\checkmark$ & $\checkmark$ & $\checkmark$ & & $\checkmark$ & & $\checkmark$ & \\
\hline Portugal & Single-stage & & & & & & & & & \\
\hline Slovak Republic & Multi-stage (4) & $\checkmark$ & $\checkmark$ & $\checkmark$ & & $\checkmark$ & $\checkmark$ & & $\checkmark$ & \\
\hline Slovenia & Multi-stage (4) & $\checkmark$ & & $\checkmark$ & $\checkmark$ & $\checkmark$ & $\checkmark$ & & $\checkmark$ & \\
\hline Spain & Single-stage & & & & & & & & & \\
\hline Sweden & Multi-stage (2) & & $\checkmark$ & $\checkmark$ & $\checkmark$ & & $\checkmark$ & & $\checkmark$ & $\checkmark$ \\
\hline Turkey & Single-stage & & & & & & & & & \\
\hline Uruguay & Single-stage & & & & & & & & & \\
\hline
\end{tabular}

Notes: Teacher career stages refer to a structured succession of formal positions with distinct task profiles and progressive responsibilities (as distinct from salary increments), while typically maintaining classroom teaching responsibilities. The duration of appointment to a career stage can also refer to the length of validity of a certification.

Q: Qualifications, C: Competencies, Ex: Experience, P: Performance, PD: Professional Development, E: Evaluation, Ce: Certification, OE: Open-ended, FT: Fixed-term.

Czech Republic: Principal evaluation; Lithuania: Certification (voluntary); Mexico: Evaluation by the Teachers Professional Service (Servicio Profesional Docente); Slovak Republic: Evaluation by examination board chaired by school principal (stage 2), Certification (stages 3/4); Slovenia: Evaluation by school leader, school teacher assembly and ministry; Sweden: School leader evaluation and central approval; Estonia: Open-ended for stages $1 / 2$ in general education, 5 years for stages $3 / 4$ in general education, 7 years for all stages in VET; Kazakhstan: 5 years (all stages); Sweden: Fixed term or open-ended (local authority discretion).

1. Chile introduced a new career structure in 2016 that entails progression through five different stages. While teachers at the advanced stage have access to functions such as mentor teacher and team leader, and teachers in the voluntary stages of expert teacher have preferential access to leadership and guidance roles, different stages are not formally linked to new roles and responsibilities.

Sources: Based on Country Background Reports and Country Review Reports (http://www.oecd.org/education/school/school-resources-review-reports-participating-countries.htm).

\section{Articulating stages of vertical career progression}

When designing multi-stage career structures, policy makers need to make a series of decisions concerning the number of stages, their associated roles and responsibilities, as well as the links between the career structure, professional standards and remuneration. Among the OECD review countries, vertically differentiated career structures comprise between two and six distinct stages. In many cases, the first career stages are reserved for novice teachers. They may correspond to teachers' probation period or their enrolment in 
induction programmes before attaining fully qualified teacher status. The first steps in a teacher's career can also be associated with a reduced teaching load and additional support by mentors.

Reaching higher stages in the career ladder tends to be associated with increased responsibilities and elevated expectations. In Lithuania, for example, teachers in more senior positions ("methodologists" and "teacher experts") are expected to contribute to the improvement of the teaching profession more broadly and to develop and spread good practice both within and beyond their schools. This can include such diverse tasks as co-authoring text books, evaluating, supporting and guiding beginning teachers, or contributing to local, regional and national pedagogical events (Shewbridge et al., 2016, p. $\left.132_{[37]}\right)$. The Estonian career structure, which is described in Box 2.1, also provides teachers with multiple levels of professional advancement within the classroom (Santiago et al., 2016 $[38])$.

\section{Box 2.1. Multi-stage structure of the teaching career in Estonia}

In 2013, Estonia introduced a new vertical career structure alongside a reformed system of teacher professional qualifications. Its main aim is to serve as a reference for teachers' competency development and it comprises four distinct stages, reflecting different levels of professional skills and experience. Unlike many other multi-stage career structures, the stages are not formally linked to salaries and access to higher stages is voluntary. The career stage Levels 6 and 7.1 are awarded indefinitely, while Levels 7.2 and 8 are awarded for a five-year period after which the teacher must reapply.

- Teacher (Level 6): Applies only to pre-primary teachers upon entrance into the teaching profession, following the completion of an initial teacher education programme (at bachelor's degree level) or following the recognition of professional qualifications for this level by the teacher professional body.

- Teacher (Level 7.1): Awarded upon entrance into the teaching profession, following the completion of an initial teacher education programme (at master's degree level) or following the recognition of professional qualifications for this level by the teacher professional body.

- Senior teacher (Level 7.2): Awarded to teachers who, in addition to their regular teaching activities, support the development of the school and of other teachers and are involved in methodological work at the school level.

- Master teacher (Level 8): Awarded to teachers who, in addition to their regular teaching activities, participate in development and creative activities in and outside their school and closely co-operate with a higher education institution.

The Estonian Qualifications Authority has developed professional standards that define the competencies associated with each stage of the career structure. A teacher professional organisation (the Estonian Association of Teachers) is responsible for the certification process that determines teachers' advancement across career stages. Twice a year, teachers can apply for a new certification. A three-member committee oversees the two-stage application process, which involves an evaluation of the candidate's application materials and an interview.

Source: Santiago, P., A. Levitas, P. Radó, C. Shewbridge (2016), OECD Reviews of School Resources: Estonia 2016, OECD Publishing, Paris, http://dx.doi.org/10.1787/9789264251731-en. 
Aligning teachers' career stages with professional standards

Ideally, each stage of a teacher's career should be associated with a clear set of progressively increasing responsibilities and competencies. One way of doing so is to link them to differentiated teaching standards that specify what is expected of teachers at different stages of their career (Hooge, 2016 [39]). These standards can not only enhance professionalism in schools and foster a shared understanding of good teaching, they can also provide a basis for certification procedures or assist school leaders or education authorities in their promotion decisions and the appraisal of teachers at different career stages. They also give teachers a clear sense of the steps they can take to advance their careers, especially if these standards are aligned with opportunities for professional development and direct teachers to the most relevant course offerings.

While the link between teaching standards and promotions is not always explicit, multiple OECD review countries have established direct connections between competency frameworks and teachers' career structures. Estonia, for example, has developed professional standards specifying the skills, knowledge and attitudes teachers are expected to demonstrate at each stage of their career in order to facilitate their linkage to appraisal procedures and career advancement.

In other cases, such as the Flemish Community of Belgium, differentiated professional standards exist, but they are not linked to a corresponding vertically differentiated career structure. First established in 1998 and updated in 2007, the Flemish Community provides teachers with a list of basic teacher competencies, describing the knowledge, skills and attitudes that graduates from initial teacher education need to acquire. In addition, a set of professional profiles is aimed to guide the development of in-service teachers, describing the knowledge, skills and attitudes expected of them. Both the basic competencies and the professional profiles are adapted for pre-primary, primary and secondary education and cover specific teacher functions such as educator, content expert, organiser, innovator and researcher, partner of parents, member of a school team and member of the educational community (Nusche et al., 2015, p. 148 [40] $)$.

Although the Flemish Community's teacher standards thus provide a strong basis to underpin teachers' professional advancement, the lack of a multi-stage career structure means that their full potential is not exploited. This may explain why the OECD review team observed that the standards were not widely known in schools and that they were not systematically used to plan the professional development of teachers or guide their appraisal (Nusche et al., 2015, pp. 148, 164 [40] $)$.

\section{Criteria and process for career advancement}

Teachers can advance their positions in multilevel career structures based on a variety of criteria and on the basis of different procedures. Experience or seniority - while rarely sufficient - is often a necessary condition for teachers' vertical career progression. In Lithuania, for example, "senior teachers" are required to have at least four years of teaching experience, "teacher methodologists" need five years, and "teacher experts" need six years (Shewbridge et al., 2016, p. 126 ${ }_{[37]}$ ). Similarly, among ten high-performing countries and economies participating in PISA 2015, six out of ten placed a moderate or high importance on teachers' length of service when deciding on their career advancement (OECD, 2018, pp. 61, Figure $\left.2.8_{[5]}\right)$. Beyond this, promotion criteria vary considerably and may include appraisal or evaluations results, demonstrated pedagogical competency and qualifications or the completion of professional development. Among the OECD review countries, 
teachers' competency was the most frequently employed criterion for promotion decisions after experience (see Table 2.1).

For vertical career structures to effectively motivate and reward professional growth, teachers' access to higher career stages should be voluntary and meritocratic. Standardised certification or registration systems can be one such way to regulate teachers' career advancement and a number of OECD review countries, such as Estonia, Kazakhstan and the Slovak Republic, have introduced certification procedures to confirm teachers' competence for a given career stage (see Box 2.1 and Table 2.1). Teachers are usually certified (permanently or provisionally) upon completing their initial teacher education and may choose to apply for advanced certifications confirming their readiness to assume additional responsibilities or roles. To ensure fairness and consistency, certification procedures typically involve external evaluators, a national teaching agency or a teacher council.

A certification process can offer a transparent means to regulate teachers' vertical career advancement based on high standards of performance, provide public assurance with regard to teachers' standards of practice, and inform teachers' further professional development. To fulfil these functions, certification procedures need to focus on and effectively assess teachers' ability to perform their pedagogical responsibilities at the level corresponding to a given career stage. Lithuania has recently reformed its certification framework with this objective in mind. While the country's old framework only specified a series of formal criteria (such as having undertaken professional development in information and communication technology [ICT] and special educational needs [SEN]) that are at best indirectly related to classroom performance, the revised framework includes well-defined competency requirements (Shewbridge et al., 2016, p. $126_{[37]}$ ).

Concerns about the relevance of certification procedures as well as their resource intensity were also raised in the OECD review of the Slovak Republic. Eligibility for higher stages in the Slovak Republic's teacher career primarily depends on the acquisition of qualifications and professional development credits, for example, received for submitting and defending an academic thesis. Despite being highly resource intensive for teachers, this process does not concentrate on their core work and whether the production of a thesis will improve student learning is unclear (Santiago et al., 2016, p. $188 \mathrm{f}_{[[25] \text { ). }}$

\section{Duration of appointments}

Teachers' promotions to a given career stage may be permanent or subject to mandatory renewal. In Lithuania and the Slovak Republic, for example, certifications for a given stage are valid for the rest of a teacher's career. This raises a number of concerns since it may reduce teachers' incentives to continuously update their knowledge and skills. Other systems, like Estonia, require teachers at higher career stages to undergo periodic re-evaluations to confirm their competency. Well-designed re-certification procedures ensure that teachers continue performing at the level that is expected of them at a given career stage and allow school leaders to detect and address consistent under-performance or professional development needs. At the same time, re-certification requirements can be a source of stress for teachers and, depending on their intensity, create a significant administrative and resource burden.

Among the OECD review countries, only a few require teachers to regularly undergo re-certification procedures (see Table 2.1). Countries with re-certification processes in place have organised them in different ways, sometimes involving as little as a simple attestation by a school-based committee that the teacher is continuing to meet the agreed 
standards of practice (this may or may not include external members). While the validity of certifications is typically around five years in OECD review countries, their duration varies - sometimes even within countries. In Australia, for example, teachers are required to renew their registrations in intervals of up to five years, depending on which jurisdiction they are employed in (Shewbridge et al., 2016, p. 141 [37]).

\section{Horizontal diversification in the teaching career}

As discussed in Chapter 1, the tasks and responsibilities that teachers are expected to assume beyond traditional classroom instruction are increasingly complex and diverse. Teachers naturally enjoy and excel in some roles more than in others. It is therefore important to acknowledge and support their capacity for leadership in some areas, just as it is to recognise their need for further development in others. Many school systems have done so by creating greater horizontal differentiation in teachers' careers and by establishing specialist roles that allow them to deepen their knowledge and apply it in a particular aspect of the teaching profession. Other than the hierarchically organised steps in a vertical career ladders, these specialist roles may be seen as a lateral career move and are frequently compensated in the form of reduced teaching hours, rather than additional pay.

Providing teachers with systematic opportunities to specialise and assume greater responsibilities in a specific part of their profession can have a range of benefits. First, allowing teachers to focus on the area of their work that they are most productive in can improve the allocation of tasks and result in a more efficient use of teachers' time, knowledge and skills. Second, it provides teachers with increased autonomy to shape their career based on their interests, which constitutes an important source of long-term motivation (Crehan, 2016 $6_{[33]}$ ). Finally, besides changes to the staffing mix in schools, the creation of new roles may be an effective response to new needs or policies that call for schools to build professional capacity and expertise in a specific area (see Chapters 1 and 3).

Several OECD review countries have increased the horizontal diversification in teachers' career structures to pursue one or more of these goals. In Chile, for example, a national initiative to foster a positive school environment was supported by creating the role of school climate co-ordinators (encargado de convivencia escolar) responsible for creating an action plan and implementing related measures at the school level. Although the creation of this role was aimed at implementing a specific policy, it also offered teachers new opportunities to apply themselves (Santiago et al., 2017[9]). Similar roles have been created in Colombia (orientador) and Uruguay (profesor orientador pedagógico) to pursue such goals as to strengthen the co-ordination between staff members, to liaise with families and communities and to foster a good school climate (Radinger et al., 2018 ${ }_{[8]}$; Santiago et al., 2016, p. 168 [41] $)$.

Most commonly, horizontal career pathways have been strengthened by introducing specialist roles, such as teacher mentors, ICT specialists or co-ordinators of school projects and professional development. In 2015, for example, Austria's new service code introduced several specialist functions (Fachkarrieren) that allow teachers with specific knowledge and skills to take on additional responsibilities without having to move to administrative and leadership roles. These specialist functions include mentors of new teachers or student teachers, learning and career counsellors, "learning designers" as well as special needs and remedial pedagogues. Some of these positions require substantial training and are tied to extra allowances (Nusche et al., 2016, p. 159[32]). In Uruguay, teachers are provided with 
multiple remunerated opportunities for horizontal specialisation, for example as pedagogical counsellors or co-ordinators, and bibliographic or technology counsellors (Santiago et al., 2016, p. 229 [41]).

In both Austria and Uruguay, teachers have limited opportunities for vertical career advancement and while the opportunities for horizontal specialisation compensate for some of these shortcomings, other systems have successfully combined both vertical and horizontal career pathways. Singapore's career structure is a good example for this, since it allows teachers to advance their capabilities through vertical progression, while allowing them to specialise in a particular role through horizontal diversification. It offers three parallel streams - the teaching track, a leadership track, and a senior specialist track, each comprising at least four stages of career advancement, culminating in the roles of Principal Master Teacher, Director-General of Education and Chief Specialist, respectively (Crehan, 2016 , p. $88_{[33]}$ ). The Slovak Republic's teaching career (Box 2.2) is also differentiated vertically, through a multi-step career structure, as well as horizontally, through a range of specialised career positions (Santiago et al., 2016, p. 169 ff.[25]).

\section{Box 2.2. Vertical and horizontal career progression in the Slovak Republic}

\section{Vertical career structure}

The Slovak Republic's career structure allows teachers to progress across four stages based on their growing professional competencies, their experience and the accumulation of credits through continuing professional development (CPD):

- Beginning teacher: Teachers start their career as "beginning teachers" and participate in mentoring programmes and adaptation courses under the supervision of a mentor teacher. During this time, the only specialised position available to them is that of "class teacher" (see below). Within two years, they must pass a school-level evaluation to attain "independent teacher" status.

- Independent teacher: Teachers at this stage are permitted to teach independently and assume any of the specialised positions described below, except that of "mentor teacher". To progress to the next stage, teachers must pass a first certification exam or hold a doctoral degree in their field of instruction. Teachers become eligible to take the certification exam by accumulating 60 professional development credits or by accumulating 30 credits and completing a preparatory training programme.

- Teacher with first certification: Teachers at this stage are permitted to perform any specialised activity in the horizontal career structure. They are also eligible to become teacher leaders, professional development trainers, and sit on exam committees for the first certification. Teachers can take a second certification exam after accumulating additional professional development credits.

- Teacher with second certification: After obtaining the second certification, teachers are eligible to sponsor professional development programmes, serve on exam committees for the second certification, become members of national and international expert committees, and conduct research activities to improve education practices in the school system. 


\section{Horizontal career structure}

A range of specialised positions provide opportunities for horizontal differentiation in the teaching career. These positions are not hierarchically organised but allow teachers to develop areas of expertise and engage more deeply with specific aspects of their job. School leaders decide on the definition of and assignment to career positions in their school. These typically include:

- Class teacher: Assumes co-ordination and communication responsibilities for one class. This involves guidance, maintaining pedagogical documentation, and communicating with parents.

- Mentor teacher: Mentors beginning teachers during their "adaptation" period. This can involve observing their classroom interactions, modelling effective teaching approaches, and providing advice on pedagogy, assessment and administration.

- Educational advisor: Provides consulting services, including methodological assistance.

- Head of subject committee (or study area), Head of methodology association (or study programme): Takes responsibility for the school's pedagogical work on a given subject (or study area) or its pedagogy more generally, with involvement in projects, advisory and evaluation work.

- Career advisor: Provides students with career guidance and counselling.

- ICT co-ordinator: Co-ordinates use of ICT in the teaching and learning process.

- Co-ordinator: Takes responsibility for a specific area of work within the school, such as that with special needs children or children from a socially disadvantaged background.

Source: Santiago, P., G. Halász, R. Levačić, C. Shewbridge (2016), OECD Reviews of School Resources: Slovak Republic 2015, OECD Publishing, Paris, http://dx.doi.org/10.1787/9789264247567-en.

In addition to horizontal mobility within schools, teachers' careers can provide them with systematic opportunities to extend their reach beyond the classroom and the individual school, and assume responsibilities at the system level. Providing such opportunities on a temporary basis (e.g. in the form of career breaks or secondments) can help to foster knowledge sharing between schools and local or central authorities without requiring teachers to leave their careers in the classroom behind (see Chapters 3 and 4).

In Denmark, for example, teachers have the opportunity to join a corps of 80 learning consultants to analyse the challenges of struggling schools and contribute to their development plans, their strategy for change management, and indicators for monitoring and evaluation. Learning consultants are typically appointed for a period of two years, after which teachers return to their schools. Learning consultants are trained for their role and meet on a monthly basis to learn about new methods and evidence and to reflect on their experiences and challenges. The role is therefore an attractive way for teachers, leaders and administrators to gain experience, learn from one another and spread their knowledge across the system (Nusche et al., 2016, p. 155 [15]). As discussed in Chapter 4, teachers may also have opportunities to take on coaching and mentoring roles across schools, which can offer similar benefits. 


\subsubsection{The structure of school leaders' careers}

The demands placed on school leaders have intensified and broadened over time (Pont, Nusche and Moorman, 2008 $\left.{ }_{[27]}\right)$. Increasing accountability demands paired with local or collaborative decision making and an emphasis on both management and leadership may have contributed to the expansion of school leaders' administrative and pedagogical responsibilities. Despite the growing awareness of school leaders' impact on schools' educational success, a number of OECD review countries, including Austria, the Czech Republic, Chile and the Slovak Republic have difficulty in making the career attractive for high-calibre candidates (Santiago et al., 2017, p. 196 $6_{[9]}$; Shewbridge et al., 2016, p. $180_{[20]) \text {. }}$

This has resulted in ageing or demographically imbalanced school leader populations or concerns over the ability to fill vacancies, especially in hard-to-staff schools as highlighted in Chapter 3. Ensuring the attractiveness of the school leader role is thus of critical importance and the structure of school leaders' careers - next to their remuneration and working conditions - can contribute to this goal by effectively regulating the entry into the profession, recognising school leaders' distinct professional status and ensuring that school leadership offers perspectives for professional growth.

\section{Recognition of school leaders' professional status}

School leadership roles involve responsibilities and require competencies that differ markedly from those of teachers. Nevertheless, the distinct features of school leadership are not always reflected in their professional status. The majority of OECD review countries do not provide a separate career structure for school leaders and either treat school leadership as the final stage of the teaching career ladder or a mere extension of the teachers' role that they can assume alongside or while temporarily replacing their teaching duties. Acknowledging the distinct responsibilities of leadership positions in schools, including those of deputy leaders, by providing them with a distinct career structure can help communicate the importance of administrative and pedagogical leadership, raise school leaders' professional status and attract potential candidates.

Portugal is an example of a system in which the role of school leaders is not clearly distinguished by a separate career structure or salary scale and where school leadership is not conceived of as a distinct profession. The OECD review team noted that leaders in Portugal placed little emphasis on instructional leadership or improvement and rarely engaged in activities like classroom instruction or the promotion of new teaching practices. Some of this stems from school leaders' limited preparation and access to high-quality continuing development, which the review concluded might be strengthened if their professional status was more clearly recognised (Liebowitz et al., 2018, p. 201 $1_{[7]}$ ).

The problem of insufficient professional recognition for school leadership roles often extends beyond principal-ship since many systems do not acknowledge the distinct competencies, preparation and support required for middle management positions and other members of school leadership teams (see Chapter 4). In Austria, for example, most schools do not have a permanent deputy principal position. Instead, school principals rely on the assistance of teachers who effectively function as administrators in all but their official title (Nusche et al., 2016, pp. 62, 154 [32]). 


\section{Opportunities for advancement within and beyond school leadership}

As for teachers, a lack of opportunities for promotion within the school leader career can diminish the attractiveness of school leadership roles and reduce the long-term motivation and retention of current principals. While many school leaders (and teachers) have opportunities to apply for positions within the education administration (e.g. in municipal education authorities), multi-level career structures that allow for professional growth within the profession are not widespread and few countries have developed robust centrally governed frameworks for leaders' career advancement that are linked to appraisal procedures (OECD, 2013, p. 547[3]).

The problems associated with single-stage career structures can be exacerbated by the increasing use of fixed-term contracts or a maximum time of service for school leaders (Pont, Nusche and Moorman, 2008, p. 178 $8_{[27]}$ ). In Portugal, for example, principals can serve two terms (four years each) within the same position, after which they either need to find a position at a different school or return to the classroom (Liebowitz et al., 2018, p. $\left.175_{[7]}\right)$. Uncertainty about employment opportunities beyond a given leadership position can make the recruitment of qualified candidates more difficult. It can also be a significant source of stress, not least because a return to teaching is sometimes considered an undesirable or problematic move for leaders (Pont, Nusche and Moorman, 2008 [27]). This makes the need for a clear career path particularly salient.

Although it remains the exception, rather than the rule, OECD countries as diverse as Australia, Canada, France, Israel, Korea, Mexico and Norway have developed multi-stage career structures for school leaders, including clearly defined opportunities for professional advancement (OECD, 2013, pp. 578, Table 7.A.2[3]). The potential benefits of these multi-stage careers structures are evident. They can create incentives for high performance, reward continuous improvement and render the profession more attractive to teachers, especially in countries facing recruitment issues. To facilitate the selection of qualified candidates, ensure that principals are well-prepared for their roles and provide a framework for their appraisal, multilevel career structures for school leaders should be underpinned by a set of standards developed jointly with the profession.

Multi-stage career structures for school leaders can extend both ways from the principal's role and include both middle leadership positions and system leadership positions extending beyond principal-ship. Formally linking intermediate leadership positions to the principal career path can increase a schools' leadership capacity, provide the basis for more distributed forms of leadership, and create a pipeline for future school leaders. Since most school leaders in OECD countries begin their professional careers as teachers, integrating middle leadership roles in well-articulated career structures can provide teachers with an opportunity to prepare for school leadership and to get a sense of their suitability for the role while at the same time providing schools with an opportunity to identify promising candidates for promotion. For more information on the preparation and development of school leaders, see Chapter 4.

In some countries, principals' career pathways do not only provide an attractive perspective for teachers who are motivated to assume leadership responsibilities but also include opportunities for system leadership that extend beyond the conventional school leader role. Encouraging the most effective leaders to take on system leadership roles can be an effective way to harness their experience and capacity to contribute to the improvement of the education system as a whole. This may involve serving as a change agent within the system, identifying best practices and transferring them to support improvement in other schools; brokering partnerships or networks across local communities and agencies; and 
mentoring other leaders or partnering with schools that face acute difficulties (OECD, 2013 [42]; Hopkins, Nusche and Pont, 2008[43]).

At the same time, the progression to system-level roles risks to deprive schools of their most effective leaders, as is the case for teachers' pathways to principal-ship. This need not be the case though, and are many ways in which school leaders can contribute to system-level leadership and quality assurance on a temporary basis or alongside their regular work as school leaders, as long as they are provided with the necessary resources and support.

In many countries, informal leadership positions developed at the school level play an important role in building a system's leadership capacity and responding to local needs. Some countries have gone beyond this and complemented them with a more formalised system of middle leadership roles associated with clear standards and processes for the selection and development of candidates (Hopkins, Nusche and Pont, 2008, p. 24 $4_{[43]}$ ). In Singapore, for example, teachers can enter a separate leadership track that includes a succession of roles ranging from subject and department heads to principal-ship. In addition, the career path extends beyond the principal's role to provide motivated and highly effective candidates an opportunity to advance to system leadership positions, such as cluster superintendent, deputy director and director-general (Crehan, 2016, p. 88[33]).

\subsubsection{Implementing career structure reforms}

Reforming teachers' and school leaders' career structures can pose a series of implementation challenges when it comes to building political consensus, involving stakeholders, aligning expectations, managing the transition between old and new systems, developing capacity, and creating broad ownership of the new system.

The difficulty of this process has recently been demonstrated in Colombia, where efforts to create greater differentiation in teachers' careers were short-lived and abandoned after only two years in 2017, following opposition by the country's largest teacher union. The government had introduced additional specialised roles to contribute to school development and student learning in the form of teacher support leaders (docente lider de apoyo) (Radinger et al., 2018, p. $250_{[8]}$ ). However, a lack of clarity around what the new role would entailed, concerns that the new position would create divisions among teachers, and perceived association of the role with other changes to teachers' working conditions (such as working time) contributed to its failure to take root. Similarly, in the Czech Republic, plans for reforming the career structure as part of the country's Strategy for Education Policy until 2020 ("Strategy 2020") could not be implemented due to teachers' resistance (more on this below).

A further recent example of teacher career reform is the French Community of Belgium's Pact for Excellence in Teaching (Pacte pour un enseignement d'excellence). This wider reform package adopted in 2017 envisages the vertical expansion of the career structure. An important element of the reform's implementation has been to involve stakeholders from the outset and clearly communicate its goals to build support. In order to engage stakeholders in the reform's design, it was preceded by a participatory consultative process involving teachers, school leaders, parents and students alongside the economic, social and cultural sectors between 2015 and mid-2016 (OECD, 2017 $[44]$ ).

The Pact for Excellence envisages a new career structure to be progressively implemented between 2020 and 2022, introducing a third career stage for experienced teachers (enseignants expérimentés) in addition to the existing two career stages (temporary and 
permanent teachers). Teachers who reach the "experienced" stage of their careers will be expected to assume additional responsibilities in exchange for a reduced teaching load, such as pedagogical co-ordination, managing relationships with external partners or mentoring beginning teachers. As such, the new positions are also intended to facilitate distributed leadership and enable principals to delegate certain aspects of their work to experienced teachers (Fédération Wallonie-Bruxelles, 2017 $[45]$ ).

The introduction of new formal positions associated with additional responsibilities and remuneration can create uncertainty among teachers and be perceived as threatening to the profession's egalitarian norms, especially in countries with a history of single-stage career structures. Creating new specialised roles in schools also requires teachers, principals and possibly other school staff to rethink their responsibilities and adapt their tasks to benefit from the new arrangements. In some cases, the creation of new formal roles for teachers can build on existing practices by institutionalising previously informal arrangements that have proven to be successful for schools' operation and whose scope teachers are already familiar with.

In other cases, designing and evaluating pilot projects can allay some of the concerns around new teacher roles and build consensus before reforms are finalised and fully rolled out. Norway, for example, launched a two-year pilot starting in 2015, which involved training 205 teachers as specialists in mathematics and Norwegian. In an effort to diversify teachers' career pathways, the specialists were given responsibility for their colleagues' professional learning and keeping them up to date with respect to subject didactics, teaching practices, and classroom management (Norwegian Ministry of Education and Research, $\left.2018_{[46]}\right)$. The pilot's evaluation concluded that the specialist role constituted an attractive career path for teachers, but that the role still needed to be more deeply anchored in the profession and each school's development plan for specialists to become an effective resource for their colleagues and their schools' improvement (Seland et al., 2017 ${ }_{[47]}$ ). The pilot has since been extended by another two years and expanded to include other subjects.

Moving from a single-stage career to a multi-stage structure or modifying the number of steps on the teaching career ladder also requires policy makers to manage the transition process. This may involve re-assigning teachers to positions that correspond most closely to their current roles and responsibilities or devising a system to accredit teachers for newly introduced senior roles. Determining the standards for teachers' initial assignment to a career stage and/or for their subsequent promotion requires striking a delicate balance. Setting the bar too low can diminish the career structure's credibility and have significant fiscal consequences if too many teachers are promoted. Likewise, setting the bar too high may lead to frustration and reduce the career structure's motivating effect (Crehan, 2016, p. 102[33]). Some of these risks can be minimised by carefully piloting the assignment system and adjusting its standards accordingly to ensure that expectations are high but realistic.

The link between career steps and salaries is another challenge in the design and implementation of teachers' and school leaders' career structures. Although multi-stage career structures are usually connected to progressive compensation, this is not necessarily the case (European Commission/EACEA/Eurydice, 2016[48]). In Estonia, for example, the four-stage career structure for teachers is not formally linked to salary levels and serves primarily as a reference for teachers' development and a means to formally recognise their competencies. Yet, the OECD review of Estonia revealed some challenges associated with this practice. Notably, in the absence of financial incentives, most teachers in the country showed little interest in attaining certifications to access the levels that corresponded to 
their competencies. Among those teachers who were informed about the career structure at all, few engaged in continuing professional development (CPD) to advance their careers. As a consequence, teachers' position in the career structure sent a relatively weak signal of their skills and had not penetrated schools' teacher management practices, e.g. the distribution of roles and tasks (Santiago et al., 2016, p. 212 [38]).

However, particularly since most career structures are linked to compensation, reforming their design can have significant fiscal consequences. Projecting the new career structure's long-term resource needs and ensuring sufficient available resources are therefore critical to ensure the reform's fiscal sustainability. In the Czech Republic, for example, the national Strategy 2020 had proposed implementing a multi-stage career structure combining performance assessment, career advancement based on standards, strengthened CPD and improved pay. Concerns that the reform's funding would be insufficient to bring about sustained improvements, however, led to resistance among part of the teaching profession and to the reform not being implemented as planned (European Union, 2018, p. $64_{[49]}$ ).

\subsection{Compensation and benefits of school staff}

Effective compensation systems in schools need to meet multiple challenges at once. With limited resources, they need to attract high-quality candidates with the right skills, while at the same time retaining effective staff once they have taken up their job and motivating them to show high performance throughout their career. The fact that teachers continue to earn less than similarly educated workers in many OECD review countries is frequently discussed as an obstacle to the recruitment of high-performing teachers or those with specific profiles. Likewise, the design of salary scales and the basis for pay differentiation and advancement over the course of teachers' careers can be critical to retain effective teachers and to motivate them to grow professionally.

While compensation and benefits are therefore rightly seen as important policy levers to make a career in schools attractive, there is no one-size-fits-all solution to the design of effective salary scales. Instead, policy makers' decisions depend on the specific challenges their country seeks to address as well as their local labour markets. While a failure to attract graduates to the profession might call for higher starting salaries, high attrition rates among mid-career teachers may indicate the need for a more attractive progression of earnings. Likewise, broader economic developments, such as the level of private sector wages or unemployment rates, can affect whether, and up to what point, higher starting salaries can be an effective means to attracting high-performing teachers and what forms of salary progression are best suited to recognise, amplify and preserve teachers' profound impact on student learning and development.

\subsubsection{The level of teachers' salaries}

Following a period of real term growth in teachers' salaries in most OECD countries and economies, the financial and economic crisis of 2008 prompted many teachers' salaries to be frozen or cut between 2009 and 2013, before rising again (OECD, 2018, p. 366 [50]). According to OECD estimates, teachers' salaries are lower than those of similarly educated workers in almost all countries and economies with available information, although they tend to increase with the level of education taught. In 2017, pre-primary teachers' average salaries amounted to $78 \%$ of the full-time earnings of tertiary-educated adults between the ages of 25 and 64 , while primary teachers earned $84 \%$ of this benchmark, lower secondary teachers $88 \%$, and upper secondary teachers $93 \%$ (OECD, 2019, pp. 411, Table D3.2a[23]). 
Evidence from the United States suggests that some of this variation in relative earnings across levels of education may reflect differences in teachers' working hours (West, $\left.2014_{[51]}\right)$. Part of it is also explained by differences in teachers' minimum required or most prevalent qualifications. In 2013, 10 of 35 OECD and partner countries with available data required teachers in pre-primary education to have earned an upper-secondary or short-cycle tertiary qualification while all but one required upper secondary teachers to hold at least a bachelor's degree to teach general subjects. In five systems, the initial education for upper secondary teachers was at the master's level, compared to the bachelor's level for lower secondary teachers (including the French Community of Belgium, Denmark and the Netherlands). In six systems (including Austria, Luxembourg, Portugal and Spain), the same discrepancy could be observed between the initial education of lower secondary and primary teachers (OECD, 2014, pp. 502, Tables D6.1.a, b, c and $\mathrm{d}_{[52])}$.

Significant salary discrepancies for similarly qualified teachers at different levels of education can make it harder to attract high-potential candidates to teach, for example, in primary or lower secondary schools. Efforts to raise qualification requirements for lower levels of education or encourage teachers to advance their professional qualifications over the course of their careers have therefore frequently been tied to commensurate adjustments to their salaries (see the discussion of entry requirements above).

Across OECD review countries, teachers' relative earnings varied widely, as can be seen in Figure 2.1. While teachers in primary to upper secondary education earned significantly more than other tertiary-educated adults in some countries, including Portugal (1.4-1.5), Luxembourg (1.9-2.0) and Mexico (1.8-3.4), they earned two thirds or less at some levels of education in countries including the Slovak Republic (0.5-0.7) and the Czech Republic (0.6-0.7) (OECD, 2019[23]). Although teachers' salaries have risen compared to those of tertiary-educated adults on average across countries and economies with available data between 2011 and 2017, salaries have become less competitive in some systems.

In Estonia, for example, teachers' salaries from the primary to the upper secondary level have almost caught up with those of other tertiary-educated workers, while those of Portuguese teachers have risen further above an already competitive level. Likewise, Austria, Chile and the Slovak Republic have narrowed the gap by eight percentage points or more at the secondary level. By contrast, over the same period, teachers' salaries have become less competitive compared to the average tertiary-educated worker in Denmark, New Zealand and Spain (see Figure 2.1).

Individuals decide to become teachers for a wide range of reasons and the factors that matter for their entry into the profession may not be the same as those that convince them to remain on the job in the long run (Hanushek, Kain and Rivkin, 2002 ${ }_{[53]}$ ). Although little is known about which factors matter the most for people's decision to join the profession and why (Dolton, 2006 ${ }_{[54]}$ ), surveys of teachers, administrative data as well as qualitative evidence from OECD reviews suggest that non-pecuniary factors are an important part of what makes the teaching profession attractive (OECD, 2018 $[5]$; OECD, 2005 $\left.{ }_{[28]}\right)$. 
Figure 2.1. Teachers' salaries relative to earnings of tertiary-educated workers, 2011-17

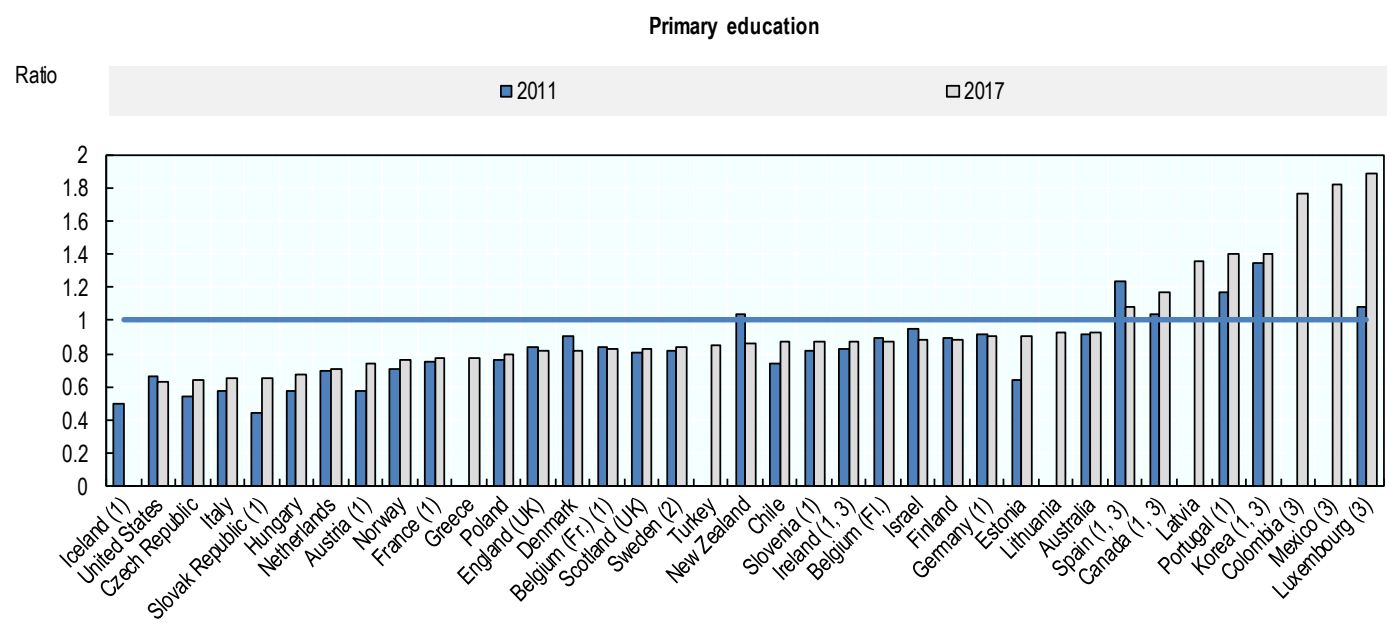

Upper secondary education

Ratio

$\square 2011$

$\square 2017$

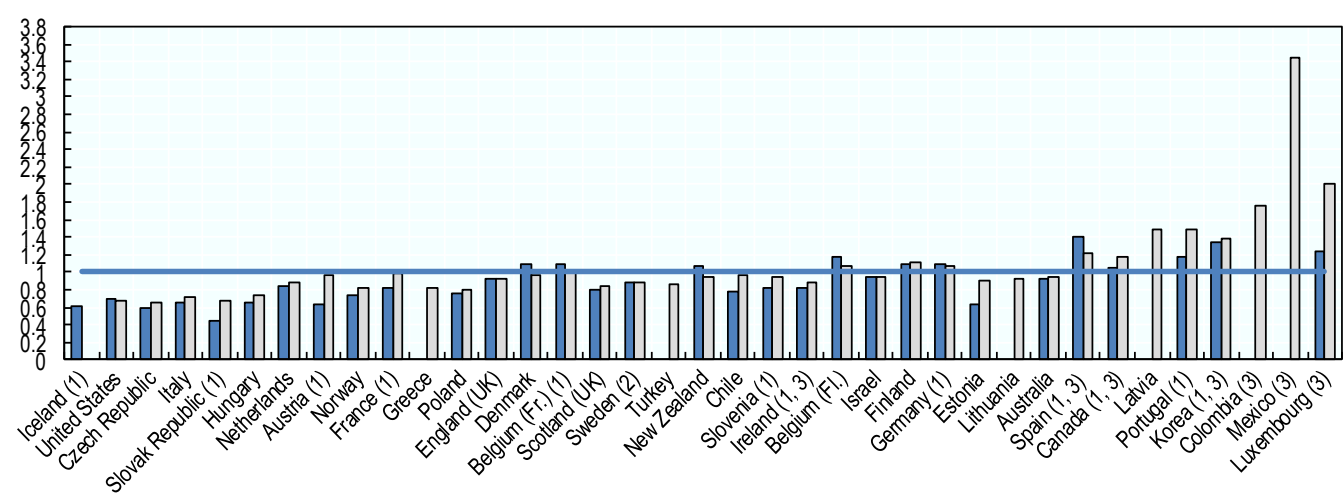

Notes: Unless otherwise noted, the ratio is based on the annual average salaries (including bonuses and allowances) of teachers aged 25-64 in public institutions relative to the wages of full-time, full-year workers with tertiary education aged 25-64. The years of reference are 2011 and 2017 or the closest available. Countries and economies are ranked in ascending order by ratio in primary education 2017.

1. 2011 values based on ratio of statutory salary after 15 years of experience and minimum training to earnings for full-time, full-year workers with tertiary education aged 25-64.

2. Salaries for 2011 not including bonus and allowances.

3. 2017 values based on ratio of statutory salary after 15 years of experience and minimum training to earnings for full-time, full-year workers with tertiary education aged 25-64.

Sources: OECD (2019) Education at a Glance 2019: OECD Indicators, OECD Publishing, Paris, https://doi.org/10.1787/f8d7880d-en, Tables D3.2a and D3.2b (web only); OECD (2013) Education at a Glance 2013: OECD Indicators, OECD Publishing, Paris, https://doi.org/10.1787/eag-2013-en, Table D3.2.

StatLink ज्ञाज https://doi.org/10.1787/888934026297 
In TALIS 2018, the great majority of in-service teachers across the OECD reported that their decision to become a teacher was motivated by a strong commitment to public service and the social impact of the profession (OECD, 2019, p. 123 $\left.{ }_{[1]}\right)$. Nevertheless, the attractiveness of teachers' salaries compared to those of alternative professions does affect the supply of teachers, the propensity of young people to enrol in teacher education programmes and the retention of early-career teachers (Dolton, 2006 [54]; Santiago, 2002 [55]).

Attracting sufficient qualified teachers is a pressing concern in some OECD countries, particularly those with rising student enrolments or a large share of teachers approaching retirement age. On average across OECD countries, 29\% of 15-year-old students were enrolled in schools whose principal considered a lack of teaching staff to hinder instruction at least to some extent as surveyed for PISA 2015 (OECD, 2016, pp. 397, Table II.6.14[56]). In $2018,21 \%$ of lower secondary school principals surveyed for TALIS reported that teacher shortages hindered their schools' capacity to provide quality instruction "quite a bit" or "a lot" (OECD, 2019, pp. 109, Table I.3.63 $\left.{ }_{[1]}\right)$. As discussed in Chapter 3, these teacher shortages can be subject to significant regional variation and tend to be more pronounced in disadvantaged schools and for subjects requiring technical skills that are in high demand outside of schools.

Comparatively low salaries are frequently regarded as one of the factors contributing to teacher shortages and a lack of qualified candidates. Across OECD countries, 15-year-old students in countries with higher teacher salaries are more likely to expect going into a teaching career (OECD, 2018, p. 142 $\left.2_{[5]}\right)$ and several countries in which teachers' salaries were significantly lower than those of similarly educated workers have considered reducing this gap to attract more high-calibre candidates to the profession. In the Czech Republic, for example, low salaries and poor working conditions have been identified as drivers of the career's low social status and attractiveness. Following an initial increase in teachers' salaries by $22 \%$ in real terms between 2009 and 2014, the government has therefore made it a priority to continue raising salaries as part of its Strategy 2020 (Shewbridge et al., 2016, p. $\left.142_{[20]}\right)$.

Uncompetitive salaries may not only limit the ability of school systems to attract high-quality graduates - they also affect practicing teachers. Across the OECD, 64\% of lower secondary teachers considered improving salaries to be a spending priority of high importance, although the proportion was significantly higher in countries with low statutory teaching salaries (OECD, 2019, pp. 112, Figure I.3.17 $\left.{ }_{[1]}\right)$. The OECD review team has observed some of the consequences that low salaries can have on the profession in countries like Uruguay, where low salaries were suspected to contribute to a lack of motivation, the frequent accumulation of excessive teaching hours and teachers holding multiple jobs at once. To address these shortcomings, Uruguay has raised the salaries of public school teachers at a higher rate than those in the general economy since 2003 (following an economic recession in the late 1990s and early 2000s) (Santiago et al., 2016, p. 235 [41]).

Occasionally, the competitiveness of teachers' salaries has been considered important not only to ensure the sector's general attractiveness, but also its appeal to graduates with specific characteristics that are underrepresented in the profession. Data from PISA 2015, for example, show that 15-year-old students' expectations to become teachers were more gender-balanced in countries with higher teachers' salaries (OECD, 2018, pp. 142, Table $\left.4.10_{[5]}\right)$. This was corroborated by the OECD reviews, for example for the Slovak Republic, where low salaries have been associated with a highly feminised workforce (Santiago et al., 2016, p. 132 [25]). 
A higher wage elasticity of male graduates' decision to teach may reflect their higher opportunity costs of becoming a teacher, but it may also reflect the complex and potentially reciprocal relationships between the profession's gender composition, its social status and remuneration. Conversely, as labour market opportunities for women expand, school systems may struggle to continue attracting the most talented women to the teaching profession at current salary levels. This phenomenon has been documented in the United States since the 1960s (Corcoran, Evans and Schwab, 2004 ${ }_{[57]}$ ) and in many Latin American countries over recent decades (Elacqua et al., 2018 [58] ).

Teacher shortages are often concentrated in specific subject areas and many schools have difficulty in recruiting teachers with skills who could command higher salaries in the general labour market. Policy makers and academics have therefore considered differentiating teachers' salaries based on their training or subject areas to reflect their opportunity costs of pursuing a teaching career (Kershaw and McKean, 1962 [59]). In the United States, as in most countries, the principle of uniform salary scales has imposed limits on subject-based pay differentiation, although some school districts facing dramatic teacher shortages in sciences or mathematics have occasionally exempted schools from these rules (Murnane, Singer and Willett, 1989 $[60]$ ).

Some evidence suggests that teachers' salaries (and the opportunity cost of foregone wages from a career outside of teaching) affect their likelihood of leaving the profession (Falch, $2011_{[61]}$ ), particularly in the early years of their careers (Hendricks, 2014 [62]; Murnane, Singer and Willett, 1989[60] $)$. Competitive salaries may therefore also support schools in retaining high-performing teachers in the profession. High rates of teacher turnover can adversely affect student achievement and place a significant burden in terms of time and resources on those responsible for recruitment and induction. A high fluctuation of teachers is a particularly pressing concern in many disadvantaged schools where students may be taught by a succession of novice teachers who are yet to make their most significant gains in effectiveness (Ronfeldt, Loeb and Wyckoff, 2013 [63]).

It is not clear whether higher salaries would enable schools to retain high-performing teachers at a higher rate than low-performing ones and teachers who leave the profession early tend to perform lower than those who stay. Yet, reducing excessive staff fluctuation may have benefits independent of its effect on the average quality of teachers. This is because student achievement tends to suffer from high turnover rates regardless, particularly due to the loss of experience and productivity caused by the forced reallocation of incumbent teachers across school years (Hanushek, Rivkin and Schiman, 2016 [64]).

Other aspects associated with teachers' remuneration should also be taken into account when assessing its competitiveness. In many OECD review countries, for example, teachers are civil servants and have a high level of job security or access to benefits like pension programmes, tax exemptions, family allowances and annual leave that workers in comparable private sector positions do not. The competitiveness of teachers' salaries should therefore be assessed against a relevant comparison group, bearing in mind both financial and non-financial benefits. 


\subsubsection{Differentiation and progression of teachers' salaries}

Although the level of teachers' salaries matters to attract a sufficient number of high-performing graduates to the profession, cross-national evidence on the relationship between teachers' compensation and system-wide performance is limited. Most countries that perform highly in PISA pay their teachers above their per capita GDP, but the same is true for some low-performing countries (OECD, 2018, p. 60 $0_{[5]}$ ). Policy makers need to consider not only the competitiveness of teachers' lifetime earnings, but also how their compensation is distributed over the course of the career and the factors that determine the salary progression. Higher starting salaries, for example, may need to be weighed against the benefits of greater pay rises over the course of the career.

The range of teachers' pay scales and their slope (i.e. the rate at which salaries increase over the course of a teacher's career) vary significantly across OECD countries with available data $\left(\mathrm{OECD}, 2019_{[23]}\right)$. On average, lower secondary teachers entering the profession with minimum qualifications earned a Purchasing Power Parity (PPP)-adjusted statutory salary of USD 34094 (US dollars) in 2018, rising to USD 47675 with 15 years of experience, and up to USD 62930 for teachers with maximum qualifications at the top of the salary scale, implying a potential salary progression of up to $85 \%$ over the course of a career (see Figure 2.2).

In a number of countries, teachers earn comparatively little as they start their career but experience a stronger salary progression as they gain further qualifications or seniority. In Chile, Hungary, Israel, England (United Kingdom) and Korea, for example, top-end salaries can exceed those of beginning teachers with minimum qualifications by more than $150 \%$. In Colombia and Mexico, salaries at the top of the scale are more than three times as high as starting salaries. By contrast, the salary scales in countries like Denmark, Germany and Switzerland, which offer some of the highest starting salaries, are comparatively compressed.

Multiple OECD review countries have sought to address challenges specific to their respective teacher labour markets by adjusting the slope of their salary scale, which involves a number of trade-offs. Broadly speaking, compressing the salary scale can free up resources to increase teachers' starting salaries at the expense of more experienced teachers, while increasing its slope can create space to provide higher salaries at the top end of the scale.

In light of local labour market conditions and different challenges related to the supply and demand for teachers, the former strategy usually aims to attract more students to the profession and to reduce turnover in the early years of the teaching career, while the latter may serve to retain and motivate more experienced teachers or offer a wider scope for salary differentiation among teachers. Although adjustments in the slope of salary scales and shifts in resources towards their lower or upper end can be budget neutral in theory, fiscal consequences can be hard to predict and they may involve significant transition costs over the course of implementation. 
Figure 2.2. Teachers' salary progression (ISCED 2), 2018

Annual statutory salaries of teachers in public institutions, in equivalent USD converted using PPPs

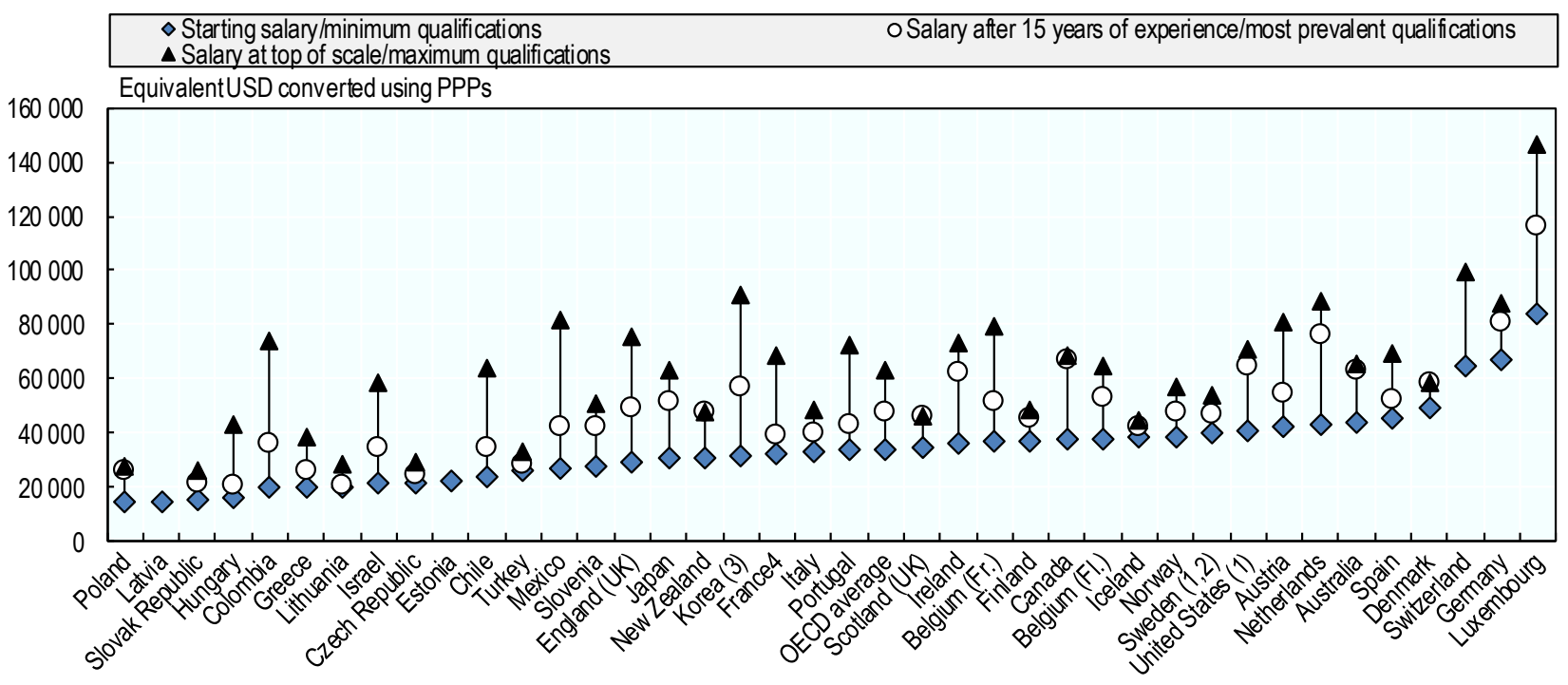

Notes: Countries and economies are ranked in ascending order of starting salaries of teachers with minimum qualifications. In some countries, teachers with minimum qualifications may represent a small proportion of beginning teachers. On 25 May 2018, the OECD Council invited Colombia to become a Member. While Colombia is included in the OECD average reported in this figure, at the time of its preparation, Colombia was in the process of completing its domestic procedures for ratification and the deposit of Colombia's instrument of accession to the OECD Convention was pending.

1. Actual base salaries.

2. Salaries at top of scale and minimum qualifications, instead of maximum qualifications.

3. Salaries at top of scale and most prevalent qualifications, instead of maximum qualifications.

4. Includes the average of fixed bonuses for overtime hours.

Source: OECD (2019) Education at a Glance 2019: OECD Indicators, OECD Publishing, Paris https://doi.org/10.1787/f8d7880d-en, Tables D3.1a, D3.1c and D3.6.

StatLink त्ञाज https://doi.org/10.1787/888934026316

In 2015, Austria implemented a new teacher service code which has been mandatory for all teachers entering the profession since 2019/20. It implied a compression of the salary scale, which provided more attractive starting salaries while reducing top-end salaries, keeping the expected lifetime earnings of teachers roughly equal. The changes have been accompanied by raised qualification requirements for new teachers in provincial schools and an increased teaching load in federal schools ${ }^{1}$.

It is expected that flattening the salary structure in Austria (whose slope had been considerably steeper than the OECD average) may lead to an increase in spending in the medium term until the more highly paid senior teachers who have a right to continue serving under the old salary system will retire. Part of this effect may be offset by longer teaching hours and the new service code's overtime regulations (Nusche et al., 2016, pp. 78, 158[32] $)$. Fewer teachers than anticipated chose to enrol under the new service code while its adoption was voluntary during a transition period, between 2015/16 and 2018/19 (Rechnungshof Österreich, 2016 $6_{[65]}$ ). 
Many OECD review systems are faced with the dual challenge of providing competitive starting salaries to attract high-calibre graduates to the teaching profession while also seeking to retain, motivate and recognise experienced, high-quality teachers through progressive salary increases. In addition, many systems aim to diversify the profession and recognise the importance of incentivising teachers to continuously develop their skills and assume responsibilities that are commensurate with their growing capacity. In light of these complex and diverse objectives, policy makers have moved beyond the starting point and slope of salary scales to consider the various ways in which differentiation and salary progression can be linked to teachers' experience, performance and responsibilities.

The practices among high-performing countries in PISA vary greatly with respect to the factors used to determine teachers' career and salary progression (i.e. the relative weight assigned to appraisal, additional responsibilities, professional development and seniority (OECD, 2018, p. 61 f.[5]). In many school systems, teachers are compensated based on some version of a step and lane structure where salary increases are based either on lateral movements along the steps of a lane (often based on seniority) or vertical movements across lanes (frequently conditional on the attainment of additional educational credentials). Under these traditional models, teachers' salary progression occurs relatively automatically or based on factors like credentials that are only indirectly related to their performance in the classroom, which provides transparency about salary progression.

To promote quality teaching, some countries have sought to strengthen the link between teachers' compensation and their performance or responsibilities. Figure 2.3 illustrates some of the salary differentiations and rewards that teachers are eligible for in OECD countries and which are discussed in the following sections. School-based monetary incentives that are designed to steer the distribution of teachers and attract them to challenging contexts or high-demand areas are discussed in Chapter 3. 
Figure 2.3. Criteria for awarding additional compensation to teachers (ISCED 1-3), 2018

Number of OECD countries

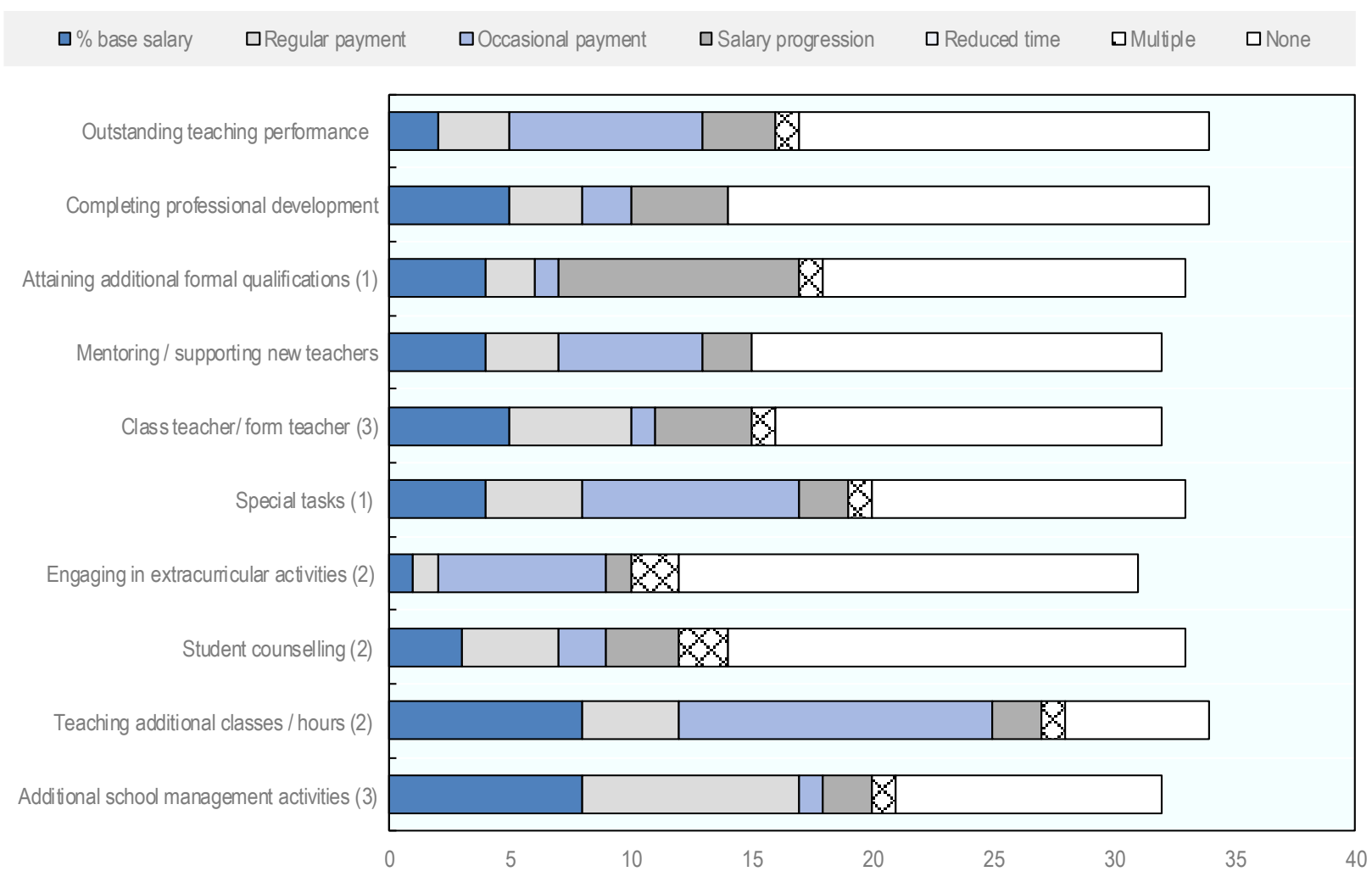

Notes: Data refers to teachers in public institutions. On 25 May 2018, the OECD Council invited Colombia to become a Member. While Colombia is included among OECD countries in this figure, at the time of its preparation, Colombia was in the process of completing its domestic procedures for ratification and the deposit of Colombia's instrument of accession to the OECD Convention was pending.

1. Refers to lower secondary and primary.

2. Refers to lower and upper secondary.

3. Refers to lower secondary

Source: OECD (2019), Education at a Glance 2019: OECD Indicators, OECD Publishing, Paris, https://doi.org/10.1787/f8d7880d-en, Table D3.7. (web only).

StatLink त्ञात https://doi.org/10.1787/888934026335

\section{Education-based progression of teachers' compensation}

As for any profession, the demands placed on teachers change over time, due to evolving student needs, technological change and the continuous refinement of pedagogical knowledge. To help the teaching profession keep up with these demands (not least in light of the ageing teacher population), many countries place an increasing emphasis on teachers' continuing professional development (CPD) and encourage them to attain additional qualifications throughout their career. In Singapore, for example, teachers are encouraged to pursue master's or $\mathrm{PhD}$ degrees mid-career to gain new insights by situating their practical experience within a more theoretical research context (Schleicher, 2018, pp. $\left.84,123_{[66]}\right)$. 
There are many ways in which governments can encourage teachers' continuous professional growth and the development of their pedagogical skills (for a more detailed discussion, see Chapter 4). Engaging in additional training can constitute a significant investment of teachers' time and financial resources. Additional payments are therefore one way in which countries have sought to compensate and incentivise teachers to undergo different forms of additional training. As can be seen in Figure 2.3, this practice is relatively widespread in OECD countries.

More than half of OECD countries and economies with available data report that teachers in primary to upper secondary school receive some form of compensation for attaining further formal qualifications (e.g. degrees that exceed the countries' minimum requirements or qualifications in additional subjects) (OECD, 2019 $\left.9_{[23]}\right)$. The evidence on the predictive power of educational credentials when estimating teachers' effectiveness at

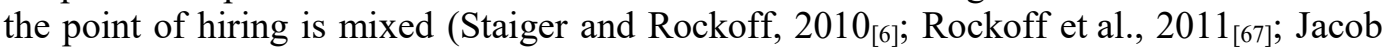
et al., 2018[68] $)$, but education-based differentiations in teachers' salaries can also serve as an incentive for teachers to update and enhance their skills mid-career.

In 10 of 33 countries (including the French Community of Belgium, Chile, Iceland and Luxembourg), further qualifications are rewarded in the form of salary progressions, i.e. an advancement to higher lanes or step increments within the salary grid. Another eight countries reward further qualifications through regular payments (e.g. the Flemish Community of Belgium), occasional payments (e.g. Denmark) or with a percentage of teachers' base salary (e.g. Colombia, Israel, the Slovak Republic and Slovenia) (OECD, $2019_{[23]) \text {. }}$

The widespread linkage of teachers' statutory salaries and their qualifications is corroborated by OECD data, which shows that - in countries where the most prevalent teacher qualification exceeds the minimum entry requirements at a given level - more highly qualified teachers earn at least $10 \%$ more than those with minimum qualifications. (OECD, 2018, p. 362 f.[50] $)^{2}$

Although less common among OECD countries, some systems also provide monetary incentives for teachers to engage in continuing professional development (CPD). Fourteen of 34 OECD countries and economies with available information reported to financially reward teachers' pursuit of CPD in one way or another (OECD, 2019 $\left.{ }_{[23]}\right)$. As described in Chapter 4, Table 4.3, for example, teachers in the Slovak Republic are eligible for a salary allowance if they engage in professional development activities and teachers in Spain can receive a salary bonus for completing 100 certified training hours. These rewards have tended to focus on traditional forms of CPD, rather than less formalised, school-based and teacher-led types of professional learning.

Another concern around linking course credits directly to financial rewards is that teachers' participation might become disconnected from their professional improvement and insufficiently guided by individual development needs. The Slovak Republic has sought to address this through a change in policy. Until 2012, school leaders in the country were legally obliged to provide bonus payments to all teachers who obtained the required amount of professional development credits. Since then, however, schools have been asked to establish internal school regulations specifying the conditions under which credit salary rises are approved. If a training is not considered relevant for the teacher's or school's development, it might therefore no longer count towards salary raises (Shewbridge et al., 2014, p. $69_{[69]) .}$ 


\section{Task-based differentiation in teachers' compensation}

Many countries recognise and financially reward teachers who fulfil tasks that go beyond core teaching-related activities such as lesson planning, marking students' work, general administrative work, communicating with parents, supervising students or working with colleagues (see Figure 2.3). These tasks can include supporting new teachers as part of mentoring and induction programmes, acting as a class teacher, counselling students (e.g. providing career guidance or delinquency prevention) or taking over managerial roles such as serving as the head of a department. Teachers may assume such remunerated responsibilities on an ad hoc basis or as part of formal positions integrated into their career structure (see sections on career structures above).

Teachers who participate in some types of management activity on top of their teaching duties are compensated in more than two thirds of the OECD countries and economies with available data (OECD, 2019 [23]). These benefits may accrue indirectly in the form of reduced teaching hours (for upper secondary teachers in the Slovak Republic), or, more commonly, take the form of occasional or regular (often annual) additional payments, as in Austria, England (United Kingdom), France, Ireland, Italy, Japan, Korea, Norway, the Slovak Republic and Spain (Figure 2.3). In Denmark, teachers who take on managerial responsibilities benefit from both reduced teaching time and a regular payment.

In many OECD countries, teachers are also compensated for taking on more classes or hours than required by their full-time contract (e.g. in the form of overtime payments) or for performing special tasks, such as training student teachers. By contrast, only about a third of OECD countries and economies with available data report compensating teachers with payments or a proportional increase in their base salary for their engagement in the organisation of extracurricular activities (examples include Chile, the Czech Republic, Estonia, Iceland, Israel, the Slovak Republic and Spain) or student counselling activities (examples include Austria, Chile, the Czech Republic, Estonia, Iceland, Israel, Lithuania, the Slovak Republic and Spain) (Figure 2.3) (OECD, 2019 $\left.{ }_{[23]}\right)$.

The financial compensation of additional tasks and responsibilities can provide recognition for teachers' efforts on relatively objective grounds and incentivise contributions that may benefit the school community as a whole. At the same time, task-based rewards offer no direct rewards for highly skilled educators or those who improve their performance in the classroom while risking to diverting the efforts of ambitious teachers away from teaching (Conley and Odden, $1995_{[70]}$ ). Other forms of differentiated pay, which are discussed in the following, have sought to bridge this gap and more explicitly link compensation to staff effectiveness and student achievement.

\section{Performance-based differentiation in teachers' compensation}

The idea of performance-based compensation for teachers (sometimes referred to as "merit pay") has a long history in countries like the United States, where school districts have experimented with merit pay programmes throughout the $20^{\text {th }}$ century, although many of them were short-lived and have since been replaced by uniform salary scales (Murnane and Cohen, $\left.1986_{[71]}\right)$. In theory, performance-based compensation is meant to motivate teachers to improve their practice and raise students' achievement by rewarding effective teaching.

Common criticisms of merit pay programmes, however, point to the difficulty of measuring performance at the level of individual teachers and to potentially perverse effects such as a narrowing of the curriculum or lower teacher efforts on tasks that are not explicitly rewarded by the programme. Some also fear that an excessive reliance on extrinsic 
incentives might undermine teachers' intrinsic motivation to do well (Christian, Jacobsen and Andersen, 2013 [72]; Bénabou and Tirole, 2003 ${ }_{[73]}$; Frey, 1997 $\left.{ }_{[74]}\right)$ or that competition among teachers may reduce co-operation, both of which could be in detriment to school's collective professional capacity and improvement in the long run.

Performance-related pay schemes can take different forms, distinguished most importantly by the mechanism through which teachers' pay is linked to their appraisal. Some systems provide a more direct link, e.g. by introducing a variable salary component or end-of-year bonus based on a given year's performance or by linking the speed of teachers' annual salary progression to their performance rather than, or in addition to their seniority. Other systems provide a more indirect link by considering teachers' performance evaluations in decisions on their career progression, which may in turn affect their salaries through a link between salary and career structures (Conley and Odden, 1995[70]).

Whether the link between performance and pay is direct, mediated via career structures or made up of elements of both, policy makers need to address a number of questions related to its design:

- How large should the incentive be? (What share of salaries should vary by performance and how large do differentials between high- and low-performing teachers' salaries need to be to incentivise positive behavioural change?)

- How should teachers' performance be evaluated? (Should additional compensation be based on principals' evaluations, on student test scores, other pre-defined indicators or a combination of the above?)

- Which aspects of performance should be evaluated? (Should non-academic outcomes, such as students' behaviour and well-being be considered or should it be limited to students' subject-specific performance? Should the focus be on absolute or relative gains and should all students' results weighed equally?)

- Should teachers' evaluations be independent of one another? (Should performance be measured at the level of the individual or groups of teachers? Should salary increases be based on a quota system limiting the number of teachers who can succeed?)

Many teachers feel like they receive little recognition or reward for high performance on the job. For example, nearly half of all teachers responding to TALIS 2018 reported that there were no incentives for them to engage in professional development (OECD, 2019, pp. 209, Table I.5.36 $[1]$ ). Likewise, for TALIS 2008, two-thirds of teachers reported receiving no recognition for being innovative or for improving the quality of their teaching and three-quarters of teachers reported that the most effective teachers in their school do not receive the greatest monetary or non-monetary rewards (OECD, 2009, p. 170 f.[75]).

Conversely, teachers in many OECD countries face no significant consequences for persistent under-performance. For TALIS 2008, just one quarter of teachers reported that colleagues in their school would be dismissed based on sustained performance concerns (OECD, 2009, pp. 188, Table 5.9[75]). This reflects the high level of job security that teachers in many systems enjoy once they have reached tenure. However, the inability to dismiss teachers with performance concerns can be just as stifling for schools as the inability to retain the most effective ones.

Of course, many of the tasks that teachers perform can provide a strong intrinsic motivation, especially if they are carried out under conditions that make them intellectually stimulating and enjoyable. A key objective in inspiring high-performing teachers is therefore to 
promote their intrinsic motivation and to create conditions that stimulate their self-motivation (as discussed further below). Yet, as in most professions, some aspects of teachers' work, while important to promote student learning, are less inspiring. Providing a measured balance of intrinsic and extrinsic sources of motivation is important to promote and reward high performance across the whole range of teachers' tasks (OECD, 2007[76]).

In recognition of this, OECD countries have experimented with various forms of performance-based differentiation in teachers' compensation. In 2017, half of the OECD countries and economies with available data compensated teachers in primary and secondary education for outstanding performance in one way or another (OECD, 2019 [23]). Four countries (Chile, Japan, Turkey and England [United Kingdom]) reported that strong performance could accelerate their teachers' progression within their salary range. More frequently, in a total of 13 schools systems, performance-based rewards took the form of occasional payments (Austria, Denmark, Estonia, Finland, Israel, Italy, Japan, Poland and the Slovak Republic), regular payments (Latvia, Norway and Slovenia) or a proportion of their base salary (the Czech Republic and Mexico) (see Figure 2.3).

\section{Measuring teacher performance}

Most performance-related pay systems rely on measuring teachers' effectiveness on the basis of classroom observations, their students' achievement or a combination thereof. A central challenge is the selection of valid indicators that can be measured transparently and reliably, that do not set perverse incentives and whose costs of measurement do not outweigh their expected impact on student performance (see Chapter 4). There are numerous methodological challenges related to the use of student test scores to evaluate teachers' performance and ongoing debates on whether value-added measures can reliably control for the effect of classroom composition on teachers' results (Rothstein, 2014 [77]; Koedel and Betts, 2011 $\left.{ }_{[78]}\right)$.

Introducing high-stakes evaluations of teachers based on their students' performance can also elicit unpredicted and potentially harmful responses. Whichever indicators are chosen to reflect students' performance, there is a risk that teachers will focus their efforts on maximising these outputs at the expense of others. This can result in opportunistic behaviour (such as teaching to the test or gaming students' scores), as well as teachers neglecting dimensions of student learning that are less amenable to measurement, or reducing their contributions outside the classroom, e.g. assisting their peers (Ballou and Springer, $\left.2015_{[79]}\right)$. While expanding the set of measured performance indicators reduces these perverse incentives, it may increase the cost of the merit pay system beyond justification.

Another concern relates to heterogeneous effects that performance-related incentives may have across the student population. In order to underline the importance of each student's progress and to eliminate factors such as their socio-economic status from teachers' evaluations, many measures of teacher effectiveness are based on students' average gains in performance. This approach provides incentives for teachers to focus on students for whom a marginal increase in attention is likely to produce the greatest gains. These are often assumed to be students in the middle of the performance spectrum, whose support may come at the expense of those who struggle the most.

Some proposed remedies, such as the weighting of performance gains based on students' characteristics, compel policy makers to engage with complex ethical problems (Murnane and Cohen, 1986, p. 13 $\left.{ }_{[71]}\right)$. Alternative indicator-based methods of teacher assessment have been suggested to resolve some of these problems and therefore merit further 
investigation. For example, measures of teacher performance that are based on changes in their students' ordinal ranking relative to their peers might remove some incentives to teach to the test or manipulate assessment scales (Barlevy and Neal, 2012[80]).

Given the validity concerns around value-added measures of teacher performance based on student test scores, classroom observations remain central to most performance pay systems. High-quality structured observations are typically performed by principals or senior teachers who have undergone training and certified their ability to generate qualitative and quantitative data following a common, detailed performance-rubric over the course of a prescribed number of observations (Goldring et al., 2015 [81]). Observations offer some distinct advantages over test scores by providing information closer to real time, richer and more teacher-specific insights and data for subjects that are not assessed.

Nevertheless, classroom observations can be subject to transparency concerns and similar validity problems as test-based measures since teachers' ratings partly reflect their students' characteristics and the non-random sorting of teachers to classes (see Chapter 3) (Steinberg and Garrett, 2016 [82]). This underlines the risks involved in staking important staff management decisions on any single indicator or source of evidence and highlights the importance of identifying and addressing potential biases and unintended consequences, whichever measure of teachers' performance is used (OECD, 2013 ${ }_{[3]}$ ).

\section{Direct links between performance and compensation}

The most straightforward ways of linking teachers' appraisal to their compensation involve payments in the form of merit increments or end-year bonuses based on their measured performance. A 2005 OECD review of teacher policy found performance-related payments to be increasingly common in public schools, although the evidence on the effectiveness of such extra payments was found to be mixed and their implementation to be highly contentious (OECD, 2005, p. 184 [28]). In practice, lump-sum and merit-increment systems may complement or substitute each other and both come with advantages and drawbacks. Due to their one-off nature, for example, lump-sum bonuses are more clearly linked to a given year's performance but might provide relatively short-lived incentives. An OECD review of public sector performance pay also found that some systems have favoured bonuses because they are more flexible and do not have a long-term impact on the wage bill or pension liabilities (OECD, 2005, p. 56[83]).

In several systems with locally operated performance pay systems, the OECD review team identified significant challenges related to their transparency and effectiveness, also given available resources at the school level. In the Slovak Republic, for example, teachers can be awarded a personal allowance based on their performance, among other factors. In the absence of a clear framework for appraising the performance of teachers, bonuses were more frequently awarded based on the assumption of additional responsibilities than teachers' effectiveness in the classroom and their impact on student learning. In the light of recent reforms to the Slovak Republic's career structure, the OECD review team concluded that additional monetary performance incentives might become redundant if teachers can advance on a career ladder with associated salary increases based on good performance (Santiago et al., 2016, pp. 193, 202 [25]).

Similar challenges were observed in the Czech Republic, where school principals have the discretion to allocate individual allowances and bonuses to reward teachers for high performance or additional work. Yet, neither the level, nor the criteria for the allocation of these personal allowances were legally defined or based on transparent and objective criteria (Shewbridge et al., 2016, p. 137 $7_{[20]}$ ). Providing agents with a clear understanding of 
the underlying evaluation criteria and the steps they can take to improve, is therefore a necessary condition for any incentive structure to have its intended effects.

High-quality evaluations of teacher performance pay programmes have mostly been discouraging on whether incentive systems with singular, test-based measures of teacher performance can improve student learning, although there are some instances of reported positive outcomes in the United States (Podgursky and Springer, 2007[84]) and the United Kingdom (Atkinson et al., 2008 $8_{[85]}$ ).

Most studies of programmes from the United States found either no positive impact of teacher merit pay on student achievement (Fryer, 2013 [86]; Springer et al., 2010 [87]), very small effects (Sojourner, Mykerezi and West, 2014[88]), or mixed effects, subject to estimation specifications (Springer, Ballou and Peng, 2014 ${ }_{[89]}$ ). Even where positive overall effects have been found, it can be difficult to discern which mechanisms drove the results since performance pay programmes are often comprised of multiple components or form part of larger reform packages (Balch and Springer, 2015 $[90]$ ). Some more positive results were reported from performance-based compensation systems established under the Teacher Incentive Fund (TIF) and for the District of Columbia Public Schools' IMPACT evaluation system (see Box 2.3).

\section{Box 2.3. Evaluations of performance-based compensation systems in the United States}

Starting in 2006, the US Department of Education competitively awarded Teacher Incentive Fund (TIF) grants to school districts to fund the development and implementation of performance pay programmes aimed at teachers and principals. Participating districts were required to use measures of student achievement growth and at least two observations of classroom or school practices to evaluate teachers' and principals' effectiveness. Districts were given discretion to design the details of these measures and most of them measured student achievement growth both at the school and at the classroom level when evaluating teachers. In addition - although not all TIF districts successfully implemented these components - recipients had to offer educators bonuses based on their performance that were challenging to earn, substantial in size, and differentiated; they had to offer educators opportunities to earn additional pay for taking on extra roles or responsibilities; and they had to provide professional development to help educators understand the measures on which they were evaluated and improve their performance on those measures (Chiang et al., 2017 [91]).

Estimates from randomised control trials in ten participating districts suggest that the programmes funded through the 2010 round of TIF grants led to a small increase in student achievement of 1 to 2 percentile points. Fewer than half of the TIF districts planned to continue paying bonuses beyond the grants' five-year period, mostly due to concerns about their financial sustainability. Nevertheless, most districts planned to retain other components of the programme, such as measures of teacher effectiveness or offering professional development opportunities based on teachers' performance ratings (Chiang et al., 2017 $[91])$.

According to the evaluation, the TIF programmes' effectiveness may have been limited by a range of factors. For example, many teachers were unaware of their eligibility for bonuses or underestimated the amount they could receive. In addition, targeted professional development was limited (amounting to no more than six hours over the school year) and may have failed to enable teachers' use of more effective practices. However, despite their 
modest impact on student achievement, a cost-effectiveness comparison with alternative interventions suggests that the TIF pay-for-performance programmes were more efficient than class-size reduction would have been and that they were about as cost-effective as incentives for high-performing teachers to transfer to low-performing schools (Chiang et al., 2017 $[91])$.

Some positive effects were also reported from the District of Columbia Public Schools' IMPACT evaluation system, which provided unusually strong positive and negative incentives based on multiple measures of teacher performance (including test scores, but also several structured observational measures). Studies estimate that the threat of dismissal for low-performing teachers increased voluntary attrition by more than 50 percent (Dee and Wyckoff, 2015 [92] ) and that their replacement by higher-performing teachers raised student achievement in math by a small but significant 0.08 standard deviations (Adnot et al., 2017 ${ }_{[93]}$ ). The IMPACT evaluation also appears to have improved the performance of low-performing teachers who remained in the system as well as that of high-performing teachers who received significant increases in compensation (Dee and Wyckoff, 2015 [92]). These estimates are local though, i.e. they concern only those teachers around the cut-offs for negative or positive consequences and many incentive systems are less effective in motivating those in the middle of the performance spectrum who are unlikely to face consequences either way (OECD, 2005 [83]). Some of the factors thought to have contributed to the IMPACT programme's favourable evaluation, compared to other performance pay programmes include its articulation of clear standards for effective instruction, the provision of instructional coaches to help teachers meet those standards, and its multi-faceted measure of teacher performance (Dee and Wyckoff, 2015 [92]).

The implementation of systems which establish direct links between teachers' compensation and performance can come up against a range of challenges related to their to effects on teacher collaboration, their fiscal impact and the adequate and transparent measurement of teacher performance. Notably, the potential long-term effects of performance-based compensation schemes must be weighed against the risks and considerable costs that can arise in the course of their implementation. This concerns not only the challenge of achieving teacher buy-in, but also building the necessary capacity among responsible authorities for teacher evaluation, and putting in place monitoring processes to identify and remediate any unintended negative consequences early on.

Given that the implementation of performance-based compensation systems has often been highly contentious and divisive (OECD, 2005[28]), engaging stakeholders during the design and implementation process is critical to successfully manage transitions, e.g. from a seniority-based compensation system to a system that gives greater weight to individual or group-based performance and responsibilities.

It is widely acknowledged that a highly effective way to improve teachers' individual and collective professional capacity is through peer-learning and regular, growth-oriented evaluations carried out by trained supervisors in an atmosphere of mutual trust (OECD, $2013_{[3]}$ ) (see Chapter 4). A central criticism levelled at performance-based pay is that it can undermine these mutually supportive relationships and incentivise teachers to conceal their failings in fear of financial retribution, rather than openly addressing them and seeking help from peers or supervisors. Particularly where the evaluation systems used to determine teachers' salaries are not sharply distinguished from more formative forms of evaluation, the former risk to undermine the latter, which makes it harder for school leaders to provide teachers with the support they need (OECD, 2013 ${ }_{[3]}$; Murnane and Cohen, 1986 $6_{[71]}$ ). 
In addition, even if merit-pay systems were based on perfectly reliable measures of teacher performance, perceived unfairness and a lack of transparency remain potential sources of dissatisfaction and demotivation. Most principals who engage in regular classroom observations have a good sense of who their most effective teachers are. Yet, they may struggle to justify this assessment to teachers who are denied a reward and - even more problematically - may fall short of pointing them to a clear path for obtaining it, given the absence of clearly defined behaviours that consistently result in higher teaching performance (Murnane and Cohen, $1986_{[71]}$ ). The positive impact of financial rewards on the most effective teachers may thus be more than offset by its negative impact on those who fail to obtain them and the corroding effect this may have on collegial relationships.

Occasionally, performance-related pay for government employees has been proposed not only to enhance performance, but also to reduce costs, e.g. by replacing automatic seniority-based salary progressions (OECD, 2005, p. 35[83]). However, as discussed above, the experience of Teacher Incentive Fund programmes in the United States has demonstrated that the introduction of high-quality systems for performance evaluation can impose significant costs (Chiang et al., 2017 [91]). In light of the high stakes involved, providing reliable multi-dimensional estimates of teacher performance may require the use of sophisticated systems of teacher assessment, including e.g. higher-frequency observations with multiple, carefully trained evaluators (Dee and Wyckoff, 2015 [92]).

Another challenge that countries might encounter is the difficulty of predicting the fiscal impact of performance-related remuneration programmes. While the overall spending on teachers' salaries is relatively easy to forecast if they increase in line with seniority, it is considerably harder to predict individual teachers' performance and the outcomes of their evaluations. Although they can be perceived as unfair, quotas and other forms of restrictions to the magnitude and number of performance-related salary increases are common methods to control the fiscal impact of performance pay programmes across the public sector. The use of lump-sum bonus payments, rather than merit increments is another means to control their fiscal impact since they can be managed with greater flexibility and may not add to long-term fixed payroll costs, including pensions (OECD, 2005, p. $56_{[83]}$ ).

Learning from countries' experiences with the implementation of performance-related pay systems as well as isolating and evaluating their effects is difficult, given that their introduction is often accompanied by organisational changes on a larger scale. In public administrations, these have often included the reform of appraisal and goal setting processes, the clarification of tasks, acquisition of skills, creation of improved employee-manager dialogue and, in the case of schools, the reform of teaching standards and career structures. Many of these changes may have a positive impact on performance, independent of the financial incentives that accompany them (OECD, 2005, p. $\left.14_{[83]}\right)$.

\section{Group-based performance rewards}

Since many aspects of teachers' work depend on or benefit from collaboration among peers, one of the concerns most frequently raised in the context of individual-level performance rewards is that they might foster competition among teachers and undermine mutual support. In order to avoid these dynamics, some countries have therefore introduced incentive structures based on collective rather than individual performance in order to encourage collaboration and collective improvement. Group-based performance rewards also promise to resolve some of the attribution problems associated with traditional performance pay. These arise because many desirable outcomes, such as eliminating bullying or violence in schools, cannot be easily attributed to the work of any individual, 
even though teachers arguably play a critical role in their accomplishment and should be encouraged to work towards them.

Colombia is one of the countries that has introduced group-based performance rewards. At the time of the review, schools were eligible to receive a performance bonus tied to a school-level performance index, the Education Quality Synthetic Index (Índice Sintético de Calidad Educativa, ISCE), once a year. However, the index' design raised some concerns among the OECD review team since it failed to take schools' socio-economic context and the prior performance of its students into account and therefore penalised disadvantaged schools even though they might provide their students with a high value added (Radinger et al., 2018, pp. 196, 249 $9_{[8]}$ ).

Chile is another country that provides teachers and school leaders with performance-related incentives. Some of these are group-based, like the National System for Performance Evaluation (Sistema Nacional de Evaluación de Desempeño, SNED) for teachers or the Collective Performance Allowance (Asignación de Desempeño Colectivo) for school leaders, described in Box 2.4 further below (Santiago et al., 2017[9]).

The larger the groups on which collective performance rewards are based, the weaker the incentives they provide for individual behavioural change. Consistent with this, their impact on student achievement has tended to be relatively small in the few existing evaluations (Jackson, Rockoff and Staiger, 2014 [94] $)$. Evidence from a group-based teacher incentive programme in New York City (United States) also suggests that group-based incentives may be more effective in some school contexts than in others. While the programme had little overall effect on students' results, schools with a higher degree of teacher cohesion showed slight increases in maths achievement, as one might expect for a culture of team work to incentivise joint production and peer-monitoring to curtail free riding (Goodman and Turner, 2013 [95]). As for any other reward system, group-based meritpay systems should be carefully designed to avoid introducing perverse incentives. For example, an overreliance on group-based performance rewards could be expected to deter high-performing teachers from working in schools with a lower average teacher quality, even though these schools might need benefit the most from their support.

\section{Indirect links between performance and compensation}

Linking teachers' individual or collective performance directly to their compensation (e.g. through end-year bonuses or salary increments) is not the only way to financially reward and incentivise effective teaching. In practice, there are many ways in which these links can be established in more indirect ways and embedded within systems for teachers' professional advancement. As discussed above, differentiated career structures - although not necessarily tied to salary scales - tend to reward teachers' vertical advancement on the career ladder with higher compensation.

If designed well, indirect links between teachers' appraisal and their compensation promise to address some of the challenges associated with conventional performance pay. For instance, they can combine extrinsic rewards for high performance (in the form of salary increases) with intrinsic rewards in the form of professional opportunities and responsibilities that grow in line with their knowledge and skills (Conley and Odden, $\left.1995_{[70]}\right)$. For these mechanisms to be effective, teachers' career advancement would need to be linked to their demonstrated effectiveness in the classroom, for example through robust certification processes based on rigorous teaching standards. 
In addition, rewarding teachers' performance relative to their current career stage has the potential to motivate teachers across a broader spectrum of proficiency and experience to upgrade their skills. Many conventional performance-based pay systems provide bonuses for the highest-achieving staff, which may seem unattainable to the majority of teachers. Providing monetary and career incentives for teachers to gradually advance their knowledge and skills offers both novice and senior teachers realistic goals relative to their respective position on the career ladder and a clear pathway to achieve them. Implementing such systems may require countries to further develop and integrate their frameworks for teaching standards, career structures and salary scales.

Colombia's new teacher career structure, introduced in 2002 and applicable for teachers appointed following its introduction, illustrates how indirect links between appraisal and compensation can be established. In contrast to the seniority-based system in place for teachers appointed prior to 2002, teachers with a given qualification now need to undergo a system of Diagnostic and Formative Evaluation (Evaluación de Carácter Diagnóstico Formativo, ECDF) to advance their career and each the next step of the salary scale. While initially based on a written assignment, the evaluation process was reformed in 2015 to more closely measure teachers' effectiveness in the classroom. The process now emphasises peer evaluations based on video observations, and also serves to identify professional development needs and opportunities for teachers (Figueroa. et al., 2018 [96]). While the details of the process have been subject to ongoing negotiations and teachers have raised concerns about the evaluation method's reliability, the system signals a clear commitment to strengthening the indirect linkages between teachers' performance and their compensation (Radinger et al., 2018, pp. 241, 249 $9_{[8]}$ ).

Similarly, Chile uses a certification process to regulate teachers' progression across the five stages of their career structure based on competencies specified in the national teaching standards. The certification includes an external component comprising a standardised written assessment and external markers evaluating a professional portfolio, as well as classroom observation. While advancement to the two highest stages of the teaching career (Expert I and Expert II) is voluntary, teachers are expected to move from the first stage (Initial) to the second or third (Early, Advanced) after four to eight years, which also serves as a means to remove underperforming teachers from the profession if they fail the examination more than twice (Santiago et al., 2017, pp. 240, 253 ${ }_{[9]}$ ).

\subsubsection{Compensation and benefits of school leaders}

To ensure a sufficient supply of high-quality candidates for school leadership positions, their salaries need to be attractive, not only compared to those of positions with similar levels of responsibility in the public and private sectors, but also compared to those of senior teachers among whom most school leaders are recruited. In nearly all OECD review countries with available data, the maximum salaries for school leaders exceed those of teachers. Nevertheless, the salary ranges for teachers and school leaders overlap in most systems and in a number of them, including Austria, the Czech Republic, Greece and Portugal, neither the bottom, nor the top statutory salaries of school leaders with minimum qualifications are significantly different from those of teachers (see Figure 2.4) (OECD, 2019 [23]).

Evidence from OECD reviews suggests that the status and attractiveness of school leadership roles can suffer if their compensation fails to reflect their higher level of responsibility (Nusche et al., 2016, p. 172 $[32]$ ). In Colombia, for example, where school leaders do not benefit from a separate salary scale, their earnings are frequently inferior to 
those of their teachers, despite a significantly heavier workload (Radinger et al., 2018, p. $\left.185_{[8]}\right)$. Similarly, school leaders in Uruguay often earn less than their senior teachers, which discourages many of them from applying for leadership positions despite having completed the required initial preparation for the role. As a consequence, the system faces a shortage of school leaders across all levels of education (Santiago et al., 2016 ${ }_{[41]}$ ).

Furthermore, the low remuneration of school leaders in Uruguay creates incentives for school leaders to take on additional roles to supplement their salary. In some schools visited by the OECD review team, principals and deputy principals worked in private schools, teacher education institutions, or adult education in addition to their leadership role, meaning that they could dedicate less time to the improvement of their schools (Santiago et al., 2016, p. 184[41]). Establishing separate salary scales for school leadership roles can provide a good basis to recognise their distinct responsibilities, rather than treating principal-ship as a mere extension of the teaching career (see further below).

Figure 2.4. Minimum and maximum statutory salaries for teachers and school heads (ISCED 2), 2017

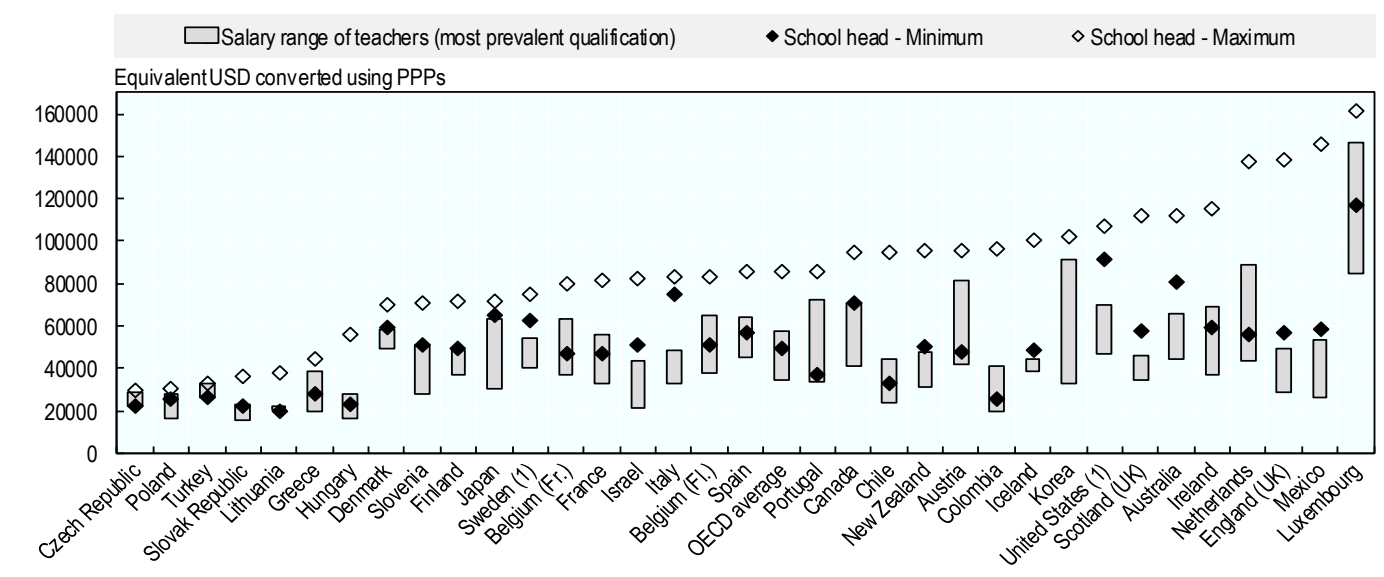

Notes: Countries and economies are ranked in descending order of maximum salaries of school heads. Salaries refer to the annual statutory teachers' and school heads' salaries in public institutions, based on teachers with most prevalent qualifications at a given level of education and school heads with minimum qualifications. On 25 May 2018, the OECD Council invited Colombia to become a Member. While Colombia is included in the OECD average reported in this figure, at the time of its preparation, Colombia was in the process of completing its domestic procedures for ratification and the deposit of Colombia's instrument of accession to the OECD Convention was pending.

1. Actual base salaries.

Source: OECD (2019), Education at a Glance 2019: OECD Indicators, OECD Publishing, Paris, https://doi.org/10.1787/f8d7880d-en, Tables D3.1b. and D3.10.

StatLink : הils https://doi.org/10.1787/888934026354

Given that school leaders' levels of responsibility, the complexity of their tasks and their administrative burden can vary considerably depending on the school they serve, some countries have sought to adjust their compensation accordingly. The majority of OECD review countries adjust school leaders' salaries based on the size and other characteristics of their school (see Table 2.2 further below). In Chile, for example, school leaders receive a bonus of $25-200 \%$ of the basic minimum teacher' salary, depending on their schools' size and socio-economic composition (MINEDUC Centro de Estudios, 2016, p. 132[97]). 
Similarly, in Austria, the service bonus that school leaders receive on top of the teacher salary varies based on the size of their schools. At the time of the OECD review in 2015, this allowance ranged from EUR 300 per month in the smallest schools (in schools with fewer than ten full-time equivalent teachers, leadership roles are assumed by teachers in exchange for a bonus and reduced teaching hours) to EUR 1650 in the largest schools (Nusche et al., 2016, p. 155 $5_{[32]}$ ). Since then, a reform has raised the bonus for the largest school principals to EUR 1850 . Principals of multiple schools receive the cumulative allowance for each school under their leadership.

In many systems, school leaders' salaries are higher at the upper or lower secondary level than at the primary level. This can be the product of larger school sizes at the secondary level or the explicit reflection of education levels in the salary scales of school leaders (or teachers, e.g. where principals' salaries are comprised of a management allowance on top

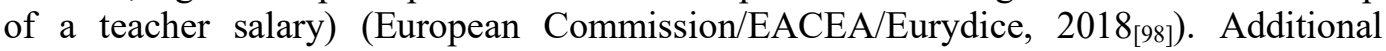
school-level factors that might affect the salaries of school principals include the school's leadership structure and the amount of support principals receive through deputy or assistant principals. Particularly in systems that struggle to fill leadership positions for schools in disadvantaged, rural or remote areas, location-based salary adjustments may also be used as a means to address regional inequalities (see Chapter 3). Including such weightings in leaders' salary scales may help that all schools are attractive to and managed by high-performing leaders (Pont, Nusche and Moorman, 2008 ${ }_{[27]}$ ).

Table 2.2 summarises some of the criteria used to determine school leaders' base salaries and their additional payments in OECD review countries. School-based weights are relatively common and some systems also provide financial incentives for professional development or the completion of further formal qualifications. About a third of the review countries' salary scales include performance-based components to determine school leaders' salaries. School leaders in Sweden, for example, receive an individualised salary based on the regional education director's assessment of their performance. The degree to which these assessments are systematised and transparent varies across municipalities and school boards. Education directors may take into account a variety of indicators, ranging from the school's academic results and teachers' or parents' testimonies to the labour market outcomes of their students. Some municipalities have taken inspiration from the private sector or other public sectors like health to design evaluation systems for their leaders (Pont, Nusche and Moorman, 2008 [27] $)$. 
Table 2.2. Factors influencing school principals' salaries (ISCED 1-3), 2018

OECD review countries, public schools

\begin{tabular}{|c|c|c|c|c|c|c|c|c|c|c|c|c|c|c|c|c|c|c|c|c|}
\hline Performance-related & 1 & & & C & $\begin{array}{l}\text { I, } \\
\text { C }\end{array}$ & & & & & & 1 & & 1 & & & 1 & 1 & & & \\
\hline Development-based & & & & $\mathrm{D}$ & & & & & $\begin{array}{c}\mathrm{D}, \\
\mathrm{Q}\end{array}$ & & & & D & & D & & D & & & \\
\hline School characteristics & & & & & & & & & & & & & & & & & & & & \\
\hline Part. in other mgmt. a & & & & & & & & & & & & & & & & & & & & \\
\hline Factors at sub-nationa & & & & & & & & & & & & & & & & & & & & \\
\hline Country & 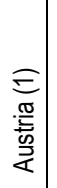 & 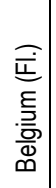 & 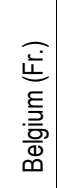 & $\begin{array}{l}\widetilde{d} \\
\frac{\omega}{\bar{t}} \\
\end{array}$ & $\begin{array}{l}\widehat{0} \\
. \frac{0}{0} \\
\overline{\bar{g}} \\
\text { 잉 }\end{array}$ & 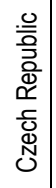 & 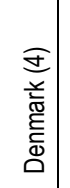 & 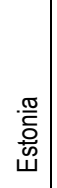 & 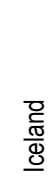 & 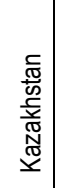 & 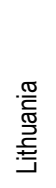 & 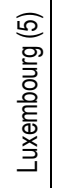 & $\begin{array}{l}\frac{8}{x} \\
\frac{\mathbb{d}}{2}\end{array}$ & 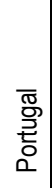 & 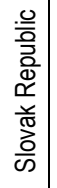 & $\begin{array}{l}\frac{\tilde{d}}{\bar{T}} \\
\frac{\partial}{\omega}\end{array}$ & 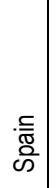 & 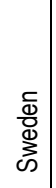 & 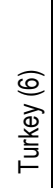 & 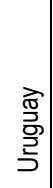 \\
\hline
\end{tabular}

Notes: For performance-related factors, "I" indicates individual performance, "C" indicates collective performance, i.e. measures based on the performance of multiple principals or schools (e.g. in a given cluster/area); For development-based factors, "D" indicates professional development, "Q" indicates formal qualifications. Performance-related compensation includes annual payments and bonuses (end-year or quarterly); Development-based compensation includes salary progression, allowances and annual payments; Compensation related to school characteristics (e.g. size, type, location) relates to a higher base salary; Compensation based on participation in management activities includes occasional or annual payments.

1. Austria: Applies to leaders working under the new teacher service code (Dienstrechts-Novelle 2013 Pädagogischer Dienst) that applies to all leaders appointed from 2019/20.

2. Chile: The performance bonus refers to the Collective Performance Allowance (Asignación de Desempeño Colectivo, ADECO) based on the results of a specific project led by the leadership team. This bonus is different to the National System for Performance Evaluation (Sistema Nacional de Evaluación de Desempeño, SNED). 3. Colombia: Individual principals can receive one extra monthly salary per year pending performance on an education management indicator. Schools exceeding improvement thresholds and meeting their excellence target as defined by a quality index (Índice Sintético de Calidad Educativa, ISCE) receive a collective bonus. 4. Denmark: Salaries and their component parts are fixed in collective agreements.

5. Luxembourg: There are no school principal positions in primary education. School principal remuneration in secondary education is determined by seniority only.

6. Turkey: For ISCED 3, additional remuneration for school principals varies across seven school types.

Sources: OECD (2019), Education at a Glance 2019: OECD Indicators, OECD Publishing, Paris, https://doi.org/10.1787/f8d7880d-en, Table D3.11; European Commission/EACEA/Eurydice (2018) Teachers' and School Heads' Salaries and Allowances in Europe - 2016/17, https://eacea.ec.europa.eu/nationalpolicies/eurydice/publications en; Country Background Reports and Country Review Reports (http://www.oecd.org/education/school/school-resources-review-reports-participating-countries.htm).

In Austria, school principals are eligible to receive one-off bonuses for outstanding performance or their involvement in particularly successful projects (Bruneforth et al., 2016[99] $)$. Likewise, school founders in the Czech Republic may reward their school principals for outstanding performance with allowances or bonuses. The OECD review team noted, however, that evaluations of Czech principals typically focussed on the schools' financial management and budget discipline, while their educational quality often played a subordinate role at best (Shewbridge et al., 2016, p. 177 ${ }_{[20]}$ ). To recognise and reward principals' performance holistically, evaluations for performance-related bonuses would need to take into account not only their administrative, but also pedagogical leadership. 
Another critical condition for the success of performance-related pay for principals is to ensure that the process is transparent and perceived as a fair, positive encouragement by principals themselves. It is therefore essential to develop reliable indicators and clear assessment criteria, to prepare and train evaluators and to ensure that assessment procedures take into account the context in which principals are working. As with the performance-based compensation of teachers, incentives for school leaders can be provided at the individual or group level. Chile's Collective Performance Allowance system (Asignación de Desempeño Colectivo), for example, uses collective incentives to encourage collaboration and distributed leadership (see Box 2.4).

\section{Box 2.4. Group-based incentives for school leaders in Chile}

Based on the belief that good leadership is the product of organisational as well as individual qualities, the Collective Performance Allowance system (Asignación de Desempeño Colectivo) is designed to improve the practices and capacity of leadership teams and encourage school leaders to collaborate. By setting and evaluating collective objectives and targets, the system seeks to encourage school leaders' commitment to the improvement of teaching and learning in their school, and to facilitate and encourage successful collaboration among leadership teams. Participation in the Collective Performance Allowance process is voluntary for school leaders in all public and government-dependent private schools with at least 250 students. First implemented in 2005 , an increasing number of school leadership teams are taking part.

The Collective Performance Allowance system is built around the development of an institutional objective and two to four institutional targets that form the basis for an agreement of collective performance. The development of this agreement involves the distribution of related tasks and responsibilities between school principals and other technical-pedagogical school leaders. The institutional targets correspond to local contexts and priorities, but need to be linked to five areas of school leadership (leadership, curriculum management, school climate and support to students, financial management, and results). At least one of the institutional targets needs to be related to leadership or curriculum management, another to results.

To align the process with other measures for improving school leadership, the institutional objective and institutional targets need to be defined with reference to the Annual Development Plan of Municipal Education (Plan Anual de Desarrollo Educativo Municipal, PADEM) and the School Development Plan (Proyecto Educativo Institucional, PEI). Since 2016, the Ministry of Education provides templates for agreements (convenios tipos) to leadership teams. These templates are prepared based on current themes and ministerial regulations, which influence the approaches and tasks for leadership teams across the country.

Once a school leadership team has established an agreement of collective performance, it collaborates with the school provider to develop strategies to monitor the achievement of the objective, each of the targets and the related leadership practices and behaviours. The responsible provincial department of education (Departamento Provincial de Educación, DEPROV) then has to approve or revise the agreement to ensure that it complies with legislation and corresponds to national education goals. Once approved, the school leadership team presents the agreement, institutional objective and targets to the school community. 
The school provider assesses whether the institutional objective and each of the institutional targets have been met based on an implementation report and an evidence portfolio compiled by the school leadership team. The results are passed on to the provincial department of education for validation. School leadership teams that have attained a rating above $75 \%$ or $90 \%$ receive a financial allowance equivalent to $10 \%$ or $20 \%$ of the national minimum basic salary. The Chilean Ministry of Education can audit schools to ensure that they correctly implement the process.

Source: OECD (2013), Synergies for Better Learning: An International Perspective on Evaluation and Assessment, OECD Publishing, Paris, http://dx.doi.org/10.1787/9789264190658-en.

\subsubsection{Compensation of professional support, administrative and maintenance staff in schools}

Although - as discussed in Chapter 1 - professional support, administrative and maintenance staff play an important role in schools, there is no internationally comparable data on their remuneration. This may be because the employees conventionally subsumed under these categories perform a wide range of different roles and vary considerably with respect to their qualifications, salaries and employment contracts. Furthermore, unlike teachers' and principals' salaries, the remuneration of other school staff tends to be more heterogeneous and may not be regulated by national statutes or service codes.

Since many non-teaching employees schools (especially those in maintenance or operational roles, such as security guards, electricians, cooks, gardeners or drivers) could engage in comparable work outside the education sector, schools or local authorities may benefit from some flexibility in adjusting their salaries based on local labour market conditions. In the Czech Republic, for example, the OECD review team noted that salaries of operations staff were considerably higher in the capital and wealthier cities than in other regions, and that adapting the expenditure on technical staff to local labour market conditions could lead to a more efficient use of school funding. Whereas rich municipalities with higher local salaries may be unable to attract sufficient operations staff if they were obliged to remunerate them at the national average, poorer authorities could avoid excess spending by adjusting the salaries of their operations staff based on local market rates (Shewbridge et al., 2016, p. $119_{[20]}$ ).

Some professionals working in schools, such as psychologists, may also have a significantly higher earnings potential working in a private or clinical environment and face foregone earnings that schools are unlikely to match. This can create difficulties in attracting high-performing candidates to serve in these roles, which raises serious questions given the increasing commitment to strengthening socio-emotional and psychological support in schools.

\subsubsection{Implementing compensation reforms}

Adjusting salaries in the education sector can pose significant challenges related to the political economy of reform. Compensation reforms are prone to create uncertainty about the size and distribution of their benefits and are likely to face the resistance of those who stand to lose out, whether in absolute or relative terms. At the same time, given the collective bargaining arrangements governing educators' salaries and the well-organised, politically active unions in many OECD countries, the implementation of reforms is often impossible without the co-operation of teachers (Wurzburg, 2010 $0_{[100]}$ ). The complex and 
often divided governance arrangements underpinning staff salaries and related aspects of their careers (as discussed in the next paragraphs), further complicate the implementation of reforms since they may require multiple levels of government to act in concert.

In light of these challenges, as for the implementation of new school funding formulas (OECD, 2017, p. 122 ${ }_{[101]}$ ), the experience of OECD review countries highlights the importance of effectively managing these reform processes, having realistic expectations concerning the costs and challenges involved, and ensuring sufficient budgetary resources. Policy makers also need to bear in mind the inertia of reform processes and the significant amount of time that it can take for a change in teachers' career structures or compensation systems to reach all or even just a majority of the profession. In Austria, for example, the newly introduced qualification requirements and service codes are expected to take about 40 years to apply to all teachers (Nusche et al., 2016, p. 29[32]).

\section{Teacher and school leader salaries can be subject to complex governance arrangements}

The teacher labour market and its wage-setting institutions differ from traditional labour markets in that salaries are determined through a political process that may involve multiple levels of government and is frequently subject to collective bargaining agreements (Santiago, 2002, p. 67 $7_{[55]}$ ). The authorities responsible for deciding on the compensation of teachers and other school staff vary significantly across countries, which affects both the process of reform implementation and the strategies that might facilitate it. The level at which teachers' salaries are determined can also have implications for regional competition to attract high-performing teachers and their mobility across jurisdictions, which need to be borne in mind when implementing reforms. For example, in contrast to decentralised systems like the United States, where salaries are determined at the district level, in centralised systems, non-pecuniary factors may play a more important role for teachers' mobility and in addressing shortages (Falch and Strøm, 2005 [102] ).

On average across OECD countries, decisions concerning human resource management in schools are relatively evenly distributed across different levels of government (see Figure 2.5). While decisions on teachers' duties and working conditions are highly decentralised, only $16 \%$ of countries report that schools or local authorities are responsible for setting teachers' salaries and the majority vests this authority in the central or state level. Decisions concerning the salaries of principals - as for their hiring, duties and working conditions - are even more centralised, and largely rest with central or state authorities (OECD, 2018, pp. 413, Figure D6.3a[50]).

A complicating factor is that decisions on teachers' working conditions and salaries are often taken by more than one authority. Even in countries where a single level of government has the ultimate authority across all of these domains, they usually operate in consultation with or within frameworks set by at least one other level of administration. Under these circumstances, split responsibilities for some aspects of human resource management are inevitable. For example, in 11 of 41 OECD countries and economies with available data, multiple authorities are responsible for fixing teachers' and school leaders' salaries (OECD, 2018, pp. 417, Table D6.6a[50]). As with any domain of decision making that involves authorities from different levels of government, careful co-ordination is then essential to avoid misalignments that could undermine successful reform implementation. 


\section{Figure 2.5. Responsibilities for human resource management in public education (ISCED 2),} 2017

Percentage of decisions taken at each level of government

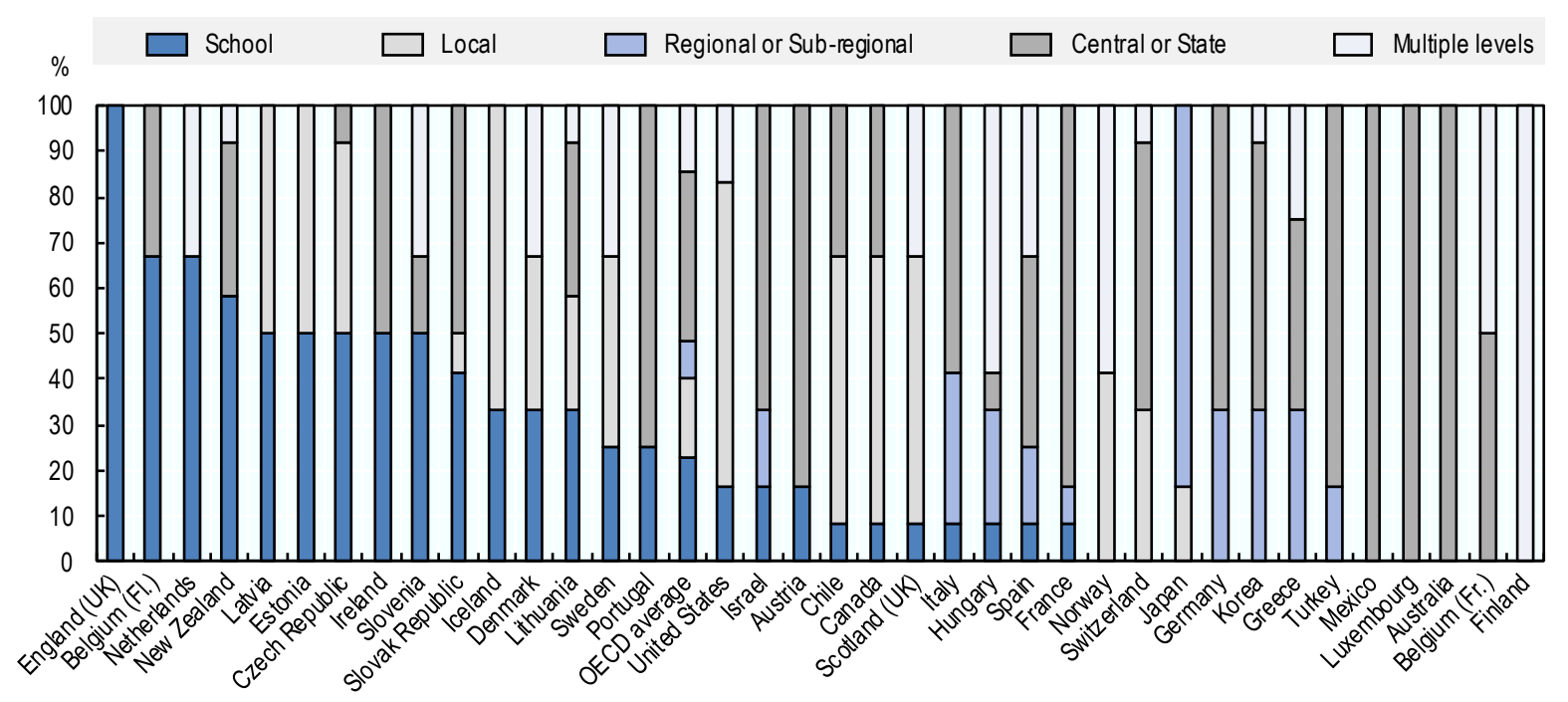

Notes: Countries and economies are ranked in descending order of the percentage of decisions about organisation of instruction taken at the school level. For a definition of levels of government, see the Glossary in Annex B.

Source: OECD (2018), Education at a Glance 2018: OECD Indicators, OECD Publishing, Paris, https://doi.org/10.1787/eag-2018-en, Table D6.2.

StatLink 세대 https://doi.org/10.1787/888934026373

\section{Ensuring stakeholder involvement and teachers' buy-in}

In many school systems, teachers' salaries are subject to collective bargaining agreements negotiated by teachers' unions, although the extent and mode of their engagement in the wider development of education policy varies significantly across countries. Teachers unions have occasionally been charged with impeding vital reforms in defence of vested interests and the empirical effects of unionisation on student learning have been positive in some contexts (Matsudaira and Patterson, 2017 [103]; Steelman, Powell and Carini, 2000 [104]) and negative in others (Kingdon and Teal, 2009 ${ }_{[105]}$; Eberts, 2007 $\left.{ }_{[106]}\right)$. Nevertheless, unions are generally recognised for their potential to play a significant role in the professionalisation of teaching and to act as constructive partners for educational improvement (Bruns and Luque, 2015 $5_{[107]}$; OECD, 2015 $5_{[108]}$ ).

In Chile, for example, negotiations between the government and the Colegio de Profesores - the country's main teacher union - have facilitated the passage and implementation of teacher evaluation and incentive systems. This was in part made possible by the union's adoption of a technical and proactive approach to policy making since the late 1990s. In turn, the government has involved the union in the design of teacher reforms, for example by creating a tripartite technical committee that provided a platform for the union, central and local education authorities to develop consensus positions (Gindin and Finger,

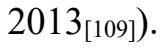


A country's institutional history and degree of corporatism can have profound implications for the implementation of human resource policies. Reforms in consensus-oriented systems with strong social partners, such as Austria, may be subject to prolonged decision-making processes and a larger number of potential veto players. On the other hand, they ensure that competing interests of relevant stakeholders balance each other out and preclude one particular set of organised interests from monopolising access to policy making. A strong role for intermediary actors, such as employers' associations, can also reduce administrations' problem of "information overload" by supplying decision makers with policy-relevant information on behalf of their constituents (Nusche et al., 2016, p. 22 [32]). Systems with less developed corporatist structures and more majoritarian traditions of decision making may require a very different approach to human resource policy reforms and a more proactive inclusion of stakeholders' views to foster ownership among the social partners and ensure that decisions are sustainable.

Engaging in an open dialogue with stakeholders and involving them in reform design and implementation processes are key principles of effective governance (Burns and Köster, $2016_{[110]}$; Viennet and Pont, 2017 $\left.[111]\right)$. These stakeholders include the relevant unions representing teachers in different sectors and at different levels of administration. To build and sustain trust for the implementation of reforms, they must be underpinned by clear communication, consensus building, and a process for prioritising competing claims on resources. Education authorities can facilitate this process by communicating their long-term vision and by enabling stakeholders to understand the educational rationale behind the proposed reform packages (Burns and Köster, 2016 ${ }_{[110]}$ ). Failing to effectively engage stakeholders in compensation reforms can come at a high cost and some OECD review countries have had to delay or abandon their projects in the face of stakeholders' resistance (Liebowitz et al., 2018 $\left.8_{[7]}\right)$.

\section{Providing fair arrangements for reform transition periods}

Reforms of teachers' salary scales are often part of larger adjustments to teacher service codes. Particularly where they involve amendments to the distribution of earnings over the course of the career or changes to the salary progression process, collective agreements may require governments to allow teachers who took up work prior to a given date to continue their career on the previous terms. The result is often a divided teaching profession that is subject to different working conditions for extended periods of time. Managing these transition periods in an equitable way can be a significant challenge.

In Austria, a new teacher service code introduced in September 2015 has compressed the slope of teachers' compensation structure to provide higher statutory starting salaries while roughly maintaining their lifetime earnings. The salaries of teachers who joined the profession under the old service code will not be affected and new teachers joining the profession until September 2019 have been given the choice between the old and the new salary structure (Nusche et al., 2016, p. 78[32]). During the review visit, teachers in Austria expressed concerns that the employment under different service codes and the differences in salaries and benefits associated with them might create tensions among colleagues that will negatively affect the school climate (Nusche et al., 2016, p. 160 [32]).

Similar challenges have been observed in Colombia since introducing a new employment framework and salary scale for public school teachers in 2002, which left the old system in place for all teachers recruited prior to this date. While salary increases under the new statute are conditional on teachers' performance, teachers under the old statute benefit from automatic salary progression. The resulting differences in employment conditions have 
occasionally placed a strain on the working climate and collegiality in schools, particularly since opportunities for salary progression under the new teacher statue have been restricted, causing a large share of teachers to remain on the first step of their respective scales. In addition, teachers working under the new statute are subject to annual evaluations by their school principals, which teachers under the old statute are not (Radinger et al., 2018, pp. $\left.25,241_{[8]}\right)$.

When Chile introduced a new salary and career structure from 2016, it addressed these challenges by re-assigning practicing teachers to those positions in the new structure that corresponded most closely to their current roles. All new teachers were assigned to the lowest stage, while current ones were designated a step based on their years of experience and their previous results in multiple teacher evaluation processes (Santiago et al., 2017, p. $\left.240_{[9]}\right)$.

\subsection{Working conditions in schools}

Working conditions in schools are usually understood to encompass the working environment and all circumstances that affect the daily work of teachers, leaders and other staff. This includes, but is not limited to, their working hours, the organisation of their work, health and safety at the workplace, and employer-employee relations ${ }^{3}$. Working conditions shape both the demands that school staff face in their jobs and the resources they have at their disposal to meet them.

Conducive conditions that enable school staff to work effectively are critical to support their students' success and can be an important lever to make schools more attractive places to work. Not surprisingly, the governance of working time, the organisation of administrative support and possibilities for involvement in school-level decision making played an important role for enhancing the individual and collective professional capacity of teachers and school leaders in many OECD review countries. Teachers' opportunities for professional learning - another central factor - are discussed in more detail in Chapter 4.

The pressures faced by teachers and school leaders in their daily work are well-documented, as are the prevalence and harmful impact of stress, exhaustion and burnout in schools (Viac and Fraser, forthcoming ${ }_{[12]}$; Hakanen, Bakker and Schaufeli, $\left.2006_{[113]}\right)$. Supporting staff in coping with these pressures by shaping their working conditions is therefore an important policy goal as highlighted in Chapter 1. While some aspects of teachers' and school leaders' working conditions are highly variable across schools - such as the quality of school facilities, the level of administrative support or the student population served - system-level policies can exert a significant influence on many of them. This includes setting standards for class sizes, the flexibility of working practices, the teaching load or professional development (Dolton, 2006 $[54]$ ).

Good working conditions are also thought to play an important role in attracting and retaining high-performing teachers. At the same time, some frequently discussed responses to staff shortages (such as increasing teachers' instruction hours or class sizes) might have a detrimental effect on working conditions. Potential trade-offs between the supply and retention of teachers, their effectiveness and working conditions are therefore highly relevant for policy makers (Santiago, 2002, p. 63 ${ }_{[55]}$ ). Nevertheless, robust evidence concerning the effect of working conditions on individual teacher supply decisions, motivation and attrition remains scarce and difficult to establish, not least since working conditions tend to be highly correlated with other school characteristics, such as their socio-economic composition (Horng, 2009 [114] ). 
According to PISA data, cross-country differences in working conditions (teaching load and class sizes) are not significantly associated with the proportion of 15-year-olds expecting to pursue a teaching career (Won Han, Borgonovi and Guerriero, 2018 ${ }_{[115]}$ ). Yet, practicing school teachers in a Europe-wide survey ranked improvements in working conditions and lower class sizes as one of the factors with the greatest potential to make the profession more attractive - after higher salaries and social status (European Commission, 2013 , p. $72_{[116]}$ ). Teachers' desire for good working conditions that allow them to focus on student learning was corroborated by the results of TALIS 2018. Across the OECD, $65 \%$ of teachers considered reducing class sizes to be highly important (compared to 64\% for improved salaries) and 55\% attached a high importance to reducing teachers' administration load (OECD, 2019, pp. 110, Figure I.3.16 $\left.{ }_{[1]}\right)$.

The degree of autonomy that teachers and school leaders have over their work mediates not only the subjective experience of their working conditions, but also shapes their professional identity and collective agency. Professional autonomy relates to the scope that individuals are given in deciding how to fulfil a specific set of tasks, but also their involvement in defining the parameters of their roles and the conditions they require to carry them out effectively.

Highly qualified teachers can be relied upon to exercise their professional judgement when tailoring their pedagogical approaches to their students' needs and to continuously improve their practice. Fostering trusting relationships that allow professionals to individually or collectively take control over their work can strengthen their motivation and self-efficacy, but also generate positive outcomes at the organisational level (Wrzesniewski and Dutton, $\left.2001_{[117]}\right)$. However, professional autonomy is no substitute for a supportive work environment. For autonomy to lead to positive results at both the school and classroom levels, certain conditions need to be in place, which will be discussed in the following sections.

\subsubsection{Teachers' working conditions, working time and teaching hours}

Teachers' work is highly complex and involves a great variety of responsibilities and activities that compete for their time during the school week (see Figure 2.6 and Chapter 1). In addition to regular classroom instruction, teachers are usually expected to spend time preparing their lessons, correcting students' work, collaborating with their peers, counselling students, communicating with parents and engaging in professional learning. They may also - sometimes on a voluntary basis - engage in mentoring or induction activities for new teachers, substitute for colleagues, contribute to school projects or the organisation of extracurricular activities and participate in school self-evaluation and improvement planning (OECD, 2019, p. $72 \mathrm{f}_{[[1]}$; OECD, 2014, p. 162 $\left.{ }_{[2]}\right)$. Ensuring that teachers are empowered and supported in pursuing all activities that form the basis of high-quality teaching is an important dimension of their professionalism and an important condition for schools' success. 
Figure 2.6. Teachers' working hours (ISCED 2), 2018

Average number of total 60-minute hours teachers report having worked during the most recent complete calendar week and estimated shares of individual tasks

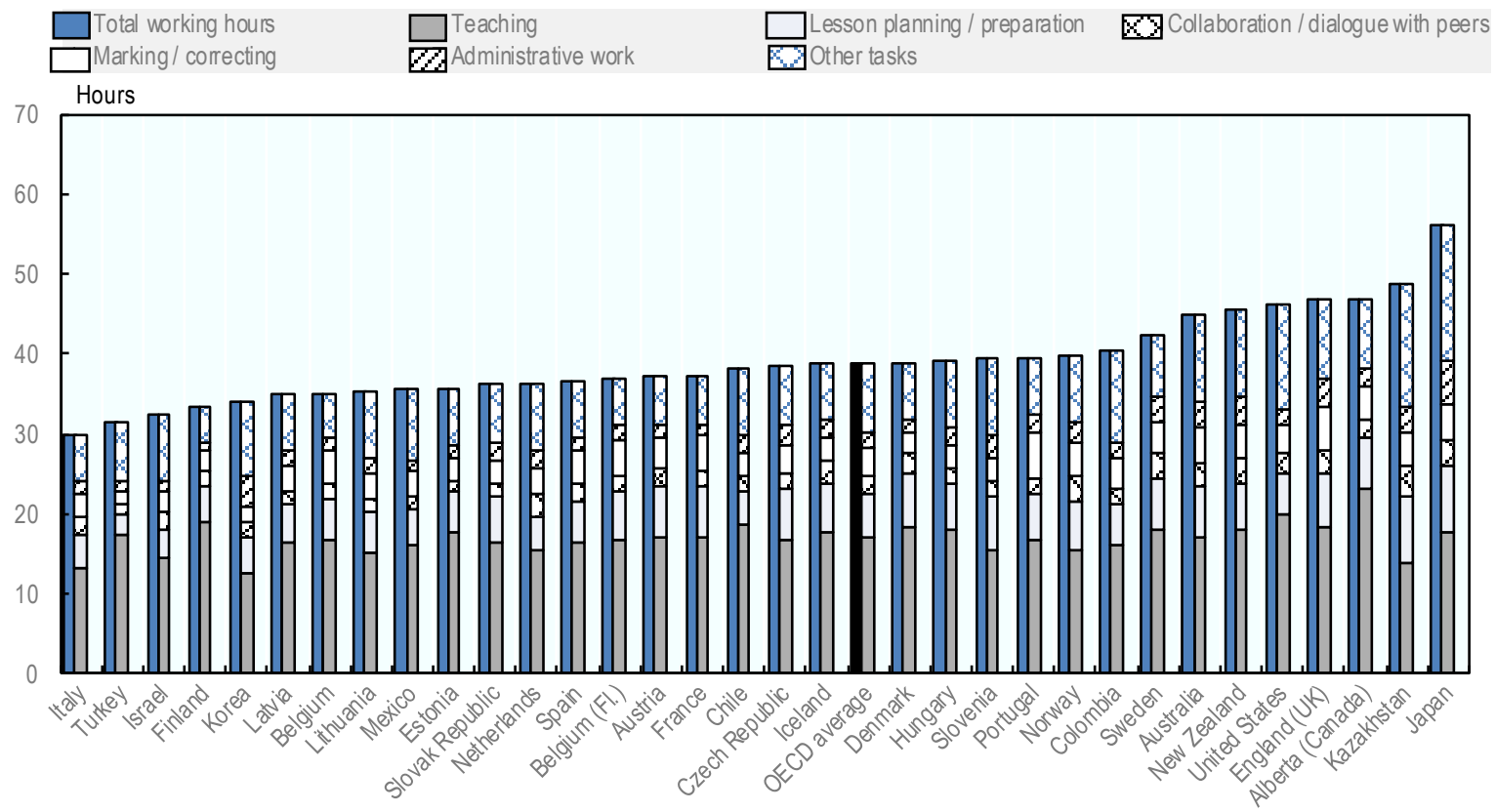

Notes: The reported times are national averages of all surveyed teachers, including part-time teachers. Time spent on individual tasks was proportionally adjusted to match total reported working hours; "Other tasks" include student counselling, participation in school management, professional development, engagement with parents and extracurricular activities; A "complete" calendar week is one that was not shortened by breaks, public holidays, sick leave, etc. Also included tasks that took place during weekends, evenings or other off-classroom hours.

Source: OECD (2019), TALIS 2018 Results (Volume I): Teachers and School Leaders as Lifelong Learners, OECD Publishing, Paris, https://doi.org/10.1787/1d0bc92a-en, Table I.2.27.

StatLink त्ञाI

The excessive working hours observed in some school systems point to the challenges in providing teachers with the time and space to fulfil their various individual and collective professional demands (see Figure 2.6). This is particularly concerning since insufficient recovery time during and after the school day can exacerbate the negative impact of work-related stress on teachers' health, long-term motivation and efficacy (Gluschkoff et al., 2016[118]). Developing frameworks for teachers' working time that prevent excessive workloads, that are aligned with the breadth of their professional roles and that enable schools to effectively manage the use of their staff time - individually and collectively while retaining teachers' autonomy is a critical challenge for any school system.

The relative amount of time that teachers dedicate to instruction, collaboration, administrative work and other tasks also varies considerably across countries. Some of this reflects different cultural traditions and conceptions of the teacher's pedagogical and professional role. Japanese schools, for example, emphasise teachers' involvement in certain non-instruction tasks (e.g. supervising children as they clean the school and or serve school lunches to classmates) as central to their pedagogical philosophy, which emphasises the cultivation of life competencies as part of a holistic education (OECD, 2018, p. 53 [119]). 
In some contexts, however, teachers feel that they lack the time to prepare lessons, collaborate with peers, reach out to parents or engage in professional learning due to excessive instruction hours, administrative tasks or accountability requirements. As discussed below, such imbalances in teachers' task profiles can have a variety of causes that countries may need to address to ensure that teachers can use their time effectively.

\section{Recognition of teachers' non-teaching tasks}

The tasks that teachers perform outside of the classroom are increasingly recognised as an integral part of their professional roles. Nevertheless, in many countries, teachers are left with too little time to prepare their lessons, collaborate with colleagues, and engage in peer observation or knowledge creation. While the reasons for these shortcomings are manifold and vary across systems (as elaborated below), adopting a conception of teachers' working time that accounts for their responsibilities both within and outside the classroom is an important precondition.

In many OECD school systems, service codes and other statutes that regulate how teachers spend their time are based on a narrow conception of the profession. They primarily regulate teaching hours, (i.e. the time teachers are expected to spend on classroom instruction) while only vaguely defining non-teaching time. According to information collected for OECD Education at a Glance, at least 20 of the 34 countries with available data for 2012, required lower secondary teachers to plan and prepare lessons, to engage in teamwork and peer exchange or communicate and co-operate with parents during their statutory working time. Around half of the countries also required teachers to mark or correct students' work, engage in general administrative communication and paperwork, and professional development activities (OECD, 2014 $\left.{ }_{[52]}\right)$. Nevertheless, although many OECD countries specify the non-teaching tasks required of teachers in their working conditions, most countries do not make explicit how many hours teachers should allocate for each or sum of these activities.

The teachers service code for Austrian federal schools does not specify an overall workload but, prior to the implementation of a new regulations in 2015 (see Box 2.5), merely provided them with a basic teaching assignment of 20 hours, weighted by the subjects they taught (Nusche et al., 2016, p. 151 $1_{[32]}$ ). In the Flemish Community of Belgium, regulations stipulate a minimum and maximum teaching load but do not specify teachers' overall working hours or the time they are expected to spend on non-teaching tasks, which are established by schools on an individual basis (Nusche et al., 2015, p. 142 [40]). Likewise, teachers' contracts in Uruguay are based exclusively on a stipulated number of teaching units. Even though the contracts in secondary education stipulate anywhere between 20 and 48 teaching hours, low salaries have compelled many teachers in Uruguay to supplement them with additional teaching hours in a second or third school, which leaves little room for non-teaching activities or professional learning (Santiago et al., 2016, p. 230 [41] $)$.

Failing to explicitly account for teachers' time spent on non-instruction tasks has a number of negative consequences for the effective use of their time and the status of the profession. On the one hand, it fails to provide any formal recognition for the important work that teachers perform outside of the classroom, which can have a detrimental effect on their motivation. On the other hand, it diminishes school leaders' capacity to plan their teachers' time based on a holistic conception of their tasks. Failing to account for teachers' non-teaching tasks can leave them with insufficient time to pursue these duties, which in turn has a negative impact on the quality of their teaching and their engagement with peers or the wider school community. 
To address these challenges, all factors contributing to teachers' workload - including their non-teaching obligations - should be taken into account when determining their teaching hours. This principle was already recognised in the 1966 ILO/UNESCO Recommendation concerning the Status of Teachers (ILO/UNESCO, 2016, pp. 36, $\S 90-93_{[120]}$ ). Reflecting the time teachers are expected to commit to non-instruction tasks in service codes and working regulations is an important step to align regulations with modern conceptions of teacher professionalism. Moving towards an employment framework that recognises teachers' entire workload can also provide a good basis for moving towards a greater diversity in teachers' roles and granting schools more flexibility in allocating individual teachers' time to instructional and non-instructional activities, depending on the functions they perform at the school.

Examples of workload-based conceptions of teachers' working time can be found in a number of OECD review countries, including Chile, Estonia, Lithuania and the Slovak Republic. There are different ways for introducing such employment systems (see Box 2.5 for examples). Some school systems specify nothing but the overall workload, leaving it to school principals to assign teachers' time across different kinds of activities. Others indicate the total number of hours or a proportion of teachers' time that should be dedicated to teaching and non-teaching activities (e.g. 60/40 or 75/25), or they might be even more prescriptive, stipulating guidelines or requirements for the weekly time to be spent on specific non-instruction tasks or categories of tasks.

\section{Box 2.5. Workload-based models of teacher working time}

\section{Shifting from employment based on teaching hours to a workload system in Estonia}

In 2013, teacher employment in Estonia was reformed based on the Working Time of Educational Staff Act. The reform marked a shift from a teaching load system - in which staff contracts only specified teaching hours - to a workload system that specifies the total number of working hours and defines the full range of tasks that teachers are expected to perform. The reform implicitly acknowledged 290 annual hours spent on non-teaching activities in pre-primary education, 921 in primary and lower secondary education and 972 in upper secondary education, yielding a total annual workload of 1610 statutory working hours in pre-primary education and 1540 hours in primary to upper secondary education (corresponding to 35 weekly hours). These overall working hours are below the OECD average, as were the teaching hours specified by the old system. Given that the new regulations no longer specify teaching hours, the distribution of teachers' overall workload across individual teaching and non-teaching tasks is at the discretion of the school management. In some cases, school leaders' decisions on the use of teachers' time are subject to political agreements at the municipal level or with a school's teacher council.

Source: Santiago, P., A. Levitas, P. Radó, C. Shewbridge (2016), OECD Reviews of School Resources: Estonia 2016, OECD Publishing, Paris, http://dx.doi.org/10.1787/9789264251731-en.

\section{Creating more time for non-teaching activities through a workload system in Chile}

Chilean teachers are employed on the basis of a workload system that stipulates their total working hours and the teaching and non-teaching activities they are expected to perform within this time. In 2014, teachers at all levels had 2006 annual working hours, of which $75 \%$ were designated to classroom activities, which constituted both a heavy workload and a high proportion of contact hours by international comparison. Motivated in part by a desire to ameliorate these working conditions, Chile introduced a new System for Teacher Professional Development in 2016. The new law initiated a reduction in the proportion of 
teaching time to $70 \%$ of the workload by 2017 and to $65 \%$ of the workload by 2019 . This provides teachers with more time to engage in non-teaching activities, fosters teachers' engagement in the school and provides greater opportunities for collaboration among peers since teachers are required to stay at the school during some of their non-instruction hours.

Source: Santiago, P., A. Fiszbein, S. Garçia, T. Radinger (2017), OECD Reviews of School Resources: Chile 2017, OECD Publishing, Paris, http://dx.doi.org/10.1787/9789264285637-en.

\section{Workload-based systems in provincial and federal schools in Austria}

In Austria, the workload of teachers in provincial schools is regulated to comprise 1736 hours of work per year for teachers aged 43 or older, and 1776 hours of work per year for all younger teachers. The annual standard is divided into three activity areas: teaching duty including supervision; preparation, follow-up and correction; and hours for other activities such as substitute teaching, class co-ordination, administrative tasks and school projects. Over one year, 720 to 792 hours, that is about 20 to 22 hours a week, have to be dedicated to direct teaching, 600 to 660 hours are foreseen for the planning and follow-up of lessons, and the remaining 324 to 456 hours of the annual standard are available for other activities. For all teachers, the task of student assessment is regulated and typically takes up a substantial amount of their teaching time. While no such workload system exists in federal schools yet, a new teacher service code (Dienstrechts-Novelle 2013 - Pädagogischer Dienst) implemented in 2015 has sought to harmonise the working time arrangements of federal school teachers with those in provincial schools. This included a slight increase in their teaching load from 20 to 24 units of 50 minutes per week and the specification that two of these need to be spent on non-instructional tasks, such as student counselling and mentoring new teachers, which had not previously been acknowledged.

Sources: Bruneforth, M. et al. (2016), OECD Review of Policies to Improve the Effectiveness of Resource Use in Schools, Country Background Report for Austria, Bundesministerium für Bildung und Frauen, Vienna; http://www.oecd.org/education/schoolresourcesreview.htm; Nusche, D., T. Radinger, M. R. Busemeyer, H. Theisens (2016), OECD Reviews of School Resources: Austria 2016, OECD Publishing, Paris, http://dx.doi.org/10.1787/9789264256729-en.

Of course, other obstacles besides a lack of official recognition, may impede teachers from using their non-teaching time effectively to engage in collaboration and the preparation of lessons. In Uruguay's general and technical-professional secondary schools, for example, teachers' working time includes a number of hours for non-instructional activities. Given that many teachers are required to work in multiple schools, though, teachers' ability to make use of this time to collaborate with other teachers or participate in co-ordination meetings is significantly diminished (Santiago et al., 2016, p. 187 ${ }_{[41]}$ ).

\section{Scope for teaching load adjustments}

Some countries allow statutory teaching hours to be adjusted to reflect teachers' other commitments, their experience, their effectiveness or the subjects they teach. At the time of the OECD review in 2015, for example, Austrian federal schools adjusted their teachers' basic instruction time of 20 hours depending on the subjects taught (e.g. German language instruction receives a higher weighting than physical education, resulting in a range of about 17 to 21 teaching hours) and the fulfilment of additional responsibilities, such as managing the school library or providing administrative support for the principal (Nusche et al., 2016, p. 151 $1_{[32]}$ ). Since 2019, all new teachers entering Austrian federal or provincial schools are expected to teach 22 hours per week, regardless of their subjects, and to spend an additional two hours on mentoring and counselling or some form of leadership activities 
(with the exception of upper secondary core subject teachers, who are expected to teach only 20 hours).

Of the 39 OECD members and review countries with available data for OECD Education at a Glance 2019, only a few reported to adjust teachers' instruction hours to incentivise their engagement in non-teaching tasks. In Denmark instruction hours are lower for teachers who take on additional school management activities and those who teach students with special educational needs (SEN). In Slovenia, teachers benefited from reduced instruction hours for serving as class teachers and, at the upper secondary level, for engaging in management activities. In the Slovak Republic, instruction hours were reduced

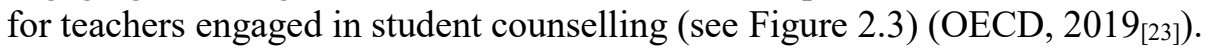

Teaching loads can also be adjusted to respond to teachers' changing capacity and needs over the course of their career. Beginning teachers, for example, tend to report lower levels of self-efficacy and effectiveness in the classroom, are at the highest risk of leaving the profession, and tend to be assigned to more challenging schools (OECD, 2019, p. $39_{[1]}$; Jensen et al., 2012[31]). Reducing novice teachers' teaching load could help them to focus on developing their teaching skills at the beginning of their careers, while experienced or highly effective teachers might cope more easily with additional instruction hours or larger, more challenging classes. Other strategies, such as team teaching, could allow effective teachers to share responsibility for the quality of a less experienced teacher in exchange, for example, for a reduced administrative workload (Jensen et al., 2012, p. 110[31]).

Despite the various ways in which teaching load adjustments could improve a school's effectiveness, teachers' working time and how they are expected to use it changes remarkably little over the course of their careers. According to TALIS 2018 data, for example, most OECD countries do not adapt the teaching load of novice teachers in any meaningful way to reflect their lack of experience and their potentially greater need for professional development. On average across the OECD, novice teachers report having about the same number of teaching hours as their more experienced peers, even though teachers' effectiveness is known to increase markedly during the first years on the job (Kraft and Papay, 2014 ${ }_{[121]}$ ). In ten countries and economies, novice teachers reported a higher teaching load and although the opposite pattern can be observed in 18 systems, there are only six countries and economies in which novice teachers have to teach at least two hours less than their experienced peers (OECD, 2019, pp. 208, Table I.4.57 $7_{[1]}$ ).

Some OECD review countries adjust teachers' instruction hours towards the end of their careers. For example, while novice teachers in Portugal benefit from reduced teaching hours, the same is true for senior primary school teachers who benefit from a reduction of five teaching hours at the age of 60 and the completion of 25 years of full service. Those in secondary education receive a reduction of two hours at the age of 50 (and 15 years of service), another two at the age of 55 (and 20 years of service), and another four hours at the age of 60 (and 25 years of service). Although their overall working hours remain unchanged, they are not required, for example, to use this additional time to support less experienced peers (Liebowitz et al., 2018 $8_{[7]}$ ).

OECD review countries also assign varying degrees of responsibility to school leaders in adjusting individual teachers' teaching load and assigning non-instructional tasks and responsibilities. In theory, greater flexibility in the allocation of teaching hours could allow for a more efficient management of teachers' time by adapting it to the learning needs of their students as well as the competencies, strengths, weaknesses and learning needs of staff. Whether or not expanding school leaders' scope for adjustments would lead to a more efficient allocation of tasks and responsibilities in practice depends on a range of factors, 
including the ability of school leaders to recognise teachers' needs and potential and to work with them to address students' needs. In any case, translating this flexibility into practical improvements can take time and requires strong leadership.

In 2013, Denmark passed new legislation (Act no. 409) which gave school leaders greater scope in determining the use of teachers' working hours. While agreements had regulated the amount of teaching hours and given every teacher a dedicated amount of preparation time for each class they taught (regardless of their subjects or experience) prior to this, the new framework enabled school leaders to, for example, assign more teaching hours to experienced teachers or reduce their contact hours with students to let them support newly qualified colleagues in their school or collaborate with peers on their areas of expertise.

While the new regulations established the necessary conditions for managing teachers' time more efficiently, the OECD review team noted that not all school principals were prepared to make the most of it. Many school leaders lacked examples of effective ways to allocate the working and teaching hours of their workforce based on the needs of teachers and students and reported a lack of capacity to evaluate the effectiveness of their interventions (Nusche et al., 2016, pp. 52, 147, 169 $9_{[15]}$ ).

At the same time, the new framework has prompted some concerns since it has not only led to a redistribution of instruction hours across teachers, but also their overall increase by an average of two hours per week. To balance teaching and non-teaching hours and ensure that the overall workload system supports rather than restricts teachers' work outside the classroom, many Danish municipalities have therefore introduced upper limits for teachers' weekly instruction hours (Nusche et al., 2016, p. 52 $2_{[15])}$.

\section{Accountability and presence at school}

In many OECD review countries, teachers have traditionally enjoyed a high degree of autonomy over the use of their non-teaching time, deciding not only how, but also where to spend it. Many school systems thus do not prescribe whether teachers should spend any of their non-teaching time at school, leaving it to them to work from home. This is the case in Austria, for example, where the teacher service codes do not regulate the hours that teachers are expected to be present at school (Nusche et al., 2016, p. 151 ${ }_{[32]}$ ). By contrast, full-time teachers in Colombia are required to spend at least six of their eight daily working hours on school premises (Radinger et al., 2018, p. $235_{[8]}$ ), whereas teachers at the pre-primary and primary level in the Flemish Community of Belgium, are required to spend a certain amount of time at the school, but only marginally more than their teaching hours (Nusche et al., 2015, p. 143 [40]).

Where national service codes do not prescribe the amount of on-site presence or the tasks that teachers are expected to perform in their non-instruction time, doing so may be at the discretion of school leaders, as is the case in Flemish secondary schools (Nusche et al., 2015 , p. $143_{[40]}$ ). Yet, principals' leverage over their teachers' presence in schools may be limited. Even though Portuguese teachers are normally expected to devote about ten hours of their weekly non-teaching time to tasks like grading assignments, contacting families and planning lessons at school, their principals can only define the content of up to 2.5 of these hours (Liebowitz et al., 2018 $8_{[7]}$ ).

In 2018, more than half of OECD countries and economies with available data specified the overall amount of time that primary and secondary teachers are required to be available at school. The differences between teachers' statutory teaching hours, their overall working time and the hours to be spent at school provide some indication of where teachers are 
expected to work when not teaching and reveal large differences across countries. In general programmes at the lower secondary level, official regulations suggest that teachers are expected to spend at least 500 hours a year performing non-teaching duties on school premises in Chile, Greece, Hungary, Iceland and Norway and at least 300 hours a year in Canada, Colombia, Israel, New Zealand, Spain, Turkey and the United States. However, in almost half of the countries, central regulations do not mandate teachers to spend any at school beyond their teaching hours, or relatively little (e.g. 85 hours in Ireland and 30 hours in Latvia) (OECD, 2019, pp. 427, Table 4.1b $b_{[23]}$ ).

Teachers' shared presence in schools can make it easier for them to engage in informal professional exchange, observe each other's practice, collaborate on projects, engage in collective knowledge creation, and innovate (Paniagua and Istance, 2018 [122] $_{\text {). According }}$ to TALIS results, having a collaborative culture within the school, the use of team teaching, peer observation and feedback, and collaborative professional learning, are also some of the factors that show the strongest association with teachers' self-efficacy and job satisfaction (OECD, 2014, pp. 424 f., Tables 7.16 and 7.17 $[2]$ ). Yet, not all schools provide teachers with physical spaces to work with colleagues, and opportunities for interaction among peers are often limited in practice due to a lack of shared non-teaching time at school.

In order to facilitate teachers' collaboration and increase accountability around their non-instruction time, countries like Denmark have taken steps to increase teachers' presence at school beyond their teaching hours. Following the passage of the above-mentioned legislation that afforded greater flexibility in the organisation of teachers' time (Act no. 409) in 2013, more than half of Danish municipalities introduced attendance requirements that demand teachers to be present at school for a certain duration of the day, irrespective of their number of teaching hours (Nusche et al., 2016, p. $52_{[15]}$ ).

Of course, building a collaborative culture in schools requires more than teachers' shared presence and attempts to impose professional collaboration may be counter-productive and poorly received by teachers. Conversely, teachers who perceive their school's atmosphere to be collegial and conducive to their professional learning may spend more time on the school premises of their own volition. As discussed in more detail in Chapter 4, the importance of ensuring that teachers can spend time together at the school therefore needs to be balanced against the risk of imposing collegiality or crowding teachers' agenda with time requirements that might inhibit bottom-up professional initiatives and true collaboration (Schleicher, 2018, p. 88 ${ }_{[66]}$ ). The strong resistance experienced in Denmark demonstrates that changes to teachers' working hours can be seen as an infringement on their autonomy and it underlines the importance of ensuring buy-in from teachers and stakeholder support (Nusche et al., 2016, p. 52 [15]).

\section{Professional autonomy and self-governance}

An extensive body of research points to professional autonomy as a key dimension of job characteristics that affect workers' sense of self-efficacy, their satisfaction and intrinsic motivation (OECD, 2013 [123]; Hackman and Oldham, 1976 $\left.{ }_{[124]}\right)$. Conversely, a desire for autonomy is driving many professionals to engage in an ongoing process of reinterpreting and reshaping the tasks, meanings and relationships associated with their jobs (Wrzesniewski and Dutton, $2001_{[117]}$ ). In this context, the organisational factors that shape teachers' control over their working conditions may have a significant bearing on their professional efficacy, job satisfaction and well-being. Teachers' autonomy in the classroom, i.e. the extent to which they are entrusted with exercising professional 
judgement over curricular choices, instructional planning and classroom practices is a central component of professionalism (OECD, 2016, p. $\left.33_{[125]}\right)$. It has also been shown to affect turnover rates among some groups of teachers (Ingersoll and May, 2012 [126]).

Multiple OECD review countries provide teachers and school leaders with considerable professional autonomy. In the Czech Republic, for example, schools and teachers are given significant flexibility in designing and adapting school-level curricula based on a set of broad national education objectives. In addition, teachers have a high level of autonomy in their choice of adequate pedagogical methods and educational materials. This provides a strong foundation for teacher professionalism and reflects the Czech Republic's high level of trust in teachers' professional judgement and their ability to tailor teaching practices to students' needs (Shewbridge et al., 2016, p. 143[20]).

Of course, greater classroom autonomy needs to be complemented by adequate support and collective capacity to enable teachers to make effective use of this autonomy. In the Czech Republic, for example, school-level co-ordinators provide advice on the development of local curricula and teachers can rely on assistants to help them, for example with non-teaching tasks or in supporting students with special needs (Shewbridge et al., 2016 , p. $\left.165_{[20]}\right)$. Other important conditions for effective teacher autonomy are sufficient opportunities for professional exchange, regular feedback, mentoring and professional learning (see Chapter 4).

Teachers' involvement in decision-making processes that affect their work is another significant dimension of their autonomy. The degree of staff involvement in school-level decisions plays a critical role in strengthening teachers' professionalism (OECD, 2016, p. $34_{[125]}$ ). It can provide a means for schools to mobilise leadership capacity at all levels and offers teachers an opportunity to communicate their needs while also assuming collective responsibility for their school's improvement. As discussed above, establishing roles that allow teachers to take on leadership tasks allows schools to draw on their growing expertise while at the same time providing attractive opportunities for professional growth within the teaching career.

Beyond the permanent assumption of leadership roles, there are many ways in which teachers can play a role in school management, either as individuals or collectively. These practices are not always formalised and their prevalence varies significantly both across and within countries. In most OECD systems, however, the majority of principals surveyed in PISA 2012 reported that they provide their teachers with regular opportunities to make decisions on school practices between once a month and once a week. By contrast, teachers' opportunities to engage in reviewing their schools' management practices was a lot more variable across OECD countries and, on average, $50 \%$ of principals reported this to happen never or only once or twice a year (OECD, 2013, pp. 396, Table IV.4.8[127]).

The TALIS 2013 survey conceptualised teachers' decision-making autonomy to include their involvement in decisions concerning five domains: content, course offerings, discipline practices, assessment and materials (OECD, 2016, p. $55_{[125]}$ ). The average number of decision-making domains that principals reported their teachers to be significantly involved in ranged from a high of 4.1 to a low of 0.9 across TALIS countries. However, the number of domains that teachers are reported to be involved in did not appear to have a strong relationship with teachers' predicted satisfaction, their perceived professional status, their satisfaction with the work environment or their self-efficacy (OECD, 2016, p. 55 $5_{[125]}$ ). 
This seeming lack of association may reflect differences between principals' and teachers' perception of their opportunities to be involved in school management. The experience of the OECD reviews also suggests, however, that teachers' involvement cannot be reduced to a simple binary and that the quality and type of involvement determines its potential for strengthening collective professional capacity and improving students' learning in school.

In Colombia, for example, the OECD review team observed a range of ways in which teachers are given a say in their schools' governance, but also in the development of their profession and education policy more widely. Within the school, teachers have a prominent role in decision making through their participation in the governing board (consejo directivo) and the academic council (consejo académico), which are responsible for the organisation, pedagogical orientation, implementation and continuous improvement of the school curriculum and study plan (Radinger et al., 2018 $8_{[8]}$ ). Similar teacher bodies exist in the schools of a range of OECD review countries, including the Czech Republic, Estonia, Portugal, the Slovak Republic and Spain.

In Colombia, the school calendar furthermore includes five annual weeks dedicated to institutional development, during which teachers work on the school's educational project (Proyecto Educativo Institucional), its study plan, pedagogical developments, self-evaluation, and partnerships with other institutions (Radinger et al., 2018, p. $245 \mathrm{f}_{\text {[8] }}$ ).

Teachers' involvement in educational governance at the school level can also feed into the formulation and implementation of education policy at higher levels of administration, complementing the critical roles that teacher unions and professional bodies, such as teacher or school leadership councils, often play in this processes. In Uruguay, for example, schools are required to organise two Teachers Technical Assemblies (Asambleas Técnico Docentes) a year, which serve as a platform for teachers to consult their school leadership and to voice their views on national policy initiatives (Santiago et al., 2016, p. 174 ${ }_{[41]}$ ).

\subsubsection{School leaders' working conditions, task profiles and time use}

The tasks and responsibilities associated with school leadership roles and positions vary across OECD countries and, to some extent, among schools within them. Yet, it is widely acknowledged that the role of principals has expanded and become increasingly complex. In many systems, this is reflected in a high workload (Pont, Nusche and Moorman, $2008_{[27]}$ ). Survey data from the United States, for example, suggest that principals spend on average 60 hours per week on school-related activities (Mitani, 2018, p. 841 ${ }_{[128]}$ ) and that as few as $4 \%$ of principals work 40 hours a week or less (Yan, 2019 $9_{[129]}$ ).

Besides their formal responsibilities, a range of factors related to principals' working conditions can moderate their task profile, workload and ability to live up to the demands placed upon them. These include the support they receive from the education administration, administrative staff and middle management within their school, and networks that connect them with peers, but also their individual skills and preparation.

\section{School leaders' task profile and autonomy}

School leaders typically function as the supervisors for all school staff, including teachers, advising them on their teaching and pedagogical work and monitoring their instruction and students' achievement. They are also responsible for liaising between the school, its students, their parents, the school partners and the wider community, and for implementing the decisions adopted by school boards as well as laws and directives issued by education 
authorities. In addition, they are held accountable for and may be expected to report data on various aspects of the school's conditions to the responsible authorities.

The task profile of school leaders differs markedly when it comes to their pedagogical, organisational, staff and financial responsibilities, depending on the schools' curricular autonomy and their scope to manage their own budget and recruit staff for their school. The extent of school leaders' autonomy is an important dimension of their working conditions. Sufficient levels of autonomy for school leaders can enhance their ability to engage in pedagogical leadership while control over resource allocation decisions can have positive effects on student outcomes in specific contexts (Hanushek, Link and Woessmann, $2013_{[130]}$ ), provided that principals possess sufficient managerial and leadership capacity and adequate accountability and support mechanisms are in place.

In some OECD review countries, principals are entrusted with little formal power to engage in autonomous decisions (Santiago et al., 2016 $[41]$ ). For example, in systems with centralised processes for the selection and distribution of teachers, school leaders' contribution to the hiring process may be limited to submitting estimates of their demand for human resources, serving in an advisory capacity or exercising the right to veto proposed appointments (see Chapter 3).

Limiting the scope of school leaders' decision-making authority can be a pragmatic response to limited leadership capacity and resources. On average across the OECD, school principals report spending $30 \%$ of their time on administrative tasks or meetings and a shortage of time for instructional leadership was among the most frequently cited resource issues hindering quality instruction among school leaders participating in TALIS 2018 (OECD, 2019, pp. 109, Figure I.3.15 [1] ).

In some OECD school systems, principals - especially in smaller schools - may have a substantial teaching load or lack administrative support and middle leadership staff. Local or central authorities may therefore seek to reduce their administrative burden and allow principals to focus on other areas of work by retaining certain responsibilities, e.g. related to budgeting and accounting (OECD, 2017 $\left.7_{[101]}\right)$. It must be borne in mind, however, that school leaders' limited autonomy or a lack of support to exercise it effectively reduces their ability to align budget allocations and operations with their schools' pedagogical needs and may also render a leadership career less attractive to some candidates.

\section{School leaders' use of time}

In addition to the various dimensions of leadership and conflicting demands placed on school leaders' time, additional external responsibilities can limit the time that principals have at their disposal to engage in the management and improvement of their schools. Not all school leaders, for example, are exempt from teaching duties and although countries such as Austria have lifted teaching requirements for most school leaders, they remain in place in small and very small schools (Nusche et al., 2016, p. 157[32]). Principals' involvement in regular instruction activities can take away time from other tasks, notably organisational management activities (such as managing budgets and staff and hiring personnel), which studies of principals in the United States have shown to be associated with positive school outcomes (Horng, Klasik and Loeb, 2010 [131]).

In other OECD review countries, like Uruguay, low salaries have created incentives for school leaders to take on additional roles in private schools, teacher education institutions, or adult education to supplement their income, diminishing the time and energy they can devote to effectively run their schools (Santiago et al., 2016, p. 184 ${ }_{[41]}$ ). In situations like 
these, an adequate level of remuneration combined with effective accountability systems around school leaders' use of time may help to ensure that they commit sufficient time and energy to the management of their schools.

Even where principals can dedicate themselves exclusively to their leadership role, there is considerable variation in the way they organise their time and disagreement over the kinds of activities that they should prioritise. One of the many trade-offs principals face is the question how to divide their time among tasks associated with administrative, organisational and pedagogical leadership. Studies drawing on time-use data collected by trained observers in the United States find that while principals' overall time invested in instruction-related activities does not predict their students' achievement growth, some forms of pedagogical leadership are more effective than others. The time principals spend on teacher coaching, evaluation, and developing the school's educational program, for example, was associated with achievement gains, while the time they spent on informal classroom walkthroughs had a negative impact - possibly because they tended not to be integrated in the schools' broader school improvement strategy (Grissom, Loeb and Master, $\left.2013_{[132]}\right)$.

Considering the intense demands placed on school leaders' schedules, their effectiveness depends on an ability to prioritise and manage their time efficiently, which may include identifying priorities, remaining organised, setting achievable goals and monitoring one's progress towards them. In a study of a large school district in the United States, principals with stronger time-management skills reported lower levels of stress and appeared to be better at prioritising tasks that they considered to be of high priority, particularly instructional leadership. Principals' time-management skills were also associated with the positive evaluation of their job effectiveness by assistant principals and teachers at the upper secondary level, although not at the lower secondary and primary levels (Grissom, Loeb and Mitani, 2015 $\left.{ }_{[133]}\right)$. Since time-management skills are comparatively easy to impart, the study's authors conclude that offering training to principals could be an effective means to increase their time spent on high-priority tasks and reduce stress. A precondition for this is to build a shared understanding of priorities for principals to spend their time on, for example through a set of school leadership standards, jointly developed with the profession.

Although the general effect of workplace stress on performance and other outcomes, such as turnover, is well-documented (Jamal, $1984_{[134]}$ ), relatively little is known about the specific ways in which intensified work demands and stress affect principals' ability to engage in administrative and pedagogical leadership, as well as their relationships with teachers. The few studies investigating the impact of principals' working conditions on turnover rates have failed to established consistent effects and suffered from data limitations, such as the inability to distinguish between principals' voluntary departure and their dismissal due to under-performance (Yan, 2019 ${ }_{[129]}$ ).

Investigating the potential negative consequences of principals' workload and strategies to address them therefore remains a priority. This is particularly critical at a time when some OECD school systems are looking for ways to increase school-level accountability (OECD, 2013 $3_{[3]}$ ), since sanction systems (such as those introduced under the No Child Left Behind Act in the United States) are likely to further intensify the pressures experienced by principals (Mitani, 2018 ${ }_{[128]}$ ). 


\subsubsection{Administrative tasks and support}

Teachers' work is associated with a range of administrative tasks, both inside and outside of the classroom. On average across the OECD, teachers report spending 2.7 hours per week engaging in general administrative work. This includes various forms of communication, paperwork and other clerical duties, for example keeping systematic minutes of meetings, documenting their year planning, or justifying decisions they take in writing (e.g. to fail a student or take specific remedial measures). In addition, teachers report spending $8 \%$ of an average lesson on administrative tasks (e.g. recording students' attendance) (OECD, 2019, pp. 205, Tables I.2.27 and I.2.10[1]).

Countries differ not only with regard to the administrative requirements that schools are expected to fulfil, but also in the extent to which these duties are shared between teachers and administrative staff. Receptionists, secretaries, bookkeepers and clerks can assume various secretarial and logistical tasks to enable teachers and school leaders to focus on their core pedagogical responsibilities. In addition, professional pedagogical support staff or teacher aides may assume administrative tasks that other systems consider to be the responsibility of teachers (also see Chapter 3).

Regardless of these differences, the management of administrative tasks and support is an important concern for teachers across OECD review countries. Administrative overload is frequently cited as a source of frustration among teachers and one of the factors that reduce the attractiveness of their profession (Nusche et al., 2015, p. 151 ${ }_{[40]}$ ). Not surprisingly, on average $55 \%$ of teachers in OECD countries said that reducing the administrative workload was of high importance when asked for their spending priorities in TALIS 2018. In 24 of the 48 participating countries and economies, teachers ranked "reducing teachers' administration load by recruiting more support staff" as one of their top three priorities (OECD, 2019, pp. 110, Table I.3.66[1]).

The inadequate organisation and distribution of administrative work can also be a significant source of inefficiency. In some countries, such as Austria, for example, the OECD review team observed that many teachers have to assume a significant share of logistical and secretarial tasks due to a lack of sufficient administrative support - sometimes in return for a reduced teaching load. This not only reduces the time that they can spend on instruction and the preparation or follow-up of classes, it is also inefficient, given that teachers' time tends to be more highly remunerated than that of administrative staff (Nusche et al., 2016, p. 171 [32]).

In other cases, for example in primary schools of the Flemish Community of Belgium, similar challenges have been observed for school leaders, many of whom reported that they lacked the time to engage in teacher appraisal and coaching due to their administrative workload (Nusche et al., 2015, p. 164 [40] $)$. The distribution of administrative tasks among teachers has also been a cause for concern in some OECD review countries, since novice teachers have been reported to be disproportionately burdened with these duties (Nusche et al., 2016, p. 171 $\left.1_{[32]}\right)$.

The causes of administrative overload can be complex and vary across contexts. In some cases, excessive administrative requirements may be at the heart of teachers' administrative burden and technological solutions, such as advanced data management systems, can undoubtedly play a role in alleviating them in some cases. Nevertheless, the mix of staff in schools and the distribution of responsibilities among them tends to be at the forefront of both practitioners and policy makers' concerns when it comes to teachers' administrative work (see Chapters 1 and 3). Across the OECD countries and economies participating in 
TALIS 2018, for example, a lack of support personnel remains the resource shortage most frequently reported by principals (OECD, 2019, pp. 109, Table I.3.63 $\left.{ }_{[1]}\right)$.

The way in which teachers and school leaders are supported in their work varies significantly across OECD school systems (see Figure 2.7 and Chapter 3). According to lower secondary principals' reports, there are on average seven teachers for each administrative or managerial school staff member across the OECD, but the ratio ranges from as little as 3 in New Zealand to 20 in Austria. Between 2013 and 2018, this ratio has remained relatively stable across TALIS countries (see Chapter 1). Some school systems, such as Iceland and Sweden, appear to compensate for a relatively small number of administrative staff by employing a greater number of other pedagogical support personnel (including teacher aides and other non-teaching instruction support staff, curriculum specialists, educational media specialists, psychologists or nurses), while other OECD systems, such as Austria and the Flemish Community of Belgium, provide teachers with little of both (OECD, 2019, pp. 207, Table I.3.74.[1]).

Different strategies have been invoked to alleviate teachers' administrative workload and to help them focus on their core pedagogical work, notably increasing the administrative support for schools and using existing support staff more effectively. Austria, for example, encourages groups of schools within a region to share their support staff (e.g. to provide IT support) and in some cases redeployed civil servants who had become redundant in other public services to provide administrative support to schools (Nusche et al., 2016, p. 172 [32]). Yet, the marginal impact and effectiveness of hiring more staff to support teachers in their administrative duties is contested.

Across countries, there is no statistically significant association between the average proportion of teachers' working time devoted to general administrative tasks and the number of administrative and managerial staff per teacher employed in their schools (see Figure 2.7). In some of the systems with the most administrative support staff, such as Korea and England (United Kingdom), teachers devote the largest share of their working time to administrative tasks. By contrast, in countries like Finland and the Flemish Community of Belgium, teachers perform considerably less administrative work despite a small number of administrative and management support staff. A similar pattern holds for pedagogical support personnel, whose number is not related to the time teachers report spending on administrative tasks over the course of the week or during lessons (OECD, 2019, pp. 207, Table I.3.74 and authors' analysis $\left.{ }_{[1]}\right)$. 
Figure 2.7. Teachers' administrative work and support (ISCED 2), 2018

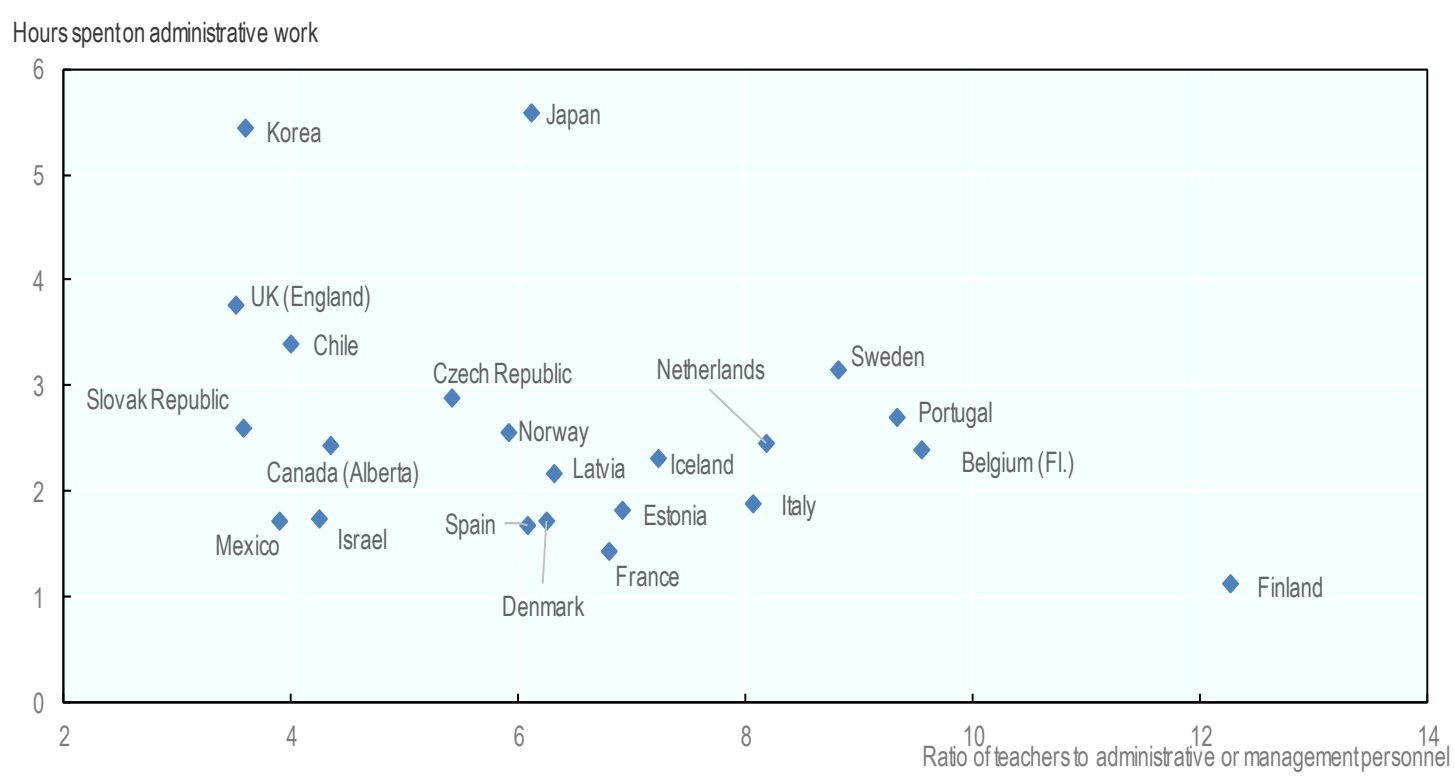

Note: School administrative personnel include receptionists, secretaries and administration assistants; while management personnel include principals, assistant principals, and other management staff whose main activity is management.

Source: OECD (2019), TALIS 2018 Results (Volume I): Teachers and School Leaders as Lifelong Learners, OECD Publishing, Paris, https://doi.org/10.1787/1d0bc92a-en, Tables I.3.74 and I.2.30.

StatLink 제은 https://doi.org/10.1787/888934026411

Although the international comparison suggests that the employment of support staff might neither be sufficient nor necessary to ease teachers' administrative burden, the country-level data need to be interpreted with care. School systems differ with respect to the administrative duties that teachers are expected to fulfil and other factors that may mediate the observed relationship, such as the average school size. Nevertheless, some national evidence at the school level has corroborated that more administrative staff may not be correlated with lower workload. Across schools in England (United Kingdom), for example, the time teachers spent on administrative work was unrelated to both the number of classroom assistants and the ratio of administrative and managerial staff to teachers in 2013 (Sellen, 2016 ${ }_{[135]}$ ). The relationship was equally non-significant in 40 of the 49 OECD countries and economies in TALIS 2018 with available data (authors' analysis).

Previously, starting in 2003, England had undertaken a large workforce remodelling reform, which included expanding the number and administrative responsibilities of teaching assistants with the aim to ease teachers' workload and permit them to spend more time on pedagogical tasks like planning, preparation and assessment. Despite the reform's high cost of implementation, evaluations showed mixed results, highlighting the reform's negative impact on the working conditions of support staff, its minimal impact on the time teachers spend on administrative tasks, as well as difficulties in delineating the tasks that should be transferred from those that teachers should retain (i.e. those that require their professional skills and judgement) and the transaction costs involved (Hutchings et al., $\left.2009_{[136]}\right)$. 
Since then, between 2013 and 2015, England significantly reduced its use of pedagogical support personnel. By 2018, England was the only TALIS country with available data to report a significant reduction in the level of administrative support, from 4.1 teachers per pedagogical support staff in 2013 (the second highest level among TALIS countries) to 6.5 five years later (OECD, 2014, pp. 285, Table 2.18 ${ }_{[2]}$; OECD, 2019, pp. 207, Table I.3.74 ${ }_{[1]}$ ).

For support staff to have an effect on alleviating teachers' administrative burden, it is essential to consider how their tasks are defined, how they collaborate and co-ordinate their work with that of teachers, and how these factors interact with other developments that transform schools as working environments (Masdeu Navarro, 2015 [137]). It is also important to recognise that changes in the staff composition of schools can have significant effects on the work of school staff that are not easily captured by either their overall working time or their time dedicated to individual tasks. To investigate its effects on dynamics like task compression or intensification, stress and interpersonal relationships, more fine-grained analyses are needed.

\subsection{Policy options}

\subsubsection{Setting entry and qualification requirements that reflect professional responsibilities and respond to system needs}

The mechanisms that regulate prospective teachers' entry into initial education and the profession play an important role in attracting, selecting and retaining effective staff. They affect the quality and quantity of prospective teachers and school leaders and contribute to shaping the social status of their careers. The significant heterogeneity among high-performing school systems suggests that there is no one-size-fits-all solution to the process, timing or criteria used to select effective school staff. Instead, the design of entry and qualification requirements should be informed by a range of contextual factors, including recruitment needs and the characteristics of the teacher labour market.

Whichever process the selection and retention of teachers is based on, it should be informed by teachers' demonstrated effectiveness in a classroom environment. Some school systems have chosen to engage in selection early on and raised the bar that candidates need to clear before entering the profession (e.g. by introducing stricter admissions criteria for initial preparation or additional examinations to obtain a teaching qualification). This approach tends to reduce the overall supply of teachers and risks to screen out some potential high-quality candidates since most teacher characteristics that can be readily observed prior to their entry into the classroom are imprecise indicators - at best - of their future teaching quality.

Making practical teaching experience an integral part of teacher education can alleviate some of these concerns by ensuring that initial qualifications more meaningfully reflect classroom teaching abilities. Other systems have reduced the hurdles that teachers need to take prior to entering the classroom and instead introduced a higher bar for retention later on, which may help to alleviate teacher shortages and gives schools or education authorities an opportunity to evaluate teachers based on their performance after a few years on the job. Involving teachers, leaders and their professional bodies in the design of the requirements and standards that regulate entry and retention in their profession can help ensure that they are fit for purpose and foster professional self-regulation. 
Qualification requirements should reflect the fact that not all teachers of a school perform the same work and that their qualifications may evolve in line with changing task profiles and responsibilities over the course of their career. Allowing for some diversity in teachers' qualification requirements can also allow schools to recruit the right mix of expertise and skills to meet their needs. At the same time, generalised differences in qualification requirements for teachers at different levels of education (e.g. for primary versus secondary education) are rarely justified by the nature of teachers' work and can have undesirable consequences, such as reducing the supply of highly qualified graduates to teach students during the early years of their education.

In some cases, harmonising qualification requirements across levels of education can therefore lend greater recognition to highly qualified pedagogical work and address concerns about the distribution or mobility of teachers across different school settings, which is discussed in depth in Chapter 3. It should be noted though, that such a step can have significant budgetary implications and - given the inertia in the teacher workforce can take a very long time to be reflected among practicing teachers. Gradually phasing in the convergence of qualification requirements and salaries over time can render its fiscal impact more feasible, for example by integrating more highly qualified and paid teachers at the same rate as more experienced teachers with higher salaries retire. Where the process needs to be accelerated, school systems can extend their efforts beyond the point of entry and provide practicing teachers with targeted professional development.

There is also a growing awareness that a successful teaching record alone is not sufficient to guarantee the effectiveness of future principals and that school leadership requires a distinct set of knowledge, skills and competencies. School systems should acknowledge this by developing entry requirements based on professional standards for school leadership and by providing aspiring leaders with rigorous preparation prior to assuming their position, as analysed in Chapter 4.

\subsubsection{Creating opportunities for vertical and horizontal advancement in the teaching career}

Career structures should offer teachers opportunities to apply the skills and experiences they acquire in roles with commensurate responsibility without having to move out of the classroom and into administrative roles. Pathways for vertical career progression can incentivise teachers to perform at their best, engage in continuing professional learning and be recognised for effective teaching. Different steps in the career structure (e.g. for beginning, advanced, senior and expert teachers) should be aligned with professional standards detailing the knowledge and skills that teachers are expected to display for different roles. This can offer a transparent structure to integrate teachers' appraisal, their certifications and promotion. Position-based standards can also provide teachers with a clear sense of their needs and opportunities for growth, particularly if they are linked to professional development opportunities.

Teachers' advancement across the career structure should be voluntary and involve a formal certification process based on national frameworks of teacher competencies. Given the high stakes of certification procedures, they should be based on standard procedures and involve an external component (e.g. external markers of a professional portfolio) to ensure objectivity and fairness. The certification process should be well-aligned with students' learning needs and linked to teaching practice, for example by including classroom observation as part of teachers' evaluated portfolio. 
Once teachers have been certified as fit to perform at a given career stage, regular re-certifications after a given number of years can ensure that they remain capable of performing at a given level and reduce the risk of non-identified long-term performance concerns. Re-certification also provides incentives for teachers to continuously develop their knowledge and skills and to proactively address their learning needs. At the same time, re-certification can place significant demands on administrative resources and teachers' time, which need to be considered in its design and weighed against prospective benefits.

In addition to opportunities for vertical progression, career structures should allow for horizontal diversification and for teachers to assume leadership positions in specific areas corresponding to their interests and expertise. Allowing teachers to acquire and apply specialised knowledge and skills creates opportunities for a more effective allocation of tasks and for building both individual and collective professional capacity. It also offers teachers greater autonomy in shaping their career, which may motivate them and have a positive effect on the attractiveness of the teaching career. Examples for specialised roles that teachers might assume include teacher mentors, learning and career counsellors, curriculum experts and co-ordinators for school projects. The definition of these roles, their associated responsibilities and appropriate forms of compensation (for example reductions in teaching hours) should occur in close consultation with teachers.

\subsubsection{Establishing distinct career structures and salary scales for school leaders, underpinned by clear professional standards}

To make leadership positions attractive to senior teachers and to acknowledge school leaders' additional responsibilities, their salaries should be attractive not only relative to those of similarly educated adults in other occupations, but also relative to those of teachers. This should be accounted for in resource allocations and budgeting decisions. Adequate levels of remuneration could take the salaries of professionals with similar levels of responsibility as a benchmark. To ensure that all schools have a chance of attracting effective leaders, salary scales should also reflect school-level characteristics, such as size and the composition of their leadership teams, to account for the challenges associated with a given position. Separate salary scales and career structures for school leaders can contribute to raising the status of school leadership and communicate its importance, rather than treating school leadership as a mere extension of the teachers' career.

Multi-level career structures for school leaders should provide opportunities for professional advancement and continued motivation as they gain experience and assume progressively increasing responsibilities. These career structures should also provide opportunities for school leaders to progress to system leadership roles that allow them to contribute to the improvement of the wider education system. Each step of the career structure should be underpinned by an authoritative set of professional standards expressing the skills and competencies school principals are expected to have.

These professional standards can promote professionalism and a coherent vision of school leadership while increasing transparency since they can be used as a basis for the selection of candidates, their appraisal, professional development and career advancement. School leader standards should be developed with the profession to reflect the complexity of their role and go beyond the administrative qualities emphasised by traditional models of principal-ship in order to acknowledge their responsibility for pedagogical leadership. 


\subsubsection{Involving teachers and school leaders in the design and introduction of career structures}

Giving teachers and school leaders a prominent voice in the design of career pathways and their associated professional standards is critical to guarantee their relevance and alignment with the day-to-day experience and needs of schools. It can also be an effective means to strengthen teachers' voice and sense of self-agency, their involvement in the profession's self-regulation and to generate a sense of ownership that is critical for a new career structure to be accepted, implemented and contribute to the profession's attractiveness. Teachers' participation in the process recognises their professionalism, the importance of their skills and experience and the extent of their responsibilities.

To help teachers assume greater responsibility for the self-regulation of their profession, the authorities responsible for the development of career structures should work hand in hand with teacher unions and professional organisations as well as outstanding teachers from across the system. To ensure that career pathways and opportunities for professional advancement are well understood and contribute to teachers' motivation, their implementation needs to be accompanied by a strategy for their socialisation. Initial teacher education programmes, induction courses and professional development should be adapted to reflect new career structures, to explain their implications and to take into account teachers' needs at different stages of their careers.

\subsubsection{Ensuring that salaries are competitive for the recruitment and retention of high-quality teachers and school leaders}

Remuneration is only one of many factors that can render a profession attractive. Working conditions, opportunities for professional learning and growth, social status, as well as professional autonomy are important to make teaching careers not only financially, but also intellectually satisfying and to attract high-calibre candidates. Nevertheless, the structure of salary scales and the factors that determine salary progressions are critical policy levers that should be considered when confronting challenges related to the supply, retention and motivation of school staff.

\section{Ensuring that salaries are commensurate with teachers' roles and responsibilities}

The optimal design of a salary scale depends on a range of contextual factors, including the structure of local labour markets, the demand and supply of teachers and the wider teacher policy environment. Yet, it is widely recognised that teachers' remuneration should be competitive with that of similarly educated adults working in comparable occupations in order to attract and retain high-potential candidates.

Depending on a country's specific policy challenges, a range of strategies can bolster the system's capacity to attract new entrants (e.g. by making the salaries of beginning teachers more attractive) or to retain experienced and high-quality teachers (e.g. by expanding the potential for salary progression). Some of these adjustments can be budget neutral while others may have significant long-term fiscal implications or incur high-transition costs, which need to be accounted for in longer-term budget plans.

How salaries compare across levels of education and between different roles also affects the relative attractiveness of different careers and the distribution of qualified candidates across different staff categories. Salaries of school leaders, for example, need to be sufficiently differentiated from those of teachers to reflect their additional responsibilities and to provide incentives for motivated and qualified staff to assume leadership positions. 


\section{Recognising and encouraging high performance while balancing the risks of} extrinsic reward structures

Providing teachers' with a good balance of intrinsic and extrinsic sources of motivation is critical to promote and reward high performance across the whole range of their tasks. Teachers' self-motivation should be encouraged by providing the conditions for their work to be intellectually stimulating and enjoyable. Many countries have sought to complement these efforts with sources of extrinsic motivation, including financial incentives.

Where available, school systems should establish clear links between teachers' salary scales and the steps in their career structure. Linking teachers' performance to financial rewards by more indirect means (for example via their career progression) can avoid some of the damaging consequences that may result from badly implemented bonus systems. Robust certification systems should govern teachers' career progression on the basis of established teaching standards and competency frameworks as well as their capacity to assume responsibilities and perform at the level required by a given step in the teacher career. Linking salaries to career progression promises to incentivise high performance while at the same time affording administrations and the teaching profession greater scope in ensuring that the frameworks guiding this process are transparent, well-understood and aligned with students' learning objectives,.

Direct links between teachers' performance and their salaries have had mixed results in practice and are notoriously difficult to implement in ways that are transparent, fair and conducive to student learning. The most encouraging examples have been based on multi-dimensional measures of teacher performance, clearly articulated the system's expectations to teachers and provided them with coaching and support to meet these expectations. Doing so can require significant investments which need to be weighed against the policy's potential gains. In addition, the evidence base is insufficient to provide clear guidance on many technical aspects of performance pay programmes, such as the optimal size of rewards or the best individual- or group-based measures to use. The overall impact of incentive systems appears to be highly variable based on their design and implementation, which often entails challenges such as the resistance among teachers, insufficient fiscal resources, and other context-dependent unintended consequences.

\subsubsection{Ensuring that teachers' and school leaders' working time reflects the diversity of their tasks}

Teachers are expected to engage in a range of activities beyond classroom instruction. Ensuring that they can devote sufficient time to lesson preparation, collaboration, peer observation and knowledge creation is increasingly recognised as central to their professional role and their individual and collective effectiveness. Providing employment contracts based on a workload system that stipulates the total number of hours of work (and possibly presence at school) rather than or in addition to their teaching hours is an important step to recognise the diversity of tasks that a teaching career entails.

A holistic conception of teachers' working time can make it easier for schools to foster collaboration among their staff and develop professional learning communities, for example by formally setting aside and co-ordinating time to engage in peer feedback and joint work with colleagues. It also makes it easier for school leaders to plan and allocate teaching and non-teaching hours and tasks across all teachers within their school based on the commitments and expertise of their staff or their experience and effectiveness in the classroom. All of this has not only the potential to use teachers' time and skills in schools 
more effectively to build professional capacity and improve instruction, but also to make the profession more attractive. School systems also stand to benefit from gaining a better understanding of how teachers use their time in practice by investing in related research.

It is equally important to clarify task expectations for school principals and help them prioritise among various and competing claims on their time. Studies drawing on time-use data find that some forms of pedagogical leadership are more effective than others. Offering training to principals to manage their time could be an effective means to increase their time spent on high-priority tasks and to reduce stress. A precondition for this is to build a shared understanding of priorities for principals to spend their time on, for example through a set of school leadership standards, jointly developed with school leaders.

Another consideration is to redistribute leadership responsibilities within schools and systems, shifting some responsibilities for school management, professional evaluation and pedagogical leadership and supporting those responsible for each task to fulfil them effectively. Establishing roles that allow teachers to take on leadership tasks allows schools to mobilise their growing expertise while at the same time providing attractive opportunities for professional growth within the teaching career.

\subsubsection{Providing a good balance of autonomy and supports for school staff to collaborate}

In many OECD review countries, teachers have traditionally enjoyed a high degree of autonomy over the use of their non-teaching time, including how and where they spend it. Many school systems do not prescribe whether teachers should spend most of their non-teaching time at school, leaving it to them to work from home. However, teachers' shared presence in schools can make it easier for schools to develop a shared working culture and collaborative practice which have been shown to have some of the strongest associations with teachers' self-efficacy and job satisfaction.

While not sufficient, as discussed in Chapter 3, one way to facilitate teachers' collaboration and increase accountability around their non-instruction time is to increase teachers' presence at school beyond their teaching hours and to provide them with spaces to work independently or with colleagues. At the same time, teachers who perceive their school's atmosphere to be collegial and conducive to their professional learning may want to spend more time in schools voluntarily. In any case, requirements for teachers to spend time together at school need to be balanced with the risk of imposing collegiality or crowding schedules with time demands all of which might inhibit bottom-up professional initiative and true collaboration.

An extensive body of research also points to professional autonomy as a key dimension of job characteristics that affect workers' sense of self-efficacy, their satisfaction and intrinsic motivation. Likewise, teachers' involvement in the decision-making processes that affect their work can provide a means for schools to mobilise leadership capacity at all levels and it offers teachers an opportunity to communicate and address their needs while assuming greater collective responsibility for their school's improvement. Coupled with dedicated time for collaboration in staff schedules, evidence-based protocols or work processes and a school culture that encourages peer feedback and collaboration, a focus on teacher leadership and agency is therefore an essential ingredient to strengthen professional working environments in schools. 


\section{Notes}

${ }^{1}$ In Austria, responsibilities for school education differ between so-called federal schools and provincial schools. Federal schools (Bundesschulen) comprise academic secondary schools as well as upper secondary vocational schools and colleges (ISCED 2-3). Provincial schools (Landesschulen) include primary schools, general lower secondary schools, New Secondary Schools, special needs schools, pre-vocational schools and part-time upper secondary vocational schools (ISCED 1-3).

${ }^{2}$ In 2017, this is the case in Canada, the Flemish Community of Belgium (upper secondary level), Norway (upper secondary level), Poland (pre-primary, primary and lower secondary levels), in the United Kingdom, and the United States (primary, lower and upper secondary levels), and at some stages of the teaching career in the French Community of Belgium, Greece, Hungary, New Zealand and Norway (primary and lower secondary levels).

${ }^{3}$ The European Commission's Eurobarometer survey, for example, defines working conditions to encompass working time, work organisation, health and safety at work, employee representation and relation with the employer (European Commission, 2014 $[138]$ ). 


\section{References}

Adnot, M. et al. (2017), "Teacher turnover, teacher quality, and student achievement in DCPS",

Educational Evaluation and Policy Analysis, Vol. 39/1, pp. 54-76, http://dx.doi.org/10.3102/0162373716663646.

Atkinson, A. et al. (2008), "Evaluating the impact of performance-related pay for teachers in England", Labour Economics, Vol. 16, pp. 251-261, http://dx.doi.org/10.1016/j.labeco.2008.10.003.

Auguste, B., P. Kihn and M. Miller (2010), Closing the Talent Gap: Attracting and Retaining Top-Third Graduates to Careers in Teaching, McKinsey \& Company, https://www.mckinsey.com/industries/social-sector/our-insights/closing-the-teaching-talent-gap (accessed on 22 July 2019).

Bacharach, S., S. Conley and J. Shedd (1986), "Beyond career ladders: Structuring teacher career development systems", Teachers College Record, Vol. 87/4, pp. 563-574, https://www.tcrecord.org/.

Balch, R. and M. Springer (2015), "Performance pay, test scores, and student learning objectives", Economics of Education Review, Vol. 44, pp. 114-125, http://dx.doi.org/10.1016/j.econedurev.2014.11.002.

Ballou, D. and M. Springer (2015), "Using student test scores to measure teacher performance: Some problems in the design and implementation of evaluation systems", Educational Researcher, Vol. 44/2, pp. 77-86, http://dx.doi.org/10.3102/0013189X15574904.

Barber, M. and M. Mourshed (2007), How the World's Best-performing School Systems Come Out on Top, McKinsey \& Company, https://www.mckinsey.com/industries/social-sector/our-insights/how-theworlds-best-performing-school-systems-come-out-on-top (accessed on 22 July 2019).

Barlevy, G. and D. Neal (2012), "Pay for percentile”, American Economic Review, Vol. 102/5, pp. 18051831, http://dx.doi.org/10.1257/aer.102.5.1805.

Bénabou, R. and J. Tirole (2003), "Intrinsic and extrinsic motivation”, Review of Economic Studies, Vol. 70/3, pp. 489-520, http://dx.doi.org/10.1111/1467-937X.00253.

Boyd, D. et al. (2008), "The narrowing gap in New York City teacher qualifications and its implications for student achievement in high-poverty schools", Journal of Policy Analysis and Management, Vol. 27/4, pp. 793-818, http://dx.doi.org/10.1002/pam.20377.

Bruneforth, M. et al. (2016), OECD Review of Policies to Improve the Effectiveness of Resource Use in Schools: Country Background Report for Austria, Bundesministerium für Bildung und Frauen, Vienna, http://www.oecd.org/education/schoolresourcesreview.htm.

Bruns, B. and J. Luque (2015), Great Teachers: How to Raise Student Learning in Latin America and the Caribbean, International Bank for Reconstruction and Development / The World Bank, Washington, DC, https://doi.org/10.1596/978-1-4648-0151-8.

Burns, T. and F. Köster (eds.) (2016), Governing Education in a Complex World, Educational Research and Innovation, OECD Publishing, Paris, https://dx.doi.org/10.1787/9789264255364-en.

Chiang, H. et al. (2017), Evaluation of the Teacher Incentive Fund: Final Report on Implementation and Impacts of Pay-for-Performance Across Four Years ( NCEE 2017-4004), National Center for Education Evaluation and Regional Assistance, Institute of Education Sciences, US Department of Education, Washington, DC, https://ies.ed.gov/ncee/pubs/20184004/pdf/20184004.pdf (accessed on 28 March 2019). 
Christian, B., J. Jacobsen and L. Andersen (2013), "Command and motivation: How the perception of external interventions relates to intrinsic motivation and public service motivation", Public Administration, Vol. 92/4, pp. 790-806, http://dx.doi.org/10.1111/padm.12024.

Conley, S. and A. Odden (1995), "Linking teacher compensation to teacher career development", Educational Evaluation and Policy Analysis, Vol. 17/2, pp. 219-237, http://dx.doi.org/10.3102/01623737017002219.

Corcoran, S., W. Evans and R. Schwab (2004), "Changing labor-market opportunities for women and the quality of teachers, 1957-2000”, American Economic Review, Vol. 94/2, pp. 230-235, http://dx.doi.org/10.1257/0002828041301920.

Crehan, L. (2016), Exploring the impact of career models on teacher motivation, UNESCO International Institute for Educational Planning (IIEP), Paris, http://unesdoc.unesco.org/images/0024/002462/246252e.pdf (accessed on 11 July 2018).

Cunha, F. et al. (2006), "Interpreting the evidence on life cycle skill formation", in Hanushek, E. and F. Welch (eds.), Handbook of the Economics of Education, Elsevier B.V, Amsterdam, http://dx.doi.org/10.1016/S1574-0692(06)01012-9.

Dee, T. and J. Wyckoff (2015), "Incentives, selection, and teacher performance: Evidence from IMPACT”, Journal of Policy Analysis and Management, Vol. 34/2, pp. 267-297, http://dx.doi.org/10.1002/pam.21818.

Dolton, P. (2006), “Teacher supply”, in Hanushek, E. and F. Welch (eds.), Handbook of the Economics of Education, Elsevier, http://dx.doi.org/10.1016/S1574-0692(06)02019-8.

Eberts, R. (2007), “Teachers unions and student performance: Help or hindrance?”, The Future of Children, Vol. 17/1, pp. 175-200, http://dx.doi.org/10.1353/foc.2007.0001.

Elacqua, G. et al. (2018), Profesión: Profesor en América Latina ¿Por qué se perdió el prestigio docente y cómo recuperarlo?, Inter-American Development Bank, Washington, DC, http://dx.doi.org/10.18235/0001172.

European Commission (2014), Flash Eurobarometer 398 Working Conditions, Conducted by TNS Political \& Social at the request of the European Commission, Directorate-General Employment, Social Affairs and Inclusion, European Union, Brussels, http://dx.doi.org/10.2767/21855.

European Commission (2013), Study on Policy Measures to Improve the Attractiveness of the Teaching Profession in Europe: Vol. 2, Final Report, Publications Office of the European Union, Luxembourg, http://dx.doi.org/10.2766/41166.

European Commission/EACEA/Eurydice (2018), Teachers' and School Heads' Salaries and Allowances in Europe - 2016/17, Publications Office of the European Union, Luxembourg, http://dx.doi.org/10.2797/24212.

European Commission/EACEA/Eurydice (2016), Teaching Careers in Europe: Access, Progression and Support, Publications Office of the European Union, Luxembourg, http://dx.doi.org/10.2797/309510.

European Union (2018), Education and Training Monitor 2018, Publications Office of the European Union, Luxembourg, http://dx.doi.org/10.2766/707224.

Falch, T. (2011), "Teacher mobility responses to wage changes: Evidence from a quasi-natural experiment", American Economic Review: Papers \& Proceedings, Vol. 101/3, pp. 460-465, http://dx.doi.org/10.1257/aer.101.3.460.

Falch, T. and B. Strøm (2005), “Teacher turnover and non-pecuniary factors", Economics of Education Review, Vol. 24/6, pp. 611-631, http://dx.doi.org/10.1016/j.econedurev.2004.09.005.

Fédération Wallonie-Bruxelles (2017), Avis N 3 du Groupe central du Pacte pour un enseignement d excellence, http://www.pactedexcellence.be (accessed on 19 May 2019). 
Figueroa., S. et al. (2018), "La profesión docente en Colombia: normatividad, formación, selección y evaluación", Documentos de Trabajo Escuela de Gobierno Alberto Lleras Camargo, No. 54, Universidad de los Andes, Bogotá, DC, http://egob.uniandes.edu.co (accessed on 16 June 2019).

Frey, B. (1997), "On the relationship between intrinsic and extrinsic work motivation", International Journal of Industrial Organization, Vol. 15, pp. 427-439, http://dx.doi.org/10.1016/S01677187(96)01028-4.

Fryer, R. (2013), "Teacher incentives and student achievement: Evidence from New York City public schools", Journal of Labor Economics, Vol. 31/2, pp. 373-407, http://dx.doi.org/10.1086/667757.

Gindin, J. and L. Finger (2013), Promoting Education Quality: The Role of Teachers' Unions in Latin America, Background paper prepared for the Education for All Global Monitoring Report 2013/4 Teaching and learning: Achieving quality for all, UNESCO, Paris, https://unesdoc.unesco.org/ark:/48223/pf0000225931 (accessed on 27 April 2019).

Gluschkoff, K. et al. (2016), "Work stress, poor recovery and burnout in teachers", Occupational Medicine, Vol. 66, pp. 564-570, http://dx.doi.org/10.1093/occmed/kqw086.

Goldring, E. et al. (2015), "Make room value added: Principals' human capital decisions and the emergence of teacher observation data", Educational Researcher, Vol. 44/2, pp. 96-104, http://dx.doi.org/10.3102/0013189X15575031.

Golsteyn, B., S. Vermeulen and I. de Wolf (2016), "Teacher literacy and numeracy skills: International evidence from PIAAC and ALL", De Economist, Vol. 164, pp. 365-389, http://dx.doi.org/10.1007/s10645-016-9284-1.

Goodman, S. and L. Turner (2013), "The design of teacher incentive pay and educational outcomes: Evidence from the New York City bonus program”, Journal of Labor Economics, Vol. 31/2, pp. 409420, http://dx.doi.org/10.1086/668676.

Grissom, J., S. Loeb and B. Master (2013), "Effective instructional time use for school leaders: Longitudinal evidence from observations of principals", Educational Researcher, Vol. 42/8, pp. 433444, http://dx.doi.org/10.3102/0013189X13510020.

Grissom, J., S. Loeb and H. Mitani (2015), "Principal time management skills: Explaining patterns in principals' time use, job stress, and perceived effectiveness", Journal of Educational Administration, Vol. 53/6, pp. 773-793, http://dx.doi.org/10.1108/JEA-09-2014-0117.

Hackman, J. and G. Oldham (1976), "Motivation through the design of work: Test of a theory", Organizational Behaviour and Human Performance, Vol. 16/2, pp. 250-279, http://dx.doi.org/10.1016/0030-5073(76)90016-7.

Hakanen, J., A. Bakker and W. Schaufeli (2006), "Burnout and work engagement among teachers", Journal of School Psychology, Vol. 43, pp. 495-513, http://dx.doi.org/10.1016/j.jsp.2005.11.001.

Hanushek, E., J. Kain and S. Rivkin (2002), "Why public schools lose teachers", Journal of Human Resources, Vol. 39/2, pp. 326-354, http://dx.doi.org/10.3368/jhr.XXXIX.2.326.

Hanushek, E., S. Link and L. Woessmann (2013), "Does school autonomy make sense everywhere? Panel estimates from PISA", Journal of Development Economics, Vol. 104, pp. 212-232, http://dx.doi.org/10.1016/j.jdeveco.2012.08.002.

Hanushek, E. and R. Pace (1995), "Who chooses to teach (and why)?", Economics of Education Review, a, pp. 101-117, http://dx.doi.org/10.1016/0272-7757(95)90392-L.

Hanushek, E., M. Piopiunik and S. Wiederhold (2019), "The value of smarter teachers: International evidence on teacher cognitive skills and student performance", Journal of Human Resources, http://dx.doi.org/10.3368/jhr.55.1.0317.8619R1. 
Hanushek, E., S. Rivkin and J. Schiman (2016), "Dynamic effects of teacher turnover on the quality of instruction", Economics of Education Review, Test, pp. 132-148, http://dx.doi.org/10.1016/J.ECONEDUREV.2016.08.004.

Hendricks, M. (2014), "Does it pay to pay teachers more? Evidence from Texas", Journal of Public Economics, Vol. 109, pp. 50-63, http://dx.doi.org/10.1016/j.jpubeco.2013.11.001.

Hooge, E. (2016), "Making multiple school accountability work", in Burns, T. and F. Köster (eds.), Governing Education in a Complex World, OECD Publishing, Paris, http://dx.doi.org/10.1787/9789264255364-7-en.

Hopkins, D., D. Nusche and B. Pont (2008), Improving School Leadership, Volume 2: Case Studies on System Leadership, OECD Publishing, Paris, http://dx.doi.org/10.1787/9789264039551-en.

Horng, E. (2009), "Teacher tradeoffs: Disentangling teachers' preferences for working conditions and student demographics", American Educational Research Journal, Vol. 46/3, pp. 690-717, http://dx.doi.org/10.3102/0002831208329599.

Horng, E., D. Klasik and S. Loeb (2010), "Principal's time use and school effectiveness", American Journal of Education, Vol. 116/4, pp. 491-523, http://dx.doi.org/10.1086/653625.

Hutchings, M. et al. (2009), Aspects of School Workforce Remodelling: Strategies used and Impact on Workload and Standards, Department for Children, Schools and Families, https://dera.ioe.ac.uk/10822/1/DCSF-RR153.pdf (accessed on 25 July 2019).

ILO/UNESCO (2016), The ILO/UNESCO Recommendation concerning the Status of Teachers (1966) and the UNESCO Recommendation concerning the Status of Higher Education Teaching Personnel (1997) - Revised edition 2016, International Labour Office, Sectoral Policies Department, Geneva, https://www.ilo.org/wcmsp5/groups/public/---ed_dialogue/---sector/documents/normativeinstrument/wcms 493315.pdf (accessed on 8 November 2018).

Ingersoll, R. and H. May (2012), "The magnitude, destinations, and determinants of mathematics and science teacher turnover", Educational Evaluation and Policy Analysis, Vol. 34/4, pp. 435-464, http://dx.doi.org/10.3102/0162373712454326.

Jackson, C., J. Rockoff and D. Staiger (2014), "Teacher effects and teacher-related policies", Annual Review of Economics, Vol. 6, pp. 801-825, http://dx.doi.org/10.1146/annurev-economics-080213$\underline{040845 .}$.

Jacob, B. et al. (2018), "Teacher applicant hiring and teacher performance: Evidence from DC public schools", Journal of Public Economics, Vol. 166, pp. 81-97, http://dx.doi.org/10.1016/j.jpubeco.2018.08.011.

Jamal, M. (1984), "Job stress and job performance controversy: An empirical assessment”, Organizational Behavior and Human Performance, Vol. 33/1, pp. 1-21, http://dx.doi.org/10.1016/00305073(84)90009-6.

Jensen, B. et al. (2012), The Experience of New Teachers: Results from TALIS 2008, TALIS, OECD Publishing, Paris, https://dx.doi.org/10.1787/9789264120952-en.

Kane, T., J. Rockoff and D. Staiger (2008), "What does certification tell us about teacher effectiveness? Evidence from New York City", Economics of Education Review, Vol. 27, pp. 615-631, http://dx.doi.org/10.1016/j.econedurev.2007.05.005.

Kershaw, J. and R. McKean (1962), Teacher Shortages and Salary Schedules, RAND Corporation, Santa Monica, CA.

Kingdon, G. and F. Teal (2009), "Teacher unions, teacher pay and student performance in India: A pupil fixed effects approach", Journal of Development Economics, Vol. 91, pp. 278-288, http://dx.doi.org/10.1016/j.jdeveco.2009.09.001. 
Koedel, C. and J. Betts (2011), "Does student sorting invalidate value-added models of teacher effectiveness? An extended analysis of the Rothstein critique", Education Finance and Policy, Vol. 6/1, pp. 18-42, http://dx.doi.org/10.1162/EDFP_a 00027.

Kraft, M. and J. Papay (2014), "Can professional environments in schools promote teacher development? Explaining heterogeneity in returns to teaching experience", Educational Evaluation and Policy Analysis, Vol. 36/4, pp. 476-500, http://dx.doi.org/10.3102/0162373713519496.

Liebowitz, D. et al. (2018), OECD Reviews of School Resources: Portugal 2018, OECD Reviews of School Resources, OECD Publishing, Paris, https://dx.doi.org/10.1787/9789264308411-en.

Lortie, D. (1975), Schoolteacher: A Sociological Study, University of Chicago Press, Chicago.

Masdeu Navarro, F. (2015), "Learning support staff: A literature review", OECD Education Working Papers, No. 125, OECD Publishing, Paris, https://dx.doi.org/10.1787/5jrnzm39w451-en.

Matsudaira, J. and R. Patterson (2017), “Teachers' unions and school performance: Evidence from California charter schools", Economics of Education Review, Vol. 61, pp. 35-50, http://dx.doi.org/10.1016/j.econedurev.2017.09.005.

MINEDUC Centro de Estudios (2016), Reporte Nacional de Chile: Revisión OCDE para mejorar la efectividad del uso de recursos en las escuelas, informe preparado por el Ministerio de Educación, la Agencia de Calidad de la Educación y la Superintendencia de Educación, Ministerio de Educación, Santiago, Chile, http://www.oecd.org/education/schoolresourcesreview.htm.

Mitani, H. (2018), "Principals' working conditions, job stress, and turnover behaviors under NCLB accountability pressure", Educational Administration Quarterly, Vol. 54/5, pp. 822-862, http://dx.doi.org/10.1177/0013161X18785874.

Murnane, R. and D. Cohen (1986), "Merit pay and the evaluation problem: Why most merit pay plans fail and a few survive", Harvard Educational Review, Vol. 56/1, pp. 1-18, http://dx.doi.org/10.17763/haer.56.1.18q2334243271116.

Murnane, R., J. Singer and J. Willett (1989), "The influences of salaries and "opportunity costs" on teachers' career choices: Evidence from North Carolina", Harvard Educational Review, Vol. 59/3, pp. 325-347, http://dx.doi.org/10.17763/haer.59.3.040r1583036775um.

Natale, C. et al. (2013), Creating Sustainable Teacher Career Pathways: A 21st Century Imperative, Pearson \& National Network of State Teachers of the Year (NNSTOY), https://www.nnstoy.org/download/career_pathways/Final\%20updated\%20Research\%20Report.pdf (accessed on 11 October 2018).

Norwegian Ministry of Education and Research (2018), Teacher Education 2025: National Strategy for Quality and Cooperation in Teacher Education, Norwegian Ministry of Education and Reseach, Oslo, https://www.regjeringen.no/contentassets/d0c1da83bce94e2da21d5f631bbae817/kd teacher-education2025 uu.pdf (accessed on 10 May 2019).

Norwegian Ministry of Education and Research, Oslo (2017), White Paper No. 16 Quality Culture in Higher Education, Norwegian Ministry of Education and Reseach, https://www.regjeringen.no/en/finddocument/white-papers-/id1754 (accessed on 19 November 2018).

Nusche, D. et al. (2015), OECD Reviews of School Resources: Flemish Community of Belgium 2015, OECD Reviews of School Resources, OECD Publishing, Paris, https://dx.doi.org/10.1787/9789264247598-en.

Nusche, D. et al. (2016), OECD Reviews of School Resources: Austria 2016, OECD Reviews of School Resources, OECD Publishing, Paris, https://dx.doi.org/10.1787/9789264256729-en.

Nusche, D. et al. (2016), OECD Reviews of School Resources: Denmark 2016, OECD Reviews of School Resources, OECD Publishing, Paris, https://dx.doi.org/10.1787/9789264262430-en. 
OECD (2019), A Flying Start: Improving Initial Teacher Preparation Systems, OECD Publishing, Paris, http://dx.doi.org/10.1787/cf74e549-en.

OECD (2019), Education at a Glance 2019: OECD Indicators, OECD Publishing, Paris, http://dx.doi.org/10.1787/f8d7880d-en.

OECD (2019), TALIS 2018 Results (Volume I): Teachers and School Leaders as Lifelong Learners, TALIS, OECD Publishing, Paris, https://dx.doi.org/10.1787/1d0bc92a-en.

OECD (2018), Education at a Glance 2018: OECD Indicators, OECD Publishing, Paris, http://dx.doi.org/10.1787/19991487.

OECD (2018), Education Policy in Japan: Building Bridges towards 2030, Reviews of National Policies for Education, OECD Publishing, Paris, https://dx.doi.org/10.1787/9789264302402-en.

OECD (2018), Effective Teacher Policies: Insights from PISA, PISA, OECD Publishing, Paris, https://dx.doi.org/10.1787/9789264301603-en.

OECD (2018), Responsive School Systems: Connecting Facilities, Sectors and Programmes for Student Success, OECD Reviews of School Resources, OECD Publishing, Paris, https://dx.doi.org/10.1787/9789264306707-en.

OECD (2017), Education Policy Outlook: Belgium, OECD, Paris, http://www.oecd.org/edu/policyoutlook.htm (accessed on 9 May 2019).

OECD (2017), Starting Strong 2017: Key OECD Indicators on Early Childhood Education and Care, Starting Strong, OECD Publishing, Paris, https://dx.doi.org/10.1787/9789264276116-en.

OECD (2017), The Funding of School Education: Connecting Resources and Learning, OECD Reviews of [101] School Resources, OECD Publishing, Paris, https://dx.doi.org/10.1787/9789264276147-en.

OECD (2016), PISA 2015 Results (Volume II): Policies and Practices for Successful Schools, PISA, OECD Publishing, Paris, http://dx.doi.org/10.1787/9789264267510-en.

OECD (2016), Supporting Teacher Professionalism: Insights from TALIS 2013, TALIS, OECD Publishing, Paris, https://dx.doi.org/10.1787/9789264248601-en.

OECD (2015), Education Policy Outlook 2015: Making Reforms Happen, OECD Publishing, Paris, https://dx.doi.org/10.1787/9789264225442-en.

OECD (2014), Education at a Glance 2014: OECD Indicators, OECD Publishing, Paris, http://dx.doi.org/10.1787/eag-2014-en.

OECD (2014), TALIS 2013 Results: An International Perspective on Teaching and Learning, TALIS, OECD Publishing, Paris, https://dx.doi.org/10.1787/9789264196261-en.

OECD (2013), How's Life? 2013: Measuring Well-being, OECD Publishing, Paris, https://dx.doi.org/10.1787/9789264201392-en.

OECD (2013), Leadership for 21st Century Learning, Educational Research and Innovation, OECD Publishing, Paris, https://dx.doi.org/10.1787/9789264205406-en.

OECD (2013), PISA 2012 Results: What Makes Schools Successful (Volume IV): Resources, Policies and Practices, OECD Publishing, Paris, http://dx.doi.org/10.1787/9789264201156-en.

OECD (2013), Synergies for Better Learning: An International Perspective on Evaluation and Assessment, OECD Reviews of Evaluation and Assessment in Education, OECD Publishing, Paris, https://dx.doi.org/10.1787/9789264190658-en.

OECD (2009), Creating Effective Teaching and Learning Environments: First Results from TALIS, TALIS, OECD Publishing, Paris, http://dx.doi.org/10.1787/9789264068780-en. 
OECD (2007), "The Teaching Workforce: Meeting Aspirations and Enhancing Motivation", in Education Policy Analysis 2006: Focus on Higher Education, OECD Publishing, Paris, https://dx.doi.org/10.1787/epa-2006-4-en.

OECD (2005), Performance-related Pay Policies for Government Employees, OECD Publishing, Paris, https://dx.doi.org/10.1787/9789264007550-en.

OECD (2005), Teachers Matter: Attracting, Developing and Retaining Effective Teachers, OECD Publishing, Paris, http://dx.doi.org/10.1787/19901496.

OECD/The World Bank (2015), OECD Reviews of School Resources: Kazakhstan 2015, OECD Reviews of School Resources, OECD Publishing, Paris, https://dx.doi.org/10.1787/9789264245891-en.

Paniagua, A. and D. Istance (2018), Teachers as Designers of Learning Environments: The Importance of Innovative Pedagogies, Educational Research and Innovation, OECD Publishing, Paris, http://dx.doi.org/10.1787/9789264085374-en.

Podgursky, M. and M. Springer (2007), "Teacher performance pay: A review", Journal of Policy Analysis and Management, Vol. 26/4, pp. 909-949, http://dx.doi.org/10.1002/pam.20292.

Pont, B., D. Nusche and H. Moorman (2008), Improving School Leadership, Volume 1: Policy and Practice, OECD Publishing, Paris, https://dx.doi.org/10.1787/9789264044715-en.

Radinger, T. et al. (2018), OECD Reviews of School Resources: Colombia 2018, OECD Reviews of School Resources, OECD Publishing, Paris, http://dx.doi.org/10.1787/9789264303751-en.

Rechnungshof Österreich (2016), Wirkungsbereich des Bundesministeriums für Bildung: Bundeslehrkräfte: Vergleich Dienstrecht alt/neu, Bund 2016/16 [Scope of review: Federal Ministry of Education: Federal teachers: Comparison of service code old / new, Bund 2016/16], Rechnungshof Österreich, Wien, https://www.rechnungshof.gv.at (accessed on 5 November 2018).

Rockoff, J. et al. (2011), "Can you recognize an effective teacher when you recruit one?", Education Finance and Policy, Vol. 6/1, pp. 43-74, http://dx.doi.org/10.1162/EDFP_a_00022.

Ronfeldt, M., S. Loeb and J. Wyckoff (2013), "How teacher turnover harms student achievement", American Educational Research Journal, Vol. 50/1, pp. 4-36, http://dx.doi.org/10.3102/0002831212463813.

Rothstein, J. (2014), "Measuring the impacts of teachers: Comment", American Economic Review, Vol. 107/6, pp. 1656-1684, http://dx.doi.org/10.1257/aer.20141440.

Sánchez, J. (2018), OECD Review of Policies to Improve the Effectiveness of Resource Use in Schools: Country Background Report for Colombia, Ministerio de Educación Nacional, Bogotá, D.C., http://www.oecd.org/education/school-resources-review.

Santiago, P. (2002), "Teacher Demand and Supply: Improving Teaching Quality and Addressing Teacher Shortages", OECD Education Working Papers, No. 1, OECD Publishing, Paris, https://dx.doi.org/10.1787/232506301033.

Santiago, P. et al. (2016), OECD Reviews of School Resources: Uruguay 2016, OECD Reviews of School Resources, OECD Publishing, Paris, https://dx.doi.org/10.1787/9789264265530-en.

Santiago, P. et al. (2017), OECD Reviews of School Resources: Chile 2017, OECD Reviews of School Resources, OECD Publishing, Paris, https://dx.doi.org/10.1787/9789264285637-en.

Santiago, P. et al. (2016), OECD Reviews of School Resources: Slovak Republic 2015, OECD Reviews of School Resources, OECD Publishing, Paris, https://dx.doi.org/10.1787/9789264247567-en.

Santiago, P. et al. (2016), OECD Reviews of School Resources: Estonia 2016, OECD Reviews of School Resources, OECD Publishing, Paris, https://dx.doi.org/10.1787/9789264251731-en.

Schleicher, A. (2018), World Class: How to Build a 21st-Century School System, OECD Publishing, Paris, https://doi.org/10.1787/9789264300002-en. 
Seland, I. et al. (2017), Sluttrapport fra evaluering av pilotering av laererspesialistordningen i norsk og realfag [Final report from evaluation of the pilot of the teacher specialist arrangement in Norwegian and science subjects], The Nordic Institute for Studies in Innovation, Research and Education (NIFU), http://www.nifu.no (accessed on 10 May 2019).

Sellen, P. (2016), Teacher Workload and Professional Development in England's Secondary Schools: Insights from TALIS, Education Policy Institute, London, https://epi.org.uk/wpcontent/uploads/2018/01/TeacherWorkload_EPI.pdf (accessed on 26 April 2019).

Shewbridge, C. et al. (2016), OECD Reviews of School Resources: Lithuania 2016, OECD Reviews of School Resources, OECD Publishing, Paris, http://dx.doi.org/10.1787/9789264252547-en.

Shewbridge, C. et al. (2016), OECD Reviews of School Resources: Czech Republic 2016, OECD Reviews of School Resources, OECD Publishing, Paris, https://dx.doi.org/10.1787/9789264262379-en.

Shewbridge, C. et al. (2014), OECD Reviews of Evaluation and Assessment in Education: Slovak Republic 2014, OECD Reviews of Evaluation and Assessment in Education, OECD Publishing, Paris, https://dx.doi.org/10.1787/9789264117044-en.

Sojourner, A., E. Mykerezi and K. West (2014), "Teacher pay reform and productivity: Panel data evidence from adoptions of Q-Comp in Minnesota", Journal of Human Resources, Vol. 49/4, pp. 945981, http://dx.doi.org/10.3368/jhr.49.4.945.

Springer, M. et al. (2010), Teacher Pay for Performance Experimental Evidence from the Project on Incentives in Teaching, National Center on Performance Incentives at Vanderbilt University, Nashville, TN, https://my.vanderbilt.edu/performanceincentives (accessed on 15 February 2019).

Springer, M., D. Ballou and A. Peng (2014), "Estimated effect of the teacher advancement program on student test score gains", Education Finance and Policy, Vol. 9/2, pp. 193-230, http://dx.doi.org/10.1162/EDFP_a_00129.

Staiger, D. and J. Rockoff (2010), "Searching for effective teachers with imperfect information", Journal of Economic Perspectives, Vol. 24/3, pp. 97-118, http://dx.doi.org/10.1257/jep.24.3.97.

Steelman, L., B. Powell and R. Carini (2000), "Do teacher unions hinder educational performance? Lessons learned from state SAT and ACT scores", Harvard Educational Review, Vol. 70/4, pp. 437467, http://dx.doi.org/10.17763/haer.70.4.w17t1201442683k6.

Steinberg, M. and R. Garrett (2016), "Classroom composition and measured teacher performance: What do teacher observation scores really measure?", Educational Evaluation and Policy Analysis, Vol. 38/2, pp. 293-317, http://dx.doi.org/10.3102/0162373715616249.

Vegas, E. and A. Ganimian (2013), "Theory and Evidence on Teacher Policies in Developed and Developing Countries", IDB Working Paper Series, No. 438, Inter-American Development Bank, http://www.iadb.org (accessed on 10 September 2018).

Viac, C. and P. Fraser (forthcoming), "Teachers' well-being for quality teaching: A framework for analysis [working title]", OECD Education Working Paper, OECD Publishing, Paris.

Viennet, R. and B. Pont (2017), "Education policy implementation: A literature review and proposed framework", OECD Education Working Papers, No. 162, OECD Publishing, Paris, https://dx.doi.org/10.1787/fc467a64-en.

West, K. (2014), "New measures of teachers' work hours and implications for wage comparisons", Education Finance and Policy, Vol. 9/3, pp. 231-263, http://dx.doi.org/10.1162/EDFP a 00133.

Woessmann, L. (2008), "Efficiency and equity of European education and training policies", International Tax and Public Finance, Vol. 15, pp. 199-230, http://dx.doi.org/10.1007/s10797-008-9064-1. 
Won Han, S., F. Borgonovi and S. Guerriero (2018), "What motivates high school students to want to be teachers? The role of salary, working conditions, and societal evaluations about occupations in a comparative perspective", American Educational Research Journal, Vol. 55/1, pp. 3-39, http://dx.doi.org/10.3102/0002831217729875.

Wrzesniewski, A. and J. Dutton (2001), "Crafting a job: Revisioning employees as active crafters of their work", The Academy of Management Review, Vol. 26/2, pp. 179-201, http://dx.doi.org/10.2307/259118.

Wurzburg, G. (2010), "Making reform happen in education", in Making Reform Happen: Lessons from OECD Countries, OECD Publishing, Paris, https://dx.doi.org/10.1787/9789264086296-7-en.

Yan, R. (2019), "The influence of working conditions on principal turnover in K-12 public schools", Educational Administration Quarterly, pp. 1-34, http://dx.doi.org/10.1177/0013161X19840391. 


\section{Chapter 3. Distributing teachers, school leaders and other school staff effectively}

This chapter analyses the effective and equitable staffing of schools. All schools need competent teachers, school leaders and other staff to ensure a quality student experience. Schools however vary in their location, the student population they serve and how they are organised. As a result, they may require a different mix of staff that fits their particular context. The chapter begins by describing potential challenges in ensuring an adequate supply of high-quality staff, before discussing approaches to managing resources for the staffing of schools. It then discusses the recruitment of staff, highlighting the potential of collaboration between schools and authorities for the effective matching of staff with organisations. Finally, the chapter highlights the role of within-school sorting and the ways in which staff in schools work together to ensure high-quality teaching for all students.

The statistical data for Israel are supplied by and under the responsibility of the relevant Israeli authorities. The use of such data by the OECD is without prejudice to the status of the Golan Heights, East Jerusalem and Israeli settlements in the West Bank under the terms of international law. 
All schools need competent teachers, leaders and professional support staff to ensure a quality student experience. Schools, however, vary in their geographical location, the students and community they serve, and their organisation (e.g. specific curricular programmes and subject areas they offer at particular levels of school education). Different schools may therefore require a different mix of staff in terms of type, numbers, experience, and qualifications to support student learning and development.

This chapter analyses the effective and equitable staffing of schools which, as conceptualised in this chapter, entails the management and use of resources to create positions for employment (that is the contracting of staff) and the recruitment or hiring of specific candidates into these positions. The chapter begins with the overall supply of high-quality staff that can be recruited and employed, before discussing the resource management dimension of school staffing. It then analyses responsibilities and processes for the recruitment of staff into particular positions, highlighting the potential of collaboration between schools and education authorities for the effective matching of staff with organisations. Finally, the chapter considers the role of within-school sorting and the ways in which staff in schools work together to ensure high-quality teaching for all students (Kraft et al., 2015 [1] ; Little and Bartlett, 2010 [2]).

Shortcomings in the staffing of schools can harm both schools and students. To give a flavor of the complexities of staff distribution, the late hiring of teachers or the lack of a replacement in case of another teacher's sick or training leave can result in lost learning time for students. A shortage of teachers with specific expertise, such as advanced mathematics, can prevent schools from offering particular courses or require a teacher to instruct in a subject for which they have not been qualified. Since shortcomings in the distribution of staff may affect some schools more than others, they may also lead to inequities in opportunities for learning between students.

Particular country contexts will influence the distribution of staff. Large countries with challenging geographies or large regional disparities in socio-economic development, for example, may find it more difficult to ensure an equitable and efficient staff distribution than small and homogeneous countries (Luschei and Chudgar, 2017 ${ }_{[3]}$ ). The chapter concludes with a series of policy options that school systems may consider valuable, while recognising that local policies and implementation will need to be adapted to the particular needs of a school system.

\subsection{Inequities in the distribution of teachers and school leaders between schools}

The quantity and quality of staff working with students can vary across schools and geographical areas leading to inequities in the quality of teaching and learning. Many countries in fact struggle with inequities in the distribution of staff across schools, as a rich knowledge base has established, most notably for the case of teachers. An OECD report on effective teacher policies reviewed the international evidence on teacher sorting and selection (OECD, 2018 $\left.8_{[4]}\right)$. The review found an important body of research in the United States where inequities in the distribution of teachers have been documented at least since the early 2000s. Teachers with weaker qualifications or without certification have been found to be more likely to teach in disadvantaged schools, for example (Goldhaber, Lavery and Theobald, 2015 ${ }_{[5]}$; Jackson, 2009[6]; Boyd et al., 2008 ${ }_{[7]}$; Murnane and Steele, 2007 $[8]$; Clotfelter, Ladd and Vigdor, 2005 [9]; Lankford, Loeb and Wyckoff, $\left.2002_{[10]}\right)$. 
The report found similar emerging evidence for other countries, such as Chile, England (United Kingdom), France, Italy, Norway and Turkey (Abbiati, Argentin and Gerosa,

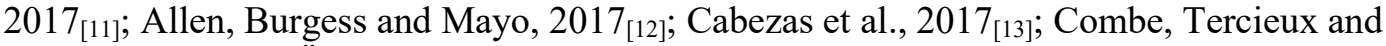
Terrier, 2016 ${ }_{[14]}$; Özoğlu, 2015 $5_{[15]}$; Bonesrønning, Falch and Strøm, 2005 $\left.5_{[16]}\right)$. The UNESCO Global Education Monitoring Report for 2013/14 similarly identified inequities in the distribution of teachers in lower income countries (UNESCO, 2014 ${ }_{[17]}$ ) as did a report for India, Mexico and Tanzania (Luschei and Chudgar, 2017 ${ }_{[3]}$ ).

An analysis of data from the OECD Programme for International Student Assessment (PISA) 2015 found that in more than a third of countries and economies participating in the assessment, teachers in the most disadvantaged schools were less qualified or experienced than those in the most advantaged schools (OECD, 2018 [4]).

Inequities in the distribution of teaching staff were also evident in a number of OECD review countries. The reviews of Colombia, Lithuania and the Slovak Republic, for instance, found inequities in the distribution of teachers for rural and small communities (Radinger et al., 2018 [18]; Santiago et al., 2016 [19]; Shewbridge et al., 2016[20]).

There is less evidence on inequities in the distribution of leadership staff, but some studies suggest that principals may sort into schools so that, similar to teachers, principals with less experience and qualifications work in more challenging contexts (Loeb, Kalogrides and Horng, 2010 $0_{[21]}$ ). Within the OECD review, the study of Uruguay identified concerns about inequities in the distribution of teacher leaders (staff who fulfil mainly administrative, but also some pedagogical tasks) across schools. Socio-economically advantaged schools had a larger number of such teacher leaders (Santiago et al., 2016 [22]). Such inequities in the distribution of leadership staff are a concern given research suggesting that effective school leadership can play a particularly important role in low-performing and disadvantaged schools (Branch, Hanushek and Rivkin, 2012 [23]; Louis et al., 2010[24]).

The distribution of staff - who represent the largest part of education expenditures influences the amount of financial resources a school and a student receive. Since the salaries of teachers and school leaders are often tied to experience and qualifications as analysed in Chapter 2, the sorting of staff with different types of qualifications and years of experience can also result in inequities in resource flows between schools, with advantaged schools receiving more funding than disadvantaged schools, for example.

When considering inequities in the distribution of school staff, one also needs to consider other features of school education, such as the degree of school choice and student sorting across schools (for an in-depth discussion of these issues, see OECD $\left(2018_{[25]}\right)$ ). Where school choice leads to segregation, this sorting of students may interact with the sorting of staff into different schools. Similarly, the extent of private provision and how it influences the labour market and distribution of staff needs to be considered (see Box 3.1). 


\section{Box 3.1. Private school provision and teacher labour markets}

It is often assumed that private schools may attract high-quality teachers away from public schools. Saying this, Hensvik (2012[26]) notes that private schools' hiring behaviour in Sweden differs from that of public schools. While they attract teachers from a different pool than public schools, her results also show that these teachers are from the higher end of the skill distribution. Behrman et al. $\left(2016_{[27]}\right)$ simulate the teacher labour force using data from Chile to show that while private schools do attract higher quality teachers, the private school sector in the school system increases the overall pool of teachers and of those of higher quality. This may also benefit public schools and improve general educational attainment. As such, competition in the school system can have ambiguous effects on the teacher labour market, though overall there is some consensus that private schools attract high-quality individuals.

Competition from private schools for teachers may also affect teachers' salaries and the distribution of education expenditure as the public school sector may have to compete to attract and retain teachers by increasing their salaries. In empirical studies for Sweden and the United States, competition from private schools raised teachers' salaries by $0.5-3 \%$, and this effect was larger for new teachers and for teachers who taught "hard-to-staff" subjects (Hensvik, 2012 [26]; Jackson, 2012 $2_{[28]}$ ). An increase in teachers' salaries may be a good thing if teachers are of a higher skill level. However, as a higher expenditure on salaries usually means a reduction of expenditure elsewhere, this cost may simply retain the same teachers or come at the cost of lower investments in other areas that also affect student outcomes. As such, the effect on student outcomes is unclear.

Inequities in the distribution of teachers and school leaders also raise questions about the extent to which these inequities contribute to achievement gaps between students. Cross-country correlations from the PISA 2015 suggest that gaps in student performance related to socio-economic status are wider when fewer qualified and experienced teachers work in socio-economically disadvantaged schools (see Figure 3.1) (OECD, 2018 [4]). However, a study from the United States found that a more equitable distribution of teachers would not substantially reduce student achievement gaps between high- and low-income students (Isenberg et al., 2016 ${ }_{[29]}$ ), which highlights the complexity of addressing student disadvantage (OECD, 2016 $\left.6_{[30]}\right)$. 
Figure 3.1. Relationship between socio-economic differences in science performance and in teacher qualifications, 2015

Socio-economic disparities in science performance and differences between advantaged and disadvantaged schools in teacher qualifications

Score-pointdifference

140
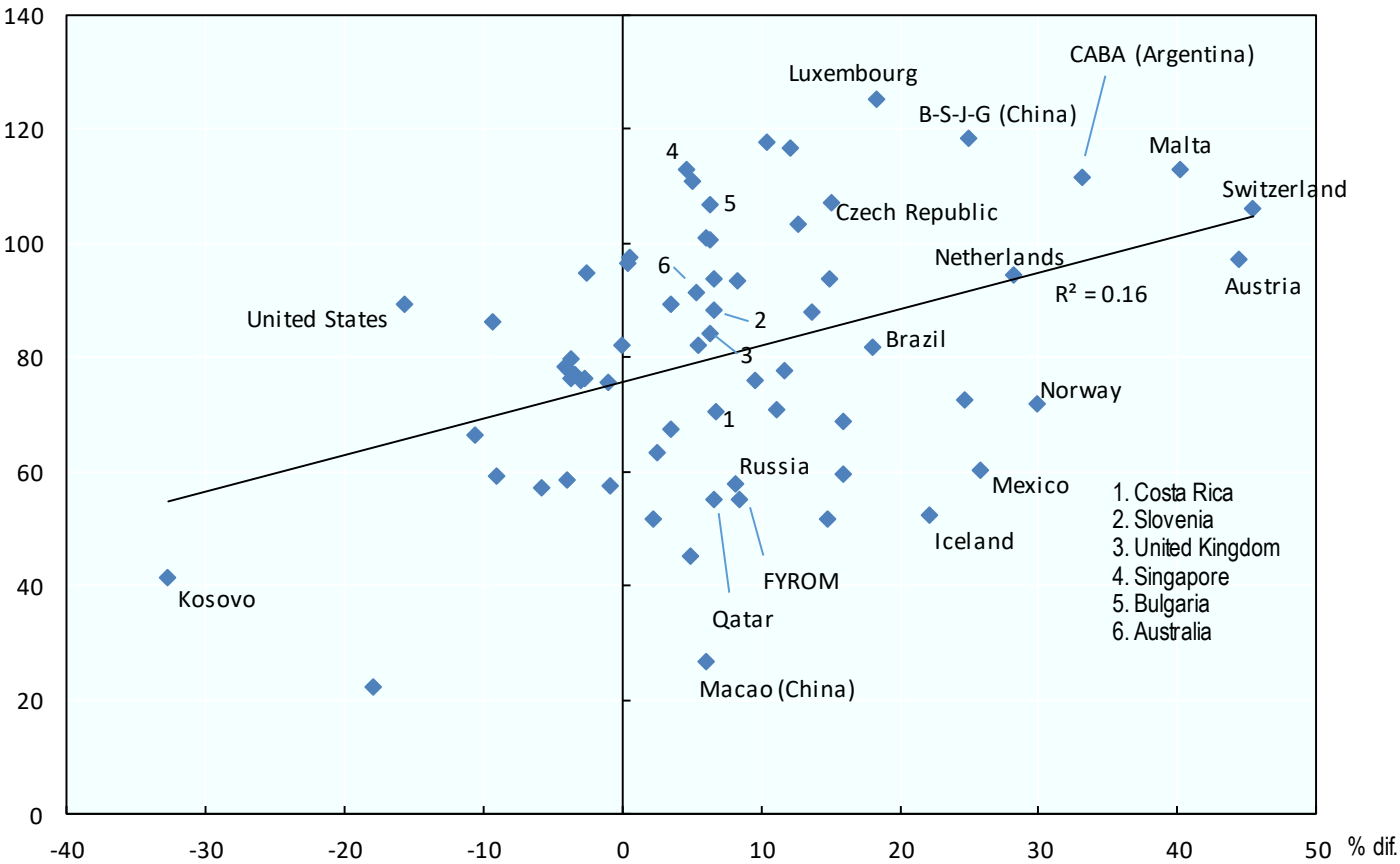

Average difference between advantaged and disadvantaged schools in the proportion of science teachers with a major in science

Notes: Countries and economies named on the chart show a significant difference between advantaged and disadvantaged schools in the proportion of science teachers with a major in science. Countries/economies where the difference is not significant are Albania, Algeria, Belgium, Canada, Chile, Colombia, Denmark, the Dominican Republic, Estonia, Finland, France, Georgia, Germany, Greece, Hong Kong (China), Hungary, Indonesia, Ireland, Israel, Jordan, Korea, Latvia, Lebanon, Lithuania, Moldova, Montenegro, New Zealand, Peru, Poland, Portugal, Romania, the Slovak Republic, Spain, Sweden, Chinese Taipei, Thailand, Trinidad and Tobago, Tunisia, Turkey, the United Arab Emirates, Uruguay and Viet Nam.

Source: OECD (2018), Effective Teacher Policies: Insights from PISA, OECD Publishing, Paris, https://doi.org/10.1787/9789264301603-en, Figure 3.13.

StatLink 제내 https://doi.org/10.1787/888934026430

\subsection{Supply of teachers, school leaders and other school staff}

Providing a high-quality and sufficiently large pool of staff that are available for recruitment and employment is the first step for making sure that schools have the staff they need. Difficulties in the overall supply of staff can result in challenges for the effective staffing of schools, and ultimately the quality of teaching and learning. For instance, it can be difficult to provide high-quality mother tongue instruction to minority students if few teachers with knowledge of a minority language enter the profession and if those that do have not been effectively prepared (Luschei and Chudgar, 2017 ${ }_{[3]}$ ). 
In Chile, indigenous students can be taught by "traditional teachers" from their own communities through a Programme for Intercultural Bilingual Education (Programa de Educación Intercultural Bilingue, PEIB) that seeks to maintain and develop indigenous languages and culture. Traditional teachers, however, often have low levels of education and often no pedagogical training which may influence the quality of instruction they are able to deliver (Santiago et al., 2017 $7_{[31]}$ ).

More generally, the nature of the pool of staff (e.g. in terms of numbers and qualifications) is shaped by the attractiveness of working conditions (Chapter 2) and professional learning systems (Chapter 4). Broader labour market conditions, such as alternative job opportunities and job security, have been found to influence the supply of new teachers (Nagler, Piopiunik and West, 2015 ${ }_{[32]}$ ), as have been education reforms linked to accountability and job security (Kraft et al., 2018[33]).

Many countries grapple with cyclical imbalances between the supply of and demand for teachers. Some school systems may find it difficult to replace a large number of teachers that are retiring or leaving the profession for other reasons, or to recruit new teachers to keep up with rising student enrolment. In others, initial teacher education may fail to provide sufficient new teachers. Teacher education may not attract sufficient candidates leaving school, student teachers may drop out before completing their teacher preparation (e.g. Denmark and Uruguay) or decide not to take up teaching after completing their studies (Nusche et al., 2016[34]; Santiago et al., 2016[22]). As a result, some countries report currently experiencing serious general shortages of teachers (e.g. Germany and Sweden) (Klemm and Zorn, 2017 [35]; Sveriges Kommuner och Landsting, 2018 [36]).

Other countries currently face the opposite problem of having to adjust the overall number of teachers to declining enrolment (e.g. Lithuania) (Shewbridge et al., 2016 ${ }_{[20]}$ ), or with teacher education institutions releasing too many graduates into the market. Shortages and oversupply however typically not only go in cycles but co-exist, as teachers are unevenly distributed across subjects and geographical areas. There are often shortages for specific subjects (e.g. mathematics or natural sciences), specialisations (e.g. special needs) and locations (e.g. rural areas or disadvantaged urban neighbourhoods).

Various school systems find it also difficult to match supply and demand for school leaders. A number of OECD review countries are facing difficulties in filling school leadership positions, and this is likely to worsen where the school leadership profession is ageing. In Austria, Colombia, Italy and Korea, more than $30 \%$ of lower secondary principals are nearing retirement (at age 60 or above), as reported for the OECD Teaching and Learning International Survey (TALIS) 2018 (see Figure 3.2) (OECD, 2019 ${ }_{[37]}$ ). School leadership is often not attractive given heavy workloads, a lack of adequate support and remuneration and uncertain career advancement prospects (see Chapter 2). School leadership in primary education and smaller rural schools may be even less attractive as there are fewer resources and administrative support to work with and as school leaders may be responsible for management and leadership while carrying a reduced teaching load. 
Figure 3.2. Principals' age (ISCED 2), 2018

Percentage of principals, by age group and average age of principals

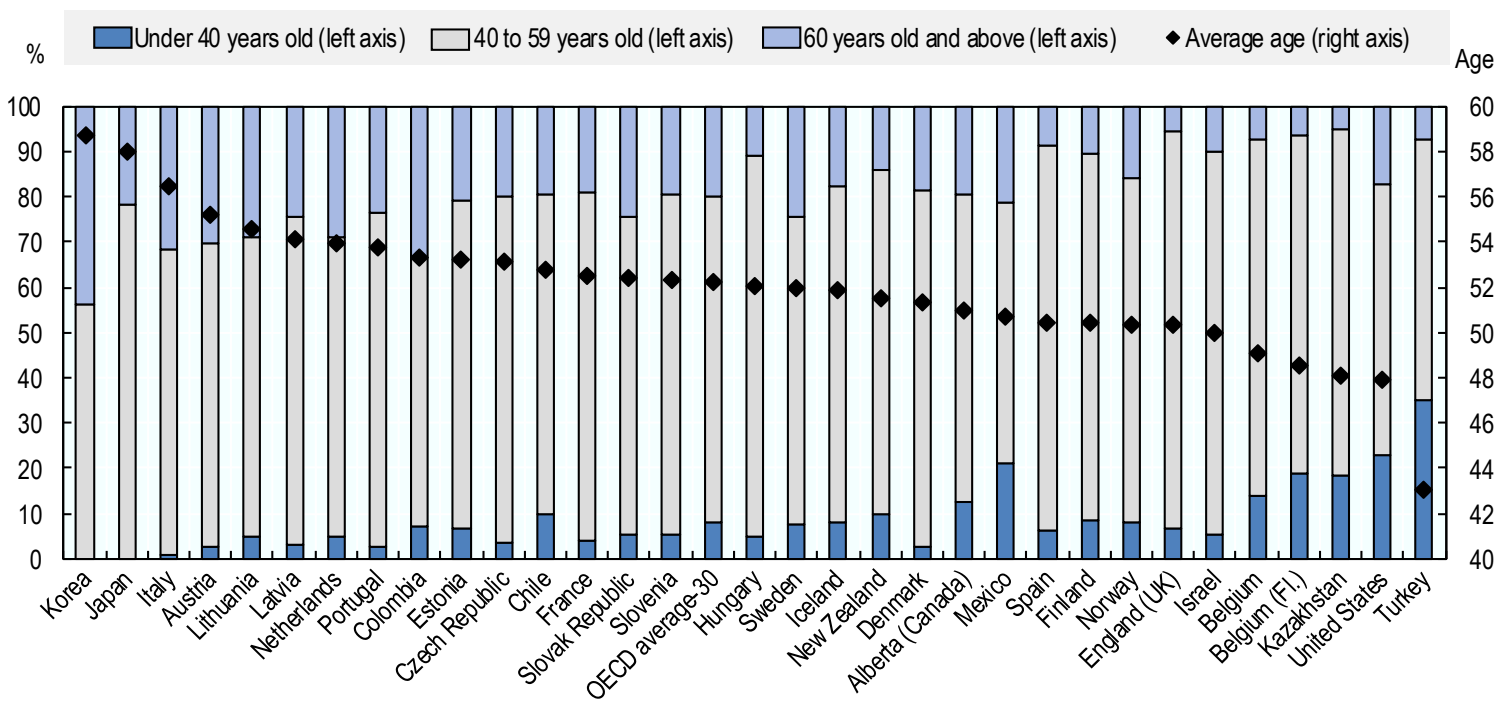

Notes: Countries and economies are ranked in descending order of the average age of principals. The number of countries or economies included in the OECD average is indicated next to that average. On 25 May 2018, the OECD Council invited Colombia to become a Member. While Colombia is included in the OECD average reported in this figure, at the time of its preparation, Colombia was in the process of completing its domestic procedures for ratification and the deposit of Colombia's instrument of accession to the OECD Convention was pending.

Source: OECD (2019), TALIS 2018 Results (Volume I): Teachers and School Leaders as Lifelong Learners, OECD Publishing, Paris, https://doi.org/10.1787/1d0bc92a-en, Figure I.3.2.

StatLink त्गाड़ https://doi.org/10.1787/888934026449

It is essential to take into account changes to framework conditions affecting supply or demand, and to then reflect this in initial preparation and continuing professional learning. For supply, this includes policies related to retirement age and working time, such as teaching load requirements or part-time work, among others. For demand, this refers to changes to students' learning time (e.g. full-day schooling), class size limits or curriculum reforms. In Ireland, for example, new curriculum initiatives related to computer science; science, technology and mathematics (STEM); and foreign languages together with an increase in student numbers in secondary education have created challenges for the adequate supply of qualified teachers (The Teaching Council, 2015[38]).

Also for professional support staff, school systems may experience supply challenges. For the case of school psychology, an analysis of available data in the United States suggests a continued, although likely declining, shortage of school psychologists, which may also limit the field's capacity to deliver or support more comprehensive services beyond needs assessments (Castillo, Curtis and Tan, 2014 ${ }_{[39]}$ ). As the study highlighted, framework conditions like changes in legislation, funding or service delivery models may have an important impact on supply and demand.

In Estonia, shortages of specialised support staff were found to limit educational opportunities for children with special educational needs (SEN) (Santiago et al., 2016 [40]). As for teachers, broader framework conditions affect demand and supply. In countries like 
Austria, the Czech Republic and Denmark, extended learning time policies and the inclusion of students with special educational needs (SEN) have changed the need for different types of staff working in schools throughout the school day (see Chapter 1) (Nusche et al., 2016 [41]; Nusche et al., 2016[34]; Shewbridge et al., 2016 ${ }_{[42]}$ ).

The next sections discuss the role of forecasting mechanisms to steer the overall supply and composition of the teacher population and strategies countries have pursued to alleviate shortages or manage oversupply.

\subsubsection{Forecasting the need for and supply of teachers}

While general labour market monitoring often provides some information on the balance between teacher supply and demand, a number of countries have specific mechanisms to forecast the need and supply of teachers in school education.

\section{Responsibilities}

Forward planning of the overall supply and demand of teachers is typically carried out at higher levels of administration, even where other education authorities or schools are responsible for employing their staff. Information from such forward-planning processes can then provide the basis for centrally steering the number of new teachers and adjusting competency profiles to the changing needs of schools (e.g. through changes to entry requirements or investments in initial teacher preparation and professional development).

In federal systems, individual states are typically responsible for forecasting and planning teacher supply and demand for their system. In the United States, for example, states have developed teacher supply and demand reports or funded related task forces in response to requirements set by their state legislature (Behrstock-Sherratt, 2016 $6_{[43]}$ ). In Austria, responsibilities for teacher employment, monitoring and data management have been split between federal and provincial authorities for the different school types that they are responsible for. As the OECD review found, this made forecasting and planning challenging and required substantial co-ordination, with no authority assuming responsibility for teacher supply for the school system as a whole (Nusche et al., 2016 ${ }_{[41]}$ ).

Some federal systems have made efforts to harmonise available data and to making them available on a national level:

- In Australia, the Australian Institute for Teaching and School Leadership has been tasked to implement an Australian Teacher Workforce Data Strategy for 2022. This strategy seeks to combine existing data on initial teacher education (such as the national Initial teacher education data report series with data on initial teacher education applicants, students and graduates) and the teaching profession to provide a comprehensive picture at the national level, enable supply pipeline modelling for workforce planning and increase the understanding of teacher career trajectories (AITSL, 2018 ${ }_{[44]}$ ).

- In Germany, individual states collect data on the demand and supply of teachers within their jurisdiction, while the Standing Conference of the Ministers of Education and Cultural Affairs combines these data into a national forecast (KMK, $\left.2018_{[45]}\right)$. 
- In Austria, some of the above-mentioned concerns have been addressed since the review through the introduction of a uniform personnel data management system which records information on the number of students and classes, and teachers' subjects, classroom assignments and tasks that are part of their teaching load (BMBWF, 2019 $[46])$.

In school systems with dedicated regulatory authorities for the teaching profession, these authorities may play a leading role in forward planning. In Ireland, the Teaching Council (the country's professional standards body for teaching) has within its remit to advise the education ministry on teacher supply issues. Between 2014 and 2015, the council led a technical working group to inform future planning and develop a teacher supply model (The Teaching Council, 2015 [38]).

In the province of Ontario (Canada), the College of Teachers (the province's self-regulatory body of the teaching profession), supports forecasting and steering with information on the demographic characteristics of the current workforce. The college surveys its members on an annual basis and the resulting report Transitions to Teaching provides information on teachers' initial and additional qualifications earned throughout their career. Based on these data, the province can anticipate teacher qualification needs and gear admissions accordingly (Ontario College of Teachers, 2018 ${ }_{[47]}$ ).

As both cases illustrate, higher education authorities may also be involved in monitoring and forecasting. In Ireland, the technical working group included representatives of the Higher Education Authority, while in Ontario, the province's Higher Education Quality Council provides research and policy advice, including on labour market trends and outlooks for teaching (HEQCO, 2019[48]; The Teaching Council, 2015 ${ }_{[38]}$ ).

\section{Processes}

Forward planning can provide information for the short, medium or long term and use different types of data to forecast supply and demand. Given the time it can take for measures to steer supply to take effect, forward planning ideally takes place for the medium to long term (European Commission, EACEA and Eurydice, 2018 [49] $)$. Data that are used for forecasting may answer questions such as those related to students' success in finding a job, the number and qualifications of teachers, out-of-field teaching, teaching loads and types of contract, or teachers intending to retire or leave the profession.

Based on a report by Eurydice, data in Europe most often relate to retiring teachers, teacher demographics, teachers by taught subject(s) and teachers leaving the profession (other than for retirement reasons). The majority of European countries also use data on the likely demand for teachers, which is mostly based on student population growth projections. Many countries go further by using data on the subjects that these teachers will need to teach, thus having a clearer picture of the type of investment required in initial teacher education. Although data on prospective teachers is used less often, nearly half of the countries take into account data on the number of initial teacher education students and graduates by specialisation. Such data on student teachers is however not straightforward to use as it is difficult to predict whether or when graduates will subsequently enter the teaching profession (European Commission, EACEA and Eurydice, 2018, pp. 24-27 [49]).

The size of school systems and the teaching profession make it difficult to forecast and steer the teacher labour market effectively, and the persistence and cyclical nature of shortages and oversupply also raises questions about forward-planning processes and the effectiveness of policy responses. The Eurydice report found that "it is interesting to see 
that many education systems face similar challenges with regard to teacher supply and demand, whether they carry out forward planning or not" (European Commission, EACEA and Eurydice, 2018, p. 31 [49]).

In terms of forecasting mechanisms, there are questions about the right conceptualisation and definition of teacher supply issues (e.g. acceptable levels and benchmarks of teacher shortage and attrition; choice of indicators to describe teacher shortages, such as number of applicants per vacancy, applicants interviewed, share of school leaders reporting shortages). Lastly, there is a question about the presentation of complex data in a digestible and actionable way (Behrstock-Sherratt, 2016[43]).

\subsubsection{Strategies to address specific challenges related to teacher shortages}

Depending on the particular challenges of a country, education authorities, teacher education institutions and schools may take specific steps for the long term or the short term, within broader efforts to make teaching attractive as highlighted in Chapter 2.

\section{Long-term strategies}

For the long term, strategies can target initial teacher education - both institutions and student teachers - and practicing teachers. For institutions, this entails the regulation of programmes and the funding of study places. Initial teacher education needs to be properly scaled. Adequate regulatory frameworks for teacher education institutions and the programmes they offer facilitate the monitoring and steering of the potential supply of teachers from initial teacher education. Where regulations are weak, more or less teachers may be being prepared than are actually needed, few new teachers may be available for scarce fields and too many for already saturated areas (Ávalos, 2008 ${ }_{[50]}$ ).

The cases of Denmark and Portugal illustrate the role of funding for initial teacher education. In Denmark, higher education is funded based on student numbers, which provides a strong incentive for teacher education institutions to enrol a large number of students. At the time of the review, the number of study places had reportedly not been adjusted sufficiently to declining demand, and institutions enrolled student teachers that were not adequately prepared for their studies. Changes to admissions procedures described below reportedly helped to address these concerns (Nusche et al., 2016 [34]). In Portugal, on the other hand, the universalisation of basic education in the 1980s resulted in shortages, which were countered with an expansion of higher education institutions offering education degrees and the certification of large numbers of new teachers (Liebowitz et al., 2018 [51]).

The funding and regulation of initial teacher education also has a role to play for preparing teachers for particular high-need areas. Research from different contexts suggests that teachers prefer to work close to their homes, families and friends, even when they gain their initial teaching qualification far from home (Prost, 2013 [52]; Jaramillo, 2012 [53]; Reininger, 2012 [54]; Barbieri, Rossetti and Sestito, 2011 $1_{[55]}$ ).

For example, Boyd et al. $\left(2005_{[56]}\right)$ found that $85 \%$ of new teachers who entered public school teaching in New York State between 1999 and 2002 took their first job in schools located within 40 miles of their hometowns. Women who make up a large share of the teaching profession in many countries have been found to be more likely to prefer working close to home and within their own communities (Engel and Cannata, 2015[57]). This research suggests that teacher labour markets are geographically relatively small and the pool of prospective teachers available to work in a given school is rather limited. 
In rural and remote areas, "Grow your own" strategies can therefore play an essential role for meeting the demand for teachers (Echazarra and Radinger, 2019 ${ }_{[58]}$ ). In Uruguay, regional teacher education institutions (Centros Regionales de Profesores, CERP) were created in the late 1990s across the country to widen access to teacher education and increase teacher supply for an expanding secondary system (Santiago et al., 2016 [22]). In Colombia, higher teaching schools (Escuelas Normales Superiores, ENS) play an important role in supplying teachers for pre-primary and primary education in more rural parts of the country (Radinger et al., 2018 $\left.{ }_{[18]}\right)$. And in Mexico, Leaders for Community Education play an important role as learning facilitators in educational models operated by a dedicated agency (Consejo Nacional de Fomento Educativo, CONAFE) to provide education to very small and remote communities (Echazarra and Radinger, 2019 [58]).

For individual student teachers, policy may consider admission processes and financial (and other) support. Admission processes may help students in the decision to enrol in initial teacher education and help reduce drop-out. In Denmark, the application process to initial teacher education programmes underwent some changes to identify students who potentially would have difficulty completing their programme. Reportedly, this has somewhat reduced the dropout rate in initial education (Nusche et al., 2016 [34]), although it may also have led to shortages in specific areas (e.g. rural parts of the country).

Support, for example in the form of scholarship programmes, may help attract students into particular areas of shortages such as specific curriculum expertise or help students complete their studies and again address issues of drop-out of initial teacher education. In the Netherlands, financial incentives, such as scholarships and subsidies, are provided for students in shortage subjects such as languages and science to enter teacher education (OECD, 2019[59]). Similarly, in the Slovak Republic, a scholarship scheme has been established to increase the supply of students for specific fields, including physics, chemistry, mathematics, information and communication technology (ICT), geography and biology (Santiago et al., 2016 ${ }_{[19]}$ ). In Kazakhstan, scholarship programmes seek to attract student teachers to rural areas (OECD/The World Bank, 2015 $[60])$.

In Uruguay, the education authorities have been providing scholarships (Uruguay Estudia and Becas Julio Castro) to stimulate the retention of teacher candidates who are close to completing their studies. This may be a particular issue given that student teachers in Uruguay often see themselves required to work while studying to finance their education (Santiago et al., 2016 [22] ), something that was also identified as a challenge for teacher education in Colombia (Radinger et al., 2018 $\left.{ }_{[18]}\right)$. More broadly, scholarship programmes may serve to raise the profile of initial teacher education and to attract highly skilled candidates into teacher education (see Box 3.2).

Given that attrition from the profession tends to be higher in the first years of the teaching career, it is essential to recognise the transition into teaching as a crucial part of the professional learning process and, accordingly, assign early career teachers a special learning status with corresponding support mechanisms (Paniagua and Sánchez-Martí, $2018_{[61]}$ ). Initial teacher education should incorporate special preparation for the teaching of particular students to support teacher graduates' smooth transition into employment in high-need areas (OECD, 2019 [59]). Initial teacher preparation for particular student populations is discussed in depth in Chapter 4.

Policy may furthermore consider the current teacher population. In Belgium, authorities have mostly responded to teacher shortages and demographic developments with changes to the age of retirement and a phasing out of early retirements, which has also led to savings 
for the federal budget between 2013 and 2016 (Ministère de la Fédération WallonieBruxelles, 2016[62]; Flemish Ministry of Education and Training, 2015 [63] $)$.

\section{Short-term strategies}

For the short term, measures that are commonly discussed include increases in teaching load and class sizes, but their effect on the supply and retention of teachers is unclear (Santiago, 2002 $[64])$. Also, retired teachers have been reactivated where no teachers could be found, as has been the case in Sweden and Estonia (Sveriges Kommuner och Landsting, 2018[36]; Santiago et al., 2016[40]).

Some countries have turned to recruiting teachers from abroad, which requires the recognition of professional qualifications and competences. Teachers may be recruited through dedicated agencies, or come independently to a country. Many large flows are between countries with linguistic and cultural connections. Teachers from other English-speaking countries, in particular the United Kingdom, are among the largest group in Australian schools, while Australians are well represented in the UK teaching population, for example. There are also specific programmes that place native-speaking language instructors in public schools in many European countries (UNESCO, 2018 [65]).

Recruitment of international teachers can have benefits for individuals and schools, for instance through diversity in the profession. But it also carries risks. The loss for sending countries can be considerable, both in terms of their investment in the education of these professionals and for their school system as a whole (UNESCO, 2018 $8_{[65]}$; Bense, 2016 $6_{[66]}$ ).

The international dimension of teacher labour markets was also evident in some OECD reviews. In the Flemish Community of Belgium, larger cities with difficulties to recruit sufficient teachers have launched recruitment campaigns also in the Netherlands to fill teaching positions (Flemish Ministry of Education and Training, 2015 [63]). Austria illustrates the other side of the coin, with the province of Vorarlberg reportedly competing for teachers with neighbouring Switzerland and the working conditions offered there (Nusche et al., 2016[41]).

Alternative entry routes provide additional flexibility to respond to increasing student numbers or to respond to a teacher shortage in specific subjects. Alternative entry has also been tried as a strategy to make teaching more attractive for those who would otherwise not be interested in teaching (see Chapter 4). Alternative entry may arguably broaden the range of backgrounds and experiences in schools and provide access to teaching for individuals at different stages of their lives and in different life circumstances (OECD, $\left.2005_{[67]}\right)$. At the same time, alternative entry raises questions as to whether teachers recruited via such pathways are as effective as conventional teachers - teaching is complex and intellectually demanding which requires expertise, discretion and judgement (Zeichner, $\left.2014_{[68]}\right)$ - and whether teachers who enter through an alternative pathway then remain in teaching (Little and Bartlett, 2010 [2]).

Changes to entry requirements may also help address short-term shortages in leadership positions. In Chile, school principal positions have been opened for teachers with less experience to respond to difficulties in filling leadership positions, as long as candidates hold a certain level of education (Santiago et al., 2017[31]). 


\section{Box 3.2. Scholarships to attract high-quality candidates into teaching}

\section{Chile}

The Teacher Vocation Scholarship (Beca Vocación de Profesor, BVP) provides academically talented secondary education graduates with a scholarship and other benefits if they choose teacher education as a higher education degree and teach in a publicly-funded school for at least three years. The extent of the benefit depends on the score obtained in the university selection test (Prueba de Selección Universitaria, PSU). In 2015, 9413 scholarships were awarded. A further initiative is the Choose to Teach (Elige Educar) campaign. This is a partnership between the education ministry and a non-governmental organisation, which seeks to promote teaching through a variety of actions, including scholarships for individuals with experience outside education who would like to teach, and interventions to raise awareness of the importance of teaching as a profession.

Source: Santiago, P., A. Fiszbein, S. García, T. Radinger (2017), OECD Reviews of School Resources: Chile 2017, OECD Publishing, Paris, http://dx.doi.org/10.1787/9789264285637-en.

\section{Estonia}

To address concerns that teacher education is not a very popular choice among upper secondary graduates, the government has started a range of programmes to raise the value of the teaching profession. A scholarship programme seeks to motivate students with talent for teaching to apply to teacher education specialisations and to acquire a teaching qualification. An allowance for beginning teaching is paid to students who enter the profession within 18 months of completing their education. Recently, the programme has been extended to professional support specialists. Also the Youth to School programme (Noored Kooli) seeks to raise interest in teaching and education by awarding scholarships to a select group of university students who teach at school for two years while taking part in teaching and leadership training. Upon completion of the programme, students can keep working at school, return to university or work elsewhere.

Source: Estonian Ministry of Education and Research (2015), OECD Review of Policies to Improve the Effectiveness of Resource Use in Schools: Country Background Report for Estonia, Estonian Ministry of Education and Research, Tartu, http://www.oecd.org/education/schoolresourcesreview.htm.

\section{Lithuania}

The Ministry of Education, Science and Sport as well as other actors in the school system have recognised that teaching is not currently perceived as an attractive profession and that high-performing graduates are reluctant to choose teaching as a career. On this basis, a range of promising initiatives have been put in place to make teaching more attractive.

In order to attract young talented people to initial teacher education, the government established a targeted teacher education scholarship in 2010 to support the acquisition of teaching qualifications for students having demonstrated good academic achievements. The government has also implemented a programme (I Choose to Teach!), to attract recent university graduates from different disciplines to work in schools. This programme was started with European Union (EU) funding and is now managed by the School Improvement Centre with business support. Programme participants receive tailored professional development to help them develop their teaching skills. Also, to attract high-performing students from a range of disciplines, the government provides funding for 400 student teacher places that are attributed based on the completion of a motivation test.

Source: Shewbridge, C., K. Godfrey, Z. Hermann, D. Nusche (2016), OECD Reviews of School Resources: Lithuania 2016, OECD Publishing, Paris, http://dx.doi.org/10.1787/9789264252547-en. 


\subsection{Management and use of resources for school staffing}

As highlighted in Chapter 1, school systems employ a diverse range of staff in different roles. This includes:

- staff responsible for school leadership and instruction, notably school leaders and teachers but also teacher aides

- professional pedagogical, health and social support staff

- administrative, maintenance and operations staff (UNESCO-OECD-Eurostat, 2018, pp. 43-48[69]).

Which types of staff are employed depends on a number of factors, notably also the definition of roles and responsibilities of different staff, including those of teachers and school leaders. While teachers' roles are broad and complex everywhere, there are differences in the non-teaching activities that are defined in regulations. In some contexts, teachers may have a reduction of their teaching responsibilities to carry out specific roles which may be part of their career progression as discussed in Chapter 2. Several OECD review countries have, for example, diversified teachers' careers on a horizontal level to build school capacity and expertise in a specific area.

Also school leaders' roles and responsibilities differ, which will shape the other types of staff that are required in schools. In some countries, school leaders hold teaching responsibilities; in others, they dedicate themselves fully to school management to name just one difference across countries (also see Annex 1.A in Chapter 1).

The staffing of schools entails essentially tasks and responsibilities related to i) the management and use of resources to create positions for employment (that is contracting staff) and ii) recruitment to select specific candidates into these positions. The following sections analyse the management and use of resources for staff employment, while section 3.4 analyses staff recruitment.

\subsubsection{Responsibilities for managing staff budgets and employment}

The mix of staff that are employed for individual schools in terms of numbers and profiles will depend on the distribution of responsibilities for staff employment, that is for establishing the employment contract, covering the payroll and managing the related budget. Those acting as employers decide how to use available resources within their competence, and to plan staffing levels and mix based on their needs and levels of funding.

The employment of staff typically involves multiple actors. For example, schools may be responsible for employing their teaching and school leadership staff, while the local authority employs administrative staff and maintenance personnel, and the central authority provides and employs professionals for social support. Table 3.1 shows the distribution of responsibilities for the employment of different types of staff in public schools and the management of the related budgets for staffing in OECD review countries.

As the table illustrates, school leaders in lower secondary education are usually employed at higher levels than the school, but in a number of countries, other school leaders may be employed directly by schools (e.g. deputy principals in the Czech Republic). Teachers and teacher aides (where these types of staff exist) are most commonly employed at an intermediate level; in only six out of 19 review countries with available data are instructional staff employed by central or, in the case of federal systems, the state level. In another six systems, instructional staff are employed by schools. 
In some OECD review countries, different authorities are responsible for the employment of professional support staff (e.g. schools in Denmark and Portugal rather than local and central education authorities respectively). As the experience of OECD review countries furthermore shows, responsibility for employment of particular staff can depend on the legal status of a school (e.g. the Slovak Republic) and be shared between authorities (e.g. for administrative, maintenance and operational staff in provincial schools in Austria).

In school systems where education authorities above the school level are responsible for staff employment, schools typically receive "in-kind" staff allocations. Austria and Uruguay illustrate this approach with direct staff allocations. In school systems where schools are themselves responsible for staff employment, schools typically receive monetary resources that they can then use to hire and employ their own staff. This is for instance the case in the Czech Republic, Iceland, Lithuania and Slovenia.

Table 3.1. Responsibility for school staff employment (ISCED 2), 2018

OECD review countries, public schools

\begin{tabular}{|c|c|c|c|}
\hline Staff type & Central or state level & $\begin{array}{l}\text { Regional/local/other intermediate } \\
\text { level }\end{array}$ & School level \\
\hline Leadership staff & $\begin{array}{l}\text { Austria, Mexico, Portugal, Spain, } \\
\text { Turkey, Uruguay }\end{array}$ & $\begin{array}{l}\text { Belgium (FI. and Fr.), Chile, } \\
\text { Colombia, Czech Republic } \\
\text { (principal), Denmark, Estonia } \\
\text { (principal), Iceland, Kazakhstan, } \\
\text { Lithuania (principal), Mexico, Slovak } \\
\text { Republic (principal), Sweden }\end{array}$ & $\begin{array}{l}\text { Czech Republic (deputy principal), } \\
\text { Estonia (head of studies), Lithuania } \\
\text { (other leaders), Slovak Republic } \\
\text { (other leaders), Slovenia }\end{array}$ \\
\hline Instructional staff & $\begin{array}{l}\text { Austria, Mexico, Portugal, Spain, } \\
\text { Turkey, Uruguay }\end{array}$ & $\begin{array}{l}\text { Belgium (Fl. and Fr.), Chile, } \\
\text { Colombia, Denmark, Iceland, } \\
\text { Mexico, Sweden }\end{array}$ & $\begin{array}{l}\text { Czech Republic, Estonia, } \\
\text { Kazakhstan, Lithuania, Slovak } \\
\text { Republic, Slovenia }\end{array}$ \\
\hline Prof. support staff & $\begin{array}{l}\text { Austria, Mexico, Spain, Turkey, } \\
\text { Uruguay }\end{array}$ & $\begin{array}{l}\text { Chile, Colombia, Iceland, Mexico, } \\
\text { Sweden }\end{array}$ & $\begin{array}{l}\text { Czech Republic, Denmark, Estonia, } \\
\text { Iceland, Kazakhstan, Lithuania, } \\
\text { Portugal, Slovak Republic, Slovenia }\end{array}$ \\
\hline Administrative staff & Austria, Spain, Turkey, Uruguay & $\begin{array}{l}\text { Austria (provincial schools), Belgium } \\
\text { (Fl. and Fr.), Chile, Colombia, } \\
\text { Mexico, Portugal, Sweden }\end{array}$ & $\begin{array}{l}\text { Czech Republic, Denmark, Estonia, } \\
\text { Iceland, Kazakhstan, Slovak } \\
\text { Republic, Slovenia }\end{array}$ \\
\hline $\begin{array}{l}\text { Maintenance and } \\
\text { operations staff }\end{array}$ & Austria, Spain, Turkey, Uruguay & $\begin{array}{l}\text { Austria (provincial schools), Belgium } \\
\text { (Fl. and Fr.), Chile, Colombia, } \\
\text { Mexico, Portugal, Slovenia, } \\
\text { Sweden, Turkey }\end{array}$ & $\begin{array}{l}\text { Czech Republic, Denmark, Estonia, } \\
\text { Iceland, Kazakhstan, Lithuania, } \\
\text { Slovak Republic, Slovenia }\end{array}$ \\
\hline
\end{tabular}

Notes: The employer is the natural or legal person with whom the employee has an employment relationship. Instructional staff includes teachers and teacher aides. Professional support staff includes pedagogical, health and social support. For complete definitions of staff types, see the Glossary in Annex B; for detailed country profiles of school staffing, see Annex 1.B in Chapter 1; for full comparative tables, see Tables A.1. and A.2. in Annex A. For teacher aides and professional support staff, the table describes employment responsibilities for those staff which exist within countries' regulations. For professional support staff, the table primarily illustrates staff positions that can be created directly in schools rather than in dedicated resource centres that serve multiple schools. In Belgium (Flemish and French Communities), for example, professional support staff is provided by state authorities through centres for student guidance and psychological, medical and social services respectively, which are not included in this table.

Sources: Based on Country Review Reports, Country Background Reports (http://www.oecd.org/education/school-resources-review) and Descriptions of National Education Systems by Eurydice (https://eacea.ec.europa.eu/national-policies/eurydice/national-description en).

As the examples of Chile, Denmark and Sweden however illustrate, even if staff are formally employed at a level above the school, the employer may delegate responsibilities and provide some or all schools with financial resources to manage their own budgets. In 
Denmark, for example, primary and lower secondary schools often receive funding from their municipality, which they can use to determine their staffing levels and mix. Schools have typically used their resources to hire a broad range of professionals: from social workers, psychologists and pedagogues to counsellors for behaviour, social inclusion and well-being (Adfcerd-Kontakt-Trivsel, AKT) (Nusche et al., 2016[34]).

The reverse can also be true and the formal employer may be supported by a higher level in the administration of financial resources. In the Flemish Community of Belgium, for example, staff are employed by school providers which receive resources in the form of staffing hours, distribute these allocated hours between their schools and hire the required instructional and professional support staff (e.g. special needs co-ordinator, ICT co-ordinator, child care workers). Salaries of teaching and school leadership staff are, however, paid centrally through an educational services agency (Agentschap voor Onderwijsdiensten, AgODI) (Nusche et al., 2015 $5_{[70]}$ ). This may reduce the administrative burden for school providers and facilitate monitoring and oversight over staff expenditures.

Staff may be recruited by the same entity which establishes the employment contract and makes decisions about the use and allocation of resources. Or a different authority may be responsible for hiring (see Table 3.2). The authority responsible for recruitment may also depend on the contract status awarded to teachers. In Colombia, Portugal and Turkey, for example, regional/local authorities or schools are responsible for recruiting temporary teaching staff, while permanent staff is hired at the central level. Staff recruitment is discussed in depth further below.

Table 3.2. Responsibility for employing and recruiting teachers (ISCED 2), 2018

OECD review countries, public schools

\begin{tabular}{|c|c|c|c|c|}
\hline \multirow{5}{*}{ 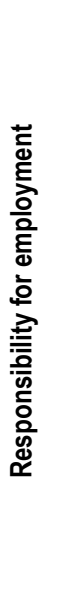 } & \multicolumn{4}{|c|}{ Responsibility for recruitment } \\
\hline & \multirow{3}{*}{$\begin{array}{l}\text { Central or state level } \\
\text { Regional/local/other } \\
\text { intermediate level }\end{array}$} & \multirow{2}{*}{$\begin{array}{l}\text { Central or state level } \\
\text { Austria, Mexico, Portugal } \\
\text { (permanent teachers), } \\
\text { Spain, Turkey (permanent } \\
\text { teachers), Uruguay }\end{array}$} & \multirow{2}{*}{$\begin{array}{l}\text { Regional/local/other } \\
\text { intermediate level } \\
\text { Turkey } \\
\text { (temporary teachers) }\end{array}$} & \multirow{2}{*}{$\begin{array}{l}\text { School level } \\
\text { Portugal } \\
\text { (temporary teachers) }\end{array}$} \\
\hline & & & & \\
\hline & & $\begin{array}{l}\text { Colombia (permanent } \\
\text { teachers), Mexico }\end{array}$ & $\begin{array}{l}\text { Belgium (FI. and Fr.), } \\
\text { Chile, Colombia } \\
\text { (temporary teachers), } \\
\text { Denmark, Sweden }\end{array}$ & Iceland \\
\hline & School level & & & $\begin{array}{l}\text { Czech Republic, Estonia, } \\
\text { Kazakhstan, Lithuania, } \\
\text { Slovak Republic, Slovenia }\end{array}$ \\
\hline
\end{tabular}

Notes: For full comparative tables on teacher employment, see Table A.1. in Annex A; for full comparative tables on teacher recruitment, see Table A.3. in Annex A.

Sources: Based on Country Review Reports, Country Background Reports (http://www.oecd.org/education/school-resources-review) and Descriptions of National Education Systems by Eurydice (https://eacea.ec.europa.eu/national-policies/eurydice/national-description_en).

Which additional staff resources may be available to schools?

Besides the staff resources that schools receive for operating and providing education, be it in the form of monetary transfers or "in-kind" human resource allocations, schools (and 
their staff, students and parents) may also be able to draw on staff provided through dedicated resource centres, or benefit from shared staffing allocations that work in multiple schools, and/or expertise provided from sources other than the education sector.

As Table 3.3 shows, a number of school systems provide specialised professional pedagogical, health or social support staff through such resource centres (see Box 3.3 for some more specific examples and Annex 1.B in Chapter 1 for country profiles). Such specialised staff can be provided in addition to or in lieu of staff working directly in schools. In the Czech Republic, Denmark, Estonia, Lithuania, Portugal, the Slovak Republic and Slovenia, resource centres are available in addition to specialist staff in school. Specialised staff resources may also be pooled at the discretion of education authorities. This is for example the case in Spain and Sweden, where local and state authorities respectively may allocate staff to work directly in schools or decide to organise centralised support services.

Of course, externally employed staff can still work closely with and in schools, for instance where staff from specialised resource centres work in different schools for some part of their working week. This may be the case for the psychological and paramedical staff working in Centres for Student Guidance (Centrum voor Leerlingenbegeleiding, CLB) in the Flemish Community of Belgium, for instance, which may have agreements with schools for staff to be present during school hours. Similarly, in the French Community, the staff of Centres for Psychological, Medical and Social Services (Centre Psycho-Médico-Social, CPMS) play an important role within schools, collaborating closely with teachers and school principals.

Moreover, schools may be able to draw on professionals providing advice on school development or coaching for teachers (which is discussed in Chapter 4). In Denmark, some municipalities, as well as the education ministry, provide learning consultants which schools can call upon for specialised advice (e.g. the use of data for improvement and change management) (Nusche et al., 2016 [34] $)$.

Similar professional bodies are in place in the Flemish Community of Belgium (Pedagogical Advisory Services of umbrella organisations of school boards), Lithuania (network of education consultants accredited by the national Education Development Centre) and Slovenia (pedagogical advisors provided through the National Education Institute) (Nusche et al., 2015 $[70]$; Shewbridge et al., 2016[20]; Slovenian Ministry of Education, 2017 [71]).

In Chile, schools (and school providers) can seek the advice of the education ministry's public technical-pedagogical consultants (Asesoría Técnica Pedagógica, ATP) on a range of issues, such as the planning of improvement strategies and the implementation of their school improvement plan. In addition, they are encouraged to contract (and pay for) private advisory services and their staff (Agencia de Asistencia Técnica Educativa, ATE), for example for advice on curriculum management, school leadership, coexistence and educational resources management (Santiago et al., 2017 [31]).

Lastly, other government agencies or authorities may provide specialised professional staff, such as for student health and well-being or career guidance. In Iceland, health staff is provided by the ministry of health, for example. In Colombia, the country's Institute of Family Welfare (Instituto Colombiano de Bienestar Familiar, ICBF) provides programmes and strategies that target risk factors for students such as child labour, teenage pregnancy and recruitment into armed groups (Radinger et al., 2018 ${ }_{[18]}$ ). Career guidance services in Austria, the Czech Republic, Estonia, Slovenia and Uruguay are also provided by authorities responsible for labour and/or social affairs (see Box 3.4). 
Table 3.3. Professional support staff provided through resource centres (ISCED 2), 2018

OECD review countries, public schools

\begin{tabular}{lcc}
\hline Country & Pedagogical support & Health and social support \\
\cline { 2 - 3 } Austria & $\mathrm{x}$ & Yes \\
Belgium (FI.) & Yes & Yes \\
Belgium (Fr.) & Yes & Yes \\
Chile & $\mathrm{x}$ & $\mathrm{x}$ \\
Colombia & $\mathrm{x}$ & $\mathrm{x}$ \\
Czech Republic & Yes & Yes \\
Denmark & Yes & Yes \\
Estonia & Yes & Yes \\
Iceland & $\mathrm{x}$ & Yes \\
Kazakhstan & $\mathrm{x}$ & $\mathrm{x}$ \\
Lithuania & Yes & Yes \\
Mexico & Yes & Yes \\
Portugal & $\mathrm{x}$ & Yes \\
Slovak Republic & Yes & Yes \\
Slovenia & Yes & Yes \\
Spain & $\mathrm{x}$ & Yes \\
Sweden & $\mathrm{x}$ & Yes \\
Turkey & $\mathrm{x}$ & $\mathrm{x}$ \\
Uruguay & $\mathrm{x}$ & $\mathrm{x}$ \\
\hline
\end{tabular}

Notes: Resource centres refer to institutions operated by education authorities that provide centralised services and specialised staff, typically to ensure the effective delivery of related services to schools and communities. In Spain and Sweden, health and social support centres may be organised by state and local education authorities respectively at their own discretion. For detailed country profiles on staff employment, see Annex 1.B in Chapter 1; for full comparative tables on the provision of professional support staff see Table A.2. in Annex A. $\mathrm{x}$ : not applicable

Sources: Based on Country Review Reports, Country Background Reports (http://www.oecd.org/education/school-resources-review) and Descriptions of National Education Systems by Eurydice (https://eacea.ec.europa.eu/national-policies/eurydice/national-description_en). 


\section{Box 3.3. Professional health and social support provided through resource centres}

In the French Community of Belgium, Psycho-Medical-Social Centres (Centre psycho-médico-social, CPMS), provide psychologists, social workers and nurses to address students' psychological, social guidance or health problems in schools at all levels of education. As part of their school development project (projet d'établissement), each school offering lower secondary education defines a Collective Action Plan (Plan d'Actions Collectives, PAC) that articulates collaboration between school staff and the team of the Psycho-Medical-Social Centre. The plan should identify and set related objectives; describe the actions to be implemented; identify the resources that can be mobilised for implementation; and define internal evaluation criteria. The Collective Action Plan should also be consistent with the General Project for Differentiated Education (Projet général d'action d'Encadrement différencié, PGAED).

Source: Ministère de la Fédération Wallonie-Bruxelles (2016), Examen de l'OCDE des politiques pour un usage plus efficace des ressources scolaires RAPPORT PAYS Communauté française de Belgique, http://www.oecd.org/education/school-resources-review/reports-for-participating-countries-countrybackground-reports.htm.

In Denmark, school hiring practices have traditionally resulted in a broad range of staff who work with students in the school. In addition, schools can draw on more specialist staff provided in the form of educational-psychological advisory services (Pcedagogisk Psykologisk Rådgivning, PPR) run by local authorities for learning support and advice. In addition, schools, municipalities and citizens can seek advice in the area of special needs education and rare special needs free of charge from a central specialised knowledge and counselling organisation (Videns- og Specialrådgivningsorganisation, VISO) within the National Board of Social Services (Socialstyrelsen). VISO provides advice about methods to organise pedagogical frameworks and to create an inclusive learning environment and can also contribute to the diagnosis of a child's behaviour and special needs. Examples for the organisation's areas of expertise include autism, cerebral palsy and diffuse brain injuries, hearing loss, and self-harm. Typically, teachers and school leaders should in the first instance discuss their needs with their local educational-psychological advisory service (PPR), which should then decide if VISO should become involved.

Source: Nusche, D., T. Radinger, T. Falch, B. Shaw (2016), OECD Reviews of School Resources: Denmark 2016, OECD Publishing, Paris, http://dx.doi.org/10.1787/9789264262430-en, pp. 154, 156.

In Portugal, an extensive network of special education resource centres (Centro de Recursos para a Inclusão, CRI) provide services and supplies to support the needs of students with special educational needs (SEN) in schools. In 2016/17, about 581 school clusters $(72 \%$ of the public school network) received support from these resource centres which deploy a total of 2251 technicians, such as occupational therapists, speech therapists, physiotherapists or psychologists. The resource centres are designed to support the inclusion of children with disabilities, build partnerships with local actors and facilitate the access of students with SEN to different activities.

Source: Liebowitz, D., P. González, E. Hooge, G. Lima et al. (2018), OECD Reviews of School Resources: Portugal 2018, OECD Publishing, Paris, https://dx.doi.org/10.1787/9789264308411-en, pp. 143-144. 
Moreover, civil society and the broader community within which the school is embedded may provide additional resources for schools and students. In Slovenia, for example, information on different occupations and vocational guidance is also provided by the country's Chamber of Commerce and Industry and the Chamber of Craft and Small Business, among others (Slovenian Ministry of Education, 2017 ${ }_{[71]}$ ).

The centralised provision of specialised staff likely entails certain trade-offs and requires attention to ensure their staff can work effectively with schools. Specialised staff can provide expertise that may not be efficiently offered at a smaller scale (OECD, 2018 $\left.{ }_{[25]}\right)$. At the same time, professionals may spend only a limited amount of time in individual schools, for example where they are shared across a number of schools. This might limit their ability to build working relationships with school staff and students and to connect their work to individual schools' development plans. This was for instance found in the provision of school psychological services in Austria (Nusche et al., 2016 ${ }_{[41]}$ ).

Studying differences in the effectiveness of instructional coaches provided by the school district and those hired by schools, Kane and Rosenquist $\left(2019_{[72]}\right)$ found significant differences in coaches' time spent on instructional work with teachers. Where a broader range of actors is involved, co-ordination of funding and competencies are likely required (Maughan, 2018[73]). Again in Austria, for example, the federal court of audit identified a potential for synergies in the organisation and work of school medical services between the responsible ministries of education and health (Rechnungshof Österreich, 2018 ${ }_{[74]}$ ).

Box 3.4. Professional support provided for schools and students through labour and social affairs authorities

In Austria, the Federal Ministry of Labour, Social Affairs and Consumer Protection (Bundesministerium für Arbeit, Soziales und Konsumentenschutz, BMASK) is the main actor and provider of funds for a system of career assistance (Netzwerk Berufliche Assistenz). Under this umbrella, the nation-wide Youth Coaching initiative provides advice and support for young people aged 15-19 at risk of dropping out from school or being marginalised. Youth coaches - who generally have a background in social work, therapeutic pedagogy, social pedagogy, social management or psychology - accompany these students and help them look for the educational pathway that works for them.

Source: Nusche, D., T. Radinger, M. R. Busemeyer, H. Theisens (2016), OECD Reviews of School Resources: Austria 2016, OECD Publishing, Paris, http://dx.doi.org/10.1787/9789264256729-en.

In Uruguay, the National Youth Institute (Instituto Nacional de la Juventud, INJU) organises career guidance workshops for young people aged 14-22 with a special focus on facilitating young people's choice between different programmes in secondary education. This includes the organisation of a career exhibition (Expo Educa) in the interior and in Montevideo, the country's capital.

Source: Santiago, P., B. Ávalos, T. Burns, A. Morduchowicz, T. Radinger (2016), OECD Reviews of School Resources: Uruguay 2016, OECD Publishing, Paris, http://dx.doi.org/10.1787/9789264265530-en. 


\subsubsection{Steering the use of resources for school staffing decisions}

\section{The role of regulations for staffing levels and mix}

A number of countries set an overall framework that guides school staffing decisions (e.g. the Czech Republic, Iceland and Lithuania) (see Tables A.1 and A.2 in Annex A and Annex 1.B in Chapter 1 for staffing profiles of OECD review countries). In Chile, for example, all schools must comply with a number of technical-pedagogical, legal and infrastructure requirements to be officially recognised and provide school education. This also includes the requirement to "have available the suitable teaching/managing professionals, technicalpedagogical and classroom staff, by taking into account the educational level and modality, as well as the right number of education assistants to provide for the school's needs according to the levels, modality and number of students" (Centro de Estudios MINEDUC, 2016, p. 92[75]).

In Denmark, national regulations specify that all children have the right to teaching in accordance with their individual needs, while in Sweden, the Education Act stipulates students' right to access medical, psychosocial and special needs staff as well as career guidance. In the Slovak Republic, students have a right to an education that reflects their educational needs and possibilities in its content, forms and methods. Students should furthermore have access to free guidance.

Within such broad frameworks, more specific regulations may influence the creation of particular instructional, leadership and other staff positions. For teachers, the number of staff that are required depends on many factors, in particular the curriculum (defining the minimum requirements regarding subjects and instruction time) and school organisation (defining the type of professionals required, workload and class size). Other aspects, such as the ratio of teaching and non-teaching hours, the number and diversity of subjects in the curriculum, and the availability of other staff, also influence the number of teachers needed in a school (Bertoni et al., 2018 $8_{[76]}$ ).

Class size regulations (which may vary across types of provision), educational levels or school size, also influence the number of teachers required in a school. Each student above the maximum permitted number of students in a class demands the forming of two classes (OECD, 2018 $\left.{ }_{[25]}\right)$. In Denmark - where schools have a large degree of autonomy in their resource allocations - national regulations on class size and teaching hours in a school year and in different subjects establish the framework for the employment of teaching staff (Nusche et al., 2016 $6_{[34]}$ ). Class size rules can, however, have undesired effects when enrolments change and classes have to be split unexpectedly, causing potential teacher shortages (OECD, 2018[25]).

For leadership positions, be it in the form of a full position or a reduction in teaching load, school size (e.g. number of students or teachers) typically plays an important role, and regulations may specify a threshold for the creation (and funding) of such positions. In Colombia, for example, school co-ordinators who are responsible for supporting school leadership and management, are appointed according to the enrolment of the school cluster. ${ }^{1}$ A rural director position is created when an individual school site within the cluster (that offers only one or more of the levels of compulsory education but not all) has more than 150 students (Radinger et al., 2018 ${ }_{[18]}$; Sánchez, 2018 $8_{[77]}$ ). In Kazakhstan, regulations determine the specific types of leadership staff to be employed in schools, depending on the type and level of education and school size (see Box 3.5). Similarly, in Austria, Belgium (French Community), Iceland, Portugal, Slovenia, the Slovak Republic and Uruguay, the creation of different school leadership positions is regulated based on school size. 
For some contexts, school size alone may, however, provide a limited measure for determining the required number of school leadership staff. In Colombia, where public schools are organised as clusters, the number of school leaders does not take the number of individual school sites and the distance between them into account. While this exerts pressures on the effective organisation of school networks and clusters, it also creates challenges for school leadership and management, particularly for small remote school sites which fulfil vital services to rural students and their communities (Radinger et al., 2018 ${ }_{[18]}$ ).

The creation of positions for other types of staff typically tends to be at the discretion of individual education authorities and/or schools. Some systems, however, have more specific regulations for the creation of such positions in place (e.g. Kazakhstan, Portugal, Slovenia and Uruguay). To give one example, in Slovenia, school principals are responsible for organising and managing their staff, but must do so according to central norms and regulations for administrative, account-keeping and technical services and seek the approval of the education ministry. Counselling services and a librarian are required by law in all schools.

Some systems require the creation of specific staff positions (e.g. school climate co-ordinators and school librarians in Chile, and school nurses in Sweden), while decisions in other school systems require the approval of another authority (e.g. Lithuania) or must be taken within a local framework (e.g. Denmark). In 2013, Estonia gave schools and school owners greater autonomy in determining their staff mix. While a ministerial decree had previously established minimum staffing numbers for management and support services, this is no longer in place.

\section{Box 3.5. School leadership teams in Kazakhstan}

In Kazakhstan, the number and responsibilities of leadership positions allocated to each school depends on the school's size and level of education offered. At the primary level, for example, the main school leader is only formally recognised as a principal when the school has at least eight classes and 240 students. Schools with at least six classes are required to create half-time deputy positions for academic affairs and educational work, while those with more than ten classes employ them full time. Schools with more than 16 classes are required to employ an additional deputy for economic activities. In leadership teams comprising one school principal and three deputy principals, responsibilities are usually divided as follows:

- School principal: Leads the overall school in compliance with norms; approves the school plan, staffing and number of classes; appoints other school leaders and recruits teachers; fosters pedagogical improvement and professional development and distributes rewards to the staff; ensures learning materials, equipment and physical infrastructure are safe and up-to-date; ensures that disadvantaged students are supported and no children are out-of-school in the neighbourhood; reports to administrative authorities.

- Deputy principal for academic affairs: Co-ordinates and supervises pedagogical improvements and the dissemination of best teaching practices; plans school educational operations including class timetables; recruits teachers and supervises professional development; organises school evaluation, teacher appraisal and student assessments; ensures learning equipment is up-to-date. 
- Deputy principal for educational work: Organises and ensures the quality of extracurricular activities and home-schooling for children with special needs; participates in the recruitment of, and supervises and supports the professional development of senior counsellors, after-school teachers, and home-school teachers; liaises with representatives of the community, law enforcement bodies, the parents' committee and individual parents.

- Deputy principal for economic activities: Administers, procures and controls expenditure on material and financial resources; supervises maintenance works; ensures compliance with fire and safety norms; monitors the operation of the school's technology and energy equipment.

Sources: OECD/The World Bank (2015), OECD Reviews of School Resources: Kazakhstan 2015, OECD Publishing, Paris, http://dx.doi.org/10.1787/9789264245891-en; Republic of Kazakhstan Government Decree No. 77 (2008), as amended by No. 150 (March 31, 2017), http://adilet.zan.kz/rus/docs/V090005750 (accessed 20 March 2019).

\section{The role of funding mechanisms for staffing levels and mix}

Funding arrangements set essential parameters for the staffing of schools. The budget that is available to an employer (be it a school or an education authority) will determine the number of staff that can be contracted and the payroll that can be paid for. This budget can be made up of a number of sources and involve the transfer of funds (which can be tied to different conditions on their use) across levels of governance. In Sweden, for instance, municipalities are responsible for staff employment and manage resources for this purpose that come from central grants and local tax revenues (Ministry of Education and Research, $\left.2016_{[78]}\right)$.

Staff funding arrangements also influence the equity and efficiency of staff employment in a school system. For example, where employers are heavily dependent on local tax bases to pay for their staff, areas with more disadvantaged students are likely to have fewer resources to meet student needs, although fiscal equalisation mechanisms may offset such resource disparities to some extent (OECD, 2017 $[79])$.

Where responsibilities for raising funds to pay for staff are misaligned, the employing authorities may have no incentive to ensure efficient staffing levels and to adjust them to changing needs, such as a fall in student enrolment (OECD, 2017 $\left.7_{[79]}\right)$. At the same time, choices about the use of staff (e.g. in terms of class size, teacher-student ratios, use of teachers' time) have a bearing on educational expenditures and efficiencies as they influence the number of staff who are required.

The staff resources that are ultimately available to schools (and possibly the scope to influence resource use decisions for staffing) can impact the pedagogical autonomy of individual schools. During the OECD review of Austria, for example, various schools felt that increasing resource constraints, i.e. a lack of teachers or teaching hours, had made it difficult to use their pedagogical autonomy, e.g. for offering optional subjects (Nusche et al., 2016 $6_{[41]}$ ). In Portugal, the review team had concerns that plans to give schools greater curricular autonomy and flexibility would likely require more resources to actually create pedagogical innovations (Liebowitz et al., 2018[51]). A minimum level of resources is then necessary to provide a high-quality education (OECD, 2017 $\left.{ }_{[79]}\right)$, including sufficient funding for the adequate staffing of schools. 
Changes to the organisation of school education, such as the length of the school day or the education of children with special needs, will be an important factor influencing the required staffing mix in schools as discussed in Annex 1.A in Chapter 1. They also require sufficient reflection about their resource implications and funding arrangements (e.g. through increases in teachers' working time, a shift of budgetary resources towards the employment of support staff, etc.).

The funding of school education is discussed in depth in OECD $\left(2017_{[79]}\right)$. The following sections discuss school funding as it relates to school staffing levels and mix.

\section{Nature of funding allocation for school staff}

The extent of decision making over the use of resources for the staffing of schools - be it at the school or another level - is influenced through the nature of that allocation. At the same time, the type of allocation determines the steering power and control over staffing decisions and salary costs for the authorities that provide the resources.

Monetary transfers without restrictions on their use give individual schools or authorities the greatest level of autonomy in terms of staff spending. At the same time, this creates a tension between flexibility and accountability. Monetary transfers that are earmarked for specific types of staff, on the other hand, give the allocating authority a degree of control over how much is spent on different types of staff (OECD, 2017 [79]).

Funding can also be linked to a minimum level of expenditure on particular staff types. In Lithuania, for example, the education ministry specifies a minimum spending level for teachers, and also a recommended amount of per-student spending on vocational and career guidance and pedagogical and psychological services. Schools propose their staff positions which are then subject to approval by the school founder. To reflect these spending requirements, the calculation of the resource envelope includes a component for pedagogical and psychological services (Shewbridge et al., 2016 $6_{[20]}$ ). The Slovak Republic provides another example, with schools and school founders being required to spend the personnel normative defined by the central ministry on teachers (Santiago et al., 2016 ${ }_{[19]}$ ).

Funds can furthermore be earmarked for the benefit of specific student groups, such as special needs students. In Chile, disadvantaged schools can receive funding through the preferential school subsidy (Subvención Escolar Preferencial, SEP). Half of the subsidy can be spent on additional staff and to develop technical-pedagogical teams made up of teachers and learning support staff, but spending must focus on the school's most vulnerable students (Santiago et al., 2017 $[31]$ ). In the Slovak Republic, funds for teaching assistants for disadvantaged students are earmarked for specific schools. Targeted funding can be a further way for shaping the staffing mix in schools (see Box 3.6). 


\section{Box 3.6. Targeted funding to provide specialised support staff for schools}

In Chile, the education ministry provides funding to school providers to finance learning support staff through its School Integration Programme (Programa de Integración Escolar, PIE). Through this programme, schools can integrate up to five students with transitory disabilities and two students with permanent disabilities per classroom. Integrated students with special needs receive at least between six (half-day school) and eight (full-day school) hours of professional support per week within the classroom.

The resources provided through this programme can be used for a range of purposes, such as the purchase of educational materials and the adaptation of the physical space, but also for hiring learning support staff. Schools can establish multidisciplinary teams that include specialists such as speech therapists, special needs teachers and psychologists to provide support for teachers and students within classrooms. Learning support staff hired through the programme also need to dedicate at least three hours to collaborative work with the school's classroom teachers. In 2015, 45\% of schools were participating in the programme.

In addition, the National Board of School Assistance and Scholarships (Junta Nacional de Auxilio Escolar y Becas, JUNAEB), an agency responsible for administering state resources to ensure that vulnerable children and adolescents can enter, stay and have success in the educational system, has established programmes to provide psychological and social support for vulnerable students at the risk of drop-out.

Through the Programme to Support School Retention (Programa de apoyo a la retención escolar) interdisciplinary teams made up of pedagogues, social workers and psychologists provide pedagogical and psychological support to groups of students or individually. The Skills for Life initiative (Habilidades Para la Vida) provides psychological and social support for the school community, including students, teachers and parents, in the two years of pre-primary education prior to entering primary education and the first two years of primary education. Teams and units of social work and psychological services within municipalities develop projects that are then presented to the regional offices of the JUNAEB. If selected and approved, teams and projects receive initial funding for three years with the option of being extended.

Source: Santiago, P., A. Fiszbein, S. García, T. Radinger (2017), OECD Reviews of School Resources: Chile 2017, OECD Publishing, Paris, http://dx.doi.org/10.1787/9789264285637-en.

In New Zealand, the education ministry funds a dedicated learning and behaviour service and provides funding and resources for Resource Teachers: Learning and Behaviour (RTLB). These learning and behaviour specialists work across a number of schools and support them in managing the additional learning needs of students. There are nearly 1000 such specialist teachers working in 40 clusters throughout the country at a cost of approximately NZD 90 million (New Zealand dollars) per year.

Funding is allocated based on student enrolment and socio-economic background and covers educational support, release time for classroom teachers to meet with the RTLB, and professional development for departments, syndicates and schools to enhance skills in behaviour management or curriculum development. In an evaluation of this type of support, the country's Education Review Office found that recent changes to the structure and governance had led to improvements in the support these specialist teachers provide.

Source: Education Review Office (2018), Resource Teachers: Learning and Behaviour Governing and Managing RTLB Clusters, Education Review Office, Wellington, https://www.ero.govt.nz/assets/Uploads/RTLB-Evaluation-Report2.pdf (accessed 5 December 2018). 
Basis for determining funding allocation

The allocation of resources for the staffing of schools - through monetary resources or "in-kind" allocations to intermediate authorities or schools - can be determined on the basis of different mechanisms as discussed in OECD $\left(2017_{[79]}\right)$. Regardless of the specific mechanism, the resource allocation typically takes a number of aspects into account, which can set incentives for the efficient use of staff and mitigate inequities in available resources.

Student enrolments will be an important factor determining allocations in all school systems to ensure sufficient teaching staff for the required instruction time. The required teachers can be determined on the basis of student numbers or the number of classes (OECD, 2017 $[79])$. Allocating teacher resources on a per-student basis promotes competition and efficiency in the organisation of schooling and the management of teachers, for example in terms of the size and number of classes which are much more important for determining the cost of teaching than total enrolment (OECD, 2017 [79]).

A teacher working with a small class of students will present a higher cost per student. Assuming that two teachers have the same salary, the salary cost per student of a teacher teaching a class of five students, for example, will be six times higher than the salary cost per student for a class of 30 students (IIEP-UNESCO, 2016 $[80]$ ). At the same time, fixed costs do not diminish with the number of students and teachers cannot be easily distributed between classes and schools. Per-student allocations of teacher resources can therefore create pressures for schools with small or declining enrolments which have high numbers of staff for few students (OECD, 2017 [79] $)$.

Where funding is allocated on a historical basis, this funds existing staff year after year and typically involves the payment of invoices submitted for supplementary costs. While this can fund the expansion of education (and the required staff), it also sets no incentives for education authorities or schools to increase their efficiency or to improve the quality of their provision (OECD, 2017 [79]).

Teachers' salaries (over which the authority responsible for hiring and paying teachers may have no control) will be a further important factor that determines the resources required to employ a certain number of staff with a particular level of qualifications and experience. Some school systems that use a funding formula to determine allocations therefore transfer funding based on some kind of estimation of average cost. Such systems i) provide a specific framework for balancing actual teacher salary expenses with the amount of funding available to pay for staff and ii) can act in an equalising way as they promote similar staffing levels across schools.

In Estonia, for example, once the total number of teaching hours and full-time equivalent teaching positions has been determined for a municipality, this figure is multiplied by a national minimum salary for teachers and increased by $20 \%$ to determine a municipality's teacher salary budget (Santiago et al., 2016 ${ }_{[40]}$ ). Similarly, in Lithuania, average teacher salaries have been an important input variable in the formula determining the allocation of resources (Shewbridge et al., 2016 [20]).

In other countries, the level of teacher salaries is not taken into account. In the Flemish Community of Belgium, for example, schools receive a total number of teaching hours which are paid by the ministry regardless of actual staff cost to provide these hours. This has led to large differences in expenditure across levels of education since teachers in upper secondary education receive higher salaries based on levels of qualifications and since classes at this level tend to be smaller (Nusche et al., 2015 [70]). 
Beyond minimum staffing levels, schools may benefit from additional monetary or "in-kind" staff resources to account for their particular contexts, either as part of the main allocation or through additional allocations. Typically, a mix of allocations is found in many systems and additional staff allocations are a common approach to addressing disadvantage in Europe (OECD, 2017 $[79]$ )

When looking at data from the PISA 2015, a number of countries allocate additional teaching staff to disadvantaged schools: in 49 out of 70 systems, disadvantaged schools (public and government-dependent private) have more teachers per student or smaller classes than advantaged schools (as reported by school principals). However, in none of these systems do principals of disadvantaged schools report that their teachers are more qualified, and in 19 of these systems science teachers are less likely to hold a major in science or full certification. The analysis of these data also suggests that compensating for disadvantage by allocating additional teaching staff is likely insufficient to close gaps in students' performance based on socio-economic status. The quality of teachers also needs to be considered (OECD, 2018 [4] ).

Indeed, additional funding that can be used to hire more or better qualified staff or additional staffing allocations that are paid for directly do not ensure first, that recruitment processes are in place that would hire more qualified staff and second, that a supply of qualified staff is available (Adamson and Darling-Hammond, 2012 [81]). As explored in the sections on staff recruitment below, the type of teachers that work in a school is also linked to the recruitment and allocation processes and criteria, as well as teachers' preferences and incentives to work in particular schools.

\subsubsection{Planning and managing schools' staffing levels and mix in line with available resources and emerging needs}

Those who are responsible for managing budgets for staff employment will have to adequately plan and manage their staffing levels and mix according to their needs and development plans as well as levels of available funding in the medium term. Projected student enrolment and staff movements will be important factors to take into account. This will also include forecasting their own teacher needs to the extent possible, collecting data on entry and attrition, as well as qualitative data such as exit interviews to better understand why some teachers leave (OECD, 2019[59]).

Where schools are responsible for managing their staffing budgets, such as England (United Kingdom) and Victoria (Australia), education authorities may provide schools with guidance and tools for this purpose (Department for Education, 2018 [82]; Department of Education and Training Victoria, 2019 [83] $)$. They may also have in place specific monitoring processes to assess financial risk and ensure the stable functioning of schools, as is the case in Chile and the Netherlands (see Box 5.7 in OECD (2017 $[79])$ for details).

\section{Predictability and flexibility in funding allocations}

Those responsible for the employment of staff require sufficient levels of stability in funding to plan staffing needs but also flexibility to respond to unforeseen needs, such as an increase in student enrolment, as the experience of the OECD review highlights.

In Colombia, for example, regular changes to the formula used to distribute resources for education as part of the country's fiscal transfer mechanism (Sistema General de Participaciones, SGP) have been found to reduce the predictability of available resources as well as the interest of regional and local Secretaries of Education in improving the 
efficiency of provision within the framework of a multi-year work plan. They furthermore limit the system's objective of ensuring the financing of the teacher payroll, especially in those regional and local authorities with fewer resources (Radinger et al., 2018 ${ }_{[18]}$ ). Similarly, in Estonia, funding of teachers' salaries has been subject to continuous and often contested adjustments in the past (Santiago et al., 2016 $[40]$ ).

While the Czech Republic has recently changed its central funding allocation for direct education costs, including teacher salaries, beginning from January 2020, the principles and technical details for these amounts had been held constant from 2012 until then. This ensured stability and predictability of financing in the past, and allowed all schools to plan their development for a number of years (Shewbridge et al., 2016 [42]). The transition to the new funding mechanism (a change from a per-student to a per-class normative) has been accompanied with the training of regional and local education authorities and schools.

At the same time, the previous regulations for allocating resources for direct costs in the Czech Republic allowed for local flexibility through negotiations in the application of the per-student normative amounts. Moreover, at the school level, an adjustable component of teacher salaries provided a sort of "cushion" to accommodate small fluctuations. In the country's previous approach to funding direct costs (notably for teacher salaries), these mechanisms recognised the risk that came from the allocation of funds to individual schools on a per-student basis. The system acknowledged that even a small decrease in the number of students may result in a corresponding decrease of funds for salaries, which may make funds insufficient for teacher salaries - which remain fixed (Shewbridge et al., 2016 $6_{[42]}$ ).

\section{Adjustments of staffing levels to changing student enrolment}

A fall in student enrolment may require changes to staffing levels, possibly together with a reorganisation of the school network as discussed in OECD $\left(2018_{[25]}\right)$. This may also involve a reorganisation of school leadership, for example by creating school clusters with multiple sites, as has been the case in Denmark and Iceland (Nusche et al., 2016 [34]; Icelandic Ministry of Education, 2014[84]). Where staffing levels cannot be adjusted to falling enrolment, the additional available teacher resources would be optimally allocated if targeted at those who are likely to benefit the most, i.e. disadvantaged groups and students in pre-primary and primary schools (OECD, 2017 $[79])$.

In systems with central teacher allocations, the transfer of staff can help adjust staffing levels to changes in enrolment in different schools. In Spain, for example, the Personnel Commissions of the Autonomous Communities organise processes for the transfer of civil service teachers within their territory on an annual basis, and for transfers between communities every two years. Similarly, in Turkey, the central ministry and regional education authorities organise such teacher transfers (Eurydice, 2019 [85]).

In systems with decentralised teacher employment, schools may be supported by central education authorities in adjusting their staffing levels:

- In Ireland, the Department of Education and Skills co-ordinates a redeployment process to facilitate the transfer of teachers on permanent contracts and contracts of an indefinite duration. To be allocated all of their teaching positions, schools have to comply with these redeployments (Department of Education and Skills, $\left.2019_{[86]}\right)$.

- In New Zealand, where school boards are responsible for teacher employment, the Ministry of Education may help cover the costs (teacher's salary and severance 
pay) when disestablishing a permanent teaching positions (Ministry of Education, $\left.2019_{[87]}\right)$.

- In Slovenia, the education ministry supports the transfer of a teacher in case a position becomes redundant due to falling student enrolment. No open recruitment process is required in this case. If a new position can be found, the teacher remains in the same wage grade, otherwise the teacher is entitled to severance pay. If a teacher refuses to be reassigned where an agreement has been found between the ministry and the old and new schools, the contract is terminated without severance pay (Eurydice, 2019[85]).

- In Victoria (Australia), a Multi-School Staffing model enables two or more schools to temporarily transfer staff between the schools on an annual basis to better meet the needs of each school (Department of Education and Training Victoria, $2019_{[88]}$ ).

However, teacher labour markets may entail certain rigidities that work against teacher mobility, such as different qualification requirements (e.g. between general and vocational or mainstream and special needs education as discussed in Chapter 2) or limited portability of statutory rights. In the United States, teachers' qualifications may not always be recognised in a different state, for example, thus reducing mobility (Goldhaber et al., $\left.2015_{[89]}\right)$. In Austria, the statutory rights which teachers acquire through seniority, such as the progression in the salary scale and pension entitlements, may also not always be recognised as teachers change employment, reducing teachers' mobility and creating in effect localised teacher labour markets (Nusche et al., 2016 [41]). In Colombia, certified regional and local education authorities can transfer staff, but this requires administrative agreements which have sometimes been difficult to establish (Radinger et al., 2018 $[18]$ ). ${ }^{2}$

Of course, student enrolment may also increase and require additional staff resources. In the OECD reviews of Colombia, Portugal and Uruguay (for early childhood education), the public funding of private providers has created essential flexibility to respond to such rising demands (Liebowitz et al., 2018 [51]; Radinger et al., 2018 [18]; Santiago et al., 2016 $6_{[22]}$ ). The review's reports on school funding and responsive school systems discuss the funding of private providers in depth $\left(\mathrm{OECD}, 2018_{[25]}\right.$; OECD, 2017 [79]).

\section{Contract conditions and working time arrangements}

Teacher salary costs and working time (e.g. full-time and part-time work) play an important role for schools or authorities to manage their available resources (Bertoni et al., 2018 ${ }_{[76]}$ ) as do contract conditions (e.g. permanent and temporary employment).

Countries typically have different types of contracts for teachers, employing some on a permanent and others on a temporary basis (see Table A.3. in Annex A). Based on data available from the TALIS 2013, the share of teachers employed on fixed-term contracts however differs widely, from less than $80 \%$ in Chile, Israel, Finland, Mexico and Portugal to more than $95 \%$ in Denmark and France ( (OECD, 2014, pp. 270, Table 2.8[90] $)$ ).

The possibility to employ staff on different types of contract can potentially create dual labour markets as has been the case in some OECD review countries:

- In the Flemish Community of Belgium, where teachers are employed by school boards, all beginning teachers are recruited on a temporary basis of one year before they can be appointed to a temporary position of continuous duration and ultimately on a permanent basis (Nusche et al., 2015 $[70]$ ). Similarly, in the French Community, 
teachers can be employed in temporary, priority temporary or permanent employment positions (Ministère de la Fédération Wallonie-Bruxelles, 2016 [62]).

- In Colombia, temporary teachers fill vacancies that cannot be filled through the central recruitment process. Candidates that were not successful in the central recruitment can become part of a register of qualified candidates and take on temporary positions which are filled directly by the regional and local authorities that provide education (Radinger et al., 2018 [18]; Sánchez, 2018 [77]).

- In Portugal, teachers with lower rankings in the central recruitment and allocation are also employed on temporary contracts (Liebowitz et al., 2018 $\left.{ }_{[51]}\right)$.

Temporary contracts (which may be limited to a specific duration or a maximum number of renewals before a staff member has to be appointed on a permanent basis) create essential levels of flexibility in the management of staffing levels to respond to changing student demographics and to keep long-term financial commitments in check. Temporary appointments may also facilitate the evaluation of a teacher's skill and ability to grow before offering a permanent contract.

However, dual labour markets can also create adverse effects for schools, teachers and students. Given different contract conditions, temporary teachers often do not benefit from the same statutory rights as their colleagues on permanent contracts (e.g. when it comes to professional development opportunities or career and salary progression). Temporary teachers may need to move from one school to another and can be dismissed in a relatively straightforward manner, also possibly affecting their motivation to stay in the profession. In school systems where there is little mobility among permanent teachers, temporary teachers may in fact ensure the necessary flexibility in the teacher labour market.

For schools and students, temporary contracts can result in a lack of stability in teaching staff if temporary teachers are at the risk of being replaced by a teacher with a permanent appointment. Where temporary teachers are not seen as full members of the school community, this can affect school climate, morale and collaboration. There can also be inequities if teachers on permanent contracts are concentrated in certain schools. Teachers in the more challenging contexts may then be employed under less favourable conditions

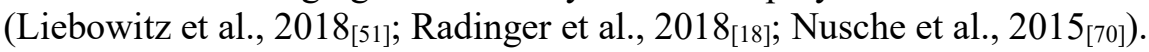

The management of working time is a further essential dimension to manage staffing levels and to ensure flexibility in staff supply as working time can be increased or reduced more easily to changing student numbers than staff positions. Depending on the working time arrangements in place as described in Chapter 2, education authorities or schools may adjust a teacher's working hours or teaching load. A number of OECD reviews illustrate the use of working time adjustments to respond to changing needs.

In Kazakhstan, for example, where teachers are employed on a teaching load basis, school principals decide how many weekly teaching hours to allocate to each teacher. As the OECD review found, school principals typically allocate fewer hours where not all teachers are required, thus avoiding staff dismissals (OECD/The World Bank, 2015, p. 35[60] ). In the OECD reviews of Austria and Colombia, on the other hand, staff were often asked to work additional hours in the form of overtime where more staff were required than currently available (Nusche et al., 2016, p. 167 ${ }_{[41]}$; Radinger et al., 2018, p. $258_{[18]}$ ). In the OECD review of the Flemish Community of Belgium, part-time work was found to provide flexibility to respond to fluctuations in demand for teachers (Nusche et al., 2015 ${ }_{[70]}$ ). 
As the TALIS 2018 documents, the use of part-time arrangements differs significantly across countries, both in terms of the overall share of teachers who work $90 \%$ or less and the share of full-time hours they work (see Figure 3.3). While more than 30\% of lower secondary teachers reported to work part-time in Estonia, Kazakhstan and Lithuania, less than $10 \%$ reported doing so in Finland, Hungary, Japan, Korea and the United States. In Mexico and the Netherlands, more than half of teachers reported working part-time.

Part-time work has become more widespread: in ten out of 24 countries with available data, the share of teachers working part-time increased significantly between the TALIS 2013 and 2018. In Chile, Portugal and Spain, the increase was more than ten percentage points (authors' analysis of TALIS database).

As highlighted in Chapter 2, the management of working time always also needs to consider implications for staff well-being and satisfaction. Concerning reduced working hours, an important distinction has to be made between voluntary and involuntary part-time work. As the TALIS 2013 highlighted, in some countries, teachers' preferences resulted in a large share of teachers on part-time contracts (e.g. Australia, Denmark, France, the Netherlands and Norway); in others, it was the result of an absence of full-time opportunities (e.g. Mexico, Poland and Portugal) (OECD, 2014, p. 40 $\left.{ }_{[90]}\right)$. Teachers who may like to work more hours may then seek additional employment, be it in multiple schools or outside of school education as discussed in Chapter 2.

In Uruguay, based on the latest national teacher census conducted by the educational administration in $2015,12 \%$ of teachers reported to work in at least three schools, with the proportion amounting $17 \%$ in public secondary and $21 \%$ in private secondary schools (Instituto Nacional de Evaluación Educativa (INEEd), 2016[91]). 
Figure 3.3. Employment status of teachers, full time or part time (ISCED 2), 2018

Percentage of teachers who are employed full time and part time (taking into account all their current teaching jobs, based on teacher reports)

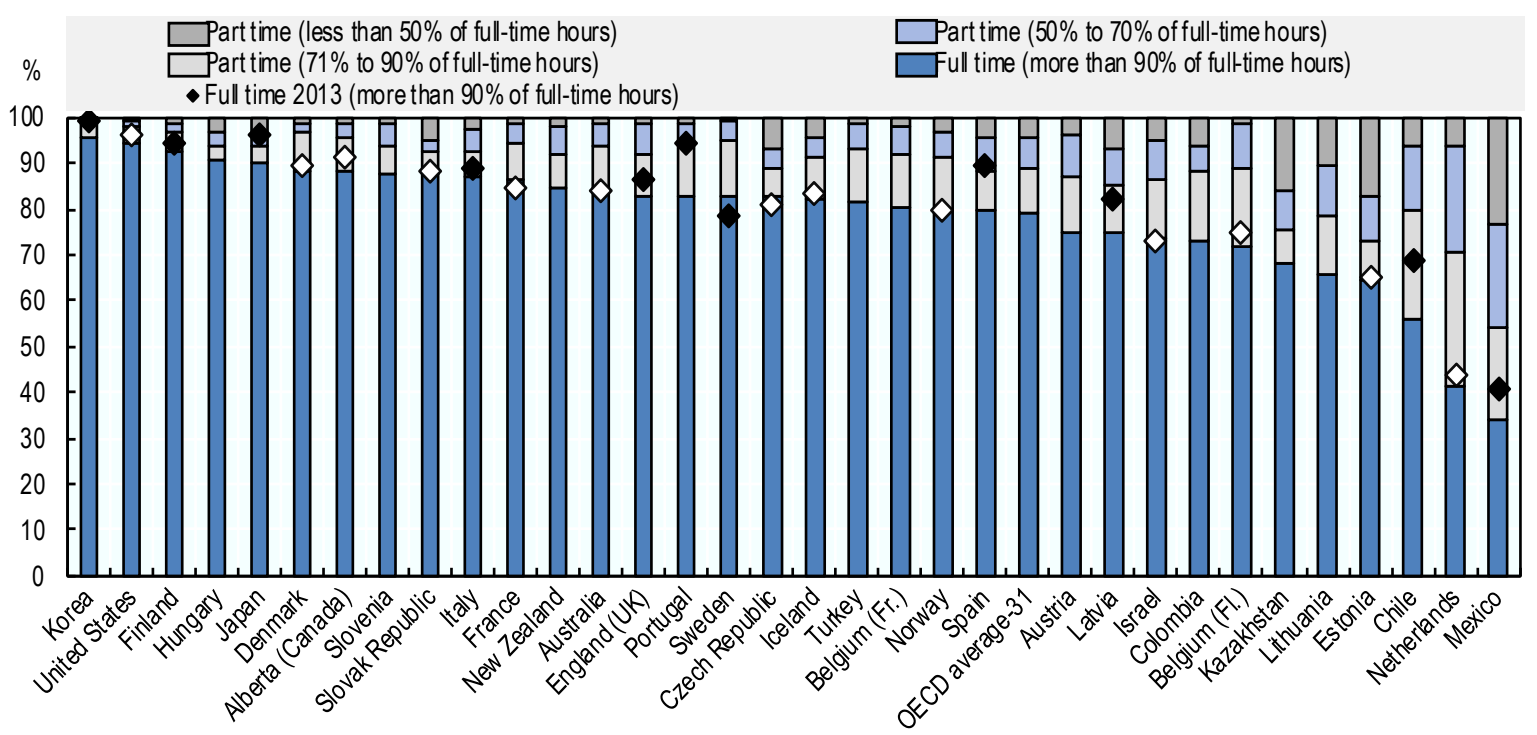

Notes: Countries and economies are ranked in descending order of the percentage of teachers working part time. The number of countries or economies included in the OECD average is indicated next to that average. On 25 May 2018, the OECD Council invited Colombia to become a Member. While Colombia is included in the OECD average reported in this figure, at the time of its preparation, Colombia was in the process of completing its domestic procedures for ratification and the deposit of Colombia's instrument of accession to the OECD Convention was pending.

Sources: OECD (2019), TALIS 2018 Database, http://www.oecd.org/education/talis/talis-2018-data.htm (accessed 17 July 2019); OECD (2014), TALIS 2013 Results: An International Perspective on Teaching and Learning, OECD Publishing, Paris, https://doi.org/10.1787/9789264196261-en, Table 2.7.

StatLink 게s https://doi.org/10.1787/888934026468

\section{Matching staff resources and mix with school needs}

Lastly, the staffing levels and mix in schools need to enable all staff to do their work effectively and to cope with new demands such as those resulting from social and demographic changes (e.g. rise in single parent families or childhood poverty). As reported by school principals and teachers for the TALIS 2018, the staff resources available may not always be perceived to be sufficient to provide quality instruction.

On average, one in three principals reported "a shortage of support personnel" as hindering the quality of instruction "quite a bit" or "a lot" (see Figure 3.4). As Figure 3.5 illustrates, this differs however significantly across countries, with more than half of principals reporting this resource shortage in Colombia, Italy and Portugal, but less than $10 \%$ in Iceland, Lithuania, the Netherlands, Norway, Slovenia and Sweden. "Time for instructional leadership" also features among the top three resource issues identified by principals, which may, among others, be related to the distributed leadership structures and administrative staff available to them (OECD, 2019, pp. 108, Table I.3.63[37]).

The TALIS 2018 also explored resource issues from the perspective of teachers, asking them to rate the importance of a number of priorities if the education budget were increased by $5 \%$. Similarly to school principals, some issues that teachers identified may be related 
to staffing arrangements in schools. In 17 out of 48 participating countries, "reducing class sizes by recruiting more staff" was the number one spending priority, while "reducing teachers' administration load by recruiting more support staff" was as one of teachers' top three priorities in 24 countries and economies (OECD, 2019, pp. 110, Table I.3.63 [37]).

In some school systems, such needs as identified by schools may point to actual shortages of specific types of staff; in others, the reasons may be more complex. In any case, changes to staffing levels and mix (and the related resource investments or reallocations) likely entail important trade-offs and should be based on a sound needs analysis. Some perceived shortages may for instance be more effectively addressed through investments in staff learning and development (e.g. for managing classroom discipline and student behaviour); others may require a more effective distribution and management of tasks and related time in schools or a shift of responsibilities to higher levels of the administration away from schools.

As analysed in Chapter 2 in relation to teachers' working conditions, for instance, the marginal impact and effectiveness of hiring more staff to support teachers in their administrative duties is contested, and, based on data from the TALIS 2018, there is no statistically significant association between the average proportion of teachers' working time devoted to general administrative tasks and the number of administrative and managerial staff per teacher employed in their schools.

Figure 3.4. Shortages of school resources (ISCED 2), 2018

Percentage of principals reporting that the following shortages of resources hinder the school's capacity to provide quality instruction "quite a bit" or "a lot" (OECD average-30)

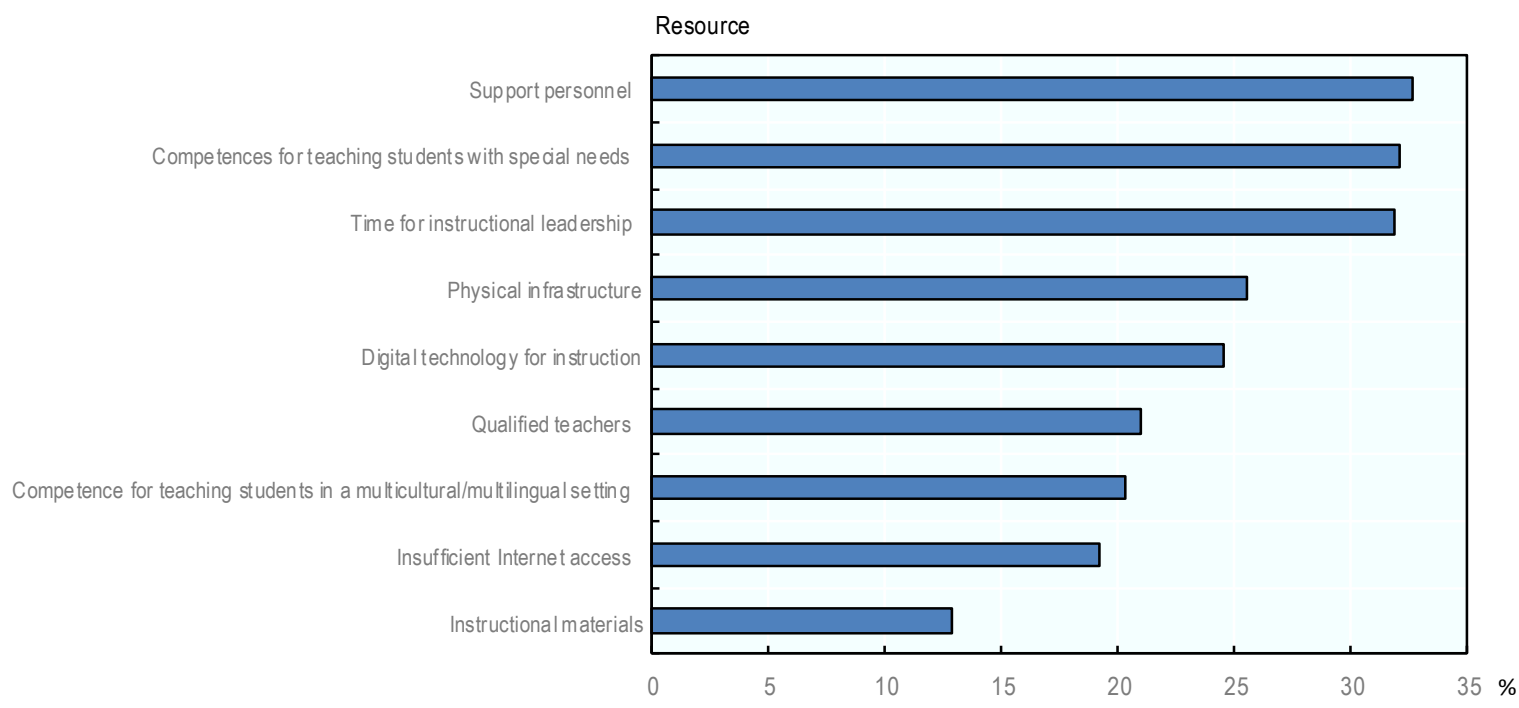

Notes: The number of countries or economies included in the OECD average is indicated next to that average. On 25 May 2018, the OECD Council invited Colombia to become a Member. While Colombia is included in the OECD average reported in this figure, at the time of its preparation, Colombia was in the process of completing its domestic procedures for ratification and the deposit of Colombia's instrument of accession to the OECD Convention was pending.

Source: OECD (2019), TALIS 2018 Results (Volume I): Teachers and School Leaders as Lifelong Learners, OECD Publishing, Paris, https://doi.org/10.1787/1d0bc92a-en, Table I.3.63. 
Figure 3.5. Impact of support staff shortages (ISCED 2), 2018

Percentage of principals reporting that a shortage of support personnel hinders the school's capacity to provide quality instruction "quite a bit" or "a lot"

$\%$

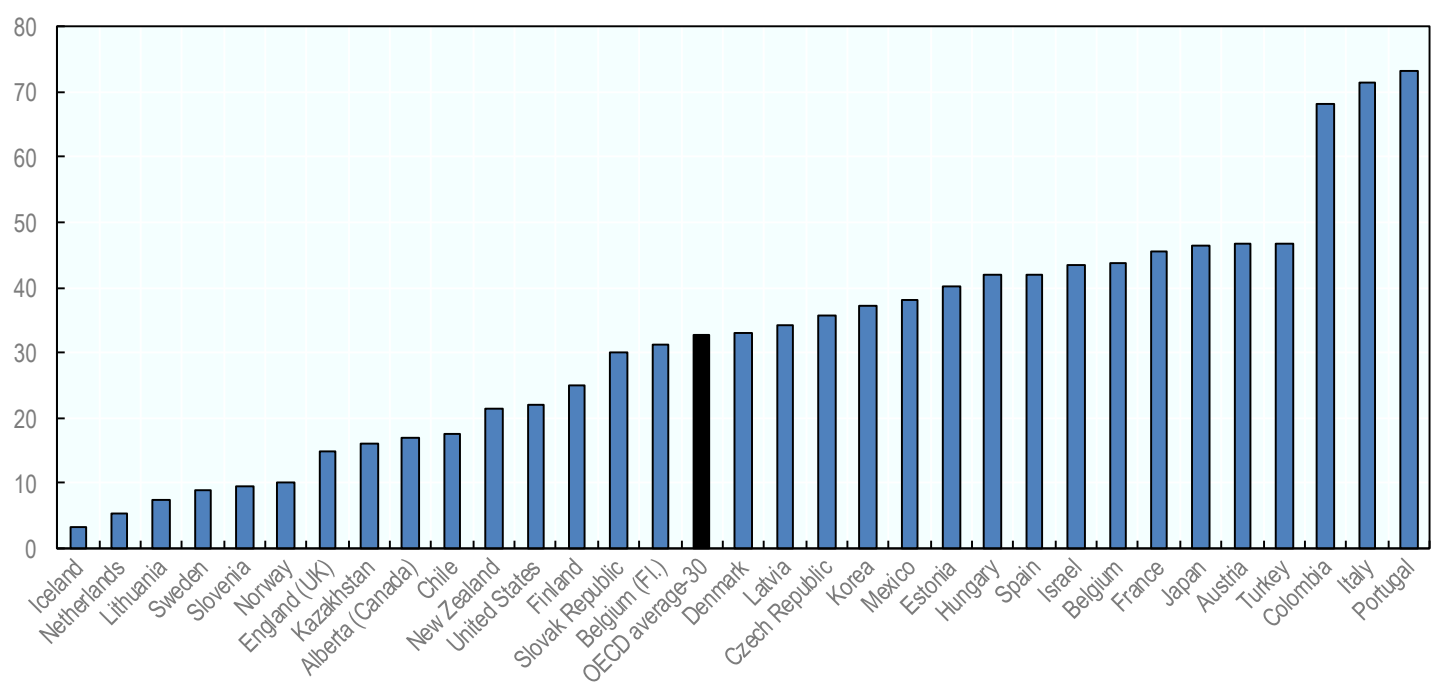

Notes: Countries and economies are ranked in ascending order of the percentage of principals reporting that a shortage of support personnel hinders the school's capacity to provide quality instruction "quite a bit" or "a lot". The number of countries or economies included in the OECD average is indicated next to that average. On 25 May 2018, the OECD Council invited Colombia to become a Member. While Colombia is included in the OECD average reported in this figure, at the time of its preparation, Colombia was in the process of completing its domestic procedures for ratification and the deposit of Colombia's instrument of accession to the OECD Convention was pending.

Source: OECD (2019), TALIS 2018 Results (Volume I): Teachers and School Leaders as Lifelong Learners, OECD Publishing, Paris, https://doi.org/10.1787/1d0bc92a-en, Table I.3.63.

StatLink त्ञाज https://doi.org/10.1787/888934026506

\subsection{Staff selection into particular schools and positions}

While funding arrangements determine the resources available to employ different types of staff in schools, the recruitment of staff relates to the choice of a particular candidate to fill a specific role or position. The distribution of responsibilities for recruitment and the processes and criteria that are used for making hiring decisions also influence effectiveness and equity in the distribution of staff across schools.

There is a rich economic literature on the effects of the worker-employer match on productivity (Fredriksson, Hensvik and Skans, 2018[92]; Woodcock, 2015[93]; Jovanovic, $\left.1979_{[94]}\right)$. While there are only a few studies on the matching of staff to schools, and some studies suggest that teacher effectiveness is portable across schools ( $\mathrm{Xu}$, Özek and Corritore, 2012 ${ }_{[95]}$ ), others suggest that the theoretical benefit of matching may be evident in education as well (Vegas and Ganimian, 2013 [96]). Using a longitudinal data set of student test scores linked to teachers and schools in North Carolina (United States), Jackson $\left(2013_{[97]}\right)$ finds that certain matches between teachers and schools seem to be associated with better student outcomes. According to this study, the quality of a teacher's match with 
a school explains two-thirds of their overall effectiveness, and effectiveness improves substantially when a teacher switches to a school that is a better match.

A good match between individuals and schools also seems essential for school leaders (Spillane, Halverson and Diamon, 2004 $\left.{ }_{[98]}\right)$. In a recent study by Dhuey and Smith $\left(2018_{[99]}\right)$ on the effects of school principals on student achievement in maths and reading again in North Carolina (United States), the match between principals and schools accounted for a significant amount of principals' value added.

\subsubsection{Teachers}

Who is responsible for the selection of teachers?

The OECD Education at a Glance provides some comparative information on the responsibilities for hiring teachers and school principals for public lower secondary education (Tables D6.6a and D6.6b in OECD (2018 $\left.8_{[100]}\right)$ available on line). Tables A.3. and A.4. in Annex A provide information for OECD review countries, which may differ from the data in Education at a Glance for some countries given differences in reporting from countries. The following provides an analysis of data available through Education at a Glance since it provides information for a larger set of countries.

Based on data from Education at a Glance, the selection of teachers is a school-level or decentralised responsibility in most countries. The responsibility for teacher recruitment lies with individual schools in 15 school systems (Austria, the Czech Republic, Denmark, England, Estonia, the Flemish Community of Belgium, Iceland, Ireland, Latvia, Lithuania, Netherlands, New Zealand, Scotland, the Slovak Republic, Slovenia, Sweden, and the United States). Ten countries indicated that this is the responsibility of an intermediate level: the regional/sub-regional level in six (Germany, Hungary, Israel, Italy, Japan, and Korea) and the local level in four countries (Canada, Chile, Norway and Switzerland). The highest level of governance, be it the central level or the state in the case of a federal system, is responsible for recruitment and allocation in seven countries (Australia, France, Greece, Luxembourg, Mexico, Spain and Turkey) (OECD, 2018 $\left.{ }_{[100]}\right)$.

Overall responsibility for teacher recruitment however does not mean that hiring decisions are taken in isolation. Decisions on recruitment at the school level are taken in full autonomy in only six out of the 15 systems (the Czech Republic, England, Iceland, Lithuania, the Slovak Republic and Sweden). In the remaining nine, decisions are either taken within a higher-level framework or in consultation with higher-level authorities. Schools are thus not always completely autonomous in filling their teacher positions.

This was also evident in OECD review countries. In the Flemish Community of Belgium, for instance, schools recruit their teachers directly through their school board with considerable involvement of the principal, but they need to observe specific regulations set by the Community on qualification requirements (Nusche et al., 2015 [70]).

Intermediate levels of governance may also need to respect central frameworks and regulations. In Mexico and Spain, for example, states and Autonomous Communities respectively are responsible for the recruitment and deployment of teachers. Recruitment and allocation processes however take place within a central framework or consultation with the central level (OECD, 2018 $\left.8_{[100]}\right)$. 
Similarly, recruitment decisions at higher administrative levels are not necessarily made by these authorities alone. Lower levels in the system, including schools, may provide input and inform allocation decisions. For OECD Education at a Glance, only Luxembourg, Portugal and Turkey reported that the central level is solely responsible for the recruitment and assignment of teachers to schools. In Australia, states make allocation decisions in consultation with schools. In France, the regional level informs assignment decisions by the central authorities (OECD, 2018 $\left.8_{[100]}\right)$.

Again, the sharing of responsibilities across levels of administration was also evident in OECD review countries. In Austria and Uruguay, the school inspection services tended to provide some input into staff allocations by state and central authorities (Santiago et al., 2016[22]; Nusche et al., 2016[41]). In Chile, the recruitment of public school teachers has formally been the responsibility of the school provider, but the selection of teachers is carried out through a process that also involves the school. The school provider is then required to select the teacher ranked at the top of the list by the selection committee (Santiago et al., 2017[31]). ${ }^{3}$

Some countries have a mixed system, as is the case in Germany. In a number of states, teachers are assigned by public authorities above the school level and teachers apply to a recruitment process managed by these authorities. In addition, schools are allowed to advertise for positions at their own institutions for a certain share of the open positions in a given year, often related to particularly urgent needs or special profiles of the school. Applicants for teaching positions can choose to apply directly for an open position at a school or to submit an application to the general pool of applicants (Nusche et al., 2016 [41]).

\section{Which procedures and criteria are used for the selection of teachers?}

Individuals who meet the required entry standards, such as qualification and registration requirements as discussed in Chapter 2 will need to pass through processes that determine where a teacher will work. The governance of teacher recruitment will influence the shape these processes take, the scope education authorities and schools have for designing their selection processes, and the rules they may have to follow in the process.

In systems with centralised teacher recruitment, teacher candidates are allocated to schools through a central process as they enter the profession and apply for transfers throughout their career should they wish to change to a different school. Some systems with decision making above the school level have mandatory transfer and mobility requirements in place, such as Japan and Korea (OECD, 2018 $\left.8_{[4]}\right)$.

In Colombia, where school education is the responsibility of certified regional and local authorities, teachers both at the beginning and throughout their career apply through a central recruitment process for vacancies that the sub-national education authorities report to the ministry of education (Radinger et al., 2018 ${ }_{[18]}$ ). Similarly, in Portugal, teacher candidates apply to a national recruitment that is open for both new and experienced teachers, disseminated in the official state journal and on the website of the education ministry (Liebowitz et al., 2018 $8_{[51]}$ ).

The central recruitment processes will entail different elements depending on their design. In Portugal, teacher candidates are assessed based on factors such as the marks they received in higher education programmes and their years of teaching experience (Liebowitz et al., 2018[51]). In Colombia, candidates have to take a written knowledge and competency exam, a psychometric test, a check of credentials and an interview. The possibility of such 
teacher tests to identify better teachers is most likely limited (Cruz-Aguayo, Ibarrarán and Schady, 2017 $[101]$ ), but they can help ensure fairness and transparency (Estrada, 2019 $[102]$ ).

In systems where teacher hiring is the responsibility of schools or intermediate authorities, candidates apply for a particular position at the school they wish to work for, either for their first position or to change jobs, while schools or intermediate authorities will be responsible for opening positions and defining the process to fill them. Recruitment processes will therefore differ. Schools and intermediate authorities may also collaborate in the recruitment process, for example through joint recruitment panels or through central support in advertising vacancies, screening applications and notifying applicants. Schools and authorities may have to comply with requirements linked to national employment regulations (e.g. in terms of publication of vacancies) or collective bargaining agreements (e.g. in terms of selection criteria) (more on this below).

\subsubsection{School leaders}

Who is responsible for the selection of school leaders?

Looking at school principal positions, recruitment is typically the responsibility of the education administration rather than individual schools. Based on data from the OECD Education at a Glance, only in eight systems with available data are schools directly responsible for the recruitment of their school principal (the Flemish Community of Belgium, England, Ireland, the Netherlands, New Zealand, Portugal, the Slovak Republic, and Slovenia). Most often, the recruitment of school principals is in the hands of an intermediate authority, such as the local, regional or sub-regional level. In seven systems, the central or, in the case of federal systems, the state administration is responsible for the selection and appointment of principals (Australia, Austria, France, Hungary, Israel, Luxembourg and Mexico) (OECD, 2018 $\left.8_{[100]}\right)$. Table A.4. in Annex A provides again information based on the qualitative data collected for this report.

Information for other formal school leadership positions which may exist in a system, such as deputy principals or department heads, is not available from OECD Education at a Glance. The OECD review, however, provides some information about the type of formal middle leadership roles that exist in schools (see Table 3.4). This will also depend on the design of teacher and leader career structures which are analysed in Chapter 2.

In most OECD review countries, specific middle leadership positions are established by law. In some countries, education authorities or schools can decide the structure of their leadership team (e.g. Denmark and Spain). In Spain, for example, school principals present their ideas for their leadership team as part of their project proposal for the school when applying for their own position. In most countries, intermediary leaders are appointed by schools and their principals, which should give them the possibility to shape their leadership team according to their needs. In only six systems are intermediary leaders appointed by an education authority. As Table 3.4 also documents, the level of decision making can differ by role and between sectors or levels of a school system. 
Table 3.4 Responsibility for appointment of intermediate school leaders (ISCED 1-3), 2018

OECD review countries, public schools

\begin{tabular}{|c|c|c|c|}
\hline Country & School level and type & Leadership function & Appointment responsibility \\
\hline \multirow{3}{*}{ Austria } & $\begin{array}{l}\text { Schools organised as } \\
\text { cluster (ISCED 1-3) }\end{array}$ & Area manager & Cluster leader \\
\hline & \multirow{2}{*}{$\begin{array}{l}\text { Schools not organised as } \\
\text { cluster (ISCED 1-3) }\end{array}$} & $\begin{array}{l}\text { Deputy principal, Administrator (federal schools only), } \\
\text { Department head, Subject head }\end{array}$ & Board of Education \\
\hline & & $\begin{array}{l}\text { Construction yard/workshop manager (in VET schools } \\
\text { and colleges only) }\end{array}$ & School principal \\
\hline \multirow{3}{*}{ Belgium (FI.) } & \multirow{3}{*}{ ISCED 1-3 } & $\begin{array}{l}\text { Technical advisor-co-ordinator, Deputy principal, } \\
\text { Technical advisor }\end{array}$ & School provider \\
\hline & & Managing director of a school group & $\begin{array}{l}\text { Board of directors of the group, } \\
\text { ratified by the group's general } \\
\text { meeting }\end{array}$ \\
\hline & & Co-ordinating director & Association of schools \\
\hline Belgium (Fr.) & ISCED 1-3 & $\begin{array}{l}\text { Deputy principal; Economic advisor; Workshop leader } \\
\text { (ISCED } 3 \text { vocational only) }\end{array}$ & School provider \\
\hline Chile & ISCED 1-3 & $\begin{array}{l}\text { Deputy principal, Head of technical-pedagogical unit, } \\
\text { General inspector }\end{array}$ & School principal \\
\hline Colombia & ISCED 1-3 & Co-ordinator and Rural director & Central authority \\
\hline Czech Republic & ISCED 1-3 & Deputy principal & School principal \\
\hline Denmark & ISCED 1-3 & $\begin{array}{l}\text { Leadership team as defined by local education authority } \\
\text { (ISCED 1-2) or school board (ISCED 3) }\end{array}$ & School principal \\
\hline Estonia & ISCED 1-3 & Head of studies & School principal \\
\hline \multirow[b]{2}{*}{ Iceland } & ISCED 1-2 & Assistant principal, Department head & School principal \\
\hline & ISCED 3 & $\begin{array}{l}\text { Assistant principal, Finance and Administration } \\
\text { manager }\end{array}$ & School principal \\
\hline Kazakhstan & ISCED 1-3 & Deputy principal & School principal \\
\hline Lithuania (1) & ISCED 1-3 & Deputy principal & School \\
\hline Portugal & ISCED 1-3 & Deputy, Assistant principal & School cluster principal \\
\hline Slovak Republic (2) & ISCED 1-3 & Deputy principal & School principal \\
\hline Slovenia (3) & ISCED 1-3 & Assistant principal, Head of unit or branch & School principal \\
\hline Spain (4) & ISCED 1-3 & $\begin{array}{l}\text { Head of studies and any other member of leadership } \\
\text { team }\end{array}$ & School principal \\
\hline Sweden & ISCED 1-3 & Deputy principal, Department head & School principal \\
\hline \multirow[b]{2}{*}{ Turkey } & ISCED 1-3 & Chief deputy principal, Deputy principal & Regional education authority \\
\hline & $\begin{array}{l}\text { Social Science, Science } \\
\text { and Project High Schools } \\
\text { (ISCED 3) }\end{array}$ & Chief deputy principal, Deputy principal & Central education authority \\
\hline Uruguay & ISCED 1-3 & Deputy principal & Central education authorities \\
\hline
\end{tabular}

Notes: For full comparative tables on the recruitment of school leaders, see Table A.4. in Annex A.

1. Lithuania: The selection is based on a competitive process.

2. Slovak Republic: The selection of deputy principals is based on central regulations.

3. Slovenia: The selection of assistant principals is based on a public call for applications according to the procedure specified by an Act. The head of unit or branch needs to be selected from among the staff of the unit or branch.

4. Spain: The members of the leadership team are selected in consultation with the teacher assembly and school council, and subject to approval by the state education authority.

Sources: Based on Country Background Reports and Country Review Reports (http://www.oecd.org/education/school-resources-review/schoolresourcesreviewreportsforparticipatingcountries.htm). 


\section{Which procedures and criteria are used for the selection of school leaders?}

Multiple OECD review countries reported difficulties in attracting qualified candidates for principalship. In some cases, recruitment issues are rooted in unattractive employment conditions, a high workload, insufficient professional support or incommensurate salaries. These issues are reviewed in depth in Chapter 2. In other cases, however, these concerns can be traced back to shortcomings in the selection procedures or a failure to effectively employ them in the recruitment process.

As for teachers, individuals who meet the required entry standards in terms of qualifications, teaching experience and leadership training (see Chapters 2 and 4), will need to pass through a process that determines the selection of particular candidates (see Table A.4. in Annex A for comparative tables on school leader recruitment on line).

Although an increasing number of countries have been developing professional standards for school leadership, the OECD reviews show that the use of detailed competency frameworks is often less advanced for leaders than it is for teachers. In some cases, school leader positions may have standardised job profiles but lack the detailed competency-based standards that could provide a clear and transparent reference for recruitment.

Some countries have introduced aptitude tests and assessment centres to inform the selection of school principals. In other countries, school leader selection is not regulated. In the Flemish Community of Belgium, for example, school boards organise the recruitment of school leaders autonomously. National standards or common required competencies for school leaders do not exist, although the Community education network has developed a set of competencies that are required for its school leaders. The extent to which school leaders are managed systematically or strategically is very much at the discretion of school boards (Nusche et al., 2015 $\left.5_{[70]}\right){ }^{4}$

Some systems allow for the involvement of the school community in the definition of the selection criteria. In Victoria (Australia) for example, school councils or committees add a community criterion to a list of five central selection criteria, and in Chile, school boards define a competency profile that then serves as a reference for a central recruitment process through national authorities (Shewbridge et al., 2016, p. 186 $6_{[42]}$ ).

More generally, given the role of school principals, their recruitment process often involves input from the school community, such as teachers, parents and sometimes students, which may help ensure a good match between school leaders and the community they will work with. In addition, other authorities, such as a public service authority, the school inspection or external experts, may provide expertise for the selection process and contribute to fairness and transparency of the process (see Table 3.5).

Concerning intermediary leadership positions, individual schools and their principals often have the say over selection into these roles as described above. In few cases, however, they also have to comply with central regulations. In Chile, for instance, principals can select their school leadership team from the municipality's teaching body, but the choice of middle leaders is restricted to those who fulfil central requirements (Santiago et al., 2017[31]). Similarly, in Lithuania, the Slovak Republic and Slovenia, schools have to follow specific selection procedures as defined in central regulations, while appointments in Spain require the approval of state education authorities (see Table 3.4). 
Table 3.5. Involvement in school principal recruitment process (ISCED 1-3), 2018

OECD review countries, public schools

\begin{tabular}{|c|c|c|c|c|c|c|}
\hline Country & $\begin{array}{l}\text { Other education } \\
\text { authority }\end{array}$ & $\begin{array}{c}\text { School } \\
\text { inspection }\end{array}$ & $\begin{array}{c}\text { School } \\
\text { community }\end{array}$ & $\begin{array}{c}\text { Other public } \\
\text { authority }\end{array}$ & External expert & Social partners \\
\hline Austria & $\checkmark$ & $\checkmark$ & $\checkmark$ & $x$ & $\checkmark$ & $\checkmark$ \\
\hline Belgium (FI.) & $d$ & $d$ & $d$ & $d$ & $d$ & $d$ \\
\hline Belgium (Fr.) & $d$ & $d$ & $d$ & $d$ & $d$ & $d$ \\
\hline Chile & $x$ & $x$ & $\checkmark$ & $\checkmark$ & $x$ & $x$ \\
\hline Colombia & $\checkmark$ & $x$ & $x$ & $x$ & $x$ & $x$ \\
\hline Czech Republic & $\checkmark$ & $\checkmark$ & $\checkmark$ & $x$ & $\checkmark$ & $x$ \\
\hline Denmark (ISCED 1-2) & $x$ & $x$ & $\checkmark$ & $x$ & $x$ & $x$ \\
\hline Denmark (ISCED 3) & $d$ & $d$ & $d$ & $d$ & $d$ & $d$ \\
\hline Estonia & $d$ & $d$ & $d$ & $d$ & $d$ & $d$ \\
\hline Iceland & $x$ & $x$ & $\checkmark$ & $x$ & $x$ & $x$ \\
\hline Kazakhstan & $x$ & $x$ & $\checkmark$ & $x$ & $x$ & $x$ \\
\hline Lithuania & $\checkmark$ & $x$ & $\checkmark$ & $x$ & $\mathrm{x}$ & $\checkmark$ \\
\hline Mexico & $\checkmark$ & $x$ & $x$ & $x$ & $x$ & $x$ \\
\hline Portugal & $\checkmark$ & $x$ & $x$ & $x$ & $x$ & $x$ \\
\hline Slovak Republic & $x$ & $\checkmark$ & $\checkmark$ & $x$ & $x$ & $x$ \\
\hline Slovenia & $\checkmark$ & $x$ & $\checkmark$ & $x$ & $x$ & $x$ \\
\hline Spain & $x$ & $x$ & $\checkmark$ & $x$ & $x$ & $x$ \\
\hline Sweden & $d$ & $d$ & $d$ & $d$ & $d$ & $d$ \\
\hline Turkey & $x$ & $x$ & $x$ & $x$ & $x$ & $x$ \\
\hline Uruguay & $x$ & $x$ & $x$ & $x$ & $x$ & $x$ \\
\hline
\end{tabular}

Notes: This table describes stakeholders involved in the recruitment process of school principals (e.g. in an advisory role, on the selection panel, for approval of the chosen candidate, etc.) other than those responsible for the recruitment itself.

Education authorities refer to those other than a recruiting authority (e.g. a central ministry where school principals are recruited at a local level). The school community includes school boards, teacher assemblies, representatives of parents, students, employers, etc. Other public authorities refer to central public service institutions, etc.

For full comparative tables on the recruitment of school leaders, see Table A.4. in Annex A.

$\mathrm{x}$ : not applicable

$\mathrm{d}$ : at discretion of recruiting authority

Sources: Based on Country Background Reports and Country Review Reports (http://www.oecd.org/education/school-resources-review/schoolresourcesreviewreportsforparticipatingcountries.htm).

\subsubsection{Matching staff with schools and students}

\section{Identifying effective teachers at the point of hiring and matching teachers with} schools' and students' needs

One difficulty for any teacher recruitment process, whether centralised or decentralised, concerns the challenge to identify effective teachers at the point of hiring (Staiger and Rockoff, $\left.2010_{[103]}\right)$. Most externally observable indicators, such as teacher certification, advanced tertiary degrees and competitiveness of post-secondary programmes, are poorly correlated with improvements in students' achievement (Rockoff et al., 2011 ${ }_{\text {[104] }}$; Boyd et al., 2008 $8_{[7]}$; Kane, Rockoff and Staiger, 2008 $\left.{ }_{[105]}\right)$. Such readily observable factors will thus likely not be sufficient to identify effective teachers. 
Furthermore, recent evidence indicates that teachers who are effective in improving students' cognitive skills may not be necessarily equally effective in supporting students in developing their non-cognitive skills, such as resilience, growth mindset, self-efficacy and behaviour in class (Gershenson, 2016 $\left.{ }_{[106]}\right)$. Affective and motivational competences therefore also need to be taken into account in selecting candidates (OECD, 2019 [59]).

As OECD (2005 $\left.5_{[67]}\right)$ argued, giving schools the authority for selecting their teachers may facilitate the ideal matching of teachers with particular talents and preferences to the needs of schools (e.g. student population, educational project, professional culture, teaching methods, extracurricular activities, etc.). A mixed-method study of a mid-sized school district in Florida (United States), for instance, found that some school principals used their influence on recruitment decisions to hire teachers that would enrich the mix of their staff in terms of race, gender, experience and skills and that they believed to be a good fit in terms of work habits (Harris et al., 2010 [107]).

The experience of OECD review countries also illustrates the potential of school involvement in staffing decisions. School communities interviewed for the review of Lithuania placed great value on local decision making, including for staffing, and the possibility this creates for ensuring connections between the school and its community (Shewbridge et al., 2016 $6_{[20]}$ ). In other reviews, a lack of school-level involvement in staffing decisions had led to workarounds with individual schools influencing allocation decisions through their personal connections, which is problematic since it obfuscates decision making for staffing (Nusche et al., 2016 $[41]$ ).

As OECD (2005 $\left.5_{[67]}\right)$ further argued, school-level hiring of teachers offers the advantage that applicants themselves can choose their workplace, have personal contact before the decision is taken and build a sense of commitment to their school. Locally determined matching has benefits in terms of job satisfaction (Daly et al., 2008 ${ }_{[108]}$ ), length of commute and absenteeism. School-based teacher selection may therefore help to reduce teacher turnover and attrition if it leads indeed to better job matching and higher staff satisfaction (Vegas and Ganimian, 2013 [96]; DeArmond, Gross and Goldhaber, 2010 [109]).

The TALIS 2018 asked lower secondary teachers about their satisfaction with their work environment (OECD, 2019[37]). On average across OECD countries, one in five teachers would like to change to another school if that were possible, but this differs quite widely across countries, from 10\% in Austria, Denmark and the Czech Republic, to more than $30 \%$ in Japan, Korea and Turkey (see Figure 3.6). Novice teachers were more likely to report wanting to change schools in 11 countries, which is possibly also related to the fact that new employees are looking for the right match with their workplace. 
Figure 3.6. Teachers' job satisfaction with their work environment, by teaching experience (ISCED 2), 2018

Percentage of teachers who reported that they "agree" or "strongly agree" that they would like to change to another school if that were possible

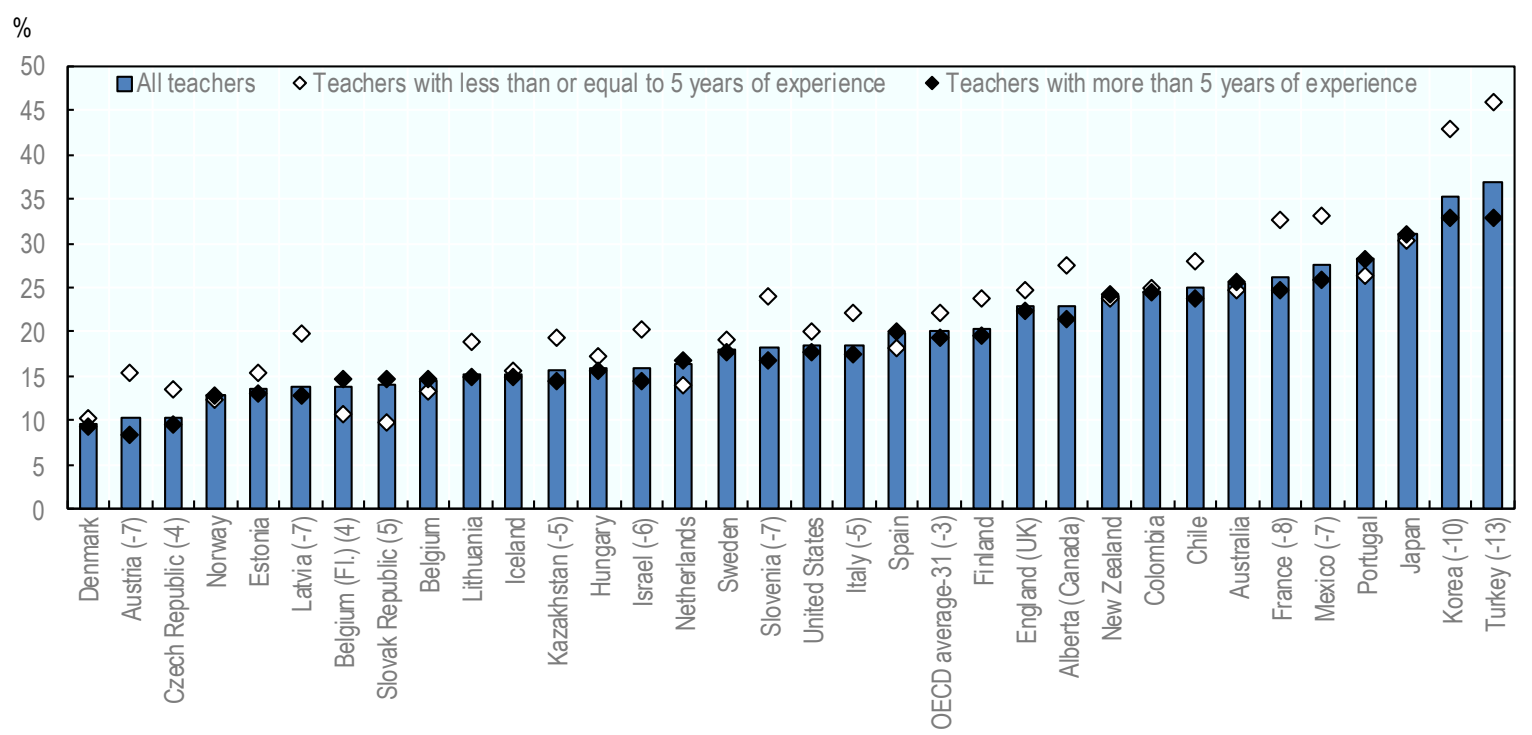

Notes: Countries and economies are ranked in ascending order of the percentage of all teachers reporting to want to change schools if they could. Significant differences between novice and experienced teachers are indicated next to the country name (percentage point difference). The number of countries or economies included in the OECD average is indicated next to that average. On 25 May 2018, the OECD Council invited Colombia to become a Member. While Colombia is included in the OECD average reported in this figure, at the time of its preparation, Colombia was in the process of completing its domestic procedures for ratification and the deposit of Colombia's instrument of accession to the OECD Convention was pending.

Source: OECD (2019), TALIS 2018 Results (Volume I): Teachers and School Leaders as Lifelong Learners, OECD Publishing, Paris, https://doi.org/10.1787/1d0bc92a-en, Table I.4.33.

StatLink त्ञाज़ https://doi.org/10.1787/888934026525

The empirical evidence on the effects of schools' autonomy to select their own teachers on student learning outcomes nevertheless is relatively scarce. A study of differences in school autonomy over teacher hiring between public and private schools in Korea under random assignment of students to both public and private schools finds that recruitment autonomy does lead to differences in the characteristics of teachers working in public and private schools. Private schools were found to have a higher share of male teachers and teachers on fixed-term contracts. Autonomy over teacher recruitment however did not affect achievement differences between public and private schools (Kim, 2017 ${ }_{[110]}$ ).

Studies of school autonomy more broadly suggest that it can have beneficial effects on the average performance of students as measured by international assessments, but that this depends on the particular domain and policy context. Analysing data from the Third International Mathematics and Science Study (TIMMS), Wössmann (2003 $\left.{ }_{[111]}\right)$ found that beneficial effects can be observed in particular when school autonomy in personnel and process (management) decisions is combined with centralised examination and accountability mechanisms. Based on a large-scale analysis of PISA data, Hanushek et al. $\left(2013_{[112]}\right)$ add the important caveat that school autonomy, in particular for academic content, but also personnel decisions, only has beneficial effects in relatively wealthy 
countries, whereas the effects turn out to be negative in lower income countries with less developed institutions.

School-based teacher recruitment and selection alone is thus unlikely to result in a more effective distribution of teachers. The quality of the recruitment processes and the tools used for screening and selecting applicants generally will depend on the capacity of recruiters (e.g. in terms of preparation, experience and time). And recruitment outcomes will also depend on other factors, such as school-level resources and working conditions as well as teacher incentives and preferences (DeArmond, Gross and Goldhaber, 2010 ${ }_{[109]}$ ). Where schools are responsible for staff recruitment, they need to establish policies to attract and retain qualified staff and ensure that their skills are matched with students' needs.

Schools may however not have the expertise to select the best candidate or time to manage applications, conduct interviews, assess candidates, extend job offers and process new hires. Recruitment needs may be difficult to predict given short-term changes in student enrolment or budgeting processes and only be known shortly ahead of the new school year at a time when it is difficult to organise activities such as classroom demonstrations. As Liu and Johnson $\left(2006_{[113]}\right)$ found for four states in the United States, teacher recruitment may be based in schools, but schools may not have the time to engage in processes such as setting up an interview panel or a classroom demonstration that would facilitate meaningful interactions between teachers and schools. The school-based recruitment process may therefore fail to provide rich information on the quality of a match (DeArmond, Gross and Goldhaber, 2010[109]). Without sufficient administrative capacity and resources, schoolbased teacher recruitment may furthermore create additional pressures for school leaders and demands on their time.

The extent of school autonomy may also be restricted by the supply of teachers willing to work in a school (Engel, Cannata and Curran, 2018 $\left.{ }_{[114]}\right)$. A study of school-based hiring in Norway found that the delegation of recruitment responsibilities from municipalities to schools was linked with greater efficiency, but that this effect was stronger for schools with an excess supply of teachers (Naper, $\left.2010_{[115]}\right)$. Schools may moreover be bound by rules and regulations or collective bargaining agreements which may limit their flexibility in staffing decisions (OECD, 2018[4]). Schools may have to give preference to certain candidates, for instance to teachers with greater seniority or voluntary transfers before considering outside candidates (Engel, Cannata and Curran, 2018 ${ }_{[114]}$ ).

While schools may have the say over their recruitment decisions, they may have less influence over other aspects of teacher employment which also influence the matching of teachers with schools, such as wage setting. In only four of the 15 systems which reported that teacher recruitment is the responsibility of individual schools, schools fix teachers' salary levels (the Czech Republic, England [United Kingdom], Estonia, and Latvia). In all of these four systems, schools need to respect central frameworks, such as nationally set minimum wages or collective bargaining agreements, when making salary-related decisions (OECD, 2018 $\left.{ }_{[100]}\right)$.

In addition, limited budgets may restrict school's wage setting autonomy in practice as was found in the reviews of the Czech Republic and Estonia or render salary decisions ambiguous (Santiago et al., 2016 [40]; Shewbridge et al., 2016 $6_{[42]}$ ). Among systems where an intermediate authority is responsible for teacher recruitment, only in Japan are they also responsible for fixing salary levels (OECD, 2018 $\left.8_{[100]}\right)$.

Particular potential seems to lie in schools and the education administration working together to build effective teacher recruitment systems. Administrators could ensure a good 
match between the person and the job, while the school ensures a match between the person and the organisation and its people (Rutledge et al., 2008 $\left.{ }_{[116]}\right)$. Recent work on teacher hiring in Washington DC (United States) suggests that the local level can play a role in identifying effective teachers. The district performed an in-depth pre-screening test to compile a shortlist of teacher candidates for principals to choose from. The test consisted of a subject-specific written assignment to assess candidates' understanding of content and instructional practices; a 30-minute structured interview with district staff; and a teaching "audition" that district staff observed and evaluated (Jacob et al., 2018 ${ }_{[117]}$ ).

Contrary to previous findings from New York City public schools (United States), the authors find that both the in-depth screening test results and the more traditional academic background variables (like the Grade Point Average) are strong predictors of teachers' future performance evaluations. However, they are weak predictors of principals' hiring decisions. So while the authors are optimistic that background data and district-level screening tests can provide useful input for decentralised hiring decisions, they conclude that principals need to be supported and encouraged to draw on this information more heavily in the application process (Jacob et al., 2018 $[117]$ ).

\section{Safeguarding transparency and fairness in recruitment}

The design of recruitment processes influences issues of fairness and transparency in selection - aspects that play an important role for candidates' decision to apply, the quality of the hired candidates and the level of staff performance and service delivery (Finan, Olken and Pande, $\left.2015_{[118]}\right)$. As in other fields, social networks can play an important role in recruitment. While social networks can facilitate the matching of job seekers to jobs, they can restrict access to jobs for those outside a network. More research about the role of social networks for teacher labour markets is needed, but research from the United States shows that teachers believe social networks to be important when looking for a position (Cannata, $\left.2011_{[119]}\right)$. Research also suggests that local ties are an important factor in explaining recruitment decisions (Boyd et al., 2013 ${ }_{[120]}$ ). In extreme cases, recruiters may not have the incentive to hire the best candidate (e.g. principals may favour someone they know personally) (DeArmond, Gross and Goldhaber, 2010[109]).

Hiring practices may furthermore be at risk of discriminating against certain types of applicants and reduce diversity in the profession. In a study of a large suburban school district in the United States that had implemented policies to increase the supply of black teachers, black candidates' chances of being hired were low. White principals hired disproportionately fewer black teachers than their black peers (D'Amico et al., 2017 [121]). This is a concern in terms of fairness in the recruitment process but also for students and schools. Growing evidence supports the value of students from minority backgrounds experiencing teachers in the classrooms who are from similar backgrounds (Gershenson, Holt and Papageorge, 2016 $\left.6_{[122]}\right)$. Moreover, given the role of schools as social institutions, diversity is arguably important in its own right (D'Amico et al., 2017 [121]).

Transparency and fairness were also concerns in a limited number of OECD reviews. To give an example, in the Flemish Community of Belgium, schools and school boards are not required to advertise their vacancies more widely, even if some of them do so in practice. They may keep lists of potential candidates and offer them employment directly without organising an open recruitment process (Nusche et al., 2015[70]). Similarly, in the Czech Republic, there is no requirement to publish vacancies for teacher positions. In the Slovak Republic, concerns about the transparency of teacher recruitment and the matching of supply and demand resulted in a requirement for school founders and schools 
to publicise their vacancies on their websites. In addition, regional and national information has also been made available to disseminate vacancies more widely (Santiago et al., $\left.2016_{[19]}\right)$.

The quality of school leadership can also be compromised by a lack of transparency and fairness in selection processes which, as in the case for teachers, can make school leadership less attractive and deter high-quality candidates from applying. There are arguments for the employer of principals to take responsibility for their selection and management. The power to select who leads their schools gives school providers the possibility to match their human resource policy with their educational strategy, but it can put appointments at risk of favouritism at the same time.

In Austria, for example, the selection process of school principals was traditionally considered to be driven by political networks rather than by an objective assessment of the candidates' skills and competencies. The risk for "political" appointments was related to the political nature of the federal and state bodies responsible for the selection process, although these authorities have been reformed as part of a broader education reform (Nusche et al., 2016[41]).

In the Czech Republic, central regulations for school founders' appointments of their school principals which are organised on the basis of an open competition provide a sound basis for the recruitment of qualified candidates. The OECD review, nevertheless, found that a risk for "political" appointments by school founders remained since school founders are free to appoint the candidate of their choice (Shewbridge et al., 2016 [42]). As for the case of teachers, hiring authorities, such as smaller municipalities, may furthermore lack the capacity to conduct high-quality recruitment processes.

\section{Filling teaching positions in time}

It can be difficult to fill teaching positions in time for the beginning of the school year, resulting in lost learning time for students which has been shown to negatively affect learning outcomes (Papay and Kraft, 2016 ${ }_{[123]}$ ). Difficulties to predict staffing arrangements can hamper the recruitment process and result in filling vacancies after the beginning of the school year. In centralised systems, assignment processes can be slow to fill positions if too few teachers were initially assigned to a school based on forecasts for the actual number of students at the beginning of the school year, which has reportedly been the case in Portugal (Liebowitz et al., 2018 [51]). In Colombia, central recruitment processes can be very lengthy and cumbersome given capacity challenges in central authorities involved in the process. This may also potentially deter high-quality candidates (Radinger et al., 2018 ${ }_{[18]}$ ).

\subsubsection{Towards an equitable distribution of teaching staff}

\section{Designing recruitment criteria and processes}

Since the effects of school autonomy for teacher recruitment will also depend on the capacity (and size) of schools, school autonomy could lead to greater disparities in teachers' qualifications and experiences among schools. Schlicht-Schmälzle et al. $\left(2011_{\text {[124] }}\right)$ confirm a weak positive effect of school autonomy on average performance, but they also find a negative effect on equity.

Teacher allocations through higher-level authorities may help steer a more equitable distribution of teachers across schools and help fill hard-to-staff positions in schools with specific profiles. Engel and Finch $\left(2014_{[125]}\right)$ found notable differences in recruitment 
practices between advantaged and disadvantaged schools. While advantaged schools could rely on their professional networks to recruit new teachers, disadvantaged schools had to rely to a greater extent on support by their school district to fill positions. In Colombia, authorities responsible for the recruitment of teaching staff have organised specific recruitments to fill hard-to staff schools in rural and remote areas (Radinger et al., 2018 ${ }_{[18]}$ )

Comparative data from PISA however in fact suggest that both systems with higher-level and school-based teacher recruitment may suffer from inequities in the distribution of teachers (OECD, 2018 $8_{[4]}$ ); something which also the experience of OECD reviews highlights. For example, inequities in the distribution of teachers seemed to be evident for systems with school-based recruitment such as the Flemish Community of Belgium and the Czech Republic but also systems with central recruitment and allocation such as Colombia and Portugal (Nusche et al., 2015[70]; Shewbridge et al., 2016 [42]; Radinger et al., $2018_{[18]}$; Liebowitz et al., 2018 [51] $)$. This essentially highlights the role of other factors, such as the levels of available resources to attract the best teachers, differences in working conditions, and the design of recruitment processes and criteria.

The criteria that systems may have in place for recruitment and allocation decisions, sometimes the result of collective bargaining agreements, combined with teachers' preferences, can contribute to disparities in the distribution of teachers (see Table 3.6). Teachers' qualifications and experience may then influence teachers' employment not only in terms of salary progression, but also the place of employment.

Table 3.6. Priority criteria for selection of teacher candidates (ISCED 1-3), 2018

OECD review countries, public schools

\begin{tabular}{|c|c|c|c|c|c|c|c|c|c|c|c|c|c|c|c|c|c|c|}
\hline Qualifications & $\checkmark$ & $\checkmark$ & & & & & & & & & & $\checkmark$ & & $\checkmark$ & $\checkmark$ & & $\checkmark$ & \\
\hline Experience & & & $\checkmark$ & & & & & & & & & $\checkmark$ & & & $\checkmark$ & & & $\checkmark$ \\
\hline Contr. status & $\checkmark$ & $\checkmark$ & & & & & & & & & & & & & & & & \\
\hline Evaluation & & $\checkmark$ & & & $\checkmark$ & & & & & & & $\checkmark$ & & & $\checkmark$ & & $\checkmark$ & $\checkmark$ \\
\hline Country & 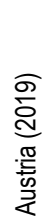 & 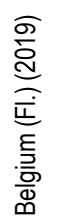 & 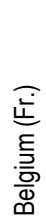 & 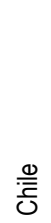 & $\begin{array}{l}\frac{\pi}{0} \\
\bar{E} \\
\text { 응 } \\
0\end{array}$ & 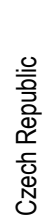 & 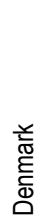 & 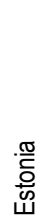 & $\begin{array}{l}\text { 믈 } \\
\text { 是 } \\
\underline{\mathbb{O}}\end{array}$ & 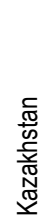 & 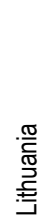 & $\begin{array}{l}\overline{\widetilde{\pi}} \\
\text { 옹 } \\
\text { 잉 }\end{array}$ & 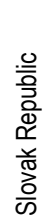 & $\begin{array}{l}\frac{0}{\bar{T}} \\
\frac{0}{0} \\
\frac{0}{\omega}\end{array}$ & 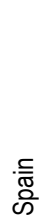 & $\begin{array}{l}\text { बे } \\
\text { d } \\
\text { के }\end{array}$ & 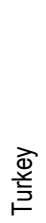 & $\begin{array}{l}\text { 홀 } \\
\text { 홀 }\end{array}$ \\
\hline
\end{tabular}

Notes: This table illustrates centrally regulated criteria that need to be taken into account in the selection of candidates into a teaching position. Evaluations may be carried out by education authorities, other public authorities (e.g. civil service commission) or schools/school principals.

For full comparative tables on the recruitment of teachers, see Table A.3. in Annex A.

Source: Based on Country Background Reports and Country Review Reports (http://www.oecd.org/education/school-resources-review/schoolresourcesreviewreportsforparticipatingcountries.htm). 
In a number of school systems, teachers' interests rather than students' needs drive the distribution of teachers and make it difficult to match the mix of teachers' experience and skills to school contexts. Where recruitment is centralised, teachers with the highest rank may for example have the first choice for the school they would like to work at. In decentralised systems, schools or sub-national authorities may have to safeguard teachers' statutory rights, such as permanent contracts or higher levels of seniority, when recruiting staff. These practices can result in a mismatch between the needs of schools and teachers' interests and skills. Large proportions of teachers may then work at school where they do not enjoy teaching, possibly concentrated in schools with more difficult working conditions.

Seniority-based systems may also work against novice teachers and fail to reflect the evidence base on teacher effectiveness. New teachers require a placement where they receive sufficient support and can grow into their professional roles. Evidence suggests that teachers' impact on student achievement grows from year to year within their first five years in the profession (Guarino, Santibañez and Daley, 2006 $\left.{ }_{[126]}\right)$. This is also evident looking at data from the TALIS 2018, with new teachers being less likely to feel confident in their teaching skills (OECD, 2019[37]). Teacher labour markets that channel these teachers to the most challenging schools may reduce their sense of efficacy and increase their likelihood of moving to another school or to leave teaching altogether (Luschei and Chudgar, 2017 [3]).

Based on the TALIS 2018, on average across OECD countries, novice teachers do tend to work in more challenging schools that have higher concentrations of students from socio-economically disadvantaged homes and immigrant students (OECD, 2019, pp. 139, Figure I.4.9, Table I.4.32[37]). Figure 3.7 shows differences in the distribution of novice teachers across schools with difference socio-economic composition. 


\section{Figure 3.7. Distribution of novice teachers by concentration of students from socio-economically disadvantaged homes (ISCED 2), 2018}

Difference in percentage of novice teachers between schools with "more than" and, "less than or equal to" $30 \%$ of students from socio-economically disadvantaged homes

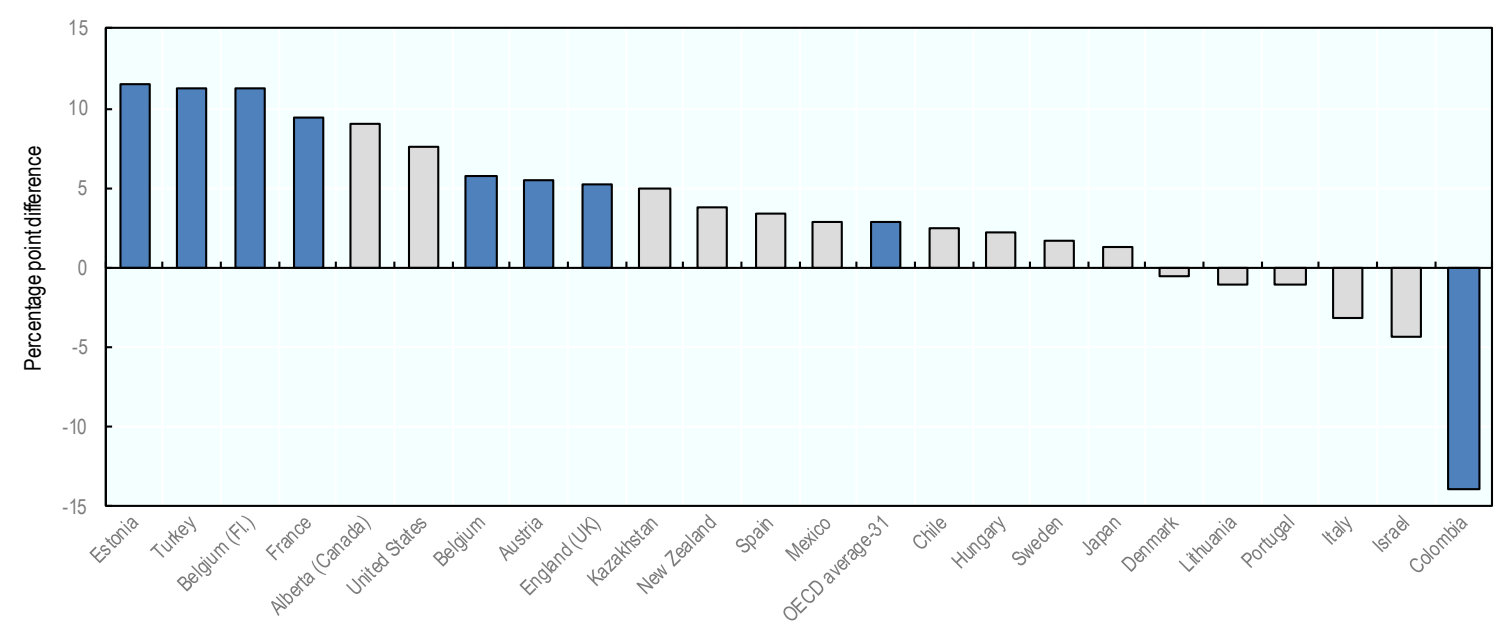

Notes: Results based on responses of teachers and principals. Novice teachers are teachers with five or less years of teaching experience. Socio-economically disadvantaged homes refers to homes lacking the basic necessities or advantages of life, such as adequate housing, nutrition or medical care. Statistical significant differences are indicated in a darker tone. The number of countries or economies included in the OECD average is indicated next to that average. On 25 May 2018, the OECD Council invited Colombia to become a Member. While Colombia is included in the OECD average reported in this figure, at the time of its preparation, Colombia was in the process of completing its domestic procedures for ratification and the deposit of Colombia's instrument of accession to the OECD Convention was pending.

Source: OECD (2019), TALIS 2018 Results (Volume I): Teachers and School Leaders as Lifelong Learners, OECD Publishing, Paris, https://doi.org/10.1787/1d0bc92a-en, Table I.4.32.

StatLink הत्मा https://doi.org/10.1787/888934026544

\section{Shaping staff preferences}

The distribution of staff across schools also depends on individuals' preferences and choices and the financial and other incentives for where to work. For the case of teachers, research suggests that, in many school systems, teacher preferences may direct the more qualified and more experienced teachers to schools enrolling mostly students with few socio-economic disadvantages (Bénabou, Kramarz and Prost, 2009 ${ }_{[127]}$; Karsten, $2006_{[128]}$; Hanushek, Kain and Rivkin, 2004 [129]]). This is likely part of the explanation why additional resources, be it in the form of funding or "in-kind" staff allocations as analysed above may not be sufficient to attract and keep better teachers in disadvantaged contexts.

Some school systems have put in place financial incentives (monetary or in-kind) for teachers to work in areas of need, such as higher salaries in schools enrolling high proportions of students from disadvantaged backgrounds. As Table 3.7 shows, such incentives are however rare among OECD Review countries. 


\section{Table 3.7. Financial incentives for teachers and school principals to work in disadvantaged or rural contexts (ISCED 1-3), 2018}

OECD review countries, public schools

\begin{tabular}{lll}
\hline Country & School in a disadvantaged context & School in a rural or remote context \\
\cline { 2 - 3 } Austria (1) & No & No \\
Belgium (FI.) & No & No \\
Belgium (Fr.) & No & No \\
Chile (2) & Higher base salary & Varies by role and location \\
Colombia (3) & No & Higher base salary, Other \\
Czech Republic & d & d \\
Denmark & No & No \\
Estonia (4) & $d$ & d \\
Iceland & No (teachers); .. (principals) & No (teachers), .. (principals) \\
Kazakhstan (5) & Salary supplement & Higher base salary, Other (teachers only) \\
Lithuania (6) & Salary supplement & No \\
Portugal & No & No \\
Slovak Republic & Salary bonus (teachers only) & No \\
Slovenia & No & No \\
Spain & Annual payment & No \\
Sweden & d & d \\
Turkey & Salary bonus & No \\
Uruguay & Higher base salary, Other (teachers only) & Higher base salary \\
\hline
\end{tabular}

Notes: School disadvantaged context refers to high concentration of students with special educational needs (SEN), low socio-economic status (SES) or immigrant background.

... missing

$\mathrm{d}$ : at discretion of authorities

1. Austria: Occasionally, (remote) municipalities offer extra benefits such as service accommodation to attract school leaders.

2. Chile: For teachers, the higher base salary amounts to $30 \%$ of the national minimum basic salary; for school principals in disadvantaged schools to $25 \%-200 \%$; for other school leaders in disadvantaged schools to $20 \%$. School leaders in remote areas receive financial compensation (asignación de zona), the value of which depends on the location. Teachers in charge of running small remote, multi-grade schools (profesor encargado) receive a different bonus.

3. Colombia: National regulations define compensation to attract staff to rural areas that are difficult to reach as designated by regional and local authorities certified to provide education according to specified criteria related to transportation. Staff working in these zones receive a $15 \%$ bonus each month over the entitled monthly salary. They also receive special permits to attend pedagogical meetings at the principal site of the school cluster. In addition, they get 5 one-day permits to go to internships in other schools. For specific departments, the Secretary of Education may provide once a year, budget allowing, a plane ticket between the departmental capital and the national capital Bogotá.

4. Estonia: Rural municipalities may offer cheaper accommodation or other benefits

5. Kazakhstan: Salary supplement for teachers and principals working with SEN students of $40 \%$ as a share of the baseline salary. Higher base salary (25\%) for teachers and principals in rural schools for holding teaching and administrative responsibilities. A scholarship programme to attend initial teacher education targeted at candidates from rural areas requires recipients to teach at least three years in rural areas following graduation. The programme With diploma to the village is targeted at higher education graduates (including teacher education graduates) who work in a village for at least three years.

6. Lithuania: Salary supplement up to $25 \%$. Disadvantage refers to SEN, low SES, immigrant children and non-Lithuanian language background.

6. Uruguay: Mainstream primary schools can operate with different modalities. Full-time schools are dual-scheduled (seven and a half hours per day) and teachers work forty hours per week, Aprender schools are simple scheduled schools (four hours per day), located in disadvantaged socio-economic contexts. For a teacher 
in a full-time school (40-hour teaching load) and a community teacher, the salary increase reaches $100 \%$ of the basic salary (for a 20-hour teaching load), for teachers in special schools $70 \%$, for teachers in rural schools $30 \%$ and for teachers in rural schools with a single teacher 50\%. "Other" refers to working time incentives for teachers, by providing the possibility to concentrate working hours in one (ISCED 1) or at most two (ISCED 2-3 general) schools. In primary education, for example, teachers typically work at two schools, 20 hours each.

Sources: Based on Country Background Reports and Country Review Reports (http://www.oecd.org/education/school-resources-review/schoolresourcesreviewreportsforparticipatingcountries.htm); OECD (2019), Education at a Glance 2019: OECD Indicators, OECD Publishing, Paris, https://doi.org/10.1787/f8d7880d-en, Tables D3.7 and D3.11 (web only).

As Vegas and Ganimian (2013 $\left.{ }_{[96]}\right)$ concluded in a review of the evidence from the United States, monetary incentives have shown promising results to allocate teachers where they are most needed (see for example Clotfelter et al. $\left(2008_{[130]}\right)$ and Steele et al. $\left(2010_{[131]}\right)$ ). A financial incentive scheme for working in disadvantaged schools in France however did not show positive results (Prost, 2013 ${ }_{[52]}$ ), highlighting that such incentives will work differently depending on the design and size of the incentives and the general framework for teacher employment and career progression (OECD, 2018 $8_{[4]}$ ).

Financial incentives have also been shown to be effective in attracting teachers to rural schools, although not for remote schools (Pugatch and Schroeder, 2014 ${ }_{[132]}$; Dal Bó, Finan and Rossi, 2013 $[133]$ ). It may moreover be important to monitor financial allocations over time to ensure they are no longer provided once teachers change schools or the context of a school changes (Urquiola and Vegas, $2005_{[134]}$ ).

However, not only financial aspects are important for the distribution of staff, but also non-financial ones, although more needs to be understood about the relevant importance of each of these aspects. As highlighted in Chapters 1 and 2, teachers are highly motivated by the intrinsic benefits of teaching - working with children and young people and helping them develop and learn as well as opportunities for personal and intellectual growth role (Lortie, $\left.1975_{[135]}\right)$. Professional factors matter, such as opportunities to take on additional responsibilities and to engage in research and innovation, and strong leadership and collegiality in professional learning (Shewbridge et al., 2016 [42] $)$, as do working conditions, such as class size, preparation time or facilities (Rice, 2010 $\left.{ }_{[136]}\right)$. Research also suggests that accountability pressures inform teachers' preferences of where to work (Feng, Figlio and Sass, 2018 ${ }_{[137]}$; Gjefsen and Gunnes, 2015 [138]).

\subsection{Staff allocation within schools}

Providing adequate and equitable funding for staff employment, attracting and recruiting high-quality professionals, and ensuring a good match between them and schools is not sufficient. Schools also often make resource decisions about the use of their staff, for instance to provide students with learning difficulties or needs with additional support, either within or outside of class. In a study in ten school districts in the United States, Barrett and Toma (2013 $\left.{ }_{[139]}\right)$ show that principals increased the class sizes of teachers they deemed effective based on their own assessments, for example.

Also the allocation of staff to specific students and vice versa within schools needs to be considered to make the best use of expertise and to promote student learning in an efficient and equitable way (Monk, 1987 $_{[140]}$ ). The optimal matching of teachers and students within schools may help improve effectiveness and efficiency, and be a tool to help retain beginning teachers by assigning them to less challenging classrooms (Feng, 2010 [141]).

What is more, the way the school operates and the supports that are available to and within schools play an important role to make staff effective and ensure high-quality teaching for 
all students and across a student's time in school (Little and Bartlett, 2010 [2]; Johnson, $2009_{[142]}$ ). After all, not all staff within a school will be equally effective, so depending on their class assignment, some students would benefit from more, others from less effective instruction. Likewise, students learn in different classes and move across grades, so their experience over time would not necessarily be consistent and successful (Johnson, $\left.2009_{[142]}\right)$. The school's organisation and culture as well as the relationships among staff will likely also influence the decision of staff to stay or to go (Kraft et al., 2015 [1]), and the quality of the learning environment that staff can create together (Bellei et al., 2014 [143]; Bryk et al., 2010 $\left.0_{[144]}\right)$.

The following discusses the assignment of staff to students within school. The role of organisational factors for schools' individual and collective professional capacity is discussed in Chapter 1.

\subsubsection{Matching teachers and students within schools}

The forming of classes of students and the assignment of teachers to work with these students in a classroom is a regularly occurring organisational feature of schools. Within their organisational structures and available resources, schools create and manage a schedule to provide an educational offer in line with the stipulated curriculum for a particular level of education, matching students, courses, teachers and time in the process.

This may also entail decisions within schools on how many classes to form, which courses to offer, how many students to teach per class, at which time of the school day and in which classrooms. In the most complex case, both students and teachers are matched in a dual assignment process. In the simplest case, there is only one teacher and one group of students, which requires essentially no matching or decision making (Burns and Mason, $1995_{[145]}$; Delany, 1991 [146]).

The grouping of students (the first part of the matching process) determines both the students' levels of learning a teacher works with and the students' peer group. Where teachers work with a heterogeneous group, they require the capacity to engage learners with a range of abilities. Grouping students by performance, on the other hand, creates more homogeneous classes. While this potentially allows teachers to present material at a more appropriate level and pace, it may also reduce opportunities for lower-performing students to learn from their higher-performing peers (OECD, 2016 ${ }_{[147]}$; Betts, $\left.2011_{[148]}\right)$.

Grouping students by different levels of performance may provide one possibility for schools to tailor their staff allocations (and their time and skills) to students' needs, such as creating smaller classes for disadvantaged students who would benefit the most from such an intervention (Betts, $\left.2011_{[148]}\right)$. In the United States, Betts and Shkolnik $\left(2000_{[149]}\right)$ found that teachers of the lowest ability classes tended to have less experience and qualifications, but that class sizes were smaller for the lowest ability groups.

In Austria, ability grouping was abolished in 2008 with a reform of lower secondary education before it was re-introduced in 2018. When ability grouping was abolished, the teachers that were needed for ability grouping (since ability groups were smaller than classes) were used for team teaching for greater individualisation and differentiation within classes. Since 2018, schools can decide whether to use their available resources for team teaching or for the creation of ability groups (Nusche et al., 2016 $6_{[41]}$ ).

Relatively little is known about the second part of the matching process, that is the assignment of teachers to classes. There is, however, a growing literature on the allocation of teachers to students within schools in the United States. This body of literature illustrates 
the role of this part of the matching process for efficiency, but also equity given that the quality of individual teachers can vary substantially within schools (Mansfield, 2015 [150]). By allocating teachers to certain levels of education or ability groups, schools determine which students get access to the most effective teachers (Allen and Sims, 2018 ${ }_{[151]}$ ).

Evidence from the United States suggests that the assignment of teachers to students is typically not random. Kalogrides et al. $\left(2013_{[152]}\right)$ looked at differences in the classrooms assignment of teachers teaching the same grade in the same school in a given year in a large urban school district. They find that teachers are sorted by characteristics, such as gender, ethnicity, experience, leadership role and attendance of a more selective undergraduate institution at all levels of school education. This sorting also led to differences in the assignment to more experienced or more highly qualified teachers who were more likely to teach classes with advantaged students. Similarly, Feng $\left(2010_{[141]}\right)$ found in a study of schools in Florida (United States) that beginning teachers were more likely to teach classrooms with a larger share of low-performing students with low discipline and students from disadvantaged backgrounds.

In a study of public schools in North Carolina (United States), Horoi and Ost $\left(2015_{[153]}\right)$ examined the assignment of students in Grades 4 and 5 that changed schools. Although schools receiving these transfer students likely have more limited information about them when making classroom assignments, their assignment was again found not to be random. Transfer students, and particularly those with low achievement or with a minority background, tended to be assigned to less experienced teachers compared to non-transfer students; emotionally disabled, low-achieving and male transfer students were all more likely to be assigned to male teachers. Lastly, transfer students from an ethnic minority were more likely to be assigned to minority teachers.

The impact of such assignments within schools on inequities in student learning over time relative to inequities created through teacher resource differences between schools is likely limited. A study on inequities in the distribution of teacher quality across all schools in the state of Washington (United States) found that inequities across classrooms also contributed to inequities in access to quality teachers as measured through value-added, but that most of the overall teacher quality gap came from sorting across school districts and schools (Goldhaber, Lavery and Theobald, 2015 $\left.5_{[5]}\right)$. Mansfield (2015 $\left.5_{[150]}\right)$ analysed teacher allocations within and across public high schools in North Carolina (United States) and their relation to inequities in student test scores. In his study, differences in quality among teachers from the same school only minimally contributed to differences in performance across students over their high school careers as most students were taught by a mix of their schools' more and less effective teachers.

\section{How are teachers assigned within schools?}

Schools need to decide about the assignment of their teachers to particular grades, subjects and classes. The decision-making responsibilities and processes will differ across schools. School leaders will generally be responsible for ensuring students' instruction across the curricular areas with their available staff, but in some schools the process may be more centralised while in others it may be more devolved to staff (Dabach, 2015 [154]).

In general, the matching of students and instruction occurs within an environment of constraints, uncertainty and change (e.g. of the curriculum, graduation and tertiary entrance requirements). More specifically, the profile of the staff in a school together with qualification requirements will set the parameters for how teachers can be deployed in a school (Delany, $\left.1991_{[146]}\right)$. In primary schools, teachers are often generalists which makes 
their assignment more flexible (Cohen-Vogel, $\left.2011_{[155]}\right)$. In secondary education, specific courses will require particular qualifications or level of expertise which may then influence the sorting of teachers across grades and subjects (Kalogrides, Loeb and Béteille, 2013 [152]).

Also teachers' contracts and teaching load requirements will put certain constraints on class assignments. Teaching staff and their time are furthermore always limited and shortages of staff may make trade-offs inevitable. School leaders may then see themselves required to assign teachers to subjects for which they have not been prepared to cover instruction time (Ingersoll, 2005 $[156])$.

The ways in which schools are organised will set certain conditions on the allocation of staff. In some school systems, schools are organised in clusters across multiple sites or across different shifts. In some OECD review countries, such a clustering has been pursued through central policies. In Colombia, public schools have been organised in clusters that group different sites under a common leadership to smooth students' transitions based on national legislation. Schools have furthermore historically operated in double shifts, one in the morning and one in the afternoon, to expand coverage, although the government has been moving towards a longer school day (jornada única) (Radinger et al., 2018 ${ }_{[18]}$ ). Similarly, Portugal has clustered schools as part of a national programme (Liebowitz et al., 2018 [51]).

In other school systems, the organisation of schools bas been left to the local level. In Austria, an educational reform in 2016 established benchmarks for the number of students in a school and the possibility for schools to form a cluster (Nusche et al., 2016 [41]). In Denmark, the local reorganisation of schools also resulted in schools under one leadership as a way of consolidating without closing school buildings (Nusche et al., 2016[34]).

The organisation of schools in multiple sites or multiple shifts provides flexibility for the allocation of teachers, but also creates demands for school leadership for the assignment and management of teachers. In particular, it creates challenges where distances are long, such as in remote areas, for example to assign teachers to work with students on different sites over the course of a school day. Further difficulties might arise given the separation of levels of education across different sites (OECD, 2018 $8_{[25]}$ ).

\section{Classroom assignments as a political process that is influenced through internal and external pressures}

School leaders, teachers, parents and students all have a stake in classroom assignments within schools. School leaders, be it at senior or middle levels, may pursue objectives related to student learning or staff and organisational management. Leaders may seek to tailor class assignments to the perceived strengths and weaknesses of teachers, to support struggling students or to raise overall school achievement. Or they may use class assignments to promote staff satisfaction and retention or to minimise conflict in the school community. As Player $\left(2010_{[157]}\right)$ found, principals may also reward teachers by assigning them to particular classes.

Teachers likely also have preferences over their assignment to specific subjects, grades and students, as do parents and students over who teaches. The assignment of teachers is then likely a complex political process with school leaders attempting to balance short- and long-term organisational goals while responding to preferences by teachers, parents and students (Kalogrides, Loeb and Béteille, 2013 ${ }_{[152]}$; Cohen-Vogel, $2011_{[155]}$ ). 
School leaders may involve teachers, parents and students to different degrees in their assignment decisions, also to potentially benefit from their knowledge on what they perceive to be the best learning environments for their students or children. Teachers and parents may provide information on students' behaviours, learning styles, personalities, and interactions with their peers, prior teachers, and general teacher types (Paufler and AmreinBeardsley, 2014 $\left.4_{[158]}\right)$. Where school leaders are new to a school, they may have to rely in particular on the insights of their teaching staff on how to group students and assign teachers (Monk, 1987 ${ }_{[140]}$ ). School leaders may also use assessment data to assign teachers to particular grades, subjects and classes (Cohen-Vogel, 2011 $\left.1_{[155]}\right)$.

Different agents may have different leverage over assignment decisions. More experienced teachers may be able to lobby their leadership to teach less challenging classrooms as they have built stronger ties over time (Grissom, Kalogrides and Loeb, 2015 ${ }_{[159]}$ ). This was also evident in some OECD review countries. In Austria, some teachers reported conflict between beginning and experienced teachers in a school, with beginning teachers being given potentially more difficult classes (Nusche et al., 2016 $\left.6_{[41]}\right)$. In Colombia, beginning teachers reported being more likely assigned to smaller and more remote school sites (Radinger et al., 2018 ${ }_{[18]}$ ). Also some parents, typically those from more advantaged backgrounds, may be more likely to request that their children are assigned to a particular teacher (Qureshi and Ost, 2018 [160]; Jacob and Lefgren, 2007 [161]).

More central policies, such as accountability pressures or qualification requirements, may also influence teacher allocations within schools. Test-based accountability systems can set strong incentives to assign the most effective teachers to subjects and grades levels with high-stakes examinations that influence rewards and sanctions for schools (Grissom, Kalogrides and Loeb, 2017 $[162]$; Chingos and West, 2011 ${ }_{[163]}$ ). This could lead to the assignment of less effective teachers to earlier years even though returns at these levels are greatest (Fuller and Ladd, 2013 ${ }_{[164]}$ ).

Changes to teachers' qualification requirements for teaching particular courses or students' course taking requirements may also influence the staffing of schools. In California (United States), the implementation of accountability policies and changes to credential requirements led to pressures on schools to staff courses for English learners with new teachers who were authorised to teach these courses since more experienced teachers had not acquired the necessary credentials during their preparation (Dabach, 2015 [154]). In England (United Kingdom), students with low performance in mathematics have been required to continue studying the subject until the age of 18 . Shortages of mathematics teachers have led to the staffing of these retake and advanced classes with the most experienced and qualified teachers (Allen and Sims, 2018 $\left.{ }_{[151]}\right)$.

\section{Grade reassignments, looping, specialisation and departmentalisation}

The assignment of teachers to a grade or subject across years also has a role to play for students and teachers in terms of learning outcomes and turnover. The reassignment of a teacher to a new grade for instance may have an impact on their workload (e.g. preparation for lesson plans) and use of grade-specific skills, and therefore induce staff turnover and harm learning (Atteberry, Loeb and Wyckoff, 2016 ${ }_{[165]}$; Ost and Schiman, 2015 [166]).

Brummet et al. $\left(2017_{[167]}\right)$ examined the frequency and predictors of within-school teacher grade-level switching using both longitudinal administrative data from the state of Michigan and nationally representative survey data for the United States. As they found, about $7 \%$ of classroom teachers change grades following any given school year. 
Inexperienced teachers are relatively more likely to switch grades, and grade-level reassignments are inequitably distributed across both schools and students.

At the primary level, there is a question if teachers instruct all core subject to their class or if they specialise in specific subjects in the higher primary level grades, also referred to as "departmentalised instruction". "Departmentalised instruction" may allow teachers to concentrate planning on fewer subjects, which may lead to more thoughtful lessons and deeper instructional or content knowledge in those subjects. Fryer $\left(2018_{[168]}\right)$ however finds that teacher specialisation reduces student achievement, arguing that this may be caused by teachers having fewer interactions with each student.

Hill and Jones $\left(2018_{[169]}\right)$ in fact provide evidence for the academic benefits of student-teacher familiarity at the primary level through "looping", that is having students and teachers progress through the early school years together. The effects were largest for minority students, and for students with generally less effective teachers (as measured by value added).

Such "looping" practices are common in some OECD review countries. In Kazakhstan, the same classroom composition and teacher is typically maintained during the first four grades of primary education, which has been found to provide a number of benefits for primary school students, such as consistency in the curriculum delivery and stronger relationships among students, teachers and parents (OECD/The World Bank, 2015 $[60])$. In Slovenia, basic education (ISCED 1 and 2) comprises three three-year cycles. In the first three-year cycle, children are taught by a generalist teacher and it is recommended that the same teacher teaches the class for all three years. In the second cycle, the generalist teacher still delivers most lessons, but individual subjects are gradually taken over by specialist subject teachers. In the third cycle, lessons are delivered by specialist subject teachers (Slovenian Ministry of Education, 2017 $[71]$ ).

\subsubsection{Handling staff absences within schools}

\section{What is the impact of staff absences on schools and students, and how do schools ensure continued learning?}

Teacher absenteeism is an unavoidable feature of education systems. At some point in time, all teachers will experience illness or family emergencies and need to be replaced temporarily.

The PISA 2015 provides some insights into the extent to which school principals perceive teacher absenteeism as hindering student learning. Across OECD countries, $17 \%$ of 15 -year-old students were enrolled in schools whose principal reported that students' learning is hindered by teacher absenteeism at least "to some extent" (see Figure 3.8) (OECD, 2016, pp. 457, Table II.3.17 $7_{[147]}$ ). The extent to which absenteeism hinders learning, as reported by principals, however, differs considerably across and within countries. In the most disadvantaged, schools, $18 \%$ of students had principals who reported so, compared to only $13 \%$ of students in the most advantaged schools, a significant difference of 5 percentage points $\left(\mathrm{OECD}, 2018\right.$, pp. 162, Table 3.9 $\left.9_{[4]}\right)$. This is echoed in national studies from Germany and the United States, for example (Helbig and Nikolai, $2019_{[170]}$; Clotfelter, Ladd and Vigdor, 2009 $[171]$ ). 
Figure 3.8. Teacher absenteeism hindering student learning, 2015

Percentage of principals reporting that teacher absenteeism hinders student learning to the following extent:

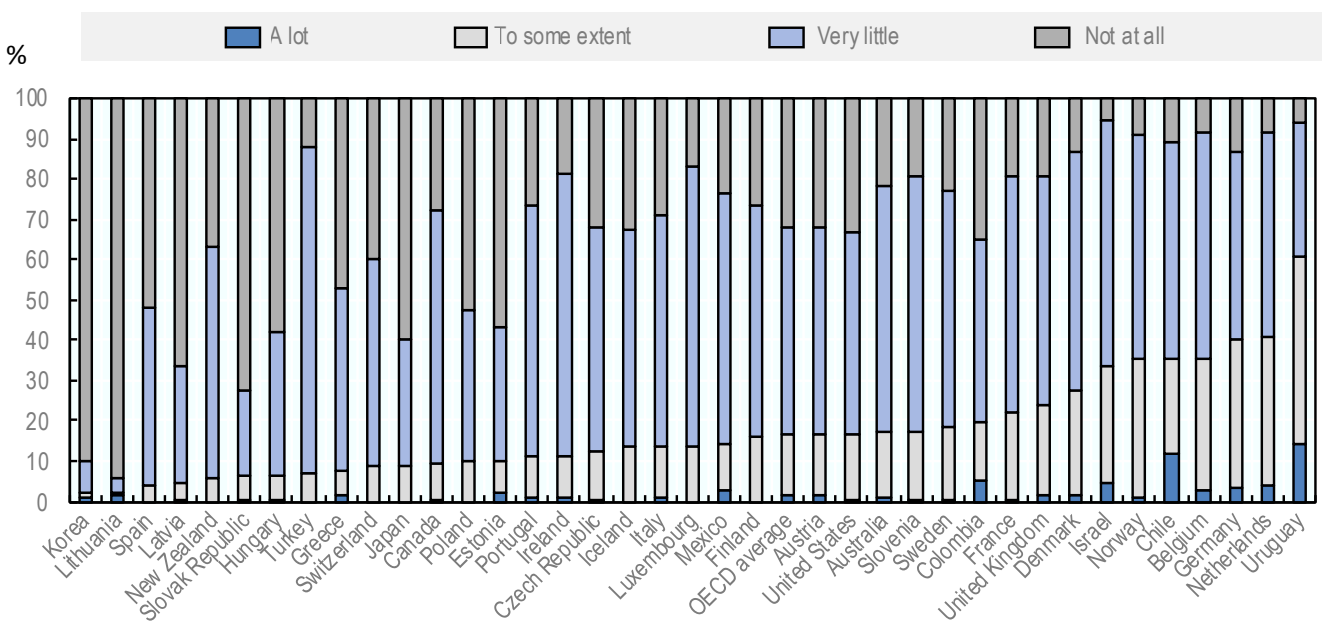

Note: Countries and economies are ranked in ascending order of the percentage of principals who reported teacher absences hinder student learning to "some extent" and "a lot".

Source: OECD (2016), PISA 2015 Results (Volume II): Policies and Practices for Successful Schools, OECD Publishing, Paris, https://doi.org/10.1787/9789264267510-en, Table II.3.17.

StatLink त्गाड़ https://doi.org/10.1787/888934026563

It is then critical to understand and address issues of absenteeism in specific contexts and the reason behind them (Guerrero et al., 2013 ${ }_{[172]}$ ), but also how teachers are replaced in their classrooms when they are absent, not least since some research has identified a negative relationship between teacher absences and students' test scores (Herrmann and Rockoff, 2012 ${ }_{[173]}$; Miller, Murnane and Willett, 2008 $\left.{ }_{[174]}\right)$. The research carried out by Miller et al. $\left(2008_{[174]}\right)$, for instance, indicates a small, statistically significant, negative impact of teacher absences on learning outcomes, with test scores decreasing by $3.3 \%$ of a standard deviation for each ten days of absence.

Many countries have a decentralised system of substitute teacher recruitment (e.g. Ireland) while some have a centralised system (e.g. primary education in France). Where the replacement of teachers through substitutes takes places at the school level, personal arrangements can aid in recruitment. Schools often seem to have a directory of substitute teachers' contact details, generally compiled over time such that substitute teachers who had previously substituted at the school and were successful would be added to aid future recruitment. The creation of this list seems to usually be based on the relationships that substitute teachers formed during their time, whether they had a positive experience or not, and whether full-time teachers and school leaders felt they had done a good job.

Technological advancements have resulted in new methods for finding substitute teachers through a range of mechanisms, including phone, text and mobile application services. The recruitment of substitute teachers may furthermore involve outsourcing, for example through agency recruitment. Where principals are responsible for recruitment, this may give them more time to carry out their other responsibilities instead of recruiting substitute teachers. At the same time, however, principals may lose control over the quality of the substitute teacher employed at their school. Depending on regulations and quality 
assurance, agencies may also be characterised by a lack of universal standards and thus negatively impact students' learning if lower quality substitutes are deployed to schools.

In the United Kingdom, agency recruitment has grown rapidly. In England and Wales, substitute teacher recruitment through agencies has increased from $63 \%$ in 2014 to $79 \%$ in 2017 while recruitment by schools and local authorities has decreased from $40 \%$ to $27 \%$ and $17 \%$ to $7 \%$ respectively during the same time period (NASUWT, 2017 $7_{[175]}$ ). As the use of supply agencies has been growing, issues surrounding these agencies have emerged, primarily around agency fees, salary rates and the exclusion from benefit entitlements. There have also been serious issues over the cost of these agencies for schools and substitute teachers such that these agencies typically earn GBP 40-50 (British pounds) per substitute teacher per day (Balakrishnan, 2017 $[176])$.

Box 3.7 highlights two interesting examples to support a more effective and efficient recruitment of substitute teachers: the work of Substantial Classrooms, a United States-based non-profit organisation, and a pilot project for substitute teacher recruitment in the Flemish Community of Belgium.

\section{Box 3.7. Building capacity for the recruitment of substitutes}

\section{Creation of a substitute teacher pool, Flemish Community of Belgium}

The Flemish Community of Belgium has recently put in place pilot projects to support school boards in replacing absent teachers through a substitute pool of teachers.

For primary education, the Flemish government has been funding 350 full-time equivalent teachers who are allocated to so-called "teacher platforms" in which schools collaborate and share substitute staff. Almost all primary schools have been participating in the project.

The teacher platforms can hire staff for one full year with these full-time equivalents on the condition that the staff member is used for replacements of less than a year or gets a stable task and that another, more experienced, staff member is used for replacements of less than one year. The staff member hired through the platform is appointed to one or more schools belonging to the platform. Staff members hired through this scheme need to hold at least a part-time appointment, which does not need to be solely through employment with the teacher platform. For example, a teacher can have a $30 \%$ workload through a regular appointment at a school belonging to the platform and a further $20 \%$ through the platform itself. Where working time or employment arrangements of staff belonging to a platform change over the year, the working time available within the platform is adjusted.

In case no replacement is needed due to staff absences, staff from the teacher platform perform other pedagogical tasks such as co-teaching or supporting their peers. Full-time equivalent teachers who are hired through the teacher platform are expected to be deployed for replacements for $85 \%$ of the time. If less time is spent on substitution in a year, less full-time equivalent teachers will be funded the following year. If more time was spent on substitution, more resources are provided subsequently.

The project started in October 2018 and has been monitored in co-operation with the labour unions and social partners. Depending on the experience, the project will be continued and/or adjustments will be made. A similar pilot has been underway for secondary education, albeit at a smaller scope this pilot is limited to 16 collaboration platforms and 350 full-time equivalent teachers have been funded by the state government.

Source: Information provided by the Ministry of Education and Training, Flemish Community of Belgium. 


\section{Substantial Classroom initiative, United States}

Founded in 2016, Substantial Classrooms aims to improve the substitute teacher experience for student and substitute teachers alike by working with school districts, non-profit organisations and individual schools across the United States. The primary objective of the initiative is to ensure that student learning time is used in the most efficient and effective way, replacing "wasted days" and "play days" with days of meaningful learning. Two distinct services - the development of leadership capacity and substitute data dashboards focus on improving the recruitment and deployment of substitute teachers.

Substantial Classrooms aims to build leadership capacity at all levels. The Substitute System Leaders Academy provides a ten-week course for staff involved in the organisation of substitute teaching. The first component - strategic focus - aims to increase awareness of and deal with substitute teacher shortages. The second component - vision and planning - allows staff to analyse available data and make immediate changes in light of these findings. The third component - design thinking and continuous improvement involves equipping participants with the skills necessary to make changes happen in a complex system through a coaching system.

The programme's second element, a substitute data dashboard provides insights into the demand and supply of substitute teachers and allows school administrators to better manage their substitute pool. This data can be analysed to identify the types of substitute teacher requests such as pre-planned, last minute and long-term absences. It also provides information about the pool of substitute teachers, such as the absolute size of the pool and the proportion of active substitutes. Finally, individual school profiles, reasons for teachers' absences, disaggregated by day and month and school types are also available.

Source: Substantial Classrooms, https://substantialclassrooms.org (accessed 20 July 2019).

\subsection{Policy options}

\subsubsection{Monitoring demand and supply of teachers, school leaders and other school staff to identify and address imbalances}

Adequate monitoring and forecasting mechanisms (e.g. through the use of rigorous supply and demand studies) that take into account a wide range of factors, including the higher education and labour market context, provide important information on the future demand for staff with specific competencies and facilitate the steering of the labour market. Based on this information, authorities can develop strategies to address potential shortages and/or oversupply of staff. In systems with shortages, authorities can for example implement measures to further increase the attractiveness of a career in schools, such as scholarship, grant or loan programmes; financial bonuses for specific geographical regions; and recruitment campaigns to attract staff in areas of need.

Research on teacher preferences suggests that teachers typically prefer to work close to their homes, families and friends, even when they gain their initial teaching qualification elsewhere. This indicates that teacher labour markets are geographically relatively small and the pool of prospective teachers available to work in a given school is limited. In specific areas facing teacher shortages, "Grow your own" strategies can therefore play an essential role for meeting the demand for teachers. 
In systems with an oversupply, authorities can develop strategies for reallocating, redeploying and retiring staff currently in schools. Some staff could assume new responsibilities, such as advisory roles within or across schools. Staff close to retirement could be offered early retirement packages. At the same time, systems with an oversupply need to plan ahead, ensure an adequate renewal of staff to provide the system with new ideas and perspectives, and address potential shortages in specific areas. Systems with an adequate supply of staff have an opportunity to be more selective about those who enter the profession and teacher education programmes (see Chapter 3 on entry requirements). Establishing a dialogue among researchers, policy makers and the profession in analysing forecasting data is key to identify problems in supply and develop timely solutions.

\subsubsection{Managing resources for school staffing}

\section{Adjusting staffing levels to changing needs}

Stability and predictability in available resources are important so that employers - be it a school or an education authority - can plan their staff levels and mix over several years, but a degree of flexibility in staff resourcing is also necessary to respond to unforeseen needs, such as changes in student enrolment.

There are two main approaches for resource allocations for staff. In systems where staff employment is centralised above the school level, schools typically receive "in-kind" staff allocations. In systems where schools are themselves responsible for staff employment, they typically receive monetary resources which they can use to hire and employ their own staff. Monetary transfers without restrictions give individual schools the greatest level of autonomy in terms of staff spending. By contrast, monetary transfers that are earmarked for a particular staff category, as well as the in-kind provision of staff, allow the allocating authority to retain a degree of control over schools' staffing levels and mix.

Staff funding may also be earmarked for the benefit of specific student groups, such as special needs students, while giving schools discretion over who to hire for this purpose. For example, some countries have dedicated funding programmes that help schools finance multidisciplinary teams including specialists such as speech therapists and psychologists to support inclusive education across classrooms.

In systems with central teacher allocations, central transfers of staff can help adjust staffing levels to changes in enrolment in different schools, possibly together with a reorganisation of the school network or of school leadership structures, for example by creating school clusters with multiple sites.

In systems with decentralised employment, central education authorities can support schools in adjusting their staffing levels, for example by managing redeployment processes, facilitating the transfer of teachers on permanent contracts, helping schools cover the costs when disestablishing permanent teaching positions, or promoting multi-school staffing models that enable two or more schools to temporarily transfer staff between them. While temporary employment contracts are an important tool to ensure flexibility in staff management, school systems should ensure an adequate balance between staff on permanent and temporary contracts, and adequate working conditions for all staff.

Teacher mobility will also be important to adjust staffing levels to changing demographics across a school system as a whole. In a number of systems, teacher mobility is hindered by inefficiencies and rigidities in the teacher labour market. To reduce such rigidities, teachers should be able to carry their statutory rights (e.g. pension entitlements and salary levels) 
with them when moving across sub-systems. Other administrative hurdles may also need to be cleared, such as processes for sub-systems to manage teacher transfers between authorities. In systems with limited mobility of teachers between schools overall, incentives or regulations could be introduced to encourage such mobility, which should be monitored and evaluated for their effectiveness.

\section{Reviewing the mix of staff and their use of time in schools}

The presence of different types of staff besides teachers and school leaders and their role for the provision of education and students' learning experience is increasingly being recognised (also see Annex 1.A in Chapter 1). While some staff may support instruction in the classroom, such as teacher aides, others support the instructional programme more broadly or provide social and health support for students. Yet others provide administrative and managerial assistance, support the maintenance and operations of schools and provide important ancillary services, such as transportation and school meals.

Much remains to be understood about the role of other types of staff besides teachers and school leaders, but the availability of a wide range of staff in and for schools has the potential to enable schools to better meet their individual students' academic, social and emotional needs. In the context of evolving social and educational contexts, such as changing family patterns or increasing diversity in schools and classrooms, professional pedagogical, health and social support likely plays an ever more relevant role for schools.

Decisions about the mix of staff in schools however involve complex trade-offs in the use of resources that need to be informed by relevant data and evidence. They also require consensus about the types of tasks and responsibilities that are expected of teachers and school leaders and the roles they may take on as they develop in their career as discussed in Chapter 2. The types of staff that are available should support schools' in realising their educational project for their students, and schools should have some level of influence over their staffing mix.

Needs-assessment studies are one tool to help determine the staffing needs of schools and inform future resource allocations. Such studies would examine what roles are currently performed by staff, how their time is spent, what needs schools have and which types of staff would help fulfil related responsibilities. They would estimate appropriate levels of different types of staff or the comparative levels of need for schools with different demographics. In the United States, for instance, evidence exists both on the optimal guidance counsellor to student ratio (one counsellor per 250 students on average for all schools) (NACAC, 2018 ${ }_{[177]}$ ) as well as on their causal impacts on student outcomes (Hurwitz and Howell, 2013 ${ }_{[178]}$ ).

As part of such a needs-assessment, it would be valuable to explore the extent to which identified needs could be addressed by investing in increased training for all school staff, including teachers. In some cases, such investments may be a more efficient and effective use of resources than the employment of additional untrained support staff. In other cases, identified needs may require the employment of additional staff and changes to the staffing mix, which may imply a potential decrease in the number of regular teachers. Schools in greatest need should be given priority in resource allocations. Where staff can be employed to respond to less complex school needs (e.g. procurement or student discipline), a change in the staffing mix may secure potential savings.

Governance and funding for the employment of different types of staff, including teacher and school leaders, will shape the staff mix in school systems. In decentralised systems, 
regulations and funding allocations provide potential steering mechanisms, for instance in the form of minimum staffing ratios or targeted funding. Horizontal and bottom-up accountability (e.g. through school boards) can help ensure an effective use of resources for school staffing (OECD, 2017[79] $)$. Where responsibilities for the employment and funding of different types of staff are split, collaboration will be essential to manage the effective staffing of schools and related trade-offs. This includes relevant authorities outside of the school sector which may provide essential professional support services.

The effective provision of staff also depends on the effective organisation of the school network (OECD, 2018 ${ }_{[25]}$ ). Where feasible in terms of geography, the sharing of specialised staff across a number of schools may help ensure a broad provision of related services, though it may involve trade-offs in the level of involvement and collaboration that can be expected of staff in individual schools. Where the organisation of school education changes, such as a change to learning time, a reflection about the funding of different types of staff is often necessary as is a review of the preparation and training of different types of staff and the introduction of potentially new staff roles.

\subsubsection{Matching staff with schools and students}

\section{Collaborating for the effective recruitment of teachers and school leaders, and ensuring fairness and transparency in recruitment processes}

In a number of countries, schools have limited influence on hiring decisions, which may be a source for mismatches and frustrations for both schools and teachers alike. Such systems could consider policies to give schools gradually greater autonomy to select their staff. Schools could be able to express their preferences over a given number of candidates ranked in a central process who have expressed an interest in working at the school or be involved in the interview and selection process. Another option is to allow schools to select part of their teaching staff while institutions above the school level remain in charge of recruiting and assigning the remaining part of the teaching force.

In Germany, the use of such a mixed system is quite common, for example, which ensures that common standards are applied and that particular schools are not systematically disadvantaged. Such mixed systems could also take off some logistical and administrative demands that are associated with recruitment, such as screening applicants, managing databases of applicants, extending the formal job offer, and processing new hires.

Steps to give schools a greater say in the distribution of teachers will need to pay adequate attention to potential inequities resulting from such a policy change and other factors, such as arrangements for funding staff positions. More advantaged schools will be better able to attract the most qualified teachers. School autonomy for recruitment requires sufficient leadership, managerial and administrative capacity, school resources and size, as well as sufficient supports and incentives for teachers to be willing to work in disadvantaged contexts.

Student teacher placements during their initial education may provide one route for schools to identify good teachers that match their organisational culture as they provide time for observing these potential teachers in the classroom. At the same time, student teachers have a chance to get to know a school and its ethos and culture. Student teacher placements may therefore have implications for the distribution of teachers among schools (Cannata, $\left.2011_{[119]}\right)$. In the Netherlands, the practical training of teachers includes a mandatory internship. Internships can be an opportunity to "try before they buy", i.e. allowing schools to recruit teachers with the right fit. In Norway, the possibility to enter the profession as a 
teaching assistant for those who are completing their studies or beginning in their careers has similar advantages. Former assistants are sometimes hired after a successful practicum (OECD, 2019[59]).

In systems where schools are more directly involved in teacher recruitment and selection, a priority should be to improve information flows. Transparent and timely information systems can help close information gaps between teachers and schools. At the same time, schools should be required to widely advertise their vacancies.

\subsubsection{Working towards equity in the distribution of staff across schools}

\section{Ensuring equitable and transparent resource allocations for school staffing}

A key concern to provide equity in the distribution of staff across schools lies in the design and implementation of equitable funding allocation mechanisms. The review's dedicated report on school funding provides an in-depth analysis (see OECD $\left(2017_{[79]}\right)$ ).

To support greater equity within a school system, funding systems should be based on a balance between targeted and regular funding. For the distribution of regular funding for current expenditures such as staff salaries, the use of a well-designed funding formula can provide an efficient, equitable, stable and transparent method of distributing resources, and a clear framework for debates on the sufficiency and equity of resource allocations. Equitable funding systems also require reliable evidence on the adequacy of funding in general, and on specific elements that funding mechanisms aim to address, such as inequities related to socio-economic disadvantage or geographical location.

Where responsibilities for the funding of staff are decentralised, sub-national authorities need to have both adequate revenues to meet the needs of their schools and students and relevant capacity to fulfil their funding responsibilities, which can be supported through well-designed equalisation mechanisms.

Many countries show a considerable financial commitment to supporting students at risk of under-performance, including through additional resources that can be used for school staffing. This focus on additional inputs needs to be matched with sufficient attention to monitoring the outcomes for different student groups. Thematic studies on the use of resources for equity are one option for monitoring the equity of the school system.

No matter how well-designed a new funding allocation mechanism is, however, there will always be winners and losers when implementing a new model unless additional resources are made available. Experiences in many countries therefore highlight the importance of effectively managing the political economy of funding reform and of having a realistic estimate of the costs involved.

\section{Reviewing regulations and criteria for recruitment, allocation and transfers}

In a number of school systems, teachers' interests rather than students' needs drive the distribution of teachers. Rules and regulations for the selection and transfer of teachers, such as the weight of seniority, together with teachers' preferences for working in particular contexts, may channel the best teachers to the most advantaged schools. Beginning teachers are then mostly assigned to schools that are more difficult, potentially harming student learning and teacher retention and satisfaction. Regulations that give priority to candidates with specific types of appointment or levels of experience may also make it more difficult to match the mix of experiences and skills of teaching staff to school contexts. To address these concerns, it could prove useful to review such regulations, creating greater flexibility 
for appointments regardless of employment status or experience. Recognising experience in difficult or remote schools for teachers' career progression is a further possibility.

\section{Providing incentives for teachers and school leaders to work in high-need areas}

In some contexts, monetary incentives have shown promising results to distribute teachers where they are most needed. One consideration then is to put in place financial incentives for staff to work in areas of need, such as higher salaries in schools enrolling high proportions of students from disadvantaged backgrounds, differential pay for particular expertise, or scholarships and subsidies for working in disadvantaged schools. But such policies will work differently depending on the design and size of the incentives and the general framework for employment and career progression (Chapter 2). Financial incentive schemes therefore require adequate evaluation and monitoring, also to inform the dialogue between decision makers and stakeholders and facilitate implementation and potential adjustments. In some contexts, financial incentives have been shown to be effective in attracting teachers to rural schools, but less so for remote schools, for example.

Of course, non-financial incentives also matter, although more needs to be understood about the relative importance of financial and non-financial aspects. Research shows that most teachers are highly motivated by the intrinsic benefits of teaching namely working with children and young people and helping them develop and learn. Professional factors, such as opportunities to take on extra responsibilities and strong leadership and collegiality in professional learning, then also need to be considered, as do working conditions, such as preparation time, accountability demands, class size or facilities. In other words, it is essential to ensure that all schools, and especially those in challenging circumstances, provide attractive conditions for staff to work in.

\subsubsection{Preparing school leaders for effective staff assignments within schools}

At the level of each individual school, the allocation of staff to specific students also plays an important role in best using teachers' expertise and promoting the learning of all students. Evidence from some contexts suggests that the assignment of teachers to students is typically not random. Teachers' characteristics, such as gender, ethnicity and experience may influence their assignment to particular student groups, with studies from the United States finding that experienced or more highly qualified teachers are more likely to teach classes with advantaged students.

The assignment of teachers to students is typically a school-level process, in which school leaders have to balance short- and long-term organisational goals while responding to preferences of teachers, parents and students. School leaders may seek to tailor class assignments to the perceived strengths and weaknesses of teachers, to promote staff satisfaction and retention, or to respond to parental demands and minimise conflict within the school community.

Hence, making the best use of staff time and competencies requires sufficient attention to the human resource management capacity in schools (e.g. planning the co-ordination time between teachers and learning support staff). School leadership needs to be adequately prepared to manage staff assignments and time with the resources they have at their disposal and to assess and monitor the effects of their decisions on student learning and well-being (e.g. the use of differential class size). Schools should also have the ability to develop their staff through arrangements such as team teaching and by matching effective with less effective teachers in their school (see Chapter 4). 


\section{Notes}

${ }^{1}$ In Colombia, public schools are organised in school clusters with a main school site typically offering all levels of education, including higher levels, and a number of smaller school sites offering only some levels of education.

${ }^{2}$ In Colombia, decentralisation in education has been managed by a process of certification of departments (the regional level) and districts and municipalities (the local level). All departments and large municipalities are certified to provide pre-school and school education. Education in municipalities that have not been certified is under the responsibility of the respective department.

${ }^{3}$ In 2017, national legislation transferred responsibility for the provision of public school education in Chile from local authorities (municipalities) to a new intermediate level in the form of local education services. Local education services are led by a national Directorate for Public Education within the Chilean Ministry of Education. Responsibilities are being transferred gradually until 2025 (with an intermediate evaluation to review the process and the possibility for the President of the Republic to postpone completion of the transfer until 2030). Where local education services act as school providers, the school principal should propose teachers' professional profiles and titular positions and participate in the selection of teachers and education assistants of education.

${ }^{4}$ Officially recognised schooling in the Flemish Community of Belgium is organised within three educational networks: a) the Community education network (Onderwijs van de Vlaamse Gemeenschap, GO!) which acts under the authority of the Flemish Community government; b) the publicly funded and publicly managed education network (Officieel gesubsidieerd onderwijs, OGO), also referred to as grant-aided public education, which includes schools organised by the provincial and city/municipal authorities; and c) the publicly funded and privately managed education network (Vrij gesubsidieerd onderwijs,VGO), also referred to as grant-aided private education, which includes denominational and non-denominational schools. 


\section{References}

Abbiati, G., G. Argentin and T. Gerosa (2017), "Different teachers for different students? Evidence on teacher-student matching and its consequences in the Italian case", Politica Economica, Journal of Economic Policy, Vol. 1, pp. 12-58, http://dx.doi.org/10.1429/86375.

Adamson, F. and L. Darling-Hammond (2012), "Funding disparities and the inequitable distribution of teachers: Evaluating sources and solutions", Education Policy Analysis Archives, Vol. 20/37, http://epaa.asu.edu/ojs/article/view/1053.

AITSL (2018), Annual Report 2017-2018 The Australian Institute for Teaching and School Leadership, Australian Institute for Teaching and School Leadership (AITSL), Melbourne, http://www.aitsl.edu.au (accessed on 31 March 2019).

Allen, R., S. Burgess and J. Mayo (2017), "The teacher labour market, teacher turnover and disadvantaged schools: New evidence for England", Education Economics, Vol. 26/1, pp. 4-23, http://dx.doi.org/10.1080/09645292.2017.1366425.

Allen, R. and S. Sims (2018), How do shortages of maths teachers affect the within-school allocation of maths teachers to pupils?, Nuffield Foundation, London, http://www.nuffieldfoundation.org (accessed on 10 March 2019).

Atteberry, A., S. Loeb and J. Wyckoff (2016), “Teacher churning: Reassignment rates and implications for student achievement”, Educational Evaluation and Policy Analysis, Vol. 39/1, pp. 3-30, http://dx.doi.org/10.3102/0162373716659929.

Ávalos, B. (2008), “Teacher education in the Latin American region: an unfinished business", Southern African Review of Education, Vol. 14/1-2, pp. 9-27, https://hdl.handle.net/10520/EJC98942.

Balakrishnan, V. (2017), Technological disruption in the teacher supply market, Grant Thornton, London, https://www.grantthornton.co.uk/insights/technological-disruption-in-the-teacher-supply-market/ (accessed on 18 June 2019).

Barbieri, G., C. Rossetti and P. Sestito (2011), "The determinants of teacher mobility: Evidence using Italian teachers' transfer applications”, Economics of Education Review, Vol. 30/6, pp. 1430-1444, http://dx.doi.org/10.1016/j.econedurev.2011.07.010.

Barrett, N. and E. Toma (2013), "Reward or punishment? Class size and teacher quality", Economics of Education Review, Vol. 35, pp. 41-52, http://dx.doi.org/10.1016/j.econedurev.2013.03.001.

Behrman, J. et al. (2016), "Teacher quality in public and private schools under a voucher system: The case of Chile", Journal of Labor Economics, Vol. 34/2, pp. 319-362, http://dx.doi.org/10.1086/683642.

Behrstock-Sherratt, E. (2016), Creating coherence in the teacher shortage debate: What policy leaders should know and do, American Institutes of Research, Washington, DC, https://www.air.org (accessed on 15 February 2019).

Bellei, C. et al. (2014), Lo apredí en la escuela: ¿Cómo se logran procesos de mejoramiento escolar?, Lom Ediciones; Universidad de Chile; UNICEF, Santiago, Chile.

Bénabou, R., F. Kramarz and C. Prost (2009), “The French zones d'éducation prioritaire: Much ado about nothing?", Economics of Education Review, Vol. 28/3, pp. 345-356, http://dx.doi.org/10.1016/j.econedurev.2008.04.005.

Bense, K. (2016), "International teacher mobility and migration: A review and synthesis of the current empirical research and literature", Educational Research Review, Vol. 17, pp. 37-49, http://dx.doi.org/10.1016/j.edurev.2015.12.001.

Bertoni, E. et al. (2018), "School Finance in Latin America: A Conceptual Framework and a Review of Policies", IDB Technical Notes, No. 1503, Inter-American Development Bank, http://dx.doi.org/10.18235/0001306. 
Betts, J. (2011), "The Economics of Tracking in Education", in Handbook of the Economics of Education, Elsevier B.V., http://dx.doi.org/10.1016/b978-0-444-53429-3.00007-7.

Betts, J. and J. Shkolnik (2000), "The effects of ability grouping on student achievement and resource allocation in secondary schools", Economics of Education Review, Vol. 19/1, pp. 1-15, http://dx.doi.org/10.1016/s0272-7757(98)00044-2.

BMBWF (2019), Das Autonomiepaket der Bildungsreform [The autonomy package of education reform], https://bildung.bmbwf.gv.at/schulen/autonomie/index.html (accessed on 15 May 2019).

Bonesrønning, H., T. Falch and B. Strøm (2005), "Teacher sorting, teacher quality, and student composition", European Economic Review, Vol. 49/2, pp. 457-483, http://dx.doi.org/10.1016/s00142921(03)00052-7.

Boyd, D. et al. (2008), "The narrowing gap in New York City teacher qualifications and its implications for student achievement in high-poverty schools", Journal of Policy Analysis and Management, Vol. 27/4, pp. 793-818, http://dx.doi.org/10.1002/pam.20377.

Boyd, D. et al. (2013), "Analyzing the determinants of the matching of public school teachers to jobs: Disentangling the preferences of teachers and employers", Journal of Labor Economics, Vol. 31/1, pp. 83-117, http://dx.doi.org/10.1086/666725.

Boyd, D. et al. (2005), "The draw of home: How teachers' preferences for proximity disadvantage urban schools", Journal of Policy Analysis and Management, Vol. 24/1, pp. 113-132, http://dx.doi.org/10.1002/pam.20072.

Branch, G., E. Hanushek and S. Rivkin (2012), "Estimating the effect of leaders on public sector productivity: The case of school principals", NBER Working Papers, No. 17803, National Bureau of Economic Research, Cambridge, MA, http://dx.doi.org/10.3386/w17803.

Brummet, Q., S. Gershenson and M. Hayes (2017), “Teachers' grade-level reassignments: Evidence from Michigan”, Educational Policy, Vol. 31/2, pp. 249-271, http://dx.doi.org/10.1177/0895904815586857.

Bryk, A. et al. (2010), Organizing schools for improvement: Lessons from Chicago, University of Chicago Press, Chicago.

Burns, R. and D. Mason (1995), "Organizational constraints on the formation of elementary school classes", American Journal of Education, Vol. 103/2, pp. 185-212, http://dx.doi.org/10.1086/444096.

Cabezas, V. et al. (2017), "First job and the unequal distribution of primary school teachers: Evidence for the case of Chile", Teaching and Teacher Education, Vol. 64, pp. 66-78, http://dx.doi.org/10.1016/j.tate.2017.01.017.

Cannata, M. (2011), "The role of social networks in the teacher job search process", The Elementary School Journal, Vol. 111/3, pp. 477-500, http://dx.doi.org/10.1086/657656.

Castillo, J., M. Curtis and S. Tan (2014), "Personnel needs in school psychology: A 10-year follow-up study on predicted personnel shortages", Psychology in the Schools, Vol. 51/8, pp. 832-849, http://dx.doi.org/10.1002/pits.21786.

Centro de Estudios MINEDUC (2016), Reporte Nacional de Chile: Revisión OCDE para mejorar la efectividad del uso de recursos en las escuelas, informe preparado por el Ministerio de Educación, la Agencia de Calidad de la Educación y la Superintendencia de Educación, Ministerio de Educación, Santiago, Chile, http://www.oecd. org/edu/school/schoolresourcesreview.htm.

Chingos, M. and M. West (2011), "Promotion and reassignment in public school districts: How do schools respond to differences in teacher effectiveness?", Economics of Education Review, Vol. 30/3, pp. 419433, http://dx.doi.org/10.1016/j.econedurev.2010.12.011.

Clotfelter, C. et al. (2008), "Would higher salaries keep teachers in high-poverty schools? Evidence from a policy intervention in North Carolina", Journal of Public Economics, Vol. 92/5-6, pp. 1352-1370, http://dx.doi.org/10.1016/j.jpubeco.2007.07.003. 
Clotfelter, C., H. Ladd and J. Vigdor (2009), “Are teacher absences worth worrying about in the US?", Education Finance and Policy, Vol. 4/2, pp. 115-149, https://doi.org/10.1162/edfp.2009.4.2.115.

Clotfelter, C., H. Ladd and J. Vigdor (2005), "Who teaches whom? Race and the distribution of novice teachers", Economics of Education Review, Vol. 24/4, pp. 377-392, http://dx.doi.org/10.1016/j.econedurev.2004.06.008.

Cohen-Vogel, L. (2011), "Staffing to the test", Educational Evaluation and Policy Analysis, Vol. 33/4, pp. 483-505, http://dx.doi.org/10.3102/0162373711419845.

Combe, J., O. Tercieux and C. Terrier (2016), “Améliorer la mobilité des enseignants: Un nouvel algorithme ne pénalisant pas les académies les moins attractives", Éducation et formations, Vol. 92, pp. 57-75, https://halshs.archives-ouvertes.fr.

Cruz-Aguayo, Y., P. Ibarrarán and N. Schady (2017), "Do tests applied to teachers predict their effectiveness?", Economics Letters, Vol. 159, pp. 108-111, http://dx.doi.org/10.1016/J.ECONLET.2017.06.035.

Dabach, D. (2015), "Teacher placement into immigrant English learner classrooms", American Educational Research Journal, Vol. 52/2, pp. 243-274, http://dx.doi.org/10.3102/0002831215574725.

Dal Bó, E., F. Finan and M. Rossi (2013), "Strengthening state capabilities: The role of financial incentives in the call to public service", The Quarterly Journal of Economics, Vol. 128/3, pp. 11691218, http://dx.doi.org/10.1093/qje/qjt008.

Daly, T. et al. (2008), MutualBenefits: New York City's Shift to Mutual Consent, The New Teacher Project, New York, https://tntp.org/assets/documents/MutualBenefits.pdf (accessed on 15 February 2019).

D'Amico, D. et al. (2017), "Where are all the black teachers? Discrimination in the teacher labor market", Harvard Educational Review, Vol. 87/1, pp. 26-49, http://dx.doi.org/10.17763/1943-5045-87.1.26.

DeArmond, M., B. Gross and D. Goldhaber (2010), "Is it better to be good or lucky? Decentralized teacher selection in 10 elementary schools", Educational Administration Quarterly, Vol. 46/3, pp. 322-362, http://dx.doi.org/10.1177/0013161x10365824.

Delany, B. (1991), "Allocation, choice, and stratification within high schools: How the sorting machine copes”, American Journal of Education, Vol. 99/2, pp. 181-207, http://dx.doi.org/10.1086/443978.

Department for Education (2018), Staffing and employment advice for schools Departmental advice for school leaders, governing bodies, academy trusts and local authorities, Department for Education, London, https://www.gov.uk/government/publications/staffing-and-employment-advice-for-schools (accessed on 2 February 2019).

Department of Education and Skills (2019), Redeployment Arrangementsat Primary Level for Surplus Permanent \&amp; CID Holding Teachers, Department of Education and Skills, Dublin, https://www.education.ie/en/Schools-Colleges/Services/Teacher-Allocations/TeacherAllocation/ta primary faq redeployment arrangements 19 20.pdf (accessed on 16 November 2018).

Department of Education and Training Victoria (2019), Human Resources: Working in more than one school, https://www.education.vic.gov.au/hrweb/workm/Pages/multiple employ.aspx (accessed on 25 January 2019).

Department of Education and Training Victoria (2019), Workforce Management - Schools, https://www.education.vic.gov.au/hrweb/workm/Pages/workforce mgmt_schools.aspx (accessed on 2 February 2019).

Dhuey, E. and J. Smith (2018), "How school principals influence student learning", Empirical Economics, Vol. 54/2, pp. 851-882, http://dx.doi.org/10.1007/s00181-017-1259-9. 
Echazarra, A. and T. Radinger (2019), "Learning in rural schools: Insights from PISA, TALIS and the literature", OECD Education Working Papers, No. 196, OECD Publishing, Paris, https://dx.doi.org/10.1787/8b1a5cb9-en.

Education Review Office (2018), Resource Teachers: Learning and Behaviour Governing and Managing RTLB Clusters, Education Review Office, Wellington, https://www.ero.govt.nz/assets/Uploads/RTLBEvaluation-Report2.pdf (accessed on 5 December 2018).

Engel, M. and M. Cannata (2015), "Localism and teacher labor markets: How geography and decision making may contribute to inequality", Peabody Journal of Education, Vol. 90/1, pp. 84-92, http://dx.doi.org/10.1080/0161956X.2015.988533.

Engel, M., M. Cannata and F. Curran (2018), "Principal influence in teacher hiring: documenting decentralization over time", Journal of Educational Administration, Vol. 56/3, pp. 277-296, http://dx.doi.org/10.1108/jea-05-2017-0061.

Engel, M. and M. Finch (2014), "Staffing the classroom: How urban principals find teachers and make hiring decisions", Leadership and Policy in Schools, Vol. 14/1, pp. 12-41, http://dx.doi.org/10.1080/15700763.2014.983131.

Estonian Ministry of Education and Research (2015), OECD Review of Policies to Improve the Effectiveness of Resource Use in Schools: Country Background Report for Estonia, Estonian Ministry of Education and Research, Tartu, http://www.oecd.org/education/schoolresourcesreview.htm.

Estrada, R. (2019), "Rules versus discretion in public service: Teacher hiring in Mexico", Journal of Labor Economics, Vol. 37/2, pp. 545-579, http://dx.doi.org/10.1086/700192.

European Commission, EACEA and Eurydice (2018), Teaching careers in Europe: Access, progression and support. Eurydice Report, Publications Office of the European Union, Luxembourg, https://eacea.ec.europa.eu/national-policies/eurydice/publications en (accessed on 18 February 2019).

Eurydice (2019), Database of National Education Systems, https://eacea.ec.europa.eu/nationalpolicies/eurydice/national-description_en.

Feng, L. (2010), "Hire today, gone tomorrow: New teacher classroom assignments and teacher mobility", Education Finance and Policy, Vol. 5/3, pp. 278-316, http://dx.doi.org/10.1162/edfp a 00002.

Feng, L., D. Figlio and T. Sass (2018), "School accountability and teacher mobility", Journal of Urban Economics, Vol. 103, pp. 1-17, http://dx.doi.org/10.1016/j.jue.2017.11.001.

Finan, F., B. Olken and R. Pande (2015), "The personnel economics of the state", NBER Working Papers, No. 21825, National Bureau of Economic Research, Cambridge, MA, http://dx.doi.org/10.3386/w21825.

Flemish Ministry of Education and Training (2015), OECD Review of Policies to Improve the Effectiveness ofResource Use in Schools: Country Background Report of the Flemish Community of Belgium, Flemish Ministry of Education and Training, Brussels, http://www.oecd.org/education/schoolresourcesreview.htm.

Fredriksson, P., L. Hensvik and O. Skans (2018), "Mismatch of talent: Evidence on match quality, entry wages, and job mobility", American Economic Review, Vol. 108/11, pp. 3303-3338, http://dx.doi.org/10.1257/aer.20160848.

Fryer, R. (2018), "The "pupil" factory: Specialization and the production of human capital in schools", American Economic Review, Vol. 108/3, pp. 616-656, http://dx.doi.org/10.1257/aer.20161495.

Fuller, S. and H. Ladd (2013), "School-based accountability and the distribution of teacher quality across grades in elementary school", Education Finance and Policy, Vol. 8/4, pp. 528-559, http://dx.doi.org/10.1162/edfp_a 00112 .

Gershenson, S. (2016), "Linking teacher quality, student attendance, and student achievement", Education Finance and Policy, Vol. 11/2, pp. 125-149, https://doi.org/10.1162/EDFP a 00180. 
Gershenson, S., S. Holt and N. Papageorge (2016), "Who believes in me? The effect of student-teacher demographic match on teacher expectations", Economics of Education Review, Vol. 52, pp. 209-224, http://dx.doi.org/10.1016/j.econedurev.2016.03.002.

Gjefsen, H. and T. Gunnes (2015), “School accountability: Incentives or sorting?", Discussion Papers, No. 8015, Statistics Norway, Research Department, https://www.ssb.no/en/forskning/discussion-papers (accessed on 15 December 2018).

Goldhaber, D. et al. (2015), "Crossing the border? Exploring the cross-state mobility of the teacher workforce", Educational Researcher, Vol. 44/8, pp. 421-431, http://dx.doi.org/10.3102/0013189x15613981.

Goldhaber, D., L. Lavery and R. Theobald (2015), "Uneven playing field? Assessing the teacher quality gap between advantaged and disadvantaged students", Educational Researcher, Vol. 44/5, pp. 293307, http://dx.doi.org/10.3102/0013189x15592622.

Grissom, J., D. Kalogrides and S. Loeb (2017), "Strategic staffing? How performance pressures effect the distribution of teachers within schools and resulting student achievement", American Educational Research Journal, Vol. 54/6, pp. 1079-1116, http://dx.doi.org/10.3102/0002831217716301.

Grissom, J., D. Kalogrides and S. Loeb (2015), "The micropolitics of educational inequality: The case of teacher-student assignments", Peabody Journal of Education, Vol. 90/5, pp. 601-614, http://dx.doi.org/10.1080/0161956x.2015.1087768.

Guarino, C., L. Santibañez and G. Daley (2006), "Teacher recruitment and retention: A review of the recent empirical literature", Review of Educational Research, Vol. 76/2, pp. 173-208, http://dx.doi.org/10.3102/00346543076002173.

Guerrero, G. et al. (2013), "Getting teachers back to the classroom. A systematic review on what works to improve teacher attendance in developing countries", Journal of Development Effectiveness, Vol. 5/4, pp. 466-488, http://dx.doi.org/10.1080/19439342.2013.864695.

Hanushek, E., J. Kain and S. Rivkin (2004), "Why public schools lose teachers", The Journal of Human Resources, Vol. 39/2, p. 326, http://dx.doi.org/10.2307/3559017.

Hanushek, E., S. Link and L. Woessmann (2013), "Does school autonomy make sense everywhere? Panel estimates from PISA”, Journal of Development Economics, Vol. 104, pp. 212-232, http://dx.doi.org/10.1016/j.jdeveco.2012.08.002.

Harris, D. et al. (2010), "Mix and match: What principals really look for when hiring teachers", Education Finance and Policy, Vol. 5/2, pp. 228-246, http://dx.doi.org/10.1162/edfp.2010.5.2.5205.

Helbig, M. and R. Nikolai (2019), “Bekommen die sozial benachteiligsten Schüler*innen die „besten“ Schulen?Eine explorative Studie über den Zusammenhang von Schulqualität und sozialer Zusammensetzung von Schulen am Beispiel Berlin”, Discussion Papers, No. 002, Wissenschaftszentrum Berlin für Sozialforschung, Berlin, http://hdl.handle.net/10419/194005.

Hensvik, L. (2012), "Competition, wages and teacher sorting: Lessons learned from a voucher reform", The Economic Journal, Vol. 122/561, pp. 799-824, http://dx.doi.org/10.1111/j.14680297.2012.02514.x.

HEQCO (2019), Higher Education Quality Council of Ontario, http://www.heqco.ca (accessed on 15 May 2019).

Herrmann, M. and J. Rockoff (2012), "Worker absence and productivity: Evidence from teaching", Journal of Labor Economics, Vol. 30/4, pp. 749-782, http://dx.doi.org/10.1086/666537.

Hill, A. and D. Jones (2018), "A teacher who knows me: The academic benefits of repeat student-teacher matches", Economics of Education Review, Vol. 64, pp. 1-12, http://dx.doi.org/10.1016/j.econedurev.2018.03.004. 
Horoi, I. and B. Ost (2015), "Disruptive peers and the estimation of teacher value added", Economics of Education Review, Vol. 49, pp. 180-192, http://dx.doi.org/10.1016/j.econedurev.2015.10.002.

Hurwitz, M. and J. Howell (2013), Measuring the Impact of High School Counselors on College Enrollment, College Board, Washington, DC, https://research.collegeboard.org/ (accessed on 16 May 2019).

Icelandic Ministry of Education, S. (2014), OECD Review of Policies to Improve the Effectiveness of Resource Use in Schools: Country Background Report for Iceland, Iceland Ministry of Education, Science and Culture, http://www.oecd.org/education/schoolresourcesreview.htm.

IIEP-UNESCO (2016), "More effective teacher allocation in Africa", Pôlemag, Vol. 24, pp. 8-13, https://poledakar.iiep.unesco.org/en/publications/polemag (accessed on 25 November 2018).

Ingersoll, R. (2005), "Four myths about America's teacher quality problem", Yearbook of the National Society for the Study of Education, Vol. 103/1, pp. 1-33, http://dx.doi.org/10.1111/j.17447984.2004.tb00029.x.

Instituto Nacional de Evaluación Educativa (INEEd) (2016), Encuesta Nacional Docente 2015: Primeros resultados, https://www.ineed.edu.uy/images/pdf/presentacion-encuesta-nacional.pdf (accessed on 30 November 2018).

Isenberg, E. et al. (2016), Do Low-Income Students Have Equal Access to Effective Teachers? Evidence from 26 Districts (NCEE 2017-4007), National Center for Education Evaluation and Regional Assistance, Institute of Education Sciences, US Department of Education, http://ies.ed.gov/ncee (accessed on 16 May 2019).

Jackson, C. (2013), "Match quality, worker productivity, and worker mobility: Direct evidence from teachers", Review of Economics and Statistics, Vol. 95/4, pp. 1096-1116, http://dx.doi.org/10.1162/rest_a 00339 .

Jackson, C. (2012), "School competition and teacher labor markets: Evidence from charter school entry in North Carolina", Journal of Public Economics, Vol. 96/5-6, pp. 431-448, http://dx.doi.org/10.1016/j.jpubeco.2011.12.006.

Jackson, C. (2009), "Student demographics, teacher sorting, and teacher quality: Evidence from the end of school desegregation", Journal of Labor Economics, Vol. 27/2, pp. 213-256, http://dx.doi.org/10.1086/599334.

Jacob, B. and L. Lefgren (2007), "What do parents value in education? An empirical investigation of parents' revealed preferences for teachers", The Quarterly Journal of Economics, Vol. 122/4, pp. 16031637, http://dx.doi.org/10.1162/qjec.2007.122.4.1603.

Jacob, B. et al. (2018), "Teacher applicant hiring and teacher performance: Evidence from DC public schools", Journal of Public Economics, Vol. 166, pp. 81-97, http://dx.doi.org/10.1016/j.jpubeco.2018.08.011.

Jaramillo, M. (2012), "The spatial geography of teacher labor markets: Evidence from a developing country", Economics of Education Review, Vol. 31/6, pp. 984-995, http://dx.doi.org/10.1016/J.ECONEDUREV.2012.07.005.

Johnson, S. (2009), "How best to add value? Strike a balance between the individual and the organization in school reform", EPI Briefing Papers, No. 249, Economic Policy Institute, Washington, DC, https://www.epi.org/publication/bp249 (accessed on 12 December 2018).

Jovanovic, B. (1979), "Job matching and the theory of turnover", Journal of Political Economy, Vol. 87/5, pp. 972-990, https://www.jstor.org/stable/1833078.

Kalogrides, D., S. Loeb and T. Béteille (2013), "Systematic sorting: Teacher characteristics and class assignments", Sociology of Education, Vol. 86/2, pp. 103-123, http://dx.doi.org/10.1177/0038040712456555. 
Kane, B. and B. Rosenquist (2019), "Relationships between instructional coaches' time use and districtand school-level policies and expectations", American Educational Research Journal, http://dx.doi.org/10.3102/0002831219826580.

Kane, T., J. Rockoff and D. Staiger (2008), "What does certification tell us about teacher effectiveness? Evidence from New York City”, Economics of Education Review, Vol. 27, pp. 615-631, https://doi.org/10.1016/j.econedurev.2007.05.005.

Karsten, S. (2006), "Policies for disadvantaged children under scrutiny: The Dutch policy compared with policies in France, England, Flanders and the USA", Comparative Education, Vol. 42/2, pp. 261-282, http://dx.doi.org/10.1080/03050060600628694.

Kim, Y. (2017), "Does autonomy over teacher hiring affect student math and science achievement?", Education Economics, Vol. 25/6, pp. 562-574, http://dx.doi.org/10.1080/09645292.2017.1328044.

Klemm, K. and D. Zorn (2017), Demographische Rendite adé Aktuelle Bevölkerungsentwicklung und Folgen für die allgemeinbildenden Schulen, Bertelsmann Stiftung, Gütersloh, https://www.bertelsmann-stiftung.de (accessed on 17 February 2019).

KMK (2018), Lehrereinstellungsbedarf und -angebot in der Bundesrepublik Deutschland 2018 - 2030, Sekretariat der Ständigen Konferenz der Kultusminister der Länder in der Bundesrepublik Deutschland, Berlin, https://www.kmk.org/fileadmin/Dateien/pdf/Statistik/Dokumentationen/Dok_216_Bericht_LEB_LEA_ 2018.pdf (accessed on 1 April 2019).

Kraft, M. et al. (2018), "Teacher accountability reforms and the supply of new teachers", https://scholar.harvard.edu/mkraft/publications (accessed on 16 April 2019).

Kraft, M. et al. (2015), "Educating amid uncertainty", Educational Administration Quarterly, Vol. 51/5, pp. 753-790, http://dx.doi.org/10.1177/0013161x15607617.

Lankford, H., S. Loeb and J. Wyckoff (2002), "Teacher sorting and the plight of urban schools: A descriptive analysis", Educational Evaluation and Policy Analysis, Vol. 24/1, pp. 37-62, http://dx.doi.org/10.3102/01623737024001037.

Liebowitz, D. et al. (2018), OECD Reviews of School Resources: Portugal 2018, OECD Reviews of School Resources, OECD Publishing, Paris, https://dx.doi.org/10.1787/9789264308411-en.

Little, J. and L. Bartlett (2010), "The teacher workforce and problems of educational equity", Review of Research in Education, Vol. 34/1, pp. 285-328, https://doi.org/10.3102/0091732X09356099.

Liu, E. and S. Johnson (2006), "New teachers' experiences of hiring: Late, rushed, and information-poor", Educational Administration Quarterly, Vol. 42/3, pp. 324-360, http://dx.doi.org/10.1177/0013161x05282610.

Loeb, S., D. Kalogrides and E. Horng (2010), "Principal preferences and the uneven distribution of principals across schools", Educational Evaluation and Policy Analysis, Vol. 32/2, pp. 205-229, http://dx.doi.org/10.3102/0162373710369833.

Lortie, D. (1975), Schoolteacher: A Sociological Study, University of Chicago Press, Chicago.

Louis, K. et al. (2010), Investigating the Links to Improved Student Learning - Final Report of Research Findings, University of Minnesota, University of Toronto, a report commissioned by the Wallace Foundation, University of Minnesota, Minneapolis, MN, https://www.wallacefoundation.org/knowledge-center/pages/investigating-the-links-to-improvedstudent-learning.aspx (accessed on 16 December 2018).

Luschei, T. and A. Chudgar (2017), Teacher Distribution in Developing Countries, Palgrave Macmillan, New York, NY, http://dx.doi.org/10.1057/978-1-137-57926-3.

Mansfield, R. (2015), “Teacher quality and student inequality", Journal of Labor Economics, Vol. 33/3, pp. 751-788, http://dx.doi.org/10.1086/679683. 
Maughan, E. (2018), "School nurses: An investment in student achievement", Phi Delta Kappan, Vol. 99/7, pp. 8-14, http://dx.doi.org/10.1177/0031721718767853.

Miller, R., R. Murnane and J. Willett (2008), "Do teacher absences impact student achievement? Longitudinal evidence from one urban school district", Educational Evaluation and Policy Analysis, Vol. 30/2, pp. 181-200, http://dx.doi.org/10.3102/0162373708318019.

Ministère de la Fédération Wallonie-Bruxelles (2016), Examen de l'OCDE des politiques pour un usage plus efficace des ressources scolaires RAPPORT PAYS Communauté française de Belgique, Ministère de la Fédération Wallonie-Bruxelles, Bruxelles, http://www.oecd.org/education/school-resourcesreview/reports-for-participating-countries-country-background-reports.htm.

Ministry of Education (2019), Surplus staffing support for a reduction in staffing entitlement, https://www.education.govt.nz/school/funding-and-financials/resourcing/school-staffing/surplusstaffing-support/ (accessed on 25 January 2019).

Ministry of Education and Research (2016), OECD Review of Policies to Improve the Effectiveness of Resource Use in Schools: Country Background Report of Sweden, Swedish Ministry of Education and Research, Stockholm, http://www.oecd.org/education/schoolresourcesreview.

Monk, D. (1987), “Assigning elementary pupils to their teachers”, The Elementary School Journal, Vol. 88/2, pp. 167-187, http://dx.doi.org/10.1086/461531.

Murnane, R. and J. Steele (2007), "What is the problem? The challenge of providing effective teachers for all children", The Future of children, Vol. 17/1, pp. 15-43, https://www.jstor.org/stable/4150018.

NACAC (2018), State-by-State Student-to-Counselor Ratio Report, National Association for College Admission Counseling, Arlington, VA, https://www.nacacnet.org/news--publications/Research/stateby-state-student-to-counselor-ratio-report2 (accessed on 17 May 2019).

Nagler, M., M. Piopiunik and M. West (2015), "Weak markets, strong teachers: Recession at career start and teacher effectiveness", NBER Working Papers, No. 21393, http://dx.doi.org/10.3386/w21393.

Naper, L. (2010), "Teacher hiring practices and educational efficiency", Economics of Education Review, Vol. 29/4, pp. 658-668, http://dx.doi.org/10.1016/j.econedurev.2009.11.002.

NASUWT (2017), "Supply Teachers annual survey of experiences", https://www.nasuwt.org.uk/uploads/assets/uploaded/e7d27137-a3cb-4db8-ae6d1c34024d344a.pdf (accessed on 12 April 2019).

Nusche, D. et al. (2015), OECD Reviews of School Resources: Flemish Community of Belgium 2015, OECD Reviews of School Resources, OECD Publishing, Paris, http://dx.doi.org/10.1787/9789264247598-en.

Nusche, D. et al. (2016), OECD Reviews of School Resources: Austria 2016, OECD Publishing, Paris, http://dx.doi.org/10.1787/9789264256729-en.

Nusche, D. et al. (2016), OECD Reviews of School Resources: Denmark 2016, OECD Publishing, Paris, http://dx.doi.org/10.1787/9789264262430-en.

OECD (2019), A Flying Start: Improving Initial Teacher Preparation Systems, OECD Publishing, Paris, http://dx.doi.org/10.1787/cf74e549-en.

OECD (2019), TALIS 2018 Results (Volume I): Teachers and School Leaders as Lifelong Learners, TALIS, OECD Publishing, Paris, https://dx.doi.org/10.1787/1d0bc92a-en.

OECD (2018), Education at a Glance 2018: OECD Indicators, OECD Publishing, Paris, http://dx.doi.org/10.1787/eag-2018-en.

OECD (2018), Effective Teacher Policies: Insights from PISA, PISA, OECD Publishing, Paris, http://dx.doi.org/10.1787/9789264301603-en. 
OECD (2018), Responsive School Systems: Connecting Facilities, Sectors and Programmes for Student Success, OECD Reviews of School Resources, OECD Publishing, Paris, https://dx.doi.org/10.1787/9789264306707-en.

OECD (2017), The Funding of School Education: Connecting Resources and Learning, OECD Reviews of School Resources, OECD Publishing, Paris, http://dx.doi.org/10.1787/9789264276147-en.

OECD (2016), Low-Performing Students: Why They Fall Behind and How To Help Them Succeed, PISA, OECD Publishing, Paris, https://dx.doi.org/10.1787/9789264250246-en.

OECD (2016), PISA 2015 Results (Volume II): Policies and Practices for Successful Schools, PISA, OECD Publishing, Paris, http://dx.doi.org/10.1787/9789264267510-en.

OECD (2014), TALIS 2013 Results: An International Perspective on Teaching and Learning, TALIS, OECD Publishing, Paris, https://dx.doi.org/10.1787/9789264196261-en.

OECD (2005), Teachers Matter: Attracting, Developing and Retaining Effective Teachers, Education and Training Policy, OECD Publishing, Paris, http://dx.doi.org/10.1787/9789264018044-en.

OECD/The World Bank (2015), OECD Reviews of School Resources: Kazakhstan 2015, OECD Reviews of School Resources, OECD Publishing, Paris, https://dx.doi.org/10.1787/9789264245891-en.

Ontario College of Teachers (2018), Transition to Teaching 2018, Ontario College of Teachers, Toronto, ON, https://www.oct.ca/becoming-a-teacher/transition-to-teaching (accessed on 1 April 2019).

Ost, B. and J. Schiman (2015), “Grade-specific experience, grade reassignments, and teacher turnover”, Economics of Education Review, Vol. 46, pp. 112-126, http://dx.doi.org/10.1016/j.econedurev.2015.03.004.

Özoğlu, M. (2015), "Mobility-related teacher turnover and the unequal distribution of experienced teachers in Turkey", Educational Sciences: Theory \& Practice, Vol. 15/4, http://dx.doi.org/10.12738/estp.2015.4.2619.

Paniagua, A. and A. Sánchez-Martí (2018), "Early Career Teachers: Pioneers Triggering Innovation or Compliant Professionals?”, OECD Education Working Papers, No. 190, OECD Publishing, Paris, https://dx.doi.org/10.1787/4a7043f9-en.

Papay, J. and M. Kraft (2016), "The productivity costs of inefficient hiring practices: Evidence from late teacher hiring", Journal of Policy Analysis and Management, Vol. 35/4, pp. 791-817, http://dx.doi.org/10.1002/pam.21930.

Paufler, N. and A. Amrein-Beardsley (2014), "The random assignment of students into elementary classrooms", American Educational Research Journal, Vol. 51/2, pp. 328-362, http://dx.doi.org/10.3102/0002831213508299.

Player, D. (2010), "Nonmonetary compensation in the public teacher labor market", Education Finance and Policy, Vol. 5/1, pp. 82-103, http://dx.doi.org/10.1162/edfp.2009.5.1.5105.

Prost, C. (2013), "Teacher mobility: Can financial incentives help disadvantaged schools to retain their teachers?", Annals of Economics and Statistics 111/112, p. 171, http://dx.doi.org/10.2307/23646330.

Pugatch, T. and E. Schroeder (2014), "Incentives for teacher relocation: Evidence from the Gambian hardship allowance", Economics of Education Review, Vol. 41, pp. 120-136, http://dx.doi.org/10.1016/J.ECONEDUREV.2014.04.003.

Qureshi, J. and B. Ost (2018), "The role of families in student sorting to teachers", Journal of Human Resources, pp. 0717-8953R2, http://dx.doi.org/10.3368/jhr.55.3.0717-8953r2.

Radinger, T. et al. (2018), OECD Reviews of School Resources: Colombia 2018, OECD Reviews of School Resources, OECD Publishing, Paris, http://dx.doi.org/10.1787/9789264303751-en. 
Rechnungshof Österreich (2018), Bericht des Rechnungshofes Gesundheit der Schüler: Schulärztlicher Dienst und Schulpsychologischer Dienst; Follow-up-Überprüfung [Report of the Court of Audit Student Health: School Medical Services and School Psychology Services; Follow up Evaluation], Rechnungshof Österreich, Wien, http://www.rechnungshof.gv.at (accessed on 15 May 2019).

Reininger, M. (2012), "Hometown disadvantage? It depends on where you're from", Educational Evaluation and Policy Analysis, Vol. 34/2, pp. 127-145, http://dx.doi.org/10.3102/0162373711420864.

Rice, S. (2010), "Getting our best teachers into disadvantaged schools: Differences in the professional and personal factors attracting more effective and less effective teachers to a school", Educational Research for Policy and Practice, Vol. 9/3, pp. 177-192, http://dx.doi.org/10.1007/s10671-010-9085-2.

Rockoff, J. et al. (2011), "Can you recognize an effective teacher when you recruit one?", Education Finance and Policy, Vol. 6/1, pp. 43-74, http://dx.doi.org/10.1162/EDFP_a_00022.

Rutledge, S. et al. (2008), "Certify, blink, hire: An examination of the process and tools of teacher screening and celection", Leadership and Policy in Schools, Vol. 7/3, pp. 237-263, http://dx.doi.org/10.1080/15700760701822132.

Sánchez, J. (2018), OECD Review of Policies to Improve the Effectiveness of Resource Use in Schools: Country Background Report for Colombia, Ministerio de Educación Nacional, Bogotá DC, http://www.oecd.org/education/schoolresourcesreview.htm.

Santiago, P. (2002), "Teacher Demand and Supply: Improving Teaching Quality and Addressing Teacher Shortages", OECD Education Working Papers, No. 1, OECD Publishing, Paris, https://dx.doi.org/10.1787/232506301033.

Santiago, P. et al. (2016), OECD Reviews of School Resources: Uruguay 2016, OECD Reviews of School Resources, OECD Publishing, Paris, http://dx.doi.org/10.1787/9789264265530-en.

Santiago, P. et al. (2017), OECD Reviews of School Resources: Chile 2017, OECD Reviews of School Resources, OECD Publishing, Paris, http://dx.doi.org/10.1787/9789264285637-en.

Santiago, P. et al. (2016), OECD Reviews of School Resources: Slovak Republic 2015, OECD Reviews of School Resources, OECD Publishing, Paris, http://dx.doi.org/10.1787/9789264247567-en.

Santiago, P. et al. (2016), OECD Reviews of School Resources: Estonia 2016, OECD Reviews of School Resources, OECD Publishing, Paris, http://dx.doi.org/10.1787/9789264251731-en.

Schlicht-Schmälzle, R., J. Teltemann and M. Windzio (2011), "Deregulation of education - What does it matter for efficiency and equality?", TransState Working Papers, No. 157, University of Bremen, Bremen, http://hdl.handle.net/10419/52224.

Shewbridge, C. et al. (2016), OECD Reviews of School Resources: Lithuania 2016, OECD Reviews of School Resources, OECD Publishing, Paris, http://dx.doi.org/10.1787/9789264252547-en.

Shewbridge, C. et al. (2016), OECD Reviews of School Resources: Czech Republic 2016, OECD Reviews of School Resources, OECD Publishing, Paris, http://dx.doi.org/10.1787/9789264262379-en.

Slovenian Ministry of Education, S. (2017), OECD Review of Policies to Improve the Effectiveness of Resource Use in Schools: Country Background Report of Slovenia, Slovenian Ministry of Education, Science and Sport, http://www.oecd.org/edu/school/schoolresourcesreview.htm.

Spillane, J., R. Halverson and J. Diamon (2004), "Towards a theory of leadership practice: a distributed perspective", Journal of Curriculum Studies, Vol. 36/1, pp. 3-34, http://dx.doi.org/10.1080/0022027032000106726.

Staiger, D. and J. Rockoff (2010), "Searching for effective teachers with imperfect information", Journal of Economic Perspectives, Vol. 24/3, pp. 97-118, http://dx.doi.org/10.1257/jep.24.3.97.

Steele, J., R. Murnane and J. Willett (2010), "Do financial incentives help low-performing schools attract and keep academically talented teachers? Evidence from California", Journal of Policy Analysis and Management, Vol. 29/3, pp. 451-478, http://dx.doi.org/10.1002/pam.20505. 
Sveriges Kommuner och Landsting (2018), Fokus pa: Skolans rekryteringsutmaningar [Focus on:

Schools' recruitment challenges], Sveriges Kommuner och Landsting, Stockholm, https://webbutik.skl.se/sv/artiklar/skolans-rekryteringsutmaningar-.html (accessed on 10 February 2019).

The Teaching Council (2015), Striking the Balance Teacher Supply in Ireland: Technical Working Group Report, An Chomhairle Mhúinteoireachta/The Teaching Council, Kildare, https://www.teachingcouncil.ie/en/Publications/Teacher-Education/Teacher-Supply-in-Ireland.pdf (accessed on 1 April 2019).

UNESCO (2018), Global Education Monitoring Report 2019: Migration, Displacement and Education Building Bridges, not Walls, UNESCO, Paris, https://en.unesco.org/gem-report/allreports (accessed on 10 May 2019).

UNESCO (2014), EFA Global Monitoring Report 2013/14 Teaching and Learning: Achieving Quality for All, UNESCO, Paris, https://en.unesco.org/gem-report/allreports (accessed on 25 November 2018).

UNESCO-OECD-Eurostat (2018), UOE Data Collection on Formal Education: Manual on Concepts, Definitions and Classifications, UNESCO, OECD. Eurostat, Montreal, Paris, Luxembourg, http://uis.unesco.org/sites/default/files/documents/uoe2016manual_11072016_0.pdf (accessed on 18 June 2019).

Urquiola, M. and E. Vegas (2005), “Arbitrary variation in teacher salaries: An analysis of teacher pay in Bolivia", in Vegas, E. (ed.), Incentives to improve teaching: Lessons from Latin America, World Bank, Washington D.C., http://hdl.handle.net/10986/7265.

Vegas, E. and A. Ganimian (2013), "Theory and evidence on teacher policies in developed and developing countries", IDB Working Paper Series, No. 438, Inter-American Development Bank, Washington, DC, https://publications.iadb.org (accessed on 15 December 2018).

Woodcock, S. (2015), "Match effects”, Research in Economics, Vol. 69/1, pp. 100-121, http://dx.doi.org/10.1016/j.rie.2014.12.001.

Wössmann, L. (2003), "Schooling resources, educational institutions and student performance: The international evidence", Oxford Bulletin of Economics and Statistics, Vol. 65/2, pp. 117-170, http://dx.doi.org/10.1111/1468-0084.00045.

Xu, Z., U. Özek and M. Corritore (2012), "Portability of teacher effectiveness across schools", CALDER Working Papers, No. 77, National Center for Analysis of Longitudinal Data in Education Research American Institutes for Research, Washington, DC, https://caldercenter.org/publications/portabilityteacher-effectiveness-across-schools.

Zeichner, K. (2014), "The struggle for the soul of teaching and teacher education in the USA", Journal of Education for Teaching, Vol. 40/5, pp. 551-568, http://dx.doi.org/10.1080/02607476.2014.956544. 



\section{Chapter 4. Promoting powerful professional learning for school staff}

Professional learning for teachers, school leaders and other staff is essential to prepare students for success in a rapidly changing world. The chapter first addresses initial teacher preparation, from initial education to induction. Next, it embeds teacher learning, often defined narrowly as professional development, as part of larger continuing adult learning processes in schools. The chapter highlights the particular potential of evaluation to serve as a formative tool for most teachers and leaders. Recognising the centrality of school leadership for quality teaching and learning, the chapter devotes a separate section to leadership capacity development, from principals and middle leaders to teachers. The chapter documents the importance of moving beyond simplified models for improvement to consider professional learning as an evolutionary process. It concludes with a series of policy options that school systems may consider valuable.

The statistical data for Israel are supplied by and under the responsibility of the relevant Israeli authorities. The use of such data by the OECD is without prejudice to the status of the Golan Heights, East Jerusalem and Israeli settlements in the West Bank under the terms of international law. 
Creating a professional learning environment in which teachers, school leaders (and other school staff) feel individually and collectively supported is essential to unleash their potential to realise the transformative impacts of highly effective teaching, school leadership and student support. Professional learning opportunities for teachers and school leaders are also essential to support evolving educational goals and the learning required for students to succeed in a rapidly changing world.

As highlighted in Chapter 1, the United Nations 2030 Agenda for Sustainable Development "calls for education that goes beyond the transfer of knowledge and desirable behaviours by focussing on multiple perspectives - economic, ecological, environmental and sociocultural - and by developing empowered, critical, mindful and competent citizens" to address complex sustainability issues (UNESCO, 2016 ${ }_{[1]}$ ).

The OECD Learning Framework 2030 articulates environmental, economic and social challenges that imply broader educational goals. These future-oriented learning goals include supporting students to master technological advances that are critical to current learners' success in the 2030 labour market, but just as importantly the ways of thinking and being necessary to adapt to uncertainty, change and nuance. Students must develop a sense of individual and collective well-being as well as an independent sense of agency (OECD, 2018 $\left.{ }_{[2]}\right)$.

Powerful and sustained professional learning begins by preparing cohorts of teachers and leaders who are ready for the particular context in which they will work with rigorous and applied preparation programmes that require demonstration of in-classroom teaching or in-school leadership skills. It continues through the early years of new teaching and leadership roles through successful induction and mentorship that promotes rapid learning and skill development in the setting where educators will do the work - schools.

Professional learning does not end after the initial years in a new position. Developing curricular, pedagogical, student support and leadership skills in a school are the shared and ongoing responsibilities of its teachers and school leaders. Schools must increasingly embrace processes that structure the school as a place where professional learning is an ongoing part of the day-to-day work of the organisation, where teachers and school leaders (and other types of staff) work collaboratively to help each other learn, where systems exist to capture and codify knowledge, and where explicit supports develop leadership among all adults. Where professional learning emerges from evaluation, systems should be designed to ensure that it accomplishes its growth-oriented intent.

Despite different efforts to address the preparation, professional development and evaluation of teachers and leaders over the past three decades, many questions remain unanswered about the most effective strategies. This chapter documents the importance of moving beyond simplified models for improvement to consider professional learning as an evolutionary process.

The chapter first addresses strategy and process improvements to initial teacher preparation, from initial education to induction. Next, it embeds teacher learning, often defined narrowly as professional development, as part of larger ongoing continuing adult learning and improvement processes in schools. While the chapter recognises evaluation and appraisal processes as part of the overall process to continuously improve, the chapter highlights the particular potential of evaluation to serve as a formative developmental tool (rather than just an accountability mechanism) for most teachers and leaders.

In recognition of its centrality for quality teaching and learning, the chapter devotes a separate section to leadership capacity development, from principals and middle leaders to 
teachers. The chapter concludes with a series of policy options that school systems may consider valuable, while recognising that local policy will need to be adapted to the particular needs of an education system. Given the challenges in design and implementation of appraisal and evaluation, the chapter provides specific policy options also for this area of human resource policies.

\subsection{Initial teacher preparation}

Concerns that entrants into initial teacher education are under-skilled compared to those in other higher education programmes have often been a central part of policy discussions to raise the quality of school education. However, as discussed in Chapter 2, academic skill level is not the primary differentiating factor for teachers in top-performing school systems, and the best causal evidence suggests that these sort of criteria are not what makes teachers most effective at improving student outcomes. Therefore, other approaches for improving initial teacher preparation seem to be necessary besides simply changing the type of people who enter teacher education.

\subsubsection{Understanding initial teacher preparation as a complex system and as part of a continuum}

A recent OECD report on initial teacher preparation highlights that evidence on effective teacher education is growing, but far from clear-cut and conclusive (see Box 4.1 for challenges and strategies identified in the study) (OECD, 2019 $\left.{ }_{[3]}\right){ }^{1}$ The report, nevertheless, suggests to understand initial teacher preparation both as a complex system and as a continuum of professional growth and development.

Understood as a continuum, initial teacher preparation comprises initial or pre-service education, but also preparation during the first years of teaching be it through formal induction or formal or informal mentoring. Initial teacher preparation should thus provide beginning teachers with a coherent learning experience across coursework, practical training, induction and early career professional development.

This requires a vision of teachers as learners and requires a system that allows them to fulfil their potential as professionals that continuously question their practice, develop their own educational ideals and strengthen their conceptions of equity and social justice; a recognition of the relevance of learning that takes place after initial preparation; and a move beyond the theory and practice divide. It also firmly broadens the range of actors, with schools (and leaders, teachers, mentors, but also parents and students) playing an important role for initial preparation (e.g. during teacher practice and induction).

As a complex system, initial preparation is shaped by the interactions of different agents including people, organisations and material artefacts (such as curricula and accreditation requirements). While most student teachers, teacher educators and researchers belong to the tertiary education system, most teacher mentors, school leaders and policy makers operate in the school system. Positive feedback loops can then play an important role in driving change as can cross-institutional and multilevel partnerships to build a coherent initial preparation system that engages different stakeholders.

Schools often have little say over the design of initial education programmes, whereas initial education institutions often have little influence over the design of school induction programmes and other support schemes provided to beginning teachers. A coherent approach to initial preparation would involve collaboration between both to provide an authentic and reflective practical training and induction experience. Strong partnerships 
would go beyond regular discussions between schools and tertiary institutions on operational issues such as practical training placements, and also include the joint design, evaluation and improvement of programmes. This requires dedicated time, sustainable funding, and professional responsibility, agency and trust (OECD, 2019 $\left.{ }_{[3]}\right)$.

The following discusses lessons learned from OECD reviews to develop high-quality initial teacher preparation systems, from initial education to preparation and support during the first years.

\section{Box 4.1. A Flying Start: Improving Initial Teacher Preparation Systems}

Drawing upon resources produced by the OECD Initial Teacher Preparation (ITP) study, the report A Flying Start aims to support stakeholders in designing and sustaining initial teacher preparation systems. The report describes some key challenges identified by the reviews and proposes strategies for different levels of the system:

\section{How to ensure an evidence-informed, self-improving initial teacher preparation} system?

- Supporting rigorous and relevant research on initial teacher preparation (ITP).

- Introducing accreditation that incentivises ITP institutions to build their own evidence and implement a continuous improvement approach.

- Fostering the dissemination and utilisation of evidence throughout the system.

How to ensure a balanced teacher workforce?

- Using diversified longitudinal ITP data in actively forecasting workforce needs.

- Raising the status of teaching and teacher education.

- Attracting, selecting and hiring "the right candidates".

\section{How to equip teachers with updated knowledge and skills?}

- Providing a coherent and comprehensive initial teacher education curriculum.

- Continuously integrating new evidence and models of teaching and learning in ITP curricula.

- Aligning initial teacher education content with the school context and curriculum.

- Teaching teachers in line with emerging evidence and new models - the role of teacher educators.

\section{How to provide integrated early professional development for new teachers?}

- Offering extensive opportunities for teacher learning in grounded practice.

- Building on the experience of effective induction and mentoring programme.

- Embedding new teachers' early development in a culture of continuing professional learning.

Source: OECD (2019), A Flying Start: Improving Initial Teacher Preparation Systems, OECD Publishing, Paris, https://doi.org/10.1787/cf74e549-en. 


\subsubsection{Linking initial teacher education to practice in schools}

Though large majorities of lower secondary teachers report having received preparation in content, pedagogy and classroom practice for some or all of the subjects they teach, sizeable proportions of teachers in some countries report feeling underprepared for the realities of classroom teaching (OECD, 2019, p. 129 $\left.9_{[4]}\right)$. In particular, as Figure 4.1 documents, at least one in two teachers in Austria, the Czech Republic, France, Iceland, Italy, Spain and Japan report feeling underprepared for subject pedagogy, classroom practice or both. Such cross-country comparisons of self-reports should be conducted with extreme caution. In fact, as these data are self-reports they do not characterise the extent to which teachers are actually prepared to be successful in these areas, and likely over-represent levels of early career teacher preparedness.

This is not unique to the education sector as various other types of professionals begin with primarily theoretical training and continue to develop their skills over the course of their careers. However, the more skills initial teacher education can impart that permit both short-term success as well as long-term capacity for growth, the more students benefit. Additionally, the more teachers feel prepared for teaching, the more likely they are to remain in the profession (Ingersoll, Merrill and May, 2014 ${ }_{[5]}$ ), thus preserving systemic investments in the next generation of teachers and reducing recruitment costs and potential detrimental effects on schools associated with turnover.

Figure 4.1. Teachers' sense of preparedness for different elements of teaching (ISCED 2), 2018

Percentage of teachers who felt "not at all" or "somewhat prepared" for the following elements

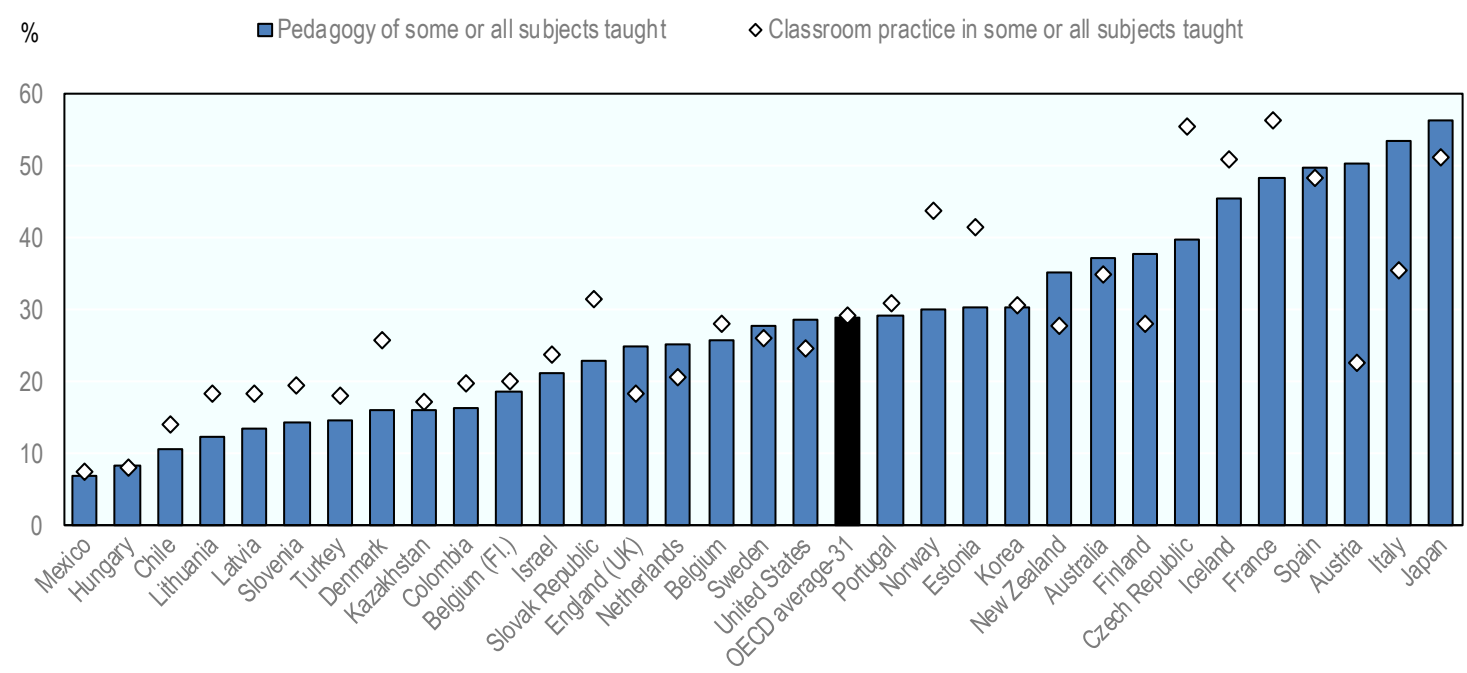

Notes: Countries and economies are ranked in ascending order in sense of preparedness in pedagogy. The number of countries or economies included in the OECD average is indicated next to that average. On 25 May 2018, the OECD Council invited Colombia to become a Member. While Colombia is included in the OECD average reported in this figure, at the time of its preparation, Colombia was in the process of completing its domestic procedures for ratification and the deposit of Colombia's instrument of accession to the OECD Convention was pending.

Source: OECD (2019), TALIS 2018 Results (Volume I): Teachers and School Leaders as Lifelong Learners, OECD Publishing, Paris, https://doi.org/10.1787/1d0bc92a-en, Table I.4.20. 
Teachers often enter the profession having experienced minimal classroom-based learning opportunities

Broad international agreement exists on the importance of opportunities to practice the skills required of teaching during initial education (OECD, 2019[3]; Grossman, Hammerness and McDonald, $2009_{[6]}$, but wide variation exists in country practice.

While in almost all OECD review countries (with the exception of Iceland and Mexico [secondary education]) the education of prospective teachers entails practical experience in school, expectations for pre-service school-based hours of practice vary widely across education systems. As Table 4.1 shows, some countries stipulate the specific number or a range of programme credits or time (e.g. in terms of hours, weeks or number of semesters) to be spent at school. Others recommend a minimum or maximum amount of practical experience, while yet others do not make any specifications about the extent of practical experience leaving the decision to individual teacher education institutions. Among those systems that specify practical experience in the form of ECTS credits, requirements range from less than 20 credits and less for some programmes for prospective secondary teachers in Denmark, Slovenia and Spain, to 60 and more credits for student teachers in Estonia and Portugal (basic school only).

This is similar to the picture provided by a report from Eurydice for education systems across Europe. In those 16 out of 28 systems that establish minimum European Credit Acquisition and Transfer System (ECTS) credit hours for student teaching in schools, the number of credits ranges from five to 60; which amounts to between 125 and 1800 hours of work (European Commission/EACEA/Eurydice, $\left.2015_{[7]}\right){ }^{2}$

Even these differences elide some within-system variation that is also related to the design of programmes to prepare prospective teachers. Prospective teachers may take their educational and professional studies alongside their academic subjects (concurrent model). Or they may take a programme of professional training in pedagogy and teaching after having completed a first degree in a discipline related to the subject taught at school (consecutive model). Countries may offer one of these types of teacher education or both, be it for all prospective teachers or for prospective teachers of specific levels of education.

In the Flemish Community of Belgium and Lithuania, for example, individuals can prepare for a career in teaching by completing an integrated programme (concurrent model of teacher education) or by gaining an additional qualification (consecutive model of teacher education). In Denmark, teacher education differs by level of education: prospective primary and lower secondary (Folkeskole) teachers follow an integrated model; prospective upper secondary teachers a consecutive one.

Given the shorter duration of professional training in pedagogy and teaching in a consecutive model, the practical component may make up a greater share of programme content. Nevertheless, the total amount of practical experience may still be greater in concurrent programmes. Put differently, concurrent models may offer more extensive, consecutive models more intensive practical training.

As the qualitative data for the OECD review also illustrate, in a number of countries, requirements for practical experience increase as student teachers progress through their programme (e.g. French Community of Belgium [primary and lower secondary teachers] and Uruguay [primary school teachers]) or as they advance from a first-cycle to a second-cycle degree (e.g. basic school teachers in Portugal). 
Table 4.1. Practical experience during initial teacher education (ISCED 1-3), 2018

OECD review countries

\begin{tabular}{|c|c|c|}
\hline Country & $\begin{array}{l}\text { Teaching qualification } \\
\text { for levels of education }\end{array}$ & Requirement for in-classroom student teaching experience \\
\hline Australia & ISCED 1-3 & Yes, minimum of 80 days (bachelor's) or 60 days (master's) \\
\hline Austria & ISCED 1-3 & Yes, minimum of 40 ECTS \\
\hline Belgium (FI.) (2019) (1) & ISCED 1-3 & Yes, minimum of 30 ECTS (associate or master's degree) or 45 ECTS (bachelor's) \\
\hline \multirow{2}{*}{ Belgium (Fr.) (2) } & ISCED $1-2$ & Yes, 16 weeks in total \\
\hline & ISCED 3 & Yes, minimum of 90 hours \\
\hline Chile & ISCED 1-3 & Yes, one semester \\
\hline \multirow{2}{*}{ Colombia (3) } & ISCED 1 & Yes, but not specified (Higher Teaching Schools [Escuela Normal Superior, ENS]) \\
\hline & ISCED 1-3 & Yes, minimum 40 credits (Faculties of Education) \\
\hline \multirow{2}{*}{ Czech Republic } & ISCED 1 & Yes, minimum of 30 ECTS \\
\hline & ISCED 2-3 & Yes, minimum of 24 ECTS \\
\hline \multirow{2}{*}{ Denmark } & ISCED 1-2 & Yes, 30 ECTS (University College) \\
\hline & ISCED 3 (general) & Yes, 20 ECTS (Paedagogikum) \\
\hline Estonia & ISCED 1-3 & Yes, minimum of 60 ECTS \\
\hline Iceland & ISCED 1-3 & No \\
\hline \multirow{2}{*}{ Kazakhstan } & ISCED 1 & Yes, but varies (vocational upper secondary or post-secondary programmes) \\
\hline & ISCED 1-3 & Yes, maximum of 34 ECTS (bachelor's) \\
\hline Lithuania & ISCED 1-3 & Yes, 30 ECTS \\
\hline \multirow{2}{*}{ Mexico } & ISCED 1 & Yes, but varies \\
\hline & ISCED 2-3 & No \\
\hline \multirow{2}{*}{ Portugal } & ISCED $1-2$ & Yes, minimum of 47 or 63 ECTS (depending on master's programme) \\
\hline & ISCED 3 & Yes, minimum of 42 ECTS \\
\hline Slovak Republic (4) & ISCED 1-3 & Yes, but varies \\
\hline \multirow{2}{*}{ Slovenia } & ISCED 1 & Yes, minimum of 30 ECTS \\
\hline & ISCED 2-3 & Yes, minimum of 15 or 30 ECTS (depending on programme) \\
\hline \multirow{2}{*}{ Spain } & ISCED 1 & Yes, 50 ECTS \\
\hline & ISCED 2-3 & Yes, 16 ECTS \\
\hline Sweden & ISCED 1-3 & Yes, 30 ECTS \\
\hline Turkey & ISCED 1-3 & Yes, 22 ECTS \\
\hline \multirow{2}{*}{ Uruguay (5) } & ISCED 1 & $\begin{array}{l}\text { Yes, } 40 \text { hours in total during the } 1^{\text {st }} \text { year, } 12 \text { hours per week in } 2^{\text {nd }} \text { and } 3^{\text {rd }} \text { years and } \\
16 \text { hours per week in } 4^{\text {th }} \text { year of education }\end{array}$ \\
\hline & ISCED 2-3 & Yes, but varies \\
\hline
\end{tabular}

Notes: In-classroom student teaching requirement refers to periods in initial teacher education programmes in which student teachers spend time either observing or teaching under the supervision of a practicing classroom teacher. For the European Credit Acquisition and Transfer System (ECTS), the correspondence of the full-time workload of an academic year to 60 credits is often formalised by national legal provisions. In most cases, workload ranges from 1500 to 1800 hours for an academic year, which means that one credit corresponds to 25 to 30 hours of work.

1. Belgium (Fl.): Every credit represents $25-30$ hours of a full study load; 60 credits are equivalent to one year. 2. Belgium (Fr.): For ISCED 1 and 2, teaching practice is organised during each of the three years of study. In the first year, this consists of participative observation in the presence of the internship supervisor; in the second and third years, the student takes charge of a class. At ISCED 3, teaching practice in real-life situations must include training periods as an observing participant, periods as a teacher (moving progressively into a teaching situation), and periods of school activities outside lessons (being involved in activities related to the running of the institution and the relationships between its players).

3. Colombia: An academic credit equals 48 total hours of student work. 
4. Slovak Republic: The duration of in-classroom experience is at the discretion of individual higher education institutions, but typically comprises at least $6 \%$ of the length of study.

5. Uruguay: For prospective teachers at secondary level, practical experience typically takes place from the second to the fourth year during a four-year programme.

Sources: Based on Country Background Reports and Country Review Reports (http://www.oecd.org/education/school-resources-review/schoolresourcesreview-

reportsforparticipatingcountries.htm), and Eurydice descriptions of national education systems (https://eacea.ec.europa.eu/national-policies/eurydice/national-description en).

Where prospective teachers have limited opportunities for practical experience they lose opportunities to practice instructional skills in settings in which they will have to later apply them (Brown, Collins, \& Duguid, 1989). A rich body of literature suggests this may leave them unprepared to transfer learning from the higher education classroom to the primary and secondary context (Feuer et al., 2013 ${ }_{[8]}$; O’Neill and Stephenson, 2012 ${ }_{[9]}$; Rockoff, $\left.2004_{[10]}\right)$. Teachers frequently note their inability to transfer complex subject-matter knowledge to pedagogical content knowledge, that is the ability to teach the concept rather than just understand it oneself (Delaney et al., 2008 ${ }_{[11]}$; Hill, Rowan and Ball, 2005 ${ }_{[12]}$ ), as well as struggles with engaging student interest and managing student misbehaviours (Reupert and Woodcock, 2015 [13]; Emmer and Stough, 2001 $\left.{ }_{[14]}\right]$.

For the OECD Teaching and Learning International Survey (TALIS) 2018, a considerable share of teachers at lower secondary level reported feeling underprepared for managing classrooms and student behaviour, ranging from more than one in four teachers in Lithuania to more than three in four in Austria and France. Mexico and Turkey are exceptions to the trend, with less than $15 \%$ of teachers reporting to feel underprepared in this area (OECD, 2019, pp. 207, Table I.4.20[4]).

Notably, the challenges of transferring academic skills in higher education to the realities of schools is not unique to teachers among school staff. While there is limited systematic and comparative knowledge about other professionals' roles and their preparation, some have argued that school social workers, for instance, would benefit from more practical applications in their training (Finigan-Carr and Shaia, 2018 $[15]$ ).

Some OECD review and other countries have sought to strengthen initial teacher preparation by increasing student teachers' share of practical experience. The education ministry of Colombia, for instance, substantially raised the requirements for practical experience for teacher education programmes at faculties of education to gain basic accreditation. The Colombian experience, however, also illustrates tensions between successfully integrating theoretical and practical application in teacher education. Efforts to establish a common set of expectations regarding the content and methods of pre-service preparation were met with resistance from higher education institutions. In addition to political challenges, stakeholders raised concerns about sufficient investments in time, resources and capacity to build tighter connections between institutions of higher education and schools (Radinger et al., 2018 $\left.{ }_{[16]}\right)$.

Besides the extent of practical experience, also the quality of school placements needs to be considered. Simply placing student teachers in classrooms with poor models for instruction, and weak guidance and supervision will not yield better prepared beginning teachers (Ronfeldt and Reininger, 2012 $2_{[17]}$ ). This is not only important as teachers and school leaders in schools play an important role in shaping new teachers' learning, but also in their socialisation into the profession as teacher colleagues (Paniagua and SánchezMartí, 2018 $\left.{ }_{[18]}\right)$. Grounded practice should take place in schools that provide a strong culture of professional learning and a sheltered environment for prospective teachers to practice and develop their teaching skills (OECD, 2019 $\left.9_{[3]}\right)$. 
To promote quality in student teachers' practical experience at school, education authorities may set requirements regarding the qualifications of teachers hosting student teachers, such as the number of years of experience and positive evaluation results, and oversee quality (e.g. through an independent screening body). In Portugal, this is the responsibility of individual teacher education institutions which screen for the quality of the co-operating teacher who provides mentoring to student teachers (Liebowitz et al., 2018 ${ }_{[19]}$ ). Education authorities may also play a role in identifying and supporting schools to provide a suitable learning environment. This is the case for the preparation of primary teachers in Uruguay where the central education authority designates specific schools as practicum sites. Teacher mentors in these "practice schools" receive dedicated training for their role and are compensated for their specific function (Santiago et al., 2016 $6_{[20]}$ ).

\section{Links between initial teacher education programmes and schools can be improved}

Many systems, cognizant of concerns about the disconnect between academic education and the realities of primary and secondary schools, have invested in developing stronger links between teacher education institutions and schools. Norway, for example, redesigned its primary and lower secondary teacher education programmes in the fall of 2017. These five-year programmes are intent on building master's candidates ability to use research-based knowledge in teaching and increasing the academic rigor of the course work. However, the programmes recognise that to be successful, they will need to be relevant to the experience of working in schools (Norwegian Ministry of Education and Research, 2018 $\left.8_{21]}\right)$. Box 4.2 presents another example, an innovative partnership between initial teacher education and networks of schools in the Netherlands.

Models of clinical practice in education, based on the medical residency system, bring a research-based understanding of teaching and learning into dialogue with the professional understandings of experienced teachers (OECD, 2019[3]). Box 4.3 provides examples of teacher residencies from the United States. These residencies integrate aspects of traditional university classroom preparation with on-the-job learning of alternative pathways into an immersive learning experience.

\section{Box 4.2. Collaboration between initial teacher education and school education in the Netherlands}

In the Netherlands, several initial teacher education pathways require substantial time spent in classrooms. School-based primary education teacher preparation programmes require 120 of 240 European Credit Acquisition and Transfer System (ECTS) credit hours to take place in a primary classroom. Similarly, secondary teaching one-year master's candidates must spend $50 \%$ of their time in a school-based practicum. To ensure that these extensive school-based experiences are successful, the Netherlands has initiated multiple school-initial teacher education partnerships.

These partnerships are supported at the system level through a requirement for programmes to demonstrate successful partnerships to maintain accreditation. An independent accreditation body approves each school-university partnership before they are funded by the Dutch Ministry of Education, Culture and Science. The accreditation body determines if there is a clear vision; a shared focus on improvement, leadership, co-operation and self-management; and a commitment to improving learning for students. 
To address concerns from schools and school boards about the "classroom readiness" of newly qualified primary teachers, the ministry launched a range of initiatives to improve the match between preparation programmes and school needs. These initiatives have facilitated and funded the much closer integration of universities with school boards, at the strategic level, and with individual schools at both the strategic and operational level.

Some examples of partnership activities that ensure schools and prospective teachers benefit include:

- The teacher education institution employs a teacher educator to oversee the partnership and provide strategic leadership.

- Schools and teacher education institutions exchange staff and work in each other's institutions.

- School and teacher education institution staff work closely together to develop and refine the initial teacher education curriculum and delivery.

- The school board and the teacher education institution jointly design how to select candidates students and both have a role in the selection.

- The teacher education institution provides training for teachers interested in being mentors.

- The school grades the student teacher on their practice; the student must achieve a pass mark to receive their teaching certificate.

Source: OECD (2019), A Flying Start: Improving Initial Teacher Preparation Systems, OECD Publishing, Paris, https://doi.org/10.1787/cf74e549-en.

In some OECD review countries, different types of institutions with their particular strengths in theory or practice prepare teachers for different levels of education (e.g. Austria, Colombia and Denmark). As the experience of the OECD review highlights, collaboration between the different institutions may strengthen teacher preparation overall.

For example, a teacher education reform in Austria (approved in 2013 and implemented since 2015/16) has brought the country's two types of teacher education institutions closer together, arguably strengthening the full initial teacher preparation system in the process. While university colleges of teacher education (Pädagogische Hochschulen, PHs) (which train teachers for provincial schools and are under leadership of the education ministry) have closer ties to schools and practice, universities (which train teachers for federal schools and enjoy greater autonomy) have particular strengths in theory and research. ${ }^{3}$ Collaboration has brought together the strengths of both types of institutions and the potential to improve both training in subject-related theory and pedagogy for all new teachers. An independent quality assurance council has supported the development of new teacher education programmes and has provided continuous advice for the further development of initial teacher education in the country (Nusche et al., 2016 $6_{[22]}$ ). 
In Colombia, there are similarly two main types of institutions with different strengths and weaknesses. While higher teaching schools (Escuelas Normales Superiores, ENS) prepare teachers for pre-primary and primary education (under leadership of the regional and local authorities that have been certified to provide education), university faculties of education prepare teachers for all levels of school education. ${ }^{4}$ Higher teaching schools, which provide a teacher education programme in addition to all levels of school education, are required to form partnerships with higher education institutions. This can potentially also create synergies between practice, theory and research (Radinger et al., 2018 ${ }_{[16]}$ ).

\section{Box 4.3. Urban teacher residencies in the United States}

Urban teacher residencies integrate aspects of traditional and alternative teacher preparation. Typically run by a school district independently or in partnership with a non-profit organisation, residency programmes select teaching candidates to work alongside a mentor for a full year before becoming a teacher of record. Residents also complete a set of coursework leading to both state certification and a master's degree from a partner university. In exchange for tuition remittance and a residency-year stipend, they commit to teaching in the district for a specified period, generally three to five years.

The teacher residency model has spread rapidly in the United States since the first programmes were launched in Chicago, Boston, and Denver between 2002 and 2004, attracting substantial public and philanthropic investment. A 2016 survey of the residency landscape found at least 50 programmes across the country (Guha, Hyler and DarlingHammond, 2016 $\left.6_{[23]}\right)$. As of August 2019, the National Center for Teacher Residencies listed 29 programmes serving some of the largest school districts (e.g. Los Angeles, Chicago and New York) (National Center for Teacher Residencies, 2018 [24]).

The federal government has provided targeted funding to support teacher residency models, and 15 states proposed in 2018 to leverage residencies to improve teacher effectiveness (National Center for Teacher Residencies, 2018 ${ }_{[25]}$ ). The practice-based training model has also influenced broader conversations about the reform of university-based teacher preparation, with an intra-state educator preparation accreditation governing body articulating clinical partnerships as one of five core principles of effective initial teacher education (Council for the Accreditation of Educator Preparation, 2013 [26]).

Most studies reveal improved retention outcomes for teachers entering the profession through these residencies, with potential but not definitive learning gains for students of teachers prepared through the residency pathway. Five empirical studies found teacher retention rates between $10 \%$ and $50 \%$ better than non-resident teachers in the same district (Guha, Hyler and Darling-Hammond, 2016 ${ }_{[23]}$ ). The only existent causal evaluation of an urban teacher residency model on student learning growth revealed mixed outcomes.

Papay et al. (2012 $\left.{ }_{[27]}\right)$ found that the Boston Teacher Residency produced graduates who were more likely to remain teaching in the school district. However, they improved their students' literacy skills at no higher rates than their early career peers who had not participated in an urban teacher residency. They initially underperformed their early career peers in improving their students' maths performance, but by their fourth year of teaching outperformed them. The authors conclude that the programme's overall effect was at best likely to improve overall student achievement only modestly. 
Teacher education programmes do often not yet sufficiently prepare teachers for the diverse backgrounds of their students

The OECD has documented growing diversity in students' learning profiles and backgrounds (OECD, 2018 ${ }_{[28]}$; OECD, 2018 [29]). In addition to growing student numbers formally classified as having special educational needs (SEN), many countries more frequently welcome students with immigrant backgrounds. Some teaching and school leadership skills cross all contexts; others may be most relevant in particular contexts. Some school systems explicitly acknowledge these differences and design training sequences for student teachers and practicing teachers that respond to these needs.

In 2012, Denmark reformed initial teacher education programme requirements so that all teachers would receive preparation in special needs and second language instruction (Nusche et al., 2016 $6_{[30]}$ ). Teacher education reform in Austria has likewise made inclusive pedagogy an integral part of the training for all new teachers (Nusche et al., 2016 $6_{[22]}$ ).

\section{Students with an immigrant or ethnic minority background}

The OECD has documented several challenges in the match between teachers' skills and the needs of their students, particularly those of an immigrant background. Students who are immigrants to their country of schooling or who had at least one parent who was themselves an immigrant represent approximately one in four 15-year-olds in OECD countries. These 15-year-olds with an immigrant background are more likely to underperform academically, have a weak sense of belonging in school, have a low satisfaction with life and have a high schoolwork-related anxiety (OECD, 2018 [29] $)$.

General strategies articulated by the OECD include adopting a holistic approach to immigrant students and identifying relationship development as key levers to create welcoming school environments for immigrant students. This is particularly salient as school climate, favouritism by teachers and lack of feedback have large impacts on the outcomes of students with immigrant backgrounds (OECD, 2018 [29]). School systems have generally taken an approach of either recruiting teachers who match the cultural backgrounds of under-served populations of students, training all teachers in cross-cultural proficiency, or a combination of these two strategies.

Austria and Germany offer two examples of the first type. At the University of Vienna, an innovative refugee teacher education programme began in September 2017 (Bildungswissenschaftliche Grundlagen für Lehrkräfte mit Fluchthintergrund) which permits refugees a pathway to teaching through alternative certification. Teachers with a refugee background are provided a fully funded education in a combination of education theory and a supervised practicum placement. In Germany, Teachers with Immigration Background (Lehrkräfte mit Zuwanderungsgeschichte) recruits and supports immigrant teachers in the state of North-Rhine Westphalia through career information events, local networks of practicing and aspiring teachers, and certification courses for migrant teachers to become "Inter-cultural Co-ordinators" who then promote diversity and inclusion in their respective schools (Cerna et al., 2019[31]).

Other programmes offer explicit strategies to teachers without immigrant or refugee backgrounds to help them build toolkits to support such students. Some institutions of higher education have leveraged technology to provide online programmes in intercultural skills, e.g. the RMIT School of Education in Melbourne's eTutor programme (Cerna et al., $\left.2019_{[31]}\right)$. Others either include mandatory coursework in diversity within a larger education 
degree programme, or offer a degree programme centred entirely on educational diversity (European Commission, 2017 [32]).

The experience of Sweden's programmatic efforts to prepare teachers for students with an immigrant background points to some potential challenges in implementation. Despite two programmes to train recent migrants with professional experience to transition into the Swedish education system, ${ }^{5}$ and elective courses for all prospective teachers on multicultural education, this has proven insufficient. Either due to weak participation from immigrant communities, the elective nature of courses, or the overly theoretical emphasis, these programmes have failed to prepare teachers to fully support students with recent immigrant backgrounds from the Middle East in Sweden (Cerna et al., 2019 [31]).

Depending on the country context, future teachers may also require the knowledge and skills to work with other ethnic minority students. OECD review and other countries have taken similar approaches as for students with an immigrant background and recruit teachers from their communities and/or train all teachers in related competencies. Teachers may benefit from professional learning that helps them to better understand their students, their students' families and communities, the history of minorities in their area and the cultural and historical significance of events, places and landmarks in the vicinity of the school community (OECD, 2017[33]).

Colombia, a country of great cultural, ethnic and geographical diversity, has specific provisions for the education of ethnic minorities with the purpose of respecting and maintaining ethnic language, culture and values. Legislation also sets some objectives for the preparation of educators of ethnic groups (etnoeducadores), which should be hired in negotiation with the ethnic communities, giving preference to members of the local community. Teacher education should provide specific training in ethnic education and opportunities for educators of ethnic groups to develop their skills and engage in research. However, provisions have not been effectively put into practice, existing programmes are few, and the quality of programmes has been a concern (Radinger et al., 2018 $8_{[16]}$ ).

The Chilean experience with its indigenous education programme (Programa de Eduación Intercultural Bilingüe, PEIB) highlights some other challenges related to the recruitment and preparation of teachers for indigenous communities. Low educational attainment of traditional teachers (average schooling of 11 years) makes entry to initial teacher education programmes difficult, while dedicated training for traditional teachers in instructional

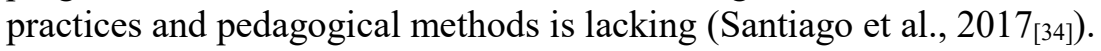

In New Zealand, multicultural goals feature prominently in systemic reforms embodied in Future Focused Initial Teacher Education, and in the standards for educator licensure (e.g. Cultural Competencies for Teachers of Māori and Pacific Learners) (Education Council New Zealand, 2011 $1_{[35]}$; New Zealand Ministry of Education, 2018 $\left.8_{[36]}\right)$. In Australia, the federal government funded the More Aboriginal and Torres Strait Islander Teachers Initiative (MATSITI) between 2011 and 2016 to attract, retain and develop Aboriginal and Torres Strait Islander peoples in teaching positions (Buckskin, 2017 $[37]$ ).

\section{Students from rural communities}

Beyond cultural and ethnic backgrounds, many systems include substantially different forms of students' needs across geographic regions. Recent work drawing on the OECD's international teacher surveys and student assessments finds that while students from rural backgrounds tend to perform academically roughly equivalently to their urban peers once their socio-economic status is taken into account. However, rural students tend to have 
lower educational expectations (Echazarra and Radinger, 2019 ${ }_{[38]}$; OECD, 2018 ${ }_{[28]}$ ). This accords with national-level studies showing that rural students often attend less competitive universities, conditional on their school performance (known as "under-matching"), or fail to attend higher education at all (Hoxby and Avery, 2013 [39]). This is a particular concern given increasing returns to higher education (Handel, 2012[40]).

Rural school settings sometimes create particular pedagogical challenges, particularly in the context of multi-grade classrooms (Echazarra and Radinger, 2019 ${ }_{[38]}$; OECD, 2018 ${ }_{[28]}$ ). Teachers, and in particular those new to rural and remote contexts, must learn strategies to adapt curriculum specific to a particular grade in a setting with different age students in the same class. To support learning for all students in a multi-grade classroom, teachers may require innovative ways to engage students, manage classroom interaction and discipline, and provide constructive feedback. This is particularly critical as the effects of learning in a multi-grade classroom may depend in part on the quality of practices used by the instructor (Echazarra and Radinger, 2019 [38]; OECD, 2018 [28]).

Given the small number of staff in rural schools, teachers may furthermore have to teach a variety of subjects, including some outside their area of expertise for which they have not received training and for which they may require additional time to prepare. Data from TALIS 2013, in fact, reveal that in several countries, and on average across OECD countries, a larger share of rural teachers than urban teachers reported that they had not received formal education or training on the content, pedagogy or classroom practice for all the subjects they teach (Echazarra and Radinger, 2019 ${ }_{[38]}$; OECD, 2018 ${ }_{[28]}$ ).

Since multi-grade teaching strategies may not feature in initial teacher education, countries with small schools and multi-grade classes should reflect on ways to provide effective professional learning opportunities and supportive working conditions for rural teachers. Facilitating peer learning, collaboration and feedback will be important to connect rural teachers to their professional community. Effective partnerships and feedback loops between rural schools, teacher education institutions and education authorities may help to inform the design of teacher education programmes and increase their relevance for rural contexts (Echazarra and Radinger, 2019 $[38]$; OECD, 2018 ${ }_{[28]}$ ).

\section{Students with special educational needs (SEN)}

In addition to efforts to better serve students with immigrant and geographically diverse backgrounds, OECD countries allocate increasing shares of their budgets to meet the needs of students with special educational needs (SEN) and to integrate them in mainstream education $\left(\mathrm{OECD}, 2018_{[28]}\right)$. Due to substantial differences in how countries classify students with special needs, it is difficult to collect internationally comparable data. Nevertheless, in 2018 , more than $30 \%$ of teachers worked in schools with at least $10 \%$ of students with special needs, on average across 30 OECD countries with available data, as reported by principals for TALIS 2018 ( (OECD, 2019, pp. 206, Table I.3.25 $\left.5_{[4]}\right){ }^{6}$

Despite increasing attention to the moral imperative of adequately serving students with special needs, as also articulated by the United Nations 2030 Sustainable Development Goals (United Nations, 2015 $5_{[41]}$ ), many educators report feeling unprepared to support their learning needs. In the OECD review of Denmark - a country which has committed itself to greater inclusion - teachers felt unprepared to draw up learning-focussed individual learning plans for their students and to use and adapt national learning goals for their students with special needs, for example. The review identified a need to further develop teachers' skills to use multiple methods and pathways to achieve learning goals to reach all students, including those with special needs (Nusche et al., 2016 $6_{[30]}$ ). 
The single highest-need topic of professional development for teachers as reported for the TALIS 2014 and 2018 was teaching students with special needs (OECD, 2014, p. 109 [42]; OECD, 2019, p. 164[4] $)$. A shortage of teachers with competencies in teaching students with special needs was also one of the three most common resource issues for schools as reported by school principals for TALIS 2018. Almost a third of teachers across OECD countries work in a school whose principal reported that such a shortage hinders the school's capacity to provide quality instruction (OECD, 2019, pp. 108, Table I.3.63 $3_{[4]}$ ). Thus, the combination of growing populations of special needs students, and their growing integration into mainstream classrooms likely contribute to teachers' sense of lack of preparedness for teaching (OECD, 2018 $\left.8_{[28]}\right)$.

Alternative pathways offer an accelerated route into teaching but the quality of preparation in these routes is uncertain

In response to concerns about the quality of candidates selected into initial teacher education programmes, as well as related concerns about the nature of the curriculum in these programmes, several alternative pathways into teaching and school leadership roles have been developed. In some cases (e.g. England [United Kingdom], the Netherlands, Latvia and Lithuania), these alternative pathways are characterised as operating largely independently from higher education institutions, as an analysis of information available in a Eurydice report suggests. In other cases (e.g. Germany, Denmark, Sweden and the Flemish Community of Belgium), they seem to be connected to higher education institutions, but to operate distinctly from typical preparation programmes (European Commission/EACEA/Eurydice, 2018 [43]).

Alternative pathways (which may also be developed as a response to teacher and school leader shortages as analysed in Chapter 3) generally involve short-term trainings lasting anywhere from a few weeks to a few months, resulting in a form of certification permitting the holder to teach or manage a school. Some of these alternative pathways appeal to career-switchers at mid-career points, while others are intended to appeal to high-skill recent tertiary graduates who might not otherwise have considered teaching (e.g. Teach for All, a network of teacher recruitment and development programmes in 45 countries that attracts teachers from non-traditional backgrounds).

In some countries, alternative pathways represent a notable share of new entrants into teaching. In Estonia and Lithuania, more than 15\% of teachers who had completed their formal teacher education in the last five years prior to TALIS 2018 had done so through a fast-track or specialised programme, as reported by teachers $(18.5 \%$ and $15.3 \%$ respectively). In three further countries, the proportion of new teachers completing such a programme amounted to around 13\% (Flemish Community of Belgium [13.3\%], Colombia [13.6\%], England (United Kingdom) [14.1\%]) (OECD, 2019, pp. 207, Table I.4.12 $\left.{ }_{[4]}\right)$.

A recent Eurydice report documents that approximately one third of European countries have some alternative pathway to a teaching qualification. These include short mid-career professional-oriented programmes in the Flemish Community of Belgium, Denmark, Germany, the Slovak Republic, Sweden, Switzerland and Turkey and employment-based, residency training in Latvia, Lithuania, the Netherlands and England and Wales (United Kingdom) (European Commission/EACEA/Eurydice, 2018, pp. 37, 38[43]).

In many systems, there is limited systematic knowledge about teachers entering through alternative pathways, the quality of their preparation, and their trajectory in the profession. The effects of alternative pathways on student learning outcomes is often uncertain and little is known about the instructional techniques employed by alternatively prepared 
teachers. Also limited internationally comparable and rigorous evidence exists on the effects of these accelerated pathways.

Concerning Teach for All, some studies find positive gains for students taught by teachers recruited under this model (e.g. Chacon and Pena $\left(2017_{[44]}\right)$ for Mexico). But these results are correlational in nature, and may be driven by teachers' and students' selection into particular schools that contribute to increased academic and socio-emotional learning gains in other ways. Studies in the United Kingdom (Allen and Allnutt, 2017 $[45]$ ) and the United States (Clark et al., 2017 $7_{[46]}$ ) tend to find either no difference or very marginal benefits to alternative pathway teachers, with unknown general equilibrium effects due to their tendency to leave teaching at more rapid rates.

One frequently noted concern about these alternative pathways is their potential for "de-professionalising" teaching (Vegas, 2011 $1_{[47]}$; Zeichner, 2014 ${ }_{[48]}$ ). Namely, if teaching candidates move quickly through a short training cycle before being placed in a classroom, it will lead to a devaluation of the complex skills of teachers. There is some evidence in the United States that alternatively certified teachers experience high rates of turnover, but these rates are no higher than similarly placed first-year teachers (Donaldson, 2011 ${ }_{\text {[49] }}$ ). At the same time, alternative pathways can offer intelligent trajectories for individuals to grow into teaching and school leadership, or even in other areas, such as policy making and social enterprise, and to become innovates in the teaching profession (Schleicher, 2018 ${ }_{[50]}$ ).

\subsubsection{Induction and mentoring}

The transition from initial education to primary and secondary teaching is a critical stage in preparing teachers and helping them to be effective in the classroom (OECD, 2019 ${ }_{[3]}$; Paniagua and Sánchez-Martí, 2018 ${ }_{[18]}$; Jensen et al., 2012[51]). Assuming the role of full-time teacher is daunting and can present unique challenges. Many teachers report significant struggles early in their careers related to classroom management and understanding school social systems (Schuck et al., 2018[52]; Cherubini, 2009 [53]). Econometric evidence, furthermore, suggests lower levels of productivity in terms of student learning outcomes early in teachers' and school leaders' careers (Papay and Kraft, 2015 [54]; Clark, Martorell and Rockoff, 2009 [55] $)$ At the same time, early career teachers bring with them enthusiasm and recent training that can be potentially valuable for schools to innovate and reflect on their own practices and for team learning among staff (OECD, 2019[3]; Paniagua and Sánchez-Martí, 2018 $[18]$ ).

A number of countries have made efforts to promote supports to new teachers so they are successful in launching their career and becoming a part of the profession. Such "induction" efforts often seek to bridge the gap between theory and practice, address workload challenges, provide strategies in classroom management and understanding school culture (OECD, 2019 [3]; Jenset, Klette and Hammerness, 2017[56]).

Though systems provide these supports in different ways, induction is generally understood as a variety of mechanisms, which may include both mentoring and coaching. Box 4.4 provides definitions. 


\section{Box 4.4. Models for staff support: induction, mentoring and coaching}

There are three common types of support provided to school staff: induction, mentoring and coaching. These types of support are related, but distinct.

- Induction: a variety of mechanisms in which beginning teachers are oriented to the profession or the context of a new school; can include new teacher orientations, sequence of first-year courses, mentoring, coaching and more (Wong and Wong, $\left.2005_{[57]}\right)$.

- Mentoring: relationship between an experienced mentor and their less experienced mentee to pass on knowledge and experience, provide guidance and facilitate connections to others; more often focusses on providing general advice rather than responding directly to observed classroom practices (Wildman et al., $1992_{[58])}$.

- Coaching: goal-oriented process to improve instructional or leadership skills; a qualified teacher or leader with specific capacities and preparation guides the learning of another adult in instructional or leadership skills, e.g. through peer-to-peer discussions that provide the person being coached with feedback on their strengths and weaknesses in areas chosen by them.

Intensive teacher coaching has been demonstrated across multiple contexts to improve teaching practice and student achievement outcomes (Kraft and Blazar, 2016 [59]; Allen

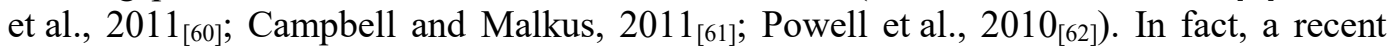
meta-analysis of 60 causal research studies found improvements in teaching practices on the order of half of a standard deviation and on student achievement of around a fifth of a standard deviation (Kraft, Blazar and Hogan, 2018 $8_{[63]}$ ). Reviews of traditional induction and mentoring programmes have found more mixed effects (Ingersoll and Strong, 2011 [64]). Context and duration seem to play an important role for the effectiveness of induction processes, but much remains to be understood about the types of support that work best, and why (Ingersoll and Strong, 2011 $1_{[64]}$ ), and also if and how induction can help retain new teachers in the classroom (Ronfeldt and McQueen, 2017 [65]; Glazerman et al., 2010[66]).

Countries also need to consider inherent resource trade-offs developing such strategies. Reducing beginning teachers' workloads, providing mentoring stipends and course releases or trainers for mentoring programmes can be costly in terms of time and money. For example, in England (United Kingdom), starting in autumn 2021, the Early Career Framework will guarantee a $10 \%$ timetable reduction in beginning teachers' first year of teaching, and a 5\% reduction in their second year. Regular trainings for both early career teachers and mentors will be fully funded, and a specific curriculum will be created. The anticipated cost is approximately GBP 130 million (British pounds) per year (Department for Education, 2019[67]). While the cost of mentorship can be high, so too are however high levels of teacher turnover. England's Department for Education estimates that it spends around GBP 250 million annually on teacher recruitment costs (Department for Education, $\left.2019_{[68]}\right)$. Thus, school systems which consider investing in reforms to their induction programmes must carefully estimate the relative costs and expected benefits of each policy option to determine their value. 


\section{Access to and participation in induction vary widely}

Despite widespread awareness of the challenges of beginning teachers, there seems to be scope to further support access to and participation in systematic induction processes. On average across OECD countries participating in TALIS 2018, $66 \%$ of beginning teachers (those with up to five years of teaching experience) report not having participated in any form of induction during their first employment. In Hungary, Italy and Latvia, only $15 \%$ or less of beginning teachers reportedly took part in an induction during their first employment (OECD, 2019, pp. 208, Table I.4.38[4] $)$. Figure 4.2 provides more detailed survey results for beginning teachers' participation in formal and informal induction.

Mentoring, which can be part of induction, also appears to be underexploited as a support beginning teachers (again see Figure 4.2). According to the TALIS 2018, only 22\% of teachers with up to five years of teaching experience reported to have an assigned mentor, on average across the OECD (OECD, 2019, pp. 145, Figure I.4.14, Table I.4.64[4]).

Figure 4.2. Induction and mentoring for beginning teachers (ISCED 2), 2018

Results based on responses of teachers with five years of experience or less

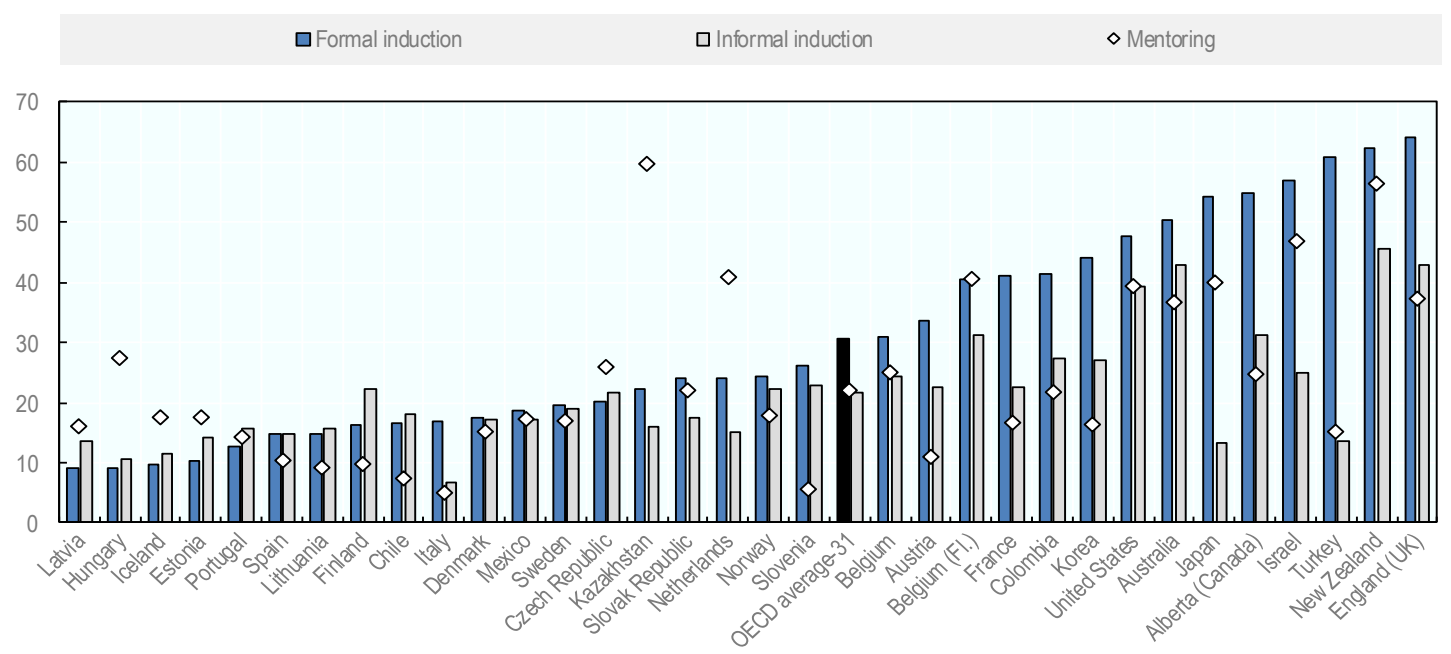

Notes: Countries and economies are ranked in ascending order of participation in formal induction. "Induction activities" are designed to support new teachers' introduction to the teaching profession and to support experienced teachers who are new to a school, either organised in formal, structured programmes or informally arranged as separate activities; "Mentoring" is defined as a support structure in schools where more experienced teachers support less experienced teachers. This structure might involve all teachers in the school or only new teachers. It does not include mentoring of student teachers doing teaching practice at this school. For induction, the sample is restricted to teachers who gave a valid answer to both questions of whether they participated in a formal induction programme and in informal induction activities during first employment. The number of countries or economies included in the OECD average is indicated next to that average. On 25 May 2018, the OECD Council invited Colombia to become a Member. While Colombia is included in the OECD average reported in this figure, at the time of its preparation, Colombia was in the process of completing its domestic procedures for ratification and the deposit of Colombia's instrument of accession to the OECD Convention was pending.

Source: OECD (2019), TALIS 2018 Results (Volume I): Teachers and School Leaders as Lifelong Learners, OECD Publishing, Paris, https://doi.org/10.1787/1d0bc92a-en, Tables I.4.38 and I.4.64.

StatLink त्गाज़ https://doi.org/10.1787/888934026601 
Looking at the experience of OECD review countries, formal induction is an integral part of new teachers' transition into the profession in less than half of participating countries (see Table 4.2).

Table 4.2. Induction requirements (ISCED 1-3), 2018

OECD review countries, public schools

\begin{tabular}{|c|c|c|c|c|c|c|c|c|c|c|c|c|c|c|c|c|c|c|c|c|}
\hline $\begin{array}{l}\text { Induction } \\
\text { required }\end{array}$ & & & & & & & & & & & & & & & & & & & & \\
\hline Country & 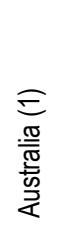 & 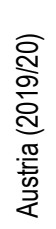 & 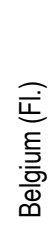 & 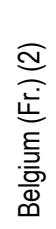 & $\begin{array}{l}\overline{\frac{0}{0}} \\
\frac{\omega}{\bar{c}} \\
\end{array}$ & $\begin{array}{l}\text { 吾 } \\
\bar{E} \\
\text { 응 } \\
\end{array}$ & 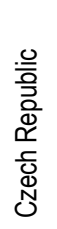 & 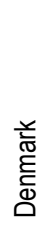 & 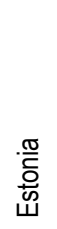 & 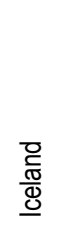 & 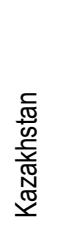 & 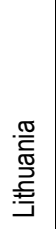 & $\begin{array}{l}\frac{8}{\frac{0}{x}} \\
\frac{\mathbb{x}}{2}\end{array}$ & 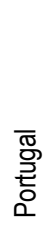 & 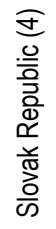 & $\begin{array}{l}\frac{\pi}{\bar{T}} \\
\frac{\mathrm{d}}{\omega} \\
\frac{0}{\omega}\end{array}$ & 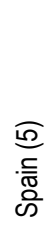 & 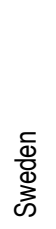 & $\begin{array}{l}\text { 离 } \\
\text { 产 }\end{array}$ & 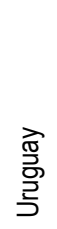 \\
\hline
\end{tabular}

Note: Induction refers to supervision/mentoring at school following completion of initial teacher education (e.g. required for employment).

1. Austria: Prior to the introduction of a new teacher service code, an induction period was only mandatory for beginning teachers at academic secondary schools. Since 2019/20, all beginning teachers under the new service code are required to complete a one-year induction phase.

2. Belgium (Fr.): Schools must define a strategy for induction as part of their steering plan.

3. Chile: Up to ten months during first or second year of professional experience.

4. Slovak Republic: One year.

5. Spain: Between three months and a year depending on state education authority (Autonomous Community).

6. Turkey: One year.

Sources: Based on Country Background Reports and Country Review Reports (http://www.oecd.org/education/school-resources-review/schoolresourcesreview-

reportsforparticipatingcountries.htm), and Eurydice descriptions of national education systems (https://eacea.ec.europa.eu/national-policies/eurydice/national-description_en).

In Spain and Turkey, traineeships are required following completion of initial teacher education to gain employment as a fully-qualified teacher.

- In Spain, beginning teachers selected through the central recruitment process start their career with a dedicated traineeship period, the successful completion of which is required for appointment as a civil servant. The specifics of the traineeships are regulated by the education authorities of the individual Autonomous Communities. Typically, however, traineeships last between three months and a full school year. During this time, trainees share responsibility for planning, teaching and assessment with their tutor. Trainees may observe other teachers' classrooms and participate in further training (e.g. distance learning or courses at Teacher and Resource Centres) (Eurydice, 2019 ${ }_{[69]}$ ).

- Similarly, beginning teachers in Turkey undertake a traineeship at the beginning of their career which is a precondition for appointment to a permanent position. As part of their traineeship, teacher candidates are mentored by experienced teachers, which can include classrooms observations and the completion of tasks for preparation and evaluation in and outside of the classroom. Teacher candidates are also expected to engage in self-study and they attend seminars and conferences to further develop their knowledge and skills (Eurydice, 2019 [69]). 
Other OECD review countries mandate induction periods for beginning teachers upon their first appointment (see Box 4.5), possibly linked to the first stage of a multi-stage career structure. Austria, the French Community of Belgium and Chile have recently put in place more systematic induction requirements (Santiago et al., 2017[34]; Ministère de la Fédération Wallonie-Bruxelles, 2016[70]; Nusche et al., 2016 [22]). In the case of Austria and Chile, these have been part of wider reforms of the teacher career.

\section{Box 4.5. Induction processes in OECD review countries}

\section{Austria}

A one-year induction phase (Unterrichtspraktikum) has traditionally been required only for teachers of academic secondary schools. Following the introduction of a new teacher service code for all teachers (Dienstrechts-Novelle 2013 - Pädagogischer Dienst), all new teachers benefit from a one-year professional entry phase. These requirements came into effect in 2019/20. During the entry phase, beginning teachers are supported by experienced mentors, that is active teachers with additional training in the area of mentoring. In addition to supervision at the school, new teachers attend induction courses at a university college of teacher education. At the end of the induction period, new teachers receive an evaluation of their performance by the school principal.

Source: Nusche, D., T. Radinger, M. R. Busemeyer, H. Theisens (2016), OECD Reviews of School Resources: Austria 2016, OECD Publishing, Paris, http://dx.doi.org/10.1787/9789264256729-en.

\section{Chile}

In Chile, the organisation of induction processes for beginning teachers was typically at the discretion of school providers and schools. A reform of the teaching career in the form of a System for Teacher Professional Development (Sistema de Desarrollo Profesional Docente, Law 20.903) introduced in 2016 established a mandatory induction process for all beginning teachers. The induction phase takes place either in the first or second year of teaching, has a duration of up to ten months, and includes mentoring at the school by an experienced teacher with a proven record of quality teaching. The induction process - both the additional hours for the beginning teacher and the hours of the mentor - is funded by the Ministry of Education. The induction process has a formative function and is not associated with a probationary period.

Source: Santiago, P., A. Fiszbein, S. García, T. Radinger (2017), OECD Reviews of School Resources: Chile 2017, OECD Publishing, Paris, https://dx.doi.org/10.1787/9789264285637-en.

\section{Slovak Republic}

At the beginning of their career, teachers are required to undertake and complete an induction programme within the first two years. Induction is organised by the school in collaboration with the respective Methodology and Pedagogy Centre (Metodicko-pedagogické centrum), which are institutions for teacher education and training, or the National Institute for Education (Štátny pedagogický ústav, ŠPÚ), an education advisory body which also provides assistance and counselling for schools. The induction process consists of "adaptation courses" (provided free of charge) and supervision by a mentor teacher at school who receive additional compensation for their role. The induction phase is completed with a final examination. Failure to complete the "adaptation courses" can lead to dismissal.

Source: Santiago, P., G. Halász, R. Levačić, C. Shewbridge (2016), OECD Reviews of School Resources: Slovak Republic 2015, OECD Publishing, Paris, https://dx.doi.org/10.1787/9789264247567-en. 
In other OECD review countries, there are no formal induction requirements and processes for beginning teachers into the teaching profession. Nevertheless, education authorities may encourage induction processes with funding and other support. In Estonia, for example, beginning teachers may voluntarily participate in a 12-month induction programme which is funded by the Ministry of Education and Research and implemented by two of the countries' three public comprehensive universities. The induction programme provides for a mentor to supervise the work of the beginning teacher. The mentor, who is a teacher at the receiving school, is appointed by the school principal and has at least three years of experience in pedagogical work and passed a specific training in supervision. The mentor is also required to provide feedback to the initial teacher education institution from which the beginning teacher received their qualification. During the induction year, the beginning teacher should prepare an individual development chart which contains a self-evaluation of their experience. Other offers include workshops for beginner teachers that address the experiences and frequent challenges of the first year(s) of work and seek solutions for them, either jointly or individually (Santiago et al., 2016 [71]).

In Slovenia, participation in an induction period represents one of two possible pathways into the profession. Teachers can either apply directly for open positions advertised by schools or - as is recommended - through an open recruitment for trainee positions advertised by the ministry of education. For the traineeships, the ministry manages the selection and placement of candidates while taking schools' needs and interests into account. Depending on the qualification of the graduate teacher, the traineeship lasts between six and ten months. During this time, trainees are accompanied by a dedicated mentor appointed by the principal. Trainees are expected to deepen their knowledge of subject-specific didactics, learn to design lesson plans, and prepare lessons and execute them while observing the mentor's classes and those of other teachers in the schools. They are also supposed to co-operate with school leadership and to work with parents. At the end of their traineeship, trainees sit an oral professional examination (Slovenian Ministry of Education, Science and Sport, 2017 $\left.{ }_{[72]}\right)$.

In yet other OECD Review countries, the availability of induction depends on local contexts. Denmark represents one such system with many municipalities and schools paying special attention to new or beginning teachers (e.g. from some informal mentoring by school staff and school leaders to having new teachers teach less and work with an experienced staff member for periods of time) (Nusche et al., 2016[30]). While efforts to offer workshops for beginning teachers, to reduce their teaching load and provide mentoring have promise, the non-systematic nature of these approaches nevertheless raises concerns that not all new teachers benefit from high-quality induction.

A recent OECD report on initial teacher preparation highlights shared challenges in induction, such as a lack of alignment between initial teacher education programmes and induction curricula, and obstacles to extending induction and connecting it with continuing professional development (OECD, 2019 $\left.{ }_{[3]}\right)$. The report, therefore, suggests that successful induction should be delivered as a coherent programme that provides personal and emotional, social and professional supports, and draws on systems for mentoring, expert inputs, peer support and self-reflection. To bridge the gap between initial preparation and continuing development, new teachers' early development should be embedded in a culture of continuing professional learning. Where schools develop a culture of critical inquiry, promote ongoing team learning, and foster collegiality, schools can "move beyond 'assisting' new teachers and engage them in their professional culture of teaching" (OECD, 2019, p. 113 $[3])$. 
Quality induction processes also need to consider implementation challenges for effective mentoring, such as preparation, workloads and experience. While a sufficient knowledge base about these aspects is lacking, some countries have sought to promote standards for mentoring $\left(\mathrm{OECD}, 2019_{[3]}\right)$. Some OECD review countries also provide direct capacity development for mentors responsible for supporting new teachers. In Estonia, for example, mentors receive support in developing their mentoring skills, participate in two to three yearly mentor seminars, and have access to electronic lists to collaborate even when they are not face-to-face (Haridus- Ja Taedusministeerium, 2016 $[73]$ ).

The TALIS 2018 asked principals about the provisions which were part of the induction processes at their school (OECD, 2019 $\left.9_{[4]}\right)$. While induction typically includes processes such as planned meetings with and supervision by the principal and/or experienced teachers, the extent to which team teaching or teaching load reductions are included differs widely across countries (see Figure 4.3), pointing to potential trade-offs in the way resources are used. Kazakhstan and the Netherlands illustrate these different resource decisions, with the former investing more in team teaching, and the latter in a reduced teaching load for beginning teachers. Most countries provide more opportunities for team teaching than teaching load reductions, and few countries provide both for a large share of teachers (e.g. England [United Kingdom], Iceland, Japan, New Zealand, Norway).

Figure 4.3. Induction activities (ISCED 2), 2018

Percentage of teachers for whom the following provisions are included in teacher induction at their school, based on principal reports

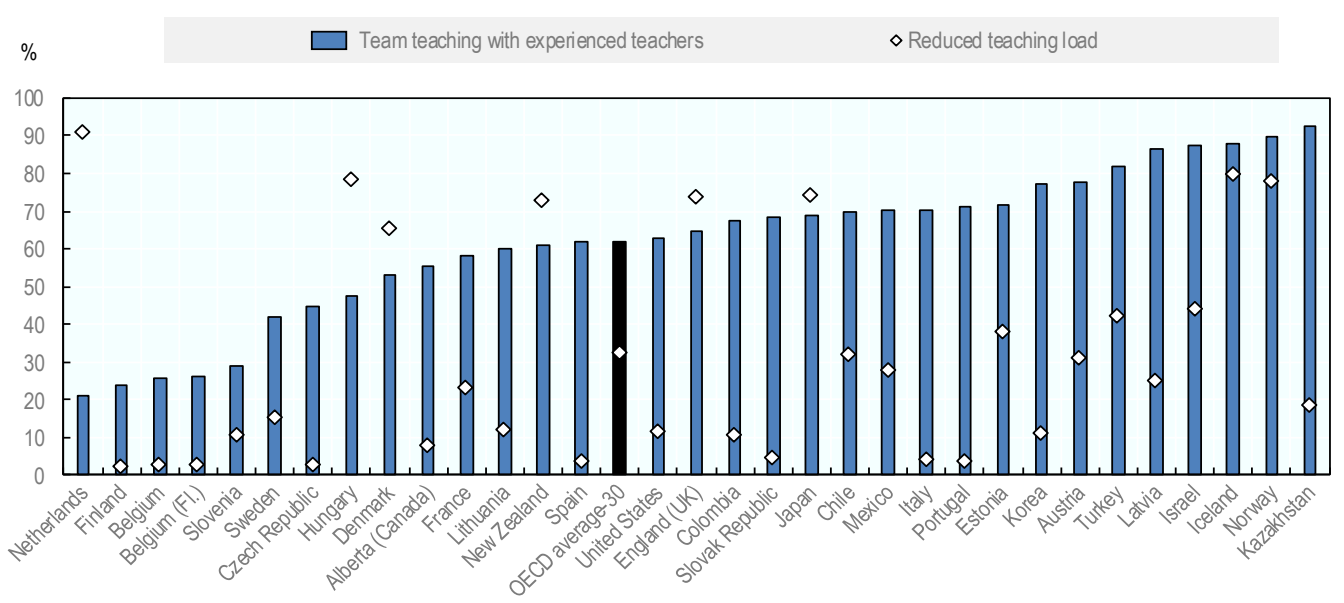

Notes: Principals reported which provisions were included in teacher induction at the school at the time of the survey. Principals' responses were merged to teacher data and weighted using teacher final weights. The sample is restricted to teachers who took part in induction activities at the current school based on teachers' responses and also have access to induction activities based on principals' responses. Countries and economies are ranked in ascending order of percentage of teachers for whom team teaching with an experienced peer was included as part of induction. The number of countries or economies included in the OECD average is indicated next to that average. On 25 May 2018, the OECD Council invited Colombia to become a Member. While Colombia is included in the OECD average reported in this figure, at the time of its preparation, Colombia was in the process of completing its domestic procedures for ratification and the deposit of Colombia's instrument of accession to the OECD Convention was pending.

Source: OECD (2019), TALIS 2018 Results (Volume I): Teachers and School Leaders as Lifelong Learners, OECD Publishing, Paris, https://doi.org/10.1787/1d0bc92a-en, Table I.4.42.

StatLink त्ञाज https://doi.org/10.1787/888934026620 


\subsection{Teachers' continuing professional learning}

A substantial body of historical education research has documented the limited opportunities teachers have had for ongoing learning and collaboration. In the 1980s and early 1990s, the research and policy community grew increasingly aware of the atomised nature of schools and the teaching profession. In response to the "egg-crate" model of teaching in which each teacher's classroom was his or her domain, and each school operated largely independently from others, with little opportunity for peer feedback and collaboration, significant research interest developed in promoting cross-teacher and cross-school collaboration and professional learning (Garet et al., 2001 [74]; Sparks, 1994 [75]; Little, 1993 ${ }_{[76]}$; Rosenholtz, 1985 $[77]$ ). While the focus on professional learning ebbed somewhat in the early 2000s, leading scholars and policy makers have since re-launched an interest in understanding how teachers' and school leaders' professional contexts support their ongoing learning and improvement (Johnson, Kraft and Papay, 2012 [78]; Timperley et al., 2007[79]).

\subsubsection{Understanding professional learning as a coherent process}

As the OECD has argued previously, understanding professional learning as a series of disconnected activities such as individual courses, training sessions, group processes, ongoing training requirements and so on, will fail to systematically support improvement processes (Kools and Stoll, 2016 ${ }_{[80]}$ ). Improvement of practice must be contextualised in clear system-wide and school goals, and then schools must redefine themselves as learning organisations for all adults as well as children (Kools and Stoll, 2016 $\left.6_{[80]}\right)$. With the support of the OECD, Wales (United Kingdom) has undertaken a series of policy and practice reforms to promote one such framework for continuing school learning: Schools as Learning Organisations (see Box 4.6).

\section{Box 4.6. Developing schools as learning organisations in Wales (United Kingdom)}

The Welsh Government considers the development of its schools as learning organisations as vital for supporting its schools to put its new curriculum into practice. Wales' model of schools as learning organisation has been developed through a process of "co-construction" involving stakeholders from different levels of the education system.

The model focusses the efforts of school leaders, teachers, support staff, parents, (local) policy makers and all others involved into realising the seven dimensions of the model in its schools: i) developing a shared vision centred on the learning of all learners, ii) creating and supporting continuing learning opportunities for all staff, iii) promoting team learning and collaboration among all staff, iv) establishing a culture of enquiry, innovation and exploration, v) embedding systems for collecting and exchanging knowledge for learning, vi) Learning with and from the external environment and wider learning system and vii) modelling and growing learning leadership. These action-oriented dimensions and their underlying elements highlight both what a school should aspire to and the processes it goes through as it transforms itself into a learning organisation. 
The realisation of the "four purposes" of the new school curriculum is placed at the heart of the model. These refer to developing children and young people into "ambitious capable and lifelong learners, enterprising and creative, informed citizens and healthy and confident individuals".

Informed by the analysis of an OECD report, the Welsh Government and four regional consortia (i.e. school improvement services) are supporting their schools to develop as learning organisations. At the time of writing, an implementation plan that forms an integrated part of larger curriculum reform effort was being finalised. Several activities had been undertaken already, were planned or ongoing as part of this plan. These include the integration of the model into leadership development programmes (autumn 2018); an online self-assessment survey that can be freely used by school staff (May 2019); the ongoing development of a school self-evaluation and development planning toolkit in which the model is likely to be integrated (started in May 2018); and ongoing efforts by the Welsh Government Education Directorate and several middle-tier organisations to develop themselves into learning organisations.

Source: OECD (2018), Developing Schools as Learning Organisations in Wales, OECD Publishing, Paris, https://doi.org/10.1787/9789264307193-en.

Various other frameworks exist in which to situate adult learning activities in schools, though many contain similar themes. This section addresses those areas that were of highest relevance to the OECD review and participating countries: i) continuing learning opportunities, ii) team learning and collaboration, iii) systems for benefiting from internal and external knowledge development and iv) evaluation and appraisal.

Effective adult learning activities may support teachers in meeting evolving needs, such as inclusion, the use of new technologies, cross-curricular teaching and individualised learning. As Figure 4.4 reveals, it is such areas where staff express particular needs for professional learning, namely teaching students with special educational needs and integrating new technologies.

Mechanisms to monitor teachers' engagement in professional learning are not widespread. As a result, there was little systematic knowledge about levels of teachers' competency development and potential competency gaps in OECD review countries. 
Figure 4.4. Teachers' needs for professional development (ISCED 2), 2018

Percentage of teachers reporting a high level of need for professional development in the following areas (OECD average-31)

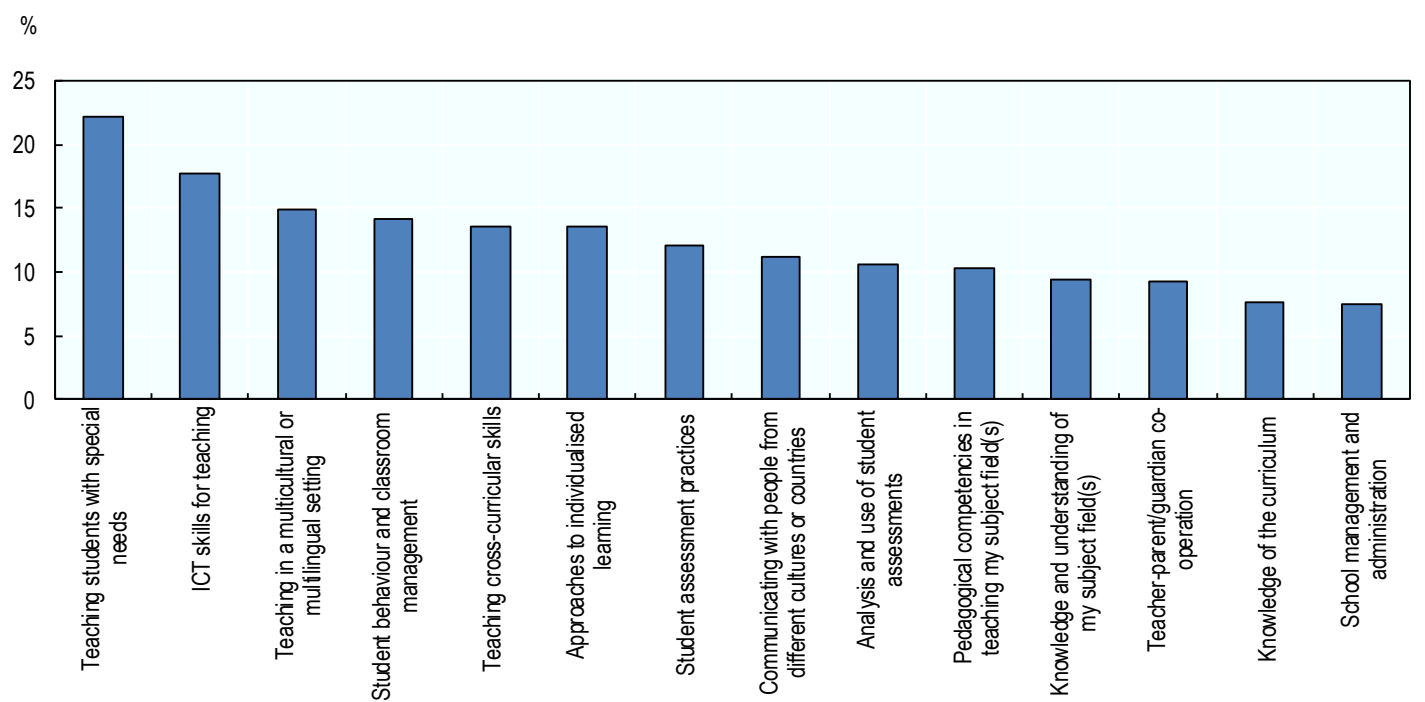

Notes: Values are ranked in descending order of the percentage of teachers who reported a high level of need for professional development in the above topics. Students with special needs are those for whom a special learning need has been formally identified because they are mentally, physically, or emotionally disadvantaged. ICT refers to Information and communication technology. The number of countries or economies included in the OECD average is indicated next to that average. On 25 May 2018, the OECD Council invited Colombia to become a Member. While Colombia is included in the OECD average reported in this figure, at the time of its preparation, Colombia was in the process of completing its domestic procedures for ratification and the deposit of Colombia's instrument of accession to the OECD Convention was pending.

Source: OECD (2019), TALIS 2018 Results (Volume I): Teachers and School Leaders as Lifelong Learners, OECD Publishing, Paris, https://doi.org/10.1787/1d0bc92a-en, Table I.5.21.

StatLink ज्ञाज https://doi.org/10.1787/888934026639

\subsubsection{Continuing learning opportunities}

\section{Access and motivation}

The experience of the OECD review suggests that relatively few requirements exist with respect to teachers' professional development. As Table 4.3 shows, in slightly more than half of OECD reviews countries are there requirements for teachers to pursue professional development (also see Table A.5. in Annex A). In a number of countries, still, there are dedicated financial incentives to complete professional development (also see Chapter 2).

Some systems provide incentives for teachers to develop their knowledge and competencies by completing postgraduate studies. In the French Community of Belgium and Colombia, teachers may move up in their salary scales by completing postgraduate qualifications, while teachers in Lithuania have a statutory right to sabbatical leave up to one year every eight-year period (although social security is not covered during this time). While not linked to salary progression, teachers in Uruguay can take postgraduate degrees depending on their career stage at the country's Institute for Advanced and Higher Studies (Instituto de Perfeccionamiento y Estudios Superiores, IPES), the main provider of teacher professional development and continuing education in the country. 
Table 4.3. Requirements and incentives for participation in professional development (ISCED 1-3), 2018

OECD review countries, public schools

\begin{tabular}{|c|c|c|c|c|c|c|c|c|c|c|c|c|c|c|c|c|c|c|c|}
\hline \multicolumn{20}{|c|}{ Requirement } \\
\hline \multicolumn{20}{|c|}{ Entitlement } \\
\hline \multicolumn{20}{|c|}{ Financial incentive } \\
\hline Country & $\frac{\text { 焉 }}{\frac{0}{2}}$ & 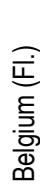 & 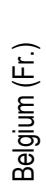 & $\frac{\mathscr{0}}{\frac{\bar{C}}{U}}$ & $\begin{array}{l}\frac{\pi}{0} \\
\frac{\mathrm{E}}{\bar{\delta}} \\
\text { 응 }\end{array}$ & 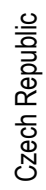 & 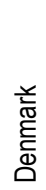 & 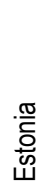 & $\begin{array}{l}\text { E } \\
\text { O } \\
\frac{\pi}{0} \\
\underline{0}\end{array}$ & 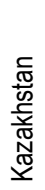 & 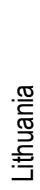 & $\frac{\stackrel{O}{x}}{\frac{0}{x}}$ & 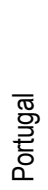 & 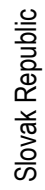 & $\begin{array}{l}\frac{\sigma}{\bar{\omega}} \\
\frac{\partial}{\omega} \\
\frac{0}{\omega}\end{array}$ & $\begin{array}{l}\frac{1}{\bar{\pi}} \\
\text { ஸे }\end{array}$ & 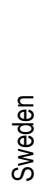 & 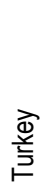 & $\begin{array}{l}\text { 히 } \\
\text { 홀 }\end{array}$ \\
\hline
\end{tabular}

Notes: Financial incentives comprise direct links between professional development and compensation or career progression. Requirements refers to regulations that stipulate that teachers need to take part in professional development and possibly the specific minimum duration. Entitlement refers to time or financial support to participate in professional development. Links to compensation or career advancement refer to requirements for completion of professional development to advance in the salary scale and/or career ladder; and salary allowances or bonuses for completion of professional development.

1. Iceland: ISCED 3 only.

For full comparative tables, see Table A.5. in Annex A.

Sources: Based on Country Background Reports and Country Review Reports (http://www.oecd.org/education/school-resources-review/schoolresourcesreview-

reportsforparticipatingcountries.htm), and Eurydice descriptions of national education systems (https://eacea.ec.europa.eu/national-policies/eurydice/national-description en).

Formal requirements and financial incentives are, however, not always effective, as a mandate of a set of hours or salary supplements tied to the completion of professional development can quickly become a bureaucratic checklist to complete, rather than an opportunity for true skill and capacity development. As analysis of data from the TALIS 2018 suggests, teachers' intrinsic motivation should be taken into account when prompting participation in professional development. On average across the OECD, after controlling for teachers' characteristics, teachers who were motivated to join the profession by the social contribution that teaching represents (as measured by a social utility index) tend to participate in more professional development activities (OECD, 2019, p. 156 [4] ).

Irrespective of the requirements and incentives in place for teachers, time constraints and limited financial support may present barriers when it comes to accessing continuing learning opportunities. For the TALIS 2018, conflicts with work schedules (54\%), financial cost $(45 \%)$ and a lack of time because of family responsibilities $(37 \%)$ featured among obstacles commonly cited by teachers (OECD, 2019, pp. 177, Table I.5.36[4] ).

Among OECD review countries, particularly high shares of lower secondary teachers reported cost as a barrier to participation in professional development in Chile $(77 \%)$, Colombia (77\%) and Portugal (66\%). Interestingly, in all three countries support for participation in the form of reimbursements or payment of costs was also relatively low, as reported by teachers (from $18 \%$ in Chile to $10 \%$ in Colombia and $6 \%$ in Portugal) (OECD, 2019, pp. 209, Table I.5.44 $[4])$. 
This brings attention to the supports that are available to schools and teachers in terms of time and funding. As Table 4.3 again illustrates, a number of OECD review countries provide time and leave entitlements for professional learning and development (sometimes as part of collective bargaining agreements), ranging from six half-days per year (in addition to a mandatory six half-days) for secondary school teachers in the French Community of Belgium to 104 hours per year in Sweden (also see Table A.5. in Annex A). While comparative and systematic knowledge is lacking, some schools may experience challenges in securing substitute teachers to permit teachers to leave their classrooms. In Denmark, for example, stakeholders in schools and municipalities raised concerns during the review visit that they lack support for the release of teachers in order for them to participate in learning opportunities (Nusche et al., 2016 $[30]$ ).

This is why leave entitlements may be tied to specific requirements how this time may be taken or why specific arrangements are in place for the school calendar. In the French Community of Belgium, for instance, teachers are both required and entitled to a number of half-days of professional development and schools can suspend courses up to six times per year for a half day in order that teachers may pursue their additional training. Outside of these half-days, teachers pursuing additional training must be replaced by other teachers in the school, student teachers or substitute teachers (within a budget determined by the education authorities of the Community) (Ministère de la Fédération Wallonie-Bruxelles, $\left.2016_{[70]}\right)$. In Portugal, teachers are allowed to take no more than five consecutive days out of their eight days of entitled training (Liebowitz et al., 2018 ${ }_{[19]}$ ), while in Austria, teachers must undertake their required hours of professional development in the lesson-free time (Nusche et al., 2016[22] $)$. In Colombia, the school calendar and teachers' working time arrangements include a dedicated number of five weeks for institutional development during which teachers may participate in continuing learning (Radinger et al., 2018 ${ }_{[16]}$ ).

In the large majority of OECD countries, however, substantial time in teachers' schedules exists outside of mandatory teaching hours (also see Chapter 2). As Figure 4.5 shows, in only five of 24 school systems with available data do teachers spend more than $50 \%$ of their total statutory working time teaching. While teachers schedules are clearly taxed with many responsibilities outside of time spent teaching in front of students, ample room exists to restructure grading, administrative and other requirements to provide additional release time opportunities to pursue professional learning. This depends on the range of responsibilities expected of teachers in a particular context.

Funding arrangements for covering the costs of participation can also be an issue. For example, in the Slovak Republic, funding for professional development is included in the block grant for salary costs (1.5\% of the school's allocated amount for salaries). As the OECD review found, teachers reported difficulty in accessing professional development due to a lack of financial support from the school budget (OECD, 2017[81]). 
Figure 4.5. Teachers' working time spent teaching (ISCED 2), 2017

Net teaching time (typical annual number of hours) as a percentage of total statutory working time in general programmes in public institutions

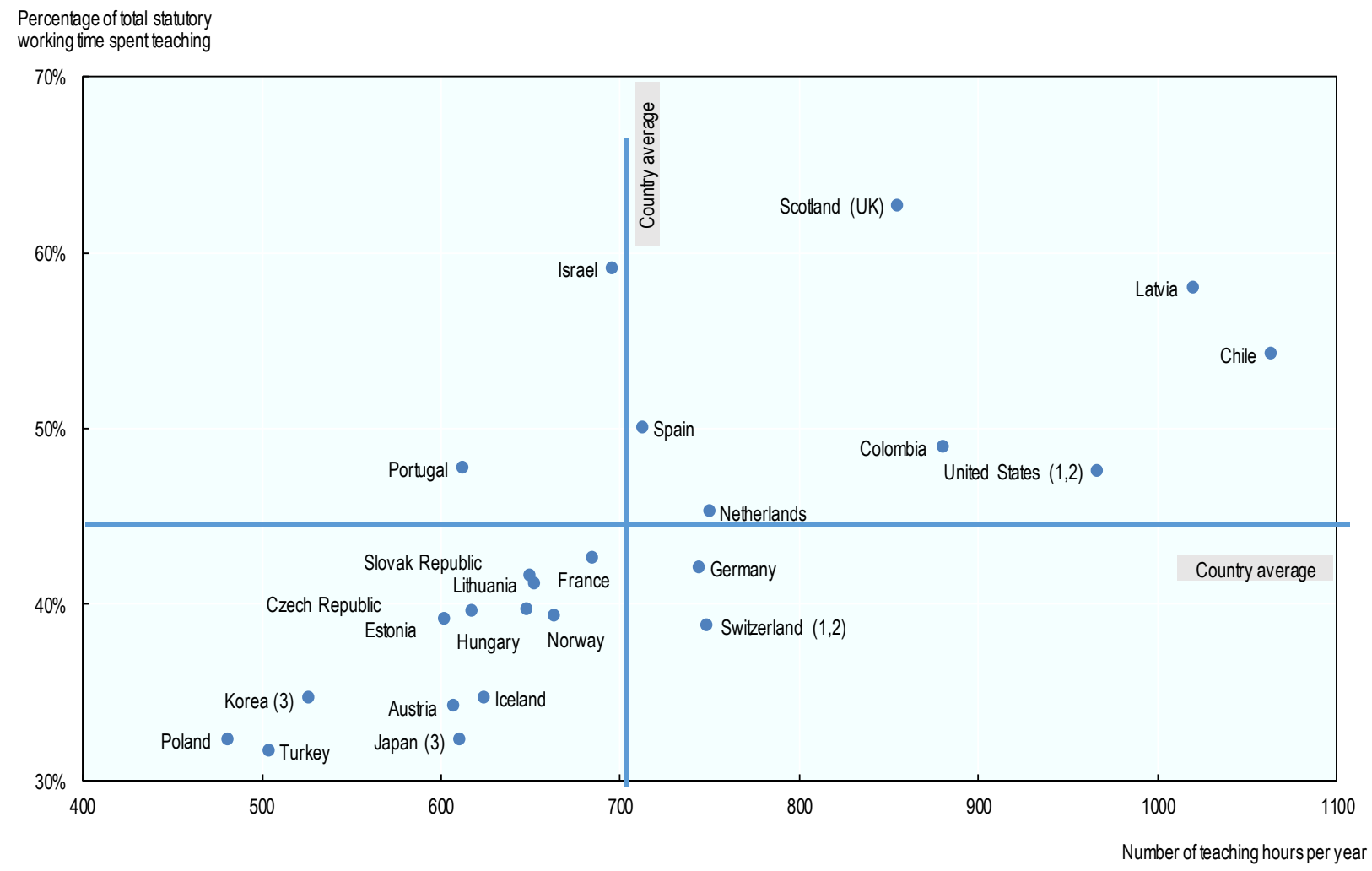

Note: On 25 May 2018, the OECD Council invited Colombia to become a Member. While Colombia is included in the OECD average reported in this figure, at the time of its preparation, Colombia was in the process of completing its domestic procedures for ratification and the deposit of Colombia's instrument of accession to the OECD Convention was pending.

1. Actual teaching time.

2. Reference year differs from 2018.

3. Average planned teaching time in each school at the beginning of the school year.

Source: OECD (2019), Education at a Glance 2019: OECD Indicators, OECD Publishing, Paris, https://doi.org/10.1787/f8d7880d-en, Figure D4.4., Tables D4.1a and D4.1b.

StatLink 제s https://doi.org/10.1787/888934026658

While requirements, incentives, barriers and supports shape how individual teachers have access to and participate in professional development in a country, lower secondary teachers report high levels of participation in some kind of professional development across OECD countries for TALIS 2018 (see Figure 4.6). With some exceptions, there are also no significant differences in participation across school types, locations or socio-demographic composition. ${ }^{7}$ However, when asked whether any of the professional learning activities they had taken part in had an impact on their teaching practices, $18 \%$ of teachers on average across OECD countries felt this was not the case. In Belgium, Denmark, France, Sweden and Turkey, less than $75 \%$ of teachers felt their professional development had a positive impact on their practice (again see Figure 4.6) (OECD, 2019, pp. 155, 156, 160, Tables I.5.1, I.5.2 and I.5.15 $5_{[4]}$ ). Issues related to the effectiveness of professional development are discussed in the next section. 


\section{Figure 4.6. Participation in professional development activities (ISCED 2), 2018}

Percentage of teachers who reported the following

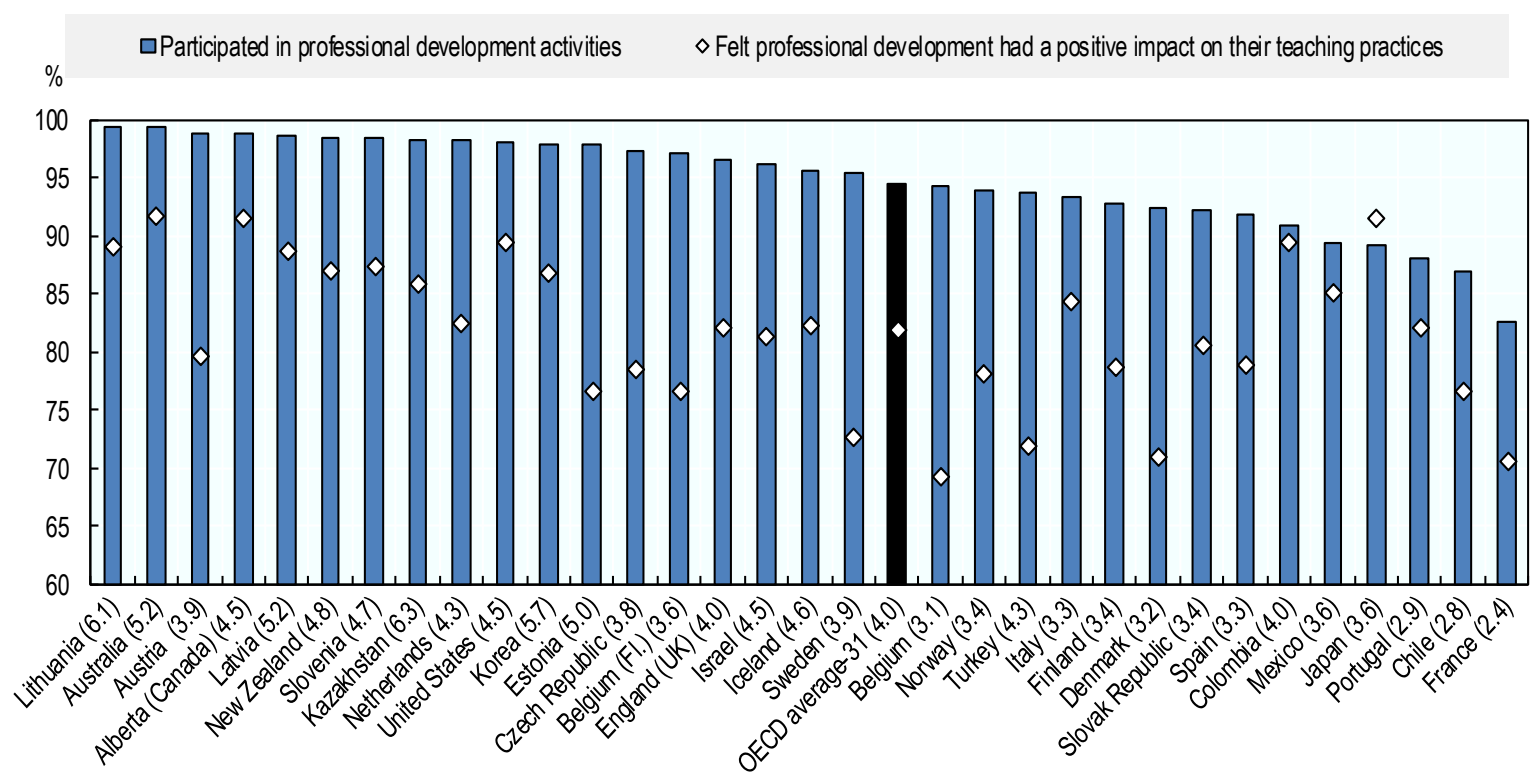

Notes: Refers to professional development activities in which teachers participated in the 12 months prior to the survey. The average number of different professional development activities teachers participated in is included in brackets with country names. Countries and economies are ranked in descending order of the percentage of teachers who participated in professional development activities in the 12 months prior to the survey. The number of countries or economies included in the OECD average is indicated next to that average. On 25 May 2018, the OECD Council invited Colombia to become a Member. While Colombia is included in the OECD average reported in this figure, at the time of its preparation, Colombia was in the process of completing its domestic procedures for ratification and the deposit of Colombia's instrument of accession to the OECD Convention was pending.

Source: OECD (2019), TALIS 2018 Results (Volume I): Teachers and School Leaders as Lifelong Learners, OECD Publishing, Paris, https://doi.org/10.1787/1d0bc92a-en, Tables I.5.1, I.5.7 and I.5.15.

StatLink : (iाls https://doi.org/10.1787/888934026677

\section{Provision, content and quality assurance}

Professional learning can be conceptualised more broadly not only as a vehicle for "personal and professional accomplishment", but also as "a life-long stance and long-term collective project with a democratic agenda" (Cochran-Smith and Lytle, 2001 [82]). Typically, however, it is more narrowly conceptualised as an avenue for changing teachers' beliefs and attitudes, teachers' practices, and student learning outcomes (Guskey, 1986 [83]).

Research based on the TALIS and PISA suggests that professional development activities not only provide teachers with necessary skills, but also improve their sense of self-efficacy and job satisfaction (OECD, 2019 ${ }_{[4]}$; Mostafa and Pál, 2018 $\left.8_{[84]}\right)$. Many have, however, expressed concerns about the effectiveness of traditional professional development, in the form of one-time or short-series of externally provided courses. Impact evaluations from the United States frequently find that professional development fails to improve teaching quality or student outcomes (Garet et al., 2016 [85]; Harris and Sass, 2011 [86]; Glazerman et al., 2010[66]; Garet et al., 2008 [87]; Jacob and Lefgren, 2004 $[88]$ ). 
Some non-causal evidence indicates important features that are suggestive of more effective traditional professional development. These include embedding learning in the already ongoing work of schools, continuing learning over an extended period, and a focus on a concrete set of teaching skills (Opfer, 2016 $[89]$; Desimone and Garet, 2015 ${ }_{[90]}$; Hill, 2007[91]; Garet et al., 2001 [74]). Yet, recent syntheses and reviews of studies estimating the extent to which these features produce improved instruction and student outcomes find decidedly mixed effects (Kennedy, 2016 ${ }_{[92]}$; Scher and O'Reilly, 2009 [93] $)$.

Several OECD review countries have attempted to integrate such "best practices" into the delivery of professional development. In Portugal, for instance, a network of School Association Training Centres (Centros de Formação de Associação de Escolas, CFAE) has been created to learn about schools' pedagogical and curricular needs, and deliver locally provided training courses corresponding to school and teacher needs (Liebowitz et al., $2018_{[19]) \text {. }}$

Given concerns that traditional professional development tends to be disconnected from the immediate needs of teachers in schools, Colombia launched a scholarship programme for teachers to pursue further study, but to link this to their local context. The Scholarships for Teaching Excellence programme (Becas para la Excelencia Docente) encourages teachers to work in their school and develop and implement a school improvement project centred on classroom practice (Figueroa. M. et al., 2018 [94]; Radinger et al., 2018 $8_{[16]}$ ).

Table 4.4 provides an overview of the types of external providers that may offer professional development activities, ranging from public education authorities to teacher education institutions and other tertiary education institutions, professional organisations and private and non-governmental providers. In some OECD review countries, central teacher development institutions play an important role in steering provision, maintaining oversight and ensuring quality. In the French Community of Belgium, professional development is co-ordinated by the Institute for In-Service Training (Institut de la Formation en cours de Carrière, IFC) (Ministère de la Fédération Wallonie-Bruxelles, 2016 $\left.{ }_{[70]}\right)$, while in Chile, a similar institution, the Centre for Pedagogical Training, Experimentation and Research (Centro de Perfeccionamiento, Experimentación $e$ Investigaciones Pedagógicas, CPEIP) is responsible for co-ordinating and accrediting supply, defining priority areas, and supplying key offerings across the country (Centro de Estudios MINEDUC, 2016[95]). 


\section{Table 4.4. Professional development providers, 2018}

OECD review countries, public schools

\begin{tabular}{|c|c|}
\hline Country & Training providers \\
\hline Austria & $\begin{array}{l}\text { Courses primarily offered by university colleges of teacher education (Pädagogische Hochschulen, PHs), organised } \\
\text { in-house or for various schools. }\end{array}$ \\
\hline Belgium (FI.) & $\begin{array}{l}\text { A range of different institutions including universities, university colleges, pedagogical guidance services of school } \\
\text { networks, private companies and the Ministry of Education and Training. }\end{array}$ \\
\hline Belgium (Fr.) & $\begin{array}{l}\text { A range of training operators (Hautes écoles, universities, teachers' associations, continuing education agencies, etc.), } \\
\text { co-ordinated by the Institute for In-Service Training (Institut de la Formation en cours de Carrière, IFC). }\end{array}$ \\
\hline Chile & $\begin{array}{l}\text { Range of providers (e.g. labour associations, education consulting companies and municipal training centres), } \\
\text { co-ordinated and accredited by the Centro de Perfeccionamiento, Experimentación e Investigaciones Pedagógicas } \\
\text { (CPEIP) and listed in the National Public Training Registry (Registro Público Nacional de Perfeccionamiento, RPNP). }\end{array}$ \\
\hline Colombia & $\begin{array}{l}\text { Regional and local education authorities certified to provide education (certified territorial entities) establish a territorial } \\
\text { teacher education committee (Comité Territorial de Formación de Docentes, CTFD) and develop a Territorial Training Plan } \\
\text { for Teachers and School Leaders (Plan Territorial de Formación para Docentes y Directivos docentes, PTFD). }\end{array}$ \\
\hline Czech Republic & $\begin{array}{l}\text { A range of accredited public and private training providers, including the National Institute for Further Education } \\
\text { (Národniho institutu pro další vzděláván, NIDV) and its } 14 \text { regional centres, and institutions for further education of } \\
\text { teachers founded by the regions. }\end{array}$ \\
\hline Denmark & $\begin{array}{l}\text { Danish School of Education, university colleges and municipalities (ISCED 1-2); Institute of Philosophy, Education and } \\
\text { Study of Religions at the University of Southern Denmark (ISCED } 3 \text { general); National Centre for Vocational Education } \\
\text { (ISCED } 3 \text { vocational); also specialised training institutions, teachers' associations and the Ministry for Education. }\end{array}$ \\
\hline Estonia & $\begin{array}{l}\text { A range of different institutions including higher education institutions, teacher education institutions, individual schools, } \\
\text { teachers' professional organisations, municipalities and private companies. }\end{array}$ \\
\hline Iceland & Teacher education institutions. \\
\hline Kazakhstan & $\begin{array}{l}\text { Regional branches of the National Center of Professional Development "Orleu"; "Higher-level" training programmes led by } \\
\text { the Center of Teaching Excellence at Nazarbayev Intellectual Schools in partnership with international partners. }\end{array}$ \\
\hline Lithuania & $\begin{array}{l}\text { National and local Education Development Centres (Ugdymo plètotés centras), methodological centres at schools, } \\
\text { municipal teacher education centres, professional development providers at higher education institutions, other institutions } \\
\text { (e.g. non-governmental organisations). }\end{array}$ \\
\hline Mexico & Agreements between the ministry of education and higher education institutions. \\
\hline Portugal & $\begin{array}{l}\text { Higher education institutions; School Association Training Centres (Centros de Formação de Associação de Escolas, } \\
\text { CFAE); Municipal and inter-municipal run initiatives; Not-for-profit professional or scientific association training centres; } \\
\text { Ministry of Education central services. }\end{array}$ \\
\hline Slovak Republic & $\begin{array}{l}\text { A range of different institutions including higher education institutions and educational organisations of the Ministry of } \\
\text { Education (the National Institute of Education, the Methodology and Pedagogy Centre and the National Institute of } \\
\text { Vocational Education). }\end{array}$ \\
\hline Slovenia & $\begin{array}{l}\text { Higher education institutions, public institutes, who are providers of different continuing professional development } \\
\text { programmes, private providers. }\end{array}$ \\
\hline Spain & $\begin{array}{l}\text { National Institute of Educational Technologies and Teacher Training (Instituto Nacional de Tecnologías Educativas y de } \\
\text { Formación del Profesorado, INTEF), Teachers and Resources Centres (linked to specific schools in Autonomous } \\
\text { Communities), higher education institutions, professional associations, trade unions. }\end{array}$ \\
\hline Sweden & $\begin{array}{l}\text { Primarily higher education institutions and regional development centres, also government authorities, the Swedish } \\
\text { National Agency for Education (Skoleverket), teachers' trade unions, independent educational companies and civil society } \\
\text { organisations. }\end{array}$ \\
\hline Turkey & A range of different institutions including universities, foundations, unions and private companies. \\
\hline Uruguay & $\begin{array}{l}\text { A number of different institutions including higher education institutions such as the Universidad de la República } \\
\text { (UDELAR) and private universities (Universidad ORT, Universidad de Montevideo and Universidad Católica); and the } \\
\text { Institute for Advanced and Higher Studies (Instituto de Perfeccionamiento y Estudios Superiores, IPES), Regional Units of } \\
\text { Continuous Education (Unidades Regionales de Educación Permanente, UREP) (ISCED 2-3 vocational). }\end{array}$ \\
\hline
\end{tabular}

Note: For full comparative tables on teacher professional learning, see Table A.5. in Annex A.

Source: Based on Country Background Reports and Country Review Reports

(http://www.oecd.org/education/school-resources-review/schoolresourcesreview-

reportsforparticipatingcountries.htm), and Eurydice descriptions of national education systems

(https://eacea.ec.europa.eu/national-policies/eurydice/national-description_en). 
For the TALIS 2018, more than one in three lower secondary teachers $(38 \%)$, on average across OECD countries, cited a lack of a relevant professional development offer as a barrier to participation (OECD, 2019, pp. 209, Table I.5.36[4] ). In various OECD review countries, there was uncertainty about the quality of provision and the related quality assurance processes. In the Czech Republic, for instance, an open market for external training providers allows for schools to select from a competitive range of training courses, but there appeared to be few mechanisms to monitor if teacher learning needs were being met (Shewbridge et al., 2016 $6_{[96]}$ ).

In other systems, there were concerns about the planning of teachers' participation in professional development. In Denmark, professional development seemed to be at times planned school-wide for all teachers to participate in without differentiating based on teachers' needs and ownership for their learning. Other times, it was more an individual teacher's choice than a sound assessment of a teacher's development need to better meet the needs of their students (Nusche et al., 2016 $[30]$ ). Planning of teachers' professional learning may also be influenced by priorities that are set by education authorities (e.g. through education strategies, dedicated funding or targeted programmes).

Figure 4.7 shows the types of activities which teachers participated in, on average across OECD countries, as reported for TALIS 2018, highlighting the role of courses, seminars, conferences and self-study in professional learning (OECD, 2019 $\left.{ }_{[4]}\right)$.

Figure 4.7. Type of professional development attended by teachers (ISCED 2), 2018

Percentage of teachers participating in the following professional development activities (OECD average-31)

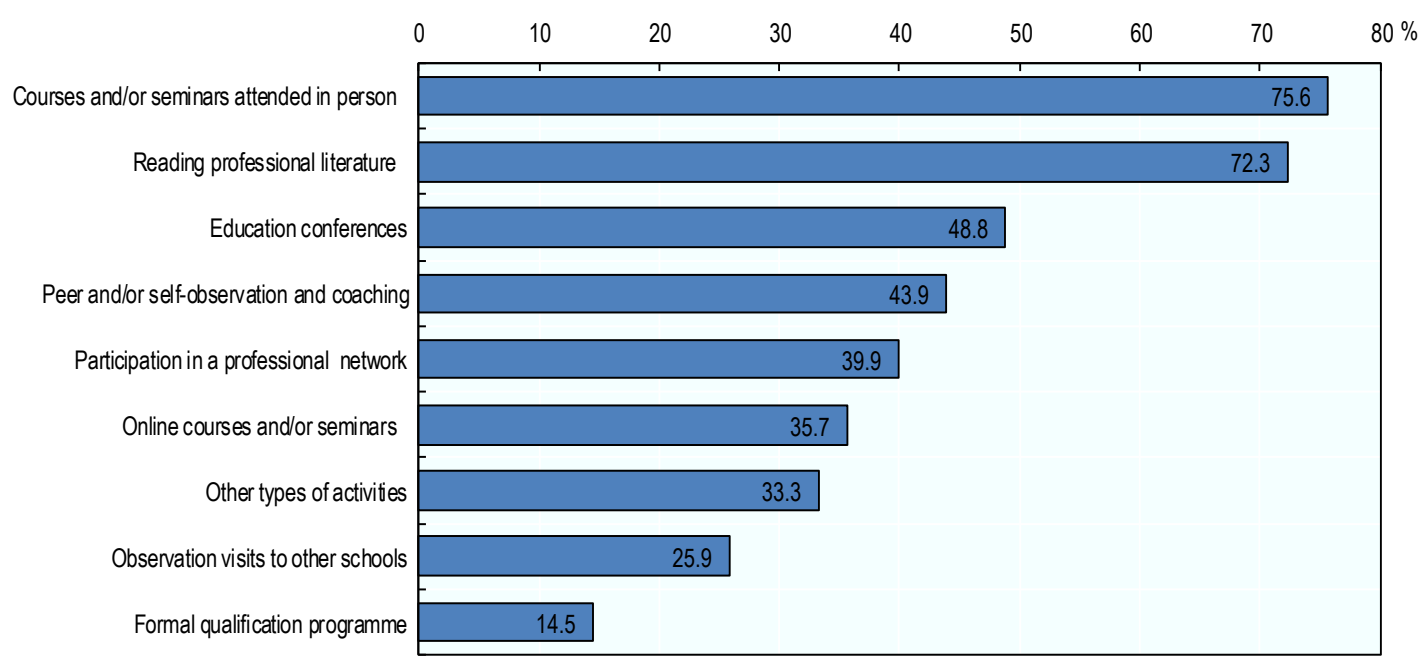

Notes: Refers to professional development activities in which teachers participated in the 12 months prior to the survey. Values are ranked in descending order of the percentage of teachers who participated in the above professional development activities. The number of countries or economies included in the OECD average is indicated next to that average. On 25 May 2018, the OECD Council invited Colombia to become a Member. While Colombia is included in the OECD average reported in this figure, at the time of its preparation, Colombia was in the process of completing its domestic procedures for ratification and the deposit of Colombia's instrument of accession to the OECD Convention was pending.

Source: OECD (2019), TALIS 2018 Results (Volume I): Teachers and School Leaders as Lifelong Learners, OECD Publishing, Paris, https://doi.org/10.1787/1d0bc92a-en, Table I.5.7. 
Certainly, such formal professional development activities, in the form of university-affiliated courses, centrally or locally provided trainings or online activities are only one component in a coherent professional learning plan. Given that the majority of skills required of teachers are not easily transmitted in a set number of days or frequencies of trainings, practical and regular coaching and mentoring opportunities hold particular promise for promoting reflection and improvement among teachers. Research shows professional learning should make a specific connection to an individual teachers' practice or to a problem within the school (Timperley et al., $2007_{[79]}$ ). Teachers will not improve by understanding theory and evidence alone, but through numerous activities such as observation, demonstration, practice, and feedback (Joyce and Showers, 2002 [97]).

Assigning individualised, structured instructional coaching to teachers, either with designated positions (Kraft and Blazar, 2016 [59]; Blazar and Kraft, 2015 [98]) or matching effective teachers with less effective ones (Papay et al., 2016 $6_{[99]}$ ), has shown promise in improving students' learning. A recent meta-analysis of 62 studies employing causal designs to estimate the effects of coaching on teachers' instructional practice and student outcomes documents improvement on the order of 0.49 standard deviations on instruction and 0.18 standard deviations on achievement (Kraft, Blazar and Hogan, 2018 [63]).

However, critically important to policy makers, this same meta-analysis found the benefits of coaching were substantially reduced in larger coaching programmes serving over 100 teachers at a time. The authors note several explanations for this variation across coaching programme size. Of most relevance here is the challenge in identifying high-quality coaches for large numbers of teachers. This challenge is only amplified at the leadership level since far fewer experienced school leaders exist.

This might imply that systems interested in taking greater advantage of coaching strategies might benefit from additional resources to promote systemic quality as the quality of the coaching seems particularly salient to its effectiveness. Box 4.7 highlights a promising coaching initiative from Colombia.

\section{Box 4.7. Large-scale teacher coaching in Colombia: Programa Todos a Aprender}

Let's All Learn (Programa Todos a Aprender, PTA) is a large-scale programme initiated by the education ministry in 2011 and implemented since 2012. The project has been funded through the ministry's budget for investment programmes and received almost half of the budget of the ministry's quality directorate for school and pre-school education in 2017, about COP 130 billion (Colombian pesos). The programme originally targeted basic primary education (Grades 0 to 5) and has pursued a multi-dimensional approach to improve student learning in language and mathematics. This has included pedagogical components related to the curriculum and educational materials, situated professional learning, school management and community involvement.

The programme's main objective has been to build teachers' skills and competencies, and to improve their practices in the classroom through coaching and mentoring provided by tutors that are selected from across the country and prepared for and supported in their role. Tutors provide situated professional development to teachers within participating schools. They work directly as peers with individual teachers in the classroom, observe teachers' practices and provide feedback on pedagogical and didactic strategies. They work with groups of teachers and organise peer learning activities and discussions around pedagogical topics within schools. Tutors are also expected to support other activities and pedagogical processes and provide support for the development and implementation of student assessments, the use of curricular guidelines, the selection and use of materials and textbooks, and the development 
of the Dia E, a day in the school calendar to discuss school development within the school, for example.

By 2017, the programme had employed 97 trainers and trained 4100 tutors. Tutors had worked with 109357 teachers in 13455 sites of 4476 public schools (which are organised as clusters) in 885 municipalities in all of the country's 32 departments. Between 2012 and 2017 , the participation of public schools in the programme had grown by $88 \%$ and the number of participating teachers had more than doubled. The programme prioritises schools with low achievements as measured by the standardised student assessments for Grades 3 and 5 (Pruebas Saber 3 and 5). Schools achieving their improvement objective in the standardised assessments end their participation in the programme, thus making resources available for support to other schools. While the programme was not designed as a strategy targeting rural schools, it has had a particular impact on schools in rural and remote areas. Recently, the programme was extended to the first two years of basic secondary education (Grades 6 and 7).

Source: Radinger, T., A. Echazarra, G. Guerrero, J. P. Valenzuela (2018), OECD Reviews of School Resources: Colombia 2018, OECD Publishing, Paris, https://doi.org/10.1787/9789264303751-en.

\subsubsection{Team learning and collaboration}

The most powerful form of professional learning occurs when it is integrated in everyday work and involves collecting, evaluating and acting on feedback to modify teaching practice. Individuals often need to see evidence of impact before changing practice. Collaborative learning communities that entail active and shared discussions can provide safe environments for teachers to challenge tacit assumptions on what works and why (Timperley et al., 2007 $[79]$ ). Opportunities for collaborative learning, then, have the potential to set teachers on a course of continuous improvement of their teaching practice related to the needs of the students in their class and school (Ronfeldt et al., 2015 [100]). As an analysis of data from the PISA 2015 moreover suggests, teacher collaboration is positively and significantly associated with teacher satisfaction (Mostafa and Pál, $\left.2018_{[84]}\right) .^{8}$

Collaboration and peer learning also seem to be important for making the most of other types of staff, such as learning support specialists (Masdeu Navarro, 2015 $5_{[101]}$ ). Where professional pedagogical, health or social support staff work in or with schools, they can support professional learning within the school drawing on specific areas of expertise. School librarians, for example, can support teachers in the development of media and literacy skills (Lance and Kachel, 2018 ${ }_{[102]}$ ) while social workers can support teachers struggling with student behavioural issues (Finigan-Carr and Shaia, 2018 ${ }_{[15]}$ ).

To provide two examples from the OECD review, in Denmark, specialist teachers with a focus on student behaviour, psychology and well-being (Adford-Kontakt-Trivsel, AKT) also initiate training in schools related to the development of social skills and inclusive communities, or general health education with a focus on social well-being and the prevention of bullying and violence at school (Nusche et al., 2016 ${ }_{[30]}$ ). In Uruguay, a policy to promote digital inclusion and greater and easier access to education and culture through the use of information and communication technology (ICT) (Plan Ceibal) entailed the creation of support teacher roles (Ceibal teachers). These specialised teachers give advice and help teachers to use laptops in their teaching in the best possible way (Santiago et al., $2016_{[20])}$. 
As data from the TALIS, however, suggest, peer learning and collaboration among teachers is still not yet commonplace. For TALIS 2013, large proportions of teachers reported never receiving feedback from either assigned mentors $(81 \%$ on average across participating countries) or other teachers $\left(58 \%\right.$ on average) $\left(\right.$ OECD, 2014 $\left.4_{[42]}\right)$. Similarly, for TALIS 2018, a considerable share of teachers reported not having participated in formal peer and/or self-observation and coaching $(56 \%)$ or a network for professional development (60\%) (see Figure 4.7) (OECD, 2019[4]).

In fact, as Table 4.5 demonstrates for OECD review countries, there is minimal systematic support for opportunities for teacher collaboration on teams or to provide each other regular feedback systems (also see Table A.5. in Annex A). In the French Community of Belgium and in Chile, a requirement exists for schools to develop strategies for collaborative work as part of their school development plans. Austria and Uruguay provide additional staff resources and time for team teaching, while the weekly working time for teachers in Portugal includes dedicated time for collaboration, and the school calendar in Colombia includes five weeks' time for institutional development.

Table 4.5. Teamwork among teachers within schools (ISCED 1-3), 2018

OECD review countries, public schools

\begin{tabular}{|c|c|c|c|c|}
\hline Country & Requirement & Policy or programme & Dedicated resources & Structures or roles \\
\hline Austria & & & $\checkmark$ & $\checkmark$ \\
\hline \multicolumn{5}{|l|}{ Belgium (FI.) } \\
\hline Belgium (Fr.) & $\checkmark$ & & & \\
\hline Chile & $\checkmark$ & $\checkmark$ & & $\checkmark$ \\
\hline Colombia & & $\checkmark$ & $\checkmark$ & $\checkmark$ \\
\hline Czech Republic & & & & $\checkmark$ \\
\hline \multicolumn{5}{|l|}{ Denmark } \\
\hline Estonia & & & & $\checkmark$ \\
\hline \multicolumn{5}{|l|}{ Iceland } \\
\hline Kazakhstan & & & & $\checkmark$ \\
\hline Lithuania & & $\checkmark$ & & \\
\hline Mexico & & & & $\checkmark$ \\
\hline Portugal & & & $\checkmark$ & $\checkmark$ \\
\hline Slovak Republic & & & & $\checkmark$ \\
\hline Slovenia & & & & $\checkmark$ \\
\hline Spain & & $\checkmark$ & & $\checkmark$ \\
\hline Sweden & & $\checkmark$ & & \\
\hline Turkey & & & & $\checkmark$ \\
\hline Uruguay & & & $\checkmark$ & $\checkmark$ \\
\hline
\end{tabular}

Notes: For full comparative tables on teacher professional learning, see Table A.5. in Annex A.

Teamwork among teachers within schools refers to requirements for teachers to work together in teams (e.g. to provide feedback to peers) as well as allocated resources (e.g. structures, scheduled time, programmes) allowing teachers to work together on curricular, pedagogical, cultural or administrative tasks. Requirement refers to regulations for schools to define strategies for teamwork, for example. Dedicated resources include staff resources or time in the school year for collaboration, for example. Structures or roles refer to school-level teacher subject boards and the organisation of schools in clusters, for example.

Source: Based on Country Background Reports and Country Review Reports (http://www.oecd.org/education/school-resources-review/schoolresourcesreviewreportsforparticipatingcountries.htm). 
Most often, collaborative opportunities seem to emerge systematically through specific structures within schools, such as subject committees and teams in Kazakhstan, and in the Czech and Slovak Republics. In some systems, there are initiatives that seek to facilitate learning between teachers of different types of school (e.g. academic secondary schools and new middle schools in Austria; private and public schools in Colombia).

Despite widespread stated interest, systems of job-embedded professional learning that create opportunities for teachers to observe each other teach for the purpose of providing feedback on pedagogical practices are few. Some school systems, however, have developed large-scale approaches to facilitate effective collaboration within and between schools. Box 4.8 describes successful collaboration practices in Ontario (Canada), where the creation of resources and protocols, and technical support have been critical tools in the codification of such practices:

- The Chilean Ministry of Education has promoted a four-pronged set of strategies for collaboration. These include: scheduled professional learning community time, lesson studies, video study clubs and investigation actions (MINEDUC, 2019 [103]). Teams of teachers participate in various methodologies intended to respond to student learning and teacher practice needs. While these strategies are just at their inception, they are particularly notable for their systematisation of group improvement practices.

- The Teacher-led Innovation Fund (TLIF) in New Zealand is a Ministry of Education initiative that provides teachers with time in their schedules and expert support to examine and improve upon their teaching practices. Teachers apply for funds, form collaborative inquiry groups, receive internal and external expert support, adapt practices as appropriate and document knowledge learned. The programme was evaluated in 2017 through survey and focus groups interviews, though not through an assessment of its impact on student learning. Participants strongly endorsed the opportunity to work in teams and reported more opportunities for peer pedagogical feedback; however, lower impacts were evident in shifts in teachers' practices or the quality of feedback they received (Sinnema, Alansari and Turner, 2018 $[104]$ ).

- In Sweden, the National Agency for Education (Skoleverket) promotes teacher collaboration by solving problems and critically scrutinising others' work so that methods, assessment and grading are improved through the creation of systems. This form of professional learning has its roots in learning studies and lesson studies, practices pioneered in Japan in which teams of teachers work collaboratively to develop a lesson, teach it in turn, providing each other feedback over time with the goal of continuous improvement of the lesson (Swedish Ministry of Education and Research, 2016 $[105])$.

What is key in promoting collaborative work between teachers in schools is to invest in more than only creating time in teachers' schedules (which is an important precondition). This distinction between creating time in teachers schedules to meet and developing practices to promote collaboration was highlighted in the OECD review of the Czech Republic and Portugal (Liebowitz et al., 2018 ${ }_{[19]}$; Shewbridge et al., 2016 ${ }_{[96]}$ ). To make teams effective, it is crucial to support collaborative working cultures with evidence-based structures (Hargreaves and O'Connor, 2018 $\left.{ }_{[106]}\right)$. Done well, with dedicated and shared time in teachers' schedules, teacher leadership, protocols and attention to culture, this can increase teachers' job satisfaction and students' growth (Charner-Laird et al., 2017 ${ }_{[107]}$; Kraft and Papay, 2014 ${ }_{[108]}$; Johnson, Kraft and Papay, 2012 $\left.{ }_{[78]}\right)$. It is 
important to keep in mind that improvements in teachers' collaboration often take time to manifest on external indicators, which can make the effectiveness of these interventions difficult to estimate.

Collaborative efforts that go beyond teachers and involve other staff working in schools likewise depend on the creation of both structures and cultures for collaboration. In Denmark, pedagogues (professionals that support human development more broadly from birth to old age and might be compared to recreational instructors, play workers or social workers in other contexts) have been working increasingly within schools as part of a broader reform of the organisation of the school day (Nusche et al., 2016 [30]). However, these professionals are most effective where schools already have a culture of collaboration, where school leaders promote a horizontal culture and explicit time is created in schedule to support collaboration (Jensen and Nielsen, 2018 ${ }_{[109]}$ ).

More generally, school leaders' competencies to support collaboration seems to be an important area for development, as reported by lower secondary principals themselves for the TALIS 2018. The promotion of collaborative work was the highest-ranked item when asked about their professional development needs, on average across OECD countries (OECD, 2019, pp. 169, Table I.5.32 $[4]$ ).

\section{Box 4.8. Types of teacher collaboration in schools in Ontario (Canada)}

The Canadian province of Ontario has invested significant energy in supporting teachers to successfully and effectively collaborate. The Ontario Ministry of Education produces a series of Capacity Building briefs that share actionable strategies for teachers and leaders to improve their practice. The ministry supports a process of "collaborative inquiry" in which teachers working in teams at their school research problems of practice. They generate evidence of what is and is not working at their school, make decisions about interventions, take action and then evaluate the effectiveness of their intervention before starting the cycle over again - a modified version of Deming's Plan-Do-Study-Act cycle.

Among other actions that teachers are encouraged to participate in through collaborative inquiry include:

- Co-teaching classes: Involves a small group of teachers co-planning a lesson, co-teaching that lesson with assigned roles and reflecting on the student learning outcomes of the learning experience, including naming evidence of the impact on student learning.

- Teaching Learning Critical Pathway: Inquiry involving the gathering of data, analysing it to determine area of greatest student need, identifying relevant curriculum, reviewing current practice, determining assessments to be used to monitor student learning, planning a teaching block of time (approximately six weeks), sharing evidence of student learning with other teachers, developing and administering a culminating task, engaging in teacher moderation of student work from the task and reflecting on what has been learned and what are the next steps in teacher learning. 
- Looking at Student Work (LASW): Educators collaboratively discuss student work based on common assessment criteria.

- Deconstructing curriculum: Educators examine curriculum expectations in order to understand what is written as it might be translated into what students learn.

- Examining student learning progression: Deconstruct a curriculum concept from when a child enters schools through many grades or levels to understand what a student is expected to learn at each level of the system.

- Monitoring marker students: Teachers pick a small number of students in a class, grade or school, share their assessment results with others in the school and document the use of teaching strategies against the learning outcomes for these students.

Sources: Nusche, D. et al. (2016), OECD Reviews of School Resources: Denmark 2016, OECD Publishing, Paris, http://dx.doi.org/10.1787/9789264262430-en; Ontario Ministry of Education (2014), Capability Building Series: Collaborative Inquiry in Ontario, https://thelearningexchange.ca/wpcontent/uploads/2017/02/CBS_CollaborativeInquiry.pdf (accessed 22 November 2018); Deming, W. (2000), The New Economics: For Industry, Government, Education, MIT Press, Cambridge, MA.

\subsubsection{Internal and external knowledge development}

It is critically important that schools and systems codify the knowledge they gain about which teaching and other processes are and are not effective so that educators within them retain and build on this knowledge base, even when staff transitions occur.

Teachers and school leaders acquire different types of knowledge that may be either generalisable or apply to the particular context of their community and school, also since students' learning needs differ over time and form one child to another. For example, a particular class project that takes advantage of strong relationships with a highly engaging local industry leader to improve students' scientific inquiry skills may be only valuable for that particular school community. Ensuring that a successful class project in one year, with one particular teacher and group of students, can be replicated in future years can be a challenge. Documenting how these projects were then successfully executed can be critical to maintain their success where possible.

By contrast, teachers and school leaders across multiple locations may find that a particular mathematical instructional strategy using manipulatives may help to support the re-teaching of systems of linear equations for students who struggle initially to understand such problems conceptually or procedurally. In order to formally generalise such knowledge, a causal research design may be necessary. However, since such an evaluation is costly and time-intensive and requires specific knowledge and skills, an intermediate level of evidence for this practice may be to collect insights across multiple teachers on the effectiveness of such a strategy. Such a process of external knowledge development, that includes both cross-school and research-practice partnerships, is an equally critical part of developing the knowledge base in teaching. Practitioners and researchers alike have advocated for similar methods to assist in the process of developing externally generalisable knowledge across schools (Kane, 2018 [110]; Goldstein, 2012 [111]).

Many schools and school systems struggle to layer improvement strategies on top of each other. Often a school leader, education administration (be it central or local) or educational trend may mobilise efforts to implement a particular new approach or strategy. However, 
when leadership changes or trends shift, schools and their staff struggle to retain whatever knowledge or skill may have been generated. When the next innovation arrives, prior learning can be lost.

Internal school evaluation processes can be one tool to address such challenges where procedural compliance does not dominate over quality assessment and learning (OECD, $2013_{[112]}$ ), and the results of self-evaluation become living documents guiding daily life. A number of OECD review countries have made attempts at introducing more strategic planning into the way schools operate that may support internal knowledge codification processes. Austria, the Czech Republic and Denmark have all instituted efforts to make self-evaluation processes more robust and to document what steps are undertaken to respond to the self-evaluation and how effective these are or are not (Nusche et al., 2016 [22]; Nusche et al., 2016[30]; Shewbridge et al., 2016[96]).

Just as codifying internally developed knowledge is important, so too are networks for collaboration and knowledge-sharing across schools, also to enable schools to combat their isolated natures and gain insights from effective practices in near or distant peer institutions. Teachers, school leaders and other school staff stand to benefit from networks and school-to-school collaborations. Some have argued that learning is maximised when understood as mutually beneficial to all schools, where schools can share some of their local knowledge with others in some situations while benefiting from others' knowledge in other situations (OECD, 2013 [113]; Katz, Earl and Ben Jaafar, 2009 [114]).

Table 4.6 provides information about opportunities for collaboration across schools in OECD review countries (also see Tables A.5. and A.6. in Annex A). Box 4.9 provides examples from New Zealand and the United States. Generally, practices are still limited, as also principal reports for the TALIS 2018 suggest (OECD, 2019, p. 160 $\left.{ }_{[4]}\right)$. In some school systems, however, collaborative networks are built into the governance structures of schools (sometimes as part of initiatives to reorganise the school network to changing demands and to improve student transitions as discussed in OECD (2018 $\left.\left.{ }_{[28]}\right)\right)$. In Portugal, for instance, school clusters unite between two and 29 schools under a single administrative team. This structure permits some degree of knowledge sharing. Similarly, in Colombia, public schools operate as clusters of multiple school sites, while Austria has given schools the possibility to cluster as of 2019 , as part of a wider school reform. 
Table 4.6. Opportunities for teacher and school leader collaboration beyond the individual school (ISCED 1-3), 2018

OECD review countries, public schools

\begin{tabular}{|c|c|c|c|c|}
\hline Country & $\begin{array}{c}\text { Support from } \\
\text { education authorities }\end{array}$ & Digital resource & $\begin{array}{l}\text { Teacher professional } \\
\text { body }\end{array}$ & $\begin{array}{l}\text { School leader } \\
\text { professional body }\end{array}$ \\
\hline Austria & & & $\checkmark$ & \\
\hline Belgium (FI.) & $\checkmark$ & $\checkmark$ & & \\
\hline Belgium (Fr.) & & & & $\checkmark$ \\
\hline Chile & $\checkmark$ & & & \\
\hline Colombia & $\checkmark$ & $\checkmark$ & & \\
\hline Czech Republic & $\checkmark$ & & & $\checkmark$ \\
\hline Denmark & $\checkmark$ & & & \\
\hline Estonia & & $\checkmark$ & $\checkmark$ & $\checkmark$ \\
\hline \multicolumn{5}{|l|}{ Iceland } \\
\hline Kazakhstan & & $\checkmark$ & & \\
\hline Lithuania & $\checkmark$ & & $\checkmark$ & $\checkmark$ \\
\hline \multicolumn{5}{|l|}{ Mexico } \\
\hline Portugal & & & $\checkmark$ & $\checkmark$ \\
\hline Slovak Republic & & $\checkmark$ & $\checkmark$ & $\checkmark$ \\
\hline Slovenia & $\checkmark$ & $\checkmark$ & & $\checkmark$ \\
\hline \multicolumn{5}{|l|}{ Spain } \\
\hline Sweden & $\checkmark$ & & $\checkmark$ & $\checkmark$ \\
\hline Turkey & & $\checkmark$ & & \\
\hline Uruguay & $\checkmark$ & $\checkmark$ & & \\
\hline
\end{tabular}

Note: This table presents a summary of the data available for teachers and school leaders on line (see Table A.5. in Annex A for full comprehensive tables on teacher professional learning and Table A.6. in Annex A on school leader preparation and development). Depending on the country context, opportunities specified in this table may refer to teachers, school leaders, or both.

Opportunities for collaboration beyond an individual school include structures and resources that facilitate exchange, support and knowledge sharing (e.g. on curricular and pedagogical issues). This includes support from education authorities (e.g. through policies and programmes, the facilitation of meetings or conferences) (systematically or at their own discretion); digital resources (e.g. online communities of practice) and teacher and school leader professional bodies (e.g. unions and associations).

Sources: Based on Country Background Reports and Country Review Reports (http://www.oecd.org/education/school-resources-review/schoolresourcesreviewreportsforparticipatingcountries.htm).

In some school systems, collaboration between schools has been facilitated in the form of targeted policies or programmes. While such policies and programmes support the development of valuable experiences, they also entail a risk that practices are discontinued over time where the continuity of programmes depends on the political decisions of successive governments.

In Chile, for example, School Improvement Networks (Redes de Mejoramiento Escolar) promote learning between school leaders and other educational supervisory staff, while in Colombia, the ministry of education has established and funded a national School to School Programme (Programa Escuela a Escuela, previously called Aliados 10) to generate collaborative and collective work, to facilitate the sharing of successful experiences and to improve managerial, academic, pedagogical and community aspects of schools. In Lithuania, projects such as Creative Partnerships for Schools (Kürybinès partnerystès) facilitate professional networking across schools. Similarly, in Slovenia, a Learning 
Schools Network (Mreža učečih se šo) promotes the exchange of experiences and good practice systematically between schools.

In other systems, collaboration between schools has come at the initiative of respective education authorities which facilitate meetings and exchange among the principals of their schools (e.g. the Czech Republic, Denmark, Sweden and Uruguay). Frequently, school leader and/or teacher unions or associations provide additional opportunities for the exchange of experiences.

External advisory networks of pedagogical experts can also support knowledge creation and sharing within a system and across levels of governance (also see Chapters 2 and 3). In this respect, Denmark has developed an interesting initiative. Here, the education ministry has created a national body of learning consultants who work with schools and municipalities in their improvement efforts. As part of their work, learning consultants facilitate peer exchange through their work in groups of schools. The work of learning consultants is overseen by the ministry's Resource Centre for the Folkeskole (Ressourcecenter for folkeskolen), which brings together both evidence from research and practical knowledge from the field.

The learning consultant initiative thus creates a circle of learning and evidence that brings central knowledge to schools and municipalities, but also from the local to the central level. In addition, the ministry has been taking on an increasing role in collecting and disseminating knowledge of good practice, for example through the creation of a specific division for knowledge mobilisation. During the review visit, there seemed to be good levels of trust and co-operation between the central and local level in the effort towards making educational practice more evidence-based (Nusche et al., 2016[30]).

Technology can be a key mechanism to codify findings across schools (see Table 4.6). OECD $\left(2015_{[115]}\right)$ details several strategies to connect school networks for learning and codify knowledge via ICT platforms. Among OECD review countries, Uruguay provides an example through the country's Ceibal initative and participation in a Global Learning Network (Red Global de Aprendizajes) (Santiago et al., 2016 $6_{[20]}$ ). In Austria, the federal education ministry facilitates learning among new secondary schools through its Centre for Learning Schools (Bundeszentrum für lernende Schulen), for schools to build up knowledge and expertise in areas of curriculum and instructional development. ${ }^{9}$ Specifically, the centre provides a virtual networking and learning space to connect teacher leaders (Lerndesigner) and promote their exchange and learning (Nusche et al., 2016 [22]). Similarly, in Kazakhstan and Turkey, teachers can share and search for pedagogical and curricular materials on dedicated digital platforms, for example. 


\section{Box 4.9. Collaboration between schools in New Zealand and the United States}

In New Zealand, education and training providers (schools, kura [schools which reflect Māori language, knowledge and culture in philosophy and practice], early learning services and post-secondary providers) can seek permission from the education ministry to form a community of learning. If approved, the community of practice receives resources to allow time for teachers to work together on meeting the achievement challenges, drawing on each other's skills, knowledge and experience. Communities of learning can also adjust the roles of staff, and establish additional leadership and teacher (across community and within school) roles.

Source: New Zealand Ministry of Education, Communities of Learning/Kāhui Ako, https://www.education.govt.nz/communities-of-learning (accessed 15 June 2019).

In the United States, a large new initiative to generate codified learning across schools has recently been launched, funded by the Bill and Melinda Gates Foundation. Schools work together to identify and solve common challenges. In the Networks for School Improvement (NSI), schools use data to identify a problem, select a strategy to address the problem, set goals, and cycle through these steps to refine their approach. As part of the networks' participation in the programme, they commit to participating in formative and summative evaluations that will codify learning about the improvement process, including benefits of the network model. Unfortunately, the NSI is a too new project and no evaluations of it exist yet.

Source: Bill \& Melinda Gates Foundation (2018), Networks for School Improvement: Working together to help students succeed, http://k12education.gatesfoundation.org/what-we-do/networks-for-school-improvement (accessed 3 May 2019).

\subsubsection{Evaluation and appraisal}

Staff evaluation, appraisal (terms used interchangeably across country contexts and in this report) and feedback are critical tools across public and private sectors to support growth and promote accountability for performance. In the education sector, the evaluation of teachers has occupied substantial attention in the policy and research communities over the past thirty years. More recently, similar attention has turned to the evaluation of school leaders (more on this below) (OECD, 2013 $\left.{ }_{[112]}\right)$.

The growing realisation of the impact of teachers on student achievement and the wide variability of teachers' impact on student learning and other outcomes, prompted interest in ways to improve the quality of the teaching pool through human resource management, including rigorous evaluation systems, among researchers and policy makers in a number of contexts (OECD, 2013 [112]; Rockoff and Speroni, 2011 [116]; Rockoff et al., 2012 [117]; Jackson, Rockoff and Staiger, $\left.2014_{[118]}\right)$.

Some countries, such as Chile, Colombia and the United States, underwent major overhauls of their teacher evaluation policies resulting in new systems in which teacher evaluation had multiple implications, such as continued employment, promotion, and/or merit pay

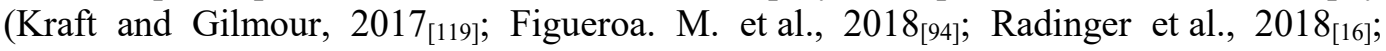
Santiago et al., 2017 [34]). In 2015, 30 out of 37 OECD and partner countries with available data legislated or required some form of teacher appraisal, most often in the form of regular performance appraisal (OECD, 2015 $[120])$. 
Typically, stated policy around appraisal involves some dimensions of reviewing the performance of students under the teacher's charge, some observation of the practitioner's work - either through direct observation or portfolio review and sometimes via feedback from various stakeholders in the school community (OECD, 2013 $3_{[12]}$; OECD, 2015 [120]). Nevertheless, despite formal policies that, on paper, indicate outcome-based measures and observation of practice as critical factors in the appraisal process, concerns persist about whether the process generates improved skill in teachers and improved results for students.

At the time of writing, only data from the TALIS 2013 were available. As Figure 4.8 suggests, based on these data, many teachers believe that the appraisal process does not have substantial impact on classroom practice and that it is primarily conducted to satisfy bureaucratic requirements (TALIS average: $43 \%$ and 51\% respectively) (OECD, 2014 ${ }_{[42]}$ ). These patterns are echoed in some OECD reviews in which teacher stakeholder groups reported little impact of teacher evaluation on their practice (Liebowitz et al., 2018 [19]; Radinger et al., 2018 [16]; Santiago et al., 2016 [20]). Various theories attempt to explain the persistence of the weak effects of appraisal on teaching practice, ranging from institutional cultures, to the loose coupling of system goals and instructional practice (Elmore, $2004_{[121]}$ ), to school leader time constraints (Kraft and Gilmour, 2016 ${ }_{[122]}$ ).

Figure 4.8. Impact of teacher appraisal and feedback systems in schools (ISCED 2), 2013

Percentage of teachers who "agree" or "strongly agree" with the following statements about teacher appraisal and feedback systems in their school

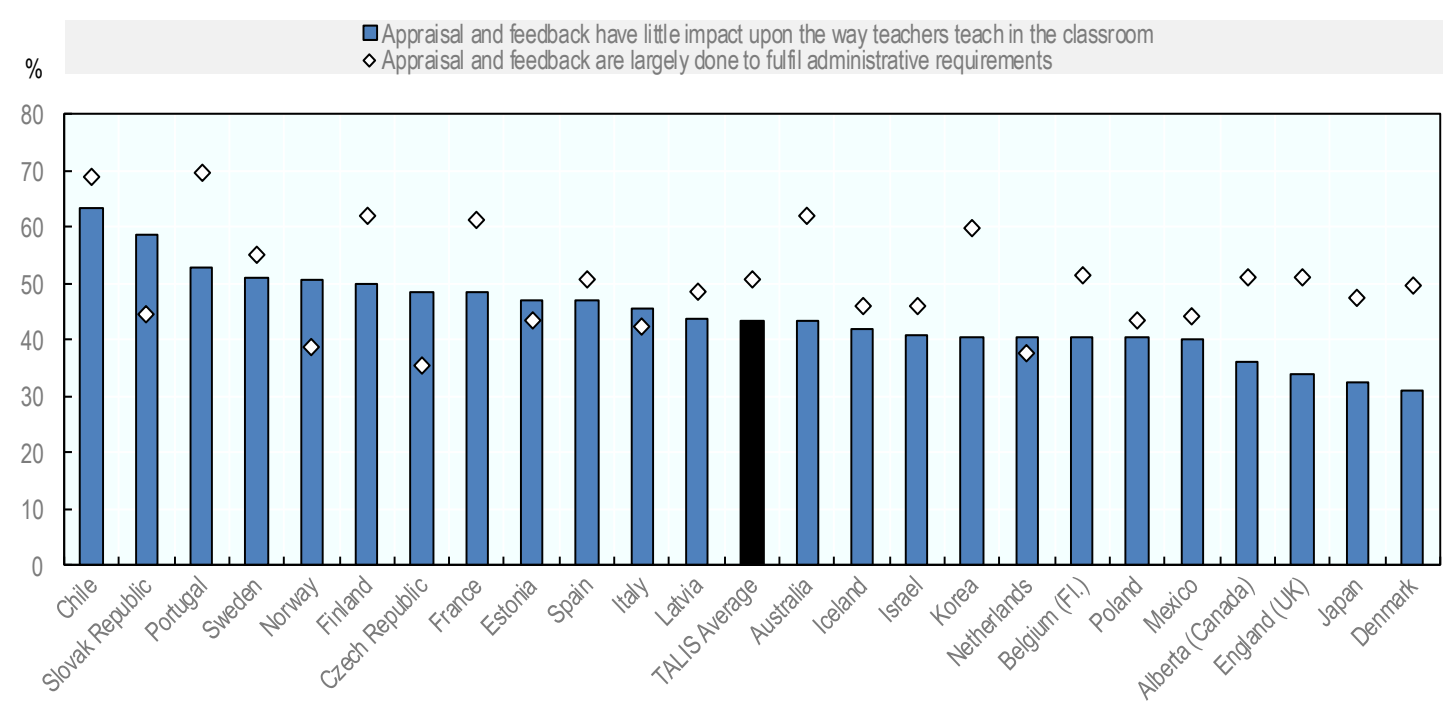

Notes: Countries and economies are ranked in descending order in the percentage of teachers who agreed or strongly agreed that appraisal and feedback had little impact upon the way they teach. The TALIS average is calculated as the mean of the data values of all countries and economies participating in the survey.

Source: OECD (2014), TALIS 2013 Results: An International Perspective on Teaching and Learning, OECD Publishing, Paris, https://doi.org/10.1787/9789264196261-en, Table 5.8. 


\section{Staff evaluation systems often fail to resolve tensions between multiple purposes}

One central question related to staff evaluation is how to align appraisal with professional improvement. Many appraisal systems attempt to accomplish two goals: i) use the evaluation process to stimulate learning for the teacher or leader and ii) use the evaluation process to hold staff accountable for low effort or skill. These two aims can sometimes support each other and sometimes be in conflict with each other. In some school systems, the priorities of appraisal policy aim at one at the expense of the other. In other systems, appraisal policy attempts to accomplish both objectives simultaneously, but struggles to effectively resolve conflicts between the two ends.

Only one study credibly estimates the effect of teacher evaluation on teaching practice and student learning outcomes. Tyler and Taylor $\left(2012_{[123]}\right)$ demonstrate in the city of Cincinnati (United States) that students improve by one-tenth of a standard deviation in mathematics when they are taught by a teacher who has been evaluated compared to a similar teacher who has not been evaluated. Importantly, this study examined an appraisal system with low stakes. Thus, while there appears to be value in the appraisal process, much more remains to be understood about how to leverage it to maximise teacher and student growth.

Among OECD review countries, there is a wide range of functions and purposes for which the appraisal process serves. In some cases it may influence teachers' eligibility to progress through career steps, in others it may impact their ability to earn additional pay (see Chapter 2). There are some exceptions, but in most cases, appraisal is relatively low stakes, particularly after teachers' first years. For these systems, it is hard to envision how the accountability goals of the evaluation system can be realised. While few systems emphasise the accountability dimensions of teacher appraisal, it is simultaneously true that appraisal's function as a formative tool to build capacity is also underdeveloped.

There exist limited structures for tying teacher learning to the outcomes of the appraisal process, either in the form of professional development or structured improvement plans. In Lithuania and Estonia, for example, few links exist between the results of the evaluation system and professional development opportunities for teachers despite well-developed appraisal system (Santiago et al., 2016 $6_{[71]}$; Shewbridge et al., 2016 $\left.6_{[124]}\right)$. In Uruguay, despite defined lesson observation protocols, frameworks for teaching excellence and expectations regarding the teacher evaluations by school inspectors and school leaders, evaluation continues to be seen as only a high-stakes accountability tool, rather than an opportunity for developmental growth (Santiago et al., 2016 [20]).

In addition to using teacher (and other staff) appraisals to proscribe professional development at the individual level, results from individual appraisals can be aggregated or whole-school evaluation results can replace them to generate topics for professional development. Understood as such, evaluation-informed professional development can explicitly recognise the ecological context in which educators work. Teachers improve most when they work in supportive environments of peers who seek to improve on similar dimensions (Johnson, Kraft and Papay, 2012 ${ }_{[78]}$ ). Thus, a collective focus to linking appraisal with professional learning holds promise.

In spite of the shortcomings of many appraisal systems, there is clear interest on the part of teachers in receiving high-quality feedback. In fact, for the TALIS 2013, $61 \%$ of lower secondary teachers reported improvements in public recognition, $63 \%$ in job satisfaction, $65 \%$ in job motivation, and $71 \%$ in confidence in teaching abilities after receiving feedback, on average across participating countries (OECD, 2014, p. 136 $6_{[42]}$ ). Thus, 
ensuring that appraisal results in strategies for improvement alongside any accountability aims appears critical. Evaluation and appraisal represent an opportunity for continuing learning, can be promoted within the context of teams, requires important leadership skills, and insights gained from it should be systematically captured.

\section{The successful implementation of staff evaluation systems has proved a barrier}

Beyond challenges in the aims and design of evaluation systems, their successful implementation has proved a significant barrier. While successful implementation is frequently one of the largest barriers to any education reform effort (Viennet and Pont, $2017_{[125]}$ ), the domain of appraisal has been particularly difficult as it combines resource, capacity, technical, political and cultural barriers.

\section{Time and capacity constraints}

School leaders experience intense demands on their time, often working well beyond standard professional working hours. In Portugal and the United States, for example, school leaders report working upwards of 60 hours per week (Liebowitz et al., 2018 [19]; National Center for Education Statistics, 2017 $\left.{ }_{[126]}\right)$. Despite the long hours of those generally responsible for evaluating teachers (though not in all systems), many teachers report dissatisfaction with the quality of their appraisals. Many OECD reviews found school leaders' time was taken up by administrative and managerial tasks (e.g. for Austria, the Czech Republic and Portugal) (Liebowitz et al., 2018 ${ }_{[19]}$; Nusche et al., 2016 $6_{[22]}$; Shewbridge et al., 2016 $\left.{ }_{[96]}\right)$.

Thus, simply demanding more of school leaders in terms of the time they devote to appraisal is unlikely to either generate positive results or improve school leader recruitment and retention in an already challenging role (see Chapter 2). Thus a critical consideration is to redistribute resources within schools and systems to shift responsibilities of evaluation and management to permit those responsible for evaluation to be able to do so effectively.

A separate, though related concern, are constraints related to the skills of teacher evaluators. In both the research literature and OECD reviews, teacher evaluators (largely school principals and other leaders) report having not only limited time to engage meaningfully in evaluation, but also needing additional training to successfully observe classroom practice and provide feedback (Santiago et al., 2016 $[20]$; Shewbridge et al., 2016 $6_{[96]}$ ).

\section{Measurement constraints}

Measurement challenges exist across the three primary sources of information typically used in appraisals: observations of practice, student outcomes and surveys.

Appraisal operates from the premise that if teacher and leader standards are clear and rigorous and evaluators are trained to observe and rate staff against those standards, evaluators will reach valid and reliable conclusions about teachers' and leaders' effectiveness. Setting aside the technical definitions of these terms, the "validity" assumption implies that evaluator ratings of an individual reveal meaningful information about their skill and effectiveness and the "reliability" assumption implies that multiple evaluators in multiple time periods would rate the staff member similarly. These two assumptions are critical for the appraisal effort to be of value (OECD, 2013 [112]).

However, reviews of evaluation procedures in the context of the United States found minimal efforts to assess the validity and reliability of teacher ratings (Herlihy et al., $\left.2014_{[127]}\right)$. Kraft et al. $\left(2019_{[128]}\right)$ document a reliability coefficient on overall teacher 
performance appraisal of approximately 0.8 . While this coefficient is relatively high, it nevertheless implies that $20 \%$ of teachers are rated in a different rank order from year to year. Measurement issues are even more of a challenge when policy makers seek to incorporate student performance measures as part of the appraisal process.

There has been substantial debate in the policy and research communities around the use of student performance on external assessments as part of teacher evaluation. There are numerous methodological challenges to the use of test scores in teacher evaluation. Most notably, these include that different models and tests produce different ratings for teachers, that the student composition of classrooms affects the results, and that there is potential for gaming the scores by teaching to the test (Rothstein, 2017 $[129]$; Ballou and Springer, 2015 [130]; Guarino, Reckase and Wooldridge, 2015 [131]; American Statistical Association,

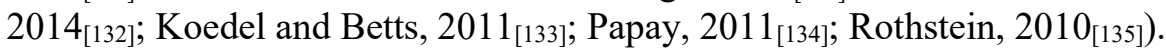

Furthermore, recent evidence indicates that teachers' impacts on test score outcomes do not correlate well with teachers' impact on other desirable outcomes such as student attendance (Gershenson, 2016 $6_{[136]}$ ) and non-cognitive skills such as resilience, growth mindset, self-efficacy and behaviour in class (Blazar and Kraft, 2017 $7_{[137]}$; Kraft, 2017 $[138]$ ). While others maintain that teacher value-added estimates provide unbiased, causal estimates of teachers' productivity that predict long-term labour market outcomes (Chetty, Friedman and Rockoff, 2017 ${ }_{[139]}$; Chetty, Friedman and Rockoff, 2014 $\left.{ }_{[140]}\right)$, this literature remains very much in controversy.

Finally, surveys of students, families, peers and other education stakeholders have become increasingly common parts of school leaders' and sometimes teachers' appraisals. In the large-scale Measures of Effective Teaching (MET) study, combining the experiences of 3000 teachers in school districts across the United States, the strongest predictor of teacher contributions to student learning gains were student surveys (Kane and Staiger, 2012 [141]). In the aftermath of these findings, various private providers developed commercial surveys that purport to measure teacher or school leader quality. While these may have potential, caution must be used to avoid unintended consequences since these instruments may not reflect expert judgement on teacher or leader effectiveness but only individual preferences (Isoré, 2009 $[142]$ ), and may distort behaviour to earn higher ratings in the short term at the expense of longer-term educationally beneficial behaviours.

\section{Cultural, normative and political constraints}

Even in contexts where recent reforms to evaluation have been undertaken, the actual ratings assigned frequently continue to be plagued by a lack of differentiation across teachers. In the United States, despite cross-state teacher evaluation reforms that created multiple rating categories and frequently assigned components of teacher ratings to student test score outcomes and sometimes parent surveys, follow-up studies find that the overwhelming majority of teachers continue to receive positive appraisals (more than $95 \%$ ) (Kraft and Gilmour, 2017 ${ }_{[119]}$ ). In fact, on average, the higher the stakes of the evaluation, the more common it was that ratings would be high (Grissom and Loeb, $2017_{[143]}$ ). Similar policy developments are apparent in Chile where complex, purportedly rigorous evaluation was introduced, but most teachers continue to be rated positively (Santiago et al., 2017 [34]).

While Pope $\left(2019_{[144]}\right)$ finds that the mere act of publically labelling teachers based on their effectiveness at improving student outcomes led to the improvement of low-performing teachers, it remains an open question as to whether the act of labelling teachers as high- or low-performing would be beneficial. What cross-national patterns of high appraisal-rating scores may reveal is the struggle that many evaluators experience in providing challenging, 
constructive feedback to teachers and other staff. Some have pointed to the cultural and normative conditions in schools that promote a flat organisational structure and avoid creating between-teacher competition as potential sources of this constraint.

In addition to within-school normative presses against rating teachers poorly, teachers' professional associations have often raised objections to what they have described as capricious and poorly designed appraisal systems (Figazzolo, 2013 ${ }_{[145]}$ ). The professional associations' concerns tend to accord with those outlined above, with the additional concern that teachers are rarely included as key decision makers in the design of appraisal policies. A concern frequently raised by professional associations is that the use of a high-stakes evaluation system which might result in the dismissal of teachers is highly problematic when the appraisal system is unable to reliably distinguish between higherand lower-performing teachers. As a result, substantial political controversy has followed in most systems that have attempted to implement high-stakes evaluations.

While there exist capacity, technical and political constraints to the development of higher-stakes appraisal systems, for the TALIS 2013, 44\% of lower secondary teachers reported that they worked in schools in which poor appraisals never led to "dismissal or non-renewal of contract" (OECD, 2014 $\left.{ }_{[42]}\right)$. Thus, while concerns about high-stakes appraisal systems have led to political mobilisation against them, a solution to solve the challenge of weak or middling teaching remains outstanding.

\subsection{Developing leadership for inquiry, dialogue and learning}

\subsubsection{School principals are faced with a wide variety of professional responsibilities, but there are shortcomings in preparing them for their role}

Research increasingly recognises the positive effect that well-prepared school leaders can have on their students' learning outcomes (Gates et al., 2019 [146]; Clark, Martorell and Rockoff, $\left.2009_{[55]}\right)$. Based on this is a growing awareness that a successful teaching record alone is not sufficient and that school leadership is a specialist occupation that requires rigorous preparation and entry requirements. As school leaders are predominantly recruited from the teaching profession, many of the organisational competencies at the heart of their role are not covered during initial teacher preparation.

Thus, there is value in investing in school leader development strategies, even if there is likely no programme that could fully prepare prospective school leaders for the position, given the wide range of knowledge and skills required of school leaders (see Annex 1.A in Chapter 1). Indeed, for the TALIS 2018, principals of lower secondary schools reported a wide range of development needs, which likely reflect that they need to be proficient in multiple roles, from financial management to pedagogical leadership (see Figure 4.9) (OECD, 2019, pp. 168, Table I.5.32[4]). 
Figure 4.9. Principals' needs for professional development (ISCED 2), 2018

Percentage of principals reporting a high level of need for professional development in the following areas (OECD average-30)

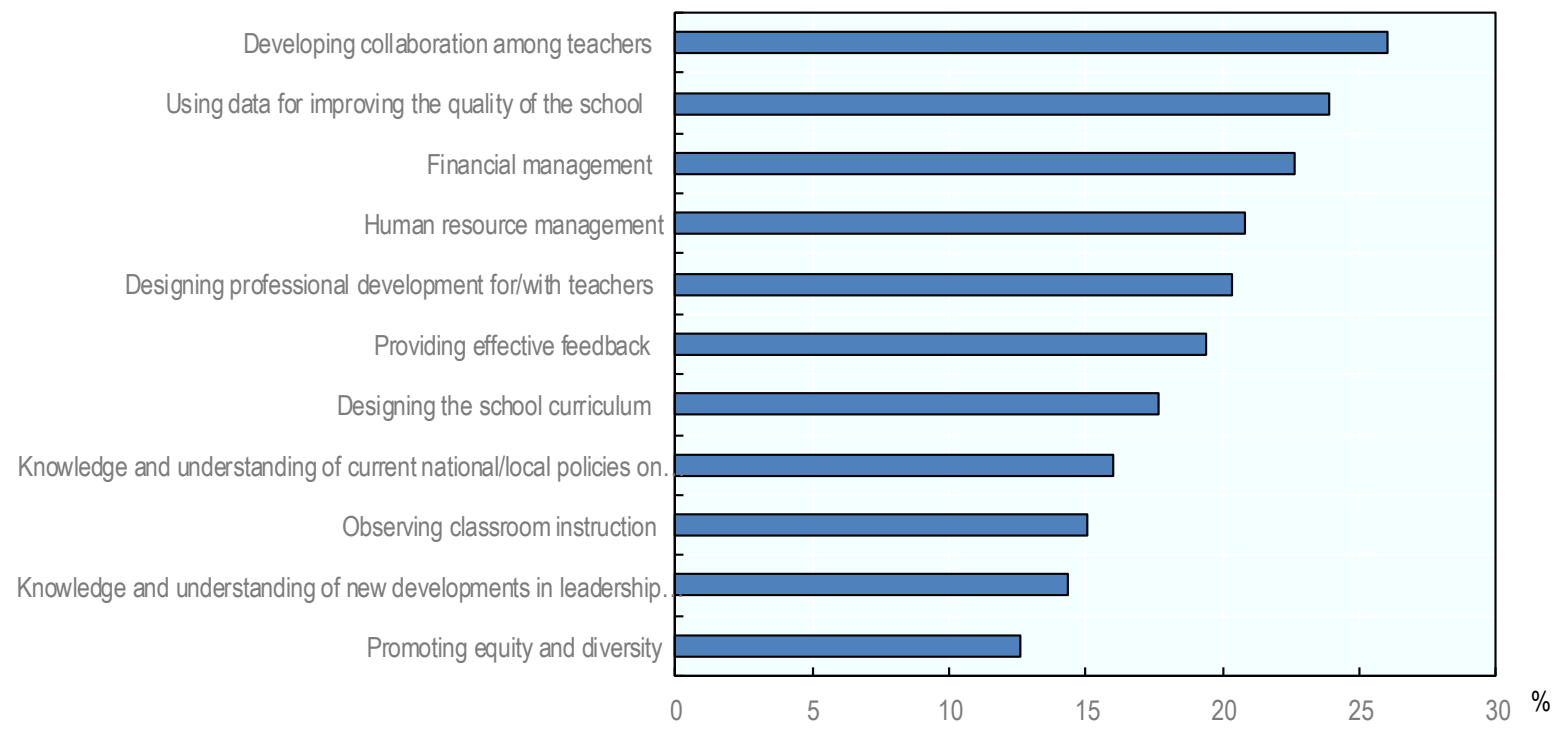

Notes: Values are ranked in descending order of the percentage of principals who reported a high level of need for professional development in the above topics. The number of countries or economies included in the OECD average is indicated next to that average. On 25 May 2018, the OECD Council invited Colombia to become a Member. While Colombia is included in the OECD average reported in this figure, at the time of its preparation, Colombia was in the process of completing its domestic procedures for ratification and the deposit of Colombia's instrument of accession to the OECD Convention was pending.

Source: OECD (2019), TALIS 2018 Results (Volume I): Teachers and School Leaders as Lifelong Learners, OECD Publishing, Paris, https://doi.org/10.1787/1d0bc92a-en, Table I.5.32.

StatLink 제내 https://doi.org/10.1787/888934026734

A number of countries, however, do not require school leaders to exhibit or acquire qualifications that distinguish them from teachers. In fact, some have moved in the opposite direction and relaxed entry requirements for school leaders, sometimes motivated by a difficulty to recruit sufficient number of candidates to the profession. In England (United Kingdom), since 2013, aspiring school leaders no longer need to acquire the National Professional Qualification for Headship (NPQH) or hold Qualified Teachers Status, which had previously been compulsory.

Among OECD review countries, initial preparation requirements vary substantially for school principals as Table 4.7 documents. Some systems have no fixed requirements for preparation beyond a teaching qualification (e.g. Denmark, Kazakhstan, Lithuania and Turkey); others have no preparation requirements to enter the principal position, but require training within a fixed amount of time once appointed to remain in the position (e.g. the Czech Republic, Slovenia and Sweden); others require minor trainings prior to beginning the role (e.g. Uruguay); and still others have extensive pre-service preparation requirements (e.g. Chile and Spain). 
Table 4.7. School principal preparation requirements (ISCED 1-3), 2018

OECD review countries, public schools

\begin{tabular}{|c|c|c|c|c|c|c|c|c|c|c|c|c|c|c|c|c|c|c|}
\hline \multicolumn{19}{|c|}{ Pre-appointment } \\
\hline \multicolumn{19}{|c|}{ Post-appointment } \\
\hline Country & $\frac{\text { 䨠 }}{\frac{2}{2}}$ & 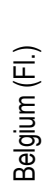 & 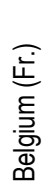 & $\frac{\omega}{\frac{\underline{C}}{\bar{U}}}$ & $\begin{array}{l}\frac{\text { 믕 }}{\text { ह }} \\
\text { 응 } \\
\end{array}$ & 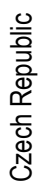 & 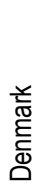 & 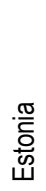 & $\begin{array}{l}\text { 음 } \\
\text { 응 } \\
\underline{0}\end{array}$ & 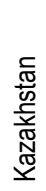 & 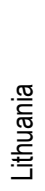 & 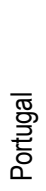 & 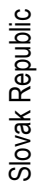 & $\begin{array}{l}\frac{\pi}{\bar{T}} \\
\frac{\mathrm{d}}{\omega} \\
\frac{0}{\omega}\end{array}$ & $\begin{array}{l}\text { क्ञ } \\
\text { कू }\end{array}$ & $\begin{array}{l}\text { d } \\
\text { के } \\
\text { के }\end{array}$ & $\begin{array}{l}\frac{\vec{d}}{\bar{y}} \\
\qquad\end{array}$ & 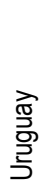 \\
\hline
\end{tabular}

Note: For full comparative tables on school leader preparation and development, see Table A.6. in Annex A.

Sources: Based on Country Background Reports and Country Review Reports (http://www.oecd.org/education/school-resources-review/schoolresourcesreviewreportsforparticipatingcountries.htm).

Austria and the Slovak Republic provide interesting examples with school principals being required to take part of their training prior to appointment, and to continue preparation during their first years on the job. The French Community of Belgium has developed another interesting approach, with aspiring school principals having to undertake training and an entry phase which lead to appointment in the case of positive evaluations. Box 4.10 provides more in-depth descriptions of approaches to school principal preparation in select OECD review countries.

\section{Box 4.10. Approaches to school principal preparation in OECD review countries}

\section{Austria}

Austria has recently moved to an approach where aspiring school principals are required to undergo part of their training programme (20 ECTS) prior to their recruitment rather than - as was previously the case - during their first four years in service. Once appointed, school principals complete a second part of the leadership development course (40 ECTS) within four years and six months of their time at school.

Source: Eurydice (2019), Database of National Education Systems, https://eacea.ec.europa.eu/nationalpolicies/eurydice/national-description en (accessed 15 June 2019).

\section{French Community of Belgium}

Since 2007, school principals have been required to complete training and a mandatory entry phase (stage) for appointment. Since September 2019, the duration of training has increased from 120 hours to 180 hours, while the entry phase has increased from two to three years as part of the French Community's Pact for Excellence in Teaching (Pacte pour un enseignement d'excellence). Following successful evaluations during the entry phase, the candidate is appointed to principalship.

Training covers pedagogical, educational, administrative, financial and relational aspects and should provide principals with a portfolio of knowledge and skills. Since education in the French Community is organised in educational networks (public, government-aided public and government-aided private), half of the training is organised jointly for all networks, the other half for each specific network. Since September 2019, the inter-network part comprises two axes: administration and steering (itself composed of a module on "educational vision and management" and a module on "the development of 
relational, interpersonal and group skills and aptitudes and the construction of professional identity").

The network-specific part addresses issues specific to the network, in terms of its educational and pedagogical or educational and artistic project, its specific legal and administrative provisions as well as material and financial management. The network-specific part moreover includes time for coaching and induction (30 hours) to support the principal in different areas: for example, teamwork, time management, priority setting or the application of laws and regulations. Coaching and induction are provided by trainers without any hierarchical relationship during the three-year entry phase; may include exchanges with other school principals and a self-assessment to highlight strengths and areas for improvement.

Sources: Ministère de la Fédération Wallonie-Bruxelles (2016), Examen de l'OCDE des politiques pour un usage plus efficace des ressources scolaires RAPPORT PAYS Communauté française de Belgique; Ministère de la Fédération Wallonie-Bruxelles, Bruxelles, http://www.oecd.org/education/school-resourcesreview/reports-for-participating-countries-country-background-reports.htm; Parlement de la Fédération Wallonie-Bruxelles (2019), Décret du 14-03-2019 modifiant diverses dispositions relatives aux fonctions de directeur et directrice, aux autres fonctions de promotion et aux fonctions de sélection, https://www.gallilex.cfwb.be/document/pdf/46328_001.pdf (accessed 25 July 2019).

\section{Slovak Republic}

School principals are required to complete "functional training", which is an officially approved professional development course in specific management competencies. Functional training courses are offered by the central Methodology and Pedagogy Centre (Metodicko-pedagogické centrum, MPC), universities and other providers. The basic training modules need to be completed prior to appointment; the extended modules within five years of appointment. The full functional training (basic and extended modules) comprises 320 hours of training. It covers a range of issues, from school legislation and finance, pedagogical management (preparing the school education programme and working with the curriculum) and human resource management (the school as the employer), to conceptual management (responsibility for the school development plan and strategic issues).

Source: Santiago et al. (2016), OECD Reviews of School Resources: Slovak Republic 2015, OECD Publishing, Paris, https://doi.org/10.1787/9789264247567-en.

\section{Spain}

Before they are appointed as school principals, candidates have to pass a training course on the development of leadership of a duration of 120 hours. Training, which is organised by the state and central education authorities, includes a theoretical and a practical part. It has a modular structure of a varying length, according to the content, and covers at a minimum the following areas: i) regulatory framework for educational institutions, ii) organisation and management of educational institutions, iii) management of school resources, iv) key factors for effective leadership, v) accountability and educational quality and vi) management project.

Source: Eurydice (2019), Database of National Education Systems, https://eacea.ec.europa.eu/nationalpolicies/eurydice/national-description_en (accessed 15 June 2019). 
Successful school leadership development fosters both instructional and managerial skills. As for teachers, residency models hold promise for the effective preparation of school leaders for their role. One highly regarded model is the New Leaders residency programme for school leaders in the United States. In one of the few well-designed credible estimates of the impact of school leadership preparation programmes, school leaders trained by the New Leaders residency preparation programme improved student learning outcomes in their schools compared to non-residency trained leaders, though the magnitude of these improved test score outcomes was relatively small (Gates et al., 2014).

Another model is the School Leader Offspring Programme in Estonia, a 24-month development programme for future school leaders, open to school staff, plus individuals from other sectors. Participants are selected via a competition. Each participant has a mentor and performs field training in schools. The programme offers different modules, including an introduction to pedagogy and the management of learning for those not in the education sector (Estonian Ministry of Education and Research, 2015 [147]).

In addition to such leadership residencies, clearer consistent expectations for initial preparation (and the school leadership role) that combine instructional, management and operational skill development are critical.

\subsubsection{More knowledge about preparation and support for middle leadership roles and teacher leaders is required}

In addition to traditional preparation programmes geared towards a leadership role with supervisory responsibility for all others in a school organisational hierarchy (e.g. head teacher, principal, headmaster), some school systems have focussed on preparing candidates for intermediary leadership roles such as department heads or curriculum leaders. A key consideration is how to provide diverse developmental opportunities relevant to the varied intermediary leadership roles in a resource-constrained environment. A recent review of best practices in these areas finds that critical strategies are to empower middle leaders to own their roles and be subject-matter and pedagogical experts within their schools, and to provide them with support to build knowledge and skills (HammersleyFletcher, Ainsworth and Davies, 2018 $\left.{ }_{[148]}\right)$.

In general, minimal evidence from either the research literature or the OECD review provides guidance on the best ways to develop such leaders, independent from general strategies for school leadership (Wenner and Campbell, 2016 $6_{[149]}$ ). This is an important area of future research and policy development. Nevertheless, comparative information for OECD review countries illustrates that a number of systems have requirements or opportunities for the development of leadership more broadly (see Table 4.8 and Table A.6. in Annex A).

In the Flemish Community of Belgium and the Slovak Republic, training is required for specific leadership roles other than the principal. In Slovenia, the National School of Leadership in Education provides professional development also for other leadership roles, notably a training programme for middle leadership intended for subject and group leaders, and a leadership support programme developed for staff to encourage learning communities and develop knowledge and skills in some areas of their work. 
Table 4.8. Development requirements and opportunities for intermediary formal school leadership roles (ISCED 1-3), 2018

OECD review countries, public schools

\begin{tabular}{|c|c|c|c|c|c|c|c|c|c|c|c|c|c|c|c|c|c|}
\hline \multicolumn{18}{|c|}{ Requirements } \\
\hline \multicolumn{18}{|c|}{ Opportunities } \\
\hline Country & $\frac{\text { 吾 }}{\frac{5}{2}}$ & 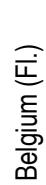 & 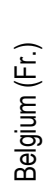 & $\frac{\mathscr{\omega}}{\frac{Z}{U}}$ & $\begin{array}{l}\frac{\pi}{0} \\
\frac{\bar{E}}{0} \\
\frac{0}{O} \\
\end{array}$ & 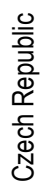 & 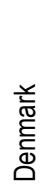 & 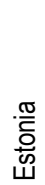 & 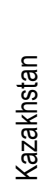 & 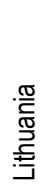 & $\begin{array}{l}\overline{\widetilde{\pi}} \\
\text { ్ㅡㅇ } \\
\text { 응 }\end{array}$ & 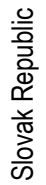 & $\begin{array}{l}\frac{\pi}{\bar{C}} \\
\frac{0}{\omega} \\
\frac{0}{\omega}\end{array}$ & 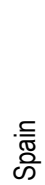 & 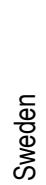 & 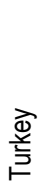 & 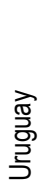 \\
\hline
\end{tabular}

Notes: For full comparative tables on school leader preparation and development, see Table A.6. in Annex A. Shaded boxes indicate where requirements and opportunities are in place for some formal school leadership positions. This may not be relevant for all types of other formal leadership positions besides the school principal in a school system.

Source: Based on Country Background Reports and Country Review Reports (http://www.oecd.org/education/school-resources-review/schoolresourcesreviewreportsforparticipatingcountries.htm).

In Austria, aspiring school leaders can take the first part of the leadership development programme for principals (20 ECTS), while aspiring administrators can participate in a development programme (10 ECTS) offered by university colleges. The creation of a new teacher leader role (Lerndesigner) in schools was accompanied with the development of a new qualification programme to provide theoretical and practical insights in areas of expertise related to instructional quality, to develop the knowledge and skills to be effective teacher leaders and to help staff network with one another (Nusche et al., 2016 [22]).

One specific model that involves intermediary leader preparation was developed in Estonia. Since 2015, the School Team Development programme, a 12-month management training programme with the school leader and two other staff members, covers different school management topics. This serves as both a professional learning opportunity for school leaders as well as future leadership development for these middle leaders (Estonian Ministry of Education and Research, $\left.2015_{[147]}\right)$.

Box 4.11 highlights programmes that Singapore uses to develop early career leaders (Management and Leadership Studies Programme) and promising mid-career leaders (Leaders in Education Programme). Critically, Singapore conceives of the progression of teachers interested in leadership as one requiring a sequential progression in which key skills must be acquired at benchmark points during their career development.

Scotland (United Kingdom) provides another example for leadership development on a continuum throughout teachers' and leaders' careers. In response to Teaching Scotland's Future, a review of the state of teacher education, in the early 2010s, Scotland established a College for Educational Leadership to support the leadership professional learning of all educators, from teachers to middle leaders, headteachers and system leaders (Scottish College for Educational Leadership, 2019[150]). 


\section{Box 4.11. Preparing leaders in Singapore}

\section{The Management and Leadership Studies (MLS) Programme}

Tis programme is designed for teacher leaders who are department, grade or subject group heads. It comprises 17 weeks of funded training, during which time staff receive their full salary. During this training, teacher leaders participate in a series of courses to develop leadership, teaming and operational management skills. They also spend a week travelling to another Asian Pacific country to provide them with new perspectives on the Singaporean context (Keo, 2016 $\left.6_{[151]}\right)$. From this programme, candidates become competitive for the positions of assistant principal or may move to the National Institute for Education (NIE), the country's national teacher education institute, or the national Ministry of Education.

\section{The Leaders in Education Program (LEP)}

This is a highly selective programme that prepares highly effective assistant principals and ministry officials for principalship. The programme was launched in 2001 by the National Institute for Education (NIE). Between 30 and 40 candidates are selected in each cohort for an intensive six-month executive education programme based on their prior performance appraisals, situational tests, a professional portfolio and selection interviews. Once selected, participants receive a full salary, while participating full-time in the programme. The programme aims to develop capacity that is, "values-based, purposeful, and forward looking, anchored on both strong people leadership and instructional leadership" (Jayapragas, 2016 $[152])$. The curriculum draws on leaders in adult learning to develop five skill sets: i) the disciplined mind, ii) the synthesising mind, iii) the creating mind, iv) the respectful mind and v) the ethical mind (Walker, Bryant and Lee, 2013 ${ }_{[153]}$ ).

Every cohort member is placed in a local school in Singapore where they are mentored by an experienced principal. In the school, they conduct a Creative Action Project to design an innovation alongside the school's faculty with the goal of transforming the school over the long term. Participants also take part in a two-week international study trip in order to gain comparative perspectives on school leadership.

The initiative has had positive participant feedback, but to date no formal evaluation exists assessing its impact on leaders' future skills or on student learning outcomes.

\subsubsection{School principals and other leaders often lack sufficient ongoing support and relevant development opportunities throughout their career}

While the early career growth trajectories in the effectiveness of teachers is well-documented (Papay and Kraft, 2015 [54]; Boyd et al., 2008 ${ }_{[154]}$; Rivkin, Hanushek and Kain, $2005_{[155]}$; Rockoff, $2004_{[10]}$ ), much less is known about the development trajectories of principals. While consistent evidence indicates a correlation between experience as a school leader and student outcomes (Grissom, Blissett and Mitani, 2018 ${ }_{[156]}$; Bastian and Henry, 2015 $5_{[157]}$; Clark et al., 2017 $\left.{ }_{[46]}\right)$, this evidence struggles to disentangle the effects of school leader learning on the job and more effective leaders remaining in their positions for longer periods.

Thus, while it is fairly evident that school leaders are likely to benefit from experience in their position, relatively little is known about how to influence their growth trajectories such that they improve more rapidly and throughout the course of their professional careers. 
One key strategy to affect the development trajectories of school leaders is through continuing opportunities for professional learning. Fryer $\left(2017_{[158]}\right)$ examined the impact of school principal training on teacher productivity over two years in a randomised controlled trial, showing that management training can be a very cost-effective way to improve student outcomes across many subjects as training helps increase teacher productivity across the school.

OECD review countries provide a range of professional learning opportunities for their school principals (see Table A.9. in Annex A). Many of these supports for learning as school leaders are valuable, in principle. There is a range of providers in OECD review countries, such as tertiary education institutions, teacher education institutions, or dedicated leadership institutions (such as in Chile and Slovenia) that offer ongoing school management or instructional leadership courses. In the Czech Republic, a project was ongoing at the time of writing to set up a permanent conference of school principals, which was planned to act as a managing body to ensure an up-to-date and systematic support system for school management and leadership development.

In Chile, the Slovak Republic and Spain, professional learning activities for school leaders are incorporated as required elements for all school leaders' regular work in a way that can be guided at the systemic level. In these systems, all leaders are mandatorily engaged in either a learning network or series of ongoing professional learning courses. In several systems, there are also explicit resources in the form of guaranteed time or money devoted to the ongoing development for school leaders.

In some countries, professional organisations or civil society play an important role in leadership development. To give an example, in Slovenia, the professional association of school leaders provides additional learning opportunities (e.g. offering a network for peer learning) to those provided by the country's leadership institute (Slovenian Ministry of Education, Science and Sport, 2017[72] . Similarly, in Denmark, the professional association of school leaders supports their members with a range of training activities (Nusche et al., $2016_{[30]}$ ), while in the French Community of Belgium and Portugal school leader associations facilitate exchange and support among their members (Liebowitz et al., 2018[19]; Ministère de la Fédération Wallonie-Bruxelles, 2016 $\left.6_{[70]}\right)$.

In Colombia, a cohort of school leaders has been exposed to experts and academics from across multiple sectors who provide managerial and educational training through the Transformative School Principals programme (Rectores Lideres Transformadores, RLT) (Radinger et al., 2018 $8_{[16]}$ ). Under leadership of the Business Leaders Foundation for Education (Fundación Empresarios por la Educación), the programme has strong links with the regions and is aligned with central policies as well as local education strategies through a working agreement. The programme not only involves the school principal, but all members of the school leadership team who participate in training in different ways.

The development programme comprises elements of intensive training (four weeks classroom training) and continuous elements (36 weeks of support in the educational institution), and is built on a number of formats, including coaching strategies (individually, through shadowing, and in groups). After ten months of training, the school principal and his or her school prepare a plan and concrete actions to transform the school which is then implemented over two years (UNESCO, 2014 ${ }_{[159]}$ ). An evaluation of the programme has shown a positive impact on learning outcomes and drop-out rates, but also the challenge of maintaining results in the medium term (Escallón et al., 2018 $\left.8_{[160]}\right)$. 
While most systems then offer various opportunities from which school leaders might benefit - as is also evident from principals' reported participation in professional development for the TALIS 2018 (OECD, 2019, p. 153[4]) - few provide large-scale development systems for all school leaders that are aligned with strategic priorities. The broader literature on school leader professional development suggests that there is little value derived from it, despite its apparent potential in developing principal capacity and retaining them in their positions (Pont, 2014 ${ }_{[161]}$ ). The lack of a relevant offer was a commonly cited barrier for participation in professional development among school principals for the TALIS 2018 (27\% on average across participating OECD countries). As Figure 4.10 shows, the extent of this, however, differs widely across countries, from less than $10 \%$ in the Flemish Community of Belgium, England (United Kingdom), Kazakhstan, Norway and Sweden, to more than $45 \%$ in Italy, Portugal, the Slovak Republic and Spain (OECD, 2019, pp. 208, Table I.5.40[4]).

Some OECD reviews witnessed reports of limited value in school leadership development courses. For instance, in Portugal, school leaders have access to a series of industry-supported leadership courses as well as ongoing educational management courses at institutions of higher education. However, leaders of school principals' associations commented that the most effective trainings benefited only a small cohort of school leaders, and that school leaders often had difficulty finding time in their schedules to attend or did not perceive value in the courses offerings (Liebowitz et al., 2018 ${ }_{[19]}$ ).

Figure 4.10. Relevance of professional development on offer (ISCED 2), 2018

Percentage of principals who "agreed" or "strongly agreed" that the lack of a relevant offer presents a barrier to their participation in professional development

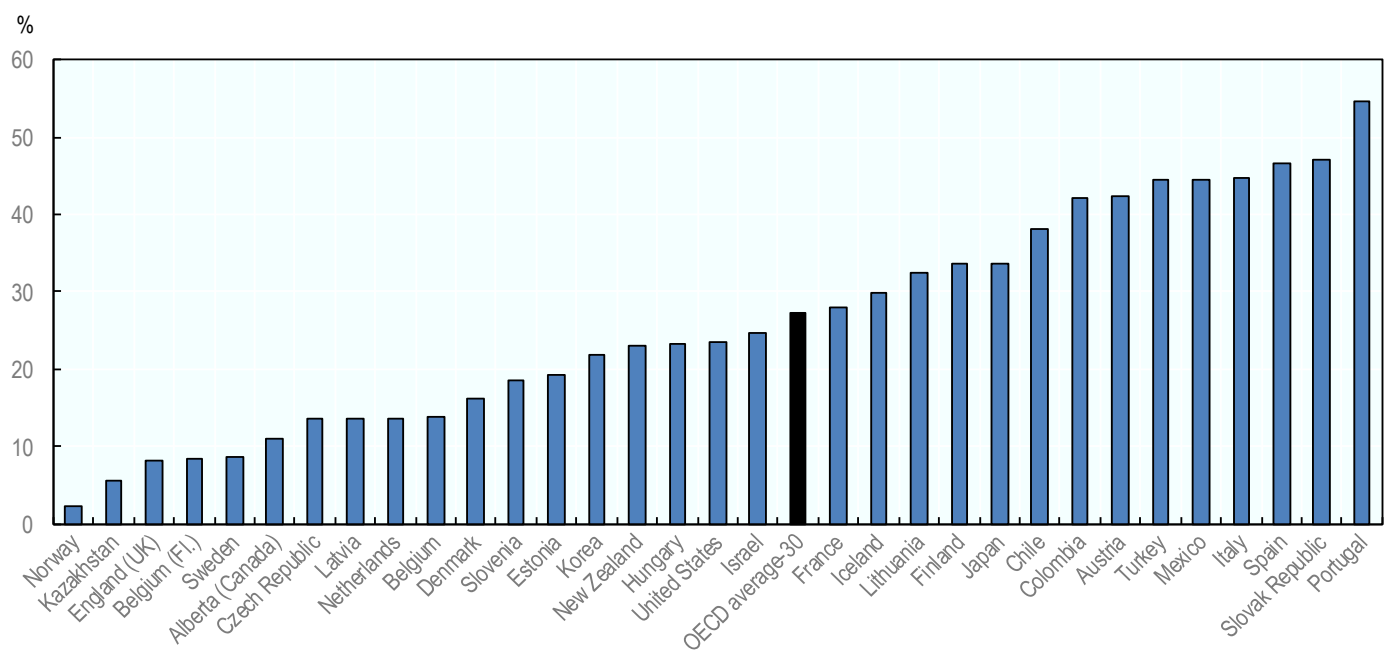

Notes: Countries and economies are ranked in ascending order in the percentage of principals who agreed or strongly agreed that the lack of a relevant offer presents a barrier to their participation in professional development. The number of countries or economies included in the OECD average is indicated next to that average. On 25 May 2018, the OECD Council invited Colombia to become a Member. While Colombia is included in the OECD average reported in this figure, at the time of its preparation, Colombia was in the process of completing its domestic procedures for ratification and the deposit of Colombia's instrument of accession to the OECD Convention was pending.

Source: OECD (2019), TALIS 2018 Results (Volume I): Teachers and School Leaders as Lifelong Learners, OECD Publishing, Paris, https://doi.org/10.1787/1d0bc92a-en, Table I.5.40. 
Where courses and networks align with a set of educational priorities, of course trade-offs exist between ensuring alignment with national or sub-national improvement areas and the value of crafting a professional learning plan most relevant to the particular school leader. The Chilean School Improvement Networks (Redes de Mejoramiento Escolar) promote this sort of learning by permitting networks to define learning priorities most relevant to them, while still focussing on system goals (Santiago et al., 2017 [34]).

Education authorities, such as municipalities, have an important role to play in supporting the development of their school leaders (Lavy and Boiko, 2017 [162]; Honig, 2012 [163]). Administrators may, however, face difficulties, such as capacity challenges, to provide support in a range of areas, including instructional improvement. In the Czech Republic, for example, school founders typically focus on support in budgetary and administrative issues, leaving pedagogical advice to the school inspection (Shewbridge et al., 2016 $6_{[96]}$ ).

Performance management and evaluation often constitutes an important element of education authorities' work with school leaders as Table 4.9 demonstrates (also see Table A.6. in Annex A). While appraisal systems for teachers are relatively infrequent and generally low stakes, the appraisal process for school leaders, while varied, is more consistently frequent and high stakes. However, school principals rarely benefit from formative feedback or receive professional development linked to their appraisal results (Radinger, 2014 $[164]$; OECD, 2013 ${ }_{[112]}$ ).

Table 4.9. School leader evaluation (ISCED 1-3), 2018

OECD review countries, public schools

\begin{tabular}{|c|c|c|c|c|c|c|c|c|c|c|c|c|c|c|c|c|c|c|c|}
\hline \multirow{2}{*}{ Ind. appraisal } & Mandatory & & & & & & & & & & & & & & & & & & \\
\hline & Discretionary & & & & & & & & & & & & & & & & & & \\
\hline \multicolumn{20}{|c|}{ External school evaluation } \\
\hline Country & & $\frac{\text { 焉 }}{\frac{0}{20}}$ & 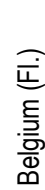 & 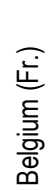 & $\frac{\Phi}{\frac{E}{U}}$ & 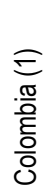 & 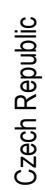 & 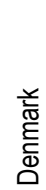 & 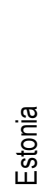 & $\begin{array}{l}\text { 음 } \\
\text { 元 } \\
\underline{0}\end{array}$ & 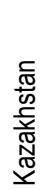 & 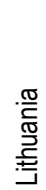 & $\begin{array}{l}\overline{\widetilde{O}} \\
\text { 흥 } \\
\text { D }\end{array}$ & 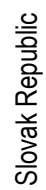 & $\begin{array}{l}\frac{\pi}{\frac{\pi}{D}} \\
\frac{0}{\omega} \\
\frac{0}{\omega}\end{array}$ & $\begin{array}{l}\text { ป } \\
\text {-⿳亠口冋] } \\
\text { की }\end{array}$ & 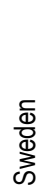 & 离 & $\begin{array}{l}\text { 홈 } \\
\text { 홀 }\end{array}$ \\
\hline
\end{tabular}

Note: For full comparative tables on school leader professional learning, see Table A.6. in Annex A.

1. Colombia: Principals of the new teacher statute (1278 of 2002) are evaluated on an annual basis; principals of the old teacher statute (2277 of 1979) are not evaluated.

2. Spain: School evaluations are carried out at discretion of state education authorities.

Source: Based on Country Background Reports and Country Review Reports

(http://www.oecd.org/education/school-resources-review/schoolresourcesreview-

reportsforparticipatingcountries.htm).

In this respect, Estonia has recently developed and promoted an innovative 360 degree feedback model which school owners may use to evaluate their principals. The school principal completes a self-assessment about their competencies, while those working with $\mathrm{him} / \mathrm{her}$ also complete an evaluation of the principal's work. This provides feedback from multiple sources and a basis to compare the self-assessment with the assessment of others, which can serve as input to an individual development plan.

In addition, school leaders are often evaluated as part of an external school evaluation and supervision process (also see Table 4.9). On one level, linking the whole-school evaluation to the individual evaluation of the school leader logically connects the performance appraisal of the school leader with the overall success of the school. On the other hand, 
such an approach risks conflating external factors such as levels of student disadvantage, poor prior culture and systems with the efforts and skills of the current school leader. In fact, credible evidence indicates that from a purely quantitative perspective, school leaders' effects on student test score outcomes are distinct from contemporaneous school effects on student outcomes (Chiang, Lipscomb and Gill, 2016 $[165]$ ).

\subsection{Policy options}

\subsubsection{Initial preparation}

Designing preparation requirements to ensure candidates have extensive opportunities for situated learning in primary and/or secondary school settings

Learning about teaching and leading requires a complex blend of theoretical and applied knowledge. Successful teachers have deep subject-matter knowledge, an understanding of child development and psychology, an awareness of the principles of the learning sciences, and a set of practiced routines for operationalising these in the context of a classroom. To be able to practice applying these skills with children, prospective teachers must have the opportunity to practice in schools. The analogous condition holds for school leaders (and potentially other types of staff and professionals in schools). School leadership requires knowledge of legal and financial requirements, an understanding of management, a deep knowledge of pedagogical and instructional techniques, and the ability to bring these to life amidst the hectic schedule of a school operational manager. Thus, preparation requirements should provide ample opportunities for teachers and leaders to learn in primary and secondary school settings.

Curriculum development for preparation programmes should receive guidance from a broad set of stakeholders including academic experts in higher education institutions, practitioners working in schools, and professional associations.

Teacher education providers should consider partnering with local school networks to identify the particular challenges specific to their communities that early career teachers face and then design curriculum in response. Following guidance from OECD (2019 $\left.9_{[3]}\right)$, ensuring that practicing teachers who serve as co-operating or supervising mentors have a say in the design of curriculum will be critical to both tailor learning for prospective teachers and provide leadership and growth opportunities for expert practitioners.

From a resource perspective, shifting credits away from classroom settings in teacher education institutions to practicum or internship experiences will require some re-adjustments. Teacher education institution may find that they will need to prioritise hiring more practitioner instructors rather than academic researchers.

\section{Investing in teacher and school leader residency programmes}

While the majority of prospective teachers and school leaders will continue to receive their training through traditional initial preparation programmes, systems may find value in investing in experimental residency programmes both for the benefit of teachers and leaders who participate in the residencies as well as for the potential of system-wide learning.

School systems might pilot a master's-level training programme (ISCED 7) that prioritises the development of applied pedagogical skills in an intensive teaching residency. Models of teacher residency exist in OECD countries developed based on the medical residency system (see Box 4.3 for examples from the United States). Candidates could be screened 
for academic skill at bachelor's level (ISCED 6) and then placed for a one-year residency in a local school. In line with the previous recommendation to encourage more in-school learning during preparation, residency programmes invert the learning model so that the overwhelming majority of candidate teacher and leaders' time is spent in a school. Prospective teachers could spend four days per week in the classroom with a highly effective experienced teacher, progressively taking more responsibility for leading the classroom. The fifth week day could be spent learning with the cohort of residents at a local teacher education institution.

The effective development of this pilot would depend on the quality of the partnership, the skill of the host classroom teachers and the design of the residency pilot in such a way to evaluate its effectiveness. In order for the residency to provide the appropriate mix of skills, the co-operating department would need to agree to design the programme curriculum to align with the goals of the project. Specifically, the coursework should efficiently introduce key theory around learning sciences, while primarily supporting teaching candidates in building skills in response to the realities they face in their classrooms. This may mean participating in non-traditional learning pedagogies.

A second key determinant of the success of residencies will be the quality of the co-operating teachers in which the residents are placed. Working with school leadership, residency programme leaders should work to identify high-capacity experienced teachers to serve as host classrooms for teaching candidates. Instructional as well as adult coaching skills are important in these roles. Finally, if the pilot is to provide valuable lessons for the broader development of teacher education, formal evaluation structures should be in place. The design of such a pilot should consider the most appropriate actor to manage the pilot.

\section{Mandating or strongly incentivising induction programmes for new or new-to-school teachers and leaders}

Formal induction and coaching supports for new teachers that focus on providing direct feedback on practice could have significant positive impacts on teachers' growth trajectories. Such a priority will require strategic resource allocations as coaching positions require dedicated time out of teachers' schedules - either a full- or part-time allocation of teaching hours is required. As discussed previously, this form of individualised support is more intensive than traditional mentoring. School systems will need to find efficiencies or trade-offs with other resources, such as class size, to invest in this resource.

\section{Creating formalised roles for early career coaches with rigorous selection processes and supporting curricula geared to adult learners}

If mentoring or coaching relationships are to be effective, the individuals in these positions must be of high capacity. Mentors and coaches should go through a rigorous selection process that requires demonstration of prior instructional effectiveness, demonstration of observation and feedback skills, and an awareness of adult learning principles. Selection might happen either through a system-wide contest or through school-site hiring processes, which would largely depend on the level of centralised governance within that country's context. Importantly, however, mentors and coaches should be selected with an eye towards the alignment of their skills to particular areas of need. The needs of early career teachers vary across impoverished rural settings, high-needs recent immigrant communities or socio-economically advantaged urban areas. Thus, the instructional and mentoring skill sets to accompany early career staff will vary too. 
Once in their roles, mentors and coaches should receive regular professional learning opportunities to grow their capacity to support early career staff. Dedicated time should be devoted in their schedules to sharing challenges and providing counsel to others in similar positions. They should also regularly receive feedback on their coaching practices from expert coaches.

In addition to the creation of the positions, the time and staff resources involved in selection and continuing development will also create resource demands that should be estimated and accounted for in budgeting processes.

\subsubsection{Continuing professional learning}

Creating supports for schools to develop coherent learning goals and designing embedded learning opportunities directed towards these goals

As OECD (2013 [112] $)$ notes, many school systems expect some or all schools to create yearly or multi-year strategies to improve learning outcomes for students. A less common feature of these requirements is to pair goal setting with supports to permit staff within the school to gain the skills and knowledge to achieve these goals. As Elmore's $\left(2004_{[121]}\right)$ principle of reciprocity suggests: "for every unit of performance I demand of you, I have a reciprocal responsibility to provide you with a unit of capacity".

Thus, policy makers could couple school-level goal setting with the design of embedded learning opportunities that help teachers and school leaders achieve these goals. Depending on the context and the nature of the needed capacity, this might take the form of time in the schedule for teachers to meet, ongoing professional development courses, support networks of schools sharing similar learning goals, electronic teaching libraries, or other tools to support adult learning. The critical aspect is that the ongoing learning experience be aligned to the school (and potentially system) goals. This ensures that colleagues can work together on their improvement.

Supporting schools to contextualise adult learning goals to the specific community they serve

Related to the importance of connecting supports to goals, schools must develop adult learning goals that respond to the needs of their school community. Emerging examples of preparation programmes exist that tailor preparation to the cultural and demographic context in which teachers will work. Though these programmes exist only in some countries and even there are still in their infancy, evidence strongly supports the value of teachers who can serve as positive cultural models (Papageorge, Gershenson and Kang, $2019_{[166]}$; Holt and Gershenson, 2017 $\left.{ }_{[167]}\right)$. Similar principles apply to continuing professional learning.

Schools (or networks of schools) should receive support to create goals that match the particular needs of their community and students. Once these goals are established, the learning opportunities provided to teacher and school leaders should reflect these needs. Culturally specific content is only one dimension for specialisation. In some contexts, strategies for connecting academic subject matter to vocational education and training (VET) courses might be particularly valuable. While in some schools, an attention to how to teach procedural mathematics skills might address a staff or student skill gap, in others providing teachers support for guiding students to explain their mathematical thinking may 
be most relevant. In some systems it may be helpful to create a database of supports that the relevant system can provide to schools which indicate a particular type of need.

\section{Identifying opportunities to create and support school-based learning teams}

While many schools and systems have traditions of staff meetings (e.g. departmental meetings, grade-level meetings, etc.), these are distinct in nature from learning teams. While schools and their teachers benefit from the traditional work of department meetings (e.g. agreement on the dates of major assessments of student work, discussion of particular student needs or alignment of tasks to learning standards), these types of activities tend to change teaching practice minimally.

The work of a learning team requires minimally i) regular, dedicated time in working schedules, ii) leadership roles, including for practicing teachers, responsible for helping to guide the work of the team, iii) supports in the form of protocols or defined processes to ensure work remains focussed on instructional and organisational improvement and iv) a school culture that tolerates and encourages peer-to-peer feedback and constructive feedback and exhortation from colleagues to attempt different instructional strategies.

Such opportunities, particularly defining time in working schedules, represent significant resource investments. While resource-constrained systems may find it tempting to seek to minimise these expenditures by focussing only on the schedule time, this may ultimately lead to the inefficient reality of increased costs with minimal improvements. Policy makers interested in the potential benefits of school-based learning teams should budget for the relatively smaller supports for team leader capacity development and resources to support teams' work.

\section{Investing in high-quality, individualised coaching for teachers and school leaders}

The benefits of coaching for early career teachers and school leaders noted above are equally present for teachers and school leaders throughout the career trajectory.

School systems which have no tradition of teacher coaching might begin by recruiting coaching staff to support, perhaps, only early career and struggling teachers. Once awareness of these programmes become more widespread, interest in serving in these roles (and willingness to receive support) may grow. School systems that already have pockets of instructional coach (or similar) roles, might consider the use of technology (e.g. video-based and/or earpiece-facilitated coaching) to allow current coaches to have a wider reach.

Ultimately, any system considering bringing coaching to all teachers will face two budgetary options. The first option would be to invest significantly in dedicated coaching positions, including in efforts to recruit coaches and provide ongoing support for coaches to ensure their coaching remains of high quality. The second option is to integrate coaching responsibilities into the duties of existing classroom teachers who would continue to have teaching as their primary responsibility. They might receive either small periods of non-instructional time or an additional stipend to provide feedback to their colleagues. The second option has the benefit of being less costly and coaches in these roles will have both current teaching experience and credibility. The evident drawback is that their attention will be spread thin and the quality of their coaching may suffer as a result. 
Investing in digital progress monitoring tools to permit schools to capture teaching and learning strategies that work, and those that do not

In order to ensure that local knowledge about effective practices persists, school systems might support the development or acquisition of electronic tools to help retain this knowledge. OECD (2017 $\left.7_{[168]}\right)$ notes that evidence-based research only partially permeates teachers' practice. Alongside strong research-practitioner partnerships, it is critical to ensure that teachers and school leaders have tools to document and sustain practices that are effective in their contexts. If an instructional strategy that a learning team of teachers is piloting leads to higher levels of learning for their students, they should have ways to codify the components of this strategy so that it will retain its effectiveness and be able to communicate its success to others.

Similarly, if a school leader identifies an effective strategy for coaching a teacher with weak classroom management skills, they should have opportunities to share this with other school leaders, test whether it is effective in other contexts and share details of the practice. Just as importantly, if a team of teachers working towards a given school-wide goal finds a particular instructional practice to be ineffective, this should also be documented to avoid similar mistakes.

One such tool might be a digital progress monitoring tool. As part of each learning team's improvement strategies, yearly or multi-year goals would have associated activities that members of the team would take to accomplish these goals. Teams would then regularly update the results of the activities undertaken. The effectiveness of the results could be evaluated against a variety of qualitative and quantitative standards. Details of the implementation of activities with positive results would be preserved for the members of the team. Staff in other contexts could then attempt similar activities and test for their effectiveness. Results could be collected via digital platforms and repositories of emerging successful practices could be generated (OECD, 2015 [115]). As certain activities demonstrate promise, they could be the subjects of more formal impact evaluations. The results of these could then serve to strengthen research-practice partnerships.

\subsubsection{Evaluation and appraisal}

\section{Investing in resources to train evaluators and distributing responsibilities}

Evaluators of both teachers and school leaders should go through calibration exercises in which they receive training on observing successful completion of staff activities defined in national or sub-national teacher and leader standards, and then must successfully observe and rate staff performance on rubrics aligned to these professional standards. Evaluators should periodically participate in calibration exercises to ensure that their ratings remain in line with defined standards. Evaluators unable to meet expectations regarding alignment to standards might receive additional support, but ultimately not be eligible to serve as an evaluator until they reach benchmarking standards. However, calibration in the theoretical ability to accurately appraise a staff member means little if the evaluator does not have the time to provide meaningful feedback or conduct sufficient observations to collect meaningful information about instructional or leadership practice. 


\section{Using the appraisal process to reflect meaningful differences in skill and effectiveness of teachers and school leaders}

The appraisal process should be used to differentiate levels of skill and effectiveness, not primarily as a method of ranking, incentivising or rewarding particular staff, but as a way to prioritise supports. If all teachers and leaders are appraised as uniformly proficient in all domains of their jobs, it is impossible to connect the appraisal process to professional learning, coaching or any other resources to help staff improve.

Appraisal systems should include rigorous, qualitative feedback on staff performance across multiple dimensions of responsibilities (e.g. lesson and unit planning, instructional practices, and assessment practices). Feedback might reflect both observed practice in these areas as well as student outcomes (for teachers) and teacher and school outcomes (for school leaders). Such an appraisal system would then permit evaluators to prioritise areas for support both within and across staff. Some struggling teachers and school leaders might receive extra coaching support across multiple domains; others might receive less overall support, but when they do receive such support it would be clearly targeted to a particular domain. Depending on the extent to which systems rely exclusively on qualitative feedback, the prioritisation of supports might depend on close review by school leaders or education administrators to determine which staff would benefit the most from the highest level of resource allocation.

Given the cultural and normative barriers documented earlier in this chapter, there will be likely forces that encourage most appraisals to avoid constructive, critical feedback. Some approaches for ensuring appraisals that reflect the true needs of teachers might be "normative-" (i.e. mandating a range of appraisal ratings for each evaluator) or "criterion-referenced" (i.e. ensuring that evaluators are fully calibrated and preventing those who are not from evaluating). Others could involve testing the external validity of an evaluator's ratings against student outcomes or stakeholder surveys. While normative-referenced ratings might ensure that educators receive clearer indications of their areas for growth, they risk introducing inappropriate competition into the school context. Criterion-referenced ratings might avoid this challenge. In either case, significant investment in the skill development of evaluators is critical to ensure that teachers and school leaders receive fair appraisals that generate meaningful areas for improvement.

Using multiple measures, including observations, classroom or school processes, student outcomes and surveys, to conduct holistic appraisal

Teaching and school leadership are highly complex. Summarising performance in these domains in a single measurement such as a test score or single observation faces substantial reliability and validity challenges. Multiple measures of teaching and leadership practice, including observations, portfolio reviews of classroom or school processes, student outcomes, stakeholder surveys and others can help to triangulate these multiple perspectives. A critical consideration is how to weight each of these dimensions.

Weighting various factors in a multiple measure appraisal system includes both substantive and resource choices, as well as being influenced by the methodological design of the measurement. Some school systems may value the professional judgement of trained observers, whereas others may have an interest in ensuring that student and community voice is heavily represented. Measurement tools that require frequent observations, dedicated roles responsible for evaluation, or the development and administration of large-scale surveys impose considerable costs. On the other hand, measurement tools that 
leverage existing practices, such as national student testing or existing student surveys, and apply the results of them to the appraisal process are less resource intensive. That is to say that the process of attributing improvements in learning to particular teachers, while methodologically debatable, is a relatively inexpensive activity. A key consideration is that any component of a multiple measure appraisal system that does little to differentiation between staff will receive less weight compared to the other measures, even if it is designed to contribute more to the overall rating.

\section{Linking results of the appraisal process to professional development with stakes focussed on developmental plans}

If school systems have an interest in supporting professional learning and growth, results of the appraisal process should be explicitly linked to professional development. Struggling teachers and school leaders might be assigned developmental plans that require more rigorous oversight to ensure that particular tasks are completed.

More highly rated staff might have more discretion in the activities they pursue. In the interest of resource preservation, these teachers and leaders might also have fewer external supports, and instead be expected to internalise the results of their appraisals and pursue independent learning activities. Of course, there are some risks to such an approach as this may limit the development of the most promising staff and lead to performance plateaus.

Notes

${ }^{1}$ See also the project's TeacherReady! Platform (http://www.oecdteacherready.org) and ongoing work as part of the OECD Study on Supporting Teacher Learning for Quality Teaching (2019-20), which examines the continuum of teachers' professional learning from initial teacher education through to the first years in teaching and beyond.

${ }^{2}$ The European Credit Transfer and Accumulation System (ECTS) is a tool of the European Higher Education Area for making studies and courses more transparent and to facilitate student mobility. ECTS credits represent learning based on defined learning outcomes and their associated workload. 60 ECTS credits are the equivalent of a full year of study or work. In a standard academic year, these credits are usually broken down into several smaller modules.

${ }^{3}$ In Austria, responsibilities for school education differ between federal schools and provincial schools. Federal schools (Bundesschulen) comprise academic secondary schools as well as upper secondary vocational schools and colleges (ISCED 2-3). Provincial schools (Landesschulen) include primary schools, general lower secondary schools, New Secondary Schools (referred to as Secondary Schools from September 2020), special needs schools, pre-vocational schools and parttime upper secondary vocational schools (ISCED 1-3).

${ }^{4}$ In Colombia, decentralisation in education has been managed by a process of certification of departments (the regional level) and districts and municipalities (the local level). All departments and large municipalities are certified to provide pre-school and school education. Education in municipalities that have not been certified is under the responsibility of the respective department.

${ }^{5}$ The two programmes are the Fast Track for Migrant Teachers (Snabbspar) and Complimentary Pedagogical Education (Kompletterande pedagogisk utbildning, KPU). 
${ }^{6}$ On 25 May 2018, the OECD Council invited Colombia to become a Member. While Colombia is included in the OECD average reported for TALIS 2018 throughout this report, at the time of its preparation, Colombia was in the process of completing its domestic procedures for ratification and the deposit of Colombia's instrument of accession to the OECD Convention was pending.

${ }^{7}$ For instance, in Spain, teachers in urban schools report a higher level of participation compared to rural schools (3.1 percentage point difference); in Colombia, Mexico and Spain, teachers in private schools report a higher level of participation compared to public schools $(6.2,6.9$ and 4.2 percentage point difference), while the opposite is the case in Chile ( 7 percentage points); in Chile, teachers in schools with a relatively high concentration of students from socio-economically disadvantaged homes (over 30\%) report a higher level of participation compared to teachers in schools with lower concentrations of students from socio-economically disadvantaged homes (9 percentage points).

${ }^{8}$ On average across the 19 PISA-participating countries and economies with available data, a rise of one unit on the index of teacher collaboration is associated with a rise of 0.22 point in teachers' satisfaction with their profession and an increase of 0.35 point in satisfaction with their current job, after accounting for teachers' demographic characteristics. The effects are similar across countries.

${ }^{9}$ New Secondary Schools (Neue Mittelschule, NMS) were introduced in 2008 to provide a more inclusive alternative to general secondary schools, avoid early tracking and use innovative pedagogical methods. This type of school has since become the new standard school for lower secondary education and will be referred to as Secondary Schools from September 2020 onwards. 


\section{References}

Alfonso, M. and M. Bassi (2010), "Estimating the impact of placing top university graduates in vulnerable schools in Chile", Inter-American Development Bank Education Division Technical Notes, No. IDB-TN-230, Inter-American Development Bank, https://publications.iadb.org (accessed on 15 March 2019).

Allen, J. et al. (2011), “An interaction-based approach to enhancing secondary school instruction and student achievement.", Science, Vol. 333/6045, pp. 1034-7, http://dx.doi.org/10.1126/science.1207998.

Allen, R. and J. Allnutt (2017), "The impact of Teach First on pupil attainment at age 16", British Educational Research Journal, Vol. 43/4, pp. 627-646, https://doi.org/10.1002/berj.3288.

American Statistical Association (2014), American Statistical Association (ASA) Statement on Using Value-Added Models for Educational Assessment, American Statistical Association, Alexandria, VA, http://www.amstat.org/asa/files/pdfs/POL-ASAVAM-Statement.pdf (accessed on 15 April 2019).

Ballou, D. and M. Springer (2015), "Using student test scores to measure teacher performance: Some problems in the design and implementation of evaluation systems", Educational Researcher, Vol. 44/2, pp. 77-86, http://dx.doi.org/10.3102/0013189X15574904.

Bastian, K. and G. Henry (2015), "The apprentice: Pathways to the principalship and student achievement”, Educational Administration Quarterly, Vol. 51/4, pp. 600-639, http://dx.doi.org/10.1177/0013161X14562213.

Bill \& Melinda Gates Foundation (2018), Networks for School Improvement: Working together to help students succeed, http://k12education.gatesfoundation.org/what-we-do/networks-forschool-improvement/ (accessed on 3 May 2019).

Blazar, D. and M. Kraft (2017), “Teacher and teaching effects on students attitudes and behaviors", Educational Evaluation and Policy Analysis, Vol. 39/1, pp. 146-170, http://dx.doi.org/10.3102/0162373716670260.

Blazar, D. and M. Kraft (2015), "Exploring mechanisms of effective teacher coaching: A tale of two cohorts from a randomized experiment", Educational Evaluation and Policy Analysis, Vol. 37/4, pp. 542-566, http://dx.doi.org/10.3102/0162373715579487.

Boyd, D. et al. (2008), "The narrowing gap in New York City teacher qualifications and its implications for student achievement in high-poverty schools", Journal of Policy Analysis and Management, Vol. 27/4, pp. 793-818, http://dx.doi.org/10.1002/pam.20377.

Buckskin, P. (2017), More Aboriginal and Torres Strait Islander Teachers Initiative Final Report, University of South Australia, Adelaide, http://matsiti.edu.au/wpcontent/uploads/2017/02/MATSITI-Final-Report-1.0.pdf (accessed on 5 February 2019).

Campbell, P. and N. Malkus (2011), "The impact of elementary mathematics coaches on student achievement", The Elementary School Journal, Vol. 111/3, pp. 430-454, http://dx.doi.org/10.1086/657654.

Centro de Estudios MINEDUC (2016), Reporte Nacional de Chile: Revisión OCDE para mejorar la efectividad del uso de recursos en las escuelas, informe preparado por el Ministerio de Educación, la Agencia de Calidad de la Educación y la Superintendencia de Educación, Ministerio de Educación, Santiago, Chile, http://www.oecd.

org/edu/school/schoolresourcesreview.htm. 
Cerna, L. et al. (2019), "Strength through diversity's Spotlight Report for Sweden", OECD

Education Working Papers, No. 194, OECD Publishing, Paris, https://dx.doi.org/10.1787/059ce467-en.

Chacon, A. and P. Pena (2017), El impacto de Enseña por México en las habilidades socioemocionales de los estudiantes: Resumen de Resultados, https://www.ensenapormexico.org (accessed on 15 June 2019).

Charner-Laird, M. et al. (2017), "Gauging goodness of fit: Teachers' responses to their instructional teams in high-poverty schools", American Journal of Education, Vol. 123/4, pp. 553-584, http://dx.doi.org/10.1086/692663.

Cherubini, L. (2009), "Reconciling the tensions of new teachers' socialisation into school culture: A review of the research", Issues in Educational Research, Vol. 19/2, pp. 83-99, http://www.iier.org.au/iier19/cherubini.pdf.

Chetty, R., J. Friedman and J. Rockoff (2017), "Measuring the Impacts of Teachers: Reply", American Economic Review, Vol. 107/6, pp. 1685-1717, http://dx.doi.org/10.1257/aer.20170108.

Chetty, R., J. Friedman and J. Rockoff (2014), "Discussion of the American Statistical Association's Statement (2014) on using value-added models for educational assessment", Statistics and Public Policy, Vol. 1/1, pp. 111-113, http://dx.doi.org/10.1080/2330443X.2014.955227.

Chiang, H., S. Lipscomb and B. Gill (2016), "Is school value added indicative of principal quality?", Education Finance and Polciy, Vol. 11/3, pp. 283-309, https://doi.org/10.1162/EDFP_a_00184.

Clark, D., P. Martorell and J. Rockoff (2009), "School principals and school performance", CALDER Working Paper Series, No. 38, https://caldercenter.org/publications/schoolprincipals-and-school-performance (accessed on 18 April 2019).

Clark, M. et al. (2017), Impacts of the Teach for America Investing in Innovation Scale-Up, Mathematica Policy Research, https://www.mathematica-mpr.com/ (accessed on 17 April 2019).

Cochran-Smith, M. and S. Lytle (2001), "Beyond certainty: taking an inquiry stance on practice", in Lieberman, A. and L. Miller (eds.), Teachers Caught in the Action: Professional Development That Matters, Teachers College Press, New York, NY.

ouncil for the Accreditation of Educator Preparation (2013), 2013 CAEP Standards, CAEP, Washington, DC, http://caepnet.org (accessed on 1 April 2019).

Delaney, S. et al. (2008), "Adapting U.S. measures of "Mathematical Knowledge for Teaching" for use in Ireland", Journal of Mathematics Teacher Education, Vol. 11/3, pp. 171-197, https://doi.org/10.1007/s10857-008-9072-1.

Deming, W. (2000), The New Economics: For Industry, Government, Education, MIT Press, Cambridge, MA.

Department for Education (2019), Early Career Framework, https://www.gov.uk/government/publications/supporting-early-career-teachers (accessed on 19 March 2019).

Department for Education (2019), Teacher Recruitment and Retention Strategy, https://www.gov.uk/government/publications/teacher-recruitment-and-retention-strategy (accessed on 1 April 2019).

Desimone, L. and M. Garet (2015), "Best practices in teachers' professional development in the United States", Psychology, Society and Education, Vol. 7, pp. 252-263, http://dx.doi.org/10.25115/psye.v7i3.515. 
Donaldson, M. (2011), "Teach for America teachers: How long do they teach? Why do they leave?”, Phi Delta Kappan, Vol. 93/2, pp. 47-51, https://doi.org/10.1177/003172171109300211.

Echazarra, A. and T. Radinger (2019), "Learning in rural schools: Insights from PISA, TALIS and the literature", OECD Education Working Papers, Vol. No. 196, http://dx.doi.org/10.1787/8b1a5cb9-en.

Education Council New Zealand (2011), Cultural Competencies for Teachers of Māori Learners, Ministry of Education, Wellington, https://teachingcouncil.nz/sites/default/files/Tataiako_FINAL_web_mar16.pdf (accessed on 15 February 2019).

Elmore, R. (2004), School Reform from the Inside Out, Harvard Education Press, Cambridge, MA.

Emmer, E. and L. Stough (2001), "Classroom management: A critical part of educational psychology with implications for teacher education", Educational Psychologist, Vol. 36/2, pp. 103-112, http://dx.doi.org/10.1207/S15326985EP3602_5.

Escallón, E. et al. (2018), Evaluación de impacto del programa Rectores Líderes TransformadoresResumen Ejecutivo -Fase II, Fundación Empresarios por la Educación (FExE), Bogotá, DC, https://fundacionexe.org.co/wp-content/uploads/2018/07/ResumenEjecutivo-Evaluacio\%CC\%81n-RLT-Fase-II-26-09-2017-.pdf (accessed on 14 May 2019).

Estonian Ministry of Education and Research (2015), OECD Review of Policies to Improve the Effectiveness of Resource Use in Schools: Country Background Report for Estonia, Estonian Ministry of Education and Research, Tartu, http://www.oecd.org/education/schoolresourcesreview.htm.

European Commission (2017), Preparing Teachers for Diversity: The Role of Initial Teacher Education. Final Report to DG Education, Youth, Sport and Culture of the European Commission Written by Public Policy and Management Institute (PPMI), Publications Office of the European Union, Luxembourg, https://publications.europa.eu (accessed on 15 November 2018).

European Commission/EACEA/Eurydice (2018), Teaching Careers in Europe: Access, Progression and Support, Publications Office of the European Union, Luxembourg, https://eacea.ec.europa.eu/national-policies/eurydice/content/teaching-careers-europeaccess-progression-and-support_en (accessed on 15 February 2019).

European Commission/EACEA/Eurydice (2015), The Teaching Profession in Europe: Practices, Perceptions, and Policies, Publications Office of the European Union, Luxembourg, https://eacea.ec.europa.eu/national-policies/eurydice/content/teachingprofession-europe-practices-perceptions-and-policies_en (accessed on 9 February 2018).

Eurydice (2019), Database of National Education Systems, https://eacea.ec.europa.eu/nationalpolicies/eurydice/national-description_en.

Feuer, M. et al. (2013), Evaluation of teacher preparation programs: Purposes, methods and policy options, National Academy of Education, Washington, DC, https://naeducation.org (accessed on 1 March 2019).

Figazzolo, L. (2013), The use and misuse of teacher appraisal: An overview of cases in the developed world, https://download.ei-ie.org/Docs/WebDepot/TeacherAppraisal.pdf (accessed on 1 April 2019).

Figueroa. M., S. et al. (2018), "La profesión docente en Colombia: normatividad, formación, selección y evaluación”, Documentos de Trabajo Escuela de Gobierno Alberto Lleras Camargo, No. 54, Universidad de los Andes, Bogotá, DC, http://egob.uniandes.edu.co (accessed on 1 May 2019). 
Finigan-Carr, N. and W. Shaia (2018), "School social workers as partners in the school mission", Phi Delta Kappan, Vol. 99/7, pp. 26-30, https://doi.org/10.1177/0031721718767856.

Fryer, R. (2017), "Management and student achievement: Evidence from a randomized field experiment", NBER Working Papers, No. 23437, National Bureau of Economic Research, Cambridge, MA, http://dx.doi.org/10.3386/w23437.

Garet, M. et al. (2008), The Impact of Two Professional Development Interventions on Early Reading Instruction and Achievement. (NCEE 2008-4030), US Department of Education, Institute of Education Sciences, Washington, DC, http://ies.ed.gov/ncee (accessed on 15 June 2019).

Garet, M. et al. (2016), Focusing on Mathematical Knowledge: The Impact of Content-Intensive Teacher Professional Development (NCEE 2016-4010), US Department of Education, Institute of Education Sciences, https://ies.ed.gov/ncee/ (accessed on 4 June 2019).

Garet, M. et al. (2001), "What makes professional development effective? Results from a national sample of teachers", American Educational Research Journal Winter, Vol. 38/4, pp. 915-945, http://dx.doi.org/10.3102/00028312038004915.

Gates, S. et al. (2019), Preparing School Leaders for Success: Evaluation of New Leaders' Aspiring Principals Program, 2012-2017, Rand Corporation, Santa Monica, CA, http://dx.doi.org/10.7249/RR2812.

Gershenson, S. (2016), "Linking teacher quality, student attendance, and student achievement", Education Finance and Policy, Vol. 11/2, pp. 125-149, http://dx.doi.org/10.1162/EDFP a 00180.

Glazerman, S. et al. (2010), Impacts of Comprehensive Teacher Induction Final Results from a Randomized Controlled Study (NCEE 2010-4027), US Department of Education, Institute for Education Sciences, Washington, DC, http://ies.ed.gov/ncee/ (accessed on 5 April 2019).

Goldstein, M. (2012), "Studying teacher moves", Education Next, Vol. 12/1, pp. 23-28, https://www.educationnext.org/studying-teacher-moves (accessed on 1 March 2019).

Grissom, J., R. Blissett and H. Mitani (2018), "Evaluating school principals: Supervisor ratings of principal practice and job performance", Educational Evaluation and Policy Analysis, Vol. 40/3, pp. 446-472, http://dx.doi.org/10.3102/0162373718783883.

Grissom, J. and S. Loeb (2017), “Assessing principals' assessments: Subjective evaluations of teacher effectiveness in low- and high-stakes environments", Education Finance and Policy, Vol. 12/3, pp. 369-395, http://dx.doi.org/10.1162/EDFP a 00210.

Grossman, P., K. Hammerness and M. McDonald (2009), "Redefining teaching, re-imagining teacher education", Teachers and Teaching, Vol. 15/2, pp. 273-289, http://dx.doi.org/10.1080/13540600902875340.

Guarino, C., M. Reckase and J. Wooldridge (2015), "Can value-added measures of teacher performance be trusted?", Education Finance and Policy, Vol. 10/1, pp. 117-156, http://dx.doi.org/10.1162/EDFP a 00153.

Guerriero, S. (ed.) (2017), Pedagogical Knowledge and the Changing Nature of the Teaching Profession, Educational Research and Innovation, OECD Publishing, Paris, https://dx.doi.org/10.1787/9789264270695-en.

Guha, R., M. Hyler and L. Darling-Hammond (2016), The Teacher Residency: An Innovative Model for Preparing Teachers, Learning Policy Institute, Palo Alto, CA, https://learningpolicyinstitute.org/product/teacher-residency. (accessed on 23 June 2018).

Guskey, T. (1986), "Staff development and the process of teacher change", Educational Researcher, Vol. 15/5, pp. 5-12, http://dx.doi.org/10.3102/0013189x015005005. 
Hammersley-Fletcher, L., S. Ainsworth and C. Davies (2018), Literature review and comparative analysis on subject-specific development needs of middle leaders, Final report to Ambition School Leadership and Institute for Teaching, Ambition Institute, London, https://www.ambition.org.uk/blog/developing-subject-specialisms-middle-leaders (accessed on 16 April 2019).

Handel, M. (2012), "Trends in Job Skill Demands in OECD Countries", OECD Social, Employment and Migration Working Papers, No. 143, OECD Publishing, Paris, https://dx.doi.org/10.1787/5k8zk8pcq6td-en.

Hargreaves, A. and M. O'Connor (2018), "Solidarity with solidity", Phi Delta Kappan, Vol. 100/1, pp. 20-24, http://dx.doi.org/10.1177/0031721718797116.

Haridus- Ja Taedusministeerium (2016), Teacher and School leader Training and development, https://www.hm.ee/et/tegevused/opetaja-ja-koolijuht/koolitus-ja-arendustegevus (accessed on 15 January 2019).

Harris, D. and T. Sass (2011), "Teacher training, teacher quality and student achievement", Journal of Human Resources, Vol. 95, pp. 798-812, http://dx.doi.org/10.1016/j.jpubeco.2010.11.009.

Herlihy, C. et al. (2014), "State and local efforts to investigate the validity and reliability of scores from teacher evaluation systems", Teachers College Record, Vol. 116/1, pp. 1-28, https://www.tcrecord.org.

Hill, H. (2007), "Learning in the teacher workforce", Future of Children, Vol. 17, pp. 111-127, https://www.jstor.org/stable/4150022.

Hill, H., B. Rowan and D. Ball (2005), "Effects of teachers' mathematical knowledge for teaching on student achievement", American Education Research Journal, Vol. 42/2, pp. 371-406, https://doi.org/10.3102/00028312042002371.

Holt, S. and S. Gershenson (2017), "The impact of demographic representation on absences and suspensions", Policy Studies Journal, Vol. 0/0, pp. 1-31, https://doi.org/10.1111/psj.12229.

Honig, M. (2012), "District central office leadership as teaching", Educational Administration Quarterly, Vol. 48/4, pp. 733-774, http://dx.doi.org/10.1177/0013161x12443258.

Hoxby, C. and C. Avery (2013), "The missing "one-offs": The hidden supply of highachieving, low-income students", Brookings Papers on Economic Activity, Vol. 2013/1, pp. 1-65, http://dx.doi.org/doi:10.1353/eca.2013.0000.

Ingersoll, M., L. Merrill and H. May (2014), What are the effects of teacehr education and preparation on beginning teacher attrition? Research Report (\#RR-82), Consortium for Policy Research in Education, University of Pennsylvania, Philadelphia, https://www.cpre.org (accessed on 16 March 2019).

Ingersoll, R. and M. Strong (2011), "The impact of induction and mentoring programs for beginning teachers: A critical review of the reseasrch", Review of Educational Research, Vol. 81/2, pp. 201-233, https://doi.org/10.3102/0034654311403323.

Isoré, M. (2009), "Teacher Evaluation: Current Practices in OECD Countries and a Literature Review", OECD Education Working Papers, No. 23, OECD Publishing, Paris, http://dx.doi.org/10.1787/223283631428.

Jackson, C., J. Rockoff and D. Staiger (2014), "Teacher effects and teacher-related policies", Annual Review of Economics, Vol. 6/1, pp. 801-825, http://dx.doi.org/10.1146/annureveconomics-080213-040845.

Jacob, B. and L. Lefgren (2004), "The impact of teacher training on student achievement qusaiexperimental evidence from school reform efforts in Chicago", Journal of Human Resources, Vol. 39/1, pp. 50-79, http://dx.doi.org/10.2307/3559005. 
Jayapragas, P. (2016), "Leaders in Education Program: The Singapore model for developing effective principal-ship capability", Current Issues in Comparative Education, Vol. 19/191, pp. 92-108, https://www.tc.columbia.edu/cice.

Jensen, B. et al. (2012), The Experience of New Teachers: Results from TALIS 2008, TALIS, OECD Publishing, Paris, https://dx.doi.org/10.1787/9789264120952-en.

Jensen, V. and C. Nielsen (2018), Viden om Folkeskolereformen: Opsamling af resultater fra følgeforskningsprogrammet 2015-2018 [Knowledge about the Folkeskole reform: Collection of results from the follow-up research programme, 2015-2018], VIVE, Copenhagen, https://www.vive.dk/da/udgivelser/viden-om-folkeskolereformen-11269 (accessed on 3 May 2019).

Jenset, I., K. Klette and K. Hammerness (2017), "Grounding teacher education in practice around the world: An examination of teacher education coursework in teacher education programs in Finland, Norway, and the United Sates", Journal of Teacher Education, Vol. 69/2, pp. 184-197, http://dx.doi.org/10.1177/0022487117728248.

Johnson, S., M. Kraft and J. Papay (2012), "How context matters in high-need schools: The effects of teachers' working conditions on their professional satisfaction and their students' achievement", Teachers College Record, Vol. 114/10, pp. 1-39, https://www.tcrecord.org/.

Joyce, B. and B. Showers (2002), Student achievement through staff development, Association for Supervision and Curriculum Development, Alexandria, VA.

Kane, T. (2018), Develop and validate - Then scale, https://www.educationnext.org/developvalidate-scale-lessons-gates-foundation-effective-teaching-strategy (accessed on 6 April 2019).

Kane, T. and D. Staiger (2012), Gathering Feedback on Teaching: Combining High-Quality Observations with Student Surveys and Achievement Gains. Research Paper. MET Project, Bill \& Melinda Gates Foundation, Seattle, WA, http://www.gatesfoundation.org (accessed on 20 September 2017).

Katz, S., L. Earl and S. Ben Jaafar (2009), How networked learning communities work, Corwin, Thousand Oaks, CA, http://dx.doi.org/10.4135/9781452219196.n2.

Kennedy, M. (2016), “How does professional development improve teaching?", Review of Educational Research, Vol. 86, pp. 945-980, http://dx.doi.org/10.3102/0034654315626800.

Keo, S. (2016), Shaping strong principals in Singapore: Success by design, National Center on Education and the Economy Top of the Class Series, http://ncee.org/2016/02/shapingstrong-principals-in-singapore-success-by-design/ (accessed on 22 February 2018).

Koedel, C. and J. Betts (2011), "Does student sorting invalidate value-added models of teacher effectiveness? An extended analysis of the Rothstein critique", Education Finance and Policy, Vol. 6/1, pp. 18-42, http://dx.doi.org/10.1162/EDFP_a 00027.

Kools, M. and L. Stoll (2016), "What Makes a School a Learning Organisation?”, OECD Education Working Papers, No. 137, OECD Publishing, Paris, http://dx.doi.org/10.1787/5jlwm62b3bvh-en.

Kraft, M. (2017), "Teacher effects on complex cognitive skills and social-emotional competencies", Journal of Human Resources, Vol. 0/0, http://dx.doi.org/10.3368/jhr.54.1.0916.8265R3.

Kraft, M. and D. Blazar (2016), "Individualized coaching to improve teacher practice across grades and subjects: New experimental evidence", Educational Policy, Vol. 0/0, pp. 1-36, http://dx.doi.org/10.1177/0895904816631099. 
Kraft, M., D. Blazar and D. Hogan (2018), "The effect of teacher coaching on instruction and achievement: A meta-analysis of the causal evidence", Review of Educational Research, http://dx.doi.org/10.3102/0034654318759268.

Kraft, M. and A. Gilmour (2017), "Revisiting the widget effect: Teacher evaluation reforms and the distribution of teacher effectiveness", Educational Researcher, Vol. 46/5, pp. 234-249, http://dx.doi.org/10.3102/0013189X17718797.

Kraft, M. and A. Gilmour (2016), "Can principals promote teacher development as evaluators? A case study of principals' views and experiences", Educational Administration Quarterly, Vol. 52/5, pp. 711-753, http://dx.doi.org/10.1177/0013161X16653445.

Kraft, M. and J. Papay (2014), "Can professional environments in schools promote teacher development? Explaining heterogeneity in returns to teaching experience", Educational Evaluation and Policy Analysis, Vol. 36/4, pp. 476-500, http://dx.doi.org/10.3102/0162373713519496.

Kraft, M., J. Papay and O. Chi (2019), “Teacher skill development: Evidence from performance ratings by principals", Working Paper, Brown University, Providence, RI, https://scholar.harvard.edu/files/mkraft/files/kraft_papay_chi_2018 teacher_skill_developm ent.pdf (accessed on 19 April 2019).

Lance, K. and D. Kachel (2018), "Why school librarians matter: What years of research tell us", Phi Delta Kappan, Vol. 99/7, pp. 15-20, https://doi.org/10.1177/0031721718767854.

Lavy, V. and A. Boiko (2017), "Management quality in public education: Superintendent valueadded, student outcomes and mechanisms", NBER Working Papers, No. 24028, National Bureau of Economic Research, Cambridge, MA, http://dx.doi.org/10.3386/w24028.

Liebowitz, D. et al. (2018), OECD Reviews of School Resources: Portugal 2018, OECD Reviews of School Resources, OECD Publishing, Paris, https://dx.doi.org/10.1787/9789264308411-en.

Little, J. (1993), “Teachers' professional development in a climate of educational reform”, Educational Evaluation and Policy Analysis Summer, Vol. 15/2, pp. 129-151, http://dx.doi.org/10.3102/01623737015002129.

Masdeu Navarro, F. (2015), “Learning support staff: A literature review”, OECD Education Working Papers, No. 125, OECD Publishing, Paris, https://dx.doi.org/10.1787/5jrnzm39w451-en.

MINEDUC (2019), Trabajo Collaborativo y Desarrollo Profesional Docente en la Escuela, Ministerio de Educación, Santiago, Chile, https://bibliotecadigital.mineduc.cl/handle/20.500.12365/2266 (accessed on 10 March 2019).

Ministère de la Fédération Wallonie-Bruxelles (2016), Examen de l'OCDE des politiques pour un usage plus efficace des ressources scolaires RAPPORT PAYS Communauté française de Belgique, Ministère de la Fédération Wallonie-Bruxelles, Bruxelles, http://www.oecd.org/education/school-resources-review/reports-for-participating-countriescountry-background-reports.htm.

Mostafa, T. and J. Pál (2018), "Science teachers' satisfaction: Evidence from the PISA 2015 teacher survey", OECD Education Working Papers, No. 168, OECD Publishing, Paris, https://dx.doi.org/10.1787/1ecdb4e3-en.

National Center for Education Statistics (2017), National Teacher and Principal Survey (NTPS), Public School Principal Data File, 2015-16, https://nces.ed.gov (accessed on 16 April 2019). 
National Center for Teacher Residencies (2018), NCTR's Teacher Residency Program Partners, https://nctresidencies.org/about/who-residencies-serve/ (accessed on 22 February 2018).

National Center for Teacher Residencies (2018), Part 2: States' ESSA Plans and Teacher Residencies - NCTR, https://nctresidencies.org/part-2-states-essa-plans-teacher-residencies/ (accessed on 22 February 2018).

New Zealand Ministry of Education (2019), Communities of Learning/Kāhui Ako, https://www.education.govt.nz/communities-of-learning (accessed on 15 June 2019).

New Zealand Ministry of Education (2018), Tapasā: Cultural competencies framework fo teachers of Pacific Learners, Ministry of Education, Wellington, https://teachingcouncil.nz/content/tapas\%C4\%81-cultural-competencies-frameworkteachers-of-pacific-learners (accessed on 19 April 2019).

Norwegian Ministry of Education and Research (2018), Teacher Education 2025: National Strategy for Quality and Cooperation in Teacher Education, Norwegian Ministry of Education and Research, Oslo, https://www.regjeringen.no/contentassets/d0c1da83bce94e2da21d5f631bbae817/kd teacher -education-2025_uu.pdf (accessed on 19 February 2019).

Nusche, D. et al. (2016), OECD Reviews of School Resources: Austria 2016, OECD Reviews of School Resources, OECD Publishing, Paris, http://dx.doi.org/10.1787/9789264256729-en.

Nusche, D. et al. (2016), OECD Reviews of School Resources: Denmark 2016, OECD Reviews of School Resources, OECD Publishing, Paris, http://dx.doi.org/10.1787/9789264262430en.

OECD (2019), A Flying Start: Improving Initial Teacher Preparation Systems, OECD Publishing, Paris, https://dx.doi.org/10.1787/cf74e549-en.

OECD (2019), TALIS 2018 Results (Volume I): Teachers and School Leaders as Lifelong Learners, TALIS, OECD Publishing, Paris, https://dx.doi.org/10.1787/1d0bc92a-en.

OECD (2018), Developing Schools as Learning Organisations in Wales, Implementing Education Policies, OECD Publishing, Paris, https://dx.doi.org/10.1787/9789264307193-en.

OECD (2018), OECD Future of Education and Skills 2030Conceptual learning framework. Concept note: OECD Learning Compass 2030, OECD, Paris, https://www.oecd.org/education/2030-project (accessed on 24 March 2019).

OECD (2018), Responsive School Systems: Connecting Facilities, Sectors and Programmes for Student Success, OECD Reviews of School Resources, OECD Publishing, Paris, https://dx.doi.org/10.1787/9789264306707-en.

OECD (2018), The Resilience of Students with an Immigrant Background: Factors that Shape Well-being, OECD Reviews of Migrant Education, OECD Publishing, Paris, https://dx.doi.org/10.1787/9789264292093-en.

OECD (2017), Promising Practices in Supporting Success for Indigenous Students, OECD Publishing, Paris, https://dx.doi.org/10.1787/9789264279421-en.

OECD (2017), The Funding of School Education: Connecting Resources and Learning, OECD Reviews of School Resources, OECD Publishing, Paris, https://dx.doi.org/10.1787/9789264276147-en.

OECD (2015), Education at a Glance 2015: OECD Indicators, OECD Publishing, Paris, https://dx.doi.org/10.1787/eag-2015-en. 
OECD (2015), Schooling Redesigned: Towards Innovative Learning Systems, Educational Research and Innovation, OECD Publishing, Paris, http://dx.doi.org/10.1787/9789264245914-en.

OECD (2014), TALIS 2013 Results: An International Perspective on Teaching and Learning, OECD Publishing, Paris, http://dx.doi.org/10.1787/9789264196261-en.

OECD (2013), Innovative Learning Environments, Educational Research and Innovation, OECD Publishing, Paris, https://dx.doi.org/10.1787/9789264203488-en.

OECD (2013), Synergies for Better Learning: An International Perspective on Evaluation and Assessment, OECD Reviews of Evaluation and Assessment in Education, OECD Publishing, Paris, http://dx.doi.org/10.1787/9789264190658-en.

O’Neill, S. and J. Stephenson (2012), "Does classroom management coursework influence preservice teachers' perceived preparedness or confidence?", Teaching and Teacher Education, Vol. 28/8, pp. 1131-1143, https://doi.org/10.1016/j.tate.2012.06.008.

Ontario Ministry of Education (2014), Collaborative Inquiry in Ontario: What Have We Learned adn Where are We Now, Capabity Building Series, No. 39, Ontario Ministry of Education, Toronto, ON, http://www.edu.gov.on.ca/eng/literacynumeracy/inspire/research/CBS_CollaborativeInquiry .pdf (accessed on 22 February 2018).

Opfer, D. (2016), "Conditions and Practices Associated with Teacher Professional Development and Its Impact on Instruction in TALIS 2013", OECD Education Working Papers, No. 138, OECD Publishing, Paris, https://dx.doi.org/10.1787/5jlss4r01rg5-en.

Paniagua, A. and A. Sánchez-Martí (2018), "Early Career Teachers: Pioneers Triggering Innovation or Compliant Professionals?", OECD Education Working Papers, No. 190, OECD Publishing, Paris, https://dx.doi.org/10.1787/4a7043f9-en.

Papageorge, N., S. Gershenson and K. Kang (2019), “Teacher expectations matter”, The Review of Economics and Statistics, pp. 1-46, http://dx.doi.org/10.1162/rest_a_00838.

Papay, J. (2011), "Different tests, different answers: The stability of teacher value-added estimates across outcome measures", American Education Research Journal, Vol. 48/1, pp. 163-193, http://dx.doi.org/10.3102/0002831210362589.

Papay, J. and M. Kraft (2015), "Productivity returns to experience in the teacher labor market: Methodological challenges and new evidence on long-term career improvement", Journal of Public Economics, Vol. 130/Oct 2015, pp. 105-119, http://dx.doi.org/10.1016/j.jpubeco.2015.02.008.

Papay, J. et al. (2016), "Learning job skills from colleagues at work: Evidence from a field experiment using teacher performance data", NBER Working Paper, No. 21986, National Bureau of Economic Research, Cambridge, MA, http://dx.doi.org/10.3386/w21986.

Papay, J. et al. (2012), "Does an urban teacher residency increase student achievement? Early evidence from Boston”, Educational Evaluation and Policy Analysis, Vol. 34/4, pp. 413434, http://dx.doi.org/10.3102/0162373712454328.

Parlement de la Fédération Wallonie-Bruxelles (2019), Décret du 14-03-2019 modifiant diverses dispositions relatives aux fonctions de directeur et directrice, aux autres fonctions de promotion et aux fonctions de sélection, https://www.gallilex.cfwb.be/document/pdf/46328_001.pdf (accessed on 5 July 2019).

Pont, B. (2014), "School leadership: From practice to policy", Journal of Educational Leadership and Management, Vol. 2/1, pp. 4-28, http://dx.doi.org/10.4471/ijelm.2014.07.

Pope, N. (2019), "The effect of teacher ratings on teacher performance", Journal of Public Economics, Vol. 172, pp. 84-110, https://doi.org/10.1016/j.jpubeco.2019.01.001. 
Powell, D. et al. (2010), "Effects of an early literacy professional development intervention on head start teachers and children.", Journal of Educational Psychology, Vol. 102/2, pp. 299312, http://dx.doi.org/10.1037/a0017763.

Radinger, T. (2014), "School leader appraisal - A tool to strength school leaders' pedagogical leadership and skills for teacher management?", European Journal of Education, Vol. 49/3, pp. 378-394, https://doi.org/10.1111/ejed.12085.

Radinger, T. et al. (2018), OECD Reviews of School Resources: Colombia 2018, OECD Reviews of School Resources, OECD Publishing, Paris, https://dx.doi.org/10.1787/9789264303751-en.

Reupert, A. and S. Woodcock (2015), "Does a year make a difference? The classroom management practices of primary student teachers before and after a one-year teacher education programme", Emotional and Behavioural Difficulties, Vol. 20/3, pp. 265-276, https://doi.org/10.1080/13632752.2014.949986.

Rivkin, S., E. Hanushek and J. Kain (2005), "Teachers, schools, and academic achievement", Econometrica, Vol. 73/2, pp. 417-458, http://dx.doi.org/10.1111/j.1468-0262.2005.00584.x.

Rockoff, J. (2004), "The impact of individual teachers on student achievement: Evidence from panel data", American Economic Review, Vol. 94/2, pp. 247-252, http://dx.doi.org/10.1257/0002828041302244.

Rockoff, J. and C. Speroni (2011), "Subjective and objective evaluations of teacher effectiveness: Evidence from New York City", Labour Economics, Vol. 18/5, pp. 687-696, http://dx.doi.org/10.1016/j.labeco.2011.02.004.

Rockoff, J. et al. (2012), "Information and employee evaluation: Evidence from a randomized intervention in public schools", The American Economic Review, Vol. 102/7, pp. 31843213, https://www.jstor.org/stable/41724631.

Ronfeldt, M. et al. (2015), "Teacher collaboration in instructional teams and student achievement", American Educational Research Journal, Vol. 52/3, pp. 475-514, http://dx.doi.org/10.3102/0002831215585562.

Ronfeldt, M. and K. McQueen (2017), "Does new teacher induction really improve retention?", Journal of Teacher Education, Vol. 68/4, pp. 394-410, http://dx.doi.org/10.1177/0022487117702583.

Ronfeldt, M. and M. Reininger (2012), "More or better student teaching?", Teaching and Teacher Education, Vol. 28/8, pp. 1091-1106, http://dx.doi.org/10.1016/J.TATE.2012.06.003.

Rosenholtz, S. (1985), "Effective schools: Interpreting the evidence", American Journal of Education, Vol. 93/3, pp. 352-388, http://dx.doi.org/10.1086/443805.

Rothstein, J. (2017), "Measuring the impacts of teachers: Comment", American Economic Review, Vol. 107/6, pp. 1656-1684, http://dx.doi.org/10.1257/aer.20141440.

Rothstein, J. (2010), "Teacher quality in educational production: Tracking, decay, and student achievement", Quarterly Journal of Economics, Vol. 125/1, pp. 175-214, http://dx.doi.org/10.1162/qjec.2010.125.1.175.

Santiago, P. et al. (2016), OECD Reviews of School Resources: Uruguay 2016, OECD Publishing, Paris, http://dx.doi.org/10.1787/9789264265530-en.

Santiago, P. et al. (2017), OECD Reviews of School Resources: Chile 2017, OECD Reviews of School Resources, OECD Publishing, Paris, https://dx.doi.org/10.1787/9789264285637-en. 
Santiago, P. et al. (2016), OECD Reviews of School Resources: Slovak Republic 2015, OECD Reviews of School Resources, OECD Publishing, Paris, https://dx.doi.org/10.1787/9789264247567-en.

Santiago, P. et al. (2016), OECD Reviews of School Resources: Estonia 2016, OECD Reviews of School Resources, OECD Publishing, Paris, https://dx.doi.org/10.1787/9789264251731en.

Scher, L. and F. O'Reilly (2009), "Professional development for K-12 math and science teachers: What do we really know?", Journal of Research on Educational Effectiveness, Vol. 2, pp. 209-249, http://dx.doi.org/10.1080/19345740802641527.

Schleicher, A. (2018), World Class: How to Build a 21st-Century School System, Strong Performers and Successful Reformers in Education, OECD Publishing, Paris, https://dx.doi.org/10.1787/9789264300002-en.

Schuck, S. et al. (2018), "The experiences of early career teachers: New initiatives and old problems", Professional Development in Education, Vol. 44/2, pp. 209-221, http://dx.doi.org/10.1080/19415257.2016.1274268.

Scottish College for Educational Leadership (2019), Scottish College for Educational Leadership, https://www.scelscotland.org.uk (accessed on 19 March 2019).

Shewbridge, C. et al. (2016), OECD Reviews of School Resources: Lithuania 2016, OECD Reviews of School Resources, OECD Publishing, Paris, https://dx.doi.org/10.1787/9789264252547-en.

Shewbridge, C. et al. (2016), OECD Reviews of School Resources: Czech Republic 2016, OECD Reviews of School Resources, OECD Publishing, Paris, http://dx.doi.org/10.1787/9789264262379-en.

Sinnema, C., M. Alansari and H. Turner (2018), The Promise of Improvement Through and of the Teacher-Led Innovation Fund. Evaluation of the Teacher-Led Innovation Fund Final Report, University of Auckland, Auckland, https://www.educationcounts.govt.nz/publications (accessed on 5 December 2018).

Slovenian Ministry of Education, Science and Sport (2017), OECD Review of Policies to Improve the Effectiveness of Resource Use in Schools - Country Background Report for Slovenia, Slovenian Ministry of Education, Science and Sport, Ljubljana, http://www.oecd.org/education/school-resources-review.

Sparks, D. (1994), “A paradigm shift in staff development”, Journal of Staff Development, Vol. 15/4, pp. 26-29.

Swedish Ministry of Education and Research (2016), OECD Review of Policies to Improve the Effectiveness of Resource Use in Schools: Country Background Report Sweden, Ministry of Education and Research, Stockholm, http://www.oecd.org/education/school-resourcesreview.

Taylor, E. and J. Tyler (2012), "The effect of evaluation on teacher performance", American Economic Review, Vol. 102/7, pp. 3628-3651, http://dx.doi.org/10.1257/aer.102.7.3628.

Timperley, H. et al. (2007), Teacher Professional Learning and Development: Best Evidence Synthesis Iteration, New Zealand Ministry of Education, Wellington, http://www.educationcounts.govt.nz/publications/curriculum/2515/15341 (accessed on 6 November 2019).

UNESCO (2016), Global Education Monitoring Report 2016: Education for People and Planet: Creating Sustainable Futures for All, UNESCO, Paris, https://en.unesco.org/gemreport/allreports (accessed on 29 May 2019). 
UNESCO (2014), El Liderazgo Escolar en América Latina y el Caribe: Un Estado del Arte en

[159] Base a Ocho Sistemas Escolares de la Region, OREALC/UNESCO, Santiago, Chile, http://unesdoc.unesco.org/images/0023/002327/232799s.pdf (accessed on 15 April 2019).

United Nations (2015), Transforming Our World: The 2030 Agenda for Sustainable Development, Resolution adopted by the General Assembly on 25 September 2015, https://sustainabledevelopment.un.org/post2015/transformingourworld (accessed on 15 December 2018).

Vegas, E. (2011), Are Alternative Pathways into Teaching Bad for Students?, http://blogs.worldbank.org/education/are-alternative-pathways-into-teaching-bad-forstudents (accessed on 4 April 2019).

Viennet, R. and B. Pont (2017), "Education policy implementation: A literature review and proposed framework", OECD Education Working Papers, No. 162, OECD Publishing, Paris, https://dx.doi.org/10.1787/fc467a64-en.

Walker, A., D. Bryant and M. Lee (2013), "International patterns in principal preparation: Commonalities and variations in pre-service programmes", Educational Management Administration \& Leadership, Vol. 41/4, pp. 405-434, http://dx.doi.org/10.1177/1741143213485466.

Wenner, J. and T. Campbell (2016), "The theoretical and empirical basis of teacher leadership", Review of Educational Research, Vol. 87/1, pp. 134-171, http://dx.doi.org/10.3102/0034654316653478.

Wildman, T. et al. (1992), "Teacher mentoring: An analysis of roles, activities, and conditions", Journal of Teacher Education, Vol. 43/3, pp. 205-213, http://dx.doi.org/10.1177/0022487192043003007.

Wong, H. and R. Wong (2005), The First Days of School: Unit E Epilogue, Harry K. Wong Publications, Inc., Mountain View, CA.

Zeichner, K. (2014), "The struggle for the soul of teaching and teacher education in the USA", Journal of Education for Teaching, Vol. 40/5, pp. 551-568, https://doi.org/10.1080/02607476.2014.956544. 


\section{Annex A. List of tables available on line}

Table A.1. Provision of instructional and leadership staff (ISCED 2), 2018

Table A.2 Provision of professional support, administrative and maintenance staff (ISCED 2), 2018

Table A.3 Recruitment of teachers (ISCED 1-3), 2018

Table A.4 Recruitment of school leaders (ISCED 1-3), 2018

Table A.5 Teacher professional learning (ISCED 1-3), 2018

Table A.6 School leader preparation and development (ISCED 1-3), 2018
StatLink त्ताI

https://doi.org/10.1787/888934026772

StatLink 게내

https://doi.org/10.1787/888934026791

StatLink त्ञाजप

https://doi.org/10.1787/888934026810

StatLink त्ताजा

https://doi.org/10.1787/888934026829

StatLink त्ञाजL

https://doi.org/10.1787/888934026848

StatLink त्ताड़

https://doi.org/10.1787/888934026867 


\section{Annex B. Glossary}

\section{Levels of education according to the UNESCO International Standard Classification of Education (ISCED 2011)}

Early childhood education (ISCED 0): Provides learning and educational activities with a holistic approach to support children's early cognitive, physical, social and emotional development and introduce young children to organised instruction outside of the family context to develop some of the skills needed for academic readiness and to prepare them for entry into primary education. ISCED level 0 is further divided into two sub-levels: ISCED 01 (early childhood educational development) and ISCED 02 (pre-primary education).

Primary education (ISCED 1): Usually begins at age 5, 6 or 7, and has a typical duration of six years. Programmes at ISCED level 1 are normally designed to give students a sound basic education in reading, writing and mathematics, along with an elementary understanding of other subjects such as history, geography, natural science, social sciences, art and music. The commencement of reading activities alone is not a sufficient criterion for classification of an education programme at ISCED level 1. Programmes classified at ISCED level 1 may be referred to in many ways, for example: primary education, elementary education or basic education (stage 1 or lower grades if an education system has one programme that spans ISCED levels 1 and 2).

Lower secondary education (ISCED 2): Programmes are designed to lay the foundation across a wide range of subjects and to prepare children and young people for more specialised study at upper secondary and higher levels of education. The beginning - or the end - of lower secondary education often involves a change of school for young students and also a change in the style of instruction. Programmes classified at ISCED level 2 may be referred to in many ways, for example: secondary school (stage 1/lower grades), junior secondary school, middle school or junior high school. If a programme spans ISCED levels 1 and 2, the terms elementary education or basic school (stage 2/upper grades) are often used.

Upper secondary education (ISCED 3): Programmes are more specialised than those at lower secondary and offer students more choices and diverse pathways for completing their secondary education. The range of subjects studied by a single student tends to be narrower than at lower levels of education, but the content is more complex and the study more in depth. Programmes offered are differentiated by orientation and often by broad subject groups. Programmes classified at ISCED level 3 may be referred to in many ways, for example, secondary school (stage 2 /upper grades), senior secondary school or (senior) high school.

General, pre-vocational and vocational education: Programmes at ISCED levels 2 and 3 can also be subdivided into two categories based on the degree to which the programme is specifically oriented towards a specific class of occupations or trades and leads to a labour-market relevant qualification: general programmes and pre-vocational/vocational programmes. 
General programmes: Refers to programmes that are not designed explicitly to prepare participants for a specific class of occupations or trades or for entry into further vocational or technical education programmes.

Pre-vocational/vocational programmes: This category encompasses both pre-vocational and vocational education. Pre-vocational education is mainly designed to introduce participants to the world of work and to prepare them for entry into further vocational or technical programmes. Successful completion of such programmes does not lead to a labour-market relevant vocational or technical qualification. Vocational programmes prepare participants for direct entry into specific occupations without further training. Successful completion of such programmes leads to a labour-market relevant vocational qualification.

For further details, see:

UNESCO Institute for Statistics (2012), International Standard Classification of Education ISCED 2011, UNESCO Institute for Statistics, Montreal, Quebec, www.uis.unesco.org/E ducation/Documents/isced-2011-en.pdf.

OECD/Eurostat/UNESCO Institute for Statistics (2015), ISCED 2011 Operational Manual: Guidelines for Classifying National Education Programmes and Related Qualifications, OECD Publishing, Paris, http://dx.doi.org/10.1787/9789264228368-en.

\section{School staff based on the UOE Manual on concepts, definitions and classifications for data} collection on formal education (2018)

The UNESCO-UIS/OECD/EUROSTAT (UOE) classification of educational staff is intended to serve as a framework to classify educational staff for all levels of education (ISCED levels 0 through 8). The classification is based on the primary or major functions performed by staff and organises staff into four main functional categories: i) instructional personnel, ii) professional support for students, iii) management/quality control/administration, iv) maintenance and operations personnel. Three of these four main functions contain sub-functions with specialised types of staff.

Given the scope and focus of this report, the following provides definitions for the relevant functions and sub-functions for ISCED levels 1-3 mainstream settings. This excludes, for example, "higher level management and administrative personnel" which are not covered in this report. For consistency with the analysis in this report, the UOE manual's main function of "classroom teachers" is referred to as "teachers"; the sub-function of "school-level management" is referred to as "school leaders". Instructional staff includes both teachers and teacher aides; professional support includes both pedagogical and health and social support.

Teachers are employed in a professional capacity to guide and direct the learning experiences of students, irrespective of their training, qualifications or delivery mechanism (i.e. face-to-face or at distance). Teaching involves planning, organising and conducting group activities whereby students' knowledge, skills and competencies develop as stipulated by the educational programme in which they participate.

This includes classroom teachers and other teachers who work with students as a whole class in a classroom, in small groups in a resource room, or one-on-one inside or outside a regular classroom. This excludes educational staff who have few or no teaching duties but whose primary function is not teaching (e.g. it is managerial or administrative) as well as student teachers, teachers' aides, and paraprofessionals. 
School leaders cover professional personnel who are responsible for school management/administration. This includes principals, assistant principals, headteachers, assistant headteachers, and other management staff with similar responsibilities. It excludes receptionists, secretaries, clerks, and other staff who support the administrative activities of the school.

Teacher aides include non-professional personnel who support teachers in providing instruction to students, and teacher aides and other para-professional personnel who are employed on a full-time or part-time basis by an education system. This excludes student teachers or other personnel who do not get paid for their employment.

Professional pedagogical support staff covers professional staff providing services to students to support their instructional programme. In many cases these personnel were licensed originally as teachers but then moved into other professional positions in education systems. This staff classification includes the following types of personnel: guidance counsellors, librarians, and attendance officers.

Professional health and social support staff covers all personnel employed in education systems who provide health and social support services to students. This includes the following types of personnel:

- health professionals such as doctors, dentists, ophthalmologists, optometrists, hygienists, nurses, and diagnosticians;

- psychiatrists and psychologists;

- $\quad$ speech pathologists and audiologists;

- social workers.

School-level administrative staff covers all personnel who support the administration and management of the school. It includes receptionists, secretaries, bookkeepers and clerks.

Maintenance and operations staff covers personnel who support the maintenance and operation of schools, school security, and ancillary services, such as the transportation of students to and from school, food services operations. It includes the following types of staff:

- masons, carpenters, electricians, locksmiths, maintenance repairers, painters and paperhangers, plasterers, plumbers, and vehicle mechanics;

- bus drivers and other vehicle operators, construction workers, gardeners and groundskeepers, bus monitors and crossing guards, cooks/food caterers, custodians, food servers, dormitory supervisors, and security guards.

For further details, see:

UNESCO-UIS/OECD/Eurostat (2018), UOE Data Collection on Formal Education: Manual on Concepts, Definitions and Classifications, UNESCO-OECD-Eurostat, Montreal, Paris, Luxembourg, pp. 42-48, http://uis.unesco.org/sites/default/files/documents/uoe2016manual_11072016_0.pdf. 


\section{Levels of governance and administration}

For international comparability, levels of governance and administration are described following a standard terminology. The report may, however, use the particular terms of a specific national context where country approaches are described in greater detail. For example, for Austria, the report may refer to "states" when information is presented in a comparable format (e.g. for a group of countries with a similar approach or in comparative tables) or to "provinces" when the Austrian school system is analysed in greater detail.

Central level: The central level specifies authorities that make decisions or participate in different aspects of decision making on a national scale. This includes, among others, the central government and central education and legislative authorities. All authorities below the central level in administrative terms are referred to as sub-central authorities or the sub-central level.

State level: The state level refers to the first territorial unit below the nation in federal countries or countries with similar types of governmental structures. The state level includes, among others, state governments, state education and legislative authorities. In Austria, for example, the state level refers to the level of the "provinces". In Belgium, the state level refers to the level of the "Communities".

Regional level: The region level is the first territorial unit below the national level in countries that do not have a federal or similar type of governmental structure, and the second territorial unit below the national level in countries with federal or similar types of governmental structures. The regional level includes, among others, regional governments, and regional education authorities. In the Czech Republic and the Slovak Republic, for example, the regional level refers to the "self-governing regions".

Local level: The local level corresponds to the smallest territorial unit with a governing authority, such as municipalities or communities. This includes local governments and local education authorities. The local authority may be the education department within a general-purpose local government or it may be a special-purpose government whose sole area of authority is education. 


\section{Annex C. How the School Resources Review was conducted}

\section{National co-ordinators}

As described in Chapter 1 (Box 1.2) the OECD School Resources Review is conducted in collaboration with countries and under the guidance of the OECD Group of National Experts on School Resources. Participating countries appoint a national co-ordinator responsible for: liaising with the OECD Secretariat and co-ordinating activities of the review within the country; ensuring that the country background report is completed on schedule; planning with the OECD Secretariat the organisation of the review team visit, for those countries which opted for a country review; attending meetings of the Group of National Experts on School Resources; co-ordinating country feedback on the review's qualitative data on human resource policies; co-ordinating country feedback on draft materials; and assisting with dissemination activities. Past and present national co-ordinators in participating countries are listed in Table C.1.

Table C.1. National co-ordinators

\begin{tabular}{|c|c|}
\hline Country & National co-ordinator(s) \\
\hline Austria & Bernhard Chabera, Austrian Federal Ministry for Education, Science and Research \\
\hline Belgium (Flemish Community) & $\begin{array}{l}\text { Marie-Anne Persoons, Flemish Ministry of Education and Training } \\
\text { Pieter Vos, Flemish Ministry of Education and Training }\end{array}$ \\
\hline Belgium (French Community) & Philippe Dieu, International Relations Directorate, Ministry of the Wallonia-Brussels Federation \\
\hline Chile & $\begin{array}{l}\text { Eduardo Candia Agusti, Chilean Ministry of Education } \\
\text { Amanda Castillo Rodríguez, Chilean Ministry of Education } \\
\text { Carla Guazzini, Chilean Ministry of Education }\end{array}$ \\
\hline Colombia & $\begin{array}{l}\text { Victoria Gómez, Colombian Ministry of National Education } \\
\text { José Luis Sánchez, Colombian Ministry of National Education }\end{array}$ \\
\hline Czech Republic & $\begin{array}{l}\text { Lucie Priknerová, Czech Ministry of Education, Youth and Sports } \\
\text { Michael Vlach, Czech Ministry of Education, Youth and Sports }\end{array}$ \\
\hline Denmark & $\begin{array}{l}\text { Jon Jespersen, Danish Ministry of Education } \\
\text { Sigrid Lundetoft Clausen, Danish Ministry of Education } \\
\text { Cathrine Scheuermann, Danish Ministry of Education } \\
\text { Morten Theis Pedersen, Danish Ministry of Education }\end{array}$ \\
\hline Estonia & Kadi Serbak, Estonian Ministry of Education and Research \\
\hline Iceland & Sigríður Lára Ásbergsdóttir, Icelandic Ministry of Education, Science and Culture \\
\hline Kazakhstan & $\begin{array}{l}\text { Zhannat Mussina, Kazakh Information Analytic Center } \\
\text { Assem Satmukhambetova, Kazakh Information Analytic Center }\end{array}$ \\
\hline Lithuania & $\begin{array}{l}\text { Aidas Aldakauskas, Lithuanian Ministry of Education, Science and Sports } \\
\text { Vilma Bačkiūtè, Lithuanian Ministry of Education, Science and Sports }\end{array}$ \\
\hline Luxembourg & $\begin{array}{l}\text { Amina Kafai, Luxembourg Ministry of National Education and Vocational Training } \\
\text { Charlotte Mahon, Luxembourg Ministry of National Education and Vocational Training }\end{array}$ \\
\hline Portugal & $\begin{array}{l}\text { Pedro Abrantes, Portuguese Ministry of Education } \\
\text { Ana Neves, Portuguese Ministry of Education }\end{array}$ \\
\hline Slovak Republic & $\begin{array}{l}\text { Matej Šiškovič, Slovak Education Policy Institute } \\
\text { Ján Toman, Slovak Education Policy Institute }\end{array}$ \\
\hline Slovenia & Klemen Surk, Slovenian Ministry of Education, Science and Sport \\
\hline
\end{tabular}




\begin{tabular}{ll}
\hline Country & National co-ordinator(s) \\
\hline Spain & Vicente Alcañiz, Spanish National Institute for Educational Assessment \\
& Jorge Berné Espinosa, Spanish Ministry of Education, Culture and Sport \\
& Isabel Couso Tapia, Spanish Ministry of Education, Culture and Sport \\
Sweden & Tor Petersson, Swedish Ministry of Education and Research \\
& Gunnar Stenberg, Swedish Ministry of Education and Research \\
& Merja Strömberg, Swedish Ministry of Education and Research \\
Uruguay & Cecilia Llambi, National Institute for Educational Evaluation of Uruguay \\
& Cecilia Oreiro, National Institute for Educational Evaluation of Uruguay \\
\hline
\end{tabular}

\section{Collaboration with the European Commission}

Within a broader framework of collaboration, the OECD School Resources Review has benefited from a partnership with the European Commission (EC) that was established for the project. The support of the EC has covered part of the participation costs for members of the European Union Erasmus ${ }^{+}$programme and contributed significantly to the preparation of the review's series of thematic comparative reports, including this publication. Within the EC Directorate-General for Education and Culture, the collaboration was organised by Unit A.2: Education and Training in Europe 2020 through Mónika Képe-Holmberg under the leadership of Michael Teutsch (until December 2016) and Denis Crowley (since January 2017), and Unit B.2: Schools and Multilingualism through Marco Montanari under the leadership of Sophie Beernaerts (until December 2016) and Michael Teutsch (since January 2017). Through its Country Analysis unit, the EC contributed to planning individual country reviews in the countries listed in Table C.2, with the relevant country desk officers participating in planning visits, providing input for the organisation of the main visit and offering feedback on draft country review reports.

Table C.2. European Commission contribution to country reviews

\begin{tabular}{ll}
\hline Country & EC Country Desk Officer \\
\hline Austria & Klaus Koerner \\
Belgium (Flemish Community) & Patricia De Smet \\
Czech Republic & Christèle Duvieusart \\
Denmark & Joanna Basztura \\
Estonia & Krzysztof Kania \\
Lithuania & Joanna Basztura \\
Portugal & Antonio Garcia Gómez \\
Slovak Republic & Christèle Duvieusart \\
\hline
\end{tabular}

\section{Country Background Reports}

Information on countries' policies and practices was gathered through country background reports (CBRs). The CBRs were prepared in response to a common set of questions, and used a common framework to facilitate comparative analysis and maximise the opportunities for countries to learn from each other. The CBRs were a key source of information for the review's thematic comparative reports. The guidelines for the preparation of CBRs are set out in a dedicated document available on the review website (www.oecd.org/education/schoolresourcesreview.htm). 
The CBRs were structured around the following main chapters:

1. The national context

2. The school system

3. Governance of resource use in schools

4. Resource distribution

5. Resource utilisation

6. Resource management

The CBRs are intended for four main audiences: the OECD Secretariat and OECD Member and partner countries to share experiences and identify common challenges and policy options; the team of external reviewers who visited the countries which opted for a country review; those interested in the use of school resources in the country concerned; and those interested in the use of school resources at international level and in other countries. All CBRs are available on the website: www.oecd.org/education/schoolresourcesreview.htm.

\section{Qualitative data collection}

In addition to the country background reports, the OECD School Resources Review collected information on countries' national approaches to human resource policies through a set of comparative tables prepared by the OECD Secretariat. In total, 21 systems participated in this qualitative data collection. The comparative tables focussed on formal frameworks for human resource policies in terms of laws and regulations that were in place in 2018. It did generally not cover observed practices which can vary considerably.

The comparative tables covered the following issues as defined at a central level: teacher career structures; factors influencing school principals' salaries; provision of instruction and leadership staff; provision of professional support, administrative, maintenance and operational staff; recruitment of teachers and school leaders; incentives for teachers and school principals to work in particular contexts; practical experience during initial teacher preparation; teacher professional learning; and school leader preparation and development.

The qualitative data collection provided crucial information to complement the information available and support the review's analysis. Selected information gathered through the comparative tables is reflected throughout this report; additional comparative tables are available on line (see Annex A). The review team made every effort to ensure in collaboration with countries that the information available in this report is as valid and robust as possible and reflects specific country contexts while being comparable across countries. However, given the complexity of human resource policies and the qualitative nature of this exercise, information should be interpreted with care. Country contacts for the verification of the comparative tables are listed in Table C.3. 
Table C.3. Country contacts for the qualitative data collection

\begin{tabular}{|c|c|}
\hline Country & Country contact(s) \\
\hline Australia & Edward Harvey, Permanent Delegation of Australia to the OECD \\
\hline Austria & $\begin{array}{l}\text { Bernhard Chabera, Austrian Federal Ministry for Education, Science and Research } \\
\text { Benjamin Podirsky, Austrian Federal Ministry for Education, Science and Research }\end{array}$ \\
\hline Belgium (Flemish Community) & $\begin{array}{l}\text { Pieter Vos, Flemish Ministry of Education and Training } \\
\text { Marc Leunis, Flemish Ministry of Education and Training } \\
\text { Teun Pawels, Flemish Ministry of Education and Training }\end{array}$ \\
\hline Belgium (French Community) & Philippe Dieu, International Relations Directorate, Ministry of the Wallonia-Brussels Federation \\
\hline Chile & $\begin{array}{l}\text { Amanda Castillo Rodriguez, Chilean Ministry of Education } \\
\text { Felipe Coloma Alamos, Chilean Ministry of Education } \\
\text { Juan Luis Cordero Becker, Chilean Ministry of Education }\end{array}$ \\
\hline Colombia & Victoria Gómez, Colombian Ministry of National Education \\
\hline Czech Republic & Lucie Priknerová, Czech Ministry of Education, Youth and Sports \\
\hline Denmark & Morten Theis Pedersen, Danish Ministry of Education \\
\hline Estonia & Kadi Serbak, Estonian Ministry of Education and Research \\
\hline Iceland & $\begin{array}{l}\text { Gunnar Jóhannes Árnason, Icelandic Ministry of Education, Science and Culture } \\
\text { Lára Ásbergsdóttir, Icelandic Ministry of Education, Science and Culture }\end{array}$ \\
\hline Kazakhstan & Zhanna Jumabayeva, Kazakh Information Analytic Center \\
\hline Lithuania & Vilma Bačkiūtè, Lithuanian Ministry of Education and Science \\
\hline Luxembourg & $\begin{array}{l}\text { Amina Afif, Ministry of National Education and Vocational Training of Luxembourg } \\
\text { Charlotte Mahon, Ministry of National Education and Vocational Training of Luxembourg }\end{array}$ \\
\hline Mexico & $\begin{array}{l}\text { Paula Pérez Muleiro, Permanent Delegation of Mexico to the OECD } \\
\text { Gerardo Bracho Carpizo, Permanent Delegation of Mexico to the OECD }\end{array}$ \\
\hline Portugal & Pedro Abrantes, Portuguese Ministry of Education \\
\hline Slovak Republic & Ján Toman, Slovak National Institute for Educational Assessment \\
\hline Slovenia & Klemen Surk, Slovenian Ministry of Education, Science and Sport \\
\hline Spain & Jorge Berné Espinosa, Spanish Ministry of Education, Culture and Sport \\
\hline Sweden & $\begin{array}{l}\text { Gunnar Stenberg, Swedish Ministry of Education and Research } \\
\text { Tor Petersson, Swedish Ministry of Education and Research }\end{array}$ \\
\hline Turkey & $\begin{array}{l}\text { Adnan Boyaci, Turkish Ministry of National Education } \\
\text { Alper Yatmaz, Turkish Government Presidency of The Directorate of Strategy and Budgeting }\end{array}$ \\
\hline Uruguay & $\begin{array}{l}\text { Melissa Hernández, National Institute for Educational Evaluation of Uruguay } \\
\text { Cecilia Oreiro, National Institute for Educational Evaluation of Uruguay }\end{array}$ \\
\hline
\end{tabular}

\section{Country review reports}

Another major source of material for this report was the set of country review reports prepared by the external review teams that visited countries engaging in a full country review. By providing an external perspective on the use of school resources in the countries concerned, the country review reports are intended to contribute to national discussions, as well as inform other countries about policy innovations underway. The country review reports are also published as part of the publication series, OECD Reviews of School Resources, to ensure the visibility of these country-specific outputs as part of the review.

For each country visited, a team of up to five reviewers (including at least two OECD Secretariat members) analysed the country background report and associated materials and subsequently undertook an intensive case study visit over the course of about eight days. The reviewers were selected in consultation with the country authorities to ensure that they had experience relevant to the main policy issues in the country concerned. The study visit aimed to provide the review team with a variety of perspectives on the governance, distribution and management of school resources and included meetings with education and finance authorities at national and sub-national levels; relevant agencies (e.g. audit 
offices); teacher professional organisations and unions; parents' organisations; representatives of schools and school leaders; students' organisations; teacher educators; researchers; employers; as well as students, teachers, school leaders and parents at the schools visited. The objective was to accumulate sufficient information and understanding on which to base the analysis and policy recommendations.

At the time of publication, 12 review visits had been conducted, involving 25 external reviewers from a range of different backgrounds and areas of expertise. The reviews involved a planning visit and a main review visit. Details on the composition of the review teams for the main visits can be found in Table C.4. The country review reports are published on the project website: www.oecd.org/education/schoolresourcesreview.htm.

Table C.4. Country reviews and team members

\begin{tabular}{|c|c|}
\hline Country & Review visit team \\
\hline $\begin{array}{l}\text { Kazakhstan } \\
31 \text { March-9 April } 2014\end{array}$ & $\begin{array}{l}\text { Anna Pons, OECD Secretariat (co-ordinator) } \\
\text { Jeremie Amoroso, World Bank } \\
\text { Jan Herczyński, Institute for Educational Research, Poland } \\
\text { lgor Kheyfets, World Bank } \\
\text { Marlaine Lockheed, Princeton University, United States } \\
\text { Paulo Santiago, OECD Secretariat }\end{array}$ \\
\hline $\begin{array}{l}\text { Slovak Republic } \\
\text { 7-14 October } 2014\end{array}$ & $\begin{array}{l}\text { Paulo Santiago, OECD Secretariat (co-ordinator) } \\
\text { Gábor Halász, University Eötvös Loránd, Hungary } \\
\text { Rosalind Levačić, Institute of Education - University of London, United Kingdom } \\
\text { Claire Shewbridge, OECD Secretariat }\end{array}$ \\
\hline $\begin{array}{l}\text { Estonia } \\
\text { 20-27 October } 2014\end{array}$ & $\begin{array}{l}\text { Paulo Santiago, OECD Secretariat (co-ordinator) } \\
\text { Anthony Levitas, Brown University, United States } \\
\text { Péter Radó, Education Consultant, Hungary } \\
\text { Claire Shewbridge, OECD Secretariat }\end{array}$ \\
\hline $\begin{array}{l}\text { Belgium (Flemish } \\
\text { Community) } \\
\text { 3-10 November } 2014\end{array}$ & $\begin{array}{l}\text { Deborah Nusche, OECD Secretariat (co-ordinator) } \\
\text { Gary Miron, Western Michigan University, United States } \\
\text { Paulo Santiago, OECD Secretariat } \\
\text { Richard Teese, University of Melbourne, Australia }\end{array}$ \\
\hline $\begin{array}{l}\text { Lithuania } \\
\text { 2-9 December } 2014\end{array}$ & $\begin{array}{l}\text { Claire Shewbridge, OECD Secretariat (co-ordinator) } \\
\text { Katrina Godfrey, Department of Education of Northern Ireland, United Kingdom } \\
\text { Zoltán Hermann, Institute of Economics - Academy of Sciences, Hungary } \\
\text { Deborah Nusche, OECD Secretariat }\end{array}$ \\
\hline $\begin{array}{l}\text { Uruguay } \\
\text { 17-25 March } 2015\end{array}$ & $\begin{array}{l}\text { Paulo Santiago, OECD Secretariat (co-ordinator) } \\
\text { Beatrice Ávalos, Universidad de Chile, Chile } \\
\text { Tracey Burns, OECD Secretariat } \\
\text { Alejandro Morduchowicz, Inter-American Development Bank } \\
\text { Thomas Radinger, OECD Secretariat }\end{array}$ \\
\hline $\begin{array}{l}\text { Denmark } \\
\text { 22-29 April } 2015\end{array}$ & $\begin{array}{l}\text { Deborah Nusche, OECD Secretariat (co-ordinator) } \\
\text { Torberg Falch, Norwegian University of Science and Technology, Norway } \\
\text { Thomas Radinger, OECD Secretariat } \\
\text { Bruce Shaw, Ontario Ministry of Education, Canada }\end{array}$ \\
\hline $\begin{array}{l}\text { Czech Republic } \\
26 \text { May - } 2 \text { June } 2015\end{array}$ & $\begin{array}{l}\text { Claire Shewbridge, OECD Secretariat (co-ordinator) } \\
\text { Jan Herczyński, Institute for Educational Research, Poland } \\
\text { Thomas Radinger, OECD Secretariat } \\
\text { Julie Sonneman, Learning First, Australia }\end{array}$ \\
\hline $\begin{array}{l}\text { Austria } \\
24-30 \text { June } 2015\end{array}$ & $\begin{array}{l}\text { Deborah Nusche, OECD Secretariat (co-ordinator) } \\
\text { Marius R. Busemeyer, University of Konstanz, Germany } \\
\text { Thomas Radinger, OECD Secretariat } \\
\text { Henno Theisens, The Hague University of Applied Sciences, Netherlands }\end{array}$ \\
\hline
\end{tabular}




\begin{tabular}{ll}
\hline Country & Review visit team \\
\hline Chile & Paulo Santiago, OECD Secretariat (co-ordinator) \\
22-30 September 2015 & Ariel Fiszbein, Inter-American Dialogue, United States \\
& Sandra García Jaramillo, Universidad de los Andes, Colombia \\
& Thomas Radinger, OECD Secretariat \\
& Thomas Radinger, OECD Secretariat (co-ordinator) \\
Colombia & Alfonso Echazarra, OECD Secretariat \\
5-13 December 2017 & Gabriela Guerrero, GRADE, Peru \\
& Juan Pablo Valenzuela, Universidad de Chile, Chile \\
& David Liebowitz, OECD Secretariat (co-ordinator) \\
Portugal & Pablo González, University of Chile \\
8-12 January 2018 & Edith Hooge, Tilburg University, Netherlands \\
& Gonçalo Lima, OECD Secretariat \\
& Deborah Nusche, OECD Secretariat \\
\hline
\end{tabular}

\section{Analytical background papers}

The School Resources Review has been informed by the following analytical background papers prepared in the context of the project:

Learning in rural schools: Insights from PISA, TALIS and the literature, by Alfonso Echazarra and Thomas Radinger, OECD Education Working Paper No. 196 (2019), https://doi.org/10.1787/8b1a5cb9-en.

Regulating Publicly Funded Private Schools: A Literature Review on Equity and Effectiveness, by Luka Boeskens, OECD Education Working Paper No. 147 (2016), http://dx.doi.org/10.1787/5jln6jcg80r4-en.

Budgeting and Accounting in OECD Education Systems: A Literature Review, by Tala Fakharzadeh, OECD Education Working Paper No. 128 (2016), http://dx.doi.org/10.1787/5jm3xgsz03kh-en.

Student Learning Time: A Literature Review, by Anna Gromada and Claire Shewbridge, $\begin{array}{lllll}\text { OECD Education Working Paper } & \text { No. }\end{array}$ http://dx.doi.org/10.1787/5jm409kqqkjh-en.

Learning Support Staff: A Literature Review, by Francesc Masdeu, OECD Education Working Paper No. 125 (2015), http://dx.doi.org/10.1787/5jrnzm39w451-en.

School Size Policies: A Literature Review, by Macarena Ares Abalde, OECD Education Working Paper No. 106 (2014), http://dx.doi.org/10.1787/5jxt472ddkjl-en.

\section{Dissemination}

To facilitate dissemination and encourage feedback, all project documents and outputs are published on the project website (www.oecd.org/education/schoolresourcesreview.htm). Throughout the review, the OECD Secretariat presented the project and its findings at a wide range of internal and external meetings and a significant number of countries organised national events to discuss both the international results from the review and the conclusions of specific country reviews. 



\section{ORGANISATION FOR ECONOMIC CO-OPERATION AND DEVELOPMENT}

The OECD is a unique forum where governments work together to address the economic, social and environmental challenges of globalisation. The OECD is also at the forefront of efforts to understand and to help governments respond to new developments and concerns, such as corporate governance, the information economy and the challenges of an ageing population. The Organisation provides a setting where governments can compare policy experiences, seek answers to common problems, identify good practice and work to co-ordinate domestic and international policies.

The OECD member countries are: Australia, Austria, Belgium, Canada, Chile, the Czech Republic, Denmark, Estonia, Finland, France, Germany, Greece, Hungary, Iceland, Ireland, Israel, Italy, Japan, Korea, Latvia, Lithuania, Luxembourg, Mexico, the Netherlands, New Zealand, Norway, Poland, Portugal, the Slovak Republic, Slovenia, Spain, Sweden, Switzerland, Turkey, the United Kingdom and the United States. The European Union takes part in the work of the OECD.

OECD Publishing disseminates widely the results of the Organisation's statistics gathering and research on economic, social and environmental issues, as well as the conventions, guidelines and standards agreed by its members. 


\section{OECD Reviews of School Resources}

\section{Working and Learning Together}

\section{RETHINKING HUMAN RESOURCE POLICIES FOR SCHOOLS}

The staff working in schools are the most important resource for today's education systems, both educationally and financially. This report aims to provide guidance for the design of human resource policies that strengthen, recognise and preserve the positive impact that teachers, school leaders and other school staff have on their students. It offers an in-depth analysis of how human resource policies can make the best use of available resources to create supportive working environments and build both individual and collective professional capacity in schools. This includes the design of entry requirements, career structures, salary schedules and working time arrangements to attract, retain and motivate high-quality staff; the effective and equitable matching of staff with schools through fair and transparent staff funding and recruitment; and informed investments in professional learning, from initial preparation to continuing development. Throughout its analysis, the report looks at implementation challenges and considers under which conditions human resource policy reforms are most likely to have the desired effects on schools and their staff. This report is the third in a series of thematic comparative reports bringing together findings from the OECD School Resources Review. 